Max-Planck-Institut für ausländisches öffentliches Recht und Völkerrecht

Beiträge zum ausländischen öffentlichen Recht und Völkerrecht 297

Valentina Volpe

Anne Peters

Stefano Battini (eds.)

\title{
Remedies against Immunity?
}




\section{Beiträge zum ausländischen öffentlichen Recht und Völkerrecht}

Begründet von Viktor Bruns

Herausgegeben von

Armin von Bogdandy • Anne Peters

Band 297 
Valentina Volpe - Anne Peters - Stefano Battini

Editors

\author{
Violetta Ritz
}

Assistant Editor

\title{
Remedies against Immunity?
}

Reconciling International and Domestic Law after the Italian Constitutional Court's

Sentenza 238/2014 


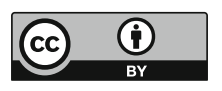

ISSN 0172-4770

ISSN 2197-7135 (electronic)

Beiträge zum ausländischen öffentlichen Recht und Völkerrecht

ISBN 978-3-662-62303-9

ISBN 978-3-662-62304-6 (eBook)

https://doi.org/10.1007/978-3-662-62304-6

This book is an open access publication.

(C) The Editor(s) (if applicable) and The Author(s) 2021

Open Access This book is licensed under the terms of the Creative Commons Attribution 4.0 International License (http://creativecommons.org/licenses/by/4.0/), which permits use, sharing, adaptation, distribution and reproduction in any medium or format, as long as you give appropriate credit to the original author(s) and the source, provide a link to the Creative Commons license and indicate if changes were made.

The images or other third party material in this book are included in the book's Creative Commons license, unless indicated otherwise in a credit line to the material. If material is not included in the book's Creative Commons license and your intended use is not permitted by statutory regulation or exceeds the permitted use, you will need to obtain permission directly from the copyright holder.

The use of general descriptive names, registered names, trademarks, service marks, etc. in this publication does not imply, even in the absence of a specific statement, that such names are exempt from the relevant protective laws and regulations and therefore free for general use.

The publisher, the authors, and the editors are safe to assume that the advice and information in this book are believed to be true and accurate at the date of publication. Neither the publisher nor the authors or the editors give a warranty, expressed or implied, with respect to the material contained herein or for any errors or omissions that may have been made. The publisher remains neutral with regard to jurisdictional claims in published maps and institutional affiliations.

This Springer imprint is published by the registered company Springer-Verlag GmbH, DE, part of Springer Nature.

The registered company address is: Heidelberger Platz 3, 14197 Berlin, Germany 


\section{Acknowledgements}

This project has travelled a long way and we owe numerous debts of gratitude to those who have helped along this journey. Violetta Ritz (assistant editor), Anette Kreutzfeld, Giuseppina De Marco, Elisa Andreotti, and Trevor Krayer have provided an incredible support over the months with research assistance, organizational tasks, and enthusiasm during each phase of this undertaking. Verena Schaller-Soltau and Angelika Schmidt provided valuable technical and editorial assistance.

The Max Planck Institute for Comparative Public Law and International Law (MPIL) in Heidelberg and the Istituto di Ricerche sulla Pubblica Amministrazione (IRPA) in Rome, along with Villa Vigoni, co-organized and co-financed an authors' workshop at Villa Vigoni, on Lake Como in May 2017. The colleagues of Villa Vigoni, in particular the former Secretary General professor Immacolata Amodeo and the legal adviser Dr Julian Stefenelli, were ideal partners, also in conceiving the initial idea. The Fritz Thyssen Foundation granted generous financial support.

We are also grateful to Maximilian Steinbeis for providing a livestreamed online conference on Verfassungsblog. The Corte Costituzionale kindly gave permission to reproduce the English translation of Sentenza 238/2014 provided by the Court, in this volume. Matthew Milbourne polished the English language of the book's chapters.

During our long journey towards the book, Jörg Luther, a friend and colleague, sadly passed away. His contribution in this study is the best way to remember him as a man and a scholar, and allow his ideas to live on.

Lille, France

Heidelberg, Germany

Viterbo, Italy

February 2021
Valentina Volpe Anne Peters

Stefano Battini 


\section{Contents}

\section{Part I Introduction}

Reconciling State Immunity with Remedies for War Victims

in a Legal Pluriverse

Anne Peters and Valentina Volpe

\section{Part II Immunity}

Right of Access to (Italian) Courts über alles? Legal Implications

Beyond Germany's Jurisdictional Immunity . . . . . . . . . . . . . . . . . . 3

Paolo Palchetti

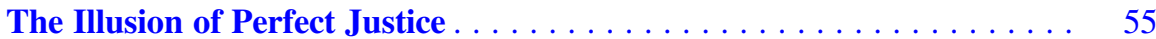

Christian Tomuschat

Sentenza 238/2014: A Good Case for Law-Reform? . . . . . . . . . . . . . 71

Heike Krieger

\section{Part III Remedies}

A Plea for Legal Peace . . . . . . . . . . . . . . . . . . . . . . . . . . . . 93

Riccardo Pavoni

A Story of 'Trials and Errors' That Might Have No Happy End . . . . . . 119 Jörg Luther†

State Immunity, Individual Compensation for Victims of Human

Rights Crimes, and Future Prospects . . . . . . . . . . . . . . . . . . . . . 143

Stefan Kadelbach

Sketches for a Reparation Scheme: How Could a German-Italian

Fund for the IMIs Work? . . . . . . . . . . . . . . . . . . . . . . . . . . . . . 159

Filippo Fontanelli 


\section{Part IV European Perspectives}

Waiting for Negotiations: An Italian Way to Get Out of the Deadlock . . . 191 Alessandro Bufalini

Sentenza 238/2014: EU Law and EU Values . . . . . . . . . . . . . . . . . 209 Bernardo Giorgio Mattarella

The Consequences of Sentenza 238/2014: What to Do Now? . . . . . . . 215 Doris König

Would the World Be a Better Place If One Were to Adopt a European Approach to State Immunity? Or, 'Soll am Europäischen Wesen die Staatenimmunität Genesen'? . . . . . . . . . . . . . . . . . . . . . 219 Andreas Zimmermann

\section{Part V Courts}

A Dangerous Last Line of Defence: Or, A Roman Court Goes Lutheran . . . . . . . . . . . . . . . . . . . . . . . . . 237 Christian J. Tams

Teaching the World Court Makes a Bad Case: Revisiting the Relationship Between Domestic Courts and the ICJ . . . . . . . . . . 259 Raffaela Kunz

Between Cynicism and Idealism: Is the Italian Constitutional Court

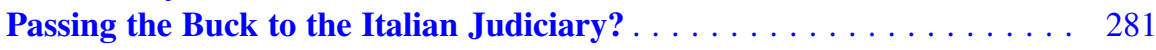
Giovanni Boggero and Karin Oellers-Frahm

\section{Part VI Negotiations}

Deadlocked in Dualism: Negotiating for a Final Settlement . . . . . . . . 313 Andreas von Arnauld

Moving Beyond Judicial Conflict in the Name of the Pre-Eminence of Fundamental Human Rights . . . . . . . . . . . . . . . . . . . . 331 Valerio Onida

Between a Rock and a Hard Place: Italian Concerns Between Constitutional Rights and International Law . . . . . . . . . . . . . . . 337 Andreas L. Paulus

Overcoming the Judicial Conundrum: The Road to a Diplomatic Solution . . . . . . . . . . . . . . . . . . . . . . . . . . . 343 Francesco Francioni 
Part VII The Past and Future of Remedies

Recollections of a Judge . . . . . . . . . . . . . . . . . . . . . . 353

Sabino Cassese

A Dialogical Epilogue . . . . . . . . . . . . . . . . . . . . . . . . . . . . . . . . . 359

Joseph H. H. Weiler

Annex

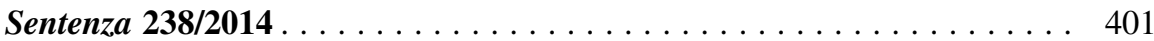




\section{Contributors}

Andreas von Arnauld Professor of Public Law, Public International Law, and European Law, Kiel University, Kiel, Germany

Director of the Walther Schücking Institute for International Law, Kiel, Germany

Stefano Battini President of the Italian National School of Administration, Rome, Italy

Professor of Administrative Law, Tuscia University, Viterbo, Italy

Giovanni Boggero Assistant Professor of Constitutional Law, University of Turin, Turin, Italy

Alessandro Bufalini Assistant Professor of Public International Law, Tuscia University, Viterbo, Italy

Sabino Cassese Professor at the School of Government, LUISS Guido Carli University, Rome, Italy

Justice Emeritus of the Italian Constitutional Court, Rome, Italy

Professor Emeritus, Scuola Normale Superiore, Pisa, Italy

Filippo Fontanelli Senior Lecturer in International Economic Law, University of Edinburgh, Edinburgh, UK

Adjunct Professor of Fundamental Rights, LUISS Guido Carli University, Rome, Italy

Francesco Francioni Professor of International Cultural Heritage Law, LUISS Guido Carli University, Rome, Italy

Professor Emeritus of International Law, European University Institute, Florence, Italy 
Stefan Kadelbach Professor of Public Law, European Law, and International Law, Goethe University Frankfurt, Frankfurt am Main, Germany

Doris König Vice President of the German Federal Constitutional Court, Karlsruhe, Germany

Professor of Public Law, European Law, and International Law, Bucerius Law School, Hamburg, Germany

Heike Krieger Professor of Public Law and International Law, Freie Universität Berlin, Berlin, Germany

Max Planck Fellow, Max Planck Institute for Comparative Public Law and International Law, Heidelberg, Germany

Raffaela Kunz Senior Research Fellow, Max Planck Institute for Comparative Public Law and International Law, Heidelberg, Germany

Jörg Luther $\dagger$ Professor of Public Law, University of Eastern Piedmont Amedeo Avogadro, Alessandria, Italy

Bernardo Giorgio Mattarella Professor of Administrative Law, LUISS Guido Carli University, Rome, Italy

Karin Oellers-Frahm Senior Research Affiliate, Max Planck Institute for Comparative Public Law and International Law, Heidelberg, Germany

Valerio Onida President and Justice Emeritus of the Italian Constitutional Court, Rome, Italy

Professor Emeritus of Constitutional Law, University of Milan, Milan, Italy

Paolo Palchetti Professor of International Law, University Paris 1 Panthéon Sorbonne, Paris, France

University of Macerata, Macerata, Italy

Andreas L. Paulus Justice of the German Federal Constitutional Court, Karlsruhe, Germany

Professor of Public Law and International Law, Georg August University of Göttingen, Göttingen, Germany

Riccardo Pavoni Associate Professor of International Law and European Law, University of Siena, Siena, Italy 
Anne Peters Professor of International Law and Director at the Max Planck Institute for Comparative Public Law and International Law, Heidelberg, Germany

Christian J. Tams Professor of International Law, University of Glasgow, Glasgow, UK

Director of the Glasgow Centre for International Law and Security, Glasgow, UK

Christian Tomuschat Former Member of the UN Human Rights Committee and International Law Commission, Geneva, Switzerland

Former President of the OSCE Court of Conciliation and Arbitration, Geneva, Switzerland

Professor Emeritus of International Law, Humboldt University of Berlin, Berlin, Germany

Valentina Volpe Associate Professor of Public Law and International Law, Lille Catholic University, Lille, France

Senior Research Affiliate, Max Planck Institute for Comparative Public Law and International Law, Heidelberg, Germany

Joseph H. H. Weiler Professor of Law, NYU School of Law, New York, NY, USA Senior Fellow, Harvard Centre for European Studies, Cambridge, MA, USA

Andreas Zimmermann Professor of International Law and European Law, University of Potsdam, Potsdam, Germany

Director of the Potsdam Centre of Human Rights, Potsdam, Germany 


\section{Selected Cases}

\section{International Cases}

\section{International Court of Justice}

ICJ, Corfu Channel (United Kingdom v Albania), Judgment of 9 April 1949, ICJ Reports 1949, 4 ICJ, Asylum (Colombia v Peru), Judgment of 20 November 1950, ICJ Reports 1950, 266

ICJ, Request for Interpretation of the Judgment of 20 November 1950 in the Asylum Case (Colombia v Peru), Judgment of 27 November 1950, ICJ Reports 1950, 395 ICJ, Haya de la Torre (Colombia v Peru), Judgment of 13 June 1951, ICJ Reports 1951,71

ICJ, North Sea Continental Shelf (Federal Republic of Germany v Netherlands), Judgment of 20 February 1969, ICJ Reports 1969, 3

ICJ, Fisheries Jurisdiction (Federal Republic of Germany v Iceland), Judgment of 2 February 1973, ICJ Reports 1973, 49

ICJ, Fisheries Jurisdiction (Federal Republic of Germany v Iceland), Judgment of 25 July 1974, ICJ Reports 1974, 175

ICJ, United States Diplomatic and Consular Staff in Tehran (United States of America v Iran), Judgment of 24 May 1980, ICJ Reports 1980, 3

ICJ, Military and Paramilitary Activities in and against Nicaragua (Nicaragua $v$ United States of America), Judgment of 27 June 1986, ICJ Reports 1986, 14

ICJ, Gabčíkovo-Nagymaros Project (Hungary $v$ Slovakia), Judgment of 25 September 1997, ICJ Reports 1997, 7

ICJ, LaGrand (Germany v United States of America), Judgment of 27 June 2001, ICJ Reports 2001, 466

ICJ, Arrest Warrant of 11 April 2000 (Democratic Republic of the Congo v Belgium), Judgment of 14 February 2002, ICJ Reports 2002, 3

ICJ, Avena and Other Mexican Nationals (Mexico v United States of America), Judgment of 31 March 2004, ICJ Reports 2004, 12 
ICJ, Legal Consequences of the Construction of a Wall in the Occupied Palestinian Territory, Advisory Opinion of 9 July 2004, ICJ Reports 2004, 136

ICJ, Certain Questions of Mutual Assistance in Criminal Matters (Djibouti v France), Judgment of 4 June 2008, ICJ Reports 2008, 177

ICJ, Request for Interpretation of the Judgment of 31 March 2004 in the Case Concerning Avena and Other Mexican Nationals (Mexico v United States of America), Judgment of 19 January 2009, ICJ Reports 2009, 3

ICJ, Application of the International Convention on the Elimination of All Forms of Racial Discrimination (Georgia v Russian Federation), Judgment of 1 April 2011, ICJ Reports 2011, 70

ICJ, Jurisdictional Immunities of the State (Germany v Italy: Greece intervening), Judgment of 3 February 2012, ICJ Reports 2012, 99

ICJ, Questions Relating to the Obligation to Prosecute or Extradite (Belgium v Senegal), Judgment of 20 July 2012, ICJ Reports 2012, 422

ICJ, Territorial and Maritime Dispute (Nicaragua $v$ Colombia), Judgment of 19 November 2012, ICJ Reports 2012, 624

ICJ, Immunities and Criminal Proceedings (Equatorial Guinea v France), Order of 7 December 2016, ICJ Reports 2016, 1148

ICJ, Immunities and Criminal Proceedings (Equatorial Guinea v France), Judgment of 6 June 2018, ICJ Reports 2018, 292

ICJ, Certain Iranian Assets (Iran v United States of America), Judgment of 13 February 2019, ICJ Reports 2019, 7

\section{European Court of Human Rights}

ECtHR, Hornsby v Greece, Judgment of 19 March 1997, Application No 18357/91

ECtHR, Beer and Regan v Germany, Grand Chamber Judgment of 18 February 1999, Application No 28934/95

ECtHR, Waite and Kennedy v Germany, Grand Chamber Judgment of 18 February 1999, Application No 26083/94

ECtHR, Naletilić v Croatia, Decision of 4 May 2000, Application No 51891/99

ECtHR, Prince Hans Adam II of Liechtenstein v Germany, Grand Chamber Judgment of 12 July 2001, Application No 42527/98

ECtHR, Al-Adsani $v$ The United Kingdom, Grand Chamber Judgment of 21 November 2001, Application No 35763/97

ECtHR, Fogarty $v$ The United Kingdom, Grand Chamber Judgment of 21 November 2001, Application No 37112/97

ECtHR, McElhinney v Ireland, Grand Chamber Judgment of 21 November 2001, Application No 31253/96

ECtHR, Bankovic and Others v Belgium and Others, Grand Chamber Decision of 12 December 2001, Application No 52207/99

ECtHR, Kalogeropoulou and Others $v$ Greece and Germany, Decision of 12 December 2002, Application No 59021/00

ECtHR, Görgülü v Germany, Judgment of 26 February 2004, Application No $74969 / 01$ 
ECtHR, Ilascu v Moldova and Russia, Grand Chamber Judgment of 8 July 2004, Application No 48787/99

ECtHR, Bosphorus v Ireland, Grand Chamber Judgment of 30 June 2005, Application No 45036/98

ECtHR, Behrami and Behrami v France, Grand Chamber Decision of 2 May 2007, Application No 71412/01

ECtHR, Saramati v France, Germany and Norway, Grand Chamber Decision of 2 May 2007, Application No 78166/01

ECtHR, Associazione Nazionale Reduci and 275 Others $v$ Germany, Decision of 4 September 2007, Application No 45563/04

ECtHR, Gasparini v Italy and Belgium, Decision of 12 May 2009, Application No 10750/03

ECtHR, Grosz v France, Decision of 16 June 2009, Application No 14717/06

ECtHR, Sfountouris and Others $v$ Germany, Decision of 31 May 2011, Application No 24120/06

ECtHR, Al-Skeini and Others $v$ The United Kingdom, Grand Chamber Judgment of 7 July 2011, Application No 55721/07

ECtHR, Al-Khawaja and Tahery $v$ The United Kingdom, Grand Chamber Judgment of 15 December 2011, Applications Nos 26766/05 and 22228/06

ECtHR, Nada v Switzerland, Grand Chamber Judgment of 12 September 2012, Application No 10593/08

ECtHR, Jones and Others $v$ The United Kingdom, Judgment of 14 January 2014, Applications Nos 34356/06 and 40528/06

ECtHR, OAO Neftyanaya Kompaniya YUKOS v Russia, Judgment of 31 July 2014, Application No 14902/04

ECtHR, Mocanu and Others v Romania, Grand Chamber Judgment of 17 September 2014, Applications Nos 10865/09, 45886/07 and 32431/08

ECtHR, Al-Dulimi and Montana Management Inc. $v$ Switzerland, Grand Chamber Judgment of 21 June 2016, Application No 5809/08

ECtHR, Nait-Liman v Switzerland, Grand Chamber Judgment of 15 March 2018, Application No 51357/07

\section{Court of Justice of the European Union}

CJEU, Lechouritou and Others, Judgment of 15 February 2007, Case C-292/05, EU: C:2007:102

CJEU, Kadi and Al Barakaat International Foundation v Council and Commission, Judgment of 3 September 2008, Joined Cases C-402/05 P and C-415/05 P, EU: C:2008:461

CJEU, Melloni, Judgment of 26 February 2013, Case C-399/11, EU:C:2013:107

CJEU, Commission and Others v Kadi, Judgment of 18 July 2013, Joined Cases C-584/10 P, C-593/10 P and C-595/10 P, EU:C:2013:518

CJEU, Taricco and Others, Judgment of 8 September 2015, Case C-105/14, EU: C:2015:555 
CJEU, Aranyosi and Căldăraru, Judgment of 5 April 2016, Joined Cases C-404/15 and C-659/15 PPU, EU:C:2016:198

CJEU, M.A.S. and M.B., Judgment of 5 December 2017, Case C-42/17, EU: $\mathrm{C}: 2017: 936$

\section{Permanent Court of Arbitration}

Permanent Court of Arbitration, Island of Palmas case (Netherlands $v$ United States), Award of 4 April 1928, Reports of International Arbitral Awards, Volume II, 829-871

\section{Permanent Court of International Justice}

PCIJ, The Mavrommatis Palestine Concessions (Greece $v$ UK), Judgment of 30 August 1924, PCIJ Series A-No 2

PCIJ, Certain German Interests in Polish Upper Silesia (Germany v Poland), Judgment of 25 August 1925, PCIJ Series A-No 6

PCIJ, Treatment of Polish Nationals and Other Persons of Polish Origin or Speech in the Danzig Territory, Advisory Opinion of 4 February 1932, PCIJ Series A/B-No 44

PCIJ, The 'Société Commerciale de Belgique' (Belgium v Greece), Judgment of 15 June 1939, PCIJ Series A/B-No 78

\section{Inter-American Court of Human Rights}

IACtHR, Barrios Altos v Peru, Judgment of 14 March 2001, Series C No 75 IACtHR, Baena Ricardo v Panama, Judgment of 28 November 2003, Series C No 104

IACtHR, Almonacid Arellano v Chile, Judgment of 26 September 2006, Series C No 154

IACtHR, González et al. v Mexico, Judgment of 16 November 2009, Series C No 205

\section{Domestic Cases}

\section{Australia}

New South Wales Court of Appeal, Zhang v Zemin, Judgment of 5 October 2010 [2010] NSWCA 255

\section{Belgium}

Civil Tribunal of Brussels, Socobel v Greek State, Judgment of 30 April 1951 Court of First Instance of Ghent, Botelberghe $v$ German State, Judgment of 18 February 2000 


\section{Canada}

Supreme Court of Canada, Reference Re Secession of Quebec, Judgment of 20 August 1998 [1998] 2 SCR 217

Supreme Court of Canada, Kazemi Estate v Islamic Republic of Iran, Judgment of 10 October 2014 [2014] 3 SCR 176

Court of Appeal for Ontario, Bouzari v Islamic Republic of Iran, Judgment of 30 June 2004 [2004] 71 OR (3d) 675

Ontario Superior Court of Justice, Tracy $v$ The Iranian Ministry of Information and Security, Judgment of 9 June 2016 [2016] ONSC 3759

\section{Colombia}

Constitutional Court of Colombia, Judgment of 2 May 2014, No C-269/14

\section{Germany}

Bundesverfassungsgericht, Decision of 14 February 1973, 1 BvR 112/65, BVerfGE 34, 269 (Soraya)

Bundesverfassungsgericht, Decision of 29 May 1974, 2 BvL 52/71, BVerfGE 37, 271 (Solange I)

Bundesverfassungsgericht, Decision of 22 October 1986, 2 BvR 197/83, BVerfGE 73, 339 (Solange II)

Bundesverfassungsgericht, Decision of 12 October 1993, 2 BvR 2134/92, 2 BvR 2159/92, BVerfGE 89, 155 (Maastricht)

Bundesverfassungsgericht, Decision of 13 May 1996, 2 BvL 33/93, BVerfGE 94, 315 (Zwangsarbeit)

Bundesverfassungsgericht, Decision of 28 June 2004, 2 BvR 1379/01, BVerfGK 3, 277

Bundesverfassungsgericht, Decision of 14 October 2004, 2 BvR 1481/04, BVerfGE 111, 307 (Görgülü)

Bundesverfassungsgericht, Decision of 7 December 2004, 1 BvR 1804/03, BVerfGE 112, 93

Bundesverfassungsgericht, Judgment of 15 February 2006, 2 BvR 1476/03, BVerfGK 7, 303 (Distomo)

Bundesverfassungsgericht, Decision of 19 September 2006, 2 BvR 2115/01, BVerfGK 9, 174

Bundesverfassungsgericht, Judgment of 30 June 2009, 2 BvE 2/08 (Treaty of Lisbon)

Bundesverfassungsgericht, Judgment of 4 May 2011, 2 BvR 2365/09, BVerfGE 128, 326 (Sicherungsverwahrung)

Bundesverfassungsgericht, Decision of 13 August 2013, 2 BvR 2660/06 (Bridge of Varvarin)

Bundesverfassungsgericht, Decision of 15 December 2015, 2 BvL 1/12, BVerfGE 141, 1 (Treaty Override) 
Bundesverfassungsgericht, Decision of 15 December 2015, 2 BvR 2735/14, BVerfGE 140, 317 (European Arrest Warrant II/Identity Control)

Bundesverfassungsgericht, Judgment of 5 May 2020, 2 BvR 859/15

Bundesgerichtshof, Judgment of 26 June 2003, III ZR 245/98, BGHZ 155, 279 (Distomo)

Bundesgerichtshof, Judgment of 6 October 2016, III ZR 140/15, BGHZ 212, 173 (Kunduz)

Verwaltungsgericht Berlin, Judgment of 9 September 2004, 9 A 336.02

\section{Greece}

Supreme Special Court of Greece (Anotato Eidiko Dikastirio), Margellos and Others v Federal Republic of Germany, Decision of 17 September 2002, No 6/2002

Supreme Court of Greece, Prefecture of Voiotia v Federal Republic of Germany, Judgment of 4 May 2000, No 11/2000 (Distomo)

\section{Italy}

Corte Costituzionale, Judgment of 27 December 1973, No 183/1973 (Frontini)

Corte Costituzionale, Judgment of 14 July 1984, No 184/1984

Corte Costituzionale, Judgment of 6 May 1985, No 132/1984

Corte Costituzionale, Judgment of 15 July 1992, No 329/1992 (Condor)

Corte Costituzionale, Judgment of 28 February 1996, No 60/1996 (Priebke)

Corte Costituzionale, Judgment of 22 March 2001, No 73/2001

Corte Costituzionale, Judgment of 30 June 2003, No 233/2003

Corte Costituzionale, Judgment of 5 March 2007, No 77/2007

Corte Costituzionale, Judgments of 22 October 2007, Nos 348 and 349/2007

Corte Costituzionale, Order of 13 February 2008, No 103/2008

Corte Costituzionale, Judgment of 7 October 2009, No 262/2009

Corte Costituzionale, Judgment of 7 July 2010, No 281/2010

Corte Costituzionale, Judgment of 3 June 2013, No 119/2013

Corte Costituzionale, Order of 3 July 2013, No 207/2013

Corte Costituzionale, Judgment of 11 June 2014, No 182/2014

Corte Costituzionale, Judgment of 22 October 2014, No 238/2014 (Sentenza)

Corte Costituzionale, Order of 11 February 2015, No 30/2015

Corte Costituzionale, Judgment of 26 March 2015, No 49/2015

Corte Costituzionale, Order of 26 January 2017, No 24/2017

Corte di Cassazione, Order of 5 June 2002, No 8157/2002 (Markovic)

Corte di Cassazione, Judgment of 11 March 2004, No 5044/2004 (Ferrini)

Corte di Cassazione, Judgment of 12 July 2006, No 15760/2006

Corte di Cassazione, Judgment of 8 October 2007, No 20987/2007

Corte di Cassazione, Judgment of 29 May 2008, No 14199/2008

Corte di Cassazione, Orders of 29 May 2008, Nos 14200-14212/2008

Corte di Cassazione, Judgment of 24 July 2008, No 31171/2008 (Lozano)

Corte di Cassazione, Judgment of 21 October 2008, No 1072/2008 (Milde)

Corte di Cassazione, Judgment of 9 May 2011, No 10107/2011 
Corte di Cassazione, Judgment of 20 May 2011, No 11163/2011

Corte di Cassazione, Judgment of 19 March 2014, No 329/2014

Corte di Cassazione, Judgment of 28 October 2015, No 21946/2015 (Flatow)

Corte di Cassazione, Judgment of 28 October 2015, No 21947/2015 (Eisenfeld)

Corte di Cassazione, Judgment of 29 October 2015, No 43696/2015 (Opačić)

Corte di Cassazione, Judgment of 29 July 2016, No 15812/2016

Corte di Cassazione, Judgment of 13 January 2017, No 762/2017 (Parrini)

Corte di Cassazione, Judgment of 8 June 2018, No 14885/2018

Corte di Cassazione, Judgment of 3 September 2019, No 21995/2019

Corte di Cassazione, Judgment of 28 September 2020, No 20442/2020

Corte d'Appello di Brescia, Judgment of 6 June 2016, No 515/2016 (Currà)

Corte d'Appello di Milano, Judgment of 27 January 2015, No 1278/2015

Corte d'Appello di Milano, Order of 25 March 2015, No 4183/2013

Tribunale di Ascoli Piceno, Order of 8 March 2016, No 112/2015

Tribunale di Ascoli Piceno, Order of 24 February 2017, No 523/2015

Tribunale di Fermo, Judgment of 20 October 2018, No 708/2018

Tribunale di Firenze, Orders of 21 January 2014, Nos 84/2014, 85/2014, and $113 / 2014$

Tribunale di Firenze, Order of 23 March 2015, No 2012/1300

Tribunale di Firenze, Judgment of 6 July 2015, No 2468/2015 (Bergamini)

Tribunale di Firenze, Judgment of 6 July 2015, No 2469/2015 (Simoncioni)

Tribunale di Firenze, Judgment of 22 February 2016, No 691/2016 (Donati)

Tribunale di Piacenza, Judgment of 28 September 2015, No 723/2015

Tribunale di Piacenza, Judgment of 28 September 2015, No 1462/2015

Tribunale di Roma, Judgment of 20 May 2015, No 11069/2015

Tribunale di Sulmona, Order of 2 November 2017, No 20/2015

Tribunale di Torino, Judgment of 20 October 2009, No 7137/2009

\section{Netherlands}

Supreme Court of The Netherlands, Mothers of Srebrenica et al. v State of The Netherlands and the United Nations, Judgment of 13 April 2012, No 10/04437

\section{New Zealand}

High Court of New Zealand, Fang and Others $v$ Jiang Zemin and Others, 21 December 2006, No 141 ILR 702

\section{Poland}

Supreme Court of Poland, Natoniewski v Federal Republic of Germany, Judgment of 29 October 2010, No IV CSK 465/09 


\section{Republic of Korea}

Constitutional Court of Korea, Decision of 30 August 2011, 23-2(A) KCCR 366, No 2006Hun-Ma788

Seoul Central District Court, Judgment of 8 January 2021, No 2016 Ga-Hap 505092

\section{Russian Federation}

Constitutional Court of the Russian Federation, Judgment of 14 July 2015, No 21-П/ 2015

Constitutional Court of the Russian Federation, Judgment of 19 January 2017, No $1-\Pi / 2017$

\section{United Kingdom of Great Britain and Northern Ireland}

UK Court of Appeal, Al-Adsani v The Government of Kuwait and Others (No 2), CA 29 March 1996, 107 ILR 536

UK House of Lords, Jones v Ministry of Interior Al-Mamlaka Al-Arabiya AS Saudiya (the Kingdom of Saudi Arabia), 14 June 2006, UKHL 26

\section{United States of America}

US Supreme Court, Berizzi Brothers Co. v S.S. Pesaro, Decision of 7 June 1926, 271 US 562 (1926)

US Supreme Court, Verlinden BV v Central Bank of Nigeria, Decision of 23 May 1983, 461 US 480 (1983)

US Supreme Court, Dole Food Co. v Patrickson, Decision of 22 April 2003, 538 US 468 (2003)

US Supreme Court, American Insurance Association v Garamendi, Decision of 23 June 2003, 539 US 396 (2003)

US Supreme Court, Republic of Austria v Altmann, Decision of 7 June 2004, 541 US 677 (2004)

US Supreme Court, Sanchez-Llamas v Oregon, Decision of 28 June 2006, 548 US 331 (2006)

US Supreme Court, Medellín v Texas, Decision of 25 March 2008, 552 US 491 (2008)

US Supreme Court, Bank Markazi v Peterson, Decision of 20 April 2016, No 136 S. Ct. 1310

US Supreme Court, Bolivarian Republic of Venezuela v Helmerich \& Payne International Drilling Co., Decision of 1 May 2017, No 137 S.Ct. 1312

US Supreme Court, Rubin v Islamic Republic of Iran, Decision of 21 February 2018, No 138 S.Ct. 816

US Court of Appeals, District of Columbia Circuit, Committee of United States Citizens Living in Nicaragua v Reagan, 859 F.2d 929, 14 October 1988 
US Court of Appeals, District of Columbia Circuit, Princz v Germany, 26 F.3d 1166, 1 July 1994

US Court of Appeals, District of Columbia Circuit, De Csepel v Hungary, 859 F.3d 1094, 20 June 2017

US Court of Appeals, District of Columbia Circuit, Philipp v Germany, 894 F.3d 406, 10 July 2018

US Court of Appeals, District of Columbia Circuit, Simon v Hungary, No 17-7146, 28 December 2018

US Court of Appeals, Second Circuit, Whiteman v Dorotheum GmbH \& Co. Kg, 431 F.3d 57, 23 November 2005

US Court of Appeals, Second Circuit, Matar and Others $v$ Dichter, Brief for the United States of America as Amicus Curiae in Support of Affirmance, Docket No 07-2579-cv, 19 December 2007

US Court of Appeals, Second Circuit, In re Terrorist Attacks on September 11, 2001, 538 F.3d 71, 14 August 2008

US Court of Appeals, Second Circuit, Doe v Bin Laden, 663 F.3d 64, 7 November 2017

US Court of Appeals, Seventh Circuit, Sampson v Germany, 250 F.3d 1145, 23 May 2001

US Court of Appeals, Eleventh Circuit, Ungaro-Benages v Dresdner Bank AG, 379 F.3d 1227, 3 August 2004

US District Court, District of Columbia, Eisenfeld v Iran, 172 F. Supp. 2d 1, 11 July 2000

US District Court, District of Columbia, Philipp v Germany, 248 F. Supp. 3d 59, 31 March 2017

US District Court, Eastern District of Virginia, Tabion v Mufti, Memorandum Opinion of Judge Ellis, No (E.D. Va. 1995) 877 F. Supp. 285, 293, 16 February 1995

US District Court, Northern District of Illinois, Scalin v Société Nationale des Chemins de Fer Français, No 15-cv-03362, 26 March 2018

US District Court, S.D. New York, Freund $v$ France, 592 F.Supp 2d 540, 19 December 2008

US District Court, S.D. New York, Peterson et al. v Islamic Republic of Iran et al., No 10 Civ. 4518 (BSJ), 15 March 2012

US District Court, S.D. New York, The Underwriting Members of Lloyd's Syndicate 53 et al. v Kingdom of Saudi Arabia et al., No 17-02129, 23 March 2017 


\section{Abbreviations}

ACHR

ANPI

ANRP

Art

ASR

AWF

A $\$$

BGH

BVerfGE

CIHL

CIVS

CJEU

$\mathrm{CoE}$

DART

DM

EC

ECHR

ECJ

ECtHR

EU

EU Charter

EU NAVFOR

EUTM
American Convention on Human Rights

Associazione Nazionale Partigiani Italiani (National Association of Italian Partisans)

Associazione Nazionale Reduci dalla Prigionia, dall'Internamento, dalla Guerra di Liberazione (National Association of Survivors of Imprisonment, Internment, and the War of Liberation)

Article

Draft Articles on Responsibility of States for Internationally Wrongful Acts

Asian Women's Fund (Japan)

Australian Dollar

Bundesgerichtshof (Federal Court of Justice)

Entscheidungen des Bundesverfassungsgerichts (Decisions of the German Federal Constitutional Court)

Customary International Humanitarian Law

Commission pour l'indemnisation des victimes de spoliations (Commission for the Compensation of Victims of Spoliation) (France)

Court of Justice of the European Union

Council of Europe

Defence Abuse Response Taskforce (Australia)

Deutsche Mark (German Mark)

European Communities

European Convention on Human Rights

European Court of Justice

European Court of Human Rights

European Union

Charter of Fundamental Rights of the European Union

European Union Naval Force

European Union Training Mission 
FCC

FSIA

IACtHR

ICJ

IHL

IHRL

ILA

ILC

ILM

IMIs

ItCC

JASTA

JVTA

NATO

NGO

PCIJ

POW

RRF Foundation

SIA

UK

UN

UNCC

UNCSI

UNTC

UNWCC

US

US\$

WTO

WWII
German Federal Constitutional Court

Foreign Sovereign Immunities Act (US)

Inter-American Court of Human Rights

International Court of Justice

International Humanitarian Law

International Human Rights Law

International Law Association

International Law Commission

International Legal Materials

Italian Military Internees

Italian Constitutional Court

Justice Against Sponsors of Terrorism Act (US)

Justice for Victims of Terrorism Act (Canada)

North Atlantic Treaty Organization

Non-Governmental Organization

Permanent Court of International Justice

Prisoner/s of War

Foundation 'Remembrance, Responsibility and Future' (Erinnerung, Verantwortung und Zukunft)

State Immunity Act (Canada)

United Kingdom

United Nations

United Nations Compensation Commission

United Nations Convention on Jurisdictional Immunities of States and Their Property

United Nations Treaty Collection

United Nations War Crimes Commission

United States

US Dollar

World Trade Organization

World War II 
Part I

Introduction 


\title{
Reconciling State Immunity with Remedies for War Victims in a Legal Pluriverse
}

\author{
Anne Peters and Valentina Volpe
}

\begin{abstract}
The chapter explains the threefold aspiration of the book as an academic, societal, and diplomatic project. It introduces the three interwoven themes of international law arising in the German-Italian saga: state immunity, reparation for serious human rights violations committed during World War II, and the interplay between international and domestic law, notably the role of courts therein. The chapter proposes an approach of 'ordered pluralism' to coordinate this interplay, and finally tables a 'modest proposal' for a way out of the current impasse.
\end{abstract}

\section{Introduction}

We are writing this introduction while the COVID-19 pandemic has accelerated, especially in Italy, the dwindling of a generation leading to the obliteration of its memory. This book was conceived to recount that individual and collective remembrance in its intertwinements with law and history. Such entanglements are particularly painful when courts and judges are called to adjudicate on historical narratives.

\footnotetext{
The authors wish to express their gratitude to Giovanni Boggero, Giuseppina De Marco and Violetta Ritz for their valuable comments on an earlier version of this chapter and to Trevor Krayer for his helpful research assistance. The article is the result of a common reflection; nevertheless, the introduction and section II are mostly attributable to Valentina Volpe and sections III-V to Anne Peters. The concluding 'Modest Proposal' (section VI) was written four hands.
}

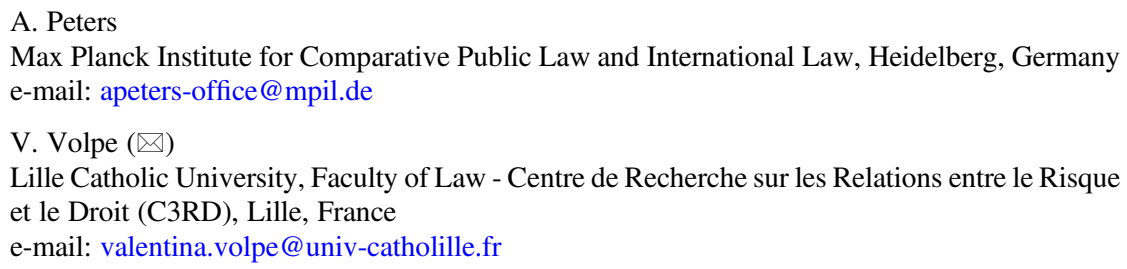


This is what happened in the litigation on reparation for German war crimes which culminated in Sentenza 238/2014. ${ }^{1}$ With this judgment, the Italian Constitutional Court (ItCC) denied the German Republic's immunity from civil jurisdiction over claims to reparation for Nazi crimes committed during World War II (WWII), indirectly challenging the International Court of Justice (ICJ)'s Jurisdictional Immunities Judgment of $2012^{2}$ and paving the way for a series of domestic proceedings against Germany.

Against this background, our work has a threefold aspiration: it provides a scholarly contribution on the issue of war crimes and reparation for the victims of armed conflict; it seeks to form part of a broader civic debate, shedding light on these topics for a larger public engagement; and it proposes concrete legal and political solutions to the parties involved to overcome the present paralysis with a view to a durable interstate conflict resolution. We submit that a latent crisis fuelled by Sentenza 238/2014 is festering in the relationship between the German and Italian Republics. Future exchanges at both institutional and civil society levels might also help judges directly involved in the post-Sentenza reparation cases which are currently pending. Keeping this objective in mind, we see the book as an exercise of academic diplomacy, in a forward-looking and conciliatory spirit.

Our authors hail from diverse academic backgrounds and represent a wide variety of perspectives across domestic and international public law. We deliberately invited only Italian and German nationals and addressed them specific sets of questions. One of our objectives was to tease out (and ideally overcome) postures of possible epistemic nationalism. ${ }^{3}$

The book's primary scholarly aim covers three legal themes: state immunity, ${ }^{4}$ reparation for serious human rights violations and war crimes, ${ }^{5}$ including historical ones, ${ }^{6}$ and the interaction between international and domestic law and institutions, notably courts. ${ }^{7}$

\footnotetext{
${ }^{1}$ Corte Costituzionale, Judgment of 22 October 2014, No 238/2014.

${ }^{2}$ ICJ, Jurisdictional Immunities of the State (Germany v Italy: Greece intervening), Judgment of 3 February 2012, ICJ Reports 2012, 99.

${ }^{3}$ The exercise brought to light that the legal assessment (positive or negative) of Sentenza 238/2014 did not coincide with nationality (see Joseph H H Weiler, 'A Dialogical Epilogue', in this volume). ${ }^{4}$ See for recent scholarship Hazel Fox/Philippa Webb, The Law of State Immunity (Oxford: OUP $3{ }^{\text {rd }}$ ed 2013); Anne Peters/Evelyne Lagrange/Stefan Oeter/Christian Tomuschat (eds), Immunities in the Age of Global Constitutionalism (Leiden: Brill 2015); Tom Ruys/Nicolas Angelet/Luca Ferro (eds), The Cambridge Handbook of Immunities and International Law (Cambridge: CUP 2019). See for an excellent compilation and analysis of the relevant case-law Rosanne van Alebeek/ Riccardo Pavoni, 'Immunities of States and their Officials', in André Nollkaemper/August Reinisch et al (eds), International Law in Domestic Courts: A Casebook (Oxford: OUP 2018), 100-169.

${ }^{5}$ See in recent scholarship Cristián Correa/Shuichi Furuya/Clara Sandoval, Reparation for Victims of Armed Conflict, Max Planck Trialogues on the Law of Peace and War, Vol 3, edited by Anne Peters/Christian Marxsen (Cambridge: CUP 2020).

${ }^{6}$ See in scholarship on reparation for historical crimes: Gerry Johnstone/Joel Quirk, 'Repairing Historical Wrongs', Social \& Legal Studies 21 (2012), 155-169; Daniel Butt, Rectifying International Injustice: Principles of Compensation and Restitution Between Nations (Oxford: OUP 2008).

${ }^{7}$ See in scholarship André Nollkaemper, National Courts and the International Rule of Law (Oxford: OUP 2012); Davíd Thór Björgvinsson, The Intersection of International Law and
} 
These three themes are interlinked: the international rules and principles of state immunity operate in proceedings before national courts, and are being developed through the practice of those courts which in turn contributes to the formation of customary law, in addition to international treaty law. ${ }^{8}$ With regard to the reparation of serious violations of international human rights, an interaction between the international and the domestic level of rules and institutions is visible as well: reparation is sometimes acknowledged and granted as a matter of international legal obligation, but needs in any case to be implemented through domestic procedures. These themes form the intertwined threads running through the volume.

After the introduction, Part II, Immunity, investigates core international law concepts, such as those of pre/post-judgment immunity and international state responsibility, as embedded in contemporary legal discourse (Paolo Palchetti, Christian Tomuschat and Heike Krieger). Part III, Remedies, examines the tension between state immunity and the right to remedy, suggesting original schemes for overcoming the legal impasse and solving the conundrum under international law (Riccardo Pavoni, Jörg Luther, Stefan Kadelbach and Filippo Fontanelli). Part IV adds European Perspectives to the main themes of the book by showcasing relevant regional examples of legal cooperation and judicial dialogue against a common European horizon (Alessandro Bufalini, Bernardo Giorgio Mattarella, Doris König and Andreas Zimmermann). Part V, Courts, addresses a series of questions on the role of judges in the areas of immunity and human rights at both the national and international level (Christian J. Tams, Raffaela Kunz, Giovanni Boggero and Karin Oellers-Frahm). Part VI, Negotiations, suggests, inter alia, concrete ways out of the impasse with a forward-looking aspiration (Andreas von Arnauld, Valerio Onida, Andreas L. Paulus and Francesco Francioni).

In Part VII, The Past and Future of Remedies, emeritus justice Sabino Cassese, sitting judge in the Court that decided Sentenza 238/2014, adds some personal recollections and critical reflections on the Judgment. Joseph H. H. Weiler's Dialogical Epilogue concludes the volume by entering into conversation with some of the authors and placing the main findings of the book in a wider European and international law perspective.

In order to set the scene for the following chapters, we first summarise the proceedings leading to Sentenza 238/2014 (section II) and then contextualise the

Domestic Law: A Theoretical and Practical Analysis (Cheltenham: Edward Elgar 2015); Helmut Philipp Aust/Georg Nolte (eds), The Interpretation of International Law by Domestic Courts: Uniformity, Diversity, Convergence (Oxford: OUP 2016); Machiko Kanetake/André Nollkaemper, The Rule of Law at the National and International Levels: Contestation and Deference (Oxford: Hart 2016).

${ }^{8}$ See van Alebeek/Pavoni, 'Immunities of States' 2018 (n 4), 169: '[T]he pivotal role of domestic courts in the development of international immunity rules translates into an interplay of domestic law and international law in domestic immunity decisions, and partly explains the many controversies on the precise parameters of the various rules in this area of the law.' Immunities are therefore 'a messy affair', Anne Peters, 'Immune against Constitutionalisation?' in Peters et al, Global Constitutionalism 2015 (n 4), 1-19, at 1. 
judgment by offering a snapshot of the law on the main themes of the volume (sections III-V), a law which is, as the European Court of Human Rights (ECtHR) put in Jones, in a 'state of flux'. ${ }^{9}$ We close with concrete legal policy suggestions for moving toward a resolution of the Italian-German controversy (section VI).

\section{Sentenza 238/2014: The Culmination of a Judicial Saga}

\section{The Historical Background}

The events leading to Sentenza 238/2014 can be traced back to the unsolved quarrels between Italy and Germany regarding WWII crimes. Sentenza is, therefore, one pronouncement in a long judicial conversation or judicial tug-of-war that has developed at the local, national, and international level. ${ }^{10}$ The facts that gave rise to the various judicial proceedings are the uncontested atrocities committed by German forces in the occupied Italian territory between September 1943 and the end of the war in May 1945. ${ }^{11}$ They notoriously included massacres of civilians and the deportation of a large number of the population for forced labour. The core issue litigated on the multilevel judicial battlefield is reparation for these civilian victims and for the 'Italian Military Internees' (IMIs), ie the several hundred thousand members of the Italian army who German forces took prisoner both in Italy and elsewhere in Europe. IMIs were denied the status of prisoner of war (POW) and were deported to Germany and German-occupied territories for use as forced labour.

\footnotetext{
${ }^{9}$ ECtHR, Jones and Others $v$ The United Kingdom, Judgment of 14 January 2014, Applications Nos 34356/06 and 40528/06, para 213 (concerning civil claims for torture lodged against foreign state officials).

${ }^{10}$ For an assessment of Sentenza 238/2014 primarily from the perspective of Italian domestic law which is not the focus of this book, see: Francesco Salerno, 'Giustizia costituzionale versus giustizia internazionale nell'applicazione del diritto internazionale generalmente riconosciuto', Quaderni Costituzionali 35 (2015), 33-58; Francesco Buffa, 'Introduzione: I diritti fondamentali tra obblighi internazionali e Costituzione', Questione Giustizia 1 (2015), 45-50; Paolo Veronesi, Colpe di stato: I crimini di guerra e contro l'umanità davanti alla Corte costituzionale (Milan: Franco Angeli 2017).

${ }^{11}$ See the German exhibition on Italian IMIs in the 'Dokumentationszentrum NS-Zwangsarbeit' in Berlin: https://www.ns-zwangsarbeit.de/italienische-militaerinternierte/themen/deutschland-unditalien-als-buendnispartner-1936-1943/. See for a more in-depth analysis, the research of a group of Italian historians: Paolo Pezzino, 'The German Military Occupation of Italy and the War against Civilians', Modern Italy 12 (2007), 173-188.
} 


\section{The Italian Corte di Cassazione and the Ferrini and Milde Judgments}

The question of war crimes reparation gained relevance and a renewed judicial and political attention in the early 2000s. ${ }^{12}$ One of the main actors of this judicial turn has been the Italian Supreme Court (Corte di Cassazione), which gained international attention with the inauguration, in those years, of a ground-breaking jurisprudence concerning state immunity and gross human rights violations.

The Corte di Cassazione adopted the well-known Ferrini judgment in 2004. ${ }^{13}$ The procedural history began in September 1998, when Luigi Ferrini instituted proceedings against the Federal Republic of Germany before the Tribunal of Arezzo. Ferrini was an Italian national who had been arrested and deported to Germany in 1944 where he had been detained and forced to work in a factory until the end of the war. He was seeking damages for the physical and psychological injuries suffered.

Unsurprisingly, in November 2000, the Tribunal of Arezzo decided that Luigi Ferrini's claim was inadmissible because Germany, as a sovereign state, was protected by jurisdictional immunity. On the same grounds, the Court of Appeal of Florence dismissed the appeal of the claimant. However, on 11 March 2004, the Italian Corte di Cassazione quite unpredictably contradicted this well-established line of jurisprudence grounded in international customary law, holding that Italian courts had jurisdiction over the claims for compensation brought against Germany by Luigi Ferrini. The Court argued that state immunity does not apply in circumstances in which the act complained of constitutes an international crime. Assuming the role of an interpreter of international law, the Italian Corte di Cassazione affirmed: 'Respect for the inviolable rights of the human person has indeed assumed the value of a fundamental principle of the international legal order (...). The emergence of this principle cannot fail to reflect on the scope of other principles to which this order is traditionally inspired and, in particular, on the "sovereign equality" of States, to which state immunity from foreign civil jurisdiction is linked'. '[T]here can be no doubt that the antinomy should be resolved by giving prevalence to the highest-ranking norms'. ${ }^{14}$

A few years later, while numerous reparation proceedings were instituted before ordinary Italian courts, the Corte di Cassazione confirmed the Ferrini jurisprudence

\footnotetext{
${ }^{12}$ In 1996 two important prodromal events fuelled a renewed political and legal interest towards Nazi crimes in Italy, the Priebke case (Corte di Cassazione, Judgment of 15 October 1996 and Corte Costituzionale, Judgment of 28 February 1996, No 60/1996. Cf as well, Corte di Cassazione, Judgments of 10 February 1997 and 16 November 1998, No 1230/1998 (Priebke and Hass)) and the discovery of the Armadio della Vergogna (the closet of shame) containing the long hidden names and files of numerous war criminals. The establishment of the German Foundation 'Remembrance, Responsibility and Future' (Erinnerung, Verantwortung und Zukunft) in 2000, which excluded the IMIs from the available financial compensation, is another important event in this judicial saga.

${ }^{13}$ Corte di Cassazione, Judgment of 11 March 2004, No 5044/2004 (Ferrini).

${ }^{14} \mathrm{Ibid}$, paras 9.2 and 9.1 (translated by the authors).
} 
in a number of cases all adjudicated in 2008. The most remarkable of them was surely the Milde case. ${ }^{15}$ Max Josef Milde had been a member of the 'Hermann Göring' division of the German armed forces who was charged with participation in massacres committed on 29 June 1944 in Civitella in Val di Chiana, Cornia and San Pancrazio in Italy. The Military Court of La Spezia had sentenced Milde in absentia to life imprisonment and ordered Milde and Germany, jointly and separately, to pay reparation to the successors in title of the victims of the massacre who appeared as civil parties in the proceedings. Germany appealed to the Military Court of Appeals in Rome against that part of the decision which was directed against the German Republic and the Court dismissed the appeal in 2007. The following year, the Corte di Cassazione rejected Germany's argument of lack of jurisdiction and confirmed the reasoning it had adopted in Ferrini: in cases of serious international law crimes, the jurisdictional immunity of states should be set aside. According to the Court, "the principle of respect for the "sovereign equality" of States must remain without effects in the event of crimes against humanity (...) whose real substance consists in an abuse of state sovereignty'. ${ }^{16}$

In the same year, the Corte di Cassazione granted an application of exequatur to the Greek courts' judgments Prefecture of Voiotia v Federal Republic of Germany concerning Nazi massacres of the Greek civilian population during WWII. ${ }^{17}$

\section{The ICJ and the Jurisdictional Immunity Judgment}

The German reaction was not long in coming. In December 2008, just a few months after the Milde judgment of the Corte di Cassazione, the Federal Republic of Germany instituted proceedings before the ICJ against the Italian Republic.

\footnotetext{
${ }^{15} \mathrm{Cf}$ Corte di Cassazione, Orders of 28 May 2008, Nos 14201/2008, 14202/2008, 14203/2008, 14204/2008, 14205/2008, 14206/2008, 14207/2008, 14208/2008, 14209/2008, 14210/2008, 14211/2008, 14212/2008. Corte di Cassazione, Judgment of 21 October 2008, No 1072/2008 (Milde). Annalisa Ciampi, 'The Italian Court of Cassation Asserts Civil Jurisdiction Over Germany in a Criminal Case Relating to the Second World War: The Civitella Case', Journal of International Criminal Justice 7 (2009), 597-615. For a critical appraisal of the case, Giovanni Boggero, 'Giustizia per i crimini internazionali di guerra nella strage di Civitella?', in Procura Generale Militare della Repubblica presso la Corte Suprema di Cassazione (ed), Casi e 'materiali' di diritto penale militare (Rome: Stabilimento Grafico Militare 2012), 277-303.

${ }^{16}$ Corte di Cassazione, Milde (n 15), para 5. As a consequence, 'the customary principle of the jurisdictional immunity of States does not have an absolute and indiscriminate character and is destined to remain inoperative in cases (...) [concerning] the reintegration of damages caused by international crimes.' Ibid, para 4 (translated by the authors).

${ }^{17}$ Corte di Cassazione, Judgments of 29 May 2008, No 14199/2008 and 20 May 2011, No 11163/ 2011. Cf, Tribunal of Leivadia, Prefecture of Voiotia v Federal Republic of Germany, 30 October 1997 and Supreme Court of Greece, Prefecture of Voiotia v Federal Republic of Germany, Judgment of 4 May 2000, No 11/2000.
} 
According to Germany, Italy through its judicial practice 'failed to respect the jurisdictional immunity which ... [the German state] enjoys under international law'. ${ }^{18}$

In the Jurisdictional Immunities Judgment, issued in 2012, the ICJ endorsed the German position. In particular, the Court openly contradicted the Ferrini jurisprudence and the legal argument that a normative hierarchy between peremptory human rights and immunity must lead to setting aside state immunity in domestic litigation dealing with ius cogens violations. The Court stated that 'under customary international law as it presently stands, a State is not deprived of immunity by reason of the fact that it is accused of serious violations of international human rights law'. ${ }^{19}$ The ICJ grounded this decision on the quite formalistic assumption that the rules of ius cogens and those of state immunity do not conflict because they operate at different levels. The rules of state immunity 'are procedural in character and are confined to determining whether or not the courts of one State may exercise jurisdiction in respect of another State', ${ }^{20}$ and these procedural immunity rules do not address the question of whether or not the conduct around which the proceedings turn in substance was lawful or unlawful. ${ }^{21}$

The ICJ also rejected an additional set of arguments brought by Italy. ${ }^{22}$ The Italian 'last resort' claim deemed 'Italian courts (...) justified in denying Germany the immunity to which it would otherwise have been entitled, because all other attempts to secure compensation for the various groups of victims involved in the Italian proceedings had failed'. ${ }^{23}$ The ICJ considered, with particular reference to the IMIs status, that it was 'a matter of surprise - and regret - that Germany decided to deny compensation to a group of victims on the ground that they had been entitled to a status [that of POW] which, at the relevant time, Germany had refused to recognize'. ${ }^{24}$ However, the Court could find 'no basis' in the state practice conditioning the entitlement of state immunity 'upon the existence of effective alternative means of securing redress'. 25

In conclusion, the ICJ held that Italy violated the jurisdictional immunity which Germany enjoys under international law by allowing civil claims based on violations of international humanitarian law by the German Reich between 1943 and 1945, ${ }^{26}$ and that Italy also committed violations of the immunity owed to Germany by taking enforcement measures against German properties, in particular Villa Vigoni, a German cultural centre on Lake Como. ${ }^{27}$

\footnotetext{
${ }^{18}$ ICJ, Jurisdictional Immunities (n 2), para 1, quoting the German application.

${ }^{19}$ Ibid, para 91 . See for the ius cogens argument paras $80,84,89$.

${ }^{20}$ Ibid, para 93.

${ }^{21}$ Ibid, para 100.

${ }^{22}$ Ibid, paras 98-104.

${ }^{23}$ Ibid, para 98 .

${ }^{24}$ Ibid, para 99 .

${ }^{25}$ Ibid, para 101.

${ }^{26}$ Ibid, para 139.

${ }^{27}$ Ibid, para 120 .
} 
The ICJ judgment received mixed assessments in the academic world, and critical voices seemed to prevail. ${ }^{28}$ Commentators found the judgment 'unsatisfying, ${ }^{29}$ with 'thin reasoning, ${ }^{30}$ and failing to give 'an encouraging legal message', while being 'not particularly persuasive', and 'collaborating in the deconstruction of jus cogens' ${ }^{31}$ They deplored the 'excessively formalistic reasoning' and 'disputable logic' of the judgment which was ultimately deemed a 'missed opportunity'. ${ }^{32}$ The fiercest critic sensed an 'air of strong conservatism' in the judgment, identified 'entirely misplaced' statements, and in the end, found the judgment's reasoning 'unacceptable'. ${ }^{33}$ In the opposing camp, defenders appraised the ICJ judgment as 'no surprise, but wise ' $^{34}$ and as making 'eminent sense'. ${ }^{35}$

Most of the Italian courts immediately acknowledged and complied with the ICJ judgment. They declared all further civil actions brought against Germany with claims for reparation for human rights violations during WWII inadmissible. ${ }^{36}$

In order to avoid further civil actions before Italian courts and obey the ICJ Judgment, the Italian Parliament adopted Law No 5/2013 by which Italy ratified the United Nations Convention on Jurisdictional Immunities of States and Their Property (UNCSI) ${ }^{37}$ The Statute prescribes how Italian courts must react to a judgment

\footnotetext{
${ }^{28}$ See for a recent critical assessment: Selman Özdan, 'State Immunity or State Impunity in Cases of Violations of Human Rights Recognised as Jus Cogens Norms', The International Journal of Human Rights 23 (2019), 1521-1545.

${ }^{29}$ François Boudreault, 'Identifying Conflicts of Norms: The ICJ Approach in the Case of the Jurisdictional Immunities of the State (Germany v Italy: Greece Intervening)', Leiden Journal of International Law 25 (2012), 1003-1012, at 1008. The author also sees merits in the judgment.

${ }^{30}$ Lorna McGregor, 'State Immunity and Human Rights: Is There a Future after Germany v. Italy?', Journal of International Criminal Justice 11 (2013), 125-145, at 128.

${ }^{31}$ Carlos Espósito, 'Jus Cogens and Jurisdictional Immunities of States at the International Court of Justice: "A Conflict Does Exist", Italian Yearbook of International Law 21 (2011), 161-174, at 174, 163, and 173.

${ }^{32}$ Stefania Negri, 'Sovereign Immunity v. Redress for War Crimes: The Judgment of the International Court of Justice in the Case Concerning Jurisdictional Immunities of the State (Germany v. Italy)', International Community Law Review 16 (2014), 123-137, at 137; Benedetto Conforti, 'The Judgment of the International Court of Justice on the Immunity of Foreign States: A Missed Opportunity', Italian Yearbook of International Law 21 (2011), 134-142.

${ }^{33}$ Benedetto Conforti, ‘A Missed Opportunity' 2011 (n 32), 142.

${ }^{34}$ Markus Krajewski/Christopher Singer, 'Should Judges be Front-Runners? The ICJ, State Immunity and the Protection of Fundamental Human Rights', Max Planck Yearbook of United Nations Law 16 (2012), 1-34, at 27.

${ }^{35}$ Stefan Talmon, 'Jus Cogens after Germany v. Italy: Substantive and Procedural Rules Distinguished', Leiden Journal of International Law 25 (2012), 979-1002, at 1002.

${ }^{36}$ Graziella Romeo, 'Looking Back in Anger and Forward in Trust: The Complicate Patchwork of the Damages Regime for Infringements of Rights in Italy', in Ewa Bagińska (ed), Damages for Violations of Human Rights: A Comparative Study of Domestic Legal Systems (Heidelberg: Springer 2016), 217-240, at 232, citing as an example Corte d'Appello di Torino, Judgment of 14 May 2012, No 941/2012 (Germany v De Guglielmi).

${ }^{37}$ Italian Law 14 January 2013, No 5. Article 3(2) of the Law added new grounds for a reopening of proceedings beyond the grounds already provided for in the Italian Code of Civil Procedure.
} 
of the ICJ declaring the immunity of a foreign state: in proceedings pending a final judgment, the courts are to pronounce ex officio their lack of jurisdiction. ${ }^{38}$ Final judgments can be appealed to be overturned ('impugnate per revocazione'). ${ }^{39}$

In the meantime, further civil proceedings were nonetheless instituted. The Tribunal of Florence heard three such proceedings. Instead of declaring the complaints inadmissible, the Tribunal stayed the proceedings and addressed a question of constitutionality to the ItCC, concerning the compatibility of Law No 5/2013 with Article 2 and Article 24 of the Italian Constitution. ${ }^{40}$ This proceeding gave rise to Sentenza 238/2014.

\section{The Italian Constitutional Court and Sentenza 238/2014}

The ItCC's Sentenza of 22 October $2014^{41}$ reopened the legal and political debate on the issue of compensation to Italian victims (and their heirs) of Nazi crimes during WWII. ${ }^{42}$

Using a different approach from the one adopted by the Corte di Cassazione in Ferrini, the Judgment of the ItCC paid lip service to the international law principle of state immunity and to the 'external' binding force of ICJ judgments (by virtue of Article 94 of the UN Charter). In Sentenza 238/2014, the ItCC neatly distinguished the 'international' from 'domestic' effects of an international norm and the ICJ judgment. The Corte Costituzionale stated that these international norms and acts

\footnotetext{
UN Convention on Jurisdictional Immunities of States and Their Property (2 December 2004), UN Doc A/RES/59/38, UN Doc A/59/49, 486 (not yet in force); The Convention has 22 ratifications as of October 2020, while 30 are needed for its entry into force.

${ }^{38}$ Italian Law, 5/2013 (n 37), Art 3(1).

${ }^{39}$ Ibid, Art 3(2).

${ }^{40}$ Article 2: 'The Republic recognizes and guarantees the inviolable rights of the person, both as an individual and in the social groups where human personality is expressed. The Republic expects that the fundamental duties of political, economic and social solidarity be fulfilled.' Article 24(1): 'Anyone may bring cases before a court of law in order to protect their rights under civil and administrative law'.

${ }^{41}$ The English translation of Sentenza 238/2014, as published on the website of the Italian Constitutional Court, is reproduced at the end of this volume, with kind permission of the Corte Costituzionale.

${ }^{42}$ The following section builds on Anne Peters, 'Let Not Triepel Triumph-How To Make The Best Out of Sentenza No. 238 of the Italian Constitutional Court for a Global Legal Order', EJIL Talk!, (22 December 2014), available at www.ejiltalk.org/let-not-triepel-triumph-how-to-make-the-bestout-of-sentenza-no-238-of-the-italianconstitutional-court-for-a-global-legal-order-part-i/. See also Anne Peters/Valentina Volpe, 'In Search for Conciliation-Conference Remedies against Immunity?', VerfBlog, (11 May 2017), available at http://verfassungsblog.de/introduction-in-search-forconciliation.
} 
could not deploy any internal effect within the Italian legal order, on the basis of a dualistic ('Triepelian') ${ }^{43}$ understanding of the relationship between domestic law and international law: '[T]he incorporation, and thus the application, of the international norm would inevitably be precluded, insofar as it conflicts with inviolable principles and rights' of the Italian constitutional order. ${ }^{44}$

Access to justice, as guaranteed by Article 24 of the Italian Constitution, is both a right and a principle in this sense. The guarantee encompasses the right to appear and to be defended before a court of law in order to protect one's rights and at the same time, in the Court's jurisprudence, it is considered among the 'supreme principles' of the Italian constitutional order.

The Italian Constitutional Court did not verbally contest the 'particularly qualified' ICJ interpretation of the international customary law regarding immunity. ${ }^{45}$ However, the Corte Costituzionale strongly affirmed its exclusive role as a guarantor of constitutional principles: 'It falls exclusively to this Court to ensure the respect of the Constitution and particularly of its fundamental principles'. ${ }^{46}$ The Corte reserved for itself the competence to review the compatibility of the international norm of state immunity from the civil jurisdiction against the benchmark of those (constitutional) principles. It ascertained whether the customary norm of immunity, as interpreted by the ICJ, can be 'incorporated into the constitutional order'. ${ }^{47}$ By framing the issue purely as a matter of 'incorporation', the ItCC 'shields Judgment 238/2014 from the obvious criticism: that the ItCC thought it knew international law better than the ICJ (...). Rather, [the ItCC] claims to know Italian constitutional law better', as Christian J. Tams puts it in his chapter. This is a particularly problematic feature of Sentenza 238/2014. The outcome is that, without openly admitting it, the ItCC reserved for itself the competence to ascertain whether international law 'is constitutional' or not. ${ }^{48}$

Despite its staunch dualism, the Corte brought international law into play, by insinuating that the Judgment 'may also contribute to a desirable—and desired by many—evolution of international law itself', ${ }^{49}$

\footnotetext{
${ }^{43} \mathrm{Cf}$ Heinrich Triepel, Völkerrecht und Landesrecht (Leipzig: Verlag von C. L. Hirschfeld 1899). ${ }^{44}$ ItCC, Judgment 238/2014 (n 1), 'The Law' para 3.4.

${ }^{45}$ ' $[\mathrm{T}]$ he interpretation by the ICJ of the customary law of immunity of States from the civil jurisdiction of other States for acts considered jure imperii is particularly qualified and does not allow further examination by national governments and/or judicial authorities, including this Court'. Ibid, 'The Law' para 3.1.

${ }^{46}$ Ibid, 'The Law' para 3.3.

${ }^{47}$ Ibid, 'The Law' para 3.4.

${ }^{48}$ Stefano Battini, 'È costituzionale il diritto internazionale?', Giornale di diritto amministrativo 3 (2015), 367-377.

${ }^{49}$ ItCC, Judgment 238/2014 (n 1), 'The Law' para 3.3.
} 
Sentenza 238/2014 has triggered extensive and heated scholarly commentary. Supporters $^{50}$ celebrated the judgment as the 'best possible solution' ${ }^{51}$ which 'deserves full appreciation' because it 'reflects the most cherished values of our civilization, ${ }^{52}$ and it was seen as 'a lesson in juridical civilization' and a 'badge of honour (...) to human rights, ${ }^{53}$ Critics $^{54}$ reproached the judgment for 'seriously imperil[ing] the authority of international law', ${ }^{55}$ as well as for being 'contradictory' and a 'breach of the law, ${ }^{56}$ and they qualified it as a 'sort of murder of international law through municipal law', even as a 'judicial putsch' ${ }^{57}$ Both sides probably agree that it was the 'judgment of the year ${ }^{58}$ and a 'historic decision'. ${ }^{59}$

Sentenza 238/2014 itself does not yet constitute an internationally wrongful act, because it does not in itself disregard state immunity. What counts are the lower courts' reconsiderations of the claims and their decisions on holding them admissible by setting aside state immunity. Arguably, the simple reopening of those proceedings, not only decisions on their merits or the execution of a judgment, could already be seen to constitute an internationally wrongful act. The content of Italian state responsibility would then be primarily restitution in kind which in our case would mean to somehow strike down the civil lawsuits against Germany.

Moreover, any execution of a substantive judgment would, in addition, violate post-judgment immunity against execution (Paolo Palchetti). The relevant parts of the pertinent provision of Article 19 of the UN Convention on State Immunity of

\footnotetext{
${ }^{50}$ See, besides the voices quoted: Gianluigi Palombella, 'German War Crimes and the Rule of International Law', Journal of International Criminal Justice 14 (2016), 607-613.

${ }^{51}$ Micaela Frulli, “"Time Will Tell Who Just Fell and Who's Been Left Behind”: On the Clash between the International Court of Justice and the Italian Constitutional Court', Journal of International Criminal Justice 14 (2016), 587-594, at 590.

${ }^{52}$ Cesare Pinelli, 'Decision no. 238/2014 of the Constitutional Court: Between Undue Fiction and Respect for Constitutional Principles', Questions of International Law: Zoom Out 2 (2014), 33-41, at 41 .

${ }^{53}$ Giuseppe Cataldi, 'A Historic Decision of the Italian Constitutional Court on the Balance between the Italian Legal Order's Fundamental Values and Customary International Law', The Italian Yearbook of International Law 24 (2015), 37-52, at 38 and 52.

${ }^{54}$ See for a different type of critique Massimo Iovane, 'The Italian Constitutional Court Judgment No. 238 and the Myth of the "Constitutionalization" of International Law', Journal of International Criminal Justice 14 (2016), 595-605.

${ }^{55}$ Enzo Cannizzaro, 'Jurisdictional Immunities and Judicial Protection: The Decision of the Italian Constitutional Court No. 238 of 2014', Rivista di diritto internazionale 98 (2015), 126-134, at 133.

${ }^{56}$ Felix Würkert, 'Historische Immunität? Anmerkung zu Sentenza Nr. 238 der Corte Costituzionale vom 22. Oktober 2014', Archiv des Völkerrechts 53 (2015), 90-120, at 108 and 110 (translated by the authors).

${ }^{57}$ Robert Kolb, 'The Relationship Between the International and the Municipal Legal Order: Reflections on the Decision no 238/2014 of the Italian Constitutional Court', Questions of International Law: Zoom Out 2 (2014), 5-16, at 11 and 13.

${ }^{58}$ Oreste Pollicino, 'From Academia to the (Constitutional) Bench', Diritto pubblico comparato ed europeo 4 (2015), 1117-1140, at 1117.

${ }^{59}$ Cataldi, ‘A Historic Decision' 2015 (n 53).
} 
2004 seem to express customary international law. ${ }^{60}$ The most attractive German object of execution, the Villa Vigoni, is protected because it serves governmental objectives in a wider sense, including cultural policy, and has a non-commercial character. ${ }^{61}$ However, a mortgage on part of this property was registered (again) in 2019 , shedding light on the persisting legal insecurity. ${ }^{62}$

Sentenza 238/2014 triggered a wave of judgments by several Italian courts. ${ }^{63}$ These lower court decisions in Florence (2015 and 2016), ${ }^{64}$ Rome (2015), ${ }^{65}$ Piacenza (2015), ${ }^{66}$ Ascoli Piceno (2016 and 2017), ${ }^{67}$ Sulmona (2017), ${ }^{68}$ and Fermo $(2018)^{69}$ ordered Germany to pay reparation to Italian victims of massacres and deportation. At least 38 cases are currently pending, ${ }^{70}$ although Germany has decided to no longer appear before Italian courts. The Corte di Cassazione ultimately

\footnotetext{
${ }^{60}$ UNCSI, 2004 (n 37).

${ }^{61}$ ICJ, Jurisdictional Immunities (n 2), para 119; cf, Art 19(c) of the UNCSI (n 37): 'No postjudgment measures of constraint, such as attachment, arrest or execution, against property of a State may be taken in connection with a proceeding before a court of another State unless and except to the extent that: (c) it has been established that the property is specifically in use or intended for use by the State for other than government non-commercial purposes and is in the territory of the State of the forum, provided that postjudgment measures of constraint may only be taken against property that has a connection with the entity against which the proceeding was directed.'

${ }^{62}$ Registry of the judicial mortgage on 11 November 2019 after the Tribunale di Sulmona had issued its Order of 2 November 2017, RGACC 20/2015. Moreover, the question of whether credits owed by the Ferrovie dello Stato to Deutsche Bahn AG can legitimately be attached by the Italian state remains open. See Giovanni Boggero/Karin Oellers-Frahm, chapter 'Between Cynicism and Idealism', in this volume.

${ }^{63}$ See on the post-238/2014 cases, Giovanni Boggero/Karin Oellers-Frahm, chapter 'Between Cynicism and Idealism', in this volume, and Karin Oellers-Frahm, 'A Never-Ending Story: The International Court of Justice-The Italian Constitutional Court-Italian Tribunals and the Question of Immunity', Heidelberg Journal of International Law 76 (2016), 193-202; Giovanni Boggero, 'The Legal Implications of Sentenza No. 238/2014 by Italy's Constitutional Court for Italian Municipal Judges: Is Overcoming the “Triepelian Approach” Possible?', Heidelberg Journal of International Law 76 (2016), 203-224.

${ }^{64}$ Tribunale di Firenze, Judgment of 6 July 2015, NRG 8879/2011 and Judgment of 22 February 2016, NRG 14740/2009.

${ }^{65}$ Tribunale di Roma, Judgment of 20 May 2015, No 11069/2015.

${ }^{66}$ Tribunale di Piacenza, Judgment of 28 September 2015, No 723/2015.

${ }^{67}$ Tribunale di Ascoli Piceno, Order of 8 March 2016, NRG 112/2015 and Order of 24 February 2017, NRG 523/2015.

${ }^{68}$ Tribunale di Sulmona, Order of 2 November 2017, RGACC 20/2015.

${ }^{69}$ Tribunale di Fermo, Judgment of 20 October 2018, No 708/2018.

${ }^{70}$ A source from the German Ministry of Foreign Affairs communicated this figure to the authors in July 2020. The text of the email reads: 'The Federal Government does not have a complete overview of the number of plaintiffs in Italy, their background, their submissions or the exact status of the proceedings, because the Federal Government does not participate in these proceedings that are contrary to international law and rejects the illegal notification of the proceedings, usually without taking note of the content of the application. We are currently aware of 38 pending proceedings' (translated by the authors).
} 
confirmed and reinforced these judgments, echoing the familiar Ferrini jurisprudence, in a recent case of September 2020. ${ }^{71}$

Moreover, just one year before, the same Corte di Cassazione seemed to have already allowed the execution of some of these lower judgments, at least against those assets of the Federal Republic of Germany that are not devoted to public purposes (Giovanni Boggero/Karin Oellers-Frahm). ${ }^{72}$

As early as 25 November 2014, one month after Sentenza 238/2014, Italy had declared its general recognition of the jurisdiction of the ICJ under the optional clause of Article 36(2) of the ICJ Statute, potentially inviting a second lawsuit before the ICJ. However, Germany decided against instituting a second proceeding before the ICJ against Italy for violating state immunity and for failing to uphold the 2012 judgment. At the time of writing, the situation does not seem any closer to a solution.

\section{Immunity and Human Rights-Based Exceptions}

The recent development of international law on immunities has been marked, in the words of Rosanne van Alebeek and Riccardo Pavoni, by 'a clear trend towards restricting immunity so as to impact least the rights and interests of private parties' ${ }^{73}$ Nevertheless, 'unabated heed is usually paid to the core rationale for immunity rules: the need to protect the sovereign rights of states' ${ }^{74}$ In a sober assessment, Ingrid Wuerth affirms that ' $[\mathrm{a}] \mathrm{s}$ international law stands today, immunity applies in suits alleging human rights violations as it does in other cases. ${ }^{, 75}$ The early millennium's momentum towards human-rights based exceptions to immunity ${ }^{76}$ has been slowed down or even cut off. This halt may be due to the experience that such exceptions cause interstate frictions (as illustrated by the German-Italian case), and it is of course a consequence of the authoritative pronouncement by the ICJ in Jurisdictional Immunities. The hesitation also corresponds to a mounting scepticism toward the humanisation of international law and what the critique calls a human rights

\footnotetext{
${ }^{71}$ Corte di Cassazione, Judgment of 28 September 2020, No 20442/2020.

${ }^{72}$ Corte di Cassazione, Judgment of 3 September 2019, No 21995/2019; Cristina M Mariottini, 'Case Note: Deutsche Bahn AG v. Regione Stereá Ellada', American Journal of International Law 114 (2020), 486-493.

${ }^{73}$ van Alebeek/Pavoni, 'Immunities of States' 2018 (n 4), 169.

${ }^{74}$ Ibid.

${ }^{75}$ Ingrid Wuerth, 'International Law in the Post-Human Rights Era', Texas Law Review 96 (2017), 279-349, at 292.

${ }^{76}$ See in scholarship among the many voices, Paola Gaeta, 'Immunity of States and State Officials: A Major Stumbling Block to Judicial Scrutiny?', in Antonio Cassese (ed), Realizing Utopia: The Future of International Law (Oxford: OUP 2012), 227-238.
} 
overreach or 'proliferation'. ${ }^{77}$ The backlash against international human rights is, to some extent, populist rhetoric. ${ }^{78}$ Nevertheless, it must be taken seriously.

The tension between immunity and the protection of private interests is most acute when it comes to claims for reparation for war crimes and crimes against humanity before national courts. While the ICJ in Jurisdictional Immunities has decided only on the immunity of the state sued as a legal person before domestic courts in civil procedures, the Court explicitly distinguished this constellation from criminal law proceedings against state officials. ${ }^{79}$ However, a range of actors is seeking to keep the door open for a further evolution of the law, notably but not strictly limited to criminal proceedings against state officials. So far, six states have deposited interpretative declarations upon their ratification of UNCSI, stating that the Convention is without prejudice to any future international development in the protection of human rights. ${ }^{80}$ In 2009, the Institut de droit international adopted its Naples Resolution which states that '[i]mmunities should not constitute an obstacle to the appropriate reparation to which victims (...) are entitled. ${ }^{81}$ A decade later, draft Article 7 'Crimes under international law in respect of which immunity ratione materiae shall not apply' was provisionally adopted within the International Law Commission. $^{82}$

\footnotetext{
${ }^{77}$ Costas Douzinas, The End of Human Rights: Critical Thought at the Turn of the Century (Oxford: Hart 2000); Jacob Mchangama/Guglielmo Verdirame, 'The Danger of Human Rights Proliferation: When Defending Liberty, Less Is More', Foreign Affairs (24 July 2013); Makau Mutua, 'Is the Age of Human Rights Over?', in Sophia A McClennen/Alexandra Schultheis Moore (eds), The Routledge Companion to Literature and Human Rights (London: Routledge 2016), 450-458; Stephen Hopgood, The Endtimes of Human Rights (Ithaca/New York: Cornell University Press 2013).

${ }^{78}$ Veronika Bílková, 'Populism and Human Rights', Netherlands Yearbook of International Law 49 (2018), 143-174.

${ }^{79}$ ICJ, Jurisdictional Immunities (n 2), para 91.

${ }^{80}$ Interpretative declarations by Norway (27 March 2006); Sweden (23 December 2009); Switzerland (16 April 2010); Italy (6 May 2013); Finland (23 April 2014); Liechtenstein (22 April 2015).

${ }^{81}$ Article 2(2) of the Resolution on the Immunity from Jurisdiction of the State and of Persons Who Act on Behalf of the State in Case of International Crimes, Rapporteur: Lady Fox. Institut de droit international, Third Commission, Naples Session, 3-11 September 2009, Annuaire de l'Institut de droit international 73 (2010), 1-231.

${ }^{82}$ ILC, Seventy-first session, Geneva, 29 April to 7 June 2019 and 8 July to 9 August 2019, Seventh report on immunity of State officials from foreign criminal jurisdiction, by Concepción Escobar Hernández, Special Rapporteur (A/CN.4/729) with Annex I: 'Draft articles on immunity of State officials from foreign criminal jurisdiction provisionally adopted by the Commission'. Draft Article 7 runs: ' 1 . Immunity ratione materiae from the exercise of foreign criminal jurisdiction shall not apply in respect of the following crimes under international law: (a) crime of genocide; (b) crimes against humanity; (c) war crimes; (d) crime of apartheid; (e) torture; (f) enforced disappearance. 2. For the purposes of the present draft article, the crimes under international law mentioned above are to be understood according to their definition in the treaties enumerated in the annex to the present draft articles.' See for state practice the criminal proceeding in Switzerland against a former Algerian minister of defence, instituted for torture, where the Swiss Federal Criminal Tribunal denied immunity ratione personae for acts which the minister had allegedly committed when still in office (Swiss Federal Criminal Tribunal, Khaled Nezzar case, Decision of 25 July 2012, BB.2011.140).
} 
Three main argumentative strategies have been employed to carve out an exception from immunity in the event of serious human rights violations and crimes: the idea of an implied waiver of immunity, the theory of a normative hierarchy under which the ius cogens status of the crimes would trump immunity, and finally the 'remedy theory' which focuses on the right to a judge which would lead to an obligation of the courts to examine the merits instead of dismissing a limine any complaint, and if only as a last resort (ultima ratio). ${ }^{83}$ However, none of these approaches has gained much ground (except the last one to which we will return below), nor has led to a broad change in practice. ${ }^{84}$

As a factual matter, the development of a new customary law-or treaty-based exception to state immunity (especially from execution) in cases of serious violations of human rights and international humanitarian law-is not impossible, but it still seems improbable, even at the highly integrated European regional level, as Andreas Zimmermann convincingly demonstrates in his chapter. A distinct question is whether and under which conditions it is desirable in legal policy terms.

Normatively, granting compensation for international crimes (notably recent ones) may form a useful part of a transitional justice strategy and contribute to the establishment of a sustainable peaceful order. Nevertheless, executive measures against foreign states based on judgments granting compensation against those countries, issued by the domestic courts of the victims' own states, risk creating significant international tensions. 'No state'-as Christian Tomuschat recalls-'is prepared to see its governmental conduct supervised by the judiciary of another country', and 'by attributing to each state its own sphere of jurisdiction (...) international law contributes to upholding peace in interstate relations'. This risk of conflict might even be exacerbated when judgments concern historical as opposed to recent crimes.

One way of containing this risk is resorting to domestic litigation in the home state of the victims only as an ultima ratio. This was, as mentioned, the Italian argument before the ICJ. ${ }^{85}$ The civil proceedings are the last resort only when alternative remedies are lacking. As previously explained, Sentenza 238/2014 and subsequent judgments by the Italian Corte di Cassazione ${ }^{86}$ have resorted to the third argumentative strategy, relying on the individual victims' right of access to a court

\footnotetext{
${ }^{83}$ See for the identification and analysis of these three strategies: Pierre D'Argent/Pauline Lesaffre, 'Immunities and Jus Cogens Violations', in Tom Ruys/Nicolas Angelet/Luca Ferro (eds), The Cambridge Handbook of Immunities and International Law (Cambridge: CUP 2019), 614-633, at 615-624.

${ }^{84}$ Ibid, 614 and 630 .

${ }^{85}$ See above text with notes 23-24. ICJ, Jurisdictional Immunities (n 2), para 98.

${ }^{86} \mathrm{Cf}$, Corte di Cassazione, Judgment of 28 October 2015, No 21946/2015 (Flatow), especially paras $4,5,6.6$. The judgment concerns the request for exequatur of a US court decision awarding damages against Iran for acts of terrorism that had killed, inter alia, Michelle Alisa Flatow and were qualified as a crime against humanity. The second judgment is Corte di Cassazione, Judgment of 29 October 2015, No 43696/2015 (Opačić), especially para 5.2.1. It concerned a war crime against an Italian non-combat helicopter during the Yugoslav Wars.
} 
(as also stressed by Valerio Onida). However, these judgments have not endorsed the condition of 'last resort'. In other words, they have not conditioned the displacement of state immunity on the absence of another effective and reasonable means for the plaintiffs to reclaim their rights. ${ }^{87}$ Before the Italian courts, applicants have not been asked to show that they do not benefit from any other effective remedy.

The weak point of the Italian case law is that it does not dwell sufficiently on the contours of how the right of access to a court (which is of course not absolute) may legitimately be restricted. The task therefore is to spell out the conditions for such restrictions.

This task has so far been undertaken mainly by the ECtHR which has been called a 'de facto court of appeal' on immunity. ${ }^{88}$ Philippa Webb finds that the Strasbourg Court 'has the potential to lead us into an age of greater accountability for human rights violations' ${ }^{89}$ The ECtHR case law on the immunity of international organizations (not of states) has gone in the direction of a balancing test, tying the denial of access to a court (as a lawful restriction of the right to access under Article 6 of the European Convention on Human Rights (ECHR)) to the existence of a reasonable alternative remedy. With regard to state immunity, such a balancing approach would however not be in line with ICJ's ruling in Jurisdictional Immunities. ${ }^{90}$ And because the ECtHR has confirmed that the 2012 ICJ Judgment 'must be considered by this Court as authoritative as regards the content of customary international law, ${ }^{91}$ a further elaboration of a balancing approach by the Strasburg Court seems unlikely.

An alternative to lifting state immunity (under certain conditions) might be to strengthen diplomatic protection, maybe by acknowledging an international law-based obligation of the states to consider properly and with due diligence any request by their citizens to undertake steps of diplomatic protection at the international level. ${ }^{92}$ Another way to secure accountability could be to establish an obligation of the states whose officials committed the crimes to grant access to judicial remedy and to award reparation under their own domestic law, ${ }^{93}$ typically state liability statutes. Such a state obligation would ultimately be enforceable in international fora, and might help victims more than adjudication and enforcement in other equally sovereign

\footnotetext{
${ }^{87}$ See explicitly, Corte di Cassazione, Opačić (n 86), para 5.2.1. See also D'Argent/Lesaffre, 'Immunities' 2019 (n 83), 623.

${ }^{88}$ Philippa Webb, 'A Moving Target: The Approach of the Strasbourg Court to Immunity', in Anne van Aaken/Iulia Motoc (eds), The European Convention on Human Rights and General International Law (Oxford: OUP 2018), 251-263, at 262.

${ }^{89}$ Ibid, 263.

${ }^{90}$ See above text with notes 23-24. ICJ, Jurisdictional Immunities (n 2), para 101.

${ }^{91}$ ECtHR, Jones (n 9), para 198.

${ }^{92}$ Anja Höfelmeier, Die Vollstreckungsimmunität der Staaten im Wandel des Völkerrechts (Berlin: Springer 2018), 306-308; Cf also Anne Peters, Beyond Human Rights: The Legal Status of the Individual in International Law (Cambridge: CUP 2016), 402-405.

${ }^{93}$ Italian (and Greek) lawsuits before German courts have been unsuccessful in this sense. Cf, Bundesverfassungsgericht, Order of 28 June 2004, 2 BvR 1379/01, BVerfGK 3, 277; Bundesverfassungsgericht, Order of 15 February 2006, 2 BvR 1476/03, BVerfGK 7, 303 (Distomo).
} 
states. ${ }^{94}$ Given the dilemma in which courts find themselves, 'between a rock and a hard place' (Andreas Paulus), it seems important to continue exploring these strategies for reconciling human rights protection with peaceful interstate coexistence.

\section{Reparation for Gross Human Rights Violations and War Crimes}

The deportation of IMIs and their exploitation as forced labourers together with the massacres against the civilian population were (as Germany acknowledges) 'a serious violation of the international law of armed conflict applicable in 1943$1945^{\prime}$ for which the state has assumed full responsibility. ${ }^{95}$ Moreover, Germany paid reparations to the state of Italy, based on two international treaties of $1961 .{ }^{96}$ Nevertheless, Germany has not granted individual reparation to large numbers of victims, and this denial is what led to Sentenza 238/2014.

The civil proceedings which ultimately involved the Corte Costituzionale might be seen in the overall current climate of addressing historical crimes. A strong wave of demands for reparation in the context of colonialism, ${ }^{97}$ violence committed against indigenous peoples, ${ }^{98}$ and slavery ${ }^{99}$ is rolling on. Germany in particular is confronted with state claims for reparation, notably for damages caused in WWII, by Greece and Poland. ${ }^{100}$ In addition, Namibia has requested reparation for crimes

\footnotetext{
${ }^{94}$ Höfelmeier, 'Vollstreckungsimmunität' 2018 (n 92), 307-308.

${ }^{95}$ ICJ, Jurisdictional Immunities (n 2), para 52.

${ }^{96}$ On 2 June 1961, two Agreements were concluded between the Federal Republic of Germany and Italy. Individual payments were nonetheless not contemplated. Agreement between the Federal Republic of Germany and Italy on the Settlement of Certain Property-Related, Economic and Financial Questions (Bonn, 2 June 1961), German and Italian version published in Bundesgesetzblatt II 26 June 1963 No 19, 668; Agreement between the Federal Republic of Germany and Italy on the Compensation for Italian Nationals Subjected to National-Socialist Measures of Persecution (Bonn, 2 June 1961), German and Italian version published in Bundesgesetzblatt II 5 July 1963 No 22, 791.

${ }^{97}$ See, eg, Larissa van den Herik, 'Reparation for Decolonisation Violence: A Short Overview of Recent Dutch Litigation', Heidelberg Journal of International Law 78 (2018), 629-633.

${ }^{98}$ Federico Lenzerini (ed), Reparations for Indigenous Peoples: International and Comparative Perspectives (Oxford: OUP 2008).

${ }^{99} \mathrm{Cf}$ the current US debate on reparation for slavery: H.R. 40 - Commission to Study and Develop Reparation Proposals for African-Americans Act, $116^{\text {th }}$ Congress $1^{\text {st }}$ Session, introduced in House 3 January 2019, available at www.congress.gov/bill/116th-congress/house-bill/40/text. Cf as well the 2021 South Korean's judgment ordering Japan to pay compensation for wartime sexual slavery, Daniel Franchini, 'South Korea's denial of Japan's immunity for international crimes: Restricting or bypassing the law of state immunity?', Voelkerrechtsblog, (18 January 2021), available at https:// voelkerrechtsblog.org/south-koreas-denial-of-japans-immunity-for-international-crimes/.

${ }^{100}$ See the Greek verbal note of 4 June 2019, available at https://www.mfa.gr/epikairotita/diloseisomilies/anakoinose-tou-upourgeiou-exoterikon-skhetika-me-ten-epidose-rematikes-diakoinosessto-germaniko-upourgeio-exoterikon-gia-tis-polemikes-epanorthoseis-kai-apozemioseis-apo-tonkai-pagkosmio-polemo-04062019.html. A Polish commission to identify damage done by
} 
committed by German officials in the colonial context against the Herero and Nama people. ${ }^{101}$ In a recent urgent debate in the UN Human Rights Council, the High Commissioner for Human Rights stated that '[b]ehind today's racial violence, systemic racism, and discriminatory policing lies the failure to acknowledge and confront the legacy of the slave trade and colonialism'. She urged states to 'make amends for centuries of violence and discrimination, including through formal apologies, truthtelling processes, and reparations in various forms.' ${ }^{102}$

It is of course a fundamental question whether and under which conditions it makes sense to draw history before courts. Indeed, as Andreas von Arnauld recalls in his chapter, 'adjudicating history might prove bottomless once one goes further back, with claims relating to early colonialism and beyond. However, in most of the recent cases of "history taken to court," compensation is but a secondary aim, the primary aim being to make the voice of the victims heard (...)'. He continues that courts are increasingly turned into fora to make one's story heard, 'and this process is used as leverage to exert pressure on the political system to listen'.

A judicial response is plausible where, as in the case leading to Sentenza 238/2014, the conduct was already unlawful according to the standards of international law applicable at the time of perpetration. Still, the issue of reparation for individual victims might need a nuanced response when the crimes lie in the distant past.

Even for contemporary atrocities, general international law as it stands does not yet fully acknowledge an individual right to reparation for victims of armed conflict. ${ }^{103}$ But individual reparation is increasingly present in special reparation schemes, established by interstate treaties, other (often hybrid international/domestic) legal instruments, and soft law. ${ }^{104}$ In other words, reparation for victims of international and non-international armed conflicts is becoming a typical feature in the ius post bellum, and this trend is unlikely to fade away. Nonetheless, as Stefan

Germany against Poland in the context of World War II has, according to the press, accomplished its work in May 2020. However, the results are not public. The commission had been established by the Polish governing party 'Law and Justice' and was chaired by a member of parliament belonging to that party.

${ }^{101}$ Negotiations between Germany and Namibia are ongoing. See for two antagonist assessments: Patrick O Heinemann, 'Die deutschen Genozide an den Herero und Nama: Grenzen der rechtlichen Aufarbeitung', Der Staat 55 (2016), 461-487; Kenneth L Lewis Jr, 'The Namibian Holocaust: Genocide Ignored, History Repeated, Yet Reparations Denied', Florida Journal of International Law 29 (2017), 133-149.

${ }^{102}$ UN High Commissioner for Human Rights, Michelle Bachelet, statement of 17 June 2020 (43 $3^{\text {rd }}$ session of the Human Rights Council, Urgent Debate on current racially inspired human rights violations, systemic racism, police brutality against people of African descent and violence against peaceful protests) (emphasis added).

${ }^{103}$ The UN General Assembly's Principles are not hard law and cannot in themselves create such an entitlement. UN General Assembly, Basic Principles and Guidelines on the Right to a Remedy and Reparation for Victims of Gross Violations of International Human Rights Law and Serious Violations of International Humanitarian Law, Annex, GA Res. 60/147, 16 December 2005.

${ }^{104}$ Christian Marxsen, 'The Emergence of an Individual Right to Reparation for Victims of Armed Conflict', in Peters/Marxsen, Max Planck Trialogues 2020 (n 5), 1-15. 
Kadelbach argues, in the law of international armed conflict, a true antagonism is visible between the substantial and procedural dimensions of the law of reparations. While the victims are recognized as holders of the claims, 'the procedural right to espouse these claims on their behalf is still in the hand of the states.' This might also explain why a gap in implementation of 'scandalous proportions' remains, as a UN Special Rapporteur-who saw a 'dismal record in the implementation of reparations'-put it. ${ }^{105}$

With regard to the German crimes in particular, Graziella Romeo deplores the 'double standards' on the side of Italy. Human rights violations committed by Italian officials during the Fascist regime, for example by adopting and applying racial laws, and also by aiding German forces in perpetrating massacres against civilians, were not compensated on an individual basis but were mainly addressed 'with legislative provisions pertaining to welfare policy and only insufficiently restored, while a general regime concerning the restoration for human rights violations is still missing. ${ }^{106}$ She opines that the 'desirable (...) evolution of international law itself', as solicited by the Corte Costituzionale, ${ }^{107}$ 'needs to be paired with a similar effort on the side of the Italian Parliament and courts'. ${ }^{108}$ This shared 'sorry saga' indeed generates a shared committment (Francesco Francioni). Similar 'double standards' seem to be applied by the German side, too. In particular, the selectivity of various compensation schemes adopted by Germany and the constant exclusion of IMIs from reparation schemes dedicated to WWII victims (Jörg Luther) are not clearly justified: 'Why the French railroad deportees and not IMIs?' (Riccardo Pavoni).

Another important point is that-in the end-reparation for victims of armed conflict can only come about in an interplay between international and domestic law. If domestic institutions and procedures are not built up, then a putative international law-based entitlement to reparation would anyway remain virtual, a 'pie in the sky' as Shuichi Furuya recently put it. ${ }^{109}$ However, the domestic reparation programmes for the victims of war crimes in both interstate and civil wars are often situated in a grey zone between law and politics. Such programmes have occasionally become an issue in regional human rights courts. These courts then examine the effectiveness of such programmes while applying the principle of subsidiarity which demands a certain amount of deference to the domestic institutions. This aspect is another manifestation of the new pluriverse made of international law and multiple domestic legal orders. This brings us to the third theme of the book: the interaction between international and domestic law and the role of domestic courts therein.

\footnotetext{
${ }^{105}$ Pablo de Greiff, Report of the Special Rapporteur on the promotion of truth, justice, reparation and guarantees of non-recurrence, UN Doc. A/69/518, 14 October 2014 (quote from the summary). 


\section{The Interplay Between International and Domestic Law}

As we have seen, state immunity, remedies and reparation for victims of atrocities are legal institutions which sit at the interface of international and domestic law. 'Cross-fertilisation' among different jurisdictions and their courts is typical in both areas. $^{110}$

Generally speaking, national courts are called to apply and enforce international rules. This role has been captured by the theory of 'dédoublement fonctionnel', 111 and by the idea that national judges are the 'natural judges of international law'.112 Thus, the activity of domestic courts strengthens and promotes international law.

On the other hand, national courts often, and maybe increasingly so, resist the application of international law and the implementation of international judgments, notably of the regional human rights courts. ${ }^{113}$ In the Inter-American human rights system, courts in Venezuela, Uruguay, Dominican Republic, Costa Rica, El Salvador, and Argentina have refused to fully implement judgments issued by the InterAmerican Human Rights Bodies since 2011. ${ }^{114}$ In the European human rights system, the resistance by the Russian Constitutional Court, followed by the legislature, is notorious, and the Court quoted Sentenza 238/2014 as a precedent. ${ }^{115}$

\footnotetext{
${ }^{110} \mathrm{Cf}$ for the issue of immunity D'Argent/Lesaffre, 'Immunities' 2019 (n 83), 629.

${ }^{111}$ See Georges Scelle, 'Le phénomène juridique du dédoublement fonctionnel', in Walter Schätzel/ Hans-Jürgen Schlochauer (eds), Rechtsfragen der internationalen Organisation: Festschrift für Hans Wehberg zu seinem 70. Geburtstag (Frankfurt a M: Vittorio Klostermann 1956), 324-342. Hans Kelsen referred to domestic criminal courts as organs of the international community that apply domestic law and international law simultaneously; Hans Kelsen, Principles of International Law (Robert W Tucker (ed), New York: Holt Rinehart and Winston $2^{\text {nd }}$ ed 1966), at 205-206 and 210 .

${ }^{112}$ Antonios Tzanakopoulos, 'Domestic Courts in International Law: The International Judicial Function of National Courts', Loyola of Los Angeles International and Comparative Law Review 34 (2011), 133-168, at 150.

${ }^{113}$ Raffaela Kunz, 'Judging International Judgments Anew? The Human Rights Courts before Domestic Courts', European Journal of International Law 30 (2019), 1129-1163; Raffaela Kunz, Richter über internationale Gerichte? (Heidelberg: Springer 2020).

${ }^{114}$ See Alexandra Huneeus, 'Courts Resisting Courts: Lessons from the Inter-American Court's Struggle to Enforce Human Rights', Cornell International Law Journal 44 (2011), 493-533; Ximena Soley/Silvia Steininger, 'Parting Ways or Lashing Back? Withdrawals, Backlash and the Inter-American Court of Human Rights', International Journal of Law in Context 14 (2018), 237-257.

${ }^{115}$ Russian Constitutional Court, Judgment of 14 July 2015, No 21-П/2015. See also Federal Law of the Russian Federation, No 7-KFZ introducing amendments to the Federal Constitutional Law, No 1-FKZ of 21 July 1994 on the Constitutional Court of the Russian Federation, entered into force on 15 December 2015; Cf, more recently, Federal Law of the Russian Federation on the amendment to the Constitution of the Russian Federation, No 1-FKZ of 14 March 2020. See on the 2015 judgment and on further decisions of the Russian Constitutional Court, Lauri Mälksoo, 'Russia's Constitutional Court Defies the European Court of Human Rights: Constitutional Court of the Russian Federation Judgment of 14 July 2015, No 21-П/2015', European Constitutional Law Review 12 (2016), 377-395; Matthias Hartwig, 'Vom Dialog zum Disput?
} 


\section{Sentenza 238/2014 in the Line of Resistance of Domestic Courts Against International Judgments}

Thus, Sentenza 238/2014 appears as one more building block in the wall of 'protection' built up by domestic courts against 'intrusion' of international law, relying on the precepts of their national constitution. ${ }^{116}$ This theme runs as a fil rouge through various chapters of the book. By way of introduction, we wish to recapitulate the most important points de repère. ${ }^{117}$ The ItCC relied on its established caselaw on the effects of European Union law, notably on the doctrine of controlimiti in order to erect a barrier to the 'introduction' of the ICJ judgment into the domestic legal order: 'As was upheld several times by this Court, there is no doubt that the fundamental principles of the constitutional order and inalienable human rights constitute a "limit to the introduction (...) of generally recognized norms of international law' (...) and serve as 'counterlimits' [controlimiti] to the entry of European Union [and now international] law"' into the domestic legal system. ${ }^{118}$

Ironically, this front of resistance had been spearheaded - as it is well knownboth by the German Federal Constitutional Court (FCC), and by the ItCC already in the 1970s. ${ }^{119}$ In 2004, the FCC denied a strictly binding effect of the ECHR and ECtHR-judgments, and instead (only) ordered German authorities and courts to 'take into account' the Convention and Strasbourg judgments, and only within the confines of the German Basic Law. ${ }^{120}$ The most recent German case of 2020 held

Verfassungsrecht vs. Europäische Menschenrechtskonvention: Der Fall der Russländischen Föderation', Europäische Grundrechtezeitschrift 44 (2017), 1-23; Ausra Padskocimaite, 'Constitutional Courts and (Non)execution of Judgments of the European Court of Human Rights: A Comparison of Cases from Russia and Lithuania', Heidelberg Journal of International Law 77 (2017), 651-684; Jeffrey Kahn, 'The Relationship between the European Court of Human Rights and the Constitutional Court of the Russian Federation: Conflicting Conceptions of Sovereignty in Strasbourg and St Petersburg', European Journal of International Law 30 (2019), 933-959; Galina A Nelaeva/Elena A Khabarova/Natalia V Sidorova, 'Russia's Relations with the European Court of Human Rights in the Aftermath of the Markin Decision: Debating the "Backlash"', Human Rights Review 21 (2020), 93-112.

${ }^{116}$ Anne Peters, 'Supremacy Lost: International Law Meets Domestic Constitutional Law', Vienna Journal on International Constitutional Law 3 (2009), 170-198. The judgments mentioned in the preceding section differ in tone and substance. But even well-meant decisions which erect moderate and good faith- 'protections' against international law can be abused as 'precedents' by actors with a pronounced anti-international law agenda.

${ }^{117}$ This section again builds on Peters, 'Triepel' 2014 (n 42).

${ }^{118}$ ItCC, Judgment 238/2014 (n 1), 'The Law', para 3.2 (emphasis and square brackets added).

${ }^{119}$ In the 1970s, both Courts mounted critique against an insufficient respect for human rights by the then European Community (Bundesverfassungsgericht, Order of 29 May 1974, 2 BvL 52/71, BVerfGE 37, 271 (Solange I) and ItCC, Judgment of 27 December 1973, No 183/1973 (Frontini)) and threatened, with different levels of intensity, to scrutinize EC-acts against the yardstick of domestic fundamental rights and to refuse to allow their application in Germany and Italy.

${ }^{120}$ Bundesverfassungsgericht, Decision of 14 October 2004, 2 BvR 1481/04, BVerfGE 111, 307 (Görgülï). 
that the Court of Justice of the European Union (CJEU)'s judgment upholding the European Central Bank's decision to establish a Public Sector Purchase Programme was 'manifestly disproportionate' and thus ultra vires. ${ }^{121}$

Sentenza 238/2014 repeats that any international norm (or international judgment) which stands in conflict with 'principi fondamentali dell'ordinamento costituzionale' may not be applied by domestic institutions. The German FCC in Görgülï had marked the boundary of applicability of judgments of the ECtHR with exactly the same wording ('tragende Grundsätze der Verfassung').

The referring court of Florence had quoted a previous Italian constitutional judgment pointing to the 'identità' of the Italian legal order. There, the ItCC had reaffirmed the principle that 'the tendency of the Italian legal order to be open to generally recognized norms of international law and international treaties is limited by the necessity to preserve its identity; thus, first of all, by the values enshrined in the Constitution'. ${ }^{122}$ This is exactly what other European courts have done before (albeit with regard to EU law): the Spanish Tribunal Constitucional, ${ }^{123}$ the French Conseil constitutionnel, ${ }^{124}$ and the German Bundesverfassungsgericht. ${ }^{125}$

Sentenza 238/2014 is in some way a follower of the CJEU's Kadi decision ${ }^{126}$ which the ItCC quotes. ${ }^{127}$ But unlike Kadi, which mounts resistance against the UN Security Council and thus against an essentially unaccountable and not fully representative body, Sentenza 238/2014 is directed against the International Court of Justice, a body which represents the international rule of law and all regions of the world. Generally speaking, this Court has so far enjoyed a high degree of acceptance. ${ }^{128}$ The de facto disobedience to the ICJ seems less justified as a matter of principle, and implies more serious damage to the normativity of the international legal system than disobeying the Security Council.

Just like Kadi, Sentenza 238/2014 insists on the fact that it has nothing to do with 'outbound' compliance of the state (Italy) with international law, but only concerns the internal compatibility of two Italian laws with the Italian Constitution: 'The

\footnotetext{
${ }^{121}$ Bundesverfassungsgericht, Judgment of 5 May 2020, 2 BvR 859/15, paras 117-143. See for a strong critique Sabino Cassese, 'Il Guinzaglio Tedesco', Il Foglio, 19 May 2020.

${ }^{122}$ ItCC, Judgment 238/2014 (n 1), para 1.2, quoting Judgment of 22 March 2001, No 73/2001 (emphasis added).

${ }^{123}$ Tribunal constitucional, Declaration of 13 December 2004, DTC 1/2004, sec II, para 3.

${ }^{124}$ Conseil constitutionnel, Decision of 27 July 2006, No 2006-540, para 19.

${ }^{125}$ Bundesverfassungsgericht, Judgment of 30 June 2009, 2 BvE 2/08 (Treaty of Lisbon), para 340. (See also Constitutional Court of Lithuania, case no 17/02-24/02-06/03-22/04 on the priority of the state constitution over EU law, 14 March 2006, sec III, para 9.4).

${ }^{126} \mathrm{CJEU}$, Kadi and Al Barakaat International Foundation v Council and Commission, Judgment of 3 September 2008, Joined Cases C-402/05 P and C-415/05 P, EU:C:2008:461.

${ }^{127}$ But see Martin Scheinin, 'The Italian Constitutional Court's Judgement 238 of 2014 Is Not Another Kadi Case', Journal of International Criminal Justice 14 (2016), 615-620.

${ }^{128}$ This acceptance is not tainted by the fact that less than half of all states have accepted the Court's compulsory jurisdiction. States regularly subject themselves to its jurisdiction and the authority of the judgments is rarely contested.
} 
result is a further reduction of the scope of this norm, with effects in the domestic legal order only.' ${ }^{129}$ Put differently, the ItCC neatly distinguishes 'internal' and 'external' effects of an international norm: 'The impediment to the incorporation of the conventional norm [Article 94 of the United Nations Charter] to our legal order-albeit exclusively for the purposes of the present case-has no effects on the lawfulness of the external norm itself, and therefore results in the declaration of unconstitutionality of the special law of adaptation, insofar as it contrasts with the abovementioned fundamental principles of the Constitution' ${ }^{130}$ So technically (in a dualist world view), the case is not about supremacy but about incorporation: 'Accordingly, the incorporation, and thus the application, of the international norm would inevitably be precluded, insofar as it conflicts with inviolable principles and rights. This is exactly what has happened in the present case. ${ }^{, 131}$

The judicial pretence that the 'internal' unconstitutionality basically does not concern international law, and the observation that the judicial pronouncement does not accord any priority or supremacy to internal law is formally correct. However, it is as unpersuasive in substance as it was in the CJEU Kadi judgment. ${ }^{132}$ That distinction between inside and outside resonates with good old nineteenth century dualism, according to which international law and domestic law are 'two circles which at best touch each other but which never intersect' ${ }^{133}$

The Italian Constitutional Court's consolation that '[i]n any other case, it is certainly clear that the undertaking of the Italian State to respect all of the international obligations imposed by the accession to the United Nations Charter, including the duty to comply with the judgments of the ICJ, remains unchanged,134 does not help much for managing the practical problem at stake.

\section{A Plea for a Pluralisme Ordonné}

That stiff dualism à la Heinrich Triepel and Dionisio Anzilotti does not only fail to resolve the practical problem but additionally bears the real risk of reinforcing the perception that international law is only soft law or even no law at all. We submit that more flexibility is warranted. Courts should entertain procedural mechanisms of reciprocal restraint, respect, and cooperation for adjusting competing claims of authority between the international and the national bodies. ${ }^{135}$

\footnotetext{
${ }^{129}$ ItCC, Judgment 238/2014 (n 1), 'The Law', para 3.3 (emphasis added).

${ }^{130} \mathrm{Ibid}$, para 4.1 (emphasis added).

${ }^{131}$ Ibid, para 3.4 (emphasis added).

${ }^{132}$ CJEU, Kadi (n 126), paras 287-288 and 299.

${ }^{133}$ Triepel, Völkerrecht (n 43), 111 (translated by the authors).

${ }^{134}$ ItCC, Judgment 238/2014 (n 1), para 4.1.

${ }^{135} \mathrm{Cf}$ also Anne Peters, 'The Refinement of International Law: From Fragmentation to Regime Interaction and Politicization', International Journal of Constitutional Law 15 (2017), 671-704.
} 
Domestic (constitutional) courts should take into consideration international law in good faith and interpret the domestic constitution in the light of international law. A domestic court could interpret the (constitutional) right of access to a court (such as under Article 24 of the Italian Constitution) in the light of the ECtHR judgment Sfountouris $v$ Germany, which implicitly held that access to domestic courts (in Germany) in suits for damages on account of German WWII-crimes appears to satisfy the standards of Article 6 ECHR. ${ }^{136}$ Against this context, Sentenza 238/2014 appears as une occasion perdue, considering that 'the ItCC had the opportunity to oppose state immunity from jurisdiction to another international law principle' (Sabino Cassese).

National courts can also use a more 'harmonising' approach à la Jones. ${ }^{137}$ Jones was a case on state immunity (involving Saudi Arabia) against allegations of torture. The ECtHR here had insisted that both issue areas of international law, the law of immunities and human rights law, must be reconciled, acknowledging 'the need to interpret the Convention so far as possible in harmony with other rules of international law of which it forms part, including those relating to the grant of State immunity'. ${ }^{138}$ This led the ECtHR 'to conclude that measures taken by a State which reflect generally recognised rules of public international law on State immunity cannot in principle be regarded as imposing a disproportionate restriction on the right of access to a court' ${ }^{139}$ But the Court also observed that 'in light of the developments currently under way in this area of public international law, this is a matter which needs to be kept under review'. ${ }^{140}$

National courts can also apply the Bosphorus strategy. ${ }^{141}$ In that approach, courts should employ a legal presumption that a legal act performed by a body rooted in 'another' legal system is in conformity with their 'own' standards. In Bosphorus, this presumption is coupled with the reciprocal recognition of such acts, 'as long as' some minimum requirements are not undercut. In this scheme, domestic courts abstain from revisiting (judicial or quasi-judicial) decisions taken by an international body on the basis of the rebuttable presumption that the respective international regime, or another state's domestic legal system (in our case Germany) offers a functionally equivalent legal protection. It is 'the admissibility of an imperfect accordance between the two systems', as Alessandro Bufalini puts it, that enhances the potentialities of equivalent protection as a technique for the balancing of different interests. Concededly, this more dialogical technique requires a close relationship or

\footnotetext{
${ }^{136}$ ECtHR, Sfountouris and Others v Germany, Decision of 31 May 2011, Application No 24120/ 06. This decision on inadmissibility found a claim based on Article 1 AP 1 in conjunction with Article 14 ECHR to be inadmissible ratione materiae.

${ }^{137}$ ECtHR, Jones (n 9).

${ }^{138}$ Ibid, para 189.

${ }^{139}$ Ibid.

${ }^{140}$ Ibid, para 215.

${ }^{141}$ ECtHR, Bosphorus v Ireland, Grand Chamber Judgment of 30 June 2005, Application No $45036 / 98$.
} 
similarity of legal orders, explaining why the technique is often used in the European context, while 'it is not used very often in genuine international law cases' (Doris König).

Most importantly, conflicts between international law and constitutional law should be resolved by balancing in the concrete case, not on the basis of a normative hierarchy or the norms' expression in international law as opposed to domestic law. Less attention should be paid to the formal sources of law, and more to the substance of the rules in question. The ranking and effects of the norms at stake should be assessed in a subtler manner according to their substantial weight and significance. ${ }^{142}$ Such a non-formalist, substance-oriented perspective implies that on the one hand, certain less significant provisions in state constitutions would have to give way to important international norms. Inversely, fundamental rights guarantees should prevail over less important norms (independent of their locus and type of codification). The fundamental idea is that what counts is the substance, not the formal category of conflicting norms. Admittedly, this new approach does not always offer strict guidance, because it is debatable which norms are 'important' in terms of substance. Still, such a flexible approach appears to correspond better with the current state of global legal integration than the idea of a strict hierarchy, particularly in human rights matters. From this perspective, international law, constitutional law, and other states' constitutional law find themselves in a fluid state of interaction and reciprocal influence, based on discourse and mutual adaptation, but not in a hierarchical relationship. ${ }^{143}$

This flexible, procedural solution also reflects the fact that many different interests and claims are at play and to a certain extent allows the multiple roles played by domestic courts to be reconciled. Raffaela Kunz invites courts to increasingly see themselves as 'mediators between orders' rather than guardian of a particular legal system. 'More than strict conflict rules and hierarchies, what better fits to the complex reality is an approach that allows to take into account the different interests at stake and to balance them'.

Is the openness of the question 'who decides who decides' and the lack of an ultimate authority -in our context a tribunal sitting over and above the ICJ and the Italian Corte Costituzionale - a merit of the global order? In theory, such openness constitutes an additional mechanism for limiting power and seems to allow for a heterarchical adjustment of regimes. Within this paradigm, the constitutional resistance of the Corte Costituzionale might be interpreted as the pulling of an 'emergency brake' whose availability had been the pre-condition for the opening-up of the states' constitutions towards the international sphere in the first place. Along this line, one could argue that —in the absence of a super-arbiter - the Italian courts are entitled to act as 'guardians' of the rights of the victims or their descendants 'as long

\footnotetext{
${ }^{142}$ Peters, 'Supremacy Lost' 2009 (n 116).

${ }^{143}$ Yota Negishi, 'The Pro Homine Principle's Role in Regulating the Relationship between Conventionality Control and Constitutionality Control', European Journal of International Law 28 (2017), 457-481.
} 
as' a customary human rights exception to state immunity has not crystallized or until a special agreement between Germany and Italy, on a special compensation programme or a claims tribunal, has been concluded. Potential models for each of these solutions already exist. In particular, numerous internal and international arrangements in the context of transitional justice might inspire the creation of a German-Italian Fund for the IMIs, as Filippo Fontanelli explains in detail in his chapter.

In the long run, reasonable resistance by national actors-if it is exercised under respect of the principles for ordering pluralism, notably in good faith and with due regard for the overarching ideal of international cooperation-might build up the political pressure needed to promote the progressive evolution of international law in the direction of a system more considerate of human rights. This is the 'barking and biting' approach mentioned by Bernardo Giorgio Mattarella: barking and a 'bite, from time to time and in exceptional circumstances, can be appropriate and necessary'. Indeed, such domestic resistance has, in the past, had salutary effects in the sense that it has stimulated an improvement in the attacked regime's fundamental rights protection: in reaction to the German Constitutional Court's Solange I decision, the EC/EU formalised its scheme of fundamental rights protection culminating in the European Charter of Fundamental Rights and-perhaps-the accession of the EU to the ECHR. Arguably, it was in reaction to the CJEU's Kadi decision and its progeny that the United Nations 1267-sanctions regime was complemented with an ombudsman procedure. ${ }^{144}$

At first glance, Sentenza 238/2014 strengthens the position of the individual against the state. But on a more profound level, it strengthens unilateralism and particularism over universalism and multilateralism. As Heike Krieger highlights, these kinds of challenges to the normativity of the international legal order are troubling. Sentenza 238/2014 ultimately gives priority to one state's national outlook about what constitutes a proper legal order over the universal standard pronounced by an international court. Concededly, this ICJ standard is unsatisfactory and seems to be biased in favour of the stability of an interstate system. On the other hand, it still has the merit of being universal. The lack of an ultimate arbiter tends to result in the political dominance of the more powerful actors which are normally the domestic ones such as the Italian Corte Costituzionale-and the German Bundesverfassungsgericht. One way out would be to establish such an arbiter. ${ }^{145}$

\footnotetext{
${ }^{144}$ UN Security Council, Resolution 1904 (17 December 2009), which has been gradually improved, UN SC Res. 1989 (17 June 2011).

${ }^{145}$ As recently proposed by Daniel Sarmiento and Joseph H H Weiler in the aftermath of the Bundesverfassungsgericht's ultra vires pronouncement. The authors suggested to establish a mixed chamber, composed of both European and national judges, to decide about allegations that an international body acts ultra vires and thereby infringes national sovereignty (and national constitutional law). Daniel Sarmiento/Joseph H H Weiler, 'The EU Judiciary After Weiss: Proposing A New Mixed Chamber of the Court of Justice', VerfBlog, (2 June 2020), available at https:// verfassungsblog.de/the-eu-judiciary-after-weiss/. See also along this line, Christine Landfried, 'Politische Versäumnisse', Neue Zürcher Zeitung (18 June 2020).
} 
As long as this is missing, we need to work towards what has been called a 'pluralisme ordonné. 146

\section{A 'Modest Proposal'}

This book reflects multiple sensibilities and different perspectives on the issue of war crimes, immunities and reparation. Although an idem sentire is recognizable among the authors, they meaningfully disagree on strategies for a sustainable solution of the stalemate. This variety of viewpoints prevents us from adopting one shared conclusion and explains the form of the 'dialogical' epilogue en lieu de conclusion.

As editors, in a purely personal capacity, we nevertheless submit a five-step 'modest proposal' which is inspired by ideas formulated by numerous authors, and represents a short manifesto ideally addressed to decisionmakers.

\section{Negotiations}

Political talks concerning the issue at hand should be resumed as soon as possible, as already encouraged by the ICJ in its 2012 Judgment. ${ }^{147}$ Further legal action, eg filing another case before the ICJ, would not lead to an effective solution and would come at the expense of the victims.

\section{Reparation}

A joint German-Italian reparation fund should be created to provide lump sum payments to the victims. A prior stocktaking of the reparation measures adopted so far and a non-bureaucratic registration of victims would form the basis for the creation of such a fund. When compiling the list of victims and determining the most important reparation criteria (eligibility requirements, level, and type of reparation), Italy could take over a leading role and send an important sign of assuming responsibility towards its own citizens. Criteria based on the economic need of victims could also be taken into consideration.

\section{Victims}

There is a need to recognize those victims who have thus far received no attention, including the IMIs. Together with the payment of an-at least symbolic_reparation sum, such recognition would generate satisfaction, encouraging pacification. $^{148}$

\footnotetext{
${ }^{146}$ Mireille Delmas-Marty, Le pluralisme ordonné: Les forces imaginantes du droit (Paris: Seuil 2006).

147 ' The Court] considers (...) that the claims (...) could be the subject of further negotiation involving the two States concerned, with a view to resolving the issue.' ICJ, Jurisdictional Immunities (n 2), para 104.

${ }^{148}$ In the end, it may be less the 'status' of victim which is disputed but the legal (and economic) consequences, namely the entitlement to financial compensation. See for an empirical analysis of the pronounced preferences of victims for monetary compensation over other forms of 'reparation',
} 
Where a direct victim had lost her or his life as a consequence of wrongful acts, the heirs can bring a case before courts. First degree relatives (in the vertical line) and the spouse should be considered as direct victims still affected by the events. In principle, no other relatives or further generations of heirs should be eligible for lump sum reparation.

\section{Actors}

Besides the Italian and German foreign ministers, the Heads of State could assume a leading role in initiating the necessary steps. It is advisable to involve civil society organizations as well as other non-state actors.

\section{Time-Factor}

Effective reparation requires adopting the aforesaid measures urgently. At the same time, determined action might be appreciated as manifesting cooperation within Europe and as underlining Italy's and Germany's unreserved commitment to safeguarding human rights and promoting human dignity.

\section{Post (Personal) Scriptum}

\section{Valentina Volpe}

For a long time, a shared family memory portrayed my grandfather Giuseppe Volpe, Maresciallo dei Carabinieri, as a deportee in the concentration camp of Dachau. We knew few things about his imprisonment: the couple of letters he sent, the watch and the wedding ring he wore, and the fact that he died in this same camp, on Christmas Eve 1944, mere months before liberation. Contradicting decades of family narrations, recent databases dedicated to non-returned IMI's indicated, in fact, a camp on the French territory, in the Vosges mountains, as the alleged destination of his European wartime journey.

Coincidenze The Natzweiler-Struthof camp was located just a few kilometers from Strasbourg, the city where I spent my Erasmus year. Exactly 60 years after the end of WWII, I was living, in the same places of my grandfather's imprisonment, one of the most genuine experiences of European companionship, and 'companion'-as Mario Rigoni Stern once wrote-etymologically unites those who shared the same bread ('cum panis'). ${ }^{149}$ As I was gradually getting used to the image of the peaceful Vosges mountains as his ultimate resting place, additional coincidences linked to this volume's research began to emerge, bringing our discontinuous stories closer. The NatzweilerStruthof concentration camp, as Dachau before, turned out to be just another intermediate stop in his deportation journey.

Prakash Adhikari/Wendy L Hansen, 'Reparations and Reconciliation in the Aftermath of Civil War', Journal of Human Rights 12 (2013), 423-446, at 441. These findings concern victims of recent conflicts who need the money to rebuild their lives out of the ruins of war. The preferences may be different when it comes to crimes lying further in the past.

${ }^{149}$ Mario Rigoni Stern, Letter to the Provincial Congress of the ANPI Treviso, 2007, Il Calendario del Popolo (August-September 2008). 
In the German city of Heilbronn, in the district of Neckargartach, there is a small concentration camp cemetery near the river Neckar in which 246 deportees were laid to rest. It was there that I discovered Giuseppe Volpe's resting place in May 2018. If finally, there is a flower on his memorial, it is thanks to this volume. ${ }^{150}$ Heilbronn is just an hour's drive from Heidelberg, the city in which I completed my postdoctoral research on human rights and international law at the MPIL, and where this book about interstate conciliation was conceived. For three years, unaware, we have been both, grandfather and granddaughter, contemplating the same Neckar river, which crosses both Heidelberg and Heilbronn, silently linking our generations.

I dedicate this book to nonno Giuseppe who I never met, to his generation and to my own, to those in-between and especially to those to come. May they handle the unprecedented, yet fragile, privilege of being com-panions in Europe with care.

\section{References}

Adhikari, Prakash/Wendy L Hansen, 'Reparations and Reconciliation in the Aftermath of Civil War', Journal of Human Rights 12 (2013), 423-446

van Alebeek Rosanne/Riccardo Pavoni, 'Immunities of States and their Officials', in André Nollkaemper/August Reinisch et al (eds), International Law in Domestic Courts: A Casebook (Oxford: OUP 2018), 100-169

Aust, Helmut Philipp/Georg Nolte (eds), The Interpretation of International Law by Domestic Courts: Uniformity, Diversity, Convergence (Oxford: OUP 2016)

Battini, Stefano, 'È costituzionale il diritto internazionale?', Giornale di diritto amministrativo 3 (2015), 367-377

Bílková, Veronika, 'Populism and Human Rights', Netherlands Yearbook of International Law 49 (2018), 143-174

Björgvinsson, Davíd Thór, The Intersection of International Law and Domestic Law: A Theoretical and Practical Analysis (Cheltenham: Edward Elgar 2015)

Boggero, Giovanni, 'The Legal Implications of Sentenza No. 238/2014 by Italy's Constitutional Court for Italian Municipal Judges: Is Overcoming the "Triepelian Approach" Possible?', Heidelberg Journal of International Law, 76 (2016), 203-224

\footnotetext{
${ }^{150}$ I particularly need to thank the precious and voluntary work of Roberto Zamboni and his website Dimenticati di Stato, https://dimenticatidistato.com. He has been the only source to correctly cite the camp of Heilbronn, where I could discover the concentration camp cemetery and memorial, while closing some family circles. He also reconstructed all the steps of my grandfather's painful European journey and found additional archive material. I also want to thank Enzo Orlanducci, President of the National Association of the POWs, military and civilian camp internees and combatants of the War of Liberation and their families (Associazione Nazionale Reduci dalla Prigionia, dall'Internamento, dalla Guerra di Liberazione e loro familiari, ANRP), for the time he kindly dedicated to me on the occasion of a visit to the Rome Museum Vite di IMIs and for having included Giuseppe Volpe's story within the IMIs' database.

Giuseppe Volpe was born on 21 January 1905 in La Maddalena, in Sardinia. Maresciallo dei Carabinieri, he was captured on the Croatian front after 8 September 1943 and deported with another 101 prisoners on a convoy leaving from Trieste in December. The train had as its destination the Dachau concentration camp. Upon arrival, he was assigned the serial number 60657 and was classified as deported for precautionary reasons (abbreviation SCH Schutzhäftlinge/ Sch. Itl. 'Italian prisoner'). On 27 March 1944, he was transferred to the Natzweiler concentration camp in Alsace and then finally deported to the Neckargartach subcamp, in Heilbronn, Germany. Giuseppe Volpe died on Christmas Eve 1944, at the age of 39.
} 
Boggero, Giovanni, 'Giustizia per i crimini internazionali di guerra nella strage di Civitella?', in Procura Generale Militare della Repubblica presso la Corte Suprema di Cassazione (ed), Casi e 'materiali' di diritto penale militare (Rome: Stabilimento Grafico Militare 2012), 277-303.

Boudreault, François, 'Identifying Conflicts of Norms: The ICJ Approach in the Case of the Jurisdictional Immunities of the State (Germany v. Italy: Greece Intervening)', Leiden Journal of International Law 25 (2012), 1003-1012

Buffa, Francesco, 'Introduzione: I diritti fondamentali tra obblighi internazionali e Costituzione', Questione Giustizia 1 (2015), 45-50

Butt, Daniel, Rectifying International Injustice: Principles of Compensation and Restitution Between Nations (Oxford: OUP 2008)

Cannizzaro, Enzo, 'Jurisdictional Immunities and Judicial Protection: The Decision of the Italian Constitutional Court No. 238 of 2014', Rivista di diritto internazionale 98 (2015), 126-134

Cassese, Sabino, 'Il Guinzaglio Tedesco', Il Foglio, 19 May 2020

Cataldi, Giuseppe, 'A Historic Decision of the Italian Constitutional Court on the Balance between the Italian Legal Order's Fundamental Values and Customary International Law', The Italian Yearbook of International Law 24 (2015), 37-52

Ciampi, Annalisa, 'The Italian Court of Cassation Asserts Civil Jurisdiction Over Germany in a Criminal Case Relating to the Second World War: The Civitella Case', Journal of International Criminal Justice 7 (2009), 597-615

Conforti, Benedetto, 'The Judgment of the International Court of Justice on the Immunity of Foreign States: A Missed Opportunity', The Italian Yearbook of International Law 21 (2011), $133-142$

Correa, Cristián/Shuichi Furuya/Clara Sandoval, Reparation for Victims of Armed Conflict, Max Planck Trialogues on the Law of Peace and War, Vol 3, edited by Anne Peters/Christian Marxsen (Cambridge: CUP 2020)

D'Argent, Pierre/Pauline Lesaffre, 'Immunities and Jus Cogens Violations', in Tom Ruys/Nicolas Angelet/Luca Ferro (eds), The Cambridge Handbook of Immunities and International Law (Cambridge: CUP 2019), 614-633

Delmas-Marty, Mireille, Le pluralisme ordonné: Les forces imaginantes du droit (Paris: Seuil 2006)

Douzinas, Costas, The End of Human Rights: Critical Thought at the Turn of the Century (Oxford: Hart 2000)

Espósito, Carlos, 'Jus Cogens and Jurisdictional Immunities of States at the International Court of Justice: A Conflict Does Exist', Italian Yearbook of International Law 21 (2011), 161-174

Fox, Hazel/Philippa Webb, The Law of State Immunity (Oxford: OUP $3^{\text {rd }}$ ed 2013)

Frulli, Micaela, “Time Will Tell Who Just Fell and Who's Been Left Behind": On the Clash between the International Court of Justice and the Italian Constitutional Court', Journal of International Criminal Justice 14 (2016), 587-594

Gaeta, Paola, 'Immunity of States and State Officials: A Major Stumbling Block to Judicial Scrutiny?', in Antonio Cassese (ed), Realizing Utopia: The Future of International Law (Oxford: OUP 2012), 227-238

Hartwig, Matthias, 'Vom Dialog zum Disput? Verfassungsrecht vs. Europäische Menschenrechtskonvention: Der Fall der Russländischen Förderation', Europäische Grundrechtezeitschrift 44 (2017), 1-23

Heinemann, Patrick O, 'Die deutschen Genozide an den Herero und Nama: Grenzen der rechtlichen Aufarbeitung', Der Staat 55 (2016), 461-487

van den Herik, Larissa, 'Reparation for Decolonisation Violence: A Short Overview of Recent Dutch Litigation', Heidelberg Journal of International Law 78 (2018), 629-633

Höfelmeier, Anja, Die Vollstreckungsimmunität der Staaten im Wandel des Völkerrechts (Berlin: Springer 2018)

Hopgood, Stephen, The Endtimes of Human Rights (Ithaca/New York: Cornell University Press 2013) 
Huneeus, Alexandra, 'Courts Resisting Courts: Lessons from the Inter-American Court's Struggle to Enforce Human Rights', Cornell International Law Journal 44 (2011), 493-533

Iovane, Massimo, 'The Italian Constitutional Court Judgment No. 238 and the Myth of the "Constitutionalization" of International Law', Journal of International Criminal Justice 14 (2016), 595-605

Johnstone, Gerry/Joel Quirk, 'Repairing Historical Wrongs', Social \& Legal Studies 21 (2012), $155-169$

Kahn, Jeffrey, 'The Relationship between the European Court of Human Rights and the Constitutional Court of the Russian Federation: Conflicting Conceptions of Sovereignty in Strasbourg and St Petersburg', European Journal of International Law 30 (2019), 933-959

Kanetake, Machiko/André Nollkaemper, The Rule of Law at the National and International Levels: Contestation and Deference (Oxford: Hart 2016)

Kelsen, Hans, Principles of International Law (Robert W Tucker (ed), New York: Holt Rinehart and Winston $2^{\text {nd }}$ ed 1966)

Kolb, Robert, 'The Relationship between the International and the Municipal Legal Order: Reflections on the Decision no 238/2014 of the Italian Constitutional Court', Questions of International Law: Zoom Out 2 (2014), 5-16

Krajewski, Markus/Christopher Singer, 'Should Judges be Front-Runners? The ICJ, State Immunity and the Protection of Fundamental Human Rights', Max Planck Yearbook of United Nations Law 16 (2012), 1-34

Kunz, Raffaela, 'Judging International Judgments Anew? The Human Rights Courts before Domestic Courts', European Journal of International Law 30 (2019), 1129-1163

Kunz, Raffaela, Richter über internationale Gerichte? (Heidelberg: Springer 2020)

Lenzerini, Federico (ed), Reparations for Indigenous Peoples: International and Comparative Perspectives (Oxford: OUP 2008)

Lewis, Kenneth L Jr, 'The Namibian Holocaust: Genocide Ignored, History Repeated, Yet Reparations Denied', Florida Journal of International Law 29 (2017), 133-149

Mariottini, Cristina M, 'Case Note: Deutsche Bahn AG v. Regione Stereá Ellada', American Journal of International Law 114 (2020), 486-493

Mälksoo, Lauri, 'Russia's Constitutional Court Defies the European Court of Human Rights: Constitutional Court of the Russian Federation Judgment of 14 July 2015, No 21-П/2015', European Constitutional Law Review 12 (2016), 377-395

McGregor, Lorna, 'State Immunity and Human Rights: Is There a Future after Germany v. Italy?', Journal of International Criminal Justice 11 (2013), 125-145

Mchangama, Jacob/Guglielmo Verdirame, 'The Danger of Human Rights Proliferation: When Defending Liberty, Less Is More', Foreign Affairs (24 July 2013)

Mutua, Makau, 'Is the Age of Human Rights Over?', in Sophia A McClennen/Alexandra Schultheis Moore (eds), The Routledge Companion to Literature and Human Rights (London: Routledge 2016), 450-458

Negishi, Yota, 'The Pro Homine Principle's Role in Regulating the Relationship between Conventionality Control and Constitutionality Control', European Journal of International Law 28 (2017), 457-481

Negri, Stefania, 'Sovereign Immunity v. Redress for War Crimes: The Judgment of the International Court of Justice in the Case Concerning Jurisdictional Immunities of the State (Germany v. Italy)', International Community Law Review 16 (2014), 123-137

Nelaeva, Galina A/Elena A Khabarova/Natalia V Sidorova, 'Russia's Relations with the European Court of Human Rights in the Aftermath of the Markin Decision: Debating the "Backlash", Human Rights Review 21 (2020), 93-112

Nollkaemper, André, National Courts and the International Rule of Law (Oxford: OUP 2012)

Oellers-Frahm, Karin, 'A Never-Ending Story: The International Court of Justice-The Italian Constitutional Court-Italian Tribunals and the Question of Immunity', Heidelberg Journal of International Law 76 (2016), 193-202 
Özdan, Selman, 'State Immunity or State Impunity in Cases of Violations of Human Rights Recognised as Jus Cogens Norms', The International Journal of Human Rights 23 (2019), 1521-1545

Padskocimaite, Ausra, 'Constitutional Courts and (Non)execution of Judgments of the European Court of Human Rights: A Comparison of Cases from Russia and Lithuania', Heidelberg Journal of International Law 77 (2017), 651-684

Palombella, Gianluigi, 'German War Crimes and the Rule of International Law', Journal of International Criminal Justice 14 (2016), 607-613

Peters, Anne, 'Supremacy Lost: International Law Meets Domestic Constitutional Law', Vienna Journal on International Constitutional Law 3 (2009), 170-198

Peters, Anne, 'Let not Triepel Triumph-How To Make The Best Out of Sentenza No. 238 of the Italian Constitutional Court for a Global Legal Order', EJIL Talk!, (22 December 2014), available at www.ejiltalk.org/let-not-triepel-triumph-how-to-make-the-best-out-of-sentenzano-238-of-the-italianconstitutional-court-for-a-global-legal-order-part-i/

Peters, Anne/Evelyne Lagrange/Stefan Oeter/Christian Tomuschat (eds), Immunities in the Age of Global Constitutionalism (Leiden: Brill 2015)

Peters, Anne, 'Immune against Constitutionalisation?' in Anne Peters/Evelyne Lagrange/Stefan Oeter/Christian Tomuschat (eds), Immunities in the Age of Global Constitutionalism (Leiden: Brill 2015), 1-19

Peters, Anne, Beyond Human Rights: The Legal Status of the Individual in International Law (Cambridge: CUP 2016)

Peters, Anne, 'The Refinement of International Law: From Fragmentation to Regime Interaction and Politicization', International Journal of Constitutional Law 15 (2017), 671-704

Peters, Anne/Valentina Volpe, 'In Search for Conciliation-Conference Remedies against Immunity?', VerfBlog, (11 May 2017), available at http://verfassungsblog.de/introduction-in-searchfor-conciliation

Pezzino, Paolo, 'The German Military Occupation of Italy and the War against Civilians', Modern Italy 12 (2007), 173-188

Pinelli, Cesare, 'Decision no. 238/2014 of the Constitutional Court: Between Undue Fiction and Respect for Constitutional Principles', Questions of International Law: Zoom Out 2 (2014), $33-41$

Pollicino, Oreste, 'From Academia to the (Constitutional) Bench', Diritto pubblico comparato ed europeo 4 (2015), 1117-1140

Romeo, Graziella, 'Looking Back in Anger and Forward in Trust: The Complicate Patchwork of the Damages Regime for Infringements of Rights in Italy', in Ewa Bagińska (ed), Damages for Violations of Human Rights: A Comparative Study of Domestic Legal Systems (Heidelberg: Springer 2016), 217-240

Ruys, Tom/Nicolas Angelet/Luca Ferro (eds), The Cambridge Handbook of Immunities and International Law (Cambridge: CUP 2019)

Salerno, Francesco, 'Giustizia costituzionale versus giustizia internazionale nell'applicazione del diritto internazionale generalmente riconosciuto', Quaderni Costituzionali 35 (2015), 33-58

Sarmiento, Daniel/Joseph H H Weiler, 'The EU Judiciary After Weiss: Proposing A New Mixed Chamber of the Court of Justice', VerfBlog, (2 June 2020), available at https://verfassungsblog. de/the-eu-judiciary-after-weiss/

Scelle, Georges, 'Le phénomène juridique du dédoublement fonctionnel', in Walter Schätzel/HansJürgen Schlochauer (eds), Rechtsfragen der internationalen Organisation: Festschrift für Hans Wehberg zu seinem 70. Geburtstag (Frankfurt a M: Vittorio Klostermann 1956), 324-342

Scheinin, Martin, 'The Italian Constitutional Court's Judgement 238 of 2014 Is Not Another Kadi Case', Journal of International Criminal Justice 14 (2016), 615-620

Soley, Ximena/Silvia Steininger, 'Parting Ways or Lashing Back? Withdrawals, Backlash and the Inter-American Court of Human Rights', International Journal of Law in Context 14 (2018), $237-257$ 
Talmon, Stefan, 'Jus Cogens after Germany v. Italy: Substantive and Procedural Rules Distinguished', Leiden Journal of International Law 25 (2012), 979-1002

Triepel, Heinrich, Völkerrecht und Landesrecht (Leipzig: Verlag von C L Hirschfeld 1899)

Tzanakopoulos, Antonios, 'Domestic Courts in International Law: The International Judicial Function of National Courts', Loyola of Los Angeles International and Comparative Law Review 34 (2011), 133-168

Veronesi, Paolo, Colpe di stato: I crimini di guerra e contro l'umanità davanti alla Corte costituzionale (Milan: Franco Angeli 2017)

Webb, Philippa, 'A Moving Target: The Approach of the Strasbourg Court to Immunity', in Anne van Aaken/Iulia Motoc (eds), The European Convention on Human Rights and General International Law (Oxford: OUP 2018), 251-263

Würkert, Felix, 'Historische Immunität? Anmerkung zu Sentenza Nr. 238 der Corte Costituzionale vom 22. Oktober 2014', Archiv des Völkerrechts 53 (2015), 90-120

Wuerth, Ingrid, 'International Law in the Post-Human Rights Era', Texas Law Review 96 (2017), 279-349

Open Access This chapter is licensed under the terms of the Creative Commons Attribution 4.0 International License (http://creativecommons.org/licenses/by/4.0/), which permits use, sharing, adaptation, distribution and reproduction in any medium or format, as long as you give appropriate credit to the original author(s) and the source, provide a link to the Creative Commons license and indicate if changes were made.

The images or other third party material in this chapter are included in the chapter's Creative Commons license, unless indicated otherwise in a credit line to the material. If material is not included in the chapter's Creative Commons license and your intended use is not permitted by statutory regulation or exceeds the permitted use, you will need to obtain permission directly from the copyright holder. 
Part II

Immunity 


\title{
Right of Access to (Italian) Courts über alles? Legal Implications Beyond Germany's Jurisdictional Immunity
}

\author{
Paolo Palchetti
}

\begin{abstract}
The main consequence of Sentenza 238/2014 is that Germany has been denied jurisdictional immunities before Italian courts. However, the inflexible conception of the right of access to courts adopted by the Corte Costituzionale gives rise to a number of questions that go well beyond the issue at stake in Judgment $238 / 2014$. First, there is the issue of whether the right of access to justice should also prevail over the international customary rule on immunity from execution. Secondly, one may ask whether the need to protect the right provided by Article 24 of the Italian Constitution could trump the criteria established by Italian law for exercising civil jurisdiction in order to allow access to justice in respect to all international crimes, even those committed outside Italian territory and involving individuals having no link to Italy. Finally, there is the question of whether a sacrifice of the right of access to justice would be justified if alternative, non-judicial means of redress were available to the victims; in particular, whether an alternative means of redress should in any case ensure to each and every individual victim full compensation or whether instead, in light of the specific circumstances of the case-the fact that the crimes occurred in the course of an international armed conflict affecting hundreds of thousands of victims-such alternative means could provide only symbolic compensation based on a lump sum settlement. This chapter aims at exploring these and possibly other issues arising in connection to the broad interpretation of the principle of access to justice given by the Corte Costituzionale.
\end{abstract}

\footnotetext{
P. Palchetti $(\bowtie)$

University Paris 1 Panthéon Sorbonne, School of Law, Paris, France

e-mail: paolo.palchetti@univ-paris1.fr 


\section{Introduction}

International legal thinking has long been dominated by the perception of the state as a unitary subject. In strict legal terms, the unity of the state entails that the conduct of any state organ is to be regarded as the conduct of the state itself for the purposes of establishing international responsibility. It also entails that, in general, in international law and practice, it is the executive of the state that represents the state in its international relations and speaks for it at the international level'. ${ }^{1}$ The concept of the state as a unitary subject evidently relies on a legal fiction. Reality is more complex: behind the unitary veil of the state, there is a plurality of organs; these organs, at times, speak in different voices on questions of international law; they may have different priorities when performing acts that have international implications; and some of these organs are constitutionally independent from the executive.

The 'need to look behind the monolithic face of the State' becomes crucial for understanding the 'Italian concerns' following Judgment $238 / 2014 .^{2}$ In parallel with the interstate dispute between Germany and Italy, the question of Germany's immunity before Italian courts has generated an intense and prolonged confrontation between different organs of the Italian state. On the one side, there is a hyperactive judiciary, which appears determined to provide court access to victims through a controversial interpretation of international rules and, in the case of the Italian Constitutional Court (ItCC), irrespective of the costs in terms of compliance with the international rule of law. On the other side, there are political organs of the state that have shown a certain reluctance in engaging in meaningful political initiatives, both at the international and the intra-national level, for addressing the claims of victims. At an initial stage, the point of conflict concerned the determination of customary international rules on state immunity, with the judiciary and the executive expressing differing views as to the existence of an exception to immunity in cases of grave breaches of human rights and humanitarian law. Later the conflict centred around the implementation of the International Court of Justice's (ICJ) Jurisdictional Immunities Judgment: while the executive and parliament focused their efforts on securing Germany's immunity without apparently taking care of the fate of the victims' claims, the ItCC had no hesitation in giving precedence to the right to jurisdictional protection over compliance with the 2012 ICJ Judgment.

This internal confrontation explains the difficulty in discerning a unitary and coherent position of the state. It also explains the current deadlock in the conflicting approaches. Admittedly, after Judgment 238/2014 the room to manoeuvre available

\footnotetext{
${ }^{1}$ ICJ, Application of the International Convention on the Elimination of All Forms of Racial Discrimination (Georgia v Russian Federation), Preliminary Objections, Judgment of 1 April 2011, ICJ Reports 2011, 70, para 37.

${ }^{2}$ I borrowed this expression from Rosalyn Higgins, 'The Concept of "The State": Variable Geometry and Dualist Perceptions', in Laurence Boisson de Chazournes/Vera Gowlland-Debbas (eds), The International Legal System in Quest of Equity and Universality, Liber Amicorum Georges Abi-Saab (The Hague: Kluwer 2001), 547-561, at 561.
} 
to political organs appears limited. Yet, the Italian judiciary itself appears to be in no better position. With dozens of proceedings against Germany nearing their completion, the question of the enforcement of these judgments looms ahead. The ItCC may soon be called upon to assess the compatibility of the Italian Constitution with the customary international rule on immunity from execution. The choice would be a hard one. Denying immunity from execution because of its inconsistency with the Constitution would have far reaching consequences. Should the ItCC reach the opposite conclusion, the protection afforded to the victims by Judgment 238/2014 would be emptied of much of its substance.

While the main consequence of Judgment 238/2014 is that Germany is currently being denied jurisdictional immunity before Italian courts, the inflexible conception of the right of access to court adopted by the Corte Costituzionale has a number of implications that go well beyond the specific question of Germany's jurisdictional immunity. First, one may ask what could be the impact of the Judgment 238/2014 on the attitude of Italian political organs as regards sovereign immunity for acta iure imperii amounting to international crimes, and in particular whether the Italian government is now constitutionally bound not to invoke immunity if claims for compensation arising from such crimes are brought against Italy before the domestic judges of another state. Secondly, there is the issue of whether, following the logic underlying Judgment 238/2014, the right of access to justice should also prevail over the international customary rule on immunity from execution. Thirdly, there is the question of whether the need to protect the right provided by Article 24 of the Italian Constitution could trump the criteria established by Italian law for exercising civil jurisdiction in order to allow access to justice in respect to all international crimes, even those committed outside the Italian territory and involving individuals having no link with Italy. And, finally, one ought to consider the question of whether a sacrifice to the right of access to justice would be justified if alternative, non-judicial means of redress were available to the victims; even assuming that Sentenza 238/2014 leaves open the possibility of having recourse to alternative means of redress, it remains to be seen what basic requirements these alternative means must meet. These are some of the issues arising in connection to the broad interpretation of the principle of access to justice given by the Corte Costituzionale. They will be examined in turn in the following paragraphs.

\section{The Impact of Judgment 238/2014 on the Italian Government As Regards the Recognition of Immunity}

The Ferrini Judgment, ${ }^{3}$ as well as all subsequent judgments of Italian courts until 2012, were based on the premise that under international law there existed an exception to immunity in cases of international crimes and that denying immunity

\footnotetext{
${ }^{3}$ Corte di Cassazione, Judgment of 11 March 2004, No 5044/2004 (Ferrini), in Rivista di diritto internazionale 87 (2004), 540 et seq.
} 
to Germany, therefore, did not engage Italy's international responsibility. Before the ICJ, the Italian government defended the view of Italian courts on the conviction that a judgment could be regarded as authoritative by the different actors involved only if rendered after an extensive review of all the arguments put forward by Italian courts. In its Jurisdictional Immunities Judgment, the ICJ addressed these arguments and found that they had no basis in current international law. ${ }^{4}$ Unlike the Ferrini Judgment, Judgment 238/2014 is not based on the view that under international law Italy is entitled to deny immunity to Germany. The ItCC recognized that, because of the authority of the ICJ, the view expressed by that Court on the content of the law on state immunity has to be regarded as reflecting the current status of the law on the matter. ${ }^{5}$

While admitting that international law currently grants immunity for acta iure imperii, even if these acts amount to international crimes, there is little doubt that, by its Sentenza, the ItCC clearly aimed at contributing to the development of the international law on state immunity. Not only did it expressly note that a further reduction of the scope of the international rule on state immunity, particularly in cases of international crimes, would be 'a desirable — and desired by many-evolution of international law, ${ }^{6}$ it also referred to the role of domestic judges in the development of customary international law. In this respect, it could be said that with Judgment 238/2014 the ItCC contributed in setting the position of the Italian state with regard to the content of the rule on state immunity in cases of grave breaches of human rights and humanitarian law. It is less clear whether and to what extent the other organs of the state will follow this view when confronted with the question of state immunity beyond the cases brought against Germany.

So far, Italian political organs appear to have refrained from openly aligning themselves to the indications coming from the ItCC. Significantly, in proceedings pending before Italian courts against Germany, the executive has continued to plead in favour of a dismissal of the case for a lack of jurisdiction. ${ }^{7}$ Since in principle Judgment 238/2014 only concerned the applicability of the international rule of immunity by Italian courts in relation to a specific situation, the executive may have an interest in containing the impact of that Judgment by denying it any possible effect beyond its strict scope of application. In this respect, the fact that the executive might continue to defend the view that a state is entitled to immunity for acta iure imperii, irrespective of whether these acts amount to international crimes, has an impact on the attempt made by the ItCC to prompt a development of the international

\footnotetext{
${ }^{4}$ ICJ, Jurisdictional Immunities of the State (Germany v Italy: Greece intervening), Judgment of 3 February 2012, ICJ Reports 2012, 99, para 139.

${ }^{5}$ Corte Costituzionale, Judgment of 22 October 2014, No 238/2014, Conclusions in point of law, para 3.1.

${ }^{6}$ Ibid, para 3.3.

${ }^{7}$ See Karin Oellers-Frahm, 'A Never-Ending Story: The International Court of Justice-The Italian Constitutional Court-Italian Tribunals and the Question of Immunity', Heidelberg Journal of International Law 76 (2016), 193-202, at 195-196. See also Heike Krieger, chapter 'Sentenza 238/ 2014: A Good Case for Law-Reform?', in this volume.
} 
law of state immunity. Since the state practice must be assessed 'as a whole', the inconsistency in the practice of different organs within the Italian state would have the effect of reducing the weight to be given to that practice. ${ }^{8}$

From this perspective, it cannot be ruled out that Italy would invoke immunity if claims for compensation arising from international crimes committed by Italy during World War II (WWII) were brought against it before the domestic judges of another state. In the long run, however, particularly if Italian courts apply the principle upheld in Judgment 238/2014 to other situations and systematically deny immunity to states in cases involving the commission of international crimes, this inconsistent behaviour of the state would hardly be sustainable, let alone acceptable.

Finally, the possible impact of Judgment 238/2014 on Italy's compliance with the obligations stemming from the 2004 UN Convention on Jurisdictional Immunities of States and Their Property (UNCSI, or Convention) deserves a mention. At the time of the UNCSI's ratification in 2012, Italy made a declaration whereby it underlined 'that Italy understands that the Convention will be interpreted and applied in accordance with the principles of international law and, in particular, with the principles concerning the protection of human rights from serious violations'. In addition, Italy made clear its understanding 'that the Convention does not apply to the activities of armed forces and their personnel, whether carried out during an armed conflict as defined by international humanitarian law, or undertaken in the exercise of their official duties'. ${ }^{9}$ Clearly, the first declaration, which only concerns 'principles of international law', cannot have the effect of ensuring the compatibility of the obligations stemming from the UNCSI with Judgment 238/2014. By limiting the Convention's scope of application in respect to Italy, the second declaration may offer some form of legal protection to Italy. Ironically, a declaration that was made essentially in order to protect Italian armed forces from the risk of being subjected to the jurisdiction of another state by virtue of the exceptions to immunity provided by the UNCSI may now become the instrument for avoiding a possible breach of the UNCSI: by excluding the activities of armed forces from the UNCSI's scope of application, the denial of immunity by Italian judges for acts committed by foreign

\footnotetext{
${ }^{8}$ See, in this regard, the work of the International Law Commission (ILC) on the identification of customary international law. Conclusion No 7, as approved on second reading in 2018, provides as follows: '1. Account is to be taken of all available practice of a particular State, which is to be assessed as a whole. 2. Where the practice of a particular State varies, the weight to be given to that practice may, depending on the circumstances, be reduced.' It should be noted that in its commentary the ILC held the view that 'the practice of the executive branch is often the most relevant on the international plane and thus has particular weight in connection to the identification of customary international law, though account may need to be taken of the constitutional position of the various organs in question'. ILC, Draft Conclusions on the Identification of Customary International Law, Report on the Work of the Seventieth session (2018), UN Doc. A/73/10, 135. In the present case, as the position of judges exercising jurisdiction over Germany finds its basis in a decision of the ItCC, it would be hard to maintain that the view of the executive should be given more weight than that accorded to the judiciary.

${ }^{9}$ The text of Italy's declaration is available at https://treaties.un.org/Pages/ViewDetails.aspx? src $=I N D \& m t d s g \_n o=I I I-13 \&$ chapter $=3 \&$ clang $=\_$en\#EndDec.
} 
troops would amount only to a breach of obligations under customary international law.

It has been suggested that the Italian government should withdraw these declarations and make a new one aimed at ensuring the compatibility of Italy's obligations under the Convention with the principles stemming from Judgment 238/2014. ${ }^{10}$ No doubt, as recognized by the International Law Commission (ILC), '[t]he fact that a treaty provision reflects a rule of customary international law does not in itself constitute an obstacle to the formulation of a reservation to that provision'. ${ }^{11}$ By making a declaration whereby, for instance, it excludes the applicability of the general rule of immunity set forth in Article 5 of the 2004 Convention in cases involving pecuniary compensation for serious human rights violations, Italy would make clear the existence of a constitutional obstacle to the full implementation of the Convention within its legal order. It remains to be seen what the reaction from the other parties would be. Considering that the UNCSI aims at enhancing 'the rule of law and legal certainty' by contributing 'to the codification and development of international law and the harmonization of practice in this area', ${ }^{12}$ it would not be surprising if this reservation could be regarded as running contrary to the object and purpose of the Convention.

\section{A 'Containment Strategy'?: Immunity from Jurisdiction and Immunity from Execution}

Among the possible solutions to the situation created by Judgment 238/2014, one is, most simply, to accept this situation on the assumption that the judgments of Italian courts ordering Germany to pay compensation to the victims and their heirs will have little practical effects thanks to the protection afforded to states' properties by the customary international rule on immunity from execution. Such a minimalistic approach, aimed only at containing the consequences of Judgment 238/2014, relies on the fact that since the ItCC's Judgment 238/2014 only deals with immunity from jurisdiction, by virtue of Article 10 of the Italian Constitution, the international rule on immunity from execution continues to produce its effect within the Italian legal order. ${ }^{13}$ The distinction between immunity from jurisdiction and immunity from

\footnotetext{
${ }^{10}$ Francesco Salerno, 'Giustizia costituzionale versus giustizia internazionale nell'applicazione del diritto internazionale generalmente riconosciuto', Quaderni Costituzionali 35 (2015), 33-58, at 57.

${ }^{11}$ See Guideline 3.1.5.3 of the Guide to Practice on Reservations to Treaties adopted by the ILC in 2011, UN Doc. A/66/10, para 75.

${ }^{12}$ See the preamble of the UN Convention on Jurisdictional Immunities of States and Their Property (2 December 2004), UN Doc A/RES/59/38, UN Doc A/59/49, 486 (not yet in force).

${ }^{13}$ See ItCC, Judgment 238/2014 (n 5), Conclusions in point of law, para 1 ('the referring judge limits the questions raised to the issue of the jurisdiction to examine the claim for compensation for damages, and does not include the issue of enforcement action'). See also Heike Krieger, chapter 'Sentenza 238/2014: A Good Case for Law-Reform?', in this volume.
} 
execution has so far been respected by Italian courts. Thus, the Court of Appeals of Milan recognized that under customary international law no post-judgment measures of constraint can be taken against the property of a state that is in use or intended to be used for non-commercial government purposes; for that reason, it confirmed the decision of the Tribunal of Como ordering that the mortgage on Villa Vigoni inscribed at the land registry be cancelled. ${ }^{14}$

The importance attached by political organs to the protection offered by immunity from execution is reflected in a new statutory provision adopted a few weeks after Judgment 238/2014. Article 19 bis of Italian Law-decree No 132, converted into Law No 162 of 10 November 2014, exempts from attachment any amount of money in the availability of subjects involved in one of the following functions: diplomatic mission of the state or its consular posts, special missions, missions to international organizations or delegations to organs of international organizations or to international conferences. ${ }^{15}$ Interestingly, such an exemption is only conditional on a declaration made by the head of the diplomatic mission, by which it is said that the relevant bank account is exclusively intended for use for the abovementioned functions. $^{16}$

No doubt, from the viewpoint of international law, the distinction between immunity from jurisdiction and immunity from execution rests on solid grounds. ${ }^{17}$ In its Jurisdictional Immunities Judgment, the ICJ observed that ' $[\mathrm{t}]$ he rules of customary international law governing immunity from enforcement and those governing jurisdictional immunity (understood stricto sensu as the right of a State not to be the subject of judicial proceedings in the courts of another State) are distinct, and must be applied separately'. ${ }^{18}$ The ItCC, in a judgment rendered in 1992, also recognized that the rule on immunity from execution is autonomous and distinct from that on immunity from jurisdiction. ${ }^{19}$

However, relying on the protection afforded to Germany by the international rule on immunity from execution can hardly be regarded as a satisfactory solution. First, as already observed, it is likely that sooner or later the question of the compatibility

\footnotetext{
${ }^{14}$ Corte d'Appello di Milano, Order of 25 March 2015, No 4183/2013.

${ }^{15}$ Italian Law 10 November 2014, No 162.

${ }^{16}$ On this point, see the critical remarks of Benedetto Conforti, 'Il legislatore torna indietro di circa novant'anni: la nuova norma sull'esecuzione su conti correnti di Stati stranieri', Rivista di diritto internazionale 98 (2015), 558-561. See also Riccardo Pavoni, chapter 'A Plea for Legal Peace', in this volume.

${ }^{17}$ On the separateness of the regimes governing immunity from jurisdiction and immunity from execution see, among others, Ian Sinclair, 'The Law of Sovereign Immunity: Recent Developments', Recueil des cours 168 (1980-II), 115-284, at 218; August Reinisch, 'State Immunity from Enforcement Measures', in Gerhard Hafner/Marcelo Kohen/Susan Breau (eds), State Practice Regarding State Immunity (Leiden/Boston: Martinus Njhoff 2006), 151-166; Xiaodong Yang, State Immunity in International Law (Cambridge: CUP 2012), at 347 et seq.

${ }^{18} \mathrm{ICJ}$, Jurisdictional Immunities (n 4), para 113.

${ }^{19}$ Corte Costituzionale, Judgment of 15 July 1992, No 329/1992, in Rivista di diritto internazionale 75 (1992), 356 et seq.
} 
of such a rule with fundamental constitutional principles will be brought before the ItCC. While it is to be expected that the ItCC will take into account that 'the immunity from enforcement enjoyed by States in regard to their property situated on foreign territory goes further than the jurisdictional immunity enjoyed by those same States before foreign courts', ${ }^{20}$ the outcome of any future decision by the ItCC on immunity from execution is difficult to predict. In this respect, the fact that political organs have taken no initiative to address the substantial concerns underlying Judgment 238/2014 may become a factor that, in the overall assessment of the weight to be given to the competing interests at stake, risks weakening the arguments in favour of preserving immunity from execution.

Even if the ItCC were to recognize the compatibility of this international rule with the Italian Constitution, the presence of dozens of final judgments ordering Germany to pay compensation risks becoming a perennial source of tension, with the claimants attempting to enforce them through measures of constraint directed against German property in use for other than government non-commercial purposes. Such an outcome would also be extremely frustrating for the victims, who after having been told that they have a right to a judge and after having been awarded compensation would discover that they have substantially little, if any, chance of having their judgments enforced. Their situation would be similar to that of the relatives of the victims of the Distomo massacre, who were found to be entitled to compensation from the German state but were unable to obtain the execution of the judgment on account of the Greek state's refusal to allow them to bring enforcement proceedings against Germany. ${ }^{21}$ As that precedent shows, victims could hardly hope to obtain some form of redress by lodging a complaint before the European Court of Human Rights (ECtHR). While recognizing that ' $[t]$ he right of access to a tribunal would be illusory if a Contracting state's legal system allowed a final, binding judicial decision to remain inoperative to the detriment of one party', in Kalogeropoulou the ECtHR denied that the conduct of Greek authorities amounted to an unjustified interference with the complainants' right of access to a tribunal. The ECtHR relied on the existence of a generally recognized rule on state immunity from execution to conclude that 'although the Greek courts ordered the German state to pay damages to the applicants, this did not necessarily oblige the Greek state to ensure that the applicants could recover their debt through enforcement proceedings in Greece'. ${ }^{22}$

\footnotetext{
${ }^{20} \mathrm{ICJ}$, Jurisdictional Immunities (n 4), para 113.

${ }^{21}$ On this case see ICJ, Jurisdictional Immunities (n 4), paras 30-31.

${ }^{22}$ ECtHR, Kalogeropoulou and Others v Greece and Germany, Decision of 12 December 2002, Application No 59021/00.
} 


\section{Beyond State Immunity: The Criteria for Establishing the Jurisdiction of Italian Judges}

Italian courts have already shown a certain willingness to apply the principle upheld in Judgment 238/2014 beyond the cases brought against Germany. In its Judgment of 29 October 2015 in the Opačić case, a criminal division of the Court of Cassation relied on Judgment 238/2014 to justify the denial of immunity to Serbia in relation to a request for compensation advanced by the heirs of Italian victims of war crimes committed in the territory of the Former Yugoslavia in $1992 .^{23}$ This Judgment of the Court of Cassation is remarkable as it appears to expand the breadth of situations in which a denial of immunity would be justified. In particular, the Court of Cassation interpreted ItCC's Sentenza 238/2014 to the effect that in cases of international crimes immunity must be denied irrespective of whether there are alternative remedies available to the complainants in order to recover damages. ${ }^{24}$ Under this interpretation, the right of access to justice as provided by Article 24 of the Italian Constitution could not suffer any limitation even if some alternative forms of redress were available to the victims of international crimes committed by a foreign state. Should one accept this interpretation of Judgment 238/2014, it would follow that the introduction of some alternative form of protection following the conclusion of an agreement between Germany and Italy would not justify the possibility of restoring the immunity of Germany in accordance to international law. ${ }^{25}$

In Flatow and Eisenfeld, the Court of Cassation was called upon to rule on an exequatur request regarding a judgment of a US court condemning Iran to pay a sum of money to compensate the heirs of victims of acts of terrorism committed in Israel. In its Judgments of 28 October 2015, the Court of Cassation recognized that, according to the principle upheld in Judgment 238/2014, Iran would not have been entitled to immunity for acts amounting to crimes against humanity. In the end, however, it denied exequatur because of the non-fulfilment of the criteria established by Italian law for exercising civil jurisdiction. ${ }^{26}$

The Judgments in Flatow and Eisenfeld reveal a possible tension between the criteria for exercising civil jurisdiction and the effective protection of the right of

\footnotetext{
${ }^{23}$ Corte di Cassazione, Judgment of 29 October 2015, No 43696/2015 (Opačić).

${ }^{24}$ See ibid, para 5.2.1, Conclusions in point of law: 'Judgment 238/2014 of the Constitutional Court did not pose the condition that, in order to establish the jurisdiction over foreign states for war crimes, it is required that there is no other possibility for the victims to obtain redress for the damages suffered' (translated by the author). On this Judgment, see Riccardo Pavoni, 'How Broad is the Principle Upheld by the Italian Constitutional Court in Judgment No. 238?', Journal of International Criminal Justice 14 (2016), 573-585, at 577.

${ }^{25} \mathrm{I}$ will return to this issue in the next section.

${ }^{26}$ Corte di Cassazione, Judgment of 28 October 2015, No 21946/2015 (Flatow); Corte di Cassazione, Judgment of 28 October 2015, No 21947/2015 (Eisenfeld).
} 
access to justice as interpreted by the ItCC. Under the criteria established by Italian law, civil jurisdiction is based on some connection between the case and the forum. ${ }^{27}$ This means that, in the absence of the required nexus, access to justice may be precluded by the lack of jurisdiction of Italian courts. In Flatow and Eisenfeld, the Court of Cassation did not uphold the claim of the applicants that jurisdiction could be based on an international rule authorizing universal civil jurisdiction in cases of international crimes. It also excluded that Judgment 238/2014 had the effect of introducing the principle of universal civil jurisdiction in the Italian legal order. By strictly abiding by the criteria established by Italian law for exercising civil jurisdiction, the Court of Cassation substantially precluded access to justice in a situation in which - as the Court itself admitted - the principle of jurisdictional protection would have justified the denial of immunity to the respondent state. However, while the distinction between jurisdiction and immunity is unobjectionable, the whole situation appears to be characterized by a certain inconsistency: ${ }^{28}$ if, in cases of claims against a foreign state for international crimes, the right to access to justice must be given a prominent value, it is hard to explain why access to justice must not be precluded by the international rule of state immunity but can be precluded by domestic laws through which Italy delimits the scope of jurisdiction of its own judges. In this respect, the Judgments in Flatow and Eisenfeld illustrate that the decision of the ItCC might have an impact that goes beyond the question of the immunity enjoyed by foreign states before Italian courts. In fact, after Judgment 238/2014, the compatibility between the right of access to justice as interpreted by the ItCC and domestic rules barring the exercise of jurisdiction over claims for compensation arising from international crimes committed by a foreign state cannot be taken for granted. Should the ItCC, following the path inaugurated by Judgment 238/2014, find that any such limitation to the jurisdiction of Italian judges would be contrary to Article 24 of the Italian Constitution, the dispute between Italy and Germany on the question of Germany's immunity would risk becoming for Italy only the first in a long list of disputes with other states.

\footnotetext{
${ }^{27}$ According to Salerno, 'Giustizia costituzionale' 2015 (n 10), 54, in cases against a foreign state and relating to acta iure imperii of that state, Art 3(2) of Italian Law No 218 of 31 May 1995 permits grounding the jurisdiction of Italian courts if, in the absence of other connections, the applicant resides in Italy. However, in Flatow and in Eisenfeld the Court of Cassation denied that the residence in Italy of the applicant was sufficient to ground the jurisdiction of Italian courts.

${ }^{28}$ For critical comments on the solution retained by the Court of Cassation, see Pavoni, 'How Broad' 2016 (n 24), 584.
} 


\section{Judgment 238/2014 and Its Silences: An Interstate Agreement on Compensation As an Alternative to Individual Access to Italian Courts?}

In its Jurisdictional Immunities Judgment the ICJ started its examination of the question concerning the alleged violation of Germany's immunity by recalling that the acts constituting the object of the proceedings before Italian courts 'can only be described as displaying a complete disregard for the "elementary considerations of humanity", and that Germany 'accepts that these acts were unlawful and stated before this Court that it "is fully aware of [its] responsibility in this regard", 29 At the same time, the Court noted that 'since the dismissal of Italy's counter-claim, it no longer has before it any submissions asking it to rule on the question of whether Germany has a duty of reparation towards the Italian victims of the crimes committed by the German Reich and whether it has complied with that obligation in respect of all those victims, or only some of them'. ${ }^{30}$ While the ICJ did not rule upon the latter questions, it made two remarks that the Parties were expected to take seriously into account, irrespective of the fact that they were not formally binding upon them.

In a first passage the ICJ noted that, while granting immunity to Germany had the effect of precluding judicial redress for the Italian victims, their claims 'could be the subject of further negotiation involving the two states concerned, with a view to resolving the issue'. ${ }^{31}$ Thus, the Court itself seemed to invite the Parties to consider the possibility of engaging in a negotiation, on the assumption that negotiation and not recourse to the domestic courts of one state is a preferable way of dealing with this matter. As to the object of this negotiation, it should be stressed that the Court referred to negotiation over 'the claims arising from the treatment of the Italian military internees (...) together with other claims of Italian nationals which have allegedly not been settled-and which formed the basis for the Italian proceedings'. ${ }^{32}$ This is a crucial point. The negotiation envisaged by the ICJ as the alternative to an (unlawful) recourse to domestic courts has to deal with the claims of the individual victims. In this respect, the fact that Germany and Italy, after the ICJ's Jurisdictional Immunities Judgment, may have agreed to engage in common cultural initiatives, such as the construction of documentation centres or memorials, without taking care to address the claims of the victims can hardly be regarded as a solution going in the direction indicated by the ICJ, the more so if one considers that the ICJ speaks of 'negotiation involving the two States' ("négociations impliquant les deux Etats') and not of 'negotiations between the two States'. As it is connoted by the word 'involving', other actors should have been given a role in the negotiation. In particular, the victims themselves should have had a role. The two states should have

\footnotetext{
${ }^{29} \mathrm{ICJ}$, Jurisdictional Immunities (n 4), para 52.

${ }^{30} \mathrm{ICJ}$, Jurisdictional Immunities (n 4), para 48.

${ }^{31} \mathrm{ICJ}$, Jurisdictional Immunities (n 4), para 104.

${ }^{32}$ Ibid.
} 
at least consulted the victims or the associations of victims. To my knowledge, nothing of the sort occurred.

The ICJ Judgment provides an additional argument in favour of an agreement aimed at addressing the individual claims of the victims. It was Germany, with the establishment in 2000 of the Foundation 'Rememberance, Responsibility and Future' (Erinnerung, Verantwortung und Zukunft), that first proposed the possibility of individual compensation for the victims of forced labour, including Italian victims. Thousands of Italian Military Internees (IMIs) lodged requests for compensation and had a reasonable expectation to be regarded as entitled to receive it. However, more than 127,000 of the 130,000 requests for compensation lodged by Italian victims were rejected. The ICJ took a very clear position on Germany's decision to reject the requests advanced by IMIs: 'it is a matter of surprise-and regret - that Germany decided to deny compensation to a group of victims on the ground that they had been entitled to a status which, at the relevant time, Germany had refused to recognize, particularly since those victims had thereby been denied the legal protection to which that status entitled them'. ${ }^{33}$ An opposition of principle towards the establishment of a mechanism for addressing individual claims of compensation is already difficult to understand, as it was Germany that in 2000 envisaged such a possibility for the victims of forced labour. Insisting on that opposition after the ICJ's strong censure would likely be perceived by Italian victims as a form of discrimination against them and would risk undermining the significance of the other common initiatives that Italy and Germany may agree to undertake in relation to the crimes committed during WWII.

No doubt a political initiative involving Germany and Italy and aimed at establishing a mechanism for addressing the reparation claims of the victims while at the same time restoring Germany's immunity before Italian courts would not only be in line with the views expressed by the ICJ in its Jurisdictional Immunities Judgment; such an outcome would also represent the most dignified way to put an end to this long-standing dispute. ${ }^{34}$ It is not clear, however, whether an interstate agreement on compensation might be regarded by the ItCC as an adequate alternative route for providing protection to the rights of the victims, thereby justifying a limitation to the right of access to court and the recognition of Germany's immunity. In fact, Judgment 238/2014 does not clarify whether or to what extent a sacrifice to the right of jurisdictional protection would be justified if alternative, non-judicial means of redress were available to the victims. The ItCC failed to assess the possible

\footnotetext{
${ }^{33} \mathrm{ICJ}$, Jurisdictional Immunities (n 4), para 99.

${ }^{34}$ An agreement between Germany and Italy may be concluded without the need to reopen the question of whether Germany has an obligation of reparation for serious violations of international humanitarian law against Italian victims. As already mentioned, in 2010 it was Italy that asked the Court, by way of a counterclaim, to establish that Germany had violated such obligation. Germany opposed the counterclaim. In the end, the ICJ found that it had no jurisdiction to rule upon it. In a pragmatic way, the two states may now accept their having different views as to the scope and effect of the waiver clause contained in the 1947 Italy's Peace Treaty without this preventing them from reaching an agreement over the compensation of Italian victims.
} 
role of alternative forms of protection. Despite the serious implications of Judgment 238/2014, no attempt was made to delineate a possible way out.

While the Court has taken a rigid stance as to the possibility of sacrificing the principle of jurisdictional protection, the conclusion of an interstate agreement would inevitably have an impact on the overall assessment of the different interests at stake. Arguably, in balancing the principle of jurisdictional protection with Italy's compliance with international law, the introduction of some alternative means of protecting the rights of the victims could tip the balance in favour of a solution that leads to better harmonization between the two conflicting interests. ${ }^{35}$

Whether an interstate agreement on compensation will be regarded as an adequate alternative remedy justifying the sacrifice of the right of access to justice will also depend on the terms of the agreement. In this respect, it is to be expected that one of the most controversial points in a possible negotiation will concern the amount of compensation due to the victims. Judgment 238/2014 gave no indication on whether an alternative means of redress should in any case ensure to each and every individual victim full compensation or whether instead, in light of the specific circumstances of the case-the fact that the crimes occurred in the course of an international armed conflict affecting hundreds of thousands of victims-it could provide only compensation based on a lump-sum settlement. While in past cases Germany only provided symbolic compensation to victims, ${ }^{36}$ there is the risk that a mechanism providing for only symbolic compensation would not be regarded by the ItCC as an adequate alternative remedy. On this and similar issues, such as that of determining the individuals that could benefit from a future reparation scheme, a flexible approach that accepts forms of redress other than full compensation appears to be warranted.

The negotiation's method of conduct may also matter. Given the nature of the dispute, the multitude of different actors involved, and the criticism and diffidence frequently addressed against the conduct of political organs in this long-standing affair, careful consideration should be given to the possibility of informing and consulting the main stakeholders (as suggested by the ICJ), as well as respecting certain standards of transparency.

\footnotetext{
${ }^{35}$ On this point, see also Remo Caponi, 'A Fresh Start: How to Resolve the Conflict between the ICJ and the Italian Constitutional Court', VerfBlog, (28 January 2015), available at http:// verfassungsblog.de/fresh-start-resolve-conflict-icj-italian-constitutional-court/; Remo Caponi, 'Immunità dello Stato dalla giurisdizione, negoziato diplomatico e diritto di azione nella vicenda delle pretese risarcitorie per i crimini nazisti', Giurisprudenza costituzionale 5 (2014), 3908-3915, at 3908 et seq. See also Riccardo Pavoni, chapter 'A Plea for Legal Peace', in this volume.

${ }^{36}$ On the decision of the German government to pay a symbolic financial compensation to some 4,000 Russian prisoners of war, see Oellers-Frahm, 'A Never-Ending Story' 2016 (n 7), at 202; see also Giovanni Boggero/Karin Oellers-Frahm, chapter 'Between Cynicism and Idealism', in this volume.
} 


\section{Conclusion}

For Italy, the consequences unleashed by Judgment 238/2014 are not confined to the question of Germany's jurisdictional immunities before Italian courts and to the ensuing risk that Germany will once more bring the case before the ICJ. After Judgment 238/2014, the Italian government faces the problem of either continuing to defend the view that a state is entitled to immunity for acta iure imperii, irrespective of whether these acts amount to international crimes, or aligning itself to the indications coming from the ItCC, which includes presenting a new declaration aimed at ensuring the compatibility of Italy's obligations under the 2004 UN Convention with the principles stemming from Judgment 238/2014. Italian courts will sooner or later be confronted with the problem of the execution of the judgments condemning Germany for the crimes committed during WWII. In the meantime, following the principle established by Judgment 238/2014, the Court of Cassation denied immunity to Serbia. While — so far - the same Court has resisted any attempt to introduce the principle of universal civil jurisdiction into the Italian legal order, the risk of Italian courts becoming an attractive forum for litigations against foreign states is high.

Judgment 238/2014 had the merit of forcefully raising the question of the rights of the victims of grave breaches of human rights and of the way in which these rights are to be protected. Unfortunately, by focusing exclusively on individual access to justice and on the need to promote an evolution of the law of state immunity, it raises more questions than it answers. Some of the consequences of Sentenza may be unintentional but, in the absence of a new decision clarifying the conditions under which a sacrifice to the right of jurisdictional protection would be justified, the current situation is one of legal uncertainty. In this scenario, political organs should attempt to provide some solutions. A political initiative aimed at addressing some of the concerns behind Judgment 238/2014 would constitute a first, important step in that direction.

\section{References}

Caponi, Remo, 'A Fresh Start: How to Resolve the Conflict between the ICJ and the Italian Constitutional Court', VerfBlog, (28 January 2015), available at http://verfassungsblog.de/ fresh-start-resolve-conflict-icj-italian-constitutional-court/

Caponi, Remo, 'Immunità dello Stato dalla giurisdizione, negoziato diplomatico e diritto di azione nella vicenda delle pretese risarcitorie per i crimini nazisti', Giurisprudenza costituzionale 5 (2014), 3908-3915

Conforti, Benedetto, 'Il legislatore torna indietro di circa novant'anni: la nuova norma sull'esecuzione su conti correnti di Stati stranieri', Rivista di diritto internazionale 98 (2015), $558-561$

Higgins, Rosalyn, 'The Concept of "The State": Variable Geometry and Dualist Perceptions', in Laurence Boisson de Chazournes/Vera Gowlland-Debbas (eds), The International Legal System 
in Quest of Equity and Universality, Liber Amicorum Georges Abi-Saab (The Hague: Kluwer 2001), 547-561

Oellers-Frahm, Karin, 'A Never-Ending Story: The International Court of Justice-The Italian Constitutional Court-Italian Tribunals and the Question of Immunity', Heidelberg Journal of International Law 76 (2016), 193-202

Pavoni, Riccardo, 'How Broad is the Principle Upheld by the Italian Constitutional Court in Judgment No. 238?', Journal of International Criminal Justice 14 (2016), 573-585

Reinisch, August, 'State Immunity from Enforcement Measures', in Gerhard Hafner/Marcelo Kohen/Susan Breau (eds), State Practice Regarding State Immunity (Leiden/Boston: Martinus Njhoff 2006), 151-166

Salerno, Francesco, 'Giustizia costituzionale versus giustizia internazionale nell'applicazione del diritto internazionale generalmente riconosciuto', Quaderni Costituzionali 35 (2015), 33-58

Sinclair, Ian, 'The Law of Sovereign Immunity: Recent Developments', Recueil des cours 168 (1980-II), 115-284

Yang, Xiaodong, State Immunity in International Law (Cambridge: CUP 2012)

Open Access This chapter is licensed under the terms of the Creative Commons Attribution 4.0 International License (http://creativecommons.org/licenses/by/4.0/), which permits use, sharing, adaptation, distribution and reproduction in any medium or format, as long as you give appropriate credit to the original author(s) and the source, provide a link to the Creative Commons license and indicate if changes were made.

The images or other third party material in this chapter are included in the chapter's Creative Commons license, unless indicated otherwise in a credit line to the material. If material is not included in the chapter's Creative Commons license and your intended use is not permitted by statutory regulation or exceeds the permitted use, you will need to obtain permission directly from the copyright holder. 


\title{
The Illusion of Perfect Justice
}

\author{
Christian Tomuschat
}

\begin{abstract}
The judgment of the Italian Constitutional Court (ItCC) of 22 October 2014 has set a bad precedent for international law by denying the implementation, within Italy, of the judgment of the International Court of Justice (ICJ) of 3 February 2012. The ICJ found that Italian courts and tribunals had violated German jurisdictional immunity by entertaining suits brought by Italian citizens against Germany on account of damages caused by war crimes committed during World War II by German occupation forces. According to a well-consolidated rule of general international law, no state may be sued before the courts of another state with regard to acts performed in the exercise of its sovereign power. In contravention of Article 94 of the UN Charter, the ItCC deemed it legitimate to discard that ruling because of the particularly grave character of many of the violations in question. It proceeded from the assumption that the right to a remedy established under the Italian Constitution was absolute and must apply even where the financial settlement of the consequences of armed conflict is at issue. However, it has failed to show the existence of any individual reparation claims and has omitted to assess the issue of war reparations owed by Germany in their broader complexity. The judgment of the ItCC might be used in the future as a pretext to ignore decisions of the World Court.
\end{abstract}

\section{Preliminary Observations}

Battles of the past should not be endlessly continued. Unfortunately, the dispute between Germany and Italy concerning the settlement of the damages caused during the occupation of Italy by the German Wehrmacht from September 1943 to May 1945 seems to have all the ingredients of an interminable confrontation where positions of principle clash with no end in sight. Though World War II (WWII)

\footnotetext{
C. Tomuschat $(\bowtie)$

Humboldt University of Berlin, Faculty of Law, Berlin, Germany 
lies more than 70 years in the past, the scars it has left have not led to the healing of the bitter wounds which that war inflicted on all of those involved-primarily the victims of deliberate persecution but also those who have had to endure the consequences of a war that was, from its very inception, criminal.

Let me make clear that no attempt will be or can be made to provide excuses for the bitter fate that struck the Italian citizens who brought actions for financial compensation against Germany, actions that eventually led to the surprising and even revolutionary outcome of the judgment of the Italian Constitutional Court (ItCC) of 22 October 2014, ${ }^{1}$ which held that under Italian constitutional law the judgment of the International Court of Justice (ICJ) of 3 February $2012^{2}$ could not be executed. Whatever judges may decide, the fact is that the German military and security forces gravely violated the applicable regime of humanitarian law. More than mere wrongdoing, this was a breach of the standards of civilization that can claim a venerable and consolidated tradition in Europe. The Nazi regime led Germany into an abyss of criminal conduct before the war machine, once set into motion, rolled back and crushed the German people themselves. Fortunately, we do not here have to argue about historical developments; we need only take note of them in a spirit of objectivity while reflecting on remedial action.

Much has already been written about that seminal ItCC judgment and its consequences. As an outside observer, one easily gets the impression that almost every Italian expert in the field, constitutionalists and internationalists alike, felt compelled to comment on the new course chosen by the ItCC in its approach to international law, as primarily determined by Article 10 of the Italian Constitution. I have made a great effort to inform myself about all of those reactions to the ItCC's findings, leggendo pure i più sottili commenti in lingua giuridica italiana. Nonetheless, I cannot pretend that I have read every single article, note and comment. Yet the overall picture seems to be fairly clear. ${ }^{3}$ I sincerely hope that I have been able to collect and assess all relevant facts without overlooking essential details.

A second clarification should be put forward at this moment. Not being a specialist of Italian constitutional law, it is not my intention to engage in a discussion about the way in which the ItCC, in its examination of the constitutionality of the relevant norms, assessed the customary rule of jurisdictional immunity under international law. Generally, such review is designed to scrutinize the constitutionality of parliamentary statutes of national origin with the Constitution (Article 134). In any event, it was inconceivable to declare Article 10 of the Constitution-the dooropener for the general rules of international law-unconstitutional without introducing a new theory about the core substance of the Constitution being placed at a

\footnotetext{
${ }^{1}$ Corte Costituzionale, Judgment of 22 October 2014, No 238/2014.

${ }^{2}$ ICJ, Jurisdictional Immunities of the State (Germany v Italy: Greece intervening), Judgment of 3 February 2012, ICJ Reports 2012, 99.

${ }^{3}$ See also Christian Tomuschat, 'The National Constitution Trumps International Law', Italian Journal of Public Law 6 (2014), 189-196.
} 
higher hierarchical level. The ItCC found indeed another, more sophisticated way to block the access of the principle of immunity to the Italian domestic legal order.

\section{The Surprise: Silence on the Main Issues}

First, the very heart of the dispute centres around the existence of reparation claims against Germany that have allegedly arisen for individual victims of the measures taken by the Nazi authorities in violation of international humanitarian law (IHL). But the ItCC nowhere raised or answered the question of whether such entitlements could have emerged as a consequence of German governmental wrongdoing. It stands to reason that the ICJ was not seized with the issue. The only charge brought by Germany consisted of the allegation that Italy had infringed her sovereign right of jurisdictional immunity. Accordingly, the ICJ could not go into an issue pertaining to the merits of the cases pending before the Italian courts and tribunals. ${ }^{4}$ On the other hand, by insisting on the imperative requirement that a legal right must be enforceable, the ItCC would have been obligated in good logic to state in unambiguous terms that such individual entitlements to reparation had to be recognized in law. Yet it has failed to raise this issue-which is obviously a fairly complex one since the doctrine of individual human rights is a post-WWII invention. The doctrine of controlimiti, however, cannot bring into being a right against a foreign state.

Second, the ItCC has failed to mention that those who chose to sue Germany before Italian courts and tribunals had an actual opportunity to bring their claims before the German judicial system. Some of the claimants did indeed pursue that course, rising up to the level of the German Constitutional Court. Eventually, all those claims were dismissed as unfounded as to their merits. ${ }^{5}$ Thus, remedies were in fact made available. It is a mistake to confound the availability of a remedy with its well-foundedness. ${ }^{6}$

Third, as far as the substantive aspects of the complex legal configuration are concerned, the ItCC has not regarded it opportune to mention that the case before it was part of a complex puzzle: the settlement of all the substantive consequences entailed by WWII in the absence of a legal instrument explicitly called a Peace Treaty.

\footnotetext{
${ }^{4}$ The few observations in ICJ, Jurisdictional Immunities (n 2), para 104, amount to no more than a signal of sympathy for the victims. For a different perspective, see Paolo Palchetti, chapter 'Right of Access to (Italian) Courts über alles?', in this volume.

${ }^{5}$ Bundesverfassungsgericht, Order of 28 June 2004, 2 BvR 1379/01, BVerfGK 3, 277, paras 29, 37; Verwaltungsgericht Berlin, Judgment of 9 September 2004, 9 A 336.02, para 52. In this context see also the Distomo cases where German courts dismissed claims brought by Greek victims of WWII massacres: Bundesverfassungsgericht, Order of 15 February 2006, 2 BvR 1476/03, BVerfGK 7, 303, paras 12, 17.

${ }^{6}$ See also Alessandro Bufalini, chapter 'Waiting for Negotiations', and Sabino Cassese, chapter 'Recollections of a Judge', in this volume. For a different perspective see Valerio Onida, chapter 'Moving Beyond Judicial Conflict in the Name of the Pre-eminence of Fundamental Human Rights', in this volume.
} 


\section{Challenge to a Foundational Rule of International Law}

Sentenza 238/2014 stands out uniquely in the history of international law. There have been other judgments of the ICJ that were ignored by the losing party; ${ }^{7}$ the refusal of the American authorities to obey the injunctions of the ICJ in the LaGrand case, ${ }^{8}$ for example, is fresh in every international lawyer's mind. Those confrontations, however, were of an incidental character and centring on individual cases. Never before has a domestic court by refusing to follow a pronouncement of the ICJ challenged a generally recognized rule of customary international law. This deeper challenge to the international legal community transcends the underlying controversy between Italy and Germany and its consequences are unfathomable. Lawyers in the US have already woken up and are considering initiating proceedings against former European colonial powers relating back to occurrences more than a hundred years ago. ${ }^{9}$

The ItCC has carefully avoided criticizing the ICJ itself by pointing to alleged errors or other imperfections in its reasoning. Only the Tribunale di Piacenza ventured to take that more direct course by holding without hesitation that the ICJ had not fully understood what stage the development of international law had reached in our contemporary epoch: it invented a class of 'super primacy' norms protecting human life and human dignity. ${ }^{10}$ Yet, notwithstanding the politeness of the ItCC's views, they nonetheless contain a strong implicit element of criticism, as noted, for instance, by Riccardo Pisillo Mazzeschi. ${ }^{11}$ Formally, however, no

\footnotetext{
${ }^{7}$ See Raffaela Kunz, chapter 'Teaching the World Court Makes a Bad Case', in this volume.

${ }^{8}$ ICJ, LaGrand Case (Germany v United States of America), Judgment of 27 June 2001, ICJ Reports 2001, 466 .

${ }^{9}$ See, eg, Sidney L Harring, 'The Herero Demand for Reparations from Germany: The Hundred Year Old Legacy of a Colonial War in the Politics of Modern Namibia', in Max Du Plessis/Stephen Peté (eds), Repairing the Past?: International Perspectives on Reparations for Gross Human Rights Abuses (Antwerpen: Intersentia 2007), 437-450.

${ }^{10}$ Tribunale di Piacenza, Judgment of 28 September 2015, No 723/2015, 1, 12. One might argue that the 2004 Ferrini Judgment by the Corte di Cassazione already contained a similar statement: 'Para 9: Indeed, these are crimes that consist of the particularly intense or systematic violation of basic human rights (...), which are protected by non-derogable norms that stand at the apex of the international legal system, taking precedence over all other norms, whether of conventional or customary nature (...) and therefore also over those norms governing immunity. Para 9.1: The recognition of immunity from jurisdiction for States that are responsible for such offences is in blatant contrast with the normative framework outlined above, since this recognition obstructs rather than protects such values, the protection of which is rather to be considered, in accordance with such norms and principles, essential for the entire international community (...). Moreover, there can be no doubt that this antinomy must be resolved by giving precedence to the higherranking norms' (Translation taken from Yale Law School, Documents Collection Center, available at https://documents.law.yale.edu/sites/default/files/ferrini_v._germany_-_italy_-_2004.pdf). The important difference, however, lies in the fact that at the time of the Ferrini Judgment no prior authoritative international judgment existed concerning the specific matter at hand.

${ }^{11}$ Riccardo Pisillo Mazzeschi, 'La sentenza n. 238/2014 della Corte costituzionale ed i suoi possibili effetti sul diritto internazionale', Diritti umani e diritto internazionale 9 (2015), 23-40, at 39. In the
} 
reproach can be levelled at the ItCC. It has acted consistently within the framework of dualism chosen as its point of departure, confining itself to pronouncing on the effect of the immunity rule within the Italian domestic legal order. Both Heinrich Triepel and Dionisio Anzilotti would have been happy with that methodological approach. This chapter, by contrast, is confined to looking into the ItCC's position under international law.

We do not know whether the ItCC was really satisfied with its feat. The sole fact that it had to admit its solitary stance, standing alone in a world that overwhelmingly recognizes the principle of the jurisdictional immunity of states in respect of acts iure imperii, may indeed provide insufficient grounds for satisfaction. In this regards, it is certainly not improper to recall that every judicial body is made up of individual members and that opinions may reasonably have diverged as to the suitability of launching a head-on attack against the principle of jurisdictional immunity. ${ }^{12}$ In any event, attention must be drawn to the jurisprudence of the European Court of Human Rights (ECtHR), which in Jones $v$ UK ruled only a few months before Sentenza $238 / 2014$ that even in instances of alleged torture the rule of immunity applies, shielding the alleged governmental offender against suits brought against it before the civil courts of foreign countries. ${ }^{13}$ The voice of the ECtHR epitomizes the European concept of human rights and would certainly have deserved being taken into account by the ItCC. Even for a constitutional court it is hard to argue that its national standard concerning legal remedies is higher and more demanding than what at the world level and at the European level is considered to be in full conformity with the rule of law. Persuasive grounds would have to be adduced to show that Italy exceeds every other nation in protecting the right to a remedy where a major human rights violation has occurred. In this regard, however, the judgment is poorly motivated.

Additionally, inconsistencies are visible in the Italian practice itself. Reference must be made to the Markovic case where the Corte di Cassazione dismissed an application for reparation of damages suffered in the former Yugoslavia during the so-called 'Kosovo War' and, it is alleged, with the complicity of Italy as a state member of NATO. The Court held that it was not the function of the judiciary to protect individuals from acts of aerial warfare since such acts were the expression of a 'political function'. ${ }^{14}$ Accordingly, the merits of the case were not considered. In Sentenza 238/2014 the ItCC deemed it unnecessary to mention this earlier pronouncement although it had been issued by the highest instance in civil matters. Furthermore, attention should be paid to the 2008 Treaty of Friendship, Partnership, and Cooperation between Italy and Libya, whose section II under the title 'Closure

\footnotetext{
same vein Riccardo Pavoni, 'Simoncioni v. Germany', American Journal of International Law 109 (2015), 400-406, at 403.

${ }^{12}$ See Sabino Cassese, chapter 'Recollections of a Judge', in this volume.

${ }^{13}$ ECtHR, Jones and Others $v$ The United Kingdom, Judgment of 14 January 2014, Applications Nos 34356/06 and 40528/06.

${ }^{14}$ Corte di Cassazione, Order of 5 June 2002, No 8157/2002.
} 
of the Chapter of the Past and of the Pending Disputes' is conceived as a final settlement against the payment by Italy of US\$5 billion spread over 20 years. ${ }^{15}$ All the monies pledged were designed for infrastructural projects. No reparation payments were set aside for the benefit of the victims of Italian warfare in Libya.

All this casts serious doubts over the central thesis of the ItCC that the right to a remedy, as stipulated in Article 24 of the Italian Constitution, has the high rank attributed to it by the ItCC. International practice has very rarely resorted to reparation measures to the benefit of individual victims after disastrous occurrences like wars or other types of armed conflicts. Primary and secondary rules have to be distinguished. A value judgment can only be attached to the infringement of a primary rule depending on the inherent character of the protected interests. The killing of a human being in violation of the right to life amounts to a serious breach either of IHL or of international human rights law (IHRL), entailing a duty of compensation and possibly also the duty to prosecute the perpetrator. But the obligation to make the required compensation payment, although undoubtedly constituting a commitment under international law, does not amount to a ius cogens rule. States, including wrongdoing states, have a large discretion as to the ways and means to acquit their debt.

\section{Jurisdictional Immunity: An Essential Structural Element of International Law}

Regarding the core issue of the compatibility of a legal enactment excluding individual claims against a foreign state, the ItCC has evolved an abstract concept of precedence of core human rights guarantees by narrowing down the complexity of the factual constellation at stake to such an extent that the key issues have remained invisible. Deliberately, or else by lack of oversight, the ItCC has constructed a strictly binary opposition between on the one hand a principle of the Italian constitutional law and, on the other, the international law principle of jurisdictional immunity. The ItCC sees this relationship as a confrontation between a good and modern human rights principle and a formalistic traditional rule that serves to shield the sovereign power interests of states against any curtailment. No serious effort is made to analyze the principle of jurisdictional immunity as to its inherent qualities. The ItCC does not see that jurisdictional immunity constitutes an essential element of the current system of international law based on sovereign equality.

\footnotetext{
${ }^{15}$ Trattato di Amicizia, 'Partenariato e Cooperazione tra la Repubblica Italiana e la Grande Giamahiria Araba Libica Popolare Socialista' (Benghazi, 30 August 2008), available at www. camera.it/_dati/leg16/lavori/schedela/apritelecomando_wai.asp?codice=16pd10017390.
} 
Most of the Italian commentators have followed the ItCC on this. ${ }^{16}$ They discuss at length the tension between a human rights guarantee and the principle of sovereign equality without ever reflecting on what interest the international community, as it is framed today, has in separating from one another the areas of jurisdiction of the states currently in existence. Many authors recall the leading role of Italian and Belgian courts, in the first half of the twentieth century, in pushing ahead with the now consolidated distinction between acta iure gestionis and acta iure imperii, purporting to suggest that the road hitherto pursued can simply be continued: in the same way as commercial activities were submitted to the scrutiny of foreign courts, acta iure imperii could also be made subject to control by foreign courts. ${ }^{17}$ This reasoning, which also underlies Sentenza $238 / 2014,{ }^{18}$ is fundamentally flawed. Where a state, through its government or special commercial agencies, enters the market, it cannot on plausible grounds claim benefits that are withheld to other market actors. However, when a state has acted in pursuit of its political choices, scrutiny of such acts will inevitably create tensions. No state is prepared to see its governmental conduct supervised by the judiciary of another country and appropriate reparation being imposed upon it. By attributing to each state its own sphere of jurisdiction and establishing rules for the settlement of cross-boundary disputes, international law contributes to upholding peace in interstate relations. ${ }^{19}$

When an armed conflict is waged on foreign territory, jurisdictional competences enter into conflict. In principle, territorial sovereignty prevails. But the armed forces of the foreign state do not forfeit their status as state organs. They retain this status, which does not yield completely to the territorial sovereignty of the adversary. International law has established rules and principles with a view to disentangling this imbroglio. Accordingly, armed conflict has become a phenomenon governed by international law. The consequences flowing therefrom must therefore be settled according to the rules and mechanisms of international law. No state can decide unilaterally what legal implications derive from such occurrences. The ancient

\footnotetext{
${ }^{16}$ See inter alia Gaetano Silvestri, 'Sovranità vs Diritti Fondamentali', Questione Giustizia 1 (2015), 57-63, at 60-63; Paolo Passaglia, 'Una sentenza (auspicabilmente) storica: la Corte limita l'immunità degli Stati esteri dalla giurisdizione civile', Diritti Comparati, (28 October 2014), available at www.diritticomparati.it/una-sentenza-auspicabilmente-storica-la-corte-limitalimmunita-degli-stati-esteri-dalla-giurisdizion/.

${ }^{17}$ See inter alia Tobia Cantelmo/Valentina Capuozzo, 'Tra Immunità e Contro-Limiti: un nuovo Traguardo della Giurisprudenza Italiana in Corte Costituzionale Sentenza n. 238/2014 e Ordinanza n. 30/2015', Rivista di Diritto Pubblico Italiano, Comparato, Europeo 1 (2016), 1-27, at 5, 9, 10, 14, 27; Andrea Guazzarotti, 'Il Paradosso della Ricognizione delle Consuetudini Internazionali. Note Minime a Corte Cost. n. 238 del 2014', Forum di Quaderni Costituzionali, (5 November 2014), available at www.forumcostituzionale.it/wordpress/wp-content/uploads/2014/11/ guazzarotti_nota_238_2014.pdf, 1-4, at 1-3; Passaglia, 'Una sentenza (auspicabilmente) storica' 2014 (n 16).

${ }^{18}$ See ItCC, Judgment 238/2014 (n 1), para 3.3.

${ }^{19}$ In this vein, see ICJ, Jurisdictional Immunities (n 2), para 57.
} 
doctrine of subjugation or debellatio, ${ }^{20}$ according to which a defeated state could be deprived of any rights, a dead body delivered to the arbitrariness of the victors, has become defunct and obsolete as it could not be reconciled with the now wellestablished principle of self-determination.

\section{The Different Methods of Reparation}

The ItCC has failed to perceive that in our time alternative methods are available for satisfying the demands of an injured state. In the present context, two main methods can be discerned. The classic method consists of resorting to intergovernmental mechanisms by relying on the assumption that harm inflicted on the nationals of a state amounts in law to harm done to that state. The government concerned then presents the losses incurred as one comprehensive claim, to be negotiated with the wrongdoing state and possibly ending up in a lump sum agreement. The other method consists of taking account of each and every item of harm, person by person, thus making individual payments to everyone recognized as having suffered damage. General international law does not acknowledge the latter method.

The traditional interstate method was imposed on Germany at the end of WWII. At that time, Germany was not recognized as a sovereign actor with equal rights. This was fully understandable. There was no legitimate representation of the German people during the months following the military surrender on 8 May 1945. The members of the last government of the Nazi Reich had all been arrested. Criminal charges were prepared against them-and rightly so. The political opponents of the Nazi regime having found refuge in other countries had not been able to form a government in exile that could have been recognized as a legitimate representation of the German people and a valid interlocutor with the victorious Allied powers. Therefore, all the mechanisms for the transition from war to peace were established without any effective German presence. At the Potsdam Conference, only the Soviet Union, the UK, and the US were present; not even France was admitted. German voices were neither heard nor consulted, meaning that the interests of the German people were sidelined. When the victorious Allied powers negotiated the peace treaty with Italy in Paris, Germany was also absent while an Italian delegation was admitted and could to the best of its abilities defend Italian interests, although it essentially had to accept the demands of the victorious powers.

Notwithstanding these procedural shortcomings, the negotiators at Potsdam agreed on a mechanism according to which the German war debt was to be settled collectively, according to the traditional method outlined above. The Potsdam Agreement, negotiated and signed only by the three main powers, but intended to become binding for all the former enemy states and the states participating in the

\footnotetext{
${ }^{20}$ See Lassa Oppenheim/Hersch Lauterpacht, International Law: A Treatise (London: Longmans, Vol II, $7^{\text {th }}$ ed 1952), 600-601.
} 
fight against the Axis powers, stated categorically that Germany will 'be compelled to compensate to the greatest possible extent for the loss and suffering that she has caused to the United Nations and for which the German people cannot escape responsibility'. ${ }^{21}$

Details of how the settlement should be effected were laid down in the subsequent provisions of the Potsdam Agreement. Three main items of reparation were considered. First, removals of German industrial equipment were envisaged-and soon carried out in particular in the Soviet zone of occupation. Second, agreement was reached on confiscating all German external assets. And last, the determination was made to separate from Germany one fourth of its national territory and to place it under Polish or Soviet administration with a view to definitively allocating these territories at a later stage to Poland and the Soviet Union under the terms of a final peace treaty. Furthermore, the concomitant expulsion of the population in these regions resulted in the confiscation of all the assets held by the German nationals concerned.

The Potsdam determination was a clear signal: the Allied powers were of the view that the war damages caused by Germany should be compensated by those collective transfers of goods and territories, not by way of providing compensation to each and every victim individually. They acted as trustees for all of the states that had participated in the armed conflict, and for the implementation of their subsequent decisions an Inter-Allied Reparation Agency was established in Paris by agreement among all of the victorious powers. ${ }^{22}$ All the assets removed from Germany were to be registered for the computation of the shares to be distributed to the countries prejudiced by the war. No account was established for Italy since under Article 77 of the Peace Treaty ${ }^{23}$ Italy, having acted as co-aggressor together with Germany, had been denied any right to compensation.

\footnotetext{
${ }^{21}$ Report on the Tripartite Conference of Berlin, 2 August 1945, Truman Paper-Naval Aide Files vol XII (Potsdam Agreement), sec IV.

${ }^{22}$ Agreement on Reparation from Germany, on the Establishment of an Inter-Allied Reparation Agency and on the Restitution of Monetary Gold, 14 January 1946, British Foreign Office Treaty Series, London 1947, No 56.

23، 1 . From the coming into force of the present Treaty property in Germany of Italy and of Italian nationals shall no longer be treated as enemy property and all restrictions based on such treatment shall be removed. 2. Identifiable property of Italy and of Italian nationals removed by force or duress from Italian territory to Germany by German forces or authorities after September 3, 1943, shall be eligible for restitution. 3. The restoration and restitution of Italian property in Germany shall be effected in accordance with measures which will be determined by the Powers in occupation of Germany. 4. Without prejudice to these and to any other dispositions in favour of Italy and Italian nationals by the Powers occupying Germany, Italy waives on its own behalf and on behalf of Italian nationals all claims against Germany and German nationals outstanding on May 8, 1945, except those arising out of contracts and other obligations entered into, and rights acquired, before September 1, 1939. This waiver shall be deemed to include debts, all inter-governmental claims in respect of arrangements entered into in the course of the war, and all claims for loss or damage arising during the war. 5. Italy agrees to take all necessary measures to facilitate such transfers of German assets in Italy as may be determined by those of the Powers occupying Germany which are empowered to dispose of the said assets.'
} 
As is well known, no peace treaty bearing that name was concluded with Germany. The political tensions arising almost immediately after the end of armed hostilities prevented such a formalized end to WWII. Only at the moment of German reunification was it deemed necessary to adopt a punto finale. Germany and the four Allied powers negotiated the Treaty on the Final Settlement with Respect to Germany. ${ }^{24}$ This treaty, although remaining silent about any measure of reparation, was indeed meant to put a definitive end to the issue of reparations. ${ }^{25}$ The great step taken by Germany was the recognition that the territories for many years provisionally placed under Polish and Soviet occupation would henceforth be considered as having passed under the jurisdiction of those countries. On the other hand, by accepting the title of 'Final Settlement', the Allied forces certified that they would be debarred from asserting any further war claims against Germany. In turn, Germany renounced any possible claims against the Allied powers on account of the breaches of humanitarian law committed by them: by attacking civilian objects, bombing cities where no military targets were present, driving out people from their ancestral lands, and thereby causing the death of millions of people.

\footnotetext{
${ }^{24}$ Treaty on the Final Settlement with Respect to Germany, 12 September 1990, 1696 UNTS 115 (Two-plus-Four Treaty).

${ }^{25}$ Ibid, see Preamble: 'The Federal Republic of Germany, the German Democratic Republic, the French Republic, the Union of Soviet Socialist Republics, the United Kingdom of Great Britain and Northern Ireland and the United States of America, Conscious of the fact that their peoples have been living together in peace since 1945; Mindful of the recent historic changes in Europe which make it possible to overcome the division of the continent; Having regard to the rights and responsibilities of the Four Powers relating to Berlin and to Germany as a whole, and the corresponding wartime and post-war agreements and decisions of the Four Powers; Resolved, in accordance with their obligations under the Charter of the United Nations to develop friendly relations among nations based on respect for the principle of equal rights and self-determination of peoples, and to take other appropriate measures to strengthen universal peace; Recalling the principles of the Final Act of the Conference on Security and Cooperation in Europe, signed in Helsinki; Recognizing that those principles have laid firm foundations for the establishment of a just and lasting peaceful order in Europe; Determined to take account of everyone's security interests; Convinced of the need finally to overcome antagonism and to develop cooperation in Europe; Confirming their readiness to reinforce security, in particular by adopting effective arms control, disarmament and confidence-building measures; their willingness not to regard each other as adversaries but to work for a relationship of trust and cooperation; and accordingly their readiness to consider positively setting up appropriate institutional arrangements within the framework of the Conference on Security and Cooperation in Europe; Welcoming the fact that the German people, freely exercising their right of self-determination, have expressed their will to bring about the unity of Germany as a state so that they will be able to serve the peace of the world as an equal and sovereign partner in a united Europe; Convinced that the unification of Germany as a state with definitive borders is a significant contribution to peace and stability in Europe; Intending to conclude the final settlement with respect to Germany; Recognizing that thereby, and with the unification of Germany as a democratic and peaceful state, the rights and responsibilities of the Four Powers relating to Berlin and to Germany as a whole lose their function; Represented by their Ministers for Foreign Affairs who, in accordance with the Ottawa Declaration of 13 February 1990, met in Bonn on 5 May 1990, in Berlin on 22 June 1990, in Paris on 17 July 1990 with the participation of the Minister for Foreign Affairs of the Republic of Poland, and in Moscow on 12 September 1990; Have agreed as follows:'.
} 


\section{The Impossibility of Reparation of War Damages by Individual Actions}

Erroneously, the ItCC has embraced the view that with regard to grave crimes under international law reparation must consist of individual payments to each and every victim of German misconduct. It does not say so openly but the inference is inherent in its insistence on the right to a remedy as a necessary consequence of the infringement of a right. Positive international law, however, does not recognize individual reparation claims. Article 3 of the 1907 Hague Agreement No IV establishes the collective responsibility of the state whose agents have committed an unlawful act. $^{26}$ Indeed, international practice has evolved a pattern according to which mass damages caused by warfare should be settled at the interstate level by agreement between the governments concerned. The bar of jurisdictional immunity favours rational proceedings organized by a victim state by way of diplomatic protection, under which all the individual claims can be aggregated in a systematic fashion according to merit.

It is an illusion to believe that destroying the bar of jurisdictional immunity could become a panacea in instances where grave violations of IHL or IHRL are in issue. First, states against whom foreign courts have delivered compensation judgments would hardly ever honour such judgments. It is remarkable that only a few authors have found it necessary to delve into this highly practical issue. ${ }^{27}$ Encouraging the victims to bring suits against a tortfeasor state may sound eminently constructive and promising. In real terms, however, the successful claimants would not gain anything tangible. They might achieve a moral victory but little else. Judgments against a foreign state can be enforced only with great difficulties, as efforts in recent years to recover monies from Argentina have amply shown. According to the UN Convention on Jurisdictional Immunities of States and their Property, ${ }^{28}$ measures of constraint against state property are admissible only under extremely strict conditions (Article 19) in consonance with firmly established rules of customary law. The ItCC has been wise enough not to challenge these rules, whose non-respect could entail highly adverse consequences for Italy as well. In sum, that great step forward praised by many voices in the legal doctrine commenting on Judgment 238/2014 leads into a vacuum where no real substance can be found. The ItCC may have secured for Italy a moral victory, but it has shattered the foundations of international law by undermining legal certainty in the operation of general international law. The rule

\footnotetext{
${ }^{26}$ See, eg, Bundesgerichtshof (Federal Court of Justice), Judgment of 6 October 2016, III ZR 140/15, BGHZ (Kunduz).

${ }^{27}$ Francesco Francioni, 'Access to Justice and Its Pitfalls', Journal of International Criminal Justice 14 (2016), 629-636, at 634; Paolo Palchetti, 'Can State Action on Behalf of Victims Be the Alternative to Judicial Access to Justice in Case of Grave Breaches of Human Rights?', Italian Yearbook of International Law 24 (2014), 53-60, at 56.

${ }^{28}$ UN Convention on Jurisdictional Immunities of States and Their Property (2 December 2004), UN Doc A/RES/59/83, UN Doc A/59/49, 486 (not yet in force).
} 
of jurisdictional immunity ensures the peaceful exercise of sovereign power according to the paradigm of equality. ${ }^{29}$ Should domestic courts gain the power of interfering in the domestic matters of other states by enjoining them to perform or not perform specific acts, sovereign equality would suffer significant damage. International disputes about controversial issues under international law must be settled by international means of settlement, inter alia, by determinations of international bodies and not by unilateral decisions of one of the parties to the relevant dispute. Nemo judex in re sua.

Coming back to the alternative between the two methods of settlement available within the present-day system of international law, it stands to reason that it is inconsistent to apply the two methods of reparation parallel to one another if not explicitly agreed to by the parties concerned or otherwise consented to by the debtor state. Thus, Germany has always been prepared to provide reparation to individual victims of racial persecution. Israel, in particular, received generous compensation payments, and a specific treaty was concluded with Italy for that purpose. ${ }^{30}$ Generally, however, where the determination is made to resort to the collective method of reparation, to open up at the same time the second avenue would lead to placing a double burden on the wrongdoing state. This brutal truth is unpleasant to hear, since it cannot be denied that those who suffered during the German occupation of Italy have not been palpably compensated as individuals. They feel entitled to be provided with compensation, arguing that they have not benefitted personally from the sacrifices that Germany had to concede under the Potsdam Agreement and its implementation. In this context, the Italian state should have helped its citizens by awarding to them, on its own initiative, appropriate reparation payments, ${ }^{31}$ given the fact that compensation for war damages is a collective responsibility of the national community.

\section{The Hard Task of Seeking an Equitable Peace Settlement}

The ItCC has closed its eyes to the context of the legal issue submitted to its legal cognizance: adjudicating the dispute on the constitutionality of the legal norms barring individual claims against Germany was an element in a comprehensive peace settlement. Settling the consequences of war is an unpleasant undertaking.

\footnotetext{
${ }^{29}$ See ICJ, Jurisdictional Immunities (n 2), para 57.

${ }^{30}$ Agreement between the Federal Republic of Germany and Italy on the Compensation for Italian Nationals Subjected to National-Socialist Measures of Persecution (Bonn, 2 June 1961), German and Italian version published in Bundesgesetzblatt II 5 July 1963 No 22, 791.

${ }^{31}$ Suggested also by Enzo Cannizzaro, 'Judicial Immunity and Judicial Protection: The Decision of the Italian Constitutional Court No. 238 of 2014', Rivista di diritto internazionale 98 (2015), 126-134, at 131; Francioni, 'Access to Justice' 2016 (n 27), 636.
} 
The modern tendency is to grant, as a matter of good policy, comprehensive compensation for the harm endured by all the victims, ${ }^{32}$ notwithstanding the fact that no such entitlements have arisen under positive law. ${ }^{33}$ Additionally, it should not be lost sight that the case at hand dates back more than 70 years to a time when individual claims against a foreign state on account of war damages were simply unheard of.

Establishing a settlement after a war constitutes a collective undertaking. All sides are entitled to come forward with their demands and claims. It is true that the countries attacked by Nazi Germany had suffered the most. At the same time, it is equally true that Italy stood at Germany's side for many years, supporting its aggressive policies. Only in September 1943 did Italy, fortunately, abandon her Berlin ally and join the anti-Axis powers. Had she left the unhappy alliance two years earlier, Hitler might not have had the courage of trying to expand Germany's dictatorial regime to the whole of Europe and the Soviet Union. In any event, if one seeks to establish a just and equitable equilibrium in a peace treaty, account must be taken of the losses suffered on all sides. As hinted at already, 12 million Germans were driven out from their ancestral homes, with millions dying during their flight. ${ }^{34}$ Since the fate and treatment of the Italian prisoners of war were at the core of the dispute before the ICJ, the treatment of German prisoners of war matters too. Contrary to the rules of the 1929 Convention on the Treatment of Prisoners of War (Article 75), Germans captured by Allied forces were not released immediately after the end of hostilities. Russia kept German prisoners until 1955, ten years after the German military surrender on 8 May $1945 .{ }^{35}$ The US and the UK sent more than 600,000 German prisoners of war from their respective zones of occupation to France where they were used as forced labourers. ${ }^{36}$ The last prisoners of war were allowed to return home from France in 1948, three years after the end of hostilities.

\footnotetext{
${ }^{32}$ UN General Assembly, Resolution 60/147 on Basic Principles and Guidelines on the Right to a Remedy and Reparation for Victims of Gross Violations of International Human Rights Law and Serious Violations of International Humanitarian Law, 16 December 2005, remains a recommendation and has not acquired the status of positive international law.

${ }^{33}$ For the position of the German Federal Court of Justice, see Judgment of 6 October 2016 (n 26).

${ }^{34}$ Exhaustive study by Ray M Douglas, Orderly and Humane: The Expulsion of the Germans after the Second World War (New Haven/London: Yale University Press 2012).

${ }^{35}$ See Rüdiger Overmans, Soldaten hinter Stacheldraht: deutsche Kriegsgefangene des Zweiten Weltkriegs (Berlin: Propyläen 2000), 258. It is true, on the other hand, that the treatment of the Soviet prisoners of war in the early stages of the war against the Soviet Union in 1941 is one of the most shameful chapters of the German military history. No adequate measures were taken to protect the captured soldiers by providing them with food and shelter. They were left in almost total abandonment without any care and consequently died in large numbers.

${ }^{36}$ See Kurt W Böhme, Die deutschen Kriegsgefangenen in französischer Hand (Zur Geschichte der deutschen Kriegsgefangenen des Zweiten Weltkrieges, Vol XIII) (Munich/Bielefeld: Verlag Ernst und Werner Gieseking 1971), 14-20.
} 


\section{Looking to the Future}

The most deplorable consequence of Sentenza 238/2014, on the basis of its key determination, would be if WWII were continued at the legal level by all victims of ill-treatment at the hands of a foreign power. This is a consequence that the ItCC has not contemplated or in any event is not explicitly dealt with in its judgment. What Italian victims could or can do in bringing claims against Germany would have to be deemed applicable to German victims of grave violations of IHL as well, or for example to African victims of Italian colonialism. International law is not a two-class legal regime made up of full rights-holders on the one side and persons belonging to a nation that forfeited all of its entitlement on the other. In terms of human rights, equality and non-discrimination are the indispensable building blocks of the effective reign of the rule of law. Consequently, the judgment of the ItCC would make impossible any peace settlement after a major armed conflict that was accompanied by massive violations of international humanitarian law or international human rights law. Every individual victim would keep their presumed or alleged entitlements notwithstanding any lump sum agreement to the contrary. ${ }^{37}$ This would be disastrous for world peace.

The case decided by the ItCC shows that in order to attain equitable peace settlements an impartial third institution is required. Such institutions may be established on a case-by-case basis - which presupposes that the parties involved are more or less of equal political weight—or else the relevant parties would have to turn to existing institutions. Obviously, in functional terms the most appropriate institution today would be the UN Peacebuilding Commission established in 2005 concurrently by the General Assembly ${ }^{38}$ and the Security Council. ${ }^{39}$ Within this Commission, fruitful cooperation of the two main bodies of the UN with any litigant parties can be brought about. The shortcomings of the Peacebuilding Commission are that it was established as an advisory body only, lacking the requisite institutional devices of constraint. Here again it appears that the members of the Security Council and their representatives on the Peacebuilding Commission need to acquire a new sense of responsibility. In fact, even the permanent members of the Security Council hold their seats only as a trust of the international community that has chosen them to ensure the general interest of humankind. Their names were not inscribed in the UN Charter as an invitation to assert, through the Security Council, their own specific interests.

Therefore, the Security Council should assume responsibility in a situation where indicia suggest that the parties involved, if left alone, would not attain a fair settlement by failing to reciprocally take account of the interests of the other side.

\footnotetext{
${ }^{37}$ See Christian Tomuschat, 'Peace Treaties and Jus Cogens', in Christian Calliess (ed), Herausforderungen an Staat und Verfassung. Liber Amicorum für Torsten Stein (Baden-Baden: Nomos 2015), 339-359.

${ }^{38}$ UN General Assembly, A/RES/60/180, 20 December 2005.

${ }^{39}$ UN Security Council, S/RES/1645, 20 December 2005.
} 
The best example of a body that discharged its function with absolute neutrality and fairness is the UN Compensation Commission, which was called upon to settle the consequences of the war waged by Iraq against Kuwait. ${ }^{40} \mathrm{With}$ an astounding degree of sober professionalism, the Commission succeeded in distributing the available assets among the claimants in a fair manner, dividing them into different classes and prioritizing those that asserted relatively small amounts of compensation payments.

The judgment of the ItCC provides a well-intentioned reflection on the relationship between the right to a remedy and the rule of jurisdictional immunity. But it has totally lost sight of the underlying landscape of the disputes. Its solution, which suggests pursuing, in cases of serious international crimes, claims against foreign states on the home ground of the victim contrary to the internationally applicable principle of jurisdictional immunity, leads astray. This would cause considerable prejudice to the legal framework of the international community and, at the end of the day, leave the happy claimants among all of the others who have not been able to obtain an enforceable judgment with empty hands.

\section{References}

Böhme, Kurt W, Die deutschen Kriegsgefangenen in französischer Hand (Zur Geschichte der deutschen Kriegsgefangenen des Zweiten Weltkrieges, Vol XIII) (Munich/Bielefeld: Verlag Ernst und Werner Gieseking 1971)

Cannizzaro, Enzo, 'Judicial Immunity and Judicial Protection: The Decision of the Italian Constitutional Court No. 238 of 2014', Rivista di diritto internazionale 98 (2015), 126-134

Cantelmo, Tobia/Valentina Capuozzo, 'Tra Immunità e Contro-Limiti: un nuovo Traguardo della Giurisprudenza Italiana in Corte Costituzionale Sentenza n. 238/2014 e Ordinanza n. 30/2015', Rivista di Diritto Pubblico Italiano, Comparato, Europeo 1 (2016), 1-27

Douglas, Ray M, Orderly and Humane: The Expulsion of the Germans after the Second World War (New Haven/London: Yale University Press 2012)

Francioni, Francesco, 'Access to Justice and Its Pitfalls', Journal of International Criminal Justice 14 (2016), 629-636

Guazzarotti, Andrea, 'Il Paradosso della Ricognizione delle Consuetudini Internazionali. Note Minime a Corte Cost. n. 238 del 2014', Forum di Quaderni Costituzionali, (5 November 2014), available at https://www.forumcostituzionale.it/wordpress/wp-content/uploads/2014/ 11/guazzarotti_nota_238_2014.pdf, 1-4

Harring, Sidney L, 'The Herero Demand for Reparations from Germany: The Hundred Year Old Legacy of a Colonial War in the Politics of Modern Namibia', in Max Du Plessis/Stephen Peté (eds), Repairing the Past?: International Perspectives on Reparations for Gross Human Rights Abuses (Antwerpen: Intersentia 2007), 437-450

Oppenheim, Lassa/Hersch Lauterpacht, International Law: A Treatise (London: Longmans, Vol II, $7^{\text {th }}$ ed 1952)

Overmans, Rüdiger, Soldaten hinter Stacheldraht: deutsche Kriegsgefangene des Zweiten Weltkriegs (Berlin: Propyläen 2000)

\footnotetext{
${ }^{40}$ Established by the United Nations, Security Council, S/RES/687, 3 April 1991. See also Filippo Fontanelli, chapter 'Sketches for a Reparation Scheme', in this volume.
} 
Palchetti, Paolo, 'Can State Action on Behalf of Victims Be the Alternative to Judicial Access to Justice in Case of Grave Breaches of Human Rights?', Italian Yearbook of International Law 24 (2014), 53-60

Pavoni, Riccardo, 'Simoncioni v. Germany', American Journal of International Law 109 (2015), 400-406

Pisillo Mazzeschi, Riccardo, 'La sentenza n. 238/2014 della Corte costituzionale ed i suoi possibili effetti sul diritto internazionale', Diritti umani e diritto internazionale 9 (2015), 23-40

Silvestri, Gaetano, 'Sovranità vs Diritti Fondamentali', Questione Giustizia 1 (2015), 57-63

Passaglia, Paolo, 'Una sentenza (auspicabilmente) storica: la Corte limita l'immunità degli Stati esteri dalla giurisdizione civile', Diritti Comparati, (28 October 2014), available at https://www. diritticomparati.it/una-sentenza-auspicabilmente-storica-la-corte-limita-limmunita-degli-statiesteri-dalla-giurisdizion/

Tomuschat, Christian, 'Peace Treaties and Jus Cogens', in Christian Calliess (ed), Herausforderungen an Staat und Verfassung. Liber Amicorum für Torsten Stein (BadenBaden: Nomos 2015), 339-359

Tomuschat, Christian, 'The National Constitution Trumps International Law', Italian Journal of Public Law 6 (2014), 189-196

Open Access This chapter is licensed under the terms of the Creative Commons Attribution 4.0 International License (http://creativecommons.org/licenses/by/4.0/), which permits use, sharing, adaptation, distribution and reproduction in any medium or format, as long as you give appropriate credit to the original author(s) and the source, provide a link to the Creative Commons license and indicate if changes were made.

The images or other third party material in this chapter are included in the chapter's Creative Commons license, unless indicated otherwise in a credit line to the material. If material is not included in the chapter's Creative Commons license and your intended use is not permitted by statutory regulation or exceeds the permitted use, you will need to obtain permission directly from the copyright holder.

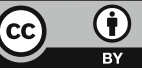




\title{
Sentenza 238/2014: A Good Case for Law-Reform?
}

\author{
Heike Krieger
}

\begin{abstract}
Sentenza 238/2014 is an important judgment which does not only concern the concrete case at hand but also pushes for a change in the law of state immunity. However, such attempts at law-making by national courts may not always attain their goal but may exert adverse effects which are harmful for the international legal order. Sentenza 238/2014 may have an impact on three different yet related issues central to the future development of international law: the relationship between international and national law, exceptions to immunities, and individual reparations in cases of mass atrocities.

This chapter criticises law-making through non-compliance with international judicial decisions by national courts. Judges in democratic states under the rule of law who try to push for law-reform, by initiating non-compliance with decisions of international courts, should be aware that they may act in the company, and thereby in support of, courts in regimes with autocratic tendencies, such as the Russian Constitutional Court, which refuses to comply with judgments of the European Court of Human Rights. Furthermore, the chapter argues that immunity from jurisdiction and immunity from execution should be kept distinct and that human rights exceptions should not be applied to immunity from execution. Such a differentiation remains justified because measures of constraint against property used for government non-commercial purposes intrude even further onto sovereign rights than the institution of proceedings before courts in the forum state. It is particularly difficult for states to protect assets and other property situated in a foreign state. These assets may therefore be more susceptible to abusive enforcement measures while simultaneously forming an essential basis for the actual conduct of international relations.
\end{abstract}

\footnotetext{
H. Krieger $(\square)$

Freie Universität Berlin, Faculty of Law, Berlin, Germany

e-mail: heike.krieger@fu-berlin.de 
The chapter concludes by advocating a cautious approach to individual reparations in cases of mass atrocities. This more cautious approach observes the complexities of ending armed conflicts and negotiating peace deals. An individual right to monetary compensation based on civil claims processes does not allow for taking into account broader political considerations related to establishing a stable post-war order. Such a right is conducive to bilateral settlements between the state parties concerned, which might create new injustices towards other groups of victims. It might also overburden negotiations for a settlement to an ongoing armed conflict.

The chapter thereby starts from the assumption that the stability of the international legal order itself as guaranteed by concepts such as immunities or the respect for its judicial organs serves to protect human rights, albeit indirectly.

\section{Introduction: A Case for Law-Reform? ${ }^{1}$}

The German-Italian dispute over the scope of sovereign immunities and reparations claims for war crimes committed by German armed forces during World War II (WWII) in Italy is in many ways specific and historically contingent. At the same time, it touches upon a number of fundamental challenges which the international community has to address in the interest of furthering the international rule of law. For many observers the dispute represents the injustices and inconsistencies inherent in the international legal order and thus seems to contribute to that order's legitimacy deficits. They doubt that a legal order which hampers redress against serious human rights violations before national courts in the interest of an abstract legal concept, such as sovereign equality protected through state immunity, can be considered as just. $^{2}$ Moreover, they criticize a consistency deficit: if a ius cogens rule is violated this should also affect relevant procedural rules. ${ }^{3}$ Such a perspective furthers the idea of lifting the dispute beyond the specific context and using it as a plea for changing the rules on state immunity. For other observers the case reflects the growing challenges which international law faces from unilateral acts of non-compliance by national courts in the interest of the protection of national constitutional law. ${ }^{4}$

\footnotetext{
${ }^{1}$ Parts of this chapter are based on Heike Krieger, 'Between Evolution and Stagnation: Immunities in a Globalized World', Goettingen Journal of International Law 6 (2014), 177-216 and Heike Krieger, 'Addressing the Accountability Gap in Peacekeeping: Law-making by Domestic Courts as a Way to Avoid UN Reform?', Netherlands International Law Review 62 (2015), 259-277.

${ }^{2}$ See Valerio Onida, chapter 'Moving beyond Judicial Conflict in the Name of the Pre-Eminence of Fundamental Human Rights', in this volume.

${ }^{3} \mathrm{Eg}$, Alexander Orakhelashvili, 'Jurisdictional Immunities of the State', American Journal of International Law 106 (2012), 609-616, at 614-615.

${ }^{4} \mathrm{Eg}$, Anne Peters, 'Let Not Triepel Triumph-How To Make the Best Out of Sentenza No. 238 of the Italian Constitutional Court for a Global Legal Order, EJIL Talk, (22 December 2014), available at www.ejiltalk.org/let-not-triepel-triumph-how-to-make-the-best-out-of-sentenza-no-238-of-theitalian-constitutional-court-for-a-global-legal-order-part-i/; Raffaela Kunz, 'The Italian Constitutional Court and "Constructive Contestation"-A Miscarried Attempt?', Journal of International
} 
Brought together, both perspectives raise the question of whether and to what extent national courts can contribute in a balanced manner to changes of international law which they consider necessary. Thus, Sentenza 238/2014 raises the hope that it 'may also contribute to a desirable — and desired by many_evolution of international law itself' ${ }^{5}$ But is Judgment 238/2014 of the Italian Constitutional Court (ItCC) a good case for law-reform?

Sentenza 238/2014 denied German immunity from civil jurisdiction against claims arising from war crimes committed by German armed forces during WWII. The ItCC argued that the customary international law rule of state immunity in such cases violated fundamental principles of the Italian Constitution. Therefore, the ItCC struck down Article 3 of the Italian Law No 5 of 14 January 2013, which had aimed to execute the 2012 International Court of Justice (ICJ) Judgment in the Jurisdictional Immunities case, ${ }^{6}$ as well as the part of the law implementing the UN Charter which relates to Article 94 of the UN Charter and thus to the compliance with the 2012 ICJ Judgment. ${ }^{7}$ In this judgment the ICJ had upheld the customary rule of jurisdictional immunities without any exceptions for claims arising from war crimes or crimes against humanity.

The creation of customary international law rules through judicial practice may be a means to overcome the opposition of a state's executive branch to further legal developments since judicial reliance on customary international law allows for a state's explicit consent to become less important. Court networks may, in horizontal and vertical dialogues, accelerate the development of customary international law rules even against the expressed intentions of the executive branch on the basis of the principle of judicial independence. Given its role in international relations, it is unsurprising that the executive branch in particular tends to be sceptical of restricting immunities even in cases of serious human rights violations. The frictions which have arisen between the executive and the judiciary in Italy are not as distinctive as they might first appear. Actually, in a number of states a split can be seen between both branches about how to deal with immunity exceptions in cases of serious violations of human rights. Comparable developments have emerged at least temporarily in Switzerland and the US. The executive may even try to stop horizontal dialogue between courts of different states by prompting the decision of an international court. Likewise, the executive — at least in a parliamentary democracy — may also hold back legal developments through instigating legislation. ${ }^{8}$

Criminal Justice 14 (2016) 621-627; Massimo Lando, 'Intimations of Unconstitutionality: The Supremacy of International Law and Judgment 238/2014 of the Italian Constitutional Court', The Modern Law Review 78 (2015), 1028-1041. See also Raffaela Kunz, chapter 'Teaching the World Court Makes a Bad Case', in this volume.

${ }^{5}$ Corte Costituzionale, Judgment of 22 October 2014, No 238/2014, para 3.3.

${ }^{6} \mathrm{ICJ}$, Jurisdictional Immunities of the State (Germany v Italy: Greece intervening), Judgment of 3 February 2012, ICJ Reports 2012, 99.

${ }^{7}$ Art 1 of the Italian Law 17 August 1957, No 848.

${ }^{8}$ Krieger, 'Between Evolution and Stagnation' 2014 (n 1), 194 et seq with further references. 
The adverse impact of such uncoordinated efforts at prompting or retaining law-reform in a decentralized legal order have culminated in the Jurisdictional Immunities Judgment and Sentenza 238/2014 and point to the need for caution by all actors involved. Such adverse consequences may affect the state itself in so far as non-compliance by courts may incur state responsibility. Simultaneously, such symbolic cases of non-compliance risk undermining the authority of international judicial organs, such as the ICJ (sections II.1 and II.2). Thus, instead of promoting the legitimacy of international law, a court opposing findings of international judicial organs might be undermining the international rule of law. Unilateralist attempts to further legal developments should be aware of such adverse effects. Otherwise they may find themselves contributing to perceived legitimacy deficits of the international legal order by furthering certain double standards, advocating highly contested standards (section II.3), or creating expectations which international law might be unable to fulfil (section II.4). Instead, any such effort for law-reform should aim at advocating standards that are generalizable outside the specific context of the dispute at hand (section III). The chapter concludes by stressing that concepts such as immunities or the respect for judicial organs of the international order guarantee its stability and thereby serve to protect human rights, albeit indirectly (section IV).

\section{Adverse Effects}

The idea to promote legal developments through judicial dialogue is ambivalent. On the one hand, the creation of customary international law can be seen as an uncoordinated, bottom-up process entailing cases of non-compliance as a starting point for new legal rules. On the other hand, where constitutional courts contest recent findings of international courts and even choose non-compliance with a decision against 'their' respective state, they risk engaging their state's responsibility under international law even though they aim to further a specific perception of the adequate legal development.

\section{Incurring State Responsibility}

According to Article 94 of the UN Charter and Article 59 of the ICJ Statute, Italy has to comply with the findings of the 2012 ICJ Judgment. Article 94 of the UN Charter requires a state to realize the obligations which stem from the operative part of the ICJ's decision, including the ratio decidendi. ${ }^{9}$ In view of Article 4 of the International Law Commission's Draft Articles on Responsibility of States for

\footnotetext{
${ }^{9}$ Karin Oellers-Frahm/Hermann Mosler, 'Art 94', in Bruno Simma et al (eds), The Charter of the United Nations (Oxford: OUP $3^{\text {rd }}$ ed 2012), 1174-1179.
} 
Internationally Wrongful Acts (ASR), ${ }^{10}$ the 2012 ICJ Judgment binds all state organs. Accordingly, the competent state organ has to follow the obligation established by the Court's Judgment. If it fails to do so, the state engages its responsibility. ${ }^{11}$ As defined in the commentary to the ASR, 'the essence of an internationally wrongful act lies in the non-conformity of the State's actual conduct with the conduct it ought to have adopted in order to comply with a particular international obligation'. ${ }^{12}$ The finding of the ItCC that Article 3 of the Law No 5/2013 - which aims to implement the ICJ's decision-'has to be declared unconstitutional' constitutes such a non-conformity. ${ }^{13}$ However, the findings of the ItCC may only establish conduct prior to a breach, so that the 'apprehended or imminent ${ }^{14}$ breach has yet to occur. ${ }^{15}$ The commentary to the ASR does not formulate any general rule in this regard but highlights that the decision needs to take into account the primary obligation, the facts of the case, and the context. It suggests that 'preparatory conduct does not itself amount to a breach if it does not "predetermine the final decision to be taken", 16

Thus, the question regarding whether Judgment 238/2014 violates Italy's obligations under the 2012 ICJ Judgment as based on Article 94 of the UN Charter depends on the effects that the decision entails within the Italian legal order for other Italian state organs in their international relations with Germany and on their actual behaviour. According to Article 136 of the Italian Constitution, a law which the ItCC has declared unconstitutional no longer has any effect from the day following the publication of the decision. As Karin Oellers-Frahm has demonstrated, because of Sentenza 238/2014 the law enacting the UN Charter-albeit merely in relation to Article 94 of the UN Charter and the law implementing the ICJ Judgment-no longer pertains to the Italian legal order; neither does the customary international law rule on state immunity insofar as it contradicts fundamental constitutional principles. ${ }^{17}$ However, as long as the decision provides a certain leeway that allows other

\footnotetext{
${ }^{10}$ ILC, Draft Articles on Responsibility of States for Internationally Wrongful Acts, adopted by the Commission at its fifty-third session in 2001 (Final Outcome), UN Doc A/56/10, 43, UN Doc A/RES/56/83, Annex, UN Doc A/CN.4/L.602/Rev.1, GAOR 56 ${ }^{\text {th }}$ Session Supp 10, 43.

${ }^{11}$ Oellers-Frahm/Mosler, 'Art 94' 2012 (n 9).

${ }^{12}$ James Crawford, The International Law Commission's Articles on State Responsibility: Introduction, Text and Commentaries (Cambridge: CUP 2002), 126 (Commentary to Art 12(3)).

${ }^{13}$ ItCC, Judgment 238/2014 (n 5), para 5.

${ }^{14}$ Crawford, International Law 2002 (n 12), 138 et seq (Commentary to Art 14(13)).

${ }^{15}$ ICJ, Gabčíkovo-Nagymaros Project (Hungary v Slovakia), Judgment of 25 September 1997, ICJ Reports 1997, 51, para 79: 'Such a situation is not unusual in international law or, for that matter, in domestic law. A wrongful act or offence is frequently preceded by preparatory actions which are not to be confused with the act or offence itself. It is as well to distinguish between the actual commission of a wrongful act (whether instantaneous or continuous) and the conduct prior to that act which is of a preparatory character and which "does not qualify as a wrongful act"”.

${ }^{16}$ Crawford, International Law 2002 (n 12), 138 et seq (Commentary to Art 14(13)).

${ }^{17}$ Karin Oellers-Frahm, 'A Never-Ending Story: The International Court of Justice-The Italian Constitutional Court-Italian Tribunals and the Question of Immunity', Heidelberg Journal of International Law 76 (2016), 193-202, at 196.
} 
courts, the executive, and the legislative branch to comply with the 2012 ICJ Judgment in a manner compatible with international law, a breach will not yet have occurred. ${ }^{18}$ After all, the ICJ in its 2012 Judgment gave Italy a certain amount of discretion in implementing the judgment when it found that 'the Italian Republic must, by enacting appropriate legislation, or by resorting to other methods of its choosing, ensure that the decisions of its courts and those of other judicial authorities infringing the immunity which the Federal Republic of Germany enjoys under international law cease to have effect' ${ }^{19}$ Thus, it is important to note that the Italian executive branch argued in the ensuing cases before Italian civil courts that the courts should grant Germany jurisdictional immunity. ${ }^{20}$ Of course, in the case at hand these reflections are already theoretical because Italian courts have issued default judgments and decisions on the merits in the wake of Sentenza 238/2014. ${ }^{21}$ These court proceedings do not only infringe the rules on state immunity but they also constitute a breach of Italy's legal obligation flowing from the findings of the 2012 ICJ Judgment.

In the academic literature, a number of voices suggest that the wrongfulness of such conduct should be precluded. A particularly far-reaching approach argues that wrongfulness could be precluded by invoking that a democratic state must respect the fundamental rights guaranteed in its constitution. ${ }^{22}$ However, such approaches are not only irreconcilable with Article 27 of the Vienna Convention on the Law of Treaties, as well as Articles 4 and 32 ASR, but would also have adverse, long-term effects for the international legal order. Such a justification would undermine the sovereign equality of states and induce a hierarchy between states, necessarily distinguishing between democratic states and other (non-democratic) states. The question that would arise is whether even an international court or tribunal would be well advised to make any determination on the basis of such value- and policyloaded criteria. Would the German and the Italian Constitutional Courts be justified

\footnotetext{
${ }^{18} \mathrm{Cf}$ Crawford, International Law 2002 (n 12), 130 (Commentary to Art 12(12)); Christian Tomuschat, 'National and International Law in Italy: The End of an Idyll', Italian Journal of Public Law 6 (2014), 187-196, at 192 et seq.

${ }^{19} \mathrm{ICJ}$, Jurisdictional Immunities (n 6), para 139.

${ }^{20}$ Oellers-Frahm, 'A Never-Ending Story’ 2016 (n 17), 195 et seq. See also Paolo Palchetti, chapter 'Right of Access to (Italian) Courts über alles?', in this volume.

${ }^{21}$ Oellers-Frahm, 'A Never-Ending Story' 2016 (n 17), 193 et seq; for decisions on the merits, see Tribunale di Firenze, Order of 23 March 2015, Case No 2012/1300 and Judgment of 6 July 2015, No 2468/2015; Tribunale di Piacenza, Judgment of 25 September 2015, No 723/2015. For an English analysis of these three decisions, see Oellers-Frahm, 'A Never-Ending Story' 2016 (n 17), 197 et seq.

${ }^{22}$ For this approach, albeit critically, Massimo Iovane, 'The Italian Constitutional Court Judgment No. 238 and the Myth of the "Constitutionalization" of International Law', Journal of International Criminal Justice 14 (2016), 595-605, at 604; with reference to Benedetto Conforti, Diritto Internazionale (Naples: Editoriale Scientifica $10^{\text {th }}$ ed 2014), 402 et seq.
} 
in refusing compliance with judgments of the European Court of Human Rights (ECtHR) on the basis of their reasoning in the Görgülü case ${ }^{23}$ or in Sentenza 238/2014 because both Germany and Italy are genuine constitutional democracies while the Russian Constitutional Court would not be justified to do so in the Yukos case? ${ }^{24}$

\section{Preserving Judicial Authority Through Legitimizing Strategies?}

Acting against traditional standards of the rule of law, national courts which choose non-compliance exceed the limits of judicial dialogue and thus challenge the authority of international judicial organs. Therefore, these courts will have to rely on additional considerations of legitimacy in order to make a tenable case to their domestic audiences and the international community. While the ItCC seems to have been aware of such dilemmas, it has not succeeded in mitigating them through its legitimizing strategy.

In its self-perception, Sentenza 238/2014 pressures for a progressive evolution of international law and aims to gain legitimacy by referring to two precedents: (1) the role of national courts in the early twentieth century, which enabled law-reform by establishing the distinction between acta iure imperii and acta iure gestionis, ${ }^{25}$ and (2) the Kadi case ${ }^{26}$ of the European Court of Justice (ECJ). ${ }^{27}$ Regarding the former, Sentenza 238/2014 stresses the historically important role Italian courts played in the process of establishing the differentiation between acta iure gestionis and acta iure imperii. $^{28}$ However, the historical comparison cannot sufficiently legitimize the

\footnotetext{
${ }^{23}$ Bundesverfassungsgericht, Order of 14 October 2004, 2 BvR 1481/04, BVerfGE 111, 307 (Görgülï).

${ }^{24}$ Constitutional Court of the Russian Federation, Judgment of 19 January 2017, No 1-П, regarding the constitutionality of execution of the ECtHR Judgment of 31 July 2014 in the case OAO Neftyanaya Kompaniya YUKOS v Russia, Judgments of 20 September 2011 and 31 July 2014, Application No 14902/04; for an analysis of the Russian Constitutional Court's approach, see Matthias Hartwig, 'Vom Dialog zum Disput? Verfassungsrecht vs. Europäische Menschenrechtskonvention-Der Fall der Russländischen Föderation', Europäische Grundrechte-Zeitschrift 44 (2017), 1-22.

${ }^{25}$ ItCC, Judgment 238/2014 (n 5), para 3.3.

${ }^{26} \mathrm{CJEU}$, Kadi and Al Barakaat International Foundation v Council of the European Union and Commission of the European Communities, Judgment of 3 September 2008, Joined Cases Nos $\mathrm{C}-402 / 05 \mathrm{P}$ and $\mathrm{C}-415 / 05 \mathrm{P}$.

${ }^{27}$ ItCC, Judgment 238/2014 (n 5), para 3.4.

${ }^{28}$ ItCC, Judgment 238/2014 (n 5), para 3.3: 'The customary international norm of immunity of States from the civil jurisdiction of other States was originally absolute, since it included all state behaviors. More recently, namely in the first half of the last century, this norm undertook a progressive evolution by virtue of national jurisprudence, in the majority of States, up until the identification of acta jure gestionis (an easily understandable expression) as the relevant limit. And
} 
ItCC's approach once we consider differences in context. In the early twentieth century, the international legal order was even more decentralized than it is today. Italian and Belgian courts acted neither in non-compliance with the judgments of the central judicial organ of the international community nor in the immediate wake of the pronouncements of said organ's decisions. Furthermore, they did not set a precedent for other courts to question the authority of such institutions. As Anne Peters and Raffaela Kunz have underlined, this last factor also constitutes a significant difference to the Kadi case of the ECJ. While both courts might aim to protect 'constitutional principles' against conflicting international obligations, the ECJ's Kadi decision is directed against a political organ whose nearly unfettered discretion is hardly controlled by international courts. ${ }^{29}$ In this respect, the ECJ can raise a much stronger claim for realizing the idea of a dédoublement fonctionnel-ie that it acts as an organ of international law-than the ItCC.

Judges who push for law-reform by initiating non-compliance with the decisions of international courts should be aware that the overall international climate is currently changing. With the lingering shift from a unipolar to a multipolar world order, certain elements of the international rule of law have come under attack. Across the board, international norms and institutions are contested and perceptions of the legitimacy of international law vary according to an increasingly diverging array of national (ideological) backdrops. ${ }^{30}$ Today national courts act in the company, and are thereby in support, of the Russian Constitutional Court, which refuses

it is well known that this limit to the application of the norm of immunity was progressively established mainly thanks to Italian judges (...) the so-called "Italian-Belgian theory". In short, national judges limited the scope of the customary international norm, as immunity from civil jurisdiction of other States was granted only for acts considered jure imperii. (...) It is of significant importance that the evolution as described above originated in the national jurisprudence, as national courts normally have the power to determine their competence, and leave to international organs the recognition of the practice for the purposes of identifying customary law and its evolution. Since such a reduction of immunity for the purposes of protection of rights took place, as far as the Italian legal order is concerned, thanks to the control exercised by ordinary judges in an institutional system characterized by a flexible Constitution (in which the recognition of rights was supported by limited guarantees only), the exercise of the same control in the republican constitutional order (founded on the protection of rights and the consequent limitation of powers, as guaranteed by a rigid Constitution) falls inevitably to this Court.'

${ }^{29}$ Peters, 'Let Not Triepel Triumph' 2014 (n 4); Kunz, 'The Italian Constitutional Court' 2016 (n 4), 626; see also Martin Scheinin, 'The Italian Constitutional Court's Judgment 238 of 2014 Is Not Another Kadi Case', Journal of International Criminal Justice 14 (2016), 615-620; and Tomuschat, 'National and International Law' 2014 (n 18), 189.

${ }^{30}$ Heike Krieger/Georg Nolte, 'The International Rule of Law-Rise or Decline?-Approaching Current Foundational Challenges', in Heike Krieger/Georg Nolte/Andreas Zimmermann (eds), The International Rule of Law: Rise or Decline? - Foundational Challenges (Oxford: OUP 2019), 3-30; see also Karin Alter, 'The Future of International Law', in Diana Ayton-Shenker (ed), The New Global Agenda: Priorities, Practices, and Pathways of the International Community, (Lanhman/ Maryland: Rowman \& Littlefield Publishers 2018); David Bosco, 'We've Been Here Before: The Durability of Multinationalism', Columbia Journal of International Affairs 70 (2017), 9-15; AnneMarie Slaughter, 'The Return of Anarchy?', Columbia Journal of International Affairs 70 (2017), Special $70^{\text {th }}$ Anniversary Issue, 11-16. 
compliance with the judgments of the ECtHR. Even if Sentenza 238/2014 claims to argue not at the level of international law but exclusively on the plane of domestic law, the ItCC is well aware that only declaring unconstitutional the legislation implementing the ICJ Judgment, and not the Judgment itself, still challenges the authority of the UN's principal judicial organ. After all, the ItCC explicitly expresses the hope of contributing to law-reform. In the past, 'reasonable resistance by national actors - if it is exercised (...) in good faith and with due regard for the overarching ideal of international cooperation-might (...) [have built] up the political pressure needed for promoting the progressive evolution of international law in the direction of a system more considerate of human rights'. 31 As Anne Peters has stressed, decisions such as Solange I of the German Federal Constitutional Court (FCC) or the ECJ's Kadi decision have indeed contributed to a progressive development of international law and international institutions. ${ }^{32}$ However, considerable changes in the overall atmosphere of today's international order affect our understanding of what should be considered as good faith. Challenges arising from the non-compliance of courts with ICJ decisions can be detrimental to the normativity of the international legal order in its current shape. ${ }^{33}$ But more troubling is that such challenges endanger the international legal order's most important foundations, namely universality and multilateralism and instead favour particularity and unilateralism. In the long run, recurring precedents of national 'civil disobedience' might be as dangerous for the normative force of international human rights law as they are detrimental at present for international law in general. The symbolism and the precedential effects of such forms of disobedience will likely not be contained to those areas the ItCC conceives to be legitimate but extend to other scenarios such as the Yukos case. Law-reform beyond formal avenues needs to make sure that its postulations are generalizable and needs to take seriously the risk of misuse. In the case of Sentenza 238/2014 the risk of abuse does not only arise from the precedential effects of non-compliance but also from the implications for the rule on immunities itself.

\section{Change 'Desired by Many'?: Highly Contested Exceptions to Immunities}

Sentenza 238/2014 hopes to 'contribute to a desirable - and desired by manyevolution of international law itself ${ }^{\text {, } 34}$ by furthering human rights-based exceptions to state immunities. It starts from the assumption that the values it wants to promote, and which are based on its reading of the Italian Constitution, are globally shared.

\footnotetext{
${ }^{31}$ Peters, 'Let Not Triepel Triumph' 2014 (n 4).

${ }^{32}$ Bundesverfassungsgericht, Order of 29 May 1974, 2 BvL 52/71, BVerfGE 37, 271 (Solange I).

${ }^{33}$ See also Christian Tomuschat, chapter 'The Illusion of Perfect Justice', in this volume.

${ }^{34}$ ItCC, Judgment 238/2014 (n 5), para 3.3.
} 
Such an understanding would be a necessary starting point for any bona fide act of non-compliance with an ICJ decision. However, in the case of human rights-based exceptions to immunities, a consensus about the desirability of change is far from clear. The 2012 ICJ Judgment was based on a thorough analysis of relevant national court decisions and other state practice, ${ }^{35}$ and in its aftermath, other courts have applied the Judgment. ${ }^{36}$ While human rights-based exceptions to the immunities of state officials have proved to be highly contested in the Sixth Committee of the $\mathrm{UN},{ }^{37}$ there are no comparable indications in international fora for such a dissent in relation to state immunities.

Even within Italy, the findings of the ItCC are not undisputed. The Italian executive branch seems well aware that changes in international law which the ItCC advocates for are likely to entail adverse consequences also for Italy itself. ${ }^{38}$ As, for instance, the US State Department has affirmed in the past regarding the claim for a ius cogens-based immunity exception for state officials in proceedings before national courts, '[t]he recognition of such an exception could prompt reciprocal limitations by foreign jurisdictions exposing U.S. state officials to suit abroad on that basis'. ${ }^{39}$ The US worries that by altering their own judicial practice, it will contribute to the creation of a new customary international law rule that would lead to US state officials being subject to similar proceedings all over the world. In particular, in the case of the US, there is a not entirely unfounded apprehension that these proceedings may not always be conducted impartially. ${ }^{40}$

Is this assumption farfetched? If proceedings are carried out against foreign states and their state officials in cases of grave violations of human rights before national

\footnotetext{
${ }^{35} \mathrm{ICJ}$, Jurisdictional Immunities (n 6), paras 65 et seq.

${ }^{36}$ Eg Supreme Court of Canada, Judgment of 10 October 2010, 2014 SCC 62, [2014] 3 S.C.R. 176 (Kazemi Estate v Islamic Republic of Iran), paras 61, 103-108.

${ }^{37}$ The 2017 debate on Draft Art 7(1) containing human rights-based exceptions to immunities of state officials can be summarized as follows: in total, 23 states have argued in favour of the general rule included in the Article while 21 disagreed with it. A number of states promoting the rule have expressed their conviction that it constitutes a progressive development of international law; see Janina Barkholdt/Julian Kulaga, 'Analytical Presentation of the Comments and Observations by States on Draft Article 7, Paragraph 1, of the ILC Draft Articles on Immunity of State Officials from Foreign Criminal Jurisdiction, United Nations General Assembly, Sixth Committee, 2017', KFG Working Paper Series 14 (Berlin Potsdam Research Group 'The International Rule of Law-Rise or Decline?'), (16 May 2018), available at https://papers.ssrn.com/sol3/papers.cfm?abstract_ $\mathrm{id}=3172104$.

${ }^{38}$ Oellers-Frahm, ‘A Never-Ending Story’ 2016 (n 17), 195 et seq.

${ }^{39}$ US Court of Appeals for the Second Circuit, Matar and Others v Dichter, Brief for the United States of America as Amicus Curiae in Support of Affirmance, 19 December 2007, Docket No 07-2579-cv, available at http://ccrjustice.org/files/Matar\%20v\%20\%20Dichter,\%20US\%20for\% 20Defendants\%20Amicus\%20Brief\%2012.19.07.pdf, 4; see also John B Bellinger, 'The Dog that Caught the Car: Observations on the Past, Present, and Future Approaches of the Office of the Legal Adviser to Official Acts Immunities', Vanderbilt Journal of Transnational Law 44 (2011), 819-835, at 833 et seq.

${ }^{40}$ Krieger, 'Between Evolution and Stagnation' 2014 (n 1), 193 et seq with reference to Bellinger, 'The Dog that Caught the Car' 2011 (n 39), 834 et seq.
} 
courts in the US, Switzerland, Canada, Italy, and the UK, these states will also have to accept such proceedings against them and their state officials before national courts in Algeria, China, Eritrea, Ethiopia, Libya, Iran, Congo, Rwanda, or Zimbabwe. ${ }^{41}$ In the end, the denial of immunity requires an international community of states under the rule of law providing an equivalent level of human rights protection. As long as there is no such international community, immunity serves to protect states themselves and their state officials from being exposed to court proceedings that do not meet the standard of the rule of law. ${ }^{42}$ Hence, Judge Ellis stated in his Memorandum Opinion in the Tabion v Mufti case that the aim of granting immunity was '[to] protect United States [officials] from (...) prosecution in foreign lands (...) [because] not all countries provide the level of due process to which United States citizens have become accustomed'. ${ }^{43}$ In light of such conflicts between normative claims and legal reality, immunity seems to be, in the words of Hazel Fox, 'a neutral way of denying jurisdiction to States over the internal administration of another State and diverting claims to settlement in the courts of that State, or by diplomatic or other international means to which that State has consented'. ${ }^{4}$

If immunity serves as a plea against the exercise of jurisdiction in a decentralized legal system where competences are divided, and is - in the words of Hazel Fox and Philippa Webb-'a signal to the forum court that jurisdiction belongs to another court or method of adjudication', 45 the question arises whether any consequences need to be attached to the fact that claims for reparation by Italian citizens have been rejected by German courts. After all, a justification for granting immunity can be seen in the fact that generally immunities do not lead to the loss of a claim or that an offender remains criminally responsible. As a rule, there are alternative legal paths and international mechanism available that correspond to each kind of immunity. ${ }^{46}$

Thus, the ItCC in Sentenza 238/2014 has been interpreted as mandating 'that the customary rule of foreign state immunity is not incorporated into the Italian legal system, insofar as that rule applies to international crimes for which there is no effective means of redress available to the victims other than a suit in the forum state'. ${ }^{7}$ However, the right of access to court, at least under the European

\footnotetext{
${ }^{41}$ Ibid, 213 et seq.

${ }^{42}$ Ibid, 214.

${ }^{43}$ US District Court for the Eastern District of Virginia, Tabion v Mufti, Memorandum Opinion of Judge Ellis, (E.D. Va. 1995) 877 F. Supp. 285, 293.

${ }^{44}$ Hazel Fox, 'In Defence of State Immunity, Why the UN Convention on State Immunity is Important', International and Comparative Law Quarterly 55 (2006), 399-406, at 405.

${ }^{45}$ Hazel Fox/Philippa Webb, The Law of State Immunity (Oxford: OUP $3^{\text {rd }}$ ed 2013), 27.

${ }^{46}$ Krieger, 'Between Evolution and Stagnation' 2014 (n 1), 204.

${ }^{47}$ Riccardo Pavoni, 'How Broad is the Principle Upheld by the Italian Constitutional Court in Judgment No. 238?', Journal of International Criminal Justice 14 (2016), 573-585, at 574; see also Riccardo Pavoni, chapter 'A Plea for Legal Peace', in this volume. See, for a comparable argument, Micaela Frulli, "TTime Will Tell Who Just Fell and Who's Been Left Behind”: On the Clash between the International Court of Justice and the Italian Constitutional Court', Journal of International Criminal Justice 14 (2016), 587-594.
} 
Convention on Human Rights (ECHR), is not per se infringed if a case is decided on the merits. Cases brought before German courts were thought to be unfounded because either the specific regime of state responsibility under German law was not applicable to military activities in armed conflicts or because there is no individual right to compensation for violations of international humanitarian law. ${ }^{48}$ While this approach may appear unjust, it conforms to the prevailing view in international humanitarian law and corresponds mutatis mutandis to approaches in other states under the rule of law. ${ }^{49}$ It therefore cannot be considered arbitrary jurisprudence.

\section{Creating False Promises: Human Rights Exceptions to Immunities from Execution?}

Has the situation of Italian claimants now been improved by Sentenza 238/2014 and the ensuing decisions of Italian civil courts? To reach this aim yet another stage in law-reform would be required: extending human rights exceptions to immunities from execution. In Sentenza 238/2014, the ItCC explicitly did not deal with immunity from measures of constraint. ${ }^{50}$ Thus, under Italian constitutional law it is not yet clear whether immunities from execution are compatible with the right of access to court where serious violations of human rights are at stake. Accordingly, in the situation at hand, policy reasons push for further human rights exceptions to immunities from execution.

Court decisions rendered in the wake of the ItCC's jurisprudence create an expectation on the side of the applicants that they will indeed receive a monetary compensation. In Italy, most German state assets are protected by immunities because they serve government non-commercial purposes, while enforcement in Germany will be unsuccessful because judgments based on a violation of German jurisdictional immunities suffer from a serious procedural defect, which means they cannot serve as a basis for measures of constraint. ${ }^{51}$ Therefore, it is reasonable to assume that the case at hand will put additional pressure on the distinction between (pre-judgment) immunity from jurisdiction and (post-judgment) immunity from execution. Moreover, it is not inconceivable that if immunity from jurisdiction was

\footnotetext{
${ }^{48} \mathrm{Cf}$ Bundesverfassungsgericht, Order of 28 June 2004, 2 BvR 1379/01, BVerfGK 3, 277, para 38 et seq; see also Bundesgerichtshof (Federal Court of Justice), Judgment of 26 June 2003, III ZR 245/98, BGHZ 155, 279 (Distomo), 293 et seq for the period before 1949 and for the current legal situation see Bundesgerichtshof, Judgment of 6 October 2016, III ZR 140/15, BGHZ 212, 173 (Kunduz).

${ }^{49}$ See Heike Krieger, 'Addressing the Accountability Gap' 2015 (n 1).

${ }^{50}$ ItCC, Judgment 238/2014 (n 5), para 1; cf Oellers-Frahm, 'A Never-Ending Story' 2016 (n 17), 194.

${ }^{51}$ Tomuschat, 'National and International Law' 2014 (n 18), 193.
} 
to be considered unconstitutional because of an infringement of the right of access to court, immunity from execution will likewise be affected. ${ }^{52}$

Such additional pressure is also buttressed by a broad expectation of consistency as an element of the rule of law concept. Expectations of consistency create an extra argumentative burden for justifying that human rights exceptions should not apply to immunities from execution. A lack of consistency is the major policy argument in favour of any kind of additional restriction of enforcement immunity because 'a denial of justice on the enforcement level would render the adjudicatory jurisdiction, granted under any restrictive immunity concept, meaningless'. 53

Accordingly, based on its jurisprudence that human rights should be effective and not illusory, the ECtHR held that the right of access to court according to Article 6 of the ECHR does not only concern the pre-judgment phase but also the post-judgment phase of execution. The right, based on Article 6 of the ECHR, would 'be illusory if a Contracting State's domestic legal system allowed a final, binding judicial decision to remain inoperative to the detriment of one party'. ${ }^{54}$ Accordingly, a consequentialist argument has been raised by two judges of the ECtHR in a concurring opinion in the Al-Adsani case, according to which restrictions on immunity for violations of the right of access to court "would thus have required a possibility of having judgments - probably often default judgments- $-(.$.$) executed against respondent$ States. This in turn would raise the question whether the traditionally strong immunity of public property from execution would also have had to be regarded as incompatible with Article 6, 55

However, the judges raising this argument actually used it as a counterargument against restricting pre-judgment immunity. They warned against the unintended consequences which result from expectations of consistency and blur more complex reasons for differentiation. Thus, the confirmation of the ICJ in the Jurisdictional Immunities Judgment that immunity from suit and immunity from execution are distinct $^{56}$ is still widely shared. ${ }^{57}$ Under customary international law, states enjoy immunity from execution in relation to property which is used for government non-commercial purposes. ${ }^{58}$ Since immunity from execution is applied separately from immunity from jurisdiction, arguments for excluding immunity from jurisdiction are not directly applicable to immunity from execution. ${ }^{59}$

\footnotetext{
${ }^{52} \mathrm{Cf}$ Fox/Webb, The Law of State Immunity 2013 (n 45), 514; see also Paolo Palchetti, chapter 'Right of Access to (Italian) Courts über alles?', in this volume.

${ }^{53} \mathrm{Cf}$ August Reinisch, 'European Court Practice Concerning State Immunity from Enforcement Measures', European Journal of International Law 17 (2006), 803-836, at 809.

${ }^{54}$ ECtHR, Hornsby v Greece, Judgment of 19 March 1997, Application No 18357/91, para 40.

${ }^{55}$ ECtHR, Al-Adsani $v$ The United Kingdom, Judgment of 21 November 2001, Application No 35763/97, Concurring Opinion of Judge Pellonpää, joined by Judge Sir Nicolas Bratza.

${ }^{56}$ ICJ, Jurisdictional Immunities (n 6), para 113.

${ }^{57}$ Fox/Webb, The Law of State Immunity 2013 (n 45), 490.

${ }^{58}$ See also Article 19 of the UN Convention on Jurisdictional Immunities of States and Their Property (2 December 2004), UN Doc A/RES/59/38, UN Doc A/59/49, 486 (not yet in force).

${ }^{59} \mathrm{ICJ}$, Jurisdictional Immunities (n 6), para 113.
} 
Such a differentiation is justified because measures of constraint against property used for government non-commercial purposes intrude even further onto sovereign rights than the institution of proceedings before courts in the forum state ${ }^{60}$ It is particularly difficult for states to protect assets and other property situated in a foreign state. These assets may therefore be susceptible to abusive enforcement measures while at the same time constituting an essential basis for the actual conduct of international relations. The rationale of strong protection for property designated for government non-commercial purposes has clearly been expressed in the presidential waiver issued by President Bill Clinton in relation to the 1976 Foreign Sovereign Immunities Act, which allows US victims of terrorism to attach and execute judgments against the diplomatic or consular properties of a foreign state: ${ }^{61}$

If this section [of the Act] were to result in attachment and execution against foreign embassy properties, it would encroach on my authority under the Constitution to "receive Ambassadors and other public Ministers". Moreover, if applied to foreign diplomatic or consular property, section 177 would place the United States in breach of its international treaty obligations. It would put at risk the protection we enjoy at every embassy and consulate throughout the world by eroding the principle that diplomatic property must be protected regardless of bilateral relations (...). In addition, section 177 could seriously affect our ability to enter into global claims settlements that are fair to all United States claimants and could result in United States taxpayer liability in the event of a contrary claims tribunal judgment. $^{62}$

\section{Generalizable Standards: Towards an Obligation to Provide for Individual Reparation in Cases of Mass Atrocities?}

The presidential waiver outlined above emphasizes a need to negotiate global claims settlements as an alternative form of compensation to individual reparation granted by national courts in the US, thus stressing the need for political leeway in such cases. Are there good reasons for retaining such leeway, or should there be an obligation incumbent upon states to provide for individual monetary compensation in cases of mass atrocities as a general rule of international law?

\footnotetext{
${ }^{60}$ Reinisch, 'European Court Practice' 2006 (n 53), 804.

${ }^{61}$ See Section 117 of the US Treasury and General Government Appropriations Act of 1999, as contained in the Omnibus Consolidated and Emergency Supplemental Appropriations Act of 1999, Public Law 21 October 1998, No 105-277, 112 Statute 2681.

${ }^{62}$ Statement on Signing the Omnibus Consolidated and Emergency Supplemental Appropriations Act, 1999, 34 Weekly Compilation of Presidential Documents 2108, 2133 (23 October 1998), quoted in Sean D Murphy, 'Contemporary Practice of the United States Relating to International Law', American Journal of International Law 93 (1999), 161-194, at 185 et seq.
} 
While international law still does not provide for a general right to compensation in cases of violations of international humanitarian law, there are increasing efforts at the international as well as the national level to change the existing law. ${ }^{63}$ Such a call for an obligation to grant individual monetary compensation is owed to changing public perceptions on the position of the individual in armed conflicts and a concerted effort by NGOs to bring pertinent cases before national courts. Indications of a change in the overall perception may, inter alia, be seen in the Basic Principles and Guidelines on the Right to a Remedy and Reparation for Victims of Gross Violations of International Human Rights Law and Serious Violations of International Humanitarian Law, ${ }^{64}$ although these principles would still not create a subjective right under international law on which an individual could rely before a domestic court. $^{65}$

With respect to the 2013 Varvarin case, even the German FCC seems to have left the door open for future judicial review of the activities of German armed forces abroad. Although it did not have to decide on the question of whether the ordinary law of state liability covers damages caused by war, ${ }^{66}$ it made clear that courts are competent and capable to judicially control the decision to qualify the object of an attack as a military object according to international humanitarian law. ${ }^{67}$ The FCC thus stressed its competence to deal with violations of international humanitarian law as a matter of human rights adjudication. Therefore, while the German Federal Court of Justice in a 2016 judgment on an air strike in Kunduz, Afghanistan, clung to the traditional interpretation that neither the specific regime of state responsibility under German law is applicable to military activities in armed conflict nor that there is an individual right to compensation for violations of international humanitarian law, ${ }^{68}$ the FCC might take a different stance in an appropriate case.

But it is not only the increasing focus on the individual in international law which fosters such a change in the conceptualization of how to treat individuals during and in the aftermath of an armed conflict. The perception that the individual should be compensated as a matter of law is also due to the predominant nature of armed conflicts during the last 20 years. Military interventions under the umbrella of the UN or by NATO member states were often not understood as being conducted against a whole state and its population but against non-state actors or 'rogue'

\footnotetext{
${ }^{63} \mathrm{Cf}$ Christian Marxsen/Anne Peters (eds), 'Reparation for Victims of Armed Conflict: Impulses from the Max Planck Trialogues', Heidelberg Journal of International Law 78 (2018), 519-633.

${ }^{64}$ UN General Assembly, Resolution on Basic Principles and Guidelines on the Right to a Remedy and Reparation for Victims of Gross Violations of International Human Rights Law and Serious Violations of International Humanitarian Law, 16 December 2005, UN Doc A/Res/60/147. See also Andreas von Arnauld, chapter 'Deadlocked in Dualism', in this volume.

${ }^{65}$ Philipp Stöckle, 'Victims Caught between a Rock and a Hard Place: Individual Compensation Claims against Troop-Contributing States', Die Friedens-Warte 88 (2013), 119-141, at 128.

${ }^{66}$ Bundesverfassungsgericht, Order of 13 August 2013, 2 BvR 2660/06, 2 BvR 487/07, (German Constitutional Court Order of Non-Acceptance), para 52.

${ }^{67}$ Ibid, para 55.

${ }^{68} \mathrm{BGH}$, Kunduz (n 48).
} 
governments. Accordingly, the post-conflict order needed to distinguish more clearly between different groups and individuals within a state. ${ }^{69}$ Accordingly, the affected population should be redressed for any harm incurred during the armed conflict, or at least during the phase of post-conflict reconstruction. However, the issue of individual reparations in cases of mass atrocities should be treated cautiously. Military interventions with an aim of stabilizing another state and even of protecting human rights may in the near future diminish in frequency while more traditional forms of armed conflict may re-emerge, such as in Ukraine and Syria.

In this context, it is important to note that in current debates within the International Law Commission on crimes against humanity, the assertion that an individual right to reparation in cases of mass atrocities exists, or should exist, under general international law is apparently being treated carefully. The Special Rapporteur emphasized in his third report of 2017 that:

[T]here appears to be recognition (...) that establishing an individual right to reparation for each victim may be problematic in the context of a mass atrocity. ${ }^{70}(\ldots)$ While reparation specific to each of the victims may be warranted, such as through the use of regular civil claims processes in national courts or through a specially designed process of mass claims compensation, in some situations only collective forms of reparation may be feasible or preferable, such as the building of monuments of remembrance or the reconstruction of schools, hospitals, clinics and places of worship. ${ }^{71}$

This more cautious approach takes into account the complexities of ending armed conflicts and negotiating peace deals. An individual right to monetary compensation based on civil claims proceedings in cases of mass atrocities does not allow for taking into account broader political considerations related to establishing a stable post-war order. Such a right is conducive to bilateral settlements between the state parties concerned, which might create new forms of injustice towards other groups of victims; it might also overburden negotiations for a settlement to an ongoing armed conflict. Take Syria as an example: the invocation of the individual criminal responsibility of Bashar al-Assad is already obstructing peace talks. Likewise, ex post claims for monetary compensation before civil courts in the aftermath of a comprehensive peace agreement entail the tangible risk that parties to a conflict will be even more reluctant to reach agreement if they cannot rely on the stability of such an agreement. ${ }^{72}$ The various armed conflicts and conditions for ending them differ considerably among each other. The specificities of these situations speak against any generalization with a view of changing existing international law. Those responsible for concluding peace agreements which allow for reconciliation should have a broad political discretion in reaching this aim. While individual claims for monetary

\footnotetext{
${ }^{69}$ Gabriela Blum, 'The Fog of Victory', European Journal of International Law 24 (2013), 391-421, at 393.

${ }^{70}$ Sean D Murphy, Third Report on Crimes against Humanity, 23 January 2017, UN Doc A/CN.4/ 704, para 191.

${ }^{71}$ Ibid, para 194.

${ }^{72}$ Tomuschat, 'National and International Law' 2014 (n 18), at 191; see also Christian Tomuschat, chapter 'The Illusion of Perfect Justice', in this volume.
} 
compensation might be part of such a process, as in Colombia, ${ }^{73}$ it seems wise to leave room for the possibility that only collective and symbolic forms of reparation will be foreseen.

\section{Concluding Remarks}

Instead of furthering the law's legitimacy, judgments such as Sentenza 238/2014 may erode the legitimacy of international law. Such a criticism is not sustained by a 'realistic' view that fosters state sovereignty for the protection of national interests. To my mind, we should not forget that the stability of the international legal order itself, as guaranteed by concepts such as immunities or the respect for its juridical organs serves to protect human rights, albeit indirectly. It might be wiser to accept that not every injustice can be addressed by law, that law cannot always provide a satisfying solution, and that such solutions are sometimes better looked for and confined to the political stage. In line with the passage of the 2012 ICJ Judgment, ${ }^{74}$ a solution sustainable for both sides could be seen in negotiations at the political level.

\section{References}

Alter, Karin, 'The Future of International Law', in Diana Ayton-Shenker (ed), The New Global Agenda: Priorities, Practices, and Pathways of the International Community, (Lanhman/Maryland: Rowman \& Littlefield Publishers 2018)

Barkholdt, Janina /Julian Kulaga, 'Analytical Presentation of the Comments and Observations by States on Draft Article 7, Paragraph 1, of the ILC Draft Articles on Immunity of State Officials from Foreign Criminal Jurisdiction, United Nations General Assembly, Sixth Committee, 2017', KFG Working Paper Series 14 (Berlin Potsdam Research Group 'The International Rule of Law-Rise or Decline?'), (16 May 2018), available at https://papers.ssrn.com/sol3/ papers.cfm?abstract_id $=3172104$

Bellinger, John B, 'The Dog that Caught the Car: Observations on the Past, Present, and Future Approaches of the Office of the Legal Adviser to Official Acts Immunities', Vanderbilt Journal of Transnational Law 44 (2011), 819-835

Blum, Gabriela, 'The Fog of Victory', European Journal of International Law 24 (2013), 391-421

Bosco, David, 'We've Been Here Before: The Durability of Multinationalism', Columbia Journal of International Affairs 70 (2017), 9-15

Conforti, Benedetto, Diritto Internazionale (Naples: Editoriale Scientifica $10^{\text {th }}$ ed 2014)

Crawford, James, The International Law Commission's Articles on State Responsibility: Introduction, Text and Commentaries (Cambridge: CUP 2002)

\footnotetext{
${ }^{73}$ Colombian Law 10 June 2011, Ley de Víctimas y Restitución de Tierras, Law No 1448, Diario Oficial No 48.096.

${ }^{74}$ ICJ, Jurisdictional Immunities (n 6), para 104; see, on preferable ways to deal with injustices that have arisen, Francesco Francioni, 'Access to Justice and Its Pitfalls Reparation for War Crimes and the Italian Constitutional Court', Journal of International Criminal Justice 14 (2016), 629-636; see also Francesco Francioni, chapter 'Overcoming the Judicial Conundrum', in this volume.
} 
Fox, Hazel, 'In Defence of State Immunity, Why the UN Convention on State Immunity is Important', International and Comparative Law Quarterly 55 (2006), 399-406

Fox, Hazel/Philippa Webb, The Law of State Immunity (Oxford: OUP $3^{\text {rd }}$ ed 2013)

Francioni, Francesco, 'Access to Justice and Its Pitfalls Reparation for War Crimes and the Italian Constitutional Court', Journal of International Criminal Justice 14 (2016), 629-636

Frulli, Micaela, “Time Will Tell Who Just Fell and Who's Been Left Behind": On the Clash between the International Court of Justice and the Italian Constitutional Court', Journal of International Criminal Justice 14 (2016), 587-594

Hartwig, Matthias, 'Vom Dialog zum Disput? Verfassungsrecht vs. Europäische Menschenrechtskonvention-Der Fall der Russländischen Föderation', Europäische Grundrechte-Zeitschrift 44 (2017), 1-22

Iovane, Massimo, 'The Italian Constitutional Court Judgment No. 238 and the Myth of the "Constitutionalization" of International Law', Journal of International Criminal Justice 14 (2016), 595-605

Krieger, Heike, 'Addressing the Accountability Gap in Peacekeeping: Law-making by Domestic Courts as a Way to Avoid UN Reform?', Netherlands International Law Review 62 (2015), 259-277

Krieger, Heike, 'Between Evolution and Stagnations: Immunities in a Globalized World', Goettingen Journal of International Law 6 (2014), 177-216

Krieger, Heike /Georg Nolte, 'The International Rule of Law-Rise or Decline?-Approaching Current Foundational Challenges', in Heike Krieger/Georg Nolte/Andreas Zimmermann (eds), The International Rule of Law: Rise or Decline? -Foundational Challenges (Oxford: OUP 2019), 3-30

Kunz, Raffaela, 'The Italian Constitutional Court and "Constructive Contestation"-A Miscarried Attempt?', Journal of International Criminal Justice 14 (2016), 621-627

Lando, Massimo, 'Intimations of Unconstitutionality: The Supremacy of International Law and Judgment 238/2014 of the Italian Constitutional Court', The Modern Law Review 78 (2015), 1028-1041

Marxsen, Christian /Anne Peters (eds), 'Reparation for Victims of Armed Conflict: Impulses from the Max Planck Trialogues', Heidelberg Journal of International Law 78 (2018), 519-633

Murphy, Sean D, Third Report on Crimes against Humanity, 23 January 2017, UN Doc A/CN.4/ 704

Oellers-Frahm, Karin, 'A Never-Ending Story: The International Court of Justice-The Italian Constitutional Court-Italian Tribunals and the Question of Immunity', Heidelberg Journal of International Law 76 (2016), 193-202

Oellers-Frahm, Karin/Hermann Mosler, 'Art 94', in Bruno Simma et al (eds), The Charter of the United Nations (Oxford: OUP $3^{\text {rd }}$ ed 2012), 1174-1179

Orakhelashvili, Alexander, 'Jurisdictional Immunities of the State', American Journal of International Law 106 (2012), 609-616

Pavoni, Riccardo, 'How Broad is the Principle Upheld by the Italian Constitutional Court in Judgment No. 238?', Journal of International Criminal Justice 14 (2016), 573-585

Peters, Anne, 'Let Not Triepel Triumph-How To Make the Best Out of Sentenza No. 238 of the Italian Constitutional Court for a Global Legal Order, EJIL Talk, (22 December 2014), available at www.ejiltalk.org/let-not-triepel-triumph-how-to-make-the-best-out-of-sentenza-no-238-ofthe-italian-constitutional-court-for-a-global-legal-order-part-i/

Reinisch, August, 'European Court Practice Concerning State Immunity from Enforcement Measures', European Journal of International Law 17 (2006), 803-836

Scheinin, Martin, 'The Italian Constitutional Court's Judgment 238 of 2014 Is Not Another Kadi Case', Journal of International Criminal Justice 14 (2016) 615-620 
Slaughter, Anne-Marie, 'The Return of Anarchy?', Columbia Journal of International Affairs 70 (2017), Special $70^{\text {th }}$ Anniversary Issue, 11-16

Stöckle, Philipp, 'Victims Caught between a Rock and a Hard Place: Individual Compensation Claims against Troop-Contributing States', Die Friedens-Warte 88 (2013), 119-141

Tomuschat, Christian, 'National and International Law in Italy: The End of an Idyll', Italian Journal of Public Law 6 (2014), 187-196

Open Access This chapter is licensed under the terms of the Creative Commons Attribution 4.0 International License (http://creativecommons.org/licenses/by/4.0/), which permits use, sharing, adaptation, distribution and reproduction in any medium or format, as long as you give appropriate credit to the original author(s) and the source, provide a link to the Creative Commons license and indicate if changes were made.

The images or other third party material in this chapter are included in the chapter's Creative Commons license, unless indicated otherwise in a credit line to the material. If material is not included in the chapter's Creative Commons license and your intended use is not permitted by statutory regulation or exceeds the permitted use, you will need to obtain permission directly from the copyright holder. 
Part III

Remedies 


\title{
A Plea for Legal Peace
}

\author{
Riccardo Pavoni
}

\begin{abstract}
This chapter advocates legal peace between Germany and Italy as the most sensible and appropriate way to deal with the aftermath of Sentenza 238/2014 of the Italian Constitutional Court and its declaration of the unconstitutionality of the 2012 International Court of Justice (ICJ) Judgment in Jurisdictional Immunities. This plea does not only arise from frustration with the current impasse but also from the suspicion that the public good of legal peace has never seriously been canvassed by the Italian and German governments. Section II takes stock of the legal developments relating to the dispute between Germany and Italy since Sentenza 238/2014 was delivered. It especially focuses on the attitudes of the governments concerned, both in the context of the ongoing proceedings before Italian courts and elsewhere. It finds such attitudes opaque and unduly dismissive of the necessity to devise legal peace in the interest of the victims and of the integrity of international law. Section III highlights how the behaviour of the governments so far was at odds with the successful outcome of other intergovernmental negotiations concerning reparations for crimes committed during World War II (WWII), a process which has not been entirely finalized, as evidenced by the 2014 Agreement between the US and France on compensation for the French railroad deportees who were excluded from prior French reparation programmes. The Agreement between the US and France and all previous similar arrangements were concluded under mounting pressure of litigation before domestic courts against those states (and/or their companies) that were responsible for unredressed WWII crimes, thus a situation resembling the current state of the dispute between Germany and Italy. It is telling that litigation ended when the courts took cognizance of the stipulation of intergovernmental agreements establishing fair mechanisms for compensating the plaintiffs and victims of the relevant crimes. Such practice, therefore, is essentially in line with the proposition that state immunity (for human rights violations) is essentially conditional on effective alternative remedies for the victims. This and other controversial aspects related to the law of state immunity-such as the nature of state
\end{abstract}

\footnotetext{
R. Pavoni $(\bowtie)$

University of Siena, Department of Law, Siena, Italy

e-mail: riccardo.pavoni@unisi.it 
immunity, the North American remedies against immunity for state sponsors of terrorism, and the persistent dynamism of pertinent practice-are revisited in section IV. The purpose is to suggest that certainty about the law of international immunities, as allegedly flowing from the 2012 ICJ Judgment, is more apparent than real and that this consideration should a fortiori urge the realization of legal peace in the German-Italian affair.

\section{Introduction}

This chapter argues that 'legal peace' between Germany and Italy is the most sensible and appropriate way of dealing with the aftermath of Sentenza 238/2014 of the Italian Constitutional Court (ItCC), ${ }^{1}$ which in substance held that the 2012 International Court of Justice (ICJ) Judgment in Jurisdictional Immunities ${ }^{2}$ could not be given effect as it breached the human right to judicial protection under the Italian Constitution. The ItCC also refused to afford any domestic legal effects to the ICJ-backed rule of state immunity for unredressed international crimes. Although such a plea for legal peace arises, in part, from the frustrating impasse that presently characterizes the dispute between Germany and Italy, it is especially driven by the disturbing impression that, in the context of unredressed World War II (WWII) crimes, the public good of legal peace has never been canvassed seriously by either the Italian or German government.

Admittedly, there is no silver bullet for shaping legal peace against the background of the German-Italian affair. Legal peace might well be channelled through arbitration, thereby conclusively determining whether Germany or Italy, or both, have defaulted with respect to compensation owed to Italian Military Internees (IMIs) and similarly situated victims of Nazi crimes. In any event, the crucial step would be the elaboration of a fair institutional and exclusive funding mechanism entrusted with processing outstanding compensation claims. While foreclosing parallel private litigation, this mechanism should be capable of giving victims a voice. The lack of an effective remedy for the victims, other than judicial proceedings in Italy, was indeed a key consideration underlying Sentenza 238/2014. ${ }^{3}$ There are sound reasons for believing that the setting up of a meaningful compensatory procedure would lead to the suspension or termination of the remaining cases pending against Germany before Italian courts. ${ }^{4}$

\footnotetext{
${ }^{1}$ Corte Costituzionale, Judgment of 22 October 2014, No 238/2014.

${ }^{2} \mathrm{ICJ}$, Jurisdictional Immunities of the State (Germany $v$ Italy: Greece intervening), Judgment of 3 February 2012, ICJ Reports 2012, 99.

${ }^{3}$ See Riccardo Pavoni, 'How Broad is the Principle Upheld by the Italian Constitutional Court in Judgment No. 238?', Journal of International Criminal Justice 14 (2016), 573-585.

${ }^{4}$ For instance, the Tribunal of Sulmona has recently awarded damages in the amount of $€ 6.6$ million against Germany and in favour of the heirs of victims of a WWII massacre in the Abruzzo region and of the Municipality of Roccaraso. See Tribunale di Sulmona, Judgment of 2 November 2017,
} 
Section II takes stock of the legal developments in the German-Italian affair since Sentenza 238/2014 was delivered. It focuses on the attitudes of the governments concerned within the proceedings before Italian courts and elsewhere. It finds these attitudes opaque and unduly dismissive of the necessity to promote legal peace in the interest of the victims and for the integrity of international law. Section III highlights how the behaviour of the two governments is at odds with the successful outcomes of other intergovernmental negotiations prompted by litigation before US courts relating to crimes committed during WWII, a process meaningfully started in the 1990s and still unfinished. Tellingly, litigation ended when the courts took cognizance of the stipulation of intergovernmental agreements establishing fair mechanisms for compensating victims, whereas the outstanding cases currently pending before US courts precisely involve situations that are not covered by such agreements. Such practice, therefore, is essentially in line with the proposition that state immunity (for human rights violations) should be conditional on effective alternative remedies for the victims. ${ }^{5}$ Accordingly, section IV underscores that a number of

Case No 20/2015, available at http://www.europeanrights.eu/public/sentenze/ITA-Tribunale_di_ Sulmona_strage_di_pietransieri_Sulmona.pdf; for a comment, see Ferdinando Franceschelli, 'Germany Held Responsible for the Nazi Massacre of Pietransieri', Italian Yearbook of International Law 27 (2017), 449-452.

Various enforcement proceedings are also ongoing. See lately, Corte di Cassazione, Judgment of 3 September 2019, No 21995/2019 (Deutsche Bahn v Sterea Ellada Region), allowing the continuation of garnishment proceedings against debts owed to Deutsche Bahn by the Italian railway company for the purpose of recovering the damages awarded to the victims (and their heirs) of the WWII Distomo massacre in Greece. However, in parallel proceedings relating to the same dispute, the Court of Cassation held that Villa Vigoni-real estate owned by Germany—enjoyed immunity from measures of constraint as it was exclusively used for sovereign, non-commercial purposes; see Corte di Cassazione, Judgment of 8 June 2018, No 14885/2018 (Sterea Ellada Region v Germany and Presidency of the Council of Ministers).

${ }^{5}$ Although with several variations and to different degrees, this view is regarded by a growing number of authors as the sole means of reconciling international and domestic law in this area, see, eg, Micaela Frulli, “"Time Will Tell Who Just Fell and Who's Left Behind": On the Clash between the International Court of Justice and the Italian Constitutional Court', Journal of International Criminal Justice 14 (2016), 587-594, at 589-592; Riccardo Pisillo Mazzeschi, 'Access to Justice in Constitutional and International Law: The Recent Judgment of the Italian Constitutional Court', Italian Yearbook of International Law 24 (2014), 7-23, at 18-20; Rosanne van Alebeek, 'Jurisdictional Immunities of the State (Germany $v$. Italy): On Right Outcomes and Wrong Terms', German Yearbook of International Law 55 (2012), 281-318, at 312 (although taking a very cautious view and, however, concluding that IMIs did have an effective remedy in Germany); Riccardo Pavoni, 'Human Rights and the Immunities of Foreign States and International Organizations', in Erika de Wet/Jure Vidmar (eds), Hierarchy in International Law: The Place of Human Rights (Oxford: OUP 2012), 71-113; Benedetto Conforti, 'The Judgment of the International Court of Justice on the Immunity of Foreign States: A Missed Opportunity', Italian Yearbook of International Law 21 (2011), 133-142, at 138-142 (largely foreshadowing the decision of the Constitutional Court discussed in the present book: '[I]mplementation [of international law] cannot be pushed to the point of compromising the fundamental values of the State community, usually guaranteed by constitutional rules (...). There is no doubt that the right of access to justice is part of such fundamental values (...), and that, consequently, a customary rule inconsistent with Article 24 [of the Italian Constitution] cannot be applied in Italy'). Other authors point out that the 
tensions and controversial issues continue to affect the doctrine of state immunity, starting from the unresolved question of its rationale and nature. The best illustration thereof is no doubt offered by the contemporary practice of Canada and the US. The ultimate purpose of section IV is to suggest that certainty about the law of international immunities, as allegedly flowing from the 2012 ICJ Judgment, is more apparent than real and that this consideration should a fortiori urge the realization of legal peace in the German-Italian affair. A few concluding remarks are made in section $\mathrm{V}$.

\section{Confrontation and Mutual Neglect Versus Legal Peace}

The conduct of the two governments concerned both prior to and in the aftermath of Sentenza 238/2014 has been characterized - to different degrees and with different modalities - by reticence, ambiguity, and underground talks. Paradigmatic of this conduct was the inaugural event in late 2016 of the permanent exhibition dedicated to IMIs in the Berlin-Schöneweide Lager, a rather well-preserved WWII concentration camp. On that occasion, speaking before a wide audience including representatives of IMIs associations, the German and Italian Foreign Ministers made absolutely no mention of the unresolved legal issues raised by the exclusion of IMIs from any meaningful WWII reparation scheme and the related litigation against Germany in Italian courts. ${ }^{6}$ After all, the two countries were smoothly proceeding along the direction set forth in their 2008 Trieste Joint Declaration, whence they announced the objective of creating a 'common culture of memory' regarding WWII (with a focus on the terrible vicissitudes of IMIs) and the establishment of an ItaloGerman Historical Commission for that purpose. There was apparently no link between the financing of the exhibition and the German-Italian dispute. It is clear, however, that the great absentees in that context were Italian judges and Sentenza $238 / 2014$.

Interestingly, a few days later the Chamber of Deputies of the Italian parliament—endorsed by the executive—passed a motion concerning WWII crimes

\footnotetext{
'alternative remedies test' also constitutes the sole means of reconciling international law with itself, see Giuseppe Cataldi, 'A Historic Decision of the Italian Constitutional Court on the Balance Between the Italian Legal Order's Fundamental Values and Customary International Law', Italian Yearbook of International Law 24 (2015), 37-52, at 46 ('When the fundamental principles of the national legal system guaranteed by the review of national supreme courts also correspond to the "common values" of the international community, these courts also act in the service of the international legal system. Essentially, in such cases, national courts protect international law from itself'). These authors evidently disapprove of the contrary conclusion reached by the ICJ in its Jurisdictional Immunities Judgment, when it flatly rejected the so-called last resort argument advanced by Italy; see ICJ, Jurisdictional Immunities (n 2), paras 101-103.

${ }^{6}$ Frank-Walter Steinmeier/Paolo Gentiloni/Michele Montagno, 'Zwischen allen Stühlen-die Geschichte der italienischen Militärinternierten 1943-1945', (28 November 2016), available at https://www.istitutocervi.it/wp-content/uploads/2017/02/Istituto-Cervi-a-Berlino.pdf.
} 
committed against Italian nationals, which indirectly allows us to understand the approach of the Italian government toward the WWII German reparations affair. ${ }^{7}$ The motion did not even mention Sentenza 238/2014, whereas it gave account of the 2012 ICJ Judgment and recalled that the latter 'unfortunately' ${ }^{\text {' upheld }}$ Germany's immunity before Italian courts. It committed the Italian government to make sure that Germany will continue to finance initiatives aimed at the reconstruction of a "shared historical memory"9 and 'moral reparation' ${ }^{10}$ for the victims of WWII crimes. The next steps, according to this motion, should therefore consist in having Germany renew its contribution to the German-Italian Fund for the Future (Fondo italo-tedesco per il futuro) for the years 2018-2021. This fund was jointly established in 2013 and operationalized thanks to an initial contribution by Germany to the amount of $€ 4$ million. These resources should be channelled into the construction or restoration of places of commemoration and comparable monuments, as well as into the development of memory-related online resources, such as an Atlas of the Nazi-Fascist massacres committed in Italy between 1943 and 1945 and a Biographic Lexicon of IMIs. ${ }^{11}$ Thus, the 2016 motion of the Italian parliament overlooked the many final judicial decisions awarding civil damages against Germany and diverted attention to the need for the government to secure German cooperation in the execution of criminal convictions of German nationals found responsible for Nazi crimes by Italian courts (which is a reference to the long-standing problem of the failed extradition of such nationals by Germany).

Therefore, several years after Sentenza 238/2014, the Italian government has yet to illustrate to its citizens its own official position on this decision, especially to those citizens most concerned: the plaintiffs and the judgment holders in the various pending or concluded proceedings relating to WWII Nazi crimes.

Clues about the Italian executive's position may emerge from a perusal of its legal arguments outlined before the Italian courts dealing or having dealt with WWII Nazi-related cases. But this is deeply unsatisfactory when seen against rule of law notions such as a government's responsiveness and transparency to its citizenry. While Sentenza 238/2014 may arguably be considered a 'shock to the international legal community', ${ }^{12}$ the Italian lay public are largely unaware of this judgment, despite its importance for Italian national history and for the evolution of Italian

\footnotetext{
${ }^{7}$ Chamber of Deputies of the Italian Parliament, Motion No 1-01375, adopted on 6 December 2016. ${ }^{8}$ Ibid (translated by the author).

${ }^{9}$ Ibid (translated by the author).

${ }^{10}$ Ibid (translated by the author).

${ }^{11}$ For an account of the genesis of this fund and a list of initiatives and projects that it has financed so far, see Rappresentanze tedesche in Italia, 'Cultura della memoria', available at https://italien.diplo. de/it-it/themen/kultur/CulturadellaMemoria-Ordner?openAccordionId=item-1599424\%2D\% 2Dpanel.

${ }^{12}$ Christian Tomuschat, 'The National Constitution Trumps International Law', Italian Journal of Public Law 6 (2014), 189-196, at 189 (emphasis added).
} 
sociological attitudes towards a tragic past which large sectors of the (older) population have never come to terms with. ${ }^{13}$

What is clear is that, regardless of their political inclination, the changing majorities leading the Italian government over the past decades have consistently pursued agendas that were decidedly at variance with the positions and parallel activities of the Italian judiciary. Soon after Sentenza 238/2014, the government surreptitiously took advantage of the parliamentary debates on the conversion into law of a decree containing a variety of measures on civil procedure in order to introduce an amendment making the attachment of any bank account held in Italy by foreign states in fact impossible. According to this provision, ${ }^{14}$ such bank accounts are not subject to execution provided that the head of a diplomatic mission or consular post of a foreign state has declared to the Italian Ministry of Foreign Affairs and the relevant bank that the money deposited therein is exclusively intended for use in the performance of diplomatic and/or consular functions. The foreign state's declaration triggers an absolute protection for such bank accounts, as it cannot be rebutted or challenged in court on any ground whatsoever. This is a very generous provision ${ }^{15}$ on foreign state bank account immunity, which goes beyond customary international law and Article 21(1)(a) of the UN Convention on Jurisdictional Immunities of States and Their Property (UNCSI). ${ }^{16}$ Arguably, by essentially obliterating the role of the judiciary in this matter, the provision is inconsistent with the Italian Constitution. ${ }^{17}$ However, the key point here is that, by hastily seeking solutions to the

\footnotetext{
${ }^{13}$ Even judges of the ItCC are not immune to this sociological dimension of WWII events and Nazi Germany's occupation of Italy from late 1943. Sabino Cassese, a member of the ItCC at the time of Sentenza 238/2014, nicely recalls how the deliberations on the case were oscillating between sophisticated reflections on the legal issues at stake and rhetorical recollections by certain judges who were evoking the 'Germans at their doorstep' ('Esercizi di ingegno, sottili domande giuridiche si alternano con esercizi di retorica di chi ricorda i tedeschi a casa propria'), Sabino Cassese, Dentro la Corte: Diario di un giudice costituzionale (Bologna: il Mulino 2015), 261.

${ }^{14}$ Art 19-bis of Italian Law-decree No 132 of 12 September 2014, converted by Law No 162 of 10 November 2014.

${ }^{15}$ For instance, compare Section 13(5) of the UK State Immunity Act (SIA), according to which the head of a foreign state's diplomatic mission is entitled to produce a certificate 'to the effect that any property is not in use or intended for use by or on behalf of the State for commercial purposes'; however, such a certificate 'shall be accepted as sufficient evidence of that fact unless the contrary is proved' (emphasis added) (SIA 1978, 17 ILM (1978) 1123). On the persistent key role of domestic courts in this specific area, see Chester Brown/Roger O'Keefe, 'Article 21', in Roger O'Keefe/ Christian J Tams (eds), The United Nations Convention on Jurisdictional Immunities of States and Their Property: A Commentary (Oxford: OUP 2013), 334-347, at 341-342, 347: 'It will probably remain the case, even in the application of Article 21(1), that one court's actum jure imperii is another's actum jure gestionis'.

${ }^{16}$ UN Convention on Jurisdictional Immunities of States and Their Property (2 December 2004), UN Doc A/RES/59/38, UN Doc A/59/49, 486 (not yet in force).

${ }^{17}$ Cf Corte Costituzionale, Judgment of 15 July 1992, No 329/1992 (Condor). For a fierce critique of the provision in question, see Benedetto Conforti, 'Il legislatore torna indietro di circa novant'anni: la nuova norma sull'esecuzione sui conti correnti di Stati stranieri', Rivista di diritto internazionale 98 (2015), 558-561.
} 
German-Italian contingencies, the Italian government runs the risk of turning a blind eye to opaque transactions and abuses facilitated by the privilege afforded to any foreign state bank accounts held in Italy. One should hope that the competent authorities will retain sufficient surveillance powers over such accounts.

Moreover, far from withdrawing from treaty provisions conferring jurisdiction on disputes involving Italy to international bodies, on 25 November 2014 the Italian government deposited its declaration of acceptance of the compulsory jurisdiction of the ICJ under Article 36(2) of the ICJ Statute. ${ }^{18}$ This course of action seems imprudent and untimely in the wake of Sentenza 238/2014, as the latter may spur domestic judicial proceedings against any foreign states accused of international crimes. ${ }^{19}$ Such proceedings may in turn be easily challenged before the ICJ on the strength of its 2012 Judgment. The Italian declaration contains no reservation to the ICJ jurisdiction relating to disputes in this area. The initiative of the Italian government in question also glaringly confirms the absence of dialogue between the executive and the judiciary on the problems arising from the Italian jurisprudence denying state immunity for international crimes.

As to the ambiguous judicial strategies pursued by the Italian government in the outstanding proceedings against Germany, very little has changed vis-à-vis the pre-Sentenza situation. ${ }^{20}$ The government supports Germany's position with respect to most of the key aspects of the dispute (such as the absence of jurisdiction of Italian courts, the unconditional obligation to comply with the 2012 ICJ Judgment, the prescription of the actions), save that it strongly contests its duty to hold Germany harmless from any WWII reparation claims by Italian nationals, a duty allegedly flowing from the 1947 Peace Treaty and the bilateral 1961 Bonn Agreements. ${ }^{21}$

On the other side, the most salient feature of Germany's recent conduct is a refusal to participate in the compensation proceedings resumed in Italian courts in the wake of Sentenza 238/2014. In all such proceedings Germany has been and will

\footnotetext{
${ }^{18}$ For the text of the declaration, see Italy, 'Declarations recognizing the jurisdiction of the Court as compulsory', (25 November 2014), available at https://www.icj-cij.org/en/declarations/it; for a comment, see Paolo Palchetti, "“A key institution for interpreting international law and guaranteeing global compliance with its provisions": la dichiarazione italiana di accettazione della competenza della Corte internazionale di giustizia', Rivista di diritto internazionale 98 (2015), 114-125.

${ }^{19}$ See Corte di Cassazione, Judgment of 29 October 2015, No 43696/2015 (In the Matter of Criminal Proceedings against Dobrivoje Opačić; Podrute Massacre case), finding Serbia liable to pay damages to the heirs of victims of the downing of a military helicopter operating on a humanitarian mission during the 1990s Yugoslav wars.

${ }^{20}$ See, eg, Tribunale di Firenze, Judgment of 6 July 2015, No 2469/2015 (Simoncioni v Germany), 3-4.

${ }^{21}$ Such a duty would most clearly emerge from the 'hold-harmless clause' of Art 2(2) of the Agreement between the Federal Republic of Germany and Italy on the Settlement of Certain Property-Related, Economic and Financial Questions (Bonn, 2 June 1961), German and Italian version published in Bundesgesetzblatt II 26 June 1963 No 19, 668. See also Stefan Kadelbach, chapter 'State Immunity, Individual Compensation for Victims of Human Rights Crimes, and Future Prospects', and Andreas von Arnauld, chapter 'Deadlocked in Dualism', in this volume.
} 
be a respondent in absentia, ${ }^{22}$ as well as the addressee of a number of default judgments awarding damages and costs. Germany has consistently communicated to the courts that its decision stemmed from the consideration that such proceedings constituted a violation of the principles of international law upheld by the 2012 ICJ Judgment and has made reference to a diplomatic Note Verbale of 5 January 2015 from Germany's embassy in Rome to the Italian Ministry of Foreign Affairs for further explanation. ${ }^{23}$ According to this Note Verbale, Sentenza 238/2014 'cannot change anything of what has been found by the ICJ with respect to the content and scope of the jurisdictional immunity enjoyed by Germany before Italian courts' ${ }^{24}$ Indeed, the Note continues, pursuant to a well-settled rule of international law 'the principle of State immunity cannot be limited by the domestic law of a State, not even by fundamental principles of the national constitutional order ${ }^{25}$ The Note also takes the view that the plaintiffs would be able to enjoy equivalent protection before German courts. ${ }^{26}$ It concludes with a 'precautionary warning ${ }^{27}$ reminding the Italian government of the risk of further litigation and outlining the consequences arising from the continuation of judicial proceedings in terms of state responsibility and reparation.

Germany has thus chosen a confrontational posture vis-à-vis Italian courts, which have at times reacted with irritation and bewilderment. ${ }^{28}$ Crucially, Germany has also taken an uncompromising attitude by refusing to accede to the requests from several courts to negotiate an out-of-court settlement with the plaintiffs (where the latter were heirs of the victims) and Italy through conciliation or mediation by a

\footnotetext{
${ }^{22}$ See, eg, Tribunale di Piacenza, Judgment of 28 September 2015, No 723/2015 (Rabizzoni v Germany); Corte d'Appello di Brescia, Judgment of 6 June 2016, No 515/2016 (Currà v Germany); Corte di Cassazione, Judgment of 13 January 2017, No 762/2017 (Parrini v Germany).

${ }^{23}$ Note Verbale of 5 January 2015, 2/15, RK 553.32.

${ }^{24}$ Ibid, para 3 (translated by the author).

${ }^{25}$ Ibid, para 4 (translated by the author, emphasis added).

${ }^{26}$ Ibid, para 6. This argument is particularly difficult to follow, as Germany is perfectly aware that all IMIs' claims have in the past been rejected by German courts, including the Federal Constitutional Court (Order of 28 June 2004, 2 BvR 1379/01, BVerfGK 3, 277). Although such courts have resorted to a variety of arguments for that purpose, the veritable stumbling block for IMIs' claimsand probably the most controversial aspect lying at the origin of the whole dispute between Germany and Italy - was their ineligibility for compensation under the funds made available by the German Foundation 'Remembrance, Responsibility and Future' (Erinnerung, Verantwortung und Zukunft) due to their freshly rediscovered, allegedly inalienable entitlement to prisoner of war (POW) status at the time of their deportation (see Section 11(3) of the German Law of 2 August 2000 establishing the Foundation, Bundesgesetzblatt I 11 August 2000 No 38, 1263). For further detail, see ECtHR, Associazione Nazionale Reduci v Germany, Decision of 4 September 2007, Application No 45563/04, 3-8.

${ }^{27}$ Note Verbale 2/15 (n 23), para 8 (translated by the author).

${ }^{28}$ Including the Court of Cassation, which has stigmatized the unorthodox means employed by Germany for communicating with the Court and accordingly declared inadmissible a letter from Germany's embassy enclosing the Note Verbale discussed in the text; see Corte di Cassazione, Judgment of 29 July 2016, No 15812/2016 (Gamba v Germany), para 1; see also Tribunale di Firenze, Judgment No 2469/2015 (n 20), 17.
} 
commission chosen by the parties and including lawyers with an expertise in public international law. The Tribunal of Florence has been the most creative in this context by submitting its own proposed settlements to the parties. For instance, the proposal in the Alessi case envisaged a study or cultural visit to Germany worth $€ 15,000$ for each of the three plaintiffs, in exchange for the withdrawal of their compensation claims. $^{29}$ In the face of Germany's tacit dismissal of these proposals, the courts proceeded to adjudicate the merits of the cases in favour of the plaintiffs and awarded them substantial damages. ${ }^{30}$ On its part, the Italian government has also never expressed any interest in participating in these non-adversarial conciliatory procedures. Given the apparent disengagement of the two governments, the Italian courts were trying to make the best out of the ICJ's consideration that the unredressed grievances of Italian victims of Nazi crimes 'could be the subject of further negotiation $(. .$.$) with a view to resolving the issue'. 31$

Despite the obiter dictum nature of this remark by the ICJ, and if only for reasons of transparency, the Italian and German governments should clearly communicate to the international community whether and to what extent they have carried out such negotiations in good faith. Most significantly, do they think they have already reckoned with the historical 'justice/equity gap', ${ }^{32}$ which has uniquely affected IMIs and similarly situated victims? Are monuments and historical reports sufficient to close in a dignified way this specific and tragic chapter of WWII ? ${ }^{33}$ Since theyas well as scholars ${ }^{34}$ _disagree on the nature and scope of the labyrinthine postWWII regulation of reparations by Germany, why has arbitration or similar means of dispute settlement not been contemplated?

While answers to these questions are long overdue, the present situation may be regarded as a recipe for failure, which especially runs against the interest of the individual direct victims who, being now in their (late) nineties, are sadly passing away at an accelerating rate. Whereas further litigation will likely perpetuate the 'zero-sum game' 35 that the whole dispute so far has turned out to be, another key

\footnotetext{
${ }^{29}$ Tribunale di Firenze, Order of 23 March 2015 (Alessi v Germany). See the case commentary by Serena Forlati, Italian Yearbook of International Law 25 (2015), 497-509, at 502.

${ }^{30}$ See, eg, Tribunale di Firenze, Judgment of 22 February 2016, No 691/2016 (Donati v Scheungraber, Stommel and Germany).

${ }^{31} \mathrm{ICJ}$, Jurisdictional Immunities (n 2), para 104.

${ }^{32}$ Michael Bothe, 'Remedies of Victims of War Crimes and Crimes against Humanities: Some Critical Remarks on the ICJ's Judgment on the Jurisdictional Immunity of States', in Anne Peters/ Evelyne Lagrange/Stefan Oeter/Christian Tomuschat (eds), Immunities in the Age of Global Constitutionalism (Leiden: Brill Nijhoff 2015), 99-115, at 110-111; 113-114.

${ }^{33} \mathrm{Cf}$ Motion No 1-01375 of the Chamber of Deputies of the Italian Parliament (n 7).

${ }^{34}$ Compare Christian Tomuschat, 'The Case of Germany v. Italy before the ICJ', in Peters, Immunities 2015 (n 32), 87-98, at 95-98, with Michael Bothe, 'The Decision of the Italian Constitutional Court Concerning the Jurisdictional Immunities of Germany', Italian Yearbook of International Law 24 (2014), 25-35, at 31-35.

${ }^{35}$ Francesco Francioni, 'Access to Justice and Its Pitfalls: Reparation for War Crimes and the Italian Constitutional Court', Journal of International Criminal Justice 14 (2016), 629-636, at 633.
} 
question remains: why have the two governments - at least throughout the past 20 years - not meaningfully embraced 'legal peace' as the overarching public good guiding their actions? Broadly understood, legal peace would involve a negotiated settlement agreement prescribing the termination of the outstanding judicial proceedings against Germany in exchange for a reasonable compensatory scheme available to the plaintiffs and co-funded by the two governments.

In the first place, legal peace would be in the interest of the victims, but it would also be in the interest of the integrity of the international and national legal orders. Taking a confrontational, unbending position is unhelpful to both sides when national supreme courts plausibly invoke fundamental constitutional principles as the last bulwark against international law rules. Such a position only exacerbates the impression that international law and domestic legal orders are two irreconcilable worlds apart. Dialogue and interaction among the relevant actors, as well as salutary competition between and mutual reinforcement of international and domestic law, seem necessary instead. Moreover, the achievement of legal peace has always been a crucial consideration for German and other governments when dealing with the outstanding problems arising from WWII reparation regimes.

\section{Why the French Railroad Deportees and Not IMIs?}

It is frequently suggested that the time factor runs against the soundness of the reparation claims of IMIs and similarly situated Italian victims of Nazi crimes. For instance, it has been stated that, as compared to state immunity litigation involving torture and comparable crimes 'of current or recent regimes', ${ }^{36}$ the issue of IMIs makes a bad case because it 'concerns crimes committed more than one generation ago'. ${ }^{37}$ This would imply that '[e]ven if we do not accept any formal prescription for the prosecution of such egregious crimes, the lapse of time does weaken the claims. 38

On the basis of intertemporal fairness and other grounds, I think that the lapse of time does weaken the argument that immunity should be lost when the defendant state is accused of grave breaches of human rights, thereby creating the possibility that the relevant 'ancient' conduct might come to be reassessed through the prism of modern legal achievements and standards. I have always had the impression that a significant part of the criticism levelled against the Italian Ferrini jurisprudence ${ }^{39}$

\footnotetext{
${ }^{36}$ Anne Peters, 'Let Not Triepel Triumph-How To Make the Best Out of Sentenza No. 238 of the Italian Constitutional Court for a Global Legal Order', EJIL:Talk!, (22 December 2014), available at www.ejiltalk.org/let-not-triepel-triumph-how-to-make-the-best-out-of-sentenza-no-238-of-theitalian-constitutional-court-for-a-global-legal-order-part-i.

${ }^{37}$ Ibid.

${ }^{38}$ Ibid.

${ }^{39}$ Corte di Cassazione, Judgment of 11 March 2004, No 5044/2004 (Ferrini). As is well-known, this is the landmark decision where for the first time a foreign state was denied immunity from the jurisdiction of Italian courts in a case involving international crimes.
} 
stems from these intertemporal considerations, ${ }^{40}$ where 'intertemporal' is not necessarily used in a technical sense but also refers to the contemporary uneasiness of Italy and Germany, and Italians and Germans alike, about discussions that might reopen the old wounds of their respective national history. With its historical overtones, the German-Italian controversy has unduly monopolized the 'human rights versus immunity' debate, thus detracting attention from the legal advancement that might result from the contemporary affirmation of a narrow human rights limitation to state immunity, namely, one confined to the most serious breaches of human rights that have not been, and cannot be, redressed by the responsible state.

Conversely, I do not think that the passage of time per se constitutes a valid reason for dismissing the substantive claim for reparation of a whole class of victims of war crimes, even though such crimes date back to many decades ago. This is especially true in our case where the responsibility for those crimes is acknowledged and what is disputed is only whether Germany has fully discharged its obligation to provide reparation for the resulting injuries. Rather, the time factor should encourage a sense of urgency in the governments' approaches to, at the very least, the outstanding claims of Italian WWII direct victims, that is, the survivors who are now in their (late) nineties.

It is precisely this sense of urgency - and the determination to attain a lasting legal peace in the face of increasing WWII litigation before national courts - that, as recently as 2014, led to an agreement between the US and France on compensation for the so-called French railroad deportees who were excluded from prior French reparation programmes. ${ }^{41}$ The basic bargain is well-known, as it builds upon extensive US practice in this area: ${ }^{42}$ France made US\$60 million available to satisfy claims of uncompensated railroad deportees, ${ }^{43}$ while the US was obligated 'to

\footnotetext{
${ }^{40}$ See, eg, Carlo Focarelli, Diritto internazionale (Padua: Cedam $4^{\text {th }}$ ed 2017), at 332: 'Quel che conta è circoscrivere l'eccezione umanitaria a specifici crimini commessi oggi o che verranno commessi in futuro-abbandonando l'idea di "punire" $i$ crimini passati, tanto meno di un unico Stato, tenuto conto che pressoché tutti gli Stati ne hanno commessi e non è chiaro quanto indietro nel tempo si debba andare' ('What is important is to circumscribe the human rights exception to specific crimes which are committed today or will be committed in the future, thereby abandoning the idea of 'punishing' past crimes, especially crimes of a single state, taking into account that nearly all states have committed such crimes and it is not clear how far back in time we should go' (translated by the author)).

${ }^{41}$ Agreement on Compensation for Certain Victims of Holocaust-Related Deportation from France Who Are not Covered by French Programs, 8 December 2014, in force 1 December 2015, TIAS No 15-1101. See Ronald Bettauer, 'A Measure of Justice for Uncompensated French Railroad Deportees during the Holocaust', ASIL Insights, (1 March 2016), available at https://www.asil.org/ insights/volume/20/issue/5/measure-justice-uncompensated-french-railroad-deportees-during-holo caust. See also Filippo Fontanelli, chapter 'Sketches for a Reparation Scheme', in this volume.

${ }^{42}$ For an exhaustive account by the key US negotiator, see Stuart Eizenstat, Imperfect Justice: Looted Assets, Slave Labor, and the Unfinished Business of World War II (New York: Public Affairs 2004).

${ }^{43}$ Agreement on Compensation for Certain Victims of Holocaust-Related Deportation from France, 2014 (n 41), Art 4(1).
} 
recognize and affirmatively protect the sovereign immunity of France within the United States legal system with regard to Holocaust deportation claims and, consistent with its constitutional structure, to undertake all actions necessary to ensure an enduring legal peace at the federal, state, and local levels of the Government of the United States of America'. ${ }^{4}$

The reason for mentioning the 2014 French Railroad Deportees Agreement is by no means to suggest that it should be taken as a template for a similar outcome to potential negotiations on the unresolved issue of Italian victims of Nazi crimes. The historical and legal backgrounds are obviously different. Instead, the Agreement is an indication that states are still reckoning with their historical wrongs and that, under the pressure of litigation and legislative initiatives jeopardizing their entitlement to immunity, ${ }^{45}$ they are willing to settle past accounts.

Indeed, the French Railroad Deportees Agreement is an example of the key role played by state immunity litigation before domestic courts in the area of human rights and international crimes. Whichever way one leans in the 'immunity versus human rights' debate, it cannot reasonably be denied that often times and for the sake of legal peace such litigation prompts the relevant states to go back to the negotiating table, take a fresh look at the underlying issues, and accordingly devise fair arrangements affording a decent measure of justice to uncompensated victims. At the time of writing, it is uncertain whether that scenario will be replicated, even to a degree, with regard to the claims lodged by IMIs and comparable victims before Italian courts. Nevertheless, we should not overlook that, were it not for the Italian Ferrini jurisprudence, the tragic and paradoxical historical trajectory of IMIs would largely have been forgotten, as has been true for too many decades.

In this context, it is clear that US immunity practice is paradigmatic. That practice is multifarious and constantly evolving and it would be unwarranted to briskly marginalize it altogether as completely detached from the international legal framework. ${ }^{46}$ Insofar as it is relevant for current purposes, such practice includes a substantial number of WWII reparations cases that have spurred intergovernmental settlements and were dismissed when those settlements were finalized. The most famous examples involve Austria, ${ }^{47}$

\footnotetext{
${ }^{44}$ Ibid, Art 2(2). See also ibid, Art 5.

${ }^{45}$ For details regarding cases and bills challenging France's jurisdictional immunity in the US, see Bettauer, 'A Measure of Justice' 2016 (n 41).

${ }^{46}$ Contra Thomas Giegerich, 'The Holy See, a Former Somalian Prime Minister, and a Confiscated Pissarro Painting: Recent US Case Law on Foreign Sovereign Immunity', in Peters, Immunities 2015 (n 32), 51-69, at 69. See further, section IV of this chapter.

${ }^{47}$ Agreement Between the Austrian Federal Government and the Government of the United States of America Concerning the Austrian Fund 'Reconciliation, Peace and Cooperation', 24 October 2000, in force 1 December 2000, 40 ILM 523 (2001); Joint Statement and Exchange of Notes Between the United States and Austria Concerning the Establishment of the General Settlement
} 
France, ${ }^{48}$ and Germany. ${ }^{49}$ In all these instances, the mounting pressure from WWII-related litigation against certain companies and agencies of those states, and/or against those states as such, was a fundamental factor paving the way for the negotiations leading up to the settlement agreements. ${ }^{50}$

Although the details of the various arrangements may be significantly different, their common rationale, or grand bargain, is a constant feature: an exclusive compensatory mechanism funded by the responsible state (and often co-funded by the companies implicated in the relevant crimes) is set up in exchange for legal peace in the forum state; legal peace involves the termination or suspension of judicial proceedings against the responsible state and its companies, as well as a bestefforts obligation on the forum state's executive to prevent and oppose any future challenges to the responsible state's immunity, or at least challenges arising from claims covered by the pertinent agreement.

As to the practice concerning Germany, it is usually recalled that US Holocaust litigation was crucial for the conclusion of the 2000 Agreement establishing the Foundation 'Remembrance, Responsibility and Future' (Erinnerung, Verantwortung und Zukunft). ${ }^{51}$ By contrast, less attention is paid to an earlier WWII reparations agreement ${ }^{52}$ stipulated in 1995 by a recently reunified Germany in the wake of the Princz affair, which had hitherto resulted in a decade-long diplomatic action by the US and one of the most famous cases discussing (and rejecting) a ius cogens exception to state immunity. ${ }^{53}$ The 1995 Agreement was thus

Fund for Nazi-Era and World War II Claims, 17 January 2001, in force 23 January 2001, 40 ILM 565 (2001).

${ }^{48}$ In addition to the 2014 Agreement between France and the US discussed earlier (n 41), see Agreement between the Government of the United States of America and the Government of France Concerning Payments for Certain Losses Suffered During World War II, 18 January 2001, in force 5 February 2001, 2156 UNTS 281, as amended 30-31 May 2002, and 21 February 2006.

${ }^{49}$ See text accompanying notes 51 and 52 .

${ }^{50}$ See Eizenstat, Imperfect Justice 2004 (n 42), 258; 321; 342: '[I]t cannot be doubted that, without the suits, the pressures they generated, and the involvement of the U.S. government they occasioned, the massive settlements would never have occurred'. Another accompanying key factor for the successful outcome of the negotiations in question was the threat of financial sanctions against the companies of the states concerned that were implicated in WWII crimes (eg insurance or manufacturing companies). This threat was repeatedly made by various US federal and local authorities.

${ }^{51}$ Agreement Concerning the Foundation 'Remembrance, Responsibility and the Future', 17 July 2000, in force 19 October 2000, 39 ILM 1298 (2000). See, eg, Bothe, 'The Decision of the Italian Constitutional Court' 2015 (n 34), 34; Roland Bank, 'The New Programs for Payments to Victims of National Socialist Injustice', German Yearbook of International Law 44 (2001), 307-352, at 309; 313-314; 321-322; 325-327; Leora Bilsky, 'Transnational Holocaust Litigation', European Journal of International Law 23 (2012), 349-375, at 353-355.

${ }^{52}$ Agreement Concerning Final Benefits to Certain United States Nationals Who Were Victims of National Socialist Measures of Persecution, 19 September 1995, and Supplementary Agreement Effected by Exchange of Notes, 25 January 1999. The 1995 Agreement is reproduced in 35 ILM 193 (1996), with an introductory note by Ronald Bettauer.

${ }^{53}$ Princz v Germany, 26 F 3d 1166 (DC Cir, 1 July 1994). See also Sampson v Germany, 250 F 3d 1145 (7th Cir, 23 May 2001). 
a sort of ad personam arrangement (and an effective exercise of diplomatic protection) making DM (Deutsche Mark) 3 million available '[f]or the prompt settlement of known cases of compensation claims ${ }^{, 54}$ advanced by victims of Nazi persecution who were US nationals at the time of the injury. ${ }^{55}$ The close link between state immunity litigation and ensuing intergovernmental negotiation and settlement is crystal clear.

Most important, legal peace was actually achieved as a result of such diplomatic activity. US courts, including the US Supreme Court, ${ }^{56}$ cooperated in good faith to that end by rejecting all remaining Holocaust claims covered by those agreements and lodged against the states concerned and/or their agencies and companies. The courts justified their decisions on a variety of grounds, which prominently feature the non-justiciability of political questions and international comity. ${ }^{57}$

Unsurprisingly, the current residues of US Holocaust litigation precisely concern situations involving either an absence of reparations agreements between the US and the respondent states along the lines mentioned earlier or subject matters that were not (or not clearly) dealt with by such agreements. The first category of situations includes a number of high-profile disputes against Hungary and several of its state agencies for their role in the mass deportation of Hungarian Jews towards the end of WWII (which resulted in the extermination of more than 500,000 persons) and the ensuing systematic deprivation of their property and assets. ${ }^{58}$ The second category involves, most significantly, cases relating to cultural property confiscated by the Nazis and their accomplices during the Third Reich. Thus, Germany was recently denied immunity in a prominent dispute involving a complaint for the restitution of precious medieval devotional objects known as the Welfenschatz and currently housed by the Museum of Decorative Arts in Berlin. ${ }^{59}$ The plaintiffs, who are

\footnotetext{
${ }^{54}$ Agreement Concerning Final Benefits, 1995 (n 52), Art 2(1) (emphasis added). Hugo Princz and thirteen similarly situated victims were compensated with these funds.

${ }^{55}$ Ibid, Art 1.

${ }^{56}$ American Insurance Association v Garamendi, 539 US 396 (Sup Ct, 23 June 2003). The Supreme Court struck down - although with a bare majority of 5:4-a California statute imposing on insurers doing business in California a duty to disclose information relating to Nazi-era insurance policies. The statute was found to be unduly interfering with the US President's foreign affairs power as expressed in this context by the 2000 German Foundation Agreement.

${ }^{57}$ On the German Foundation Agreement, see Ungaro-Benages v Dresdner Bank AG, 379 F.3d 1227 (11th Cir, 3 August 2004). For the agreements involving Austria and France, see Whiteman $v$ Dorotheum Gmbh \& Co. Kg, 431 F.3d 57 (2nd Cir, 23 November 2005), and Freund v France, 592 F.Supp 2d 540 (SDNY, 19 December 2008); Scalin v Société Nationale des Chemins de Fer Français, No 15-cv-03362, 26 March 2018 (District Court for the Northern District of Illinois [ND IIl] 2018).

${ }^{58}$ See, eg, Simon v Hungary, No 17-7146, 28 December 2018 (DC Cir 2018); de Csepel v Hungary, 859 F.3d 1094 (DC Cir, 20 June 2017).

${ }^{59}$ Philipp v Germany, 248 F. Supp. 3d 59 (DDC 2017). The Court of Appeals largely affirmed the first instance decision, see Philipp v Germany, 894 F.3d 406 (DC Cir 2018). On 2 July 2020, a petition for a writ of certiorari lodged by Germany was granted by the US Supreme Court.
} 
legal successors to the original owners, successfully claimed (so far) that these art objects were forcibly sold to the state of Prussia (a then political subdivision of the Third Reich) in 1935, as a result of persecution against the Jewish 'sellers'. Crucially, the courts held that the absence of any intergovernmental agreements with Germany covering the restitution of Nazi-looted $\operatorname{art}^{60}$ was a chief reason for dismissing all German defences based on an encroachment of the foreign affairs power of the US President, non-justiciability, international comity, and forum non conveniens. ${ }^{61}$ The 1998 Washington Conference Principles on Nazi-Confiscated Art, ${ }^{62}$ as implemented by Germany through the creation of an Advisory Commission for the Return of Cultural Property Seized as a Result of Nazi Persecution, were no bar to that conclusion, given the non-binding nature of the former instrument and the ineffectiveness of the latter remedy.

The reason for discussing this US practice is that it provides a most useful lesson to the German and Italian governments: dialogue and non-adversarial means of dispute settlement, transparently implemented with the involvement of the victims, are the only avenues to achieve legal peace and resolve the current impasse. Such conduct would also dispose of any unpleasant feelings that the US, due to its political and economic leverage, is capable of accomplishing in this area what is beyond the reach of other states.

Reliance on US Holocaust litigation and practice would have provided significant support to the Italian Ferrini jurisprudence. The Ferrini Court instead preferred to quote the controversial US terrorism exception to state immunity and related US judicial decisions. ${ }^{63}$

\section{North American Remedies Against Immunities}

The ICJ's holding that immunity gives rise to a right enjoyed by states under customary international law should not be taken as an obvious and granitic conclusion. ${ }^{64}$ A more comprehensive and nuanced position was possible and would have been preferable. ${ }^{65}$ Anne Peters, for instance, points out that immunities are a 'messy

\footnotetext{
${ }^{60}$ The German Foundation Agreement, 2000 (n 51), basically ignores this subject matter.

${ }^{61}$ DDC, Philipp (n 59), 74-87; DC Cir, Philipp (n 59), 416-418.

${ }^{62}$ This set of principles was endorsed on 3 December 1998 by 44 states and 13 NGOs participating in the Washington Conference on Holocaust Era Assets. For a follow-up, see Terezín Declaration on Holocaust Era Assets and Related Issues, adopted on 30 June 2009 by 46 states. For background, see Eizenstat, Imperfect Justice 2004 (n 42), 187-204.

${ }^{63}$ Corte di Cassazione, Judgment No 5044/2004 (n 39), para 10.2.

${ }^{64} \mathrm{ICJ}$, Jurisdictional Immunities (n 2), paras 53 and 56.

${ }^{65}$ Riccardo Pavoni, 'An American Anomaly? On the ICJ's Selective Reading of United States Practice in Jurisdictional Immunities of the State', Italian Yearbook of International Law 21 (2011), 143-159.
} 
affair' ${ }^{66}$ as they 'oscillate between law, politics, and comity', ${ }^{67}$ they are 'bastards', ${ }^{68}$ she insists, created by the 'engagement of law with politics, of international law with domestic law, of public law with private law' ${ }^{69}$ Further, she convincingly highlights that, 'to the extent that immunities do pertain to the legal realm', ${ }^{70}$ the relentless interaction of pertinent international and national jurisprudence makes this area of law 'dynamic, complex, and partly inconsistent'.

Anne Peters is in good company. In addition to a sizable scholarship, ${ }^{72}$ her views are echoed in the Kazemi decision ${ }^{73}$ of the Supreme Court of Canada involving (and upholding) state immunity for torture, a decision delivered a few days before Sentenza 238/2014. The Supreme Court noted: '[S]tate immunity is not solely a rule of customary international law. It also reflects domestic choices made for policy reasons, particularly in matters of international relations' ${ }^{74}$ The Court also made clear that comity provides a rationale for the recognition of immunity additional to, inter alia, sovereign equality, ${ }^{75}$ thus essentially endorsing the same approach that famously informs US jurisprudence. ${ }^{76}$

\footnotetext{
${ }^{66}$ Anne Peters, 'Immune against Constitutionalisation?', in Peters, Immunities 2015 (n 32), 1-19, at 1 .

${ }^{67}$ Ibid.

${ }^{68}$ Ibid, 17.

${ }^{69}$ Ibid. See also ibid, 5 ('international or rather trans-national law of immunities').

${ }^{70}$ Ibid, 5 .

${ }^{71}$ Ibid, 2 .

${ }^{72}$ See, eg, Jasper Finke, 'Sovereign Immunity: Rule, Comity or Something Else?', European Journal of International Law 21 (2010), 853-881; Riccardo Luzzatto, 'La giurisdizione sugli Stati stranieri tra Convenzione di New York, norme internazionali generali e diritto interno', Comunicazioni e studi 23 (2007), 1-21; Lee M Caplan, 'State Immunity, Human Rights, and Jus Cogens: A Critique of the Normative Hierarchy Theory', American Journal of International Law 97 (2003), 741-781.
}

${ }^{73}$ Supreme Court of Canada, Kazemi Estate v Islamic Republic of Iran, 2014 SCC 62 (10 October 2014).

${ }^{74}$ Ibid, para 45. See also ibid, para 169: 'State immunity is a complex doctrine that is shaped by constantly evolving international relations. Determining the exceptions to immunity requires a thorough knowledge of diplomacy and international politics and a careful weighing of national interests'.

${ }^{75}$ Ibid, paras 2, 36-38, 62.

${ }^{76}$ Verlinden BVv Central Bank of Nigeria, 461 US 480, 486 (Sup Ct, 23 May 1983); Dole Food Co $v$ Patrickson, 538 US 468, 479 (Sup Ct, 22 April 2003); Republic of Austria v Altmann, 541 US 677, 43 ILM 1425 (2004), 1428, 1430, 1431 (Sup Ct, 7 June 2004). The unanimous opinion of the US Supreme Court in Venezuela $v$ Helmerich signals a more internationally friendly approach to the rationale and operation of the doctrine of state immunity which was arguably dictated by the increasing tensions generated by the US practice that will now be discussed in the main text; see Bolivarian Republic of Venezuela $v$ Helmerich \& Payne International Drilling Co., 137 S.Ct. 1312 (Sup Ct, 1 May 2017). The Supreme Court held that a non-frivolous argument by the plaintiffs is an insufficient standard to sustain a claim that property has been taken by a foreign state in violation of international law, as required by the expropriation exception under Section 1605(a)(3) of the Foreign Sovereign Immunities Act (FSIA), 28 USC, Sections 1330, 1332, 1391(f), 1441(d), and 
These unprecedented observations by the Supreme Court of Canada were prompted by Canada's adoption, just a few weeks after the 2012 ICJ Judgment, of a terrorism exception to state immunity, according to which a foreign state does not enjoy immunity in proceedings relating to loss or damage arising from that state's terrorist activity (carried out on or after 1 January 1985), and provided the same state has been included in a list of supporters of terrorism by the government. ${ }^{77}$ This background led the Supreme Court to conclude that 'the amendment to the SIA [State Immunity Act] brought by Parliament in 2012 demonstrates that forum states (...) have a large and continuing role to play in determining the scope and extent of state immunity'. 78

The persistent dynamism of the law of international immunities seems beyond question. Despite the widespread impression that international court decisions like the Jurisdictional Immunities Judgment ${ }^{79}$ and the Jones Judgment ${ }^{80}$ are bound to yield a desirable stabilization of the pertinent practice, this field of law seems more vibrant than ever and continues to generate high-profile disputes. Two relevant cases are pending before the ICJ. One case ${ }^{81}$ involves the immunity from criminal jurisdiction of a senior state official and the inviolability of diplomatic premises, whereas the other ${ }^{82}$ - which is much more interesting in our context-concerns the alleged responsibility of the US for having repeatedly denied Iran's immunity from adjudication and execution in the framework of the notorious legislation ${ }^{83}$ targeting state sponsors of terrorism designated as such by the US executive (currently, Iran,

1602-1611. The Court found support for its holding in the history and basic objectives of the FSIA. It stated that the FSIA 'for the most part embodies basic principles of international law long followed both in the United States and elsewhere' (ibid, 1319 (emphasis added)), and that to grant foreign states immunity from suit in US courts "recognizes the "absolute independence of every sovereign authority" and helps to "induc[e]" each nation state, as a matter of "international comity", to "respect the independence and dignity of every other", including our own' (ibid, quoting Berizzi Brothers Co. v S.S. Pesaro, 271 US 562 (Sup. Ct., 7 June 1926)).

The unparalleled US expropriation exception to state immunity constitutes the legal basis of an overwhelming part of the Holocaust jurisprudence discussed in section III of this chapter. The exception clearly implicates iure imperii acts of foreign states, although US courts often seek to circumvent this point.

${ }^{77}$ Justice for Victims of Terrorism Act (JVTA), Bill C-10, in force 13 March 2012, Section 4(1) and SIA, as amended by the JVTA, Section 6(1) and (2).

${ }^{78} \mathrm{SCC}$, Kazemi Estate (n 73), para 44.

${ }^{79} \mathrm{ICJ}$, Jurisdictional Immunities (n 2).

${ }^{80} \mathrm{ECtHR}$, Jones and Others $v$ The United Kingdom, Judgment of 14 January 2014, Applications Nos 34356/06 and 40528/06.

${ }^{81}$ ICJ, Immunities and Criminal Proceedings (Equatorial Guinea v France), Order of 7 December 2016 (Provisional Measures), ICJ Reports 2016, 1148, Judgment of 6 June 2018 (Preliminary Objections).

${ }^{82}$ ICJ, Certain Iranian Assets (Iran v United States of America), Judgment of 13 February 2019 (Preliminary Objections). It must be noted that, with the latter judgment, the ICJ has upheld the preliminary objection to its jurisdiction raised by the US with respect to Iran's claims involving jurisdictional immunities, while dismissing the other objections, ibid, para 80.

${ }^{83}$ Currently codified at FSIA (n 76), Section 1605A. 
North Korea, Sudan, and Syria). In addition, the potentially powerful stabilizing factor represented by the UNCSI is languishing in the ratification process: more than 15 years after its adoption, only 22 states have consented to be bound by this convention, whereas 30 ratifications are necessary for its entry into force; most worryingly, however, only one state has ratified it over the last five years, and many 'key' ${ }^{84}$ states, such as Germany and the UK, appear uninterested in becoming parties. One plausible explanation is that the large majority of states are unwilling to sacrifice their scope for manoeuvre in immunity issues to the altar of legal predictability and harmonization resulting from multilateral treaty obligations.

Yet the US and Canadian terrorism exceptions to state immunity, together with the Italian Ferrini and Sentenza 238/2014 jurisprudence, remain the most controversial manifestations of the contemporary practice in the area of international immunities. Nearly 25 years after its enactment, damages awarded under the US exception have now reached much-feared 'astronomic dimensions' ${ }^{85}$ Iran is debtor to a multitude of (largely unpaid) judgments awarding damages for over US\$56 billion. ${ }^{86}$ Most significantly, a number of legislative instruments and judicial decisions have targeted various types of property held by Iran or its instrumentalities in the US, thereby paving the way for execution against them. In many instances, such property is apparently used or intended for governmental purposes, including the financial assets of the Central Bank of Iran (Bank Markazi) and state cultural objects. ${ }^{87}$ These categories of sovereign property should thus be immune under international law.

The situation became particularly troublesome for the Iranian authorities when in August 2012 the US Congress approved, and the President signed into law, the Iran Threat Reduction and Syria Human Rights Act, ${ }^{88}$ which contains a section removing any obstacle to execution against certain Iranian financial assets specifically identified as those that had already been the subject of restraining orders in a case under the terrorism exception. ${ }^{89}$ These assets amount to some US\$1.75 billion in cash proceeds of securities owned by Bank Markazi. Soon after the US Supreme Court upheld this ad hoc legislation in the 2016 Bank Markazi decision, ${ }^{90}$ Iran filed its

\footnotetext{
${ }^{84}$ If only for the volume of state immunity practice which involves them.

${ }^{85}$ Tomuschat, 'The Case of Germany v. Italy' 2015 (n 34), 94.

${ }^{86}$ ICJ, Certain Iranian Assets (n 82), Application Instituting Proceedings, 14 June 2016, Appendix 2, Table 2.

${ }^{87}$ ICJ, Certain Iranian Assets (n 82), Application Instituting Proceedings, 14 June 2016, Appendix 2, Table 3. With regard to cultural property, note, however, the decision of the US Supreme Court in the Rubin case, which effectively halted attempts of attaching priceless Persian artefacts owned by Iran and located in the US, Rubin v Islamic Republic of Iran, 138 S.Ct. 816 (2018) (Sup Ct, 21 February 2018).

${ }^{88}$ Iran Threat Reduction and Syria Human Rights Act, 10 August 2012, 22 USC Section 8772.

${ }^{89}$ Peterson et al $v$ Islamic Republic of Iran et al, Case No 10 Civ 4518 (BSJ) (GWG) (District Court for the Southern District of New York).

${ }^{90}$ Bank Markazi v Peterson, 136 S.Ct. 1310 (Sup Ct, 20 April 2016). See Kristina Daugirdas/Julian D Mortenson, 'Contemporary Practice of the United States Relating to International Law', American Journal of International Law 110 (2016), 554-595, at 555-562.
} 
application with the ICJ. The Supreme Court merely considered, and ruled out, a possible violation of separation-of-powers principles by the 2012 Act. It did not even mention international law. Only Chief Justice Roberts, in his powerful dissenting opinion, underscored that the disputed legislation 'strips the Bank of any protection that federal common law, international law, or New York State law might have offered against respondents' claims'. 91

US plaintiffs holding judgments against Iran have now found a precious ally across the northern border. One of the most salient aspects of the Canadian terrorism exception is a provision according to which Canadian courts 'must recognize a judgment of a foreign court' 92 in favour of a person who has suffered losses or damages as a result of terrorist activities by a state supporter of terrorism listed as such in Canada (presently, Iran and Syria). This provision has already been set in motion. For instance, a major case involves twelve US judgments against Iran that have been granted exequatur and whose enforcement proceedings in Canada are well underway. ${ }^{93}$ Attachment has successfully been sought against two bank accounts held in the name of Iran's embassy and real estate allegedly hosting Iranian cultural centres located in Ottawa and Toronto. ${ }^{94}$ To be sure, Canada's immunity statute makes iure imperii property held by state supporters of terrorism generally subject to execution, with the exception of diplomatic property, property that has cultural or historical value, and-possibly-military property. ${ }^{95}$ In the Tracy case, both the buildings hosting Iranian cultural centres and the embassy's bank accounts were found not to have 'cultural or historical value'; ${ }^{96}$ nor were they diplomatic property, ${ }^{97}$ given that they were listed on Canada's Department of Foreign Affairs website as 'Iran's Non-Diplomatic Assets in Canada'. The conclusion that the Iranian property at stake was not entitled to immunity from execution 'under either domestic or international

\footnotetext{
${ }^{91}$ Bank Markazi (n 90), Dissenting Opinion of Roberts CJ, joined by Sotomayor J, 1336.

${ }^{92}$ JVTA (n 77), Section 4(5).

${ }^{93}$ Tracy $v$ The Iranian Ministry of Information and Security, 2016 ONSC 3759 (Ontario Superior Court of Justice, 9 June 2016), affirmed 2017 ONCA 549 (Court of Appeal for Ontario, 30 June 2017). On 15 March 2018, the Supreme Court of Canada dismissed an application for leave to appeal from the Court of Appeal decision. By contrast, and despite Sentenza 238/2014, the Italian Court of Cassation has refused to recognize US judicial decisions arising from the terrorism exception, see Judgment of 28 October 2015, No 21946/2015 (Flatow v Iran), and Judgment of 28 October 2015, No 21947/2015 (Eisenfeld v Iran). For a critical and paradoxical case report on the Flatow decision, see Thomas Weatherall, 'Flatow v Iran', American Journal of International Law 110 (2016), 540-547.

${ }^{94}$ ONSC, Tracy (n 93), paras 50, 127-157. Most recently, these alleged cultural centres have been sold for some CAN\$28 million and the proceeds have been distributed to several victims (or their heirs) of acts of terrorism sponsored by Iran. Iranian authorities have depicted such developments as a 'clear breach of the international law'; see Dominic Dudley, 'Iran Takes Aim at Canada over Property Seizures in Toronto and Ottawa', Forbes, (17 September 2019), available at https://www. forbes.com/sites/dominicdudley/2019/09/17/iran-canada-property-seizures/\#23c8fe251910.

${ }^{95}$ SIA (n 77), Sections 12(1) and (3), and 16.

${ }^{96}$ ONSC, Tracy (n 93), paras 127-129.

${ }^{97} \mathrm{Ibid}$, paras $150,155-156$.
} 
law ${ }^{98}$ was, however, deceiving, insofar as it was not supported by any meaningful discussion of the international instruments and practice covering mixed bank accounts or, generally, property fulfilling sovereign functions. The Canadian courts never mentioned the ICJ's Jurisdictional Immunities Judgment, and particularly not the section concerning the illegality of the Italian courts' grant of exequatur to the Greek decisions awarding damages and costs in the proceedings relating to the Distomo massacre. ${ }^{99}$

One of the latest chapters in American exceptionalism within the area of international immunities is the Justice Against Sponsors of Terrorism Act (JASTA), otherwise known informally as the '9/11 Victims Bill', a statute finally passed by the US Congress on 28 September 2016 when an earlier veto by President Obama was overridden. ${ }^{100}$ JASTA amends the US Foreign Sovereign Immunities Act (FSIA) by introducing a new Section 1605B, according to which a foreign state is not immune from the jurisdiction of US courts in compensation proceedings brought by US nationals for physical injury to person or property, or for death caused by (i) an act of international terrorism in the US, and (ii) a tortious act of the foreign state, regardless where the tort occurred. ${ }^{101}$ The amendment applies to any civil action 'arising out of an injury to a person, property, or business on or after September 11, 2001'. ${ }^{102}$ The chief reason behind the adoption of JASTA is clearly to dispose of the requirement in the existing terrorism exception that a foreign state be listed as a state sponsor of terrorism in order for compensation claims to be pursued against it for terrorist acts committed in the US, especially those that were planned and/or supported outside of US territory. Indeed, mass litigation against Saudi Arabia instigated by thousands of victims (individuals, businesses, and insurance companies) of 9/11 is currently unfolding before US courts. ${ }^{103}$ Similarly, the amendment circumvents the conditions for triggering the territorial tort exception of the FSIA, which is applicable to claims for personal injury, death, or damage to property in the US, but only if the tortious act of the defendant foreign state also occurred in the US, and provided that act did not arise from the exercise of a discretionary function. ${ }^{104}$

\footnotetext{
${ }^{98} \mathrm{ONSC}$, Tracy (n 93), para 157.

${ }^{99} \mathrm{ICJ}$, Jurisdictional Immunities (n 2), paras 121-133.

${ }^{100}$ This is the sole veto override experienced by Obama during his eight years of presidency. See Jennifer Steinhauer/Mark Mazzetti/Julie Hirschfeld Davis, 'Congress Votes to Override Obama Veto on 9/11 Victims Bill', New York Times (28 September 2016).

${ }^{101}$ FSIA (n 76), Section 1605B(b) and (c).

${ }^{102}$ Justice Against Sponsors of Terrorism Act (JASTA), 28 September 2016, Section 7.

${ }^{103}$ One such case is The Underwriting Members of Lloyd's Syndicate 53 et al v Kingdom of Saudi Arabia et al, Case No 17-02129 (District Court for the Southern District of New York [SDNY]). See Jonathan Stempel, 'Saudi Arabia Faces \$6 Billion U.S. Lawsuit by Sept. 11 Insurers', Reuters (24 March 2017).

${ }^{104}$ FSIA (n 76), Section 1605(a)(5). See especially, In re Terrorist Attacks on September 11, 2001, 538 F.3d 71 (2nd Cir, 14 August 2008) (involving Saudi Arabia); Doe v Bi Laden, 663 F.3d 64 (2nd Cir, 7 November 2011) (involving Afghanistan). For background, see Sean Hennessy, 'In re the Foreign Sovereign Immunities Act: How the 9/11 Litigation Shows the Shortcomings of FSIA as a Tool in the War on Global Terrorism', Georgetown Journal of International Law 42 (2011), 855-878.
} 
How do we make sense of this North American practice? How do we square the widespread convictions and certainties relating to immunity law as bolstered by the ICJ with it? Is it nothing else than (North) American extravagance? It must be pointed out that there are robust reasons why the legislation and practice at stake cannot be equated to lawful countermeasures. It is true that in the North American context, unlike the Italian situation, the actual denial of immunity would usually be conditional on a prior executive's determination of target states and that we would not, therefore, be here confronted with an instance of misconceived judicial countermeasures. It is thus tempting to interpret ${ }^{105}$ the North American practice in light of the law of countermeasures, and there can be no doubt that troops of American lawyers would be willing to mount a major defence on this basis within the Iran $v$ US case before the ICJ and/or similar future disputes. However, when one takes a closer look at that practice and reviews it against the notion and requirements of countermeasures, this view becomes untenable. ${ }^{106}$ For present purposes, two points would suffice. First, as JASTA shows, the necessity of a prior executive's determination of the commission or support of acts of terrorism by states that may be denied immunity (for example Saudi Arabia) is not an inflexible requirement of US practice. To the contrary, JASTA has been adopted by the US legislature despite strong opposition by the executive. This is an unorthodox and clumsy situation for the implementation of veritable countermeasures. Secondly, and more fundamentally, to the best of my knowledge there exist no statements or any other documentary evidence from the governments concerned characterizing the terrorism legislation and practice at stake as countermeasures, that is, as measures which would be in breach of international obligations on state immunity were they not taken in response to wrongful acts by the target states. Accordingly, this would be an unlikely instance of implicit countermeasures. In reality, the only reasonable inference is that, at best, the governments concerned might conceive of the practice in question in terms of acts of retorsion, namely, as unfriendly conduct withdrawing a privilege predominantly afforded as a matter of grace and comity, not out of respect for international legal obligations.

To be sure, if we stick to the wisdom and certainty allegedly emanating from the 2012 ICJ Judgment, there is no alternative to regarding the US and Canadian terrorism exceptions as internationally wrongful acts sic et simpliciter. It is another thing, though, to maintain that American immunity practice must be set aside as a

\footnotetext{
${ }^{105} \mathrm{See}$, eg, Andrea Gattini, 'The Dispute on Jurisdictional Immunities of the State before the ICJ: Is the Time Ripe for a Change of the Law?', Leiden Journal of International Law 24 (2011), 173-200, at 183; van Alebeek, 'Jurisdictional Immunities of the State' 2012 (n 5), 299.

${ }^{106}$ See the excellent study by Simone Vezzani, 'Sul diniego delle immunità dalla giurisdizione di cognizione ed esecutiva a titolo di contromisura', Rivista di diritto internazionale 97 (2014), 36-87, at 82. See also Patricia Tarre Moser, 'Non-Recognition of State Immunity as a Judicial Countermeasure to Jus Cogens Violations: The Human Rights Answer to the ICJ Decision on the Ferrini Case', Goettingen Journal of International Law 4 (2012), 809-852; Giegerich, 'The Holy See' 2015 (n 46), 67 (the latter author, however, seems to start from the flawed assumption that the relevant countermeasure would be the enactment of the legislation at stake in and of itself, rather than its actual application by the governments and courts of the respective states).
} 
whole and given no weight whatsoever when assessing the state of the law in this area. ${ }^{107}$ This is the radical stance taken by authors such as Thomas Giegerich. He states: 'The proper reaction of the international community to such instances of ignorance or disregard of international law is to ignore or disregard them when it comes to gathering evidence of the development of international law'. ${ }^{108}$ This sentence proves too much. First, the North American legislation and judicial decisions in question do represent state practice. Such practice may then be considered as irrelevant for the formation of customary exceptions to state immunity, as it is not grounded in international opinio iuris but in considerations of comity and political convenience. Yet, it provides evidence contrary to the existence of customary rules in the field of state immunity. As it apparently involves two states only, the same practice is currently insufficient to override the contrary position of the majority of states. But it remains chiefly significant because it comes from two major countries that have been fundamental for the definitive consolidation of restrictive immunity standards and whose courts (especially US courts) adjudge a massive volume of immunity cases.

At the very least, the North American terrorism exceptions are a powerful reminder of the persistent strains and paradoxes in the law of international immunities. They are a crucial component of dissident views from certain key states that challenge common legal assumptions and debunk the myth of the universal acceptance of the customary status of immunity rules.

\section{Conclusion}

At the time of writing, the prospect of legal peace between Germany and Italy in relation to the litigation of Nazi war crimes reignited in Italian courts in the wake of Sentenza 238/2014 seems distant and, most worryingly, is being ignored by the governments concerned. It is as if the governments were confident that time will pass by and sooner or later heal the wounds left open by the loopholes and gaps in the reparation regimes elaborated over the past 70 years, regimes that were specifically meant to reckon with WWII crimes. However, such a failure to convincingly address the outstanding compensation claims of IMIs and comparable victims of Nazi crimes may also increasingly come to be regarded as staining the reputation of Germany and Italy, two countries which are champions of European integration and supposed to be frontrunners in the global pursuit of peace, justice, and the rule of law.

This chapter has stigmatized the opaque conduct of the governments concerned in the aftermath of Sentenza 238/2014 and their dismissive attitude vis-à-vis meaningful negotiations, which would be conducive to a just compensatory arrangement and,

\footnotetext{
${ }^{107}$ This is largely what the ICJ has done in its 2012 Judgment; see Pavoni, 'An American Anomaly?' 2011 (n 65).

${ }^{108}$ Giegerich, 'The Holy See' 2015 (n 46), 69.
} 
ultimately, legal peace. It has underscored how useful lessons in this area come from a series of WWII reparations agreements that, from the 1990s, were stipulated between the US and a number of states (including Germany) in order to put a halt to an expanding array of judicial proceedings before US courts that were endangering those states' entitlement to immunity.

Pace the ICJ, there are continuing manifestations of US practice, and lately Canadian practice, which corroborate the view that immunity for acta iure imperii is not a universally shared, inflexible international law dogma, especially when effective remedies for the victims, other than suits in the forum state, are absent. Serious violations of international humanitarian and human rights law are exerting a sustained pressure on the law of international immunities. At the very least, history and precedent show that when such egregious breaches of international law are at stake the only way of appeasing turbulent domestic courts and achieving a sustainable legal peace is the setting up of fair and reasonable means of redress for uncompensated victims.

\section{References}

Alebeek, Rosanne van, 'Jurisdictional Immunities of the State (Germany $v$. Italy): On Right Outcomes and Wrong Terms', German Yearbook of International Law 55 (2012), 281-318

Bank, Roland, 'The New Programs for Payments to Victims of National Socialist Injustice', German Yearbook of International Law 44 (2001), 307-352

Bettauer, Ronald, 'A Measure of Justice for Uncompensated French Railroad Deportees during the Holocaust', ASIL Insights, (1 March 2016), available at https://www.asil.org/insights/volume/ 20/issue/5/measure-justice-uncompensated-french-railroad-deportees-during-holocaust

Bilsky, Leora, 'Transnational Holocaust Litigation', European Journal of International Law 23 (2012), 349-375

Bothe, Michael, 'Remedies of Victims of War Crimes and Crimes against Humanities: Some Critical Remarks on the ICJ's Judgment on the Jurisdictional Immunity of States', in Anne Peters/Evelyne Lagrange/Stefan Oeter/Christian Tomuschat (eds), Immunities in the Age of Global Constitutionalism (Leiden: Brill Nijhoff 2015), 99-115

Bothe, Michael, 'The Decision of the Italian Constitutional Court Concerning the Jurisdictional Immunities of Germany', Italian Yearbook of International Law 24 (2014), 25-35

Brown, Chester/Roger O'Keefe, 'Article 21', in Roger O'Keefe/Christian J Tams (eds), The United Nations Convention on Jurisdictional Immunities of States and Their Property: A Commentary (Oxford: OUP 2013), 334-347

Caplan, Lee M, 'State Immunity, Human Rights, and Jus Cogens: A Critique of the Normative Hierarchy Theory', American Journal of International Law 97 (2003), 741-781

Cassese, Sabino, Dentro la Corte: Diario di un giudice costituzionale (Bologna: il Mulino 2015)

Cataldi, Giuseppe, 'A Historic Decision of the Italian Constitutional Court on the Balance Between the Italian Legal Order's Fundamental Values and Customary International Law', Italian Yearbook of International Law 24 (2015), 37-52

Conforti, Benedetto, 'Il legislatore torna indietro di circa novant'anni: la nuova norma sull'esecuzione sui conti correnti di Stati stranieri', Rivista di diritto internazionale 98 (2015), 558-561

Conforti, Benedetto, 'The Judgment of the International Court of Justice on the Immunity of Foreign States: A Missed Opportunity’, Italian Yearbook of International Law 21 (2011), $133-142$ 
Daugirdas, Kristina/Julian D Mortenson, 'Contemporary Practice of the United States Relating to International Law', American Journal of International Law 110 (2016), 554-595

Eizenstat, Stuart, Imperfect Justice: Looted Assets, Slave Labor, and the Unfinished Business of World War II (New York: Public Affairs 2004)

Finke, Jasper, 'Sovereign Immunity: Rule, Comity or Something Else?', European Journal of International Law 21 (2010), 853-881

Focarelli, Carlo, Diritto internazionale (Padua: Cedam $4^{\text {th }}$ ed 2017)

Forlati, Serena, 'Judicial Decisions, Immunities of Foreign States from Jurisdiction', Italian Yearbook of International Law 25 (2015), 497-509

Franceschelli, Ferdinando, 'Germany Held Responsible for the Nazi Massacre of Pietransieri', Italian Yearbook of International Law 27 (2017), 449-452

Francioni, Francesco, 'Access to Justice and Its Pitfalls: Reparation for War Crimes and the Italian Constitutional Court', Journal of International Criminal Justice 14 (2016), 629-636

Frulli, Micaela, "'Time Will Tell Who Just Fell and Who's Left Behind": On the Clash between the International Court of Justice and the Italian Constitutional Court', Journal of International Criminal Justice 14 (2016), 587-594

Gattini, Andrea, 'The Dispute on Jurisdictional Immunities of the State before the ICJ: Is the Time Ripe for a Change of the Law?', Leiden Journal of International Law 24 (2011), 173-200

Giegerich, Thomas, 'The Holy See, a Former Somalian Prime Minister, and a Confiscated Pissarro Painting: Recent US Case Law on Foreign Sovereign Immunity', in Anne Peters/Evelyne Lagrange/Stefan Oeter/Christian Tomuschat (eds), Immunities in the Age of Global Constitutionalism (Leiden: Brill Nijhoff 2015), 51-69

Hennessy, Sean, 'In re the Foreign Sovereign Immunities Act: How the 9/11 Litigation Shows the Shortcomings of FSIA as a Tool in the War on Global Terrorism', Georgetown Journal of International Law 42 (2011), 855-878

Luzzatto, Riccardo, 'La giurisdizione sugli Stati stranieri tra Convenzione di New York, norme internazionali generali e diritto interno', Comunicazioni e studi 23 (2007), 1-21

Palchetti, Paolo, "A key institution for interpreting international law and guaranteeing global compliance with its provisions": la dichiarazione italiana di accettazione della competenza della Corte internazionale di giustizia', Rivista di diritto internazionale 98 (2015), 114-125

Pavoni, Riccardo, 'An American Anomaly? On the ICJ's Selective Reading of United States Practice in Jurisdictional Immunities of the State', Italian Yearbook of International Law 21 (2011), 143-159

Pavoni, Riccardo, 'How Broad is the Principle Upheld by the Italian Constitutional Court in Judgment No. 238?', Journal of International Criminal Justice 14 (2016), 573-585

Pavoni, Riccardo, 'Human Rights and the Immunities of Foreign States and International Organizations', in Erika de Wet/Jure Vidmar (eds), Hierarchy in International Law: The Place of Human Rights (Oxford: OUP 2012), 71-113

Peters, Anne, 'Immune against Constitutionalisation?', in Anne Peters/Evelyne Lagrange/Stefan Oeter/Christian Tomuschat (eds), Immunities in the Age of Global Constitutionalism (Leiden: Brill Nijhoff 2015), 1-19

Peters, Anne, 'Let Not Triepel Triumph-How To Make the Best Out of Sentenza No. 238 of the Italian Constitutional Court for a Global Legal Order', EJIL:Talk!, (22 December 2014), available at www.ejiltalk.org/let-not-triepel-triumph-how-to-make-the-best-out-of-sentenzano-238-of-the-italian-constitutional-court-for-a-global-legal-order-part-i

Pisillo Mazzeschi, Riccardo, 'Access to Justice in Constitutional and International Law: The Recent Judgment of the Italian Constitutional Court', Italian Yearbook of International Law 24 (2014), $7-23$

Steinhauer, Jennifer/Mark Mazzetti/Julie Hirschfeld Davis, 'Congress Votes to Override Obama Veto on 9/11 Victims Bill', New York Times (28 September 2016)

Stempel, Jonathan, 'Saudi Arabia Faces \$6 Billion U.S. Lawsuit by Sept. 11 Insurers', Reuters (24 March 2017) 
Tarre Moser, Patricia, 'Non-Recognition of State Immunity as a Judicial Countermeasure to Jus Cogens Violations: The Human Rights Answer to the ICJ Decision on the Ferrini Case', Goettingen Journal of International Law 4 (2012), 809-852

Tomuschat, Christian, 'The Case of Germany v. Italy before the ICJ', in Anne Peters/Evelyne Lagrange/Stefan Oeter/Christian Tomuschat (eds), Immunities in the Age of Global Constitutionalism (Leiden: Brill Nijhoff 2015), 87-98

Tomuschat, Christian, 'The National Constitution Trumps International Law', Italian Journal of Public Law 6 (2014), 189-196

Vezzani, Simone, 'Sul diniego delle immunità dalla giurisdizione di cognizione ed esecutiva a titolo di contromisura', Rivista di diritto internazionale 97 (2014), 36-87

Weatherall, Thomas, 'Flatow v Iran', American Journal of International Law 110 (2016), 540-547

Open Access This chapter is licensed under the terms of the Creative Commons Attribution 4.0 International License (http://creativecommons.org/licenses/by/4.0/), which permits use, sharing, adaptation, distribution and reproduction in any medium or format, as long as you give appropriate credit to the original author(s) and the source, provide a link to the Creative Commons license and indicate if changes were made.

The images or other third party material in this chapter are included in the chapter's Creative Commons license, unless indicated otherwise in a credit line to the material. If material is not included in the chapter's Creative Commons license and your intended use is not permitted by statutory regulation or exceeds the permitted use, you will need to obtain permission directly from the copyright holder.

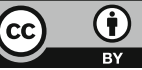




\title{
A Story of 'Trials and Errors' That Might Have No Happy End
}

\author{
Jörg Luther†
}

\begin{abstract}
The International Court of Justice (ICJ) and Italian Constitutional Court (ItCC) have created a deadlock between two diverging res iudicatae on state immunities and judicial remedies as well as a tension between two republics that do not share the same constitutional and international identities. In order to avoid a further spiralling of decisions, judges tried to promote the negotiation of 'a happy outcome' for a category of victims of war crimes that risk dying without being entitled to any compensation. This chapter analyses the general cultural context of 'academic diplomacy'. Both state sovereignty and human solidarity could be maintained through a voluntary compensation for moral damages to the victims of massacres, deportation, and forced labour during World War II. The moralresponsibility approach suggested by the ICJ could be stronger than the legalliability threat backed by the ItCC. A belated common solidarity funded by both German and Italian citizens and employers could be the best way out, but considering that many of the now elderly victims are approaching the end of their lifespans, it might be cynically too late. This could, paradoxically, help to remind the world of the injustices they suffered. Yet, on grounds of this tragic end, state immunity and fundamental rights might further be delegitimized in possible wars to come.
\end{abstract}

\section{The Complexity of the Reconciliation Task}

The bilateral and worldwide discussion on the Jurisdictional Immunities Judgment of the International Court of Justice (ICJ) ${ }^{1}$ and the Italian Constitutional Court's (ItCC) Judgment $238 / 2014^{2}$ on the right to a remedy has been conducted from

Jörg Luther was a Professor of Public Law in the Department of Law and Political Sciences, Economics and Social Sciences at the University of Eastern Piedmont Amedeo Avogadro in Alessandria, Italy. He passed away while this chapter was under revision, and Giovanni Boggero and Valentina Volpe helped to finalize it.

${ }^{1}$ ICJ, Jurisdictional Immunities of the State (Germany v Italy: Greece intervening), Judgment of 3 February 2012, ICJ Reports 2012, 99.

${ }^{2}$ Corte Costituzionale, Judgment of 22 October 2014, No 238/2014. 
different viewpoints. The facts and norms in question are the object of various legal, moral and political interests that include the victims and their heirs, the culprits, as well as involved nation-states and domestic and international institutions. The different views on German and Italian legal orders focus just on the reconciliation between the two states, but the questions involved are potentially of interest also to the former Allied Forces as well as to countries like Austria, Greece, Poland and Israel. Furthermore, the 'remedies against immunity' quandary involves the whole international legal and political order, itself shaped by a highly dynamic multilevel governance structure. All these views need a more comprehensive reconciliation that has to be carried out in different places and under different and changing legal and political conditions.

The reconciliation of colliding international and domestic laws, however, has to reckon with the specific case: the evident historical atrocities and injustices of a dreadful 'past that will not pass' ${ }^{3}$ The ICJ assigned a victory to Germany that might have been as such accepted by the Italian government, but it could not reconcile the two states with their history nor foster a shared understanding of what human dignity should mean for the future. The ItCC made an appeal to human dignity and in the name of the Italian people decided in favour of human rights protection against Germany and against those immunities that within the constitutional state have been increasingly restricted — though not abolished—over the last decades.

The decisions of international judges as defenders of sovereign state immunity and of national constitutional court judges as defenders of fundamental rights protection created a legal deadlock and have somewhat benighted diplomatic relations between Italy and Germany. In a context of amplified national passions, domestic views on the development of international law and on 'constitutional identities' appear to be diverging, if not clashing. On the one hand Germany prefers to shield behind its sovereignty to close the books on the past, looking forward to friendly relations, while supporting state immunity. On the other hand, Italy commits to an international order based on 'peace and justice' (Article 11 of the Italian Constitution) demanding the rights protection of still living victims of that 'past that will not pass'. The task of reconciliation is still in need of improvement, something different from an acquis of diplomacy that could be self-certified by governments.

The follow-up of both judgments makes this task still uncertain in its outcome. On the one hand there is an international res iudicata, formally opposed by Sentenza 238/2014, that invalidated both the specific provision of Article 3 of Italian Law No $5 / 2013$ made for the execution of the ICJ Judgment and the part of Italian Law No 848/1957 implementing the UN Charter. ${ }^{4}$ Germany might address the UN Security

\footnotetext{
${ }^{3}$ Ernst Nolte, 'Vergangenheit die nicht vergehen will', Frankfurter Allgemeine Zeitung (5 June 1986).

${ }^{4}$ This point 'concerns the execution of Article 94 of the United Nations Charter, exclusively to the extent that it obliges the Italian judge to comply with the Judgment of the ICJ of 3 February 2012, which requires that Italian courts deny their jurisdiction in case of acts of a foreign state constituting war crimes and crimes against humanity, in breach of inviolable human rights.' ItCC, Judgment 238/2014 (n 2), para 1.1.
} 
Council under Article 94(2) of the UN Charter, present a new complaint to the ICJ for a violation of state immunity and appeal, under Article 39 of the European Convention for the Peaceful Settlement of Disputes of 29 April 1957, to the Committee of Ministers of the Council of Europe, and get a two-thirds majority for issuing 'recommendations with a view to ensuring compliance with the (...) decision'. In any case, the Italian government should reserve part of its budget for mitigating the consequences of the execution of Italian judgments against Germany.

On the other hand, Judgment 238/2014 has a specific constitutional res iudicata: ${ }^{5}$ Article 136 and Article 137(3) of the Italian Constitution prescribe that the law declared unconstitutional 'ceases to have effect from the day following the publication of the decision' and no appeal can be allowed. The constitutional res iudicata applies also to the implicit declaration of the unconstitutionality of the international customary law norm. ${ }^{6}$ Furthermore, it applies to the order to give execution to the ICJ Judgment implied in the legal authorization to ratify Article 96 of the UN Charter, and the ItCC did not restrict the decision to the first section. The implementation of decisions of international bodies aiming to reproduce the same norm that ceased to have effect would violate Article 137(3) of the Italian Constitution and could be rendered ineffective by a further ItCC judgement.

This describes the deadlock created by both decisions. However, they might not be the judges' last words, and lawmakers could try to renegotiate the treaties or amend the Constitution. ${ }^{7}$ The ICJ Judgment could be not the first one to be disregarded, but Sentenza risks in turn to have a merely symbolic value. On the one hand, the ICJ Judgment's lack of implementation could be the beginning of the end of the customary law norm. If third-party judges were to join the Italian position, customs could change over time. On the other hand, as the ItCC judgement allowed only a declaratory relief in the Italian courts, the 'victorious' victims could not get any of the Italian courts' judgments enforced against the Federal Republic of Germany unless a further declaration of unconstitutionality of the international and national laws that still grant immunity from execution comes about. ${ }^{8}$ The lack of effective justice for the victims and the impact on international customary law could affect the judgment in a regrettable way.

In any case, the deadlock could be a tragedy. More than for the judges or for the respective German and Italian states, this is true for those who still have hope in receiving justice. These victims invested money in costly legal proceedings, but judges could issue only symbolic, not enforceable, decisions.

\footnotetext{
${ }^{5}$ See Francesco Dal Canto, Il giudicato costituzionale nel giudizio sulle leggi (Turin: Giappichelli 2002), 30 et seq.

${ }^{6}$ See the final judgments of the Tribunale di Firenze in the aftermath of Sentenza 238/2014, discussed by Paolo Veronesi, Colpe di stato (Milan: Franco Angeli 2017), 228 et seq.

${ }^{7}$ Stefan Rinke, Schadensersatzklagen gegen Staaten wegen schwerer Menschenrechtsverletzungen im europäischen Zivilprozessrecht (Berlin: Berliner Wissenschafts-Verlag 2017).

${ }^{8}$ See also Paolo Palchetti, chapter 'Right of Access to (Italian) Courts über alles?', in this volume.
} 
The culture of memory matters for this reconciliation and the costs of this culture may exceed the investment done so far, which emphasized monuments building and the work of historians. In a first step, this chapter focuses on the general context of 'academic diplomacy' after Sentenza 238/2014 (section II). In a second step, the common concerns for the rights of victims of war crimes and forced labour need to be addressed, reasoning on the opportunities and risks of a 'belated' solidarity solution (sections III-V). In a third step, some conclusions for the proper use of 'constitutional identities' in the context of international relations will be drawn (sections VI-VII).

\section{Academic Diplomacy as a Supplement to Governmental and Judicial Dialogues}

Academic diplomacy is a new concept in peace studies and offers a means for sustainable reconciliation. Academic culture could represent nations and become a path finder for solutions to a deadlock created by governments and judges. Academic legal culture could move beyond its role as adnotatores of conflicting decisions towards a constructive and friendly cross-border dialogue based on a search for comparative constitutional and international law solutions. But diplomacy is more a political than a legal discourse and law professors generally lack sufficient information regarding ongoing diplomatic dialogue and negotiations.

What is well known concerning the case at hand is that several scholars have already been involved through expert opinions pro veritate, advocating for governments and parliaments; others might have an interest in pursuing an international career in the judiciary. Present-day institutions fostering international academic dialogue, including the German-Italian Constitutional Colloquium (DeutschItalienisches Verfassungskolloquium), have been less engaged in currently disputed topics. The forerunner of the concept of academic diplomacy was the GermanItalian Commission of Historians (Historikerkommission, 2009-2012). ${ }^{9}$ Its political mandate prudently kept out all legal questions as well as the participation of legal historians in order not to encroach upon the work of the ICJ. ${ }^{10}$ The participating

\footnotetext{
${ }^{9}$ 'Bericht der von den Außenministern der Bundesrepublik Deutschland und der Italienischen Republik am 28.3.2009 eingesetzten Deutsch-Italienischen Historikerkommission', (July 2012), available at http://www.villavigoni.it/contents/files/Abschlussbericht.pdf, 1-180, at 45: 'Military internees cannot disappear longer from history and end up in the grey area of Italian and German memory; rather the remembrance of their innocent fate should symbolically unite Germans and Italians'; (translated by the author).

${ }^{10}$ Guido Westerwelle (former German Minister of Foreign Affairs), 'Ansprache von Außenminister Westerwelle anlässlich der Übergabe des Abschlussberichts der Deutsch-Italienischen Historikerkommission in Rom', (19 December 2012), available at www.auswaertiges-amt.de/DE/ Infoservice/Presse/Reden/2012/121219-BM_Rom.html?nn=360110: 'In the name of Germany, unjustifiable crimes were committed in Italy and against Italians in the years 1943-1945. These crimes cannot be relativized through historical differentiation either. Also, the proceedings before
} 
historians were obliged to ignore the legal questions and their attendant tensions because the governments preferred that a cultural consensus could render the legal dispute resolution sustainable. The Foreign Ministers of the governments of Angela Merkel and Silvio Berlusconi agreed to pay for the work of historians but not to pay compensation to the victims of this history and excluded any consideration of this question from the mandate of the German-Italian Commission. A number of historians complained, feeling that they were used by statesmen engaged in a larger political game. In unhappy times of financial crisis, diplomacy and political prudence led to the conclusion that 'making history with money' was better than 'making money with history'. In the end, those historians agreed that both further historical research and memorial monuments should be financed. Domestic and international judges had to enter into the scene to finally raise the issue of the rights of victims.

Academic diplomacy is now required to help reconcile a deadlock that seems to be the result of a lack of direct judicial dialogue. Transnational judicial dialogues are already well developed among constitutional judges and within international associations of judges, but there seems to be little dialogue between supreme courts. After World War II (WWII), as far as the German and Italian judiciary are concerned, a sort of a silent convention and a common interest to slow down criminal justice for war-related crimes emerged, preventing any real cooperation for an efficient prosecution.

Some of the tensions from the recent legal quarrels on the rights of victims need to be remembered.

The ItCC decided already in the Priebke case (1996) to strike down a norm of the military criminal procedure Act that excluded civilians from claiming war-crimesrelated damages in military courts. ${ }^{11}$

In the same year, the German Bundesverfassungsgericht decided that individual claims for the years 1943-1945 were to be based not on international, but on domestic law. ${ }^{12}$

The German Bundesgerichtshof decided then in the Distomo case (2003) that victims of military actions abroad were not entitled to any individual compensation, a principle that has been further developed in the more recent Kunduz case (2016). ${ }^{13}$

\footnotetext{
the International Court of Justice, which lastly created legal certainty with its judgment on the important issue of state immunity of 3 February [2012], never pursued the goal of putting German responsibility for these crimes into question. Legal issues and historical responsibility must be strictly separated the one from the other'; (translated by the author).

${ }^{11}$ Corte Costituzionale, Judgment of 28 February 1996, No 60/1996.

${ }^{12}$ Bundesverfassungsgericht, Order of 13 May 1996, 2 BvL 33/93, BVerfGE 94, 315 (Zwangsarbeit), 329 et seq.

${ }^{13}$ Bundesgerichtshof, Judgment of 26 June 2003, III ZR 245/98, BGHZ 155, 279 (Distomo); Bundesgerichtshof, Judgment of 6 October 2016, III ZR 140/15, BGHZ (Kunduz).
} 
The Italian Corte di Cassazione decided in the Ferrini case (2004) that the Federal Republic of Germany had to pay damages to citizens who were deported and coerced into forced labour camps from the Italian territory. ${ }^{14}$

The Bundesverfassungsgericht 'answered' in the same year that the right of inhabitants from an occupied territory to get international humanitarian law enforced does not include directly enforceable individual claims to compensation. All claims for compensation concerning torts and unlawful enrichment related to forced labour could be protected, if not prescribed, only as property rights. ${ }^{15}$

Between 2008 and 2011, the Corte di Cassazione allowed the enforcement of the Greek Distomo judgment and held Germany liable for massacres perpetrated during WWII. Immunity has been further weakened by allowing war-crimes-related trials even upon claims originating from municipalities and the National Association of Italian Partisans (Associazione Nazionale Partigiani Italiani, ANPI) (2014). ${ }^{16}$

These judicial dynamics show cultural differences and inner conflicts between the two legal orders with a clear lack of a real dialogue. As a matter of fact, judicial decisions and legal opinions adopted in one country rarely quote the judicial decisions and legal opinions adopted in the other. The courts of Strasbourg and Luxembourg, in turn, did not offer any common ground and even the Goethe Institute and the Dante Alighieri Society never tried to promote academic diplomacy.

Nevertheless, the absence of judicial dialogue was not offset by national governments' intervention. The Italian government did not intervene in German court proceedings and, symmetrically, the German government did not intervene in the proceeding before the ItCC. They agreed in the ICJ proceedings that Villa Vigoni needed immunity from execution. The implementation of both the ICJ Judgment and Sentenza 238/2014 was the object of further diplomatic dialogue, but this topic was left out from any discussion during the Italian-German High-Level Dialogue of the two Heads of State held in Turin in 2014 and again in 2016. ${ }^{17}$

The Foreign Ministers preferred silent diplomacy: they signed agreements with the ANPI and the National Association of Survivors of Imprisonment, Internment and the War of Liberation (Associazione Nazionale Reduci dalla Prigionia,

\footnotetext{
${ }^{14}$ Corte di Cassazione, Judgment of 11 March 2004, No 5044/2004.

${ }^{15}$ Bundesverfassungsgericht, Order of 7 December 2004, 1 BvR 1804/03, BVerfGE 112, 93; Bundesverfassungsgericht, Order of 28 June 2004, 2 BvR 1379/01, BVerfGK 3, 277.

${ }^{16}$ Corte di Cassazione, Judgment of 29 May 2008, No 14199/2008; Corte di Cassazione, Orders of 29 May 2008, No 14200-14212/2008; Corte di Cassazione, Judgment of 21 October 2008, No 1072/2008 (Milde); Corte di Cassazione, Judgment of 19 March 2014, No 329/2014: '[T]his association was born, according to its statute, with the aim of continuing the work of partisan groups, embodying their history and tradition; therefore, it should be acknowledged the right to compensation for the crimes which directly touched upon partisan groups'; (translated by the author).

${ }^{17}$ Bundespräsident, 'Opening of the Italian-German High-Level Dialogue', (11 December 2014), available at http://www.bundespraesident.de/SharedDocs/Reden/EN/JoachimGauck/Reden/2014/ 141211-Italienisch-Deutsches-Dialogforum.html; Quirinale, 'Intervento del Presidente della Repubblica, Sergio Mattarella, al Dialogo di Alto Livello italo-tedesco', (13 April 2016), available at http://www.quirinale.it/elementi/1130.
} 
dall'Internamento, dalla Guerra di Liberazione, ANRP) and set up a German-Italian Fund (deutsch-italienischer Zukunftsfond) within the German Federal Foreign Office. ${ }^{18}$ The strategy of symbolic reparation supported by historians was further developed through a temporary exhibition in Berlin.

Parliamentary diplomacy, especially within the German-Italian parliamentary group and within the European Parliament, could make further efforts towards reconciliation. The majority-approved motion of the Italian parliament demanded only the execution of the Italian judgments relating to the massacres perpetrated by German forces, excluding therefore compensation for Italian Military Internees (IMIs). The latter's interests have been defended and represented by more Eurosceptic political parties like the Lega Nord in Italy or Die Linke in Germany. ${ }^{19}$

In the context of existing governmental dialogue, the concerns of Germany and Italy are only partially conflicting. One could even conclude that a possible common German-Italian viewpoint could be to pay no compensation at all, and academic diplomacy should just sustain this 'gentle nations' agreement' ${ }^{20}$ The German government recognizes a moral rather than a legal responsibility towards individuals; this position vis-à-vis the victims could be summed up in the motto: 'memory, not money'. Following this spirit, the Italian parliament recognized already through the enactment of Law No 269/2006 that the sacrifice made by the Italian victims of deportation deserves a medal of honour 'as compensation mainly for the moral damages'. 21

\footnotetext{
${ }^{18}$ Die Linke, 'Kleine Anfrage: Arbeitsweise und Förderkriterien des deutsch-italienischen Zukunftsfonds', (4 March 2016), available at http://dip21.bundestag.de/dip21/btd/18/077/ 1807799.pdf.

${ }^{19}$ For Italy, Camera dei deputati, 'XVII Legislatura-Resoconto stenografico dell'Assemblea Seduta n 711 di martedì 6 dicembre 2016', (6 December 2016), available at http://www.camera. it/leg17/410?idSeduta=0711\&tipo=stenografico. For Germany, Federal Government, 'Antwort der Bundesregierung auf die Kleine Anfrage der Abgeordneten Ulla Jelpke, Jan Korte, Sevim Dagdelen, weiterer Abgeordneter und der Fraktion Die Linke-Drucksache 18/3333 Entschädigung für NS-Opfer in Italien', (9 December 2014), available at http://dip21.bundestag. de/dip21/btd/18/034/1803492.pdf.

${ }^{20} \mathrm{Cf}$ Franco Frattini, Italian Minister of Foreign Affairs at the time, 'Wir brauchen eine symbolische Geste', Süddeutsche Zeitung (17 May 2010): 'These people have suffered. If we give them 3,000 euros now, it is not what they need (...) I think a symbolic gesture, such as a memorial or a museum of remembrance that Germany and Italy can set up together would be much more important'; (translated by the author).

${ }^{21}$ Cf Italian Law 24 October 2006, No 269, Art 1, paras 1271-1272, (translated by the author).

1271. The Italian Republic recognizes the sacrifice of its citizens deported and interned in Nazi concentration camps in the last world conflict by entitling them to a compensation, mostly of moral nature.

1272. It has been authorized the granting of a medal of honour to Italian citizens, both military and civilians, deported and interned in Nazi concentration camps and destined to forced labour for the sake of war economy, to whom, if military, has been denied by the then Nazi government the status of prisoners of war, according to the Convention relative to the treatment of prisoners of war made in Geneva on 27 July 1929, and to the families of those who have died, who are entitled to present the application for recognition of the status of forced labourer.
} 
However, academic diplomacy's supporters could express some doubts: can states 'wash their hands' from their responsibility and limit it to monuments and medals? Is the decision to provide no financial compensation for the moral and existential damages really the best way for closing this particular historical chapter? Is it just hyper-moralism and hyper-idealism to propose a symbolic financial recognition, three decades after the fall of the Berlin Wall, as a sign of Europe's confidence in the future of an EU based on the respect of human rights, justice and solidarity (Article 2 TEU)?

In a very drastic and exaggerated way one could read the conflict assessed by the ICJ Judgment and Sentenza 238/2014 as a theatre of 'cynicism and hypocrisy'. The real conflict is not just between Germany and Italy, nations which sometimes consider themselves as being each other's victims. Instead, it is a conflict between the governments of two former belligerent states and their victims in the context of individual compensation for war crimes and forced labour. Moreover, it is a clash between humanitarian ideals and populist realities in the funding of welfare. If human and humanitarian concerns are paramount common concerns for all constitutional states in the EU and for the international community at large, the response of Germany and Italy could be to reconsider the issue of compensation for the victims of massacres, deportation, and forced labour. In this context, academic diplomacy would not just be a form of state-centred government support but an independent diplomatic action for a transnational civil society.

\section{Moral Responsibility and Legal Liability}

Are Germany and Italy obliged to open negotiations and settle the dispute? If we look at both the ICJ Judgment and Sentenza 238/2014 merely from a formal legal point of view, the answer would be 'no'. However, if we consider lifelong solidarity towards the victims as a moral duty and we refrain from the idea of having purely 'moral' or 'memory' politics then the answer could be 'yes'. 22

The ICJ Judgment as interpreted by the ItCC pointed out that the opening of new negotiations might be the only means available to settle the dispute in international law. ${ }^{23}$ The ICJ made a very strong moral obiter dictum that seems to have been neglected by the public debates: 'The Court considers that it is a matter of surpriseand regret - that Germany decided to deny compensation to a group of victims on the ground that they had been entitled to a status which, at the relevant time,

\footnotetext{
${ }^{22}$ Hanne Leßau, Conference Report, 'Entschädigung als Menschenrecht? Theorie und Praxis des Umgangs mit den Opfern kollektiver Gewalt', organizer Constantin Goschler, in H-Soz-Kult (16 October 2012), available at http://www.hsozkult.de/conferencereport/id/tagungsberichte4412 >. Cf Andreas von Arnauld, chapter 'Deadlocked in Dualism', in this volume.

${ }^{23}$ ICJ, Jurisdictional Immunities (n 1), para 104.
} 
Germany had refused to recognize, particularly since those victims had thereby been denied the legal protection to which that status entitled them. ${ }^{24}$

The 'surprise' relates to an ex post recognition of protection duties for the only purpose of denying compensation. Adolf Hitler's order of 20 September 1943 commanded the deportation to the German Reich of the captured Italian Military Internees (IMIs) as forced labour force for the production of arms and for the construction of the so called 'South-East Wall'. ${ }^{25}$ This was a deliberate violation of Article 31 of the Geneva Convention on the Treatment of Prisoners of War of 1929: 'Work done by prisoners of war shall have no direct connection with the operations of the war. In particular, it is forbidden to employ prisoners in the manufacture or transport of arms or munitions of any kind, or on the transport of material destined for combatant units. ${ }^{26}$ Furthermore, contrary to international humanitarian law, any assistance from the Red Cross was denied and fundamental social rights to adequate food and health services were violated. ${ }^{27}$ The IMIs were mishandled and treated as traitors by both German military forces and German civilians as well as by Italian fascists. Most of the captured did not actively resist, and a large number was subjected to forced 'conscription' by German troops. When the workers in what was then the occupied northern-Italian territory went on strike, Joachim Ribbentrop ordered the leaders to be killed as 'communists' and, with an eye towards deterrence, ordered that other thousands be deported as 'IMIs'. ${ }^{28}$ When Hitler decided to transform their status into a sort of fictitious 'private' labour force, a concession to both Fritz Sauckel ${ }^{29}$ and Benito Mussolini's non-sovereign Republic of Salò, they lost their status as military personnel under Italian law and were considered not victims of slavery under Article 600 of the Italian Criminal Code but 'collaborationists'. At the end of the war, the Allied Forces qualified them as 'ex allied of the enemy', with the consequence that their return to Italy was delayed. Their ex post recognition as war prisoners came first from the Italian Republic (1945) — with regard to the period from 8 September 1943 to 1 September 1944and later by Germany (2001) with regard to the remaining periods, even though the

\footnotetext{
${ }^{24}$ Ibid, para 99.

${ }^{25} \mathrm{Cf}$ Keitel Order quoted in Christian Tomuschat, 'Leistungsberechtigung der Italienischen Militärinternierten nach dem Gesetz zur Errichtung einer Stiftung "Erinnerung, Verantwortung und Zukunft"? - Rechtsgutachten' (2001), available at http://www.berliner-geschichtswerkstatt.de/ zwangsarbeit/imi/imi-tomuschat-gutachten.pdf, 1-37, at 2. See Jean Allain, Slavery in International Law-Of Human Exploitation and Trafficking (Leiden: Brill, Nijhoff 2012), 261.

${ }^{26}$ Art 31 of the Geneva Convention relative to the Treatment of Prisoners of War, 27 July 1929, 47 Stat 2021, TS No 846.

${ }^{27}$ See 'Bericht der Deutsch-Italienischen Historikerkommission' 2012 (n 9), 133.

${ }^{28}$ Joachim Ribbentrop to German Embassy, December 1944, quoted in Erich Kuby, Verrat auf Deutsch-Wie das Dritte Reich Italien ruinierte (Frankfurt: Ullstein Sachbuch 1987), 449.

${ }^{29}$ The official reconstruction of the commission of historians on the IMIs seems to be not yet sufficient, neither on the legal qualifications nor on the facts-for example regarding the forced conscription to military service and labour pushed by Sauckel. See Ulrich Herbert, Hitler's Foreign Workers: Enforced Labor in Germany under the Third Reich (Cambridge: CUP 1997), 286.
} 
recognition was exclusively for the purpose of excluding them from any social benefits.

The ICJ's 'regret' implies a clear moral condemnation of both the deportation of IMIs to forced labour camps and their lack of compensation thereof. This neither includes nor excludes a legal qualification as war crime, a violation of ius cogens, or a duty to individual compensation. The judges sitting in the ICJ did not only express their own personal concern, they also tried to embody those common human values shared by all civilized nations by adding a second obiter dictum:

[T] he Court is not unaware that the immunity from jurisdiction of Germany in accordance with international law may preclude judicial redress for the Italian nationals concerned. It considers however that the claims arising from the treatment of the Italian military internees referred to in paragraph 99, together with other claims of Italian nationals which have allegedly not been settled — and which formed the basis for the Italian proceedings — could be the subject of further negotiation involving the two states concerned, with a view to resolving the issue. ${ }^{30}$

The ICJ opted for 'could be' because 'should be' would have been seen as a declaration ultra vires, considering that its Order of 6 July 2010 had already declared inadmissible a counterclaim presented by Italy regarding the reparation owed to Italian victims of grave violations of international humanitarian law committed by the armed forces of the German Reich. The ICJ could not condemn Germany to 'offer appropriate and effective reparation to these victims, by means of its own choosing, as well as through the conclusion of agreements with Italy'. 31

Nevertheless, the clear moral condemnation in paragraph 99 of the ICJ Judgment could, in the long run, prove to be even stronger than a formal legal condemnation. Germany's book of legal debts may well be closed, the book of moral responsibility, however, could remain open-ended.

\section{The Imperfect Lump Sum Agreements of 1961}

When taking into consideration exemptions from state immunity, the ICJ mentions the lump sum agreements and Germany's strongest prima facie objection:

Moreover, if a lump sum settlement has been made-which has been the normal practice in the aftermath of war, as Italy recognizes - then the determination of whether a particular claimant continued to have an entitlement to compensation would entail an investigation by the court of the details of that settlement and the manner in which the State which had received funds (in this case the State in which the court in question is located) has distributed those funds. Where the State receiving funds as part of what was intended as a comprehensive settlement in the aftermath of an armed conflict has elected to use those funds to rebuild

\footnotetext{
${ }^{30} \mathrm{ICJ}$, Jurisdictional Immunities (n 1), para 104.

${ }^{31}$ ICJ, Jurisdictional Immunities of the State (Germany v Italy), Counter-Claim, Order of 6 July 2010, ICJ Reports 2010, 310, para 3.
} 
its national economy and infrastructure, rather than distributing them to individual victims amongst its nationals, it is difficult to see why the fact that those individuals had not received a share in the money should be a reason for entitling them to claim against the State that had transferred money to their State of nationality. ${ }^{32}$

From the opposite Italian point of view, the 'questions settled through the 1961 Agreements were (...) limited to, on the one hand, the pending economic questions to be identified merely as those covered by the 1947 waiver clause, and, on the other, compensation to victims of National Socialist persecution'. That implied three objections: first, the waiver of Article 77(4) of the Peace Treaty of $1947^{33}$ was not approved by Germany under Article 34 or 36 of the Vienna Convention of 1969 and was referred only to property-related questions, not to labour-based claims; second, the agreements of 1961 concerned only the most important 'specific claims, ${ }^{34}$ not all the reparations delayed to a final examination under Article 5(2) of the London Debt Agreement of $1953 ;{ }^{35}$ and third, the civilian massacres, deportation, and forced labour were not specific National Socialist persecutions covered by the agreements.

Regarding the first reply, the Italian interpretation has been outlined by the former judge of the Italian Constitutional Court Rita Saulle ${ }^{36}$ and has been adopted by the Italian Corte di Cassazione and ordinary judges since $2008 .{ }^{37}$ It has to be added that the Constituent Assembly authorized the ratification of the Peace Treaty of 1947, adopting a resolution that declared the punitive reparations of the treaty as incompatible with the principles of international justice and thus demanded their revision. The Minister of Foreign Affairs, Carlo Sforza, declared that Germany was obliged to provide for reparations and to give adequate guarantees but the country should not be excluded from a future European Community. ${ }^{38}$ The original Italian intent was thus not at all to accept a full and binding waiver for any future reparation claim.

As for the second objection, Article 2 of the 1961 Agreement on the Settlement of Certain Property-Related, Economic and Financial Questions established a waiver for 'all outstanding claims'. The 1961 Agreement on the Compensation for Italian

\footnotetext{
${ }^{32} \mathrm{ICJ}$, Jurisdictional Immunities (n 1), para 102.

${ }^{33}$ Treaty of Peace with Italy, 10 February 1947, 49 UNTS 3.

${ }^{34}$ Agreement between the Federal Republic of Germany and Italy on the Compensation for Italian Nationals Subjected to National-Socialist Measures of Persecution (Bonn, 2 June 1961), German and Italian version published in Bundesgesetzblatt II 5 July 1963 No 22, 791; Agreement between the Federal Republic of Germany and Italy on the Settlement of Certain Property-Related, Economic and Financial Questions (Bonn, 2 June 1961), German and Italian version published in Bundesgesetzblatt II 26 June 1963 No 19, 668.

${ }^{35}$ Agreement on German External Debts, 27 February 1953, UNTC No 4764 (London Debt Agreement).

${ }^{36}$ ANRP, 'Il libro bianco dell'A.N.R.P.', (2001), available at http://nnx.anrp.it/wp-content/uploads/ 2016/04/IL_LIBRO_BIANCO_dellANRP.pdf, 1-220, 85 et seq.

${ }^{37}$ Corte di Cassazione, Judgment of 21 October 2008, No 1072/2008; Corte militare d'appello di Roma, Judgment of 25 January 2008; Tribunale di Torino, Judgments of 20 May 2010 and of 20 October 2009.

${ }^{38}$ Carlo Sforza, Assemblea Costituente (31 July 1947), available at http://www.camera.it/_dati/ Costituente/Lavori/Assemblea/sed211/sed211.pdf, 6532-6566, at 6543.
} 
Nationals Subjected to National-Socialist Measures of Persecution (Agreement on Compensation) shows that the waiver of the first 1961 Agreement could not cover claims for war crimes and crimes against humanity. Both Agreements established only partial waivers. The German version of 'schwebend' and the Italian 'pendenti' referred only to claims which already made an object of specific judicial or administrative proceedings, not to claims of immaterial damages for war crimes that had yet to be prosecuted. Both lump sum Agreements were transitory, not final.

Finally, Article 3 of the Agreement on Compensation established a waiver for all claims of victims of National Socialist persecution. This concept was defined in section 1 of the German Federal Compensation Act (Bundesentschädigungsgesetz) of 1953: '[S]omeone who on grounds of political opposition to National Socialism or on grounds of race, belief or ideology was persecuted by violent National Socialist measures and thereby suffered damage to life, body, health, freedom, property, assets or in professional or economic advancement (persecutee)'. 39 Should massacres and deportation for forced labour of Italians be qualified as Nazi persecution? They were violent measures conducted by the armed forces under a German National Socialist government that ordered collective punishments for Italian political opposition to the Axis Powers. Even an element of racism might have influenced Adolf Hitler to urge for a 'tabula rasa' and a 'brutal friendship'. ${ }^{40}$ Nevertheless in the practice of compensation, the exploitation of forced labour seemed not to have been qualified per se as Nazi persecution. ${ }^{41}$ What is more, the Italian legislation reduced persecution to the repression of resistenza, adding the capture in action of rappresaglia and coercive conscription (Article 1, Decree of the President of the Republic No 2043/1963).

Germany after all has good arguments for considering the waivers of the lump sum Agreements as being all-inclusive, but the Italian interpretation of the Agreements as separate and partial waivers, excluding compensation for individual moral damages caused by war crimes, is also not straightforwardly unreasonable. German and Italian judges arrived at different conclusions, and the question was not decided by the ICJ. The way out of the deadlock could be an arbitration on the interpretation of the existing treaties as well as on the question of whether a relevant fundamental change of circumstances occurred. ${ }^{42}$

\footnotetext{
${ }^{39}$ German Federal Compensation Act (Bundesentschädigungsgesetz) of 18 September 1953, Bundesgesetzblatt I 21 September 1953 No 62, 1387.

${ }^{40}$ Frederick W Deakin, Die brutale Freundschaft: Hitler, Mussolini und der Untergang des italienischen Faschismus, (Cologne: Kiepenheuer \& Witsch 1962), 607.

${ }^{41}$ See also Stefan Kadelbach, chapter 'State Immunity, Individual Compensation for Victims of Human Rights Crimes, and Future Prospects', and Andreas von Arnauld, chapter 'Deadlocked in Dualism', in this volume.

${ }^{42} \mathrm{Cf}$ Francesco Francioni, chapter 'Overcoming the Judicial Conundrum', in this volume.
} 


\section{Fundamental Legal Changes Since 1961}

There is no doubt that some relevant changes regarding war crimes and forced labour have taken place, changes which Karl Carstens and Pio Quaroni could not have foreseen when negotiating the agreements in 1961: first, adjudication of individual compensation to victims of war crimes has become an essential part of international criminal justice, and solidarity with victims has been strengthened; second, the prohibition of forced labour as a guarantee of the dignity-related human right has become ius cogens; and third, not only has Europe witnessed German reunification but the EU itself has enlarged both its borders and core founding values, including solidarity and peace, though without a final decision on the reparations envisioned by the London Debt Agreement.

'[D]eportation to slave labour or for any other purpose of civilian population of or in occupied territory' was already punished as a war crime in the Nuremberg trials. ${ }^{43}$ British military courts exercised jurisdiction over approximately 50 German war criminals in Italy, ${ }^{44}$ and Italian courts exercised jurisdiction on a few other cases. ${ }^{45}$

Since the German Constitution of 1949 (Article 16) ruled out extradition of nationals (with exceptions admitted only in 1993), ${ }^{46}$ the issue of time limits for prosecution of Nazi crimes had already been discussed in $1960 .{ }^{47}$ The prosecution of all war crimes was guaranteed by Article 112 of the Italian Constitution, but Quaroni, a former Italian Ambassador to Moscow, was reluctant to punish Italian war crimes. ${ }^{48}$ The negotiators might have been informed that the Head of the military public prosecution office in Rome decided, on 14 January $1960,{ }^{49}$ to dismiss provisionally around 700 proceedings for German war crimes instead of starting

\footnotetext{
${ }^{43}$ See eg the cases Erhard Milch (Milch), Friedrich Flick et al (Flick), Carl Krauch et al (IG Farben), Alfried Krupp et al (Krupp). These are all cases from the Trials of War Criminals before the Nuremberg Military Tribunals. See Kevin John Heller, The Nuremberg Military Tribunals and the Origins of International Criminal Law (Oxford: OUP 2011).

${ }^{44}$ See eg the cases of Albert Kesselring, Eberhard von Mackensen and Max Simon. Cf Filippo Focardi, 'La questione dei processi ai criminali di guerra tedeschi in Italia: fra punizione frenata, insabbiamento di Stato, giustizia tardiva (1943-2005)', Storicamente 2 (2006), 1-27, at 6.

${ }^{45}$ See the cases of Herbert Kappler, Walter Reder, Wilhelm Schmalz, Joseph Strauch and Eduard Florin. Cf Marco De Paolis, 'La punizione dei crimini di guerra in Italia', in Silvia Buzzelli/Marco De Paolis/Andrea Speranzoni (eds), La ricostruzione giudiziale dei crimini nazifascisti in Italia: Questioni preliminari (Turin: Giappichelli 2012), 63-140, at 90 et seq.

${ }^{46}$ Art 26 of the Italian Constitution admitted extradition only under conditions of reciprocity.

${ }^{47}$ Deutscher Bundestag, Zur Verjährung nationalsozialistischer Verbrechen-Dokumentation der parlamentarischen Bewältigung des Problems 1960-1979 (Bonn: Deutscher Bundestag Presse- und Informationsamt 1980), et seq.

${ }^{48}$ Lutz Klinkhammer, 'La punizione dei crimini di guerra tedeschi in Italia dopo il 1945', in Gian Enrico Rusconi/Hans Woller (eds), Italia e Germania 1945-2000: la costruzione dell'Europa (Bologna: Il Mulino 2005), 75-90, at 82 et seq.

${ }^{49}$ Final report of the Italian Parliamentary Commission on the Causes of the Concealment of Records regarding Nazifascist Crime, 8 February 2006, available at http://www.camera.it/_dati/ leg14/lavori/documentiparlamentari/indiceetesti/023/018/INTERO.pdf.
} 
trials in contumaciam. The negotiators could have relied on delays and inefficiency in prosecution, but they could have not expected the establishment, several decades later, of an International Criminal Court that also adjudicates on 'reparations to, or in respect of, victims, including restitution, compensation and rehabilitation' (Article 75 of the Rome Statute, 1998). The compensation of victims includes the 'moral' damages recognized in Germany since 1970, and the 'existential damages' recognized in Italy since 2003. ${ }^{50}$ Despite persisting WWII traumas, the two states, as welfare states, learned that concrete solidarity compensation schemes for victims of war crimes were needed.

The Italian Constitution (Articles 1, 4 and 35) considers free labour as a fundamental principle of the Republic, the German Constitution (Article 12 (2-3)) prohibits forced labour, and the European Convention on Human Rights (Article 4 (3)) grants freedom from slavery. The Prohibition of Slavery and Forced Labour Convention of 1957 was ratified by Germany in 1959 and by Italy in $1968,{ }^{51}$ but the prohibition did not amount yet to ius cogens. ${ }^{52}$ The Geneva Convention of 1929 allowed forced labour of war prisoners but granted specific rights and humanitarian restrictions (Article 27-34) that need an extensive interpretation in the context of international human rights law. The Basic Principles and Guidelines on the Right to a Remedy and Reparation for Victims of Gross Violations of International Human Rights Law and Serious Violations of International Humanitarian Law adopted in 2005 recognized the 'victims' right to remedies', including equal and effective access to justice and 'adequate, effective and prompt reparation for harm suffered' 53 The German Foundation 'Remembrance, Responsibility and Future' (Erinnerung, Verantwortung und Zukunft) granted individual compensation for forced labour on the basis of a general principle of solidarity that could be transformed into a collective duty under the common constitutional law of social market economies.

Finally, a fundamental change of circumstances can be traced in the reunification of Germany and the transformations of the EU. The former Democratic Republic did

\footnotetext{
${ }^{50}$ Bundesverfassungsgericht, Order of 14 February 1973, 1 BvR 112/65, BVerfGE 34, 269 (Soraya); Corte Costituzionale, Judgment of 30 June 2003, No 233/2003.

${ }^{51}$ Germany ratified the first ILO Convention on Forced Labour of 1930 in 1956, Italy in 1934. Art 2 exempted 'any work or service exacted in cases of emergency, that is to say, in the event of war', see ILO Forced Labour Convention, 28 June 1930, in force 1 May 1932, 39 UNTS 55.

${ }^{52} \mathrm{Cf}$ ILO, 'Forced labour in Myanmar (Burma)', 2 July 1998, available at https://www.ilo.org/ public/english/standards/relm/gb/docs/gb273/myanmar.htm.

${ }^{53}$ UN General Assembly, Resolution on Basic Principles and Guidelines on the Right to a Remedy and Reparation for Victims of Gross Violations of International Human Rights Law and Serious Violations of International Humanitarian Law (16 December 2005), A/Res/60/147, paras 11, 15. See also para 20: 'Compensation should be provided for any economically assessable damage, as appropriate and proportional to the gravity of the violation and the circumstances of each case, resulting from gross violations of international human rights law and serious violations of international humanitarian law, such as: (a) Physical or mental harm; (b) Lost opportunities, including employment, education and social benefits; (c) Material damages and loss of earnings, including loss of earning potential; (d) Moral damages; (e) Costs required for legal or expert assistance, medicine and medical services, and psychological and social services.'
} 
not sign a lump sum agreement with Italy and reparation claims have never been settled. The EU treaties can be regarded as a surrogate for a peace treaty between Germany and Italy, however with notorious deficits of democratic accountability. The EU's fundamental values could suffer if both social principles (Article 23(1) of the German Constitution) and the ideal of 'justice among the Nations' (Article 11 of the Italian Constitution) are not guaranteed for the very same generations that inspired these human rights-centred foundational texts.

All these aspects are relevant to the question: is a (re)negotiation possible and desirable? However, it remains profoundly questionable whether these elements provide sufficient support for a legal claim under Article 62 of the Vienna Convention. Being such an interpretation controversial, one could argue though that engaging in good faith negotiations for a new bilateral or multilateral agreement (providing as well for an authentic interpretation and integration of the 1961 Bonn Agreements), would not be unreasonable.

\section{A Belated Solidarity}

Further objections concern time limitations for individual rights to compensation. ${ }^{54}$ Neither Italy nor Germany signed the European Convention on the Non-Applicability of Statutory Limitation to Crimes against Humanity and War Crimes of 1974. Italian judges could still align with the German position and consider that, except for genocide and murder, no international customary norm prohibits prescription of compensation claims for war crimes (Verjährung) ${ }^{55}$ The dispute regarding whether these or other limitations apply to individual compensation claims could be settled by way of arbitration or by a new decision of the ICJ. But from the point of view of the last survivors, there is no more time for further procedural delay. A 'belated solidarity' risks being rejected as 'too little too late' by those whose dignity has been violated.

At best, time might not be in Germany or Italy's favour. Any intent to gain time through further procedures would sound as much as a cynical solution, as an unhappy and anachronistic evocation of the past. Again, prudence invites us not to ignore morality in international relations, especially within the borders of supranational organizations based on common values.

The litigation on prescriptive norms, therefore, should not prevent reaching an agreement on payments due for reasons of equity. Equitable compensation could raise problems when it comes to finding political consensus, even though there would not be any question of constitutional legitimacy, since full reparation is not

\footnotetext{
${ }^{54} \mathrm{Cf}$ Giovanni Boggero/Karin Oellers-Frahm, chapter 'Between Cynicism and Idealism', in this volume.

${ }^{55}$ For the Italian case this was the position of Tribunale di Torino, Judgment of 20 October 2009, No 7137/2009.
} 
required by the Italian Constitution. To reply to the editors' questions, the German, as well as the Italian state, could honour the rights to compensation - as well as duties to social solidarity for the benefit of 'others' with the resources of a state's citizens and taxpayers - as long as these 'others' are victims of war crimes. Even if similar crimes and torts would not have been concretely assessed through judicial decisions, the rule of law of a welfare state always allows for specific forms of solidarity. The voting rights of citizens and property rights of taxpayers cannot be violated by otherwise lawful administrative or judicial decisions that fulfil a duty to international human solidarity.

It is a political question whether a similar gesture of a 'belated solidarity' would be a good investment for Germany's reputation in Europe and generally on the international plane or whether it would favour a more nationalist and populist opposition. On the one hand, there is the hope that a similar gesture could promote reconciliation, legal peace and social cohesion between Germany and Italy, while helping families to close the 'memory books'. On the other hand, there is the fear that it could become a model for other interested countries, creating a potentially dangerous and costly precedent.

The possibility of generating a consensus will depend on the specific models of organization, procedure and financing of this form of 'belated solidarity'. From the point of view of the associations of victims, Germany's pardon request for Marzabotto and the work towards a shared collective memory already represented a significant degree of compensation. The public discourses and the funding of the work of historians ${ }^{56}$ and lawyers could still be followed by the recognition of an at least symbolic economic benefits for the victims of massacres and/or forced labour. The rules for such compensation need to be construed in a way consistent with the principles of solidarity, equality and democratic responsibility; the existing national rules for solidarity with victims of violent crimes and forced labour could offer a general framework for this compensation scheme. The territorial and personal scope of this solidarity, the amount of compensation and the administrative procedure to be followed, along with the necessary funding have to be defined more in details, but some ideas could help clarify these highly complex practical problems.

\section{Territorial and Personal Scope of Solidarity}

Solidarity can be differentiated on the basis of criteria of proximity. One could argue that it should be limited to the 'former allied' countries, but over time a new proximity and ties of solidarity within the EU and within the Council of Europe (CoE) have been created. European solidarity with victims of war crimes has been strengthened through common ceremonies in and alongside war cemeteries and

\footnotetext{
${ }^{56} \mathrm{Cf}$ on the perspective of further 'prosopographic and social-statistical studies' in 'Bericht der Deutsch-Italienischen Historikerkommission’ 2012 (n 9), 169.
} 
monuments. Negotiations could start with the purpose of reaching an agreement for all victims of WWII war crimes who were citizens of the signatory states and received no compensation. War crimes, deportation, and forced labour occurred not only in Italy but elsewhere too. The United Nations War Crimes Commission (UNWCC) investigations went beyond German war crimes; citizens from Austria, Hungary, Romania, Bulgaria, and Albania, as well as 1,697 Italian citizens were among the 19,000 suspected war criminals listed. ${ }^{57}$ Massacres among civilians, for example, took place in Greece, the former Yugoslavia, and France, and not uncommonly prisoners of war from other nations, especially Poland and Russia, were the victims. These crimes as well as those committed by Allied Forces justify neither negationism nor oblivion. A bilateral or multilateral approach through a convention organized by the former Axis Powers, and perhaps open to all other states from the EU or the CoE, could be a good way for the 'bad boys' of the past to emerge as the heroes of solidarity and peace in Europe.

The right to compensation of immaterial damages deriving from war crimes could be limited to an individual una tantum to be divided among all surviving victims that have never received any compensation and who would be willing to sign an individual waiver.

Restrictions on the personal scope of the scheme in favour of living survivors needs further clarification. At current, the loss of life in wartime cannot be individually compensated. As Jochen Frowein correctly argued in a hearing of the Bundestag in 2015, recognising the suffering of surviving victims does not require an extension of the benefits to the surviving relatives of deceased victims. ${ }^{58} \mathrm{~A}$ 'belated solidarity' would be de facto a restricted one, but could be justified on a 'better late than never' basis. Nevertheless, in order to prevent any cynical interest in lengthy negotiations so as to possibly mitigate the financial impact of the new compensation/reparation regime, it would not be unreasonable to accept an extension so as to include the families of victims who had survived until the date of the ICJ Judgment. On the other hand, surviving victims of war crimes committed by Italian forces could not be a priori excluded.

\section{Calculation of the Reparation}

The amount could be calculated on the basis of the average compensation recognized by national administrations or courts or by the International Criminal Court, adapted

\footnotetext{
${ }^{57} \mathrm{Cf}$ the proceedings of the United Nations War Crimes Commission (UNWCC), 1943-1949.

${ }^{58}$ Jochen A Frowein, 'Stellungnahme zu den Anträgen auf symbolische Entschädigung noch lebender sowjetischer Kriegsgefangener' (13 May 2015), available at www.bundestag.de/blob/ 374858/d050da4429429f261745a4e37c1970ca/prof\%2D\%2Ddr\%2D\%2Djochen-a\%2D\% 2Dfrowein-data.pdf.
} 
to the average income of the country where the victim is living and according to a projection of the number of beneficiaries.

The case of the Italian victims of forced labour is a special one, in reason of their exclusion from the schemes of the German Foundation 'Remembrance, Responsibility and Future' (Erinnerung, Verantwortung und Zukunft). ${ }^{59}$ The proposals regarding Russian military internees and war prisoners presented in 2015 by the two then opposition parties in the German Bundestag ${ }^{60}$ proposed $€ 2,500$ (Grüne) or $€ 7,670$ (Die Linke) for each victim. The smaller sum is based on the 'recognition payment for former German forced labour workers' granted by a directive of the German Ministry of the Interior of 7 July 2016. The larger amount is equal to the payments for forced labour granted by the Foundation 'Remembrance, Responsibility and Future'. Even without any specific law or constitutional obligation, the German state, through this financial instrument, paid tribute to the hard 'destiny' of German citizens and people that carried out forced labour for a foreign power. This is an important but ambiguous precedent. It could be a model of humble and noble human solidarity, but it could also be based on a limited ideal of solidarity, since restricted exclusively to German nationals.

Another alternative or cumulative form of solidarity could be the establishment of a solidarity fund for charitable subsidies to all those victims who did not get a sufficient pension treatment or who are still suffering diseases caused by war crimes and torts in question. Even aids for concrete reconciliation initiatives in Germany and Italy (for example travel reimbursements) could be offered by this 'belated solidarity' fund.

All these benefits would need to be investigated, but no judicial decision would be required for recognising the status of the victims of crimes and forced labour. The benefits could be granted through a specific administrative procedure by national administrations under the directives and control of a common international board. ${ }^{61}$

\section{Financing}

The main question is how to finance the different forms of solidarity and financial recognition. All possible sources of solidarity funding should be considered, including private donations and contributions from all those that benefitted from forced labour, as well as military related industries and railway enterprises. Similar donations could be eligible for tax benefits. State contributions to this fund could be

\footnotetext{
${ }^{59}$ It is worth noting that the German scheme influenced also the Austrian Fund 'Reconciliation, Peace and Cooperation' (Reconciliation Fund).

${ }^{60}$ See Deutscher Bundestag, 'Plädoyer für Entschädigungen' (19 May 2015), available at www. bundestag.de/presse/hib/2015_05/-/375140.

${ }^{61}$ Cf Filippo Fontanelli, chapter 'Sketches for a Reparation Scheme', in this volume.
} 
calculated on an equal basis for each state on a personal per capita solidarity basis (specifying an amount for each citizen from the respective signatory states).

Italian participation would strengthen the principle of common European solidarity. Of course, Germany could ask the ICJ for an 'equitable satisfaction' to be granted in an analogous application of Article 30 of the European Convention on Dispute Settlement, and this satisfaction if granted might be allocated for funding. Alternatively, Italy could participate spontaneously, in part due to the force of its fundamental constitutional principle of solidarity which authorizes the Republic to concur even in international solidarity funds. The exclusion from the existing compensation schemes of victims of massacres and forced labour was a common decision of both the German and the Italian governments and common funding would therefore be the best way to render a 'belated solidarity' viable. ${ }^{62}$

Another exclusively political question is whether a similar project of 'belated solidarity' would be rejected by a majority of taxpayers who might be no longer willing to pay for past wrongdoings or to subscribe to forms of 'chequebook-baseddiplomacy'. The 'bottomless-pit' argument is always an equity blocker, but a now reunified Germany should not forget that the Two Plus Four Treaty ${ }^{63}$ was not the final peace treaty envisaged by the London Debt Agreement and that a consolidation of the lump sum agreements could be the best way to provide an acceptable monetary limit.

\section{The Proper Use of Supreme Principles as Part of the 'Constitutional Identity'}

The binational discussion on an equitable solution would likely not end the debate over the question of remedies against immunity. We are moving from a traditional dualist approach, as the likes of Dionisio Anzilotti and Heinrich Triepel, towards neither an international nor a national monism but towards a more recent pluralist approach. ${ }^{64}$ A way out of the deadlock might lay in searching for procedures that could help finding ad hoc balances, while avoiding clashes between the two parties involved. This should be done through concrete forms of communication between the diverging legal orders and cultures rather than through an a priori hierarchy between supreme constitutional principles of rights protection and sovereign immunity.

\footnotetext{
${ }^{62}$ See also Francesco Francioni, chapter 'Overcoming the Judicial Conundrum', in this volume.

${ }^{63}$ Treaty on the Final Settlement with Respect to Germany, 12 September 1990, 1696 UNTS 115 (Two-Plus-Four Treaty).

${ }^{64}$ As favoured by Anne Peters, 'Let Not Triepel Triumph: How to Make the Best Out of Sentenza No. 238 of the Italian Constitutional Court for a Global Legal Order', EJIL: Talk! (26 December 2014), available at www.ejiltalk.org/let-not-triepel-triumph-how-to-make-the-best-out-of-sentenzano-238-of-the-italian-constitutional-court-for-a-global-legal-order-part-i/.
} 
The ItCC's Sentenza 238/2014 did not use the concept of constitutional identity quoted by the Tribunal of Florence and which is not yet well established in the ItCC's jurisprudence. ${ }^{65}$ The Court preferred to invoke 'the fundamental principles of the constitutional order and inalienable human rights', which is a mix of principles that can serve for a coordination of the values of constitutionalism and international rule of law.

In the interlocutory Taricco case, a new complex case of prima facie conflict between the rule of law at the national and international level, the ItCC used the concept of constitutional identity only in the context of EU law: ${ }^{66}$ 'This Court would like to stress that, whilst the aim of the interpretation set out above is to preserve the constitutional identity of the Republic of Italy, it does not however compromise the requirements of uniform application of EU law and is thus a solution that complies with the principle of loyal cooperation and proportionality. ${ }^{67}$ The use of the concept of constitutional identity was based on a specific national tradition and constitutional culture, aimed at giving a higher protection to the citizens' legal certainty than to the state (or EU) interests.

A similar solution, encouraging a harmonized interpretation of the different legal systems, was unworkable for the ICJ Judgment because there were, and still there are, no specific forms of dialogue between the ICJ and national constitutional courts. ${ }^{68}$ The ItCC attempted to qualify the right of access to justice in cases of serious violations of fundamental rights also as an international rule of law principle to be taken seriously by all international and municipal judges. This interpretation is based on a supreme principle of the Italian Constitution (Article 2) which should be respected at least as a domestic exception to the rule of state immunity. Now, one could read Sentenza 238/2014 as a plea for tolerance and respect for a supreme constitutional principle. The Judgment outlines a distinctive Italian constitutional

\footnotetext{
${ }^{65}$ Corte Costituzionale, Judgment of 19 March 2001, No 73/2001: '[T]his Court—as the referring judge recalls-reaffirmed the principle that the tendency of the Italian legal order to be open to generally recognized norms of international law and international treaties is limited by the necessity to preserve its identity; thus, first of all, by the values enshrined in the Constitution'. In Corte Costituzionale, Judgment of 7 October 2009, No 262/2009, the concept is still synonymous with the whole constitutional design and system of equality and immunities. Cf Michel Rosenfeld, 'Constitutional Identity', in Michel Rosenfeld/András Sajó (eds), The Oxford Handbook of Constitutional Comparative Law (Oxford: OUP 2012).

${ }^{66}$ Corte Costituzionale, Order of 23 November 2016, No 24/2017: 'Naturally, the Court of Justice is not exempt from the task of defining the scope of EU law and cannot be further encumbered by the requirement of assessing in detail whether it is compatible with the constitutional identity of each Member State. It is therefore reasonable to expect that, in cases in which such an assessment is not immediately apparent, the European court will establish the meaning of EU law, whilst leaving to the national authorities the ultimate assessment concerning compliance with the supreme principles of the national order.'

${ }^{67}$ Ibid: 'The Italian Constitution construes the principle of legality in criminal matters more broadly than European law as it does not limit itself to describing the conduct constituting the offence and the penalty, but rather covers all substantive aspects of liability to punishment.'

${ }^{68}$ See also Alessandro Bufalini, chapter 'Waiting for Negotiations', in this volume.
} 
identity in the international legal order, representing as well a leading case for a moderate use of the concept of constitutional identity itself. ${ }^{69}$

On the other side and in more general terms, the invocation of a constitutional identity could also be understood as a 'trump card' that weakens international customary law and the authority of international judges, and further backs a new nationalist monism. From this more sceptical point of view, the constitutional identity exception could promote a national-constitutional-rights fundamentalism and enhance the power of domestic judges. While the first interpretation, influenced by an idealism based on tolerance, could strengthen the international rule of law; the second interpretation, inspired by legal realism, could instead promote its decline. ${ }^{70}$

The first, 'tolerant' reading could be more consistent with the Italian Constitution, but constitutional justices should acknowledge that constitutional identity includes a fundamental principle of 'internationality'. Among 'fundamental principles', the first part of the Italian Constitution recognizes the primacy of general rules of international customary law (Article 10(1)), the right of asylum of any 'foreigner who (...) is denied the actual exercise of the democratic freedoms' (Article 10(3)), the 'repudiation' of war as an instrument of aggression against the freedoms of other peoples, as well as a favour for limitations of sovereignty that 'may be necessary to a world order ensuring peace and justice among the Nations' (Article 11). These principles already moderate dualist readings and offer together with the other commitments - the protection of democracy (Article 1), human rights (Article 2), equality (Article 3), labour (Article 4), local autonomies (Article 5), linguistic minorities (Article 6), religious peace (Article 7 and 8), cultural development (Article 9)-substantial elements to an international constitutionalism, a design for a future constitution in a world governed by common principles. ${ }^{71}$ Taking these fundamental constitutional principles and human rights seriously in a pluralist perspective, the ItCC would act not only as an organ of the national constitutional state but of the international community.

The question of constitutional identity is not just about who and what we are; it deals first of all with how we interact with others. Therefore, the new tool of constitutional identity needs to be embedded in good procedures. Domestic ordinary judges, as well as constitutional and EU judges are still learning how to conduct a dialogue around identity questions, but even without preliminary question mechanisms some instruments of indirect dialogue with the ICJ could be developed.

The rules of the ICJ allow, if necessary, to arrange for an enquiry or an expert opinion (Article 67 ICJ Statute) on questions related to the respect of national 'constitutional identities' relevant for controversies on international customary

\footnotetext{
${ }^{69} \mathrm{Cf}$ Antonio Ruggeri, 'Conflitti tra norme internazionali consuetudinarie e Costituzione, atto secondo: quali i possibili “seguiti” della 238 del 2014?', Consulta Online, (5 March 2015), available at http://www.giurcost.org/studi/ruggeri45.pdf, 34-59.

${ }^{70}$ Heike Krieger/Georg Nolte, 'The International Rule of Law-Rise or Decline?-Points of Departure', KFG Working Paper Series 1 (2016), 1-23.

${ }^{71}$ Jan Klabbers/Anne Peters/Geir Ulfstein (eds), The Constitutionalization of International Law, expanded edition 2011 (Oxford: OUP 2009).
} 
law. The ICJ 'may request of public international organizations information relevant to cases before it, and shall receive such information presented by such organizations on their own initiative' (Article 34 ICJ Statute). Expert opinion as well as information procedures could involve the Venice Commission and the World Conference on Constitutional Justice. The same instruments could be used by national constitutional judges when facing potential conflicts between constitutional identity and international customary law.

In the Italian system of constitutional justice, there is no specific judicial procedure for scrutinizing whether a national legal Act is compatible with international law (such as the 'Normenverifikation' under Article 100(2) of the German Constitution). The ItCC could be asked whether an Italian legislative Act is compatible with a norm of international customary law and could then decide incidenter tantum that the customary norm is compatible with the supreme principles of constitutional identity. Furthermore, Sentenza 238/2014 created a new type of proceeding on the basis of an analogy: the other judges can refer incidenter tantum to the ItCC the question on whether or not a norm of international customary law they have to apply is compatible with the Italian constitutional identity. ${ }^{72}$

In this regard, the constitutional identity review could require specific rules made by the legislator through constitutional amendments (Article 137 of the Italian Constitution). The constitutional lawmakers could decide whether the right use of constitutional identity to international customary law implies a power to deliberately 'nullify' international judgments and the rules that govern their execution. If the constitutional judges have the power to decide that an international customary norm contrary to constitutional identity is null and void, also the European constitutional review over legislative Acts risks being transformed into the power to annul international judgments. The best way to avoid an ultra vires exception against Sentenza $238 / 2014$ could be a codification of this new self-made proceeding of constitutional justice.

Finally, the right use of constitutional identity should always require the highest possible standard of argumentation and hermeneutics. When constitutional rights and their limitations are invoked in the name of constitutional identity, ponderation even between the supreme principles has to be enhanced. The right to remedies can prevail at the national level and the privileges of state immunities at the international level, but under conditions of pluralism, ponderation in the relationship between the rule and exception is not established once and for all.

A world where the harshest forms of injustice cannot be addressed and access to justice is recognized to Arnold the Miller ${ }^{73}$ but not to a forced labourer or to a victim of war crimes would disregard its own minima moralia. Yet, a world where access to

\footnotetext{
${ }^{72}$ Following Corte Costituzionale, Order of 11 February 2015, No 30/2015, the Court had decided the 'inexistence ( $a b$ origine)' of the state immunity norm insofar as it was conflicting with a fundamental constitutional principle.

${ }^{73}$ The anecdote of the miller of Potsdam (the Miller-Arnold-Case) is famously described in Thomas Carlyle, 'History of Friedrich II of Prussia', Vol 21, The Works of Thomas Carlyle, Vol 3, (Cambridge: CUP 2010) 243 et seq.
} 
justice is used for the self-empowerment of judges to compel governments into negotiations would lead to a reality in which fiat iustitia, et pereat mundus.

If one looks at the general usage in biology, 'immunity' means the capability of multicellular organisms to resist the entrance of harmful microorganisms. ${ }^{74}$ Applied in different biological, technical and legal contexts, immunity depicts the body of a person or an organization with a life and a constitutional equilibrium. Subjective rights defended in courts can be aggressive and harmful to the whole, but they can include claims for immunities, for example the claim of soldiers to be protected by an adequate umbrella of state immunity. In its Roman law origin, immunity did not refer to the state but to the freedom of a citizen from public duties and, especially, taxes. Immunity was the opposite of community - both deriving from munus - and the idea is still that any excessive immunization could transform a protection of life into its negation. ${ }^{75}$

The balancing between remedies and immunity needs to be handled by governments alongside judges, taking into account the specific European context. More than sixty years after the signature of the first treaties, the permanent dialogue between Germany and Italy has a difficult future. ${ }^{76}$

The traumas of WWII persist. The facts at the origin of the remedies $v$ immunity controversy constitute a living history that is still awaiting a commonly agreed conclusion.

\section{References}

Allain, Jean, Slavery in International Law-Of Human Exploitation and Trafficking (Leiden: Brill, Nijhoff 2012)

Dal Canto, Francesco, Il giudicato costituzionale nel giudizio sulle leggi (Turin: Giappichelli 2002)

Deakin, Frederick W, Die brutale Freundschaft: Hitler, Mussolini und der Untergang des italienischen Faschismus (Cologne: Kiepenheuer \& Witsch 1962)

De Paolis, Marco, 'La punizione dei crimini di guerra in Italia', in Silvia Buzzelli/Marco De Paolis/ Andrea Speranzoni (eds), La ricostruzione giudiziale dei crimini nazifascisti in Italia: Questioni preliminari (Turin: Giappichelli 2012), 63-140

Esposito, Roberto, Immunitas: The Protection and Negation of Life (London: Polity Press 2011)

Focardi, Filippo, 'La questione dei processi ai criminali di guerra tedeschi in Italia: fra punizione frenata, insabbiamento di Stato, giustizia tardiva (1943- 2005)', Storicamente 2 (2006), 1-27

\footnotetext{
${ }^{74}$ See, eg, Reece Davis, Cellular and Molecular Immunology (Waltham Abbey: ED-Tech Press 2019), at 36.

${ }^{75}$ Roberto Esposito, Immunitas: The Protection and Negation of Life (London: Polity Press 2011).

${ }^{76}$ Both states should not be blind to the past, including the darker legacy of the 'establishment of a new order in Europe' envisaged in the tripartite pact of 27 September 1940. From a legal point of view, Germany invaded Italy-in a clear violation of the Briand-Kellogg Pact of 1928. The alleged violation of the obligation of military defence in the tripartite pact could not justify German aggression, answered as it was by the Italian declaration of war of 17 October 1943. This fatal mistake could be recognized in a formal public statement with which Germany assumes its responsibility.
} 
Frowein, Jochen A, 'Stellungnahme zu den Anträgen auf symbolische Entschädigung noch lebender sowjetischer Kriegsgefangener' (13 May 2015), available at www.bundestag.de/ blob/374858/d050da4429429f261745a4e37c1970ca/prof\%2D\%2Ddr\%2D\%2Djochen-a\%2D $\% 2$ Dfrowein-data.pdf

Heller, Kevin John, The Nuremberg Military Tribunals and the Origins of International Criminal Law (Oxford: OUP 2011)

Herbert, Ulrich, Hitler's Foreign Workers: Enforced Labor in Germany under the Third Reich (Cambridge: CUP 1997)

Klabbers, Jan/Anne Peters/Geir Ulfstein (eds), The Constitutionalization of International Law, expanded edition 2011 (Oxford: OUP 2009)

Klinkhammer, Lutz, 'La punizione dei crimini di Guerra tedeschi in Italia dopo il 1945', in Gian Enrico Rusconi/Hans Woller (eds), Italia e Germania 1945-2000: la costruzione dell'Europa (Bologna: Il Mulino 2005), 75-90

Krieger, Heike/Georg Nolte, 'The International Rule of Law-Rise or Decline?-Points of Departure', KFG Working Paper Series 1 (2016), 1-23

Kuby, Erich, Verrat auf Deutsch-Wie das Dritte Reich Italien ruinierte (Frankfurt: Ullstein Sachbuch 1987)

Peters, Anne, 'Let Not Triepel Triumph: How to Make the Best Out of Sentenza No. 238 of the Italian Constitutional Court for a Global Legal Order', EJIL: Talk! (26 December 2014), available at www.ejiltalk.org/let-not-triepel-triumph-how-to-make-the-best-out-of-sentenzano-238-of-the-italian-constitutional-court-for-a-global-legal-order-part-i/

Rinke, Stefan, Schadensersatzklagen gegen Staaten wegen schwerer Menschenrechtsverletzungen im europäischen Zivilprozessrecht (Berlin: Berliner Wissenschafts-Verlag 2017)

Rosenfeld, Michel, 'Constitutional Identity', in Michel Rosenfeld/András Sajó (eds), The Oxford Handbook of Constitutional Comparative Law (Oxford: OUP 2012)

Ruggeri, Antonio, 'Conflitti tra norme internazionali consuetudinarie e Costituzione, atto secondo: quali i possibili “seguiti” della 238 del 2014?', Consulta Online, (5 March 2015), available at http://www.giurcost.org/studi/ruggeri45.pdf, 34-59

Tomuschat, Christian, 'Leistungsberechtigung der Italienischen Militärinternierten nach dem Gesetz zur Errichtung einer Stiftung "Erinnerung, Verantwortung und Zukunft"?Rechtsgutachten' (2001), available at http://www.berliner-geschichtswerkstatt.de/ zwangsarbeit/imi/imi-tomuschat-gutachten.pdf, 1-37

Veronesi, Paolo, Colpe di stato (Milan: Franco Angeli 2017)

Open Access This chapter is licensed under the terms of the Creative Commons Attribution 4.0 International License (http://creativecommons.org/licenses/by/4.0/), which permits use, sharing, adaptation, distribution and reproduction in any medium or format, as long as you give appropriate credit to the original author(s) and the source, provide a link to the Creative Commons license and indicate if changes were made.

The images or other third party material in this chapter are included in the chapter's Creative Commons license, unless indicated otherwise in a credit line to the material. If material is not included in the chapter's Creative Commons license and your intended use is not permitted by statutory regulation or exceeds the permitted use, you will need to obtain permission directly from the copyright holder.

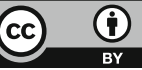




\title{
State Immunity, Individual Compensation for Victims of Human Rights Crimes, and Future Prospects
}

\author{
Stefan Kadelbach
}

\begin{abstract}
This chapter first recapitulates the state of affairs as to the principle of state immunity and why exceptions from jurisdictional immunity for gross violations of human rights and humanitarian law are not recognized. It explores customary law and the global compensation treaty between Germany and Italy. Both indicate that Italy would be obligated to indemnify Germany from individual claims raised before Italian courts.

In a second step, the development towards individual rights in public international law will be taken up. It appears that human beings are increasingly recognized as holders of individual claims but, apart from human rights treaty systems, lack the capacity under international law to invoke their rights before courts. Instead, they depend on their home states, which have standing but are not entitled to waive the individual rights of their citizens.

In order to reconcile the seemingly antagonistic regimes of state immunity and claim settlement, prospects for a friendly solution of the present dilemma will be assessed. Against the background of cases pending before Italian courts, it will be examined whether the distinction between jurisdictional immunity and immunity from execution opens up a way out of the impasse, which the two states and private capital could pursue, and whether this solution would create a precedent for other similar constellations.

Lastly, some concluding remarks will address lessons to be learnt for future conflicts. They will deal with elements of a general regime of compensation, drawing from the experience of both past reparation schemes and the experience of reconciliation in post-totalitarian societies. Such elements could be a duty to seek bona fide settlements, possible consequences of violations for domestic court proceedings, methods of assessing damages inspired by mass claim processing, the categorization of claims according to the gravity of violations, rules on evaluating evidence, procedures to give victims a say, and appropriate forms of monetary and non-pecuniary compensation including the necessary institutional framework.
\end{abstract}

\footnotetext{
S. Kadelbach $(\bowtie)$

Goethe University Frankfurt, Institute for Public Law, Frankfurt am Main, Germany

e-mail: s.kadelbach@uni-frankfurt.de 


\section{Introduction}

In Sentenza 238/2014, the Italian Constitutional Court (ItCC) ruled that it was unconstitutional for Italian courts to apply the customary principle of state immunity to war crimes and crimes against humanity. ${ }^{1}$ In the same vein, the ItCC found that the domestic law implementing the UN Charter ${ }^{2}$ did not form part of the Italian legal system, as far as it obliged Italian courts to abide by a decision of the International Court of Justice (ICJ) pursuant to Article 94(1) of the UN Charter, if such a judgment upholds state immunity for crimes under international law. The ItCC also quashed a statute that ordered Italian courts to implement the Jurisdictional Immunities Judgment. ${ }^{3}$ According to the ItCC, the fundamental rights of the Italian Constitution, and particularly the right of access to a court, were superior to obligations under international law. The Court thus transferred the controlimiti doctrine, which had been developed to allow for exceptions to the priority of EU law over domestic law, so as to allow for an exception to the obligation to abide by judgments of the World Court. $^{4}$

Irrespective of how convincing this decision is, it points towards a gap between individual rights and the capacity to invoke these rights before domestic or international courts. This gap (and the concomitant inconsistencies) is cause for concern. While international law since World War II (WWII) has witnessed an increase in norms that aim at the protection of the individual, it remains the case that states alone have standing before courts to bring suits for violations of these rights. State immunity reflects this concept. Apart from international human rights protection schemes, where individuals may raise complaints if the respondent state has recognized pertinent jurisdiction, traditional law by virtue of state immunity places the respondent state on an equal level with the state that espouses the claim and bars the holders of these rights from proceedings on their own behalf. Thus, even though Italy and its courts have a point in stressing the human rights nature of the claims concerned, they engage the international responsibility of the Italian state for violation of state immunity by enforcing such claims.

The present chapter elaborates further on this contradictory legal situation and tries to develop a notion of how contemporary international law should respond. In a first step, the complex interplay between traditional patterns of reparation, state immunity, and human rights in the Italian compensation cases is analysed (section II). Subsequently, this chapter identifies some tendencies in international law that appear to depart from this classical model (section III). These tendencies point at possible ways to better integrate victims of war crimes and crimes against humanity into compensation schemes (section IV) — and show that a conciliatory solution to

\footnotetext{
${ }^{1}$ Corte Costituzionale, Judgment of 22 October 2014, No 238/2014.

${ }^{2}$ Article 1 of the Italian Law 17 August 1957, No 848.

${ }^{3}$ ICJ, Jurisdictional Immunities of the State (Germany v Italy: Greece intervening), Judgment of 3 February 2012, ICJ Reports 2012, 99, para 136.

${ }^{4}$ See explicit reference in ItCC, Judgment 238/2014 (n 1), para 3.2.
} 
the pending cases would comply better with the development through which international law has travelled in the past decades (section V).

\section{Compensation, Immunity and Human Rights}

In its Judgment of 3 February 2012, the ICJ once again upheld state immunity from national jurisdiction, which applies as long as no specific treaty obligates a state to exert jurisdiction. ${ }^{5}$ More specifically, it found that Italian courts disregarded this principle by exercising jurisdiction over claims raised against the Federal Republic of Germany, by declaring Greek judgments against the German state enforceable, and by enforcing such judgments, which an Italian domestic court did by registering a legal charge on Villa Vigoni for the purpose of securing an acknowledged claim. After an analysis of state practice, the ICJ rejected the notion of exceptions to immunity from jurisdiction or from enforcement, including for war crimes and crimes against humanity. ${ }^{6}$ Accordingly, Italy was held responsible vis-à-vis Germany, ${ }^{7}$ even though the Court stressed that it did not rule on any individual claim for compensation under international law. ${ }^{8}$

Before reconstructing the rationale of this judgment (section II.2.), it appears useful to take a look at the legal framework for the compensation of Italian victims of persecution and crimes committed during WWII (section II.1.).

\section{Compensation Agreements and German Compensation Law After World War II}

According to Article 77(4) of the Italian Peace Treaty, Italy waived 'on its own behalf and on behalf of Italian nationals all claims against Germany and German nationals outstanding on May 8, 1945, except those arising out of contracts and other obligations entered into, and rights acquired, before September 1, 1939'. 9 This waiver referred to 'all claims for loss or damage arising during the war'.

\footnotetext{
${ }^{5}$ Cf ICJ, Arrest Warrant of 11 April 2000 (Democratic Republic of the Congo v Belgium), Judgment of 14 February 2002, ICJ Reports 2002, 3, para 51; ICJ, Certain Questions of Mutual Assistance in Criminal Matters (Djibouti v France), Judgment of 4 June 2008, ICJ Reports 2008, 177, para 170; ICJ, Questions Relating to the Obligation to Prosecute or Extradite (Belgium v Senegal), Judgment of 20 July 2012, ICJ Reports 2012, 422: the obligation under Art 7 of the UN Convention against Torture implied that immunity, even though the issue was raised in the course of proceedings before domestic courts in Senegal (ibid, para 22), could not be invoked by the accused.

${ }^{6} \mathrm{ICJ}$, Jurisdictional Immunities (n 3), paras 80-97.

${ }^{7}$ Ibid, para 136.

${ }^{8}$ Ibid, para 108.

${ }^{9}$ Treaty of Peace with Italy, 10 February 1947, 49 UNTS 3.
} 
This provision, theoretically, did not bar Italian war victims from presenting a claim under the German compensation law (Bundesentschädigungsgesetz). According to the statute's pertinent version of 1956, however, reparations depended on the qualification of the claimant as a victim of national-socialist persecution as well as a domicile or permanent residence in Germany until 31 December $1952 .^{10}$ Claims had to be registered by 1 October 1957.

In 1961, Germany and Italy concluded two bilateral compensation agreements. The Agreement on the Compensation for Italian Nationals Subjected to NationalSocialist Measures of Persecution, according to the official reasoning, was intended to include those Italian victims of persecution who did not qualify under the compensation law of $1956 .{ }^{11}$ Germany agreed to pay DM (Deutsche Mark) 40 million 'for the benefit of Italian nationals who, on grounds of their race, faith or ideology were subjected to (...) measures of persecution and who, as a result of those persecution measures, suffered loss of liberty or damage to their health, and for the benefit of the dependents of those who died in consequence of such measures'. This agreement was, according to its Article 3, meant to 'constitute final settlement' between the two states. Germany has held ever since that victims of war crimes, including Italian Military Internees (IMIs) or people deported and subjected to forced labour, were beyond the ambit of the term 'victim of Nazi persecution'.

For all other types of claims the second agreement of 1961 is of interest, which concerns the 'settlement of certain property-related, economic and financial questions'. ${ }^{12}$ Germany paid a further lump sum of DM 40 million for 'outstanding questions of an economic nature'. Italy, in turn, agreed to indemnify the Federal Republic of Germany 'for any possible judicial proceedings or other legal action by Italian natural or legal persons' in relation to claims 'based on rights and circumstances which arose' during WWII. ${ }^{13}$ Article 24 of this agreement states that Germany considered the settlement agreed therein as final. The accompanying exchange of notes between both sides make no mention of Article 24. As a consequence, Germany considers it to be the responsibility of the Italian state to compensate claims within the scope of this agreement, including victims of war crimes and persons deported and subjected to forced labour. ${ }^{14}$

\footnotetext{
${ }^{10}$ Third German Law Amending the Additional Federal Compensation Act of 29 June 1956, Bundesgesetzblatt I 29 June 1956, No 31, 559; the statute had retroactive effect as of 1 January 1953.

${ }^{11}$ Agreement between the Federal Republic of Germany and Italy on the Compensation for Italian Nationals Subject to National-Socialist Measures of Persecution (Bonn, 2 June 1961), German and Italian version published in Bundesgesetzblatt II 5 July 1963, No 22, 791; official reasoning in Bundestagsdrucksache IV/438, 9.

${ }^{12}$ Agreement between the Federal Republic of Germany and Italy on the Settlement of Certain Property-Related, Economic and Financial Questions (Bonn, 2 June 1961), German and Italian version published in Bundesgesetzblatt II 26 June 1963, No 19, 668.

${ }^{13}$ Original in German and Italian; English translation taken from ICJ, Jurisdictional Immunities (n 3), para 24.

${ }^{14} \mathrm{Cf}$ ICJ, Jurisdictional Immunities (n 3), para 102.
} 
This, however, did not happen. With the German Law of 2 August 2000 establishing the Foundation 'Remembrance, Responsibility and Future' (Erinnerung, Verantwortung und Zukunft), a further effort was made ${ }^{15}$ with the intention to cover damages for people who had not been compensated under the laws enacted or agreements concluded previously. However, it did not encompass prisoners of war (POW) for whom the allied forces had already set up a compensation scheme shortly after the war. The fact that the German Reich denied POW status to IMIs did not prevent German authorities from placing forced workers under that category. The ICJ noted that it was 'a matter of surprise - and regret - that Germany decided to deny compensation' for that reason. ${ }^{16}$

\section{Immunity As a Part of the System}

The ICJ cited ample state practice, particularly judgments of domestic courts, to support its conclusion that there is no exception from immunity even for particularly grave violations of international law. ${ }^{17}$ This is in line with the jurisprudence of the European Court of Human Rights (ECtHR), which has repeatedly held that no violation of the European Convention on Human Rights (ECHR) would ensue were courts to grant immunity from jurisdiction, including for claims against a state whose agents were accused to have committed human rights crimes such as torture and crimes against humanity. ${ }^{18}$ The rationale behind this reasoning has two aspects: a reciprocity and a policy argument.

The reciprocity argument refers to the traditional concept of state immunity. It derives from the principle of the sovereign equality of states, which implies that no state's institutions may sit as judges over the conduct of other states. ${ }^{19}$ The historical motive to exempt the monarch from the jurisdiction of courts has ceded over time to the rationale of guaranteeing the exclusive competence of the respondent state to determine its policies. ${ }^{20}$ Once an exception to the rule is made, the concern is that this would open the door for retaliation of a similar kind before other states' courts and for a politicization in the administration of justice. ${ }^{21}$ This concept seems all the

\footnotetext{
${ }^{15}$ German Law Instituting the Foundation 'Remembrance, Responsibility and Future' (Erinnerung, Verantwortung und Zukunft) of 2 August 2000, Bundesgesetzblatt I 11 August 2000 No 38, 1263.

${ }^{16}$ ICJ, Jurisdictional Immunities (n 3), para 99.

${ }^{17}$ Ibid, paras 81-97.

${ }^{18}$ ECtHR, Al-Adsani $v$ The United Kingdom, Judgment of 21 November 2001, Application No 35763/97; ECtHR, McElhinney v Ireland, Grand Chamber Judgment of 21 November 2001, Application No 31253/96; ECtHR, Kalogeropoulou and Others v Greece and Germany, Decision of 12 December 2002, Application No 59021/00.

${ }^{19}$ ICJ, Jurisdictional Immunities (n 3), para 57.

${ }^{20}$ Hazel Fox/Philippa Webb, The Law of State Immunity (Oxford: OUP $3^{\text {rd }}$ ed 2013), 26-28.

${ }^{21}$ Burkhard Hess, 'Kriegsentschädigungen aus kollisionsrechtlicher und rechtsvergleichender Sicht', Berichte der Deutschen Gesellschaft für Völkerrecht 40 (2003), 107-212, at 189.
} 
more difficult to accept when the conduct in question amounts more clearly to serious and large-scale human rights crimes. ${ }^{22}$

The policy argument addresses the possible consequences of exceptions to immunity. With respect to reparation after war and other types of conflict, opening the path to domestic courts has a potentially detrimental effect on the incentive to arrive at an agreement through compromise, because victims would prefer to go to court and seek full compensation. ${ }^{23}$ Court judgments would discourage negotiated compensation schemes, which are typically accompanied by lump sum and final settlement clauses. If obtaining such judgments is a realistic option, then state parties would be even more hesitant than they currently are to engage in such treaties. Moreover, forum-shopping might be an unwanted consequence.

\section{A Human Rights Perspective on Sentenza 238/2014}

It should not go uncommented that the solution defended by the ItCC in Sentenza 238/2014 also raises serious concerns of a more general nature. To compromise the normativity of international law and even the UN Charter at the discretion of domestic courts comes as an invitation to actors in systems that do not primarily honour the protection of individual rights. In adapting the approach the European Court of Justice (ECJ) developed in the Kadi case, ${ }^{24}$ in which the ECJ subjected sanctions by the UN Security Council to its judicial review, ${ }^{25}$ the ItCC on the face of it made an effort to align with European fundamental rights standards. However, a similar approach was also followed with regard to the $\mathrm{ECtHR},{ }^{26}$ so that the ItCC has aligned with other constitutional courts that formulate caveats to the implementation of ECtHR judgments. In an environment less prone to fundamental rights, the Russian Constitutional Court cited such jurisprudence with approval when it held that compliance with ECtHR judgments could be made conditional on a decree of

\footnotetext{
${ }^{22}$ Jürgen Bröhmer, State Immunity and the Violation of Human Rights (The Hague: Nijhoff 1997), 189-215; Fox/Webb, State Immunity 2013 (n 20), 44-48.

${ }^{23}$ The opinion that compensation treaties implicitly exclude individual claims before national courts per se, as held by German authorities for some time, however, was rejected by the German Federal Constitutional Court in the forced workers claims case, Order of 13 May 1996, 2 BvL 33/93, BVerfGE 94, 315, at 328-334.

${ }^{24}$ Cited in ItCC, Judgment 238/2014 (n 1), para 3.4.

${ }^{25} \mathrm{Cf} \mathrm{CJEU}$, Kadi and Al Barakaat International Foundation $v$ Council of the European Union and Commission of the European Communities, Judgment of 3 September 2008, Joined Cases Nos C-402/05 P and C-415/05 P, paras 316; 320-326.

${ }^{26}$ Corte Costituzionale, Judgments of 22 October 2007, Nos 348 and 349/2007, para 6.1; for a similar approach to the ECtHR, see the judgment of the German Federal Constitutional Court in the Görgülü case: Bundesverfassungsgericht, Judgment of 14 October 2004, 2 BvR 1481/04, BVerfGE 111,307 , at 329 .
} 
the President of the Russian Federation. ${ }^{27}$ Thus, probably against its own intentions, the ItCC has contributed to a dwindling fidelity to international law, of which human rights form an essential part.

In sum, also from a human rights perspective, albeit not in an obvious way, Sentenza 238/2014 entails ambivalent consequences. To conclude from this observation that fundamental rights are best served if the lines drawn by traditional international law were further followed, however, would drive the point too far. In a way, Sentenza 238/2014 goes in the direction of another trend in international law, namely the progressive development towards individualization. ${ }^{28}$ In order to better understand the dilemma of the ItCC and to put forward an informed suggestion for possible future arrangements, it should be asked what that trend means for the compensation of victims of war crimes and crimes against humanity.

\section{The Individualization of Claims Under International Law}

The Jurisdictional Immunities Judgment reaffirms a distinction between substantive and procedural law, ${ }^{29}$ which is also visible in the emancipation of individual rights from mediatisation by state interests in post-war compensation systems. In the law governing injuries against aliens, the violation of the rights of an individual foreign national was considered 'in reality' an infringement on the said individual's home state to assert its own rights. ${ }^{30}$ This so-called Vattelian fiction, ${ }^{31}$ however, has been modified. In those crucial areas of international law in which the individual is at the centre- that is in human rights law, international criminal law and in international humanitarian law_compensatory schemes for violations of the individual's rights form part of the regimes.

\footnotetext{
${ }^{27}$ Russian Constitutional Court, Judgment of 14 July 2015, No 21-П/2015 on request of State Duma deputies, translation by Maria Smirnova, available at http://transnational-constitution.blogspot. com/2015/08/russian-constitutional-court-decision.html. See also Heike Krieger, chapter 'Sentenza 238/2014: A Good Case for Law-Reform?', in this volume.

${ }^{28}$ Anne Peters, Beyond Human Rights: The Legal Status of the Individual in International Law (Cambridge: CUP 2016); see also Anne Peters, 'Immune against Constitutionalization?', in Anne Peters/Evelyne Lagrange/Stefan Oeter/Christian Tomuschat (eds), Immunities in the Age of Global Constitutionalism (Leiden: Brill 2015), 1-19.

${ }^{29}$ For a critique, see, among others, Jerzy Kranz, 'L'affaire Allemagne contre Italie ou les dilemmes du droit et de la justice', in Peters, Immunities 2015 (n 28), 116-127; Andrea Gattini, 'Immunité et souveraineté dans l'arrêt de la Cour Internationale de Justice dans l'affaire Immunités juridictionnels de l'État', ibid, 223-235; Robert Uerpmann-Wittzack, 'Serious Human Rights Violations as Potential Exceptions to Immunity: Conceptual Challenges', ibid, 236-243.

${ }^{30}$ PCIJ, Mavrommatis Palestine Concessions (Greece v UK), Judgment of 30 August 1924, PCIJ Reports Series A, No 2, 12.

${ }^{31} \mathrm{ILC}$, Draft Articles on Diplomatic Protection with Commentaries, adopted by the Commission at its fifty-eighth session in 2006, UN Doc A/61/10, Art 1, commentary, para 3.
} 
In international human rights law, the 1984 UN Convention against Torture demands that member states provide an individual right to compensation invokable by victims before domestic courts; this right must include means for comprehensive rehabilitation. ${ }^{32}$ In other protection systems such an obligation of redress is framed in more general terms. Regional human rights courts use different powers to decide on reparations. The wording of Article 41 ECHR aims at pecuniary compensation, but it is the obligation to comply with ECtHR judgments (Article 46 ECHR) which is read to encompass non-pecuniary consequences, such as the duty to halt violations and, if necessary, to amend statute law or to reopen judicial and administrative proceedings. ${ }^{33}$ The language of Article 63 of the American Convention on Human Rights goes further than Article 41 of the ECHR in spelling out that a breach of rights 'be remedied and that fair compensation is made'. ${ }^{34}$ The African Court of Human and Peoples' Rights may 'make appropriate orders to remedy the violation, including the payment of fair compensation and reparation'. ${ }^{35}$ The reach of these Conventions coincides with the 'jurisdiction' of the respondent state party, which is understood to refer to its territory and also covers exterritorial acts if the state exercises control, for example through an army in occupied territory. ${ }^{36}$

The central compensation clause in international criminal law is Article 75 of the Rome Statute. ${ }^{37}$ The International Criminal Court can develop guidelines for reparation and may order compensation for victims to be paid either by the perpetrator or by a trust fund that the state parties can establish (Article 79 Rome Statute). Victims have no right, as a party to the proceedings, to direct a claim against the accused. However, they may file an application with the registrar of the court which has the power to order pecuniary reparation if the accused is convicted. ${ }^{38}$

In humanitarian law, Article 91 of the first Additional Protocol to the Geneva Conventions of 1949 declares that states that violate the Conventions are liable for

\footnotetext{
${ }^{32}$ Art 14 of the UN Convention against Torture and Other Cruel, Inhuman or Degrading Treatment or Punishment, 10 December 1984, in force 26 June 1987, 1465 UNTS, 85.

${ }^{33}$ International Law Association, Johannesburg Conference, International Human Rights Committee, 'Final Report International Human Rights Law and the International Court of Justice (ICJ): The Domestic Implementation of Judgments/Decisions of Courts and Other International Bodies that Involve International Human Rights Law', Part Two, (2016), para 15.

${ }^{34}$ American Convention on Human Rights of 22 November 1969, UNTS 1144, 123.

${ }^{35}$ Art 27 of the Protocol to the African Charter on Human and Peoples' Rights on the Establishment of an African Court on Human and Peoples' Rights of 9 June 1998, OAU Doc OAU/LEG/EXP/ AFCHPR/PROT III; a similar formula is used in Art 45 of the Protocol on the Statute of the African Court of Justice and Human Rights of 1 July 2008, reprinted ILM 48 (2009), 334, though not yet in force.

${ }^{36}$ ECtHR, Ilascu v Moldova and Russia, Judgment of 8 July 2004, Application No 48787/99, paras 387-394; ECtHR, Al-Skeini and Others v UK, Judgment of 7 July 2011, Application No 55721/07, paras 138-142; for acts outside occupied territory, see ECtHR, Bankovic and Others v Belgium and Others, Decision of 12 December 2001, Application No 52220/99, paras 67-73.

${ }^{37}$ Rome Statute of the International Criminal Court of 17 July 1998, UNTS 2187, 3.

${ }^{38}$ William A Schabas, The International Criminal Court: A Commentary on the Rome Statute (Oxford: OUP 2010), 879-882.
} 
damages. ${ }^{39}$ The official commentary of the International Committee of the Red Cross is sympathetic to a reading that this provision presupposes a claim of the individual and to reparation, but the matter remains disputed. At least there is a tendency in customary law to recognize standing of individuals to invoke these rights before courts. ${ }^{40}$ Even though it appears that domestic courts, at least in Germany, are still reluctant to accept the individual orientation of humanitarian law when it comes to its being integrated into the domestic concept of state responsibility, ${ }^{41}$ they rarely rule out this possibility. ${ }^{42}$ At any rate, as of now the standing of the individual before courts to invoke these rights is not yet generally recognized. All that humanitarian law explicitly prescribes is that neither protected persons nor their home states may waive the rights guaranteed in the Geneva Conventions. ${ }^{43}$

A development towards individualization can also be observed in the processing of mass claims. In the administration of damages after the invasion of Kuwait by Iraq, the United Nations Compensation Commission (UNCC) dealt with different categories of individual claims. ${ }^{44}$ Eligibility for compensation included any direct loss and damage arising from this incident, which could have been a breach of humanitarian law. The home states were not regarded as holders of these claims but as agents of their nationals (and stateless persons which they represented). The UNCC also monitored payments to the claimants made by the recipient states that had an obligation to report.

The International Law Commission's (ILC) Articles on State Responsibility likewise recognize the possibility of individual rights to reparation. Their Article 33 (2) states that the rules on the content of responsibility are 'without prejudice to any right, arising from the international responsibility of a state, which may accrue

\footnotetext{
${ }^{39}$ First Protocols Additional to the Geneva Conventions of 12 August 1949, and Relating to the Protection of Victims of International Armed Conflicts of 8 June 1977, UNTS 1125, 3.

${ }^{40}$ Jean de Preux, 'Article 91-Responsibility', in Claude Pilloud et al, Commentary on the Additional Protocols of 8 June 1977 to the Geneva Conventions of 12 August 1949 in Yves Sandoz/Christophe Swinarski/Bruno Zimmermann (eds), (Geneva: Nijhoff 1987), 1053-1058, at 1056-1057; Jean-Marie Henckaerts/Louise Doswald-Beck, Customary International Humanitarian Law (Volume I: Rules), (Cambridge: CUP 2005a), 541-545.

${ }^{41}$ Bundesverfassungsgericht, Order of 13 August 2013, 2 BvR 2260/06 (Bridge of Varvarin); Bundesgerichtshof, Judgment of 6 October 2016, III ZR 140/15, NJW 2016, 3656 (Kunduz).

${ }^{42}$ See reference in Jean-Marie Henckaerts/Louise Doswald-Beck, Customary International Humanitarian Law (Volume II: Practice), (Cambridge: CUP 2005b), 3560-3609.

${ }^{43} \mathrm{Cf}$ Arts 7 and 8 of the Geneva Convention relative to the Treatment of Prisoners of War of 12 August 1949, UNTS 75, 135; Arts 7 and 8 of the Geneva Convention relative to the Protection of Civilian Persons in Time of War of 12 August 1949, UNTS 75, 287.

${ }^{44} \mathrm{Cf}$ Stefan Kadelbach, 'Staatenverantwortlichkeit für Angriffskriege und Verbrechen gegen die Menschlichkeit', Berichte der Deutschen Gesellschaft für Völkerrecht 40 (2003), 63-105, at 90-92. See also Christian Tomuschat, chapter 'The Illusion of Perfect Justice', and Filippo Fontanelli, chapter 'Sketches for a Reparation Scheme', in this volume.
} 
directly to any person or entity other than a state'. ${ }^{45}$ According to the ILC commentary thereto 'the individuals concerned should be regarded as the ultimate beneficiaries and in that sense as the holders of the relevant rights'. ${ }^{46}$

Thus, the traditional concept of state responsibility appears to be ceding to a model of split entitlement: the victims are recognized as holders of the claims, but the procedural right to espouse these claims on their behalf is still in the hands of the states. This notion is also taken up in the work of the ILC project on diplomatic protection, which recognizes that a state in presenting such a claim "in reality" (...) also asserts the rights of its injured national'. ${ }^{47}$

\section{Prospects for Future Regimes of Compensation and Reconciliation}

What would a compensation regime have to look like in order to absorb the developments sketched out in the preceding section? There can be no doubt that such a scheme would be based on the concept that individuals are the holders of claims to restitution, compensation, and satisfaction. The question is how these claims can be administered in a way that recognizes them without discouraging other efforts to reach a constructive settlement.

The central issue is who may present such claims. It is still the practice that states act on behalf of their nationals or other persons for whom they are responsible. The power of the UNCC to monitor the transfer of compensation by the victim's home state pays tribute to the fact that this state does not espouse its own claim and may serve as a model solution to the problem that victims frequently do not receive any payment. The need to concentrate the process and to administer it effectively advocates in favour of maintaining the mechanism of diplomatic protection in principle. The question is whether this model should as a matter of policy ${ }^{48}$ prevent individuals from bringing suits before domestic courts. As far as treaty systems address this point, they provide for the exclusiveness of the established scheme, such as the peace treaty between Ethiopia and Eritrea of 2000. ${ }^{49}$ Another path would be

\footnotetext{
${ }^{45}$ ILC, Draft Articles on Responsibility of States for Internationally Wrongful Acts, adopted by the Commission at its fifty-third session in 2001 (Final Outcome), UN Doc A/56/10, 43, UN Doc A/RES/56/83, Annex, UN Doc A/CN.4/L.602/Rev.1, GAOR 56 ${ }^{\text {th }}$ Session Supp 10, 43.

${ }^{46}$ Ibid.

${ }^{47}$ ILC, Draft Articles on Diplomatic Protection, 2006 (n 31), Art 1, commentary, para 3; cf also Peters, Beyond Human Rights 2016 (n 28), 161-164; 389-407.

${ }^{48}$ Compensation agreements are not a legal obstacle; see FCC, Order of 13 May 1996 (n 23).

${ }^{49}$ Agreement between the Government of the State of Eritrea and the Government of the Federal Democratic Republic of Ethiopia for the resettlement of displaced persons, as well as rehabilitation and peacebuilding in both countries (Algiers Agreement), 12 December 2000, 2138 UNTS 93, Art 5 (8).
} 
mutual exclusion such that the registration of a claim requires that no other proceedings are pending. 50

A second crucial point is whether there can be an upper ceiling to the total amount of compensation, as it is one of the rationales of a lump sum agreement. Examples in history to the contrary seem discouraging and atypical. They include past generations of peace treaties, but also the compensation obligations Iraq incurred following its invasion of Kuwait. In that case reparation was not mutually agreed but one-sidedly imposed and financed by the sequestrated proceeds of the Iraqi oil production. ${ }^{51}$ These examples notwithstanding, however, contemporary human rights law points at a distinction between damages resulting from serious crimes against life, integrity and personal liberty on the one hand, and other types of claims on the other hand. Whereas claims of the latter kind may still be negotiable, there is little space for limiting claims for serious human rights violations. It is widely recognized that serious crimes must entail investigations and, where the proceedings yield pertinent evidence, the indictment of the persons responsible. ${ }^{52}$ It would contravene the strict stance human rights law takes in this respect to exclude claims altogether, be it only by limiting the funds at a court's disposal.

However, it seems possible to provide for time limits for the registration of claims, if these limitations are not unduly short and made public in a way that the entitled can come to know of their rights. Recent models of mass claim processing are therefore compatible with the need to provide adequate reparation. They have the advantage of accelerating the procedure and of establishing unified methods for evaluating evidence. For that reason, the UNCC distinguished between different types of claims and typified the outcomes in the form of fixed amounts. There have also been inbuilt time constraints, in that deadlines for registration were set and an end to the proceedings was envisaged as a predefined point in time. In more complex proceedings one might also think of fixed time limits for every step in the procedure, as is the practice before some arbitral tribunals. Such efforts to speed up the procedure would be one lesson from past lump sum settlements, as it can take decades between the taking up of the claim and payment to the injured person.

For the financing of reparation claims, funds have been created or are foreseen which are administered by claims commissions, arbitral tribunals, or courts. Examples are national foundations in Austria and Germany and the victims trust fund mentioned in Article 79 of the Statute of the International Criminal Court.

Finally, remedies other than financial compensation, which are covered by the concept of satisfaction, may help to overcome serious human rights violations. One

\footnotetext{
${ }^{50} \mathrm{Cf}$ Hess, 'Kriegsentschädigungen' 2003 (n 21), 163.

${ }^{51}$ See Kadelbach, 'Staatenverantwortlichkeit' 2003 (n 44).

${ }^{52}$ IACtHR, Barrios Altos v Peru, Judgment of 14 March 2001, Ser C 75, operative para 4; IACtHR, Almonacid Arellano et al v Chile, Judgment of 26 September 2006, Ser C 154, para 119; ECtHR, Mocanu and Others v Romania, Judgment of 17 September 2014, Applications Nos 10865/09, 45886/07 and 32431/08, para 321.
} 
might profit from the experience of national reconciliation efforts ${ }^{53}$ but also from the jurisprudence of the Inter-American Court of Human Rights, which has ordered official apologies, memorials, the naming of streets and other measures of that kind. $^{54}$

\section{Conclusions}

If there is an inter-temporal dimension to the case, it does not show primarily in the fact that the law of compensation was different at the time of WWII compared to the present. Rather, it is to be seen in the antagonism between subject matter and procedural law: whereas we are witnessing an increasing empowerment of the individual with respect to his or her rights in international law, the modes of implementing these rights are still strictly consensual. The individual has no standing before international courts or national courts of a foreign state unless states are willing to grant it, be it by agreement or by the waiver of immunity. Two different layers in the "geology of international law" ${ }^{55}$ overlap, with the result that the ICJ has made it clear that immunity is still an obstacle to domestic jurisdiction for individual compensation claims. Therefore, Italy is under an obligation to indemnify Germany, both by virtue of this judgment and the bilateral compensation agreement of 1961, in case a domestic court should grant an order of execution.

This outcome is counter-intuitive and raises the concern of how convincing political statements embracing human rights really are. It is therefore necessary to find a conciliatory solution as it is also suggested in the obiter dictum to the ICJ judgment, which stresses that claims by Italian victims of war crimes whose entitlements to reparation have not yet been recognized 'could be the subject of further negotiations between the two States concerned with a view to resolving the issue'. ${ }^{56}$

The state of proceedings in Italy appears to open a window of opportunity. Some interpret Sentenza 238/2014 as abstract in nature, without entailing cogent consequences for pending and future cases. In particular, the distinction was stressed between immunity from jurisdiction and immunity from enforcement. The fact that the ICJ held that the latter 'goes further than the jurisdictional immunity' ${ }^{, 57}$ should be

\footnotetext{
${ }^{53}$ See also the Agreement between the Government of Canada and the National Association of Japanese Canadians of 22 September 1988, reported by Henckaerts/Doswald Beck, CIHL Rules (n 40) 542 and CIHL Practice (n 42), 3602.

${ }^{54} \mathrm{Cf}$, inter alia, IACtHR, González et al v Mexico, Judgment of 16 November 2009, Ser C 205, para 471 (Cotton Field).

${ }^{55}$ To borrow a term used by Joseph H H Weiler, 'The Geology of International Law: Governance, Democracy and Legitimacy', Heidelberg Journal of International Law 64 (2004), 547-562.

${ }^{56}$ ICJ, Jurisdictional Immunities (n 3), para 103.

${ }^{57}$ Ibid, para 113.
} 
a reason for Italian courts to reflect on the matter and halt procedures. ${ }^{58}$ The two governments, in turn, might use the period of suspension to engage in a conciliatory solution.

How could the issue be resolved? One suggestion has been to create a fund in which both states take a share: ${ }^{59}$ Germany for obvious reasons and Italy because it failed to identify victims and take care of their fate. Companies which profited from forced labour and other private donors could be encouraged to participate. The total amount available should be dependent on the number of victims still alive; claims could be restricted to direct victims and their spouses. Payment should be made directly to the entitled persons. The total sum of money to be paid out in the end would certainly not be high, considering the shrinking number of claimants, the more so if compared to other expenditures that figure prominently in state budgets. If experience with past settlement procedures and reconciliation commissions is representative, the pecuniary aspect is not even the most important. Perhaps more relevant are the ways to provide some form of recognition of the injuries suffered and the consequences they had on the lives of victims and their next of kin.

Since the affected persons lives' are approaching their end, both structure and procedure must be organized in such a way as to allow for speedy processing. This consideration points in favour of a commission rather than an arbitral tribunal, composed of representatives from both states or even independent experts who are familiar with such procedures, as they may be found, for example, in the International Organization for Migration. Procedures could follow the experience with mass claim proceedings as far as the categorization of claims and evidence are concerned. To lower the threshold, the constitutive agreement could stress that the solution found would constitute no prejudice for claims raised by other states and would not imply the recognition of a legal commitment beyond the immanent logic of the system created.

\section{Epilogue}

It is only a ten-minutes' drive away from Frankfurt University, where this chapter has been written, to the cemetery of Westhausen. A section of this cemetery is known as the Cimitero di Guerra Italiano, where 4,788 Italian men, women and

\footnotetext{
${ }^{58}$ For pertinent jurisprudence, see Karin Oellers-Frahm, 'A Never-Ending Story: The Italian Court of Justice-The Italian Constitutional Court-Italian Tribunals and the Question of Immunity', Heidelberg Journal of International Law 76 (2016), 193-202, at 197-198; Giovanni Boggero, 'The Legal Implications of Sentenza No. 238/2014 by Italy's Constitutional Court for Italian Municipal Judges: Is Overcoming the "Triepelian Approach" Possible?' Heidelberg Journal of International Law 76 (2016), 203-224, at 219-221. See also Giovanni Boggero/Karin Oellers-Frahm, chapter 'Between Cynicism and Idealism', in this volume.

${ }^{59}$ See Francesco Francioni, chapter 'Overcoming the Judicial Conundrum', in this volume. See also Andreas von Arnauld, chapter 'Deadlocked in Dualism', in this volume.
} 
children were buried. They died between 1943 and 1945, either from illness, starvation, exhaustion, or during hostilities and air raids. A number of them had come to Germany in the 1930s as workers and were interned for forced labour in 1943 after Italy had changed sides in the war; many were soldiers, and had been captured as IMIs, others were partisans, political prisoners or victims of deportation. It still happens that a family discovers the name of a grandfather, a sister or a cousin who had been missing for decades. If they wish, the Italian Consulate General organizes for the remains to be transferred back home. A plate with the inscription 'rimpatriato' is then attached to the tombstone.

The conviction that the horrors of the past must be overcome has inspired many ambitious projects, a common and unified Europe being amongst the most important. Germany and Italy have contributed to this European success for more than 60 years. To continue to do so is an obligation that goes beyond positive law.

\section{References}

Boggero, Giovanni, 'The Legal Implications of Sentenza No. 238/2014 by Italy's Constitutional Court for Italian Municipal Judges: Is Overcoming the "Triepelian Approach" Possible?' Heidelberg Journal of International Law 76 (2016), 203-224

Bröhmer, Jürgen, State Immunity and the Violation of Human Rights (The Hague: Nijhoff 1997)

Fox, Hazel/Philippa Webb, The Law of State Immunity (Oxford: OUP $3^{\text {rd }}$ ed 2013)

Gattini, Andrea, 'Immunité et souveraineté dans l'arrêt de la Cour Internationale de Justice dans l'affaire Immunités juridictionnels de l'État', in Anne Peters/Evelyne Lagrange/Stefan Oeter/ Christian Tomuschat (eds), Immunities in the Age of Global Constitutionalism (Leiden: Brill 2015), 223-235

Henckaerts, Jean-Marie/Louise Doswald-Beck, Customary International Humanitarian Law (Volume I: Rules) (Cambridge: CUP 2005a)

Henckaerts, Jean-Marie/Louise Doswald-Beck, Customary International Humanitarian Law (Volume II: Practice) (Cambridge: CUP 2005b)

Hess, Burkhard, 'Kriegsentschädigungen aus kollisionsrechtlicher und rechtsvergleichender Sicht', Berichte der Deutschen Gesellschaft für Völkerrecht 40 (2003), 107-212

Kadelbach, Stefan, 'Staatenverantwortlichkeit für Angriffskriege und Verbrechen gegen die Menschlichkeit', Berichte der Deutschen Gesellschaft für Völkerrecht 40 (2003), 63-105

Kranz, Jerzy, 'L'affaire Allemagne contre Italie ou les dilemmes du droit et de la justice', in Anne Peters/Evelyne Lagrange/Stefan Oeter/Christian Tomuschat (eds), Immunities in the Age of Global Constitutionalism (Leiden: Brill 2015), 116-127

Oellers-Frahm, Karin, 'A Never-Ending Story: The Italian Court of Justice-The Italian Constitutional Court-Italian Tribunals and the Question of Immunity', Heidelberg Journal of International Law 76 (2016), 193-202

Peters, Anne, 'Immune against Constitutionalization?', in Anne Peters/Evelyne Lagrange/Stefan Oeter/Christian Tomuschat (eds), Immunities in the Age of Global Constitutionalism (Leiden: Brill 2015), 1-19

Peters, Anne, Beyond Human Rights: The Legal Status of the Individual in International Law (Cambridge: CUP 2016)

Preux, Jean de, 'Article 91-Responsibility', in Claude Pilloud et al, Commentary on the Additional Protocols of 8 June 1977 to the Geneva Conventions of 12 August 1949 in Yves Sandoz/ Christophe Swinarski/Bruno Zimmermann (eds), (Geneva: Nijhoff 1987), 1053-1058 
Schabas, William A, The International Criminal Court: A Commentary on the Rome Statute (Oxford: OUP 2010)

Uerpmann-Wittzack, Robert, 'Serious Human Rights Violations as Potential Exceptions to Immunity: Conceptual Challenges', in Anne Peters/Evelyne Lagrange/Stefan Oeter/Christian Tomuschat (eds), Immunities in the Age of Global Constitutionalism (Leiden: Brill 2015), 236-243

Weiler, Joseph H H, 'The Geology of International Law: Governance, Democracy and Legitimacy', Heidelberg Journal of International Law 64 (2004), 547-562

Open Access This chapter is licensed under the terms of the Creative Commons Attribution 4.0 International License (http://creativecommons.org/licenses/by/4.0/), which permits use, sharing, adaptation, distribution and reproduction in any medium or format, as long as you give appropriate credit to the original author(s) and the source, provide a link to the Creative Commons license and indicate if changes were made.

The images or other third party material in this chapter are included in the chapter's Creative Commons license, unless indicated otherwise in a credit line to the material. If material is not included in the chapter's Creative Commons license and your intended use is not permitted by statutory regulation or exceeds the permitted use, you will need to obtain permission directly from the copyright holder. 


\title{
Sketches for a Reparation Scheme: How Could a German-Italian Fund for the IMIs Work?
}

\author{
Filippo Fontanelli
}

\begin{abstract}
Given the deadlock in the current negotiations between Germany and Italy and the unavailability of judicial remedies for the victims, the two states could set up a reparation scheme. This chapter sketches some of the main features of such a hypothetical scheme, considering existing internal or international arrangements in the context of transitional justice (the Foundation 'Remembrance, Responsibility and Future' (Erinnerung, Verantwortung und Zukunft) scheme; the Australian DART scheme; the deal between Japan and South Korea on reparations to 'comfort women'; the US/French schemes for reparations and restitution to holocaust victims; the Eritrea/Ethiopia reparations scheme; and the Iraq/Kuwait scheme). In particular, the emphasis is on the system of identification of the eligible victims, the question of financing and the fate of pending and future judicial claims. Assuming the states' willingness to explore this project, the chapter outlines some of the ways the scheme could operate in practice, drawing from existing models.
\end{abstract}

I am grateful to the PAX Peace Agreement Database staff who helped me to retrieve the text of several relevant agreements. I also thank the law schools of Universidad de la Sabana (Bogotá) and LUISS Guido Carli (Rome), where I resided at the time of writing.

\footnotetext{
F. Fontanelli (四)

University of Edinburgh, Law School, Edinburgh, UK

e-mail: filippo.fontanelli@ed.ac.uk 


\section{Introduction}

Should Germany and Italy decide to set up a joint compensation (or reparation) ${ }^{1}$ fund for Italian Military Internees (IMIs) and other victims of Nazi crimes (referred to, when taken together, as the 'Italian victims') who have yet to obtain any reparation, ${ }^{2}$ what would this fund look like? This chapter's analysis takes for granted some of the conclusions and findings explored more fully in the other chapters in this volume. It therefore does not seek to determine whether the two states-as a matter of law, comity or pragmatism - must, should, or even could ${ }^{3}$ accept the establishment of a joint fund. ${ }^{4}$ The working assumption here is that there nevertheless exists the political will to make such a choice. ${ }^{5}$ Arguably, this resolution would constitute an elegant way to cut the Gordian knot of the immunity deadlock and grant overdue reparation to the victims. It might also be that the operation of such a fund could suffice for the Italian Constitutional Court (ItCC) to revise its stance on the granting of immunity to Germany in civil proceedings before Italian courts. This prospect remains subject to speculation, and is more fully explored by Paolo Palchetti and Riccardo Pavoni in their respective chapters. ${ }^{6}$ Furthermore, this chapter will also not

\footnotetext{
${ }^{1}$ Words matter, and in this case the reference to reparation rather than compensation might be appropriate, both to second Germany's inclination to consider any payment made as a matter of comity rather than obligation, and to account for the lump-sum nature of any potential payment (as opposed to payments measured upon the actual extent of damage suffered by each victim). A similar switch is discernible, for instance, in the formulation of the Australian Defence Abuse Response Taskforce (DART) scheme, which was envisioned as a compensation scheme but ended up being officially labelled as a reparation scheme. See, for more details, Simone Degeling/Kit Barker, 'Private Law and Grave Historical Injustice: The Role of the Common Law', Monash University Law Review 41 (2015), 377-413, at 380 et seq, in particular note 9.

${ }^{2}$ Alongside IMIs, who are the majority of potential applicants, other groups could be covered by the compensation scheme, including civilians subjected to forced labour and victims of mass killings.

${ }^{3}$ On the legal regime on the granting of compensation under German law, see Andreas von Arnauld, 'Damages for the Infringement of Human Rights in Germany', in Ewa Bagińska (ed), Damages for Violations of Human Rights (Heidelberg: Springer 2016), 101-136.

${ }^{4}$ In short, whether Germany owes such reparation as a matter of law is disputed. The ICJ decided not to admit Italy's counterclaim in the Jurisdictional Immunities dispute and, therefore, has not addressed the issue. Germany claims that compensation for the IMIs was already included in the sums paid under the bilateral treaty of 2 June 1961.

${ }^{5}$ On the political opportunity of reparation movements, and how it affects their rate of success, see Stephanie Wolfe, The Politics of Reparations and Apologies (Heidelberg: Springer 2014), 11-12.

${ }^{6}$ See Riccardo Pavoni, chapter 'A Plea for Legal Peace', in this volume, who notes that '[t]here are sound reasons for believing that the setting up of a meaningful compensatory procedure would lead to the suspension or termination of the remaining cases pending against Germany before Italian courts', at 94. On this point, see also Paolo Palchetti, 'Italian Concerns after Sentenza 238/2014: Possible Reactions, Possible Solutions', VerfBlog, (11 May 2017), available at https:// verfassungsblog.de/italian-concerns-after-sentenza-2382014-possible-reactions-possible-solutions/ : ' $[\mathrm{A}]$ political initiative involving Germany and Italy and aimed at establishing a mechanism for addressing the reparation claims of the victims might be regarded by the Constitutional Court as an adequate alternative route for providing protection to the rights of the victims, thereby justifying a limitation to the right of access to court and the recognition of Germany's immunity'. In the chapter
} 
address the chronological conundrum regarding the victims' characterization under international humanitarian law. ${ }^{7}$ Instead, it will be assumed that, under the prevailing approach, Italian victims should receive some reparation irrespective of the legal characterization of Germany's conduct at that time.

In light of these assumptions, the narrow focus of this chapter will be on certain practical features and arrangements of the possible joint scheme to come (the 'Joint Scheme'). Selected matters will be addressed, such as the funding of the Joint Scheme, procedures for the distribution of compensation (including the criteria of eligibility and the appointment of a competent authority for the review of individual applications), and the waiver of judicial claims.

An attempt is made to draw on extant schemes without presuming any significant similarity between them. Quite simply, the idea is to look at existing solutions and provide the architects of the Joint Scheme with a range of options that could be utilised alongside a handful of warnings. As this chapter ends the substantive section of this volume, it marks an opportune moment to point the way (or ways) ahead for the Italian and German authorities.

Sections II and III concern two domestic schemes implemented by Germany and Australia respectively. Section IV addresses selected payment schemes established at the interstate level. Section V concludes the chapter by drawing the threads together and sketching some features of the Joint Scheme. Although section V provides a distilled checklist, the intermediate sections account for its composition.

This chapter's intention is to identify some valid principles that could inform the Joint Scheme's construction and compose a roadmap. Ultimately, however, the conviction is that a Joint Scheme for reparations, whatever its make-up, is preferable to none. This chapter builds on both these intuitions, which Adrian Vermeule effectively juxtaposed when concluding upon the desirability of less-than-perfect reparation schemes:

Viewed in the concrete, both transitional and nontransitional programs or awards of compensation are often disastrously unprincipled. We must step back a mile or three, to reflect that in many cases the only other option not ruled out by political constraints—doing nothing at all-would be even worse. ${ }^{8}$

A Joint Scheme would be, therefore, a vessel of 'rough justice', a device preferable to inaction albeit inevitably flawed under the prevailing standards of

\footnotetext{
'Right of Access to (Italian) Courts über alles?', of this volume, Palchetti reiterates the underlying question: 'It is not clear (...) whether an interstate agreement on compensation might be regarded by the ItCC as an adequate alternative route for providing protection to the rights of the victims, thereby justifying a limitation to the right of access to court and the recognition of Germany's immunity', at 50. This question raises the issue of Italian constitutional law, which exceeds the scope of this chapter.

${ }^{7}$ Their status as victims of war crimes was recognized after the conduct took place, in the III and IV Geneva Conventions of 1949. See also Andreas von Arnauld, chapter 'Deadlocked in Dualism', in this volume.

${ }^{8}$ Adrian Vermeule, 'Reparations as Rough Justice', University of Chicago Public Law \& Legal Theory Working Paper 105 (2005), 1-18, at 15.
} 
justice. ${ }^{9}$ While roughness is both inevitable and acceptable, the Joint Scheme should not be unprincipled. This chapter gathers, and expatiates on, the appropriate principles. While designed to address the unresolved status of IMIs, this chapter could as well work as blueprint for any mechanism of financial reparations in the wake of historical injustice, mutatis mutandis.

In particular, the Decalogue-redolent list of section V does not lay the ground rules for $a$ reparation scheme (for IMIs), but for any reparation scheme.

\section{Next of Kin: The RRF Foundation}

A useful template to shape the Joint Scheme is the law establishing the Foundation 'Remembrance, Responsibility and Future' (Erinnerung, Verantwortung und Zukunft) (RRF). ${ }^{10}$ Germany entrusted the RRF with the payment of compensation to applicants who were victims of forced labour and other 'injustices' perpetrated by the Nazi regime. ${ }^{11}$ IMIs were unable to obtain compensation under this law, which expressly excluded prisoners of war from its application. ${ }^{12}$ Other victims of Nazi crimes, including the victims of mass killings, were altogether outside the scheme's reach. The point here is not to question the Foundation's decision to reject the IMIs' applications or the scope of application of the RRF but rather to consider the functioning of the compensation system established under the RRF Law. It is quite detailed and might serve as a model for the Joint Scheme's machinery.

The financing for the RRF fund was provided by the German federal government and a consortium of German companies. ${ }^{13}$ The government and German industry each made a one-off contribution to the RRF fund of DM (Deutsche Mark) five

\footnotetext{
${ }^{9}$ Ibid, describing rough justice as 'the intuition that sometimes it is permissible, even mandatory, to enact a scheme of compensatory reparations that is indefensible according to any first-best criterion of justice. Rough justice is indefensible; it seems attractive only when compared to no justice-when it is recognized that the status quo of inaction is also a proposal, one that may fare even worse, according to the same criteria that would condemn the relevant reparations proposals'.

${ }^{10}$ German Law Instituting the Foundation 'Remembrance, Responsibility and Future' (Erinnerung, Verantwortung und Zukunft) of 2 August 2000, Bundesgesetzblatt I 11 August 2000, 1263. For a commentary, see Bardo Fassbender, 'Compensation for Forced Labour in World War II: The German Compensation Law of 2 August 2000', Journal of International Criminal Justice 3 (2005), 243-252. See also Peer Zumbansen (ed), Zwangsarbeit im Dritten Reich: Erinnerung und Verantwortung -NS-Forced Labor: Remembrance and Responsibility (Baden Baden: Nomos 2002).

${ }^{11}$ RRF Law, 2000 (n 10), Art 2, para 1.

${ }^{12} \mathrm{Ibid}$, Art 11, para 3. On the application of this carve-out, see ICJ, Jurisdictional Immunities of the State (Germany v Italy: Greece intervening), Judgment of 3 February 2012, ICJ Reports 2012, 99 , para 26 . The commentary to the law specified that 'the rules of international law allowed a detaining power to enlist prisoners of war as workers'.

${ }^{13}$ RRF Law, 2000 (n 10), Art 3, para 1.
} 
billion. ${ }^{14} \mathrm{~A}$ board of trustees, composed of 27 members, obtained responsibility for its management. These included, besides a number of German officials, one representative for each country, ethnic or national group amongst the prospective applicants (namely Israel, the US, Poland, Russia, Ukraine, Belarus, the Czech Republic, Roma and Sinti, and Jews) and other institutional members (from the UN and other international institutions). ${ }^{15}$

The Foundation did not directly carry out the distribution of compensation. The funds were made available to a series of non-profit 'partner organizations', each responsible for receiving claims from a specific group of applicants. These organizations were tasked with the liquidation of successful claims ${ }^{16}$ and with the establishment of an appeal process for the review of first instance determinations. ${ }^{17}$

Specific provisions required payments to be suspended or only partially made until the exhaustion of applications, in order to prevent the Fund from depleting its resources and becoming insolvent, thus failing to satisfy all eligible applications after paying out early processed claims. ${ }^{18}$ For instance, the maximum payable amount to each applicant eligible as 'slave labourer' was set initially at $50 \%$ of the amount owed. The outstanding portion was paid out 'after conclusion of the processing of all applications pending before the respective partner organization, to the extent possible within the framework of the available means. ${ }^{, 19}$

The RRF Law contained a specific provision detailing the eligibility of applicants for compensation. ${ }^{20}$ It covered persons subjected by German authorities or commercial companies to forced labour, and subjected to detention or harsh living conditions. ${ }^{21}$ It also stipulated the possibility of compensating property losses if the applicants had been unable to seek compensation under previous schemes. ${ }^{22}$ The burden of demonstrating eligibility lay primarily with the applicants, although the competent partner organization would normally provide and consider available

\footnotetext{
${ }^{14} \mathrm{Ibid}$, Art 3, paras 2 and 3. The current value of this 2001 donation, adjusted for inflation, would be in the area of $€ 2.64$ billion.

${ }^{15}$ Ibid, Art 5 .

${ }^{16}$ Ibid, Art 9.

${ }^{17}$ Ibid, Art 19.

${ }^{18}$ Ibid, Art 9, paras 9-10.

${ }^{19}$ Ibid, para 9 . The clause also requires that $5 \%$ of the monies allocated be set aside as a financial reserve for appeals, and that the second round of payments be made only after such reserve has been set up.

${ }^{20}$ Ibid, Art 11. In other words, the Law made hardship a necessary requirement for compensation alongside that of forced labour. See Fassbender, 'Compensation' 2005 (n 10), 249: 'Parliament's attention focused on persons detained in concentration camps on the one hand and deportees on the other-and not on forced labourers as such.'

${ }^{21}$ RRF Law, 2000 (n 10), Art 11, para 1, numbers 1 and 2.

${ }^{22}$ Ibid, Art 11, para 1, number 3. Liquidation of these claims was only residually possible, that is, 'only after all applications pending before the competent commission have been processed'.
} 
aggregate information to complement the evidence provided by the individuals. ${ }^{23}$ The competent organization was authorized to accept, on a case-by-case basis, applications deprived of supporting documentation. For the most part, claims were strictly personal and, if the application related to the loss of property, heirs could bring it only if the victims had died after February $1999 .^{24}$

As for the amount of compensation granted to successful applicants, the RRF Law set a cap of DM15,000 (approximately €7,600) for internees in concentration camps ('slave labourers') ${ }^{25}$ and DM5,000 (approximately €2,530) for applicants who, outside of concentration camps, were subjected to other forms of harsh treatment, confinement and detention ('forced labourers'). ${ }^{26}$ A total of DM8.1 billion was ear-marked for compensating slave (and forced) labour, with DM50 million and DM1 billion budgeted, respectively, to compensate other personal injuries and property losses. ${ }^{27}$ DM700 million were instead reserved for separate projects of the Foundation other than compensation. ${ }^{28}$

The transfer of funds awarded under the compensation scheme was conditional on a previous declaration of 'legal peace' made by the German parliament, certifying the dismissal of all lawsuits pending abroad. ${ }^{29}$ The Law also prescribed that compensation claims could only be brought under the procedures established thereunder, to the exclusion of all other claims. ${ }^{30}$ Applicants would waive all other avenues of redress, and the waiver would take effect at the moment of payment. ${ }^{31}$ To endorse the unilateral preclusion of other claims effected by Germany, the US government issued a statement of interest in every dispute brought before US courts-effectively validating the choice of forum made in the Law and requesting that the individual claim be redirected to the RRF. ${ }^{32}$

To ascertain the viability of adopting similar solutions in a Joint Scheme, a few essential traits of this compensation scheme should be isolated. Some elements seem

\footnotetext{
${ }^{23} \mathrm{Ibid}$, Art 11, para 2: 'Eligibility shall be demonstrated by the applicant by submission of documentation. The partner organization shall bring in relevant evidence. If no relevant evidence is available, the claimant's eligibility can be made credible in some other way.'

${ }^{24}$ Ibid, Art 13, para 1.

${ }^{25}$ This terminology is employed in Libby Adler and Peer Zumbansen, 'The Forgetfulness of Noblesse: A Critique of the German Foundation Law Compensating Slave and Forced Laborers of the Third Reich', Harvard Journal on Legislation 39 (2002), 1-62, at 2.

${ }^{26}$ RRF Law, 2000 (n 10), Art 9, para 1.

${ }^{27}$ Ibid, Art 9, paras 2-4.

${ }^{28}$ Ibid, Art 9, para 7. The Foundation has carried out several 'Funding Activities', especially in the field of historiography and the remembrance of victims, through the building of an online database, the organization of encounters with former forced labourers and other victims, the funding of educational projects, etc. See 'Funding Programmes of the Foundation EVZ', available at www. stiftung-evz.de/eng/funding/.

${ }^{29}$ RRF Law, 2000 (n 10), Art 17, para 2.

${ }^{30}$ Ibid, Art 16.

${ }^{31}$ Ibid, Art 2.

${ }^{32}$ See Adler and Zumbansen, 'The Forgetfulness' 2002 (n 25), 4.
} 
fit for transplant: the quid pro quo nature (dismissal and waiver of lawsuits in exchange for compensation), the administrative process of claims liquidation, the intentional ambiguity regarding the legal basis for addressing injustices, entrusting the governance of payment processes to non-profit organizations, the flexible evidentiary principles, and the prescription of a possibility to challenge liquidation decisions and obtain their review.

Other elements of the RRF scheme appear less appropriate. The non-eligibility of heirs would frustrate the effectiveness of the Joint Scheme, given the timeframe of the crimes for which reparation is due. Some commentators criticized the Law for showing, on the part of Germany, 'no remorse, no confession, and no sense of debt for the merciless treatment' of the victims. ${ }^{33}$ The quantification of compensation caps is also an obviously delicate matter. Forced labourers employed outside concentration camps (non-slave labourers) received a sum that could be considered low against several plausible baselines (for instance, the DM5,000 cap meant, for most applicants, that the amount awarded was lower than what they would have received had they been paid the minimum wage for the labour service supplied at that time).

\section{DART: The Australian Solution}

Since 2011, Australia has been coping with a barrage of individual complaints relating to sexual and other forms of abuse allegedly perpetrated by personnel of the Australian Defence Force. ${ }^{34}$ After evidence emerged of systemic problems, the government established the Defence Abuse Response Taskforce (DART), which was to assess individual complaints and determine the appropriate response thereto. ${ }^{35}$

A range of possible responses were offered, including restorative justice/conferencing processes, counselling, compensation capped at A (Australian Dollars) $50,000,{ }^{36}$ and the referral of matters to criminal prosecution and/or the military

\footnotetext{
${ }^{33}$ Ibid, 5-6.

${ }^{34}$ The cut-off date for the alleged actions was 11 April 2011, when the law firm DLA Piper, upon the government's commission, completed an investigation into the matter, see Garry A Rumble/ Melanie McKean/Dennis Pearce, Report of the Review of Allegations of Sexual and Other Abuse in Defence: Facing the Problems of the Past, Volume-General Findings and Recommendations (Canberra: DLA Piper 2011).

${ }^{35}$ For a positive assessment of DART, see Alikki Vernon, 'The Ethics of Appropriate Justice Approaches: Lessons from a Restorative Response to Institutional Abuse', Law in Context 35 (2017), 139-158.

${ }^{36}$ Approximately $€ 32,700$ at the rate prevailing at the time of writing.
} 
justice system. ${ }^{37}$ Nearly all applicants requested monetary reparation. ${ }^{38}$ The focus of this study will only be on the monetary reparation system. Nonetheless, the scheme was remarkable for providing a diverse set of remedies. In particular, the DART process acknowledged the need for victims to have their complaints heard and their grievances accepted by the Australian Defence Force, while also devising a specific engagement procedure to that effect. ${ }^{39}$

It is important to note that although DLA Piper (the law firm tasked with carrying out the initial investigation) recommended establishing a 'compensation' plan and the ministry initially agreed, the resulting plan was re-branded as a 'reparation' scheme. As it is expressly stated in the reparation guidelines, payments made should not be understood to represent compensation, nor to imply an assumption of state liability. ${ }^{40}$ Moreover, participation in the reparation scheme does not foreclose the right to resort to domestic courts. Tribunals are merely reminded to take into account the amount of reparation granted under the DART scheme to liquidate damages in tort or statute. ${ }^{41}$

The DART reparation scheme was handled as a purely administrative process. ${ }^{42}$ Eligible applicants were all persons who were employed in the Australian Defence Force and alleged to have suffered abuse effected by Defence Force personnel, subject to certain deadlines for the presentation of the complaint. ${ }^{43}$ Applications consisted of a reparation form, a personal account of the alleged abuse (and any related follow-up procedure exhausted within the Defence Force), and proof of

\footnotetext{
${ }^{37}$ See Australian Senate Foreign Affairs, Defence and Trade References Committee, 'Report of the DLA Piper Review and the Government's Response', (27 June 2013), available at https://www.aph. gov.au/Parliamentary_Business/Committees/Senate/Foreign_Affairs_Defence_and_Trade/Com pleted_inquiries/2010-13/dlapiper/report/index, para 2.50, referring to an action plan announced on 26 November 2012 by the Minister for Defence, the Honourable Stephen Smith MP, in response to the DLA report.

${ }^{38}$ The breakdown of remedies granted is as follows (out of 1,751 processed complaints): '[A] reparation payment (1,723 complainants at a total cost of US\$66.63 million); counselling (577 complainants); participation in the Restorative Engagement Program (715 complainants); referral to police for possible criminal investigation and prosecution (133 complainants); and referral to the Chief of the Defence Force for consideration of possible administrative or disciplinary action (132 complainants)'. See Australian government, 'Defence Abuse Response Taskforce Final Report', (31 March 2016), available at https://core.ac.uk/download/pdf/51343294.pdf, 11.

${ }^{39}$ Vernon, 'The Ethics' 2017 (n 35), 146, records the motivation of establishing the so-called Restorative Engagement Conferences: 'The consistent request from complainants was to: have their personal account of abuse listened to by Defence; have their personal account accepted as true; be given acknowledgement that the abuse was wrong and should not have happened'.

${ }^{40}$ Australian government, 'Defence Abuse Reparation Scheme Guidelines', available at www.aph. gov.au/DocumentStore.ashx?id=7d8a8c38-f721-42cf-baed-3538593a3ee4, para 1.6.1: 'A payment to a person under the Reparation Scheme is not paid as compensation or damages for any asserted, perceived, or possible legal liability on the part of the Commonwealth, or for any injury, disease or impairment, and does not constitute an admission of liability on the part of the Commonwealth.'

${ }^{41}$ Ibid, para 1.6.2.

${ }^{42} \mathrm{Ibid}$, para 2.1.6: '[H] earings, negotiations or appeals' were not envisaged for its functioning.

${ }^{43}$ Ibid, para 3.1.4.
} 
identity. Reparation was not available for applications made regarding deceased persons. $^{44}$

The evidentiary standard required of applicants is worth careful analysis. The individual account of the abuse is expressly presumed to correspond to the 'person's personal experience of alleged abuse' unless evidence emerges to contradict it. ${ }^{45}$ Additional information might be sought from either the applicant or the Defence Force. The Defence Force's failure to submit documents requested by the taskforce would result in a presumption that the Defence Force is unable to contradict the information provided by the applicant, ${ }^{46}$ though it would ultimately be for the competent assessor ${ }^{47}$ to form an opinion on the merits as to the 'plausibility' of the applicant's allegations. ${ }^{48}$ There is no classic treatment of the burden and standard of proof, nor is there a precise system of reversals; the assessor's opinion, based on any available evidence, is the controlling criterion of any payment determination. In the words of the assessor:

The plausibility test was also pivotal in humanely considering complaints from many individuals who were aged, frail or in a vulnerable state of health or wellbeing or otherwise reluctant or unable to recount often very traumatic instances of abuse. ${ }^{49}$

DART-awarded reparations were classified in pre-fixed amounts corresponding to the varying gravity of the alleged abuse. ${ }^{50}$

The DART scheme, insofar as it did not preclude the victims' access to judicial redress, is not a pertinent model for the Joint Scheme because it did not ensure legal peace. However, some of its features might be effectively transplanted. The system

\footnotetext{
${ }^{44}$ Ibid, para 3.7.1.

${ }^{45}$ Ibid, para 4.3.1.

${ }^{46}$ Ibid, para 4.4.1.

${ }^{47}$ The Reparation Payment Assessor was appointed by the Minister of Defence to review abuse applications and determine whether a payment would be made, and the amount thereof. The designated assessor was Robyn Kruk, a retired senior Australian public servant.

${ }^{48}$ Ibid, para 4.5.1: The plausibility standard entailed that individual applications were upheld when the allegations had 'the appearance of reasonableness'; see Vernon, 'The Ethics' 2017 (n 35), 146. ${ }^{49}$ Australian government, 'DART Final Report' 2016 (n 38), 62, Appendix I-Comments by the Reparation Payments Assessor.

${ }^{50}$ Categories 1 to 4 attract, respectively, a payment of $\mathrm{A} \$ 5,000$ (approx. $€ 3,200$ ); $\mathrm{A} \$ 15,000$ (approx. €9,600); $\mathrm{A} \$ 30,000$ (approx. €19,200); $\mathrm{A} \$ 45,000$ (approx. €28,800); see Australian government, Defence Abuse Reparation Scheme Guidelines (n 40), para 4.6.1. More than half of the applicants received payments relating to the most serious category of abuse. The types of abuses are reported in Annex 10 to the DLA Piper Report and are further grouped to facilitate the task of the taskforce into four genres (sexual abuse, sexual harassment, physical abuse, and harassment and bullying). Somewhat counter-intuitively, the four categories used for reparation purposes have little descriptive value and do not correspond to the type of abuse, but they are supposed to correspond to different degrees of gravity. As explained by the taskforce: 'A single incident of physical assault with no serious injury might fall in Category 1 or 2 (depending on the individual circumstances), while a serious sexual assault, such as a rape, would be expected to fall within Category 4.' See DART taskforce, 'Seventh Interim Report to the Attorney-General and Minister for Defence', (September 2014), 19.
} 
of pre-fixed reparation amounts relating to certain recurring abuses and the use of a flexible standard of evidence are two solutions that might fit well with the operation of a Joint Scheme.

\section{Other Compensation Schemes}

\section{Eritrea/Ethiopia}

Within the regime of the Algiers Agreement, which put an end to the border war between Eritrea and Ethiopia, the parties provided for the establishment of an independent Claims Commission. Such a Commission was competent to decide through arbitration the claims brought by either state party, including claims made on behalf of individual citizens. ${ }^{51}$ The Commission's jurisdiction extended, inter alia, on claims for damages relating to breaches of international humanitarian law committed during the conflict by either party. ${ }^{52}$ The Commission was entitled to draft its own rules of procedure. ${ }^{53}$

Insofar as the Commission functioned as an arbitral tribunal, it does not seem to provide an adequate model for the Joint Scheme. The great advantage of the Joint Scheme would be that Germany does not object to the assumption of responsibility for the injustices perpetrated against IMIs. A review of compensation claims under the Joint Scheme would not implicate or require a determination of state responsibility for breaches of ius in bello or ad bellum-a determination that the

\footnotetext{
${ }^{51}$ Note that individuals were not afforded access to arbitration, which remained an interstate affair only.

${ }^{52}$ Agreement between the Government of the State of Eritrea and the Government of the Federal Democratic Republic of Ethiopia for the resettlement of displaced persons, as well as rehabilitation and peacebuilding in both countries (Algiers Agreement), 12 December 2000, 2138 UNTS 93, Art 5.1: '1. Consistent with the Framework Agreement, in which the parties commit themselves to addressing the negative socio-economic impact of the crisis on the civilian population including the impact on those persons who have been deported, a neutral Claims Commission shall be established. The mandate of the Commission is to decide through binding arbitration all claims for loss, damage or injury by one Government against the other, and by nationals (including both natural and juridical persons) of one party against the Government of the other party or entities owned or controlled by the other party that are (a) related to the conflict that was the subject of the Framework Agreement, the Modalities for its Implementation and the Cessation of Hostilities Agreement, and (b) result from violations of international humanitarian law, including the 1949 Geneva Conventions, or other violations of international law. The Commission shall not hear claims arising from the cost of military operations, preparing for military operations, or the use of force, except to the extent that such claims involve violations of international humanitarian law.'

${ }^{53}$ Which are available at the dedicated website of the Permanent Court of Arbitration; see EritreaEthiopia Claims Commission, 'Rules of Procedure', available at https://pcacases.com/web/ sendAttach/774.
} 
Commission, controversially enough, resolved to make. ${ }^{54}$ The Eritrea/Ethiopia experience, in other words, is mostly instructive a contrario. The Joint Scheme should not hinge itself on the ascertainment of Germany's responsibility through judicial or arbitral proceedings but only on the administrative review of the pre-determined eligibility criteria of the applicants and their claims.

In one respect, however, the experience of the Claims Commission can be relevant. The Commission established, alongside single claims warranting ad hoc scrutiny on the merits, certain categories of claims for which a mass-claim procedure would be used instead. Applicants whose claims were aggregate into mass claims would be entitled to a fixed amount of compensation. ${ }^{55}$ In essence, once state responsibility for a certain breach of international law is determined, a random sample of individual claims hinging on the invocation of that breach would proceed to a review on the merits. Through this exercise, the Commission would determine (within the sample) the percentage of claims supported by adequate evidence. It would then order compensation to all claimants in the class, reduced in amount to match that percentage.$^{56}$ For instance, if only $50 \%$ of claims in the sample are meritorious, each claimant in that class would receive half of the compensation owed.

Neither Ethiopia nor Eritrea used this mass-claim mechanism, a choice that revealed the limits of subjecting individual claims to state espousal and the constraints imposed by a severe deadline. ${ }^{57}$ The state parties opted for a fast-track process with a predetermined conclusion date: they allowed 3 years for the exhaustion of all arbitration proceedings, and consequently envisaged a tight 1 -year deadline to present the claims. These time constraints certainly had a chilling effect on the possibility to orchestrate mass claims. ${ }^{58}$

\footnotetext{
${ }^{54}$ Christine Gray, 'The Eritrea/Ethiopia Claims Commission Oversteps Its Boundaries: A Partial Award?', European Journal of International Law 17 (2006), 699-721.

${ }^{55}$ Claims Commission, 'Rules of Procedure' (n 53), Art 30. The sub-categories refer to unlawful displacement, unlawful expulsion, unlawful treatment of prisoners of war, unlawful detention and other instances of loss, damage and injuries.

${ }^{56}$ Ibid, Art 32.3: 'If the Commission makes all of the determinations in paragraph 1, the claims in that sub-category for each of the two levels of compensation shall be subject to random sampling of their evidence to ascertain the percentage of such claims for which the evidence is inadequate to establish the claim. The compensation for all claims in that compensation level of that sub-category is automatically reduced by that percentage, and the Commission shall issue an award of such compensation for all claims in that sub-category.'

${ }^{57}$ See Ari Dybnis, 'Was the Eritrea-Ethiopia Claims Commission Merely a Zero-Sum Game: Exposing the Limits of Arbitration in Resolving Violent Transnational Conflict', Loyola of Los Angeles International and Comparative Law Review 33 (2010), 255-286, at 268: '[D]espite the availability of this mass claims option, the parties chose only to file government-to-government claims, with the exception of six claims which Eritrea filed on behalf of six individuals whom Ethiopia had expelled.'

${ }^{58}$ Ibid, '[i]f not for this deadline, then the parties might have considered collecting individuals' claims and utilizing the mass claims procedure'.
} 
The automatic reduction in the compensation paid to the individual applicants, commensurate with the percentage of unmeritorious claims in the sample, would likely have encouraged the states to exercise diligence in the collection and presentation of claims. A similar mechanism would be inherently unfair in a system where individuals can present the applications in their own name, a model that is most appropriate for a potential Joint Scheme. To the contrary, the adoption of a sample review might be an efficient solution, especially if applications share a common factual matrix and certain gateway issues are positively established for each claim (the identity of the claimant or the plausibility of their involvement in the chronological and geographical scenario of the injustice).

\section{Iraq/Kuwait Reparations}

After the end of the Gulf War of 1990-1991, the UN Security Council issued Resolution 687 in which it reaffirmed Iraq's liability for all damages caused by the unlawful occupation of Kuwait. ${ }^{59}$ It also called for the creation of a fund and a commission for the compensation of claims relating to such liability, including those brought by individuals. ${ }^{60}$ The United Nations Compensation Commission (UNCC) was thus created. ${ }^{61}$ Some of its operational features are of interest to our current purposes.

In particular, the UNCC had jurisdiction over an enormous number of individual claims for damages up to US\$100,000 (' $\mathrm{C}$ ' claims, referring to its dedicated category). It noted in its first decision that '[t]he complexities associated with the processing of "C" claims, requiring the resolution of myriad legal, factual, evidentiary and valuation issues, are compounded by the massive number of claims in this category-in excess of $415,000,{ }^{62}$ Since these complexities are, in part, comparable to those with which a Joint Scheme might have to cope, if the eligibility criteria are wide enough, it is helpful therefore to observe the solutions adopted by the UNCC.

The UNCC started from an assumption of Iraq's responsibility, and circumscribed its review to the issue of causality and quantum. ${ }^{63}$ With a view to process all ' $\mathrm{C}$ ' claims in an expedited way, the rules provided for the possibility to resort to a sample analysis of the merits of the individual claims. ${ }^{64}$ The Panel of

\footnotetext{
${ }^{59}$ UN Security Council, Resolution 687, S/RES/687, 3 April 1991, para 16.

${ }^{60}$ Ibid, paras 18 and 19.

${ }^{61}$ For more information see United Nations Compensation Commission (UNCC); see www.uncc. $\mathrm{ch} /$.

${ }^{62} \mathrm{UNCC}$, Report and Recommendations Made by the Panel of Commissioners Concerning the First Instalment of Individual Claims for Damages up to US\$100,000 (Category 'C' Claims), S/AC.26/ 1994/3, 21 December 1994, 6.

${ }^{63}$ Ibid, 9.

${ }^{64}$ Provisional Rules for Claims Procedure, S/AC.26/1992/10, 26 June 1992, Art 37(b): 'With respect to claims that cannot be completely verified through the computerized database, if the
} 
Commissioners, moreover, made its recommendations based on the documents submitted. ${ }^{65}$ This approach suggested the possibility that full evidence would not be required for every claim; indeed, the applicable rule suggests that ' $\mathrm{C}$ claims' must satisfy a relatively low evidentiary threshold, and that the smaller claims among them might be treated even more leniently:

With respect to "C" claims, Article 35(c) of the Rules provides that the claims must be documented by appropriate evidence of the circumstances and amount of the claimed loss. Documents and other evidence required will be the reasonable minimum that is appropriate under the particular circumstances of the case. A lesser degree of documentary evidence ordinarily will be sufficient for smaller claims such as those below US\$20,000. ${ }^{66}$

The Panel of Commissioners, explaining what documents might suffice to achieve a 'reasonable minimum' of evidence, stressed the importance of the claim form-corroborated by the self-declaration of veracity of the applicant and the sanctions that domestic law attaches to false statements. Alongside the claim form, the Panel considered identification documents, personal and witness statements, and other documents that could be probative of the loss claimed.

The Panel, called to consider the 'particular circumstances of the case', in determining the standard of proof required, noted all the reasons, in the circumstances of the invasion, why the applicants might not have been able to withhold, conserve and present fuller evidence in support of their claims. ${ }^{67}$ It was also noted that the scarcity of evidence in support of mass claims 'is not a phenomenon without precedent' in international practice. Therefore, the upholding of claims that, taken individually, present less than optimal evidentiary support is acceptable, owing to the circumstances in which the applicants had to gather the evidence and the nature of the UNCC's mandate. ${ }^{68}$

This is a lesson that might apply all the more plausibly to a hypothetical Joint Scheme, given that the general elements of the injustices attributed to Germany are known and that the applicants would probably not seek precise amounts of compensation relating to material losses. A Joint Scheme might be spared the difficult

volume of claims is large, the Panel may check individual claims on the basis of a sampling with further verification only as circumstances warrant.'

${ }^{65} \mathrm{Ibid}$, Art 37(c).

${ }^{66} \mathrm{Ibid}$, Art 35(c), reproduced in UNCC, Report, 1994 (n 62), 22 (emphases added).

${ }^{67} \mathrm{Ibid}, 26$.

${ }^{68}$ Ibid, 29. The panel also recalled the remark made in the Study Concerning the Right to Restitution, Compensation and Rehabilitation for Victims of Gross Violations of Human Rights and Fundamental Freedoms, presented by Theo van Boven, the Special Rapporteur appointed by the Sub-Commission on Prevention of Discrimination and Protection of Minorities of the UN Commission on Human Rights (UN Commission on Human Rights, E/CN.4/Sub.2/1993/8, 2 July 1993, available at http://hrlibrary.umn.edu/demo/van\%20Boven_1993.pdf. In particular, para 137 of the Study states that '[a]dministrative or judicial tribunals responsible for affording reparations should take into account that records or other tangible evidence may be limited or unavailable. In the absence of other evidence, reparations should be based on the testimony of victims, family members, medical and mental health professionals.' 
determination of causation and quantum that complicated the task of the UNCC. A system based on eligibility through status (eg, the applicant's condition as IMI, or heir of a victim of mass killings) and pre-fixed compensation amounts would render the review of applications significantly easier.

\section{Comfort Women}

In December 2015, Japan and South Korea reached an agreement aimed ostensibly at resolving interstate tensions with regard to Japan's practice of enforced prostitution during World War II (the so-called 'comfort women' phenomenon). ${ }^{69}$ The issue of 'comfort women' has plagued relations between the two states for decades, ${ }^{70}$ along with several other historical disputes, ${ }^{71}$ in part due to Japan's unflinching stance.

Japan, indeed, has openly accepted only its 'moral responsibilities', ${ }^{72}$ and tried to assuage the victims through monetary contributions ex gratia channelled through a newly established Asian Women's Fund (AWF). Such emoluments have not always been so well received; NGOs urged victims to boycott the $\mathrm{AWF}^{73}$ and many survivors refused to accede the payments, noting Japan's refusal to own up to its historical responsibility and provide full reparation. ${ }^{74}$ In short:

The women who would become military sex slaves have uniformly indicated that they are unsatisfied with Japan's engagement with the comfort women issue. This has been largely due to the lack of an apologetic stance by Japan. The consistent denial, acknowledgment, and then blaming the victims for the injustices experienced, has lent credence to the viewpoint that the Japanese government is insincere in its efforts to come to terms with the past. $^{75}$

\footnotetext{
${ }^{69}$ See a recent account of the controversy in Torsten Weber, 'Apology Failures: Japan's Strategies Towards China and Korea in Dealing with Its Imperialist Past', in Berber Bevernage/Nico Wouters (eds), The Palgrave Handbook of State-Sponsored History After 1945 (London: Palgrave Macmillan 2018), 801-816, at 804 et seq.

${ }^{70}$ See, for instance, Naomi Roht-Arriaza, 'Reparations in the Aftermath of Repression and Mass Violence', in Eric Stover/Harvey M Weinstein (eds), My Neighbour, My Enemy: Justice and Community in the Aftermath of Mass Atrocity (Cambridge: CUP 2010), 121-140, at 128-129; Cheah Wui Ling, 'Walking the Long Road in Solidarity and Hope: A Case Study of the Comfort Women Movement's Deployment of Human Rights Discourse', Harvard Human Rights Journal 22 (2009), 63-107.

${ }^{71}$ Spanning across trade disputes, territorial disputes, disputes on the reparations for World War II forced labourers.

${ }^{72}$ Japan's Prime Minister Junichiro Koizumi, Letter to the Former Comfort Women, [exact day unspecified] 2001, available at www.mofa.go.jp/policy/women/fund/pmletter.html.

${ }^{73}$ Wolfe, The Politics of Reparations 2014 (n 5), 275.

${ }^{74}$ Dinah Shelton, Remedies in International Human Rights Law (Oxford: OUP 2005), 437 (recounting also Japan's initiative in 1995 to establish an Asian Women's Fund, financed by private donations, which made approximately US\$19,000 available to each comfort woman).

${ }^{75}$ Wolfe, The Politics of Reparations 2014 (n 5), 276.
} 
Alongside an overdue acknowledgement of generic 'responsibilities', 76 and Japanese Prime Minister Shinzō Abe's conveyance of 'his most sincere apologies and remorse', 77 the 2015 agreement contemplated a Japanese contribution of a modest sum (approximately US $\$ 8.8$ million) towards the establishment of a Korean foundation supporting former comfort women. The Foundation for Reconciliation and Healing was effectively created in July 2016 and received the promised amount by the Japanese government. The Korean government looked after the payment of approximately US\$18,000 to the families of deceased comfort women and US $\$ 90,000$ to those still alive. ${ }^{78}$ It might be worth noticing that, out of an estimated 80,000 to 200,000 victims, only 238 Korean women have come forward to register with the scheme, of whom just 46 were alive at the time of the 2015 agreement, ${ }^{79}$ 37 in July $2017,{ }^{80} 31$ in January 2018, ${ }^{81} 27$ in November 2018, ${ }^{82} 22$ in March $2019,{ }^{83} 19$ in January 2020, and 17 in August 2020. ${ }^{84}$

In spite of the payments, the deal attracted criticism in South Korea. It was widely perceived as a diplomatic defeat for Korea and as Japan's successful attempt at

\footnotetext{
${ }^{76}$ The wording of the statement is carefully crafted to mention the notion of responsibility without attaching it to anyone in particular: 'The issue of comfort women, with an involvement of the Japanese military authorities at that time, was a grave affront to the honor and dignity of large numbers of women, and the Government of Japan is painfully aware of responsibilities from this perspective.' See the full text of the Announcement by Foreign Ministers of Japan and the Republic of Korea at the Joint Press Occasion of 28 December 2015, available at www.mofa.go.jp/a_o/na/kr/ page4e_000364.html.

${ }^{77}$ Ibid, point 1 .

${ }^{78}$ Benjamin Lee, 'South Korea-Japan Comfort Women Agreement: Where Do We Go from Here?', The Diplomat, (6 September 2016), available at https://thediplomat.com/2016/09/south-koreajapan-comfort-women-agreement-where-do-we-go-from-here/.

${ }^{79}$ Benjamin Lee, 'South Korea, Japan Agree to Irreversibly End "Comfort Women" Row', The Diplomat, (28 December 2015), available at www.reuters.com/article/us-japansouthkoreacomfortwomen/south-korea-japan-agree-to-irreversibly-end-comfort-womenrowidUSKBNOUB0EC20151228.

${ }^{80}$ 'Head of South Korean "Comfort Women" Foundation Resigns; Survivor Who Testified in U.S. Dies', The Japan Times, (23 July 2017), available at www.japantimes.co.jp/news/2017/07/ 23/national/politics-diplomacy/head-south-korean-foundation-comfort-women-steps/\#. WhoBQkqnHIU.

${ }^{81}$ Hyonhee Shin, 'Japan Rejects South Korean Call for Extra Steps over "Comfort Women", Reuters, (9 January 2018), available at www.reuters.com/article/us-korea-japan-comfortwomen/ japan-rejects-south-korean-call-for-extra-steps-over-comfort-women-idUSKBN1EY0F6.

${ }^{82}$ 'South Korea Says It Will Dissolve Japan-funded "Comfort Women" Foundation', The Japan Times, (21 November 2018), available at https://www.japantimes.co.jp/news/2018/11/21/national/ politics-diplomacy/south-korea-says-will-dissolve-japan-funded-comfort-women-foundation.

${ }^{83}$ 'Another Comfort Woman Survivor Passes Away without Apology from Japanese Government', Hankyoreh, (4 March 2019), available at http://english.hani.co.kr/arti/english_edition/e_interna tional/884479.html.

${ }^{84}$ 'Another Korean sexual slavery victim dies, number of survivors at 19', The Korea Herald, (23 January 2020), available at http://www.koreaherald.com/view.php?ud=20200123000650\& ACE_SEARCH $=1$; 'Commemorative ceremony marking Int'l Memorial Day for Comfort Women to be held in Cheonan', Arirang, (14 August 2020), available at http://www.arirang.com/News/ News_View.asp?sys_lang $=$ Eng\&nseq $=263353$.
} 
resolving 'finally and irreversibly' the row with South Korea without trying to meaningfully engage either with the victims or with its own responsibility. ${ }^{85}$ The deal came under severe scrutiny and the newly incumbent Korean government announced that it would revise its terms, causing the head of AWF to resign. ${ }^{86}$ The impression that the agreement did not take into account the voice of the victims has been compounded by Japan's attempts at silencing protests and condemning the erection of memorials. These actions are perceived as furthering an intention to erase the memory of the victims and, as a consequence, the country's full assumption of past responsibility. ${ }^{87}$ Japan's refusal to issue a letter of apology after the 2015 agreement and South Korea's refusal to remove statues paying tribute to comfort women installed in the vicinity of Japanese embassies paved the way for the current renewal of diplomatic tensions. ${ }^{88}$

In late 2017, the Korean minister of foreign affairs requested a revision of the agreement, but his Japanese counterpart, hinting at its interstate nature, refused to re-open the deal: ${ }^{89}$

The Japan-South Korea agreement is an agreement between the two governments and one that has been highly appreciated by international society (...). If the South Korean government (...) tried to revise the agreement that is already being implemented, that would make Japan's ties with South Korea unmanageable and it would be unacceptable. ${ }^{90}$

\footnotetext{
${ }^{85}$ The ambiguity of monetary payments in restorative efforts-especially when compensation is inherently incommensurable with the harm suffered and is inevitably low-is a known phenomenon. See Vermeule, 'Reparations' 2005 (n 8), 10: 'Offering an apology for some wrong one has committed would usually become a more offensive gesture, rather than a more credible expression of remorse, were a $\$ 100$ bill to be thrown in - although this may be a strictly interpersonal point that does not hold for government payments.' The South Korean case shows that the point can hold, at least in certain circumstances, also in respect of government payments, although the interstate dimension and the memory of war scenarios might exacerbate the problem. Wolfe, The Politics of Reparations 2014 (n 5), 274, remarked on the dichotomy between the domestic and the international take on the atrocities committed by Japan. In spite of the reparation scheme established, the prevailing view in Japan has remained one of denial: '[T]he tension between the international memory and the domestic memory indicates that acceptance is still contentious within Japan.'

${ }^{86}$ See Lee, 'South Korea, Japan Agree' 2017 (n 79).

${ }^{87} \mathrm{See}$, for instance, the letter sent on 1 February 2017 by the Mayor of Osaka to the Mayor of San Francisco to protest the instalment of a Comfort Women Memorial. This action is described as being 'adverse to the spirit of the agreement [with South Korea]', available, in full, at https://ww2. kqed.org/arts/wp-content/uploads/sites/2/2017/09/Ltr-of-Osaka-mayor-opposing-CWM-2-1-2017. pdf.

${ }^{88}$ Ilaria Maria Sala, 'Why Is the Plight of "Comfort Women” Still So Controversial?', The New York Times, (14 August 2017), available at www.nytimes.com/2017/08/14/opinion/comfort-womenjapan-south-korea.html.

${ }^{89}$ Annemarie Luck, 'No Comfort in the Truth: It's the Episode of History Japan Would Rather Forget. Instead Comfort Women Are Back in the News', Index on Censorship 47(1) (2018), 19-21.

${ }^{90}$ 'Japan Says Revising Comfort Women Agreement with South Korea Unacceptable', Reuters, (27 December 2017) available at https://uk.reuters.com/article/uk-southkorea-japancomfortwomen-kono/japan-says-revising-comfort-women-agreement-with-south-korea-unaccept able-idUKKBN1EL0IJ.
} 
Korea back-pedalled somewhat on its threat to denounce the agreement, but refused to use the funds provided by Japan, opting instead to inject the necessary funds to replace them from its own budget. ${ }^{91}$

The 2015 agreement has been 'effectively abandoned"92 and in December 2019 the Constitutional Court of South Korea has determined that, since it did not establish clear rights and duties for the two countries, it cannot be set aside for infringing on the victims' constitutional rights. In January 2021, a Seoul Central District Court condemned Japan to pay approximately $\$ 92,000$ each to the 12 surviving victims. ${ }^{93}$ The non-agreement remains, and so does the disagreement between the two countries.

As of early 2021, Japan has not obtained irreversible closure, and the South Korean government has received criticism from its own citizens for its mishandling of the negotiation and having to pay its way out of the mess. Furthermore, the victims have expressed no feeling of satisfaction, and the citizens of both countries have grown increasingly uneasy about the issue. None of the sought-after goals of the agreement have materialized. The circumstances evince the faux pas of the respective state authorities, who have struck a deal without consulting nor paying meaningful considerations to the victims. ${ }^{94}$

There are certain obvious differences between the Japan-South Korea tensions and the prospect of providing reparation to IMIs and other victims. The most evident is that Japan is hesitant to embrace its full responsibility and actively tries to erase the memory of the injustices (or at least what it believes to be exaggerated representations thereof), whereas Germany has unquestionably accepted legal responsibility for war crimes committed. This crucial difference might contribute to reducing the risk of a Joint Scheme being rejected by the beneficiaries on the grounds that it merely represents a buy-out. However, the lesson learnt from the fragile fate of the

\footnotetext{
${ }^{91}$ 'South Korea Not Seeking Renegotiation over Comfort Women Deal with Japan', Reuters, (9 January 2018): 'South Korea's Foreign Minister Kang Kyung-wha said it was "undeniable" the two governments formally reached the settlement, under which Japan apologised to victims and provided 1 billion yen ( $\$ 8.8$ million) to a fund to support them. Seoul will set aside its own budget to bankroll the fund and consult with Tokyo on what to do with the 1 billion yen it had given, she said', available at https://www.abc.net.au/news/2018-01-09/s.korea-not-seeking-to-renegotiate-comfortwomen-deal-with-japan/9315556.

92 'South Korea court upholds Japan 'comfort women' deal', The Straits Times, (28 December 2019), available at https://www.straitstimes.com/asia/east-asia/south-korea-court-upholds-japancomfort-women-deal.

${ }^{93}$ Seoul Central District Court, Judgment of 8 January 2021, No 2016 Ga-Hap 505092; see Daniel Franchini, 'South Korea's denial of Japan's immunity for international crimes: Restricting or bypassing the law of state immunity?', Voelkerrechtsblog, (18 January 2021), available at https:// voelkerrechtsblog.org/south-koreas-denial-of-japans-immunity-for-international-crimes/

${ }^{94}$ Weber, 'Apology Failures' 2017 (n 69), 804: 'Instead of offering an "apology” (shazai or owabi in Japanese), the terms used to convey notions of self-critical reflection were "true regret" (makoto ni ikan) in the Korean case, as well as "deep remorse" in both the Korean and Chinese cases (...). These phrases were apparently regarded as sufficient by the respective state leaders, who prioritized receiving Japanese economic assistance over emphasizing Japan's historical guilt' [notes omitted].
} 
2015 agreement is that the two states concerned must involve the victims or their representatives during the negotiation stage, and make sure that the outcome is at least reflective of their voices and acknowledges their requests. In this respect, the mere allocation of monetary awards might fall short of satisfactory reparation if the victims are cut out of the process. Reparation cannot function independently of reconciliation, and reconciliation is not solely an interstate matter.

There is, however, a striking similarity between the two scenarios. Given the shared factual taxonomy of the two underlying injustices (occurring between 80 and 70 years ago), the surviving victims are now few in numbers and are dying at an accelerating rate. A provision for the compensation of deceased victims' families, at a reduced rate, might prove acceptable. Alternatively, the Joint Scheme might provide for the descendants' right to seek full compensation on behalf of deceased IMIs if death occurred after a specific cut-off date, which might very well be set in the past (eg 2004, the date of the first Ferrini judgment, ${ }^{95}$ or February 1999, the cut-off date established in the RRF Law). Safeguards such as these would defuse the obnoxious result that any delay in fulfilling the moral duty of providing reparation might directly diminish the burden of its realization, due to the shrinking pool of beneficiaries.

\section{The US/France Agreements on Banks and Railroad Deportees}

\section{a) The 2001 Banks Agreement}

In 2001, France and the US stipulated an agreement regarding the restitution of sums held on bank accounts opened with certain French banks that had been frozen as a result of anti-Semitic legislation (the Washington Agreement). ${ }^{96}$ France committed to obtaining from the banks a US $\$ 100$ million contribution for a dedicated foundation. ${ }^{97}$ The banks also committed themselves to pay restitution claims approved by the Commission for the Compensation of Victims of Spoliation (Commission pour l'indemnisation des victimes de spoliations, or CIVS). ${ }^{98}$ The US pledged to inform

\footnotetext{
${ }^{95}$ Corte di Cassazione, Judgment of 11 March 2004, No 5044/04 (Ferrini).

${ }^{96}$ See Agreement between the Government of the United States of America and the Government of France Concerning Payments for Certain Losses Suffered During World War II (the Washington Agreement), 18 January 2001, 2156 UNTS 281, as amended 30 and 31 May 2002, 21 February 2006 (entered into force 5 February 2001).

${ }^{97}$ Fondation pour la Mémoire de la Shoah (Foundation for the Memory of the Shoah), created in France on 26 December 2000.

${ }^{98}$ For more information see www.civs.gouv.fr/. With decree No 99-778 of 10 September 1999, the French Government created a Commission for the Compensation of Victims of Spoliation Resulting from Anti-Semitic Legislation in Force during the Occupation, available at https://www.legifrance. gouv.fr/affichTexte.do?cidTexte $=$ LEGITEXT000005628500\&dateTexte $=20081229$.
} 
US courts that any claims against the French banks should be dismissed as contradicting US foreign policy interests, ${ }^{99}$ effectively designating the CIVS procedure as the preferred avenue for such claims. ${ }^{100}$

Annex B to the Washington Agreement defined the working procedure of the CIVS as one of considering the individual claims. Of particular interest is the indication that ' $[\mathrm{t}]$ he Commission will investigate and consider claims on relaxed standards of proof. A claimant's application or a simple inquiry by the claimant to the existence of a bank asset is sufficient to trigger an investigation'. ${ }^{101}$ The operation of this relaxed standard of proof is further explained when the recommendation powers of the Commission are addressed:

Following such an investigation and after communication with the claimant or their representative (...) if an account can be verified by any means, including because the claim matches a name or account on a list or other document available to the Commission, the Commission makes a recommendation on an award together with the reason(s) for that recommendation (...) the Commission will recognize as sufficient evidence to make an Award any of the following four categories: proof, presumption, indication, and intimate personal conviction. ${ }^{102}$

In other words, the Commission procedure hinged on a highly favourable standard of proof ('any means' including a plausible affidavit by the applicant ${ }^{103}$ could be sufficient to demonstrate the existence of an expropriated account) and a favourable burden of proof (the evidence might be provided by the CIVS itself rather than by the applicant). First instance decisions by the CIVS could be appealed. $^{104}$

The scheme was strictly restitutory in nature, and the Commission was not entitled to reduce the amount of compensation for any reason other than double recovery: ${ }^{105}$ the balance on the accounts would have to be repaid in full, subject to certain rounding adjustments. Until 2005, it was also possible to receive compensation of up to US $\$ 3,000$ merely on the basis of an affidavit, even if the Commission was unable to ascertain the existence of the account claimed by the applicant. ${ }^{106}$

\footnotetext{
${ }^{99}$ Washington Agreement, 2001 (n 96), Art 2.

${ }^{100}$ Consider, however, point 9 of Annex $\mathrm{C}$ to the Washington Agreement, which reproduces the Statement of Interest of the US to be submitted in the domestic proceedings: 'The United States does not suggest that its policy interests concerning the Foundation in themselves provide an independent legal basis for dismissal.' This language is perhaps obligatory to preserve the separation of powers between the executive and judicial branches.

${ }^{101}$ Washington Agreement, 2001 (n 96), Annex B.

${ }^{102}$ Ibid, principles B and D.

${ }^{103}$ Ibid, principle F.1. See also Exhibit 2 for a model of the affidavit.

${ }^{104} \mathrm{Ibid}$, principle K.

${ }^{105}$ Ibid. The Commission was also prevented from offsetting part of the compensation against other payments received by the applicants in the form of material or non-material damages.

${ }^{106} \mathrm{An}$ overview of the liquidation principles is available at www.civs.gouv.fr/en/gettingcompensation/specific-provisions-relating-to-bank-related-compensation/; 'Soft-claims' (ie, those deprived of sufficient evidence) would be paid out of a dedicated fund, capped at US\$22.5 million.
} 
Since the claims submitted to the CIVS under the Washington Agreement were only for restitution, the scheme might be a poor template for any future Joint Scheme, which would presumably focus on reparation or quasi-compensation. However, the technical provisions relating to the evidentiary regime used by the CIVS to review claims are worth taking into account, as they aimed at addressing evidentiary complications that are similar to those the IMIs and other victims might encounter.

The imposition of forced labour or the occurrence of mass killings, similar to the blocking of the French bank accounts, is not a controverted fact; several decades have passed since the unjust actions occurred and the affected individuals' age and personal history might undermine attempts to retrieve a full documentation of the harms suffered. In this respect, the value of individuals' affidavits as presumptive evidence is a possible solution that would respond to the need to afford applicants with fair treatment in the operation of a Joint Scheme for compensation.

\section{b) The 2014 Railroad Deportees Agreement}

In December 2014, the governments of France and the US stipulated an agreement regarding the treatment of certain holocaust victims - those deported from French territory who had not been covered by previous reparation schemes. ${ }^{107}$

The explicit purpose of the agreement and the compensation mechanism established therein was to achieve 'legal peace' with respect to all claims against France asserted in US courts. ${ }^{108}$ France pledged US\$60 million to a US account, from which the US government would draw funds to pay individual claimants. In return, the US would recognize French immunity, terminate legal actions pending in US courts and ensure that the beneficiaries of the compensation schemes would execute waivers of further action against France. ${ }^{109}$ The US and its affiliated authorities would take full responsibility for the distribution of the funds to the

See, for a discussion of the restitution scheme, Michael J Bazyler, 'The Holocaust Restitution Movement in Comparative Perspective', Berkeley Journal of International Law 22 (2002), 11-44, at 18-19.

${ }^{107}$ See also Riccardo Pavoni, chapter 'A Plea for Legal Peace', in this volume. Agreement between the Government of the United States of America and the Government of the French Republic on Compensation for Certain Victims of Holocaust-Related Deportation from France Who Are Not Covered by French Programs (Railroad Deportees Agreement), 8 December 2014, 55 ILM 339 (2016), available at https://www.state.gov/wp-content/uploads/2019/04/us_france_agreement. pdf.

${ }^{108}$ Railroad Deportees Agreement, 2014 (n 107), Art 4.1: 'The Parties agree that this payment constitutes the final, comprehensive, and exclusive manner for addressing, between the United States of America and France, all Holocaust deportation claims not covered by existing compensation programs, which have been or may be asserted against France in the United States of America or in France.' See also Art 4.2.

${ }^{109}$ Ibid, Art 5. An Annex to the Agreement spells out the waivers and relinquishments that all applicants will be required to sign in order to access the payment. 
victims and establish the appropriate procedure without French input; ${ }^{110}$ the US established a Deportation Claims Program that is currently processing claims. ${ }^{111}$

The programme reaches widely ratione personae. Alongside those individuals deported from France who remain alive, the programme covers their spouses and thus envisages two main categories of beneficiaries: survivors and surviving spouses. Furthermore, estates (heirs or assigns) of either category are entitled to receive compensation if the death occurred between 1948 and the date of the application. Subject to the territorial link inherent in the requirement of deportation from France, there is no nationality requirement. Whilst the incompatibility of the programme with other pre-existing compensation schemes rules out claims from citizens of certain nationalities, ${ }^{112}$ anyone can apply (ie, not just US nationals).

The US provided applicants with a statement of claim form, which required them to provide 'all available identifying information and documentation regarding the relevant individual's deportation from France during World War II, including if possible the date, convoy, and place of departure and arrival of such deportation'. The form also reminded applicants of the criminal implications in making a false statement.

The amount of compensation envisaged was significantly higher than those awarded in the schemes discussed thus far. According to the estimates released by the claims programme, survivors would receive US\$204,000 and all surviving spouses whose deported spouse died prior to 1948 would receive US\$51,000. Surviving spouses of deportees who died in or after 1948 would receive US\$750 for each year after the deportee's death. Estates of survivors or surviving spouses would receive a fraction of the amounts above, calculated on the period of survival of the eligible individual during the 1948-2015 period. ${ }^{113}$

A comment on the size of the payments is in order. ${ }^{114}$ The negotiating history shows that the allocated amount of US\$60 million was arrived at by knowing an estimate of the number of beneficiaries (486) and that the resulting average compensation of US\$100,000 would correspond to roughly 3 years of disability pension

\footnotetext{
${ }^{110}$ Ibid, Art 6.

${ }^{111}$ For more information see https://www.state.gov/notice-regarding-holocaust-deportation-claimsprogram-under-u-s-france-agreement/.

${ }^{112}$ Namely, those of France, Belgium, Poland, the UK, and the former Czechoslovakia. See FAQ page of the Claims Programme, available at https://2009-2017.state.gov/p/eur/rt/hlcst/ deportationclaims/250658.htm.

${ }^{113}$ More specifically, 'estates of survivors and estates of surviving spouses [would receive] a yearly percentage of the full $\$ 204,000$ and $\$ 51,000$ amounts, respectively. Estates of survivors will receive $\$ 3,000$ for each year that the survivor lived, beginning with 1948 and ending in 2015. Estates of surviving spouses will receive $\$ 750$ for each year that the surviving spouse lived after the year of the deportee spouse's death, again beginning with 1948 and ending in 2015.' See Claims Programme, FAQ page (n 112).

${ }^{114} \mathrm{~A}$ fuller analysis, providing the basis for the brief remarks in the text, is offered in Ronald Bettauer, 'A Measure of Justice for Uncompensated French Railroad Deportees during the Holocaust', ASIL Insights, (1 March 2016), available at https://www.asil.org/insights/volume/20/issue/5/ measure-justice-uncompensated-french-railroad-deportees-during-holocaust.
} 
under French law. ${ }^{115}$ Though it is difficult to assess the congruity of these calculations in the abstract, it is possible to note their large relative amount, as well as the low number of expected beneficiaries, which permitted the adoption of a quasicompensatory approach (as opposed to the merely reparatory scheme adopted, for instance, in the RRF Law).

This scheme is interesting because it has a residual character: it expressly covers beneficiaries that were excluded from previous schemes. In this light, it might be comparable to a future Joint Scheme insofar as the latter would essentially cover IMIs and other victims expressly excluded from the application of the 2001 RRF Law.

\section{A Ten-Step Sketch of a Future German-Italian Joint Scheme}

The previous sections sought to provide an overview of selected payment schemes. While the comparative analysis is beside the point (as the schemes differ widely along several variables), it is nonetheless possible to identify certain solutions that, with all due caution, appear appropriate also for the Joint Scheme. In what follows, I recapitulate some of the lessons learnt from this anthological survey into a ten-step sketch.

\section{Reparation or Compensation}

The Joint Scheme would plausibly grant reparation falling short of full compensation. A reasonable approach would be to consider it an extension of the RRF payment scheme. Since the whole IMI issue apparently flows from war prisoners being excluded from the RRF Law, a reliable starting point would be to ensure that the Joint Scheme produces the effects that the RRF Law could have produced had it applied to IMIs. Along these lines, it might be helpful to recall the number of IMI applications that were rejected under the RRF scheme if we are to have a working estimate of the number of beneficiaries of the Joint Scheme. ${ }^{116}$ Full compensation might be an ambitious but impracticable target, let alone a conceptually thorny issue

\footnotetext{
${ }^{115}$ Ibid, drawing extensively from the reports of the French National Assembly and the French Senate.

${ }^{116}$ According to Italy's Counter-Memorial in the Jurisdictional Immunities case before the ICJ, 127,000 such applications were rejected; see ICJ, Jurisdictional Immunities of the State (Germany $v$ Italy), Counter-Memorial of Italy of 22 December 2009, para 2.21.
} 
when (and if) reserved to heirs and descendants. ${ }^{117}$ The express language of the DART scheme, which opted for the reparation label, could serve as a template.

\section{Funding}

That Germany and Italy will both contribute to the finances of the Joint Scheme can at this stage only be assumed. Multi-source funding is not unprecedented (the German government and industry both supported the RRF Fund, for instance) and would facilitate the accumulation of a decently sized budget. Ideally, Germany would pledge to match Italy's contribution, so that an example of virtue rather than strained negotiations might ensure the scheme's financial capacity. An alternative method of quantifying the contributions to the fund, suggested by Jörg Luther, ${ }^{118}$ could be to measure them against the size of the respective national populations (roughly 82 million for Germany and 60 million for Italy). A raw equivalence of 1 person $=€ x$ would be tenable and acknowledges population differences between the two countries in setting the criterion for a comparable economic contribution. With $\mathrm{x}=€ 1$, this calculation would roughly amount to a $€ 140$ million fund, which could ensure the payment of roughly $€ 1,000$ to a number of claimants similar to those who saw their applications rejected under the RRF Law. ${ }^{119}$ It appears preferable that $\mathrm{x}>1$ (see next step), unless the estimated number of applicants is much lower. Interestingly, in one twist of the Japan-South Korean feud over the issue of comfort women, Korea has strived to increase the legitimacy of the reparation scheme by unilaterally financing the budget and announcing that the funds provided by Japan will not be used. In other words, the contribution from the state to whom the nationality of the victims belong is a powerful gesture: it avoids the impression that any agreement between the states reflects a political sellout. $^{120}$

\footnotetext{
${ }^{117}$ See, generally, Tyler Cowen, 'How Far Back Should We Go? Why Restitution Should Be Small', in Jon Elster (ed), Retribution and Reparation in the Transition to Democracy (Cambridge: CUP 2006), 17-32. Whilst the author mostly refers to restitution, the legitimacy of intergenerational compensation is similarly dubious. See also Giovanni Boggero/Karin Oellers-Frahm, chapter 'Between Cynicism and Idealism', in this volume.

${ }^{118}$ See Jörg Luther, chapter 'A Story of "Trials and Errors" that Might Have No Happy End', in this volume.

${ }^{119}$ See $\mathrm{n} 12$.

${ }^{120}$ See also Francesco Francioni, chapter 'Overcoming the Judicial Conundrum', in this volume.
} 


\section{The Amount Paid to Each Victim}

It is perhaps inevitable that IMIs and other victims receive a lump sum rather than compensation reflecting the specific damage suffered. Most systems described above adopt this lump-sum approach and the benefits in terms of expediency seem to outweigh a concern for accuracy, insofar as fair treatment is assured to all applicants. It is difficult to tell whether the system should envisage only one lump sum or a range of amounts, corresponding to several types of injustice suffered (for instance, longlasting conditions caused by forced labour might warrant a more generous reparation). The DART and RRF schemes opted for graduated amounts, but the latter essentially lumped all victims into two macro-groups ('concentration camps' and 'others'). The reparation offered to comfort women was also undifferentiated in amount. In the interest of expediting the processing of claims, the adoption of a one-size-fits-all quantum should be favourably considered. As to the magnitude of the payment, it will inevitably depend on the size of the available fund and the number of eligible applicants. Of the schemes described above, the ones that directly provided reparation for personal harms (rather than restitution) converged around a figure of US\$50,000 (the DART scheme, the reparation offered to comfort women, and railroad deportees), but the number of eligible individuals was much smaller than that of eligible IMIs and other victims. A lump sum in the $€ 10,000-€ 20,000$ bracket might be considered fair given the circumstances. A system of partial payment mechanisms could be set up, when the estimate of the number of applicants is particularly difficult and, accordingly, the amount available to each is difficult to pin down in advance. Partial payments could ensure the possibility of paying late applications and prevent the premature depletion of funds when the number of applicants is unexpectedly high or the available budget is insufficient to cover full payment to every applicant. Once all applications are processed, the residual funds can be distributed to make up for what reparations remain, or even fund further projects if any money is left unallocated.

\section{The Management of the Fund and the Organs Overseeing Its Distribution}

Again, it might be worth looking at the RRF scheme as a template. The Joint Scheme would be run by a body participated in equal measure by the German and Italian governments, that might decide to integrate its structure with representatives from civil society, victims' associations, and technical experts. The body tasked with the review of applications and liquidation of claims would reflect this balanced makeup, and operate as an administrative office, as in the DART experience, with an internal capacity to perform, upon request, the review of individual decisions. 


\section{The Eligibility Criteria}

Specific criteria should be drafted to ensure that beneficiaries correspond to the categories left out of the RRF Law: primarily war prisoners subjected to forced labour, but other internees and victims of mass killings should also be included. Limiting reparation to Italian citizens (unlike the French banks scheme) might be understandable since Italy would be responsible for the Scheme's funding. A possibility worth discussing is that claims be aggregated into mass claims (as in the Eritrea/Ethiopia scheme), or at least that the governing body make available partially pre-filled application forms for prospective applicants. Forms could be divided into categories, according to the distinguishing features of the crime at stake and the factual coordinates (provenance of the applicant, timeframe, location, and conditions of the killing/internment/forced labour). The Joint Scheme would have the same advantage as the UNCC, which reviewed the claims against Iraq: the issue of responsibility would not be in question. Since the Joint Scheme would most probably warrant reparation rather than compensation for specific damages, the issue of causation and the determination of quantum would also be minimized in the proceedings. A mere scrutiny of eligibility could suffice.

\section{The Treatment of Heirs}

The notion of descendants being eligible for compensation is not immediately intuitive. On the one hand, it defies the immediate realization that compensation should benefit the individual harmed and provide a modicum of relief for the direct victim rather than material enrichment for their family. On the other hand, two circumstances might militate in favour of providing reparation to heirs as a means to achieve fairness. First, the death of the victim might be a precise consequence of the injustice-especially in the case of mass killings, but also when the suffering of forced labour takes a permanent toll on a person's health. Second, the legal deadlock has inevitably entailed that the death of multiple victims might have occurred before the granting of reparation, which is an odious side effect of the slow course of justice (a second-order instance of injustice). In that light, 'the rough intuition is that, in strictly comparative terms, there is no better stand-in for the deceased payees-a view that seems vague and difficult to defend, but that strikes many as superior to the alternative of awarding no money at all' ${ }^{121}$ Moreover, relatives of the Italian victims have arguably suffered directly from the crimes committed, especially those causing death or permanent bodily harm. In some respect, therefore, the heirs are also direct victims of the injustice. The Joint Scheme would be too little too late, but it could be understood as a form of 'rough justice'122 and its shortcomings might be acceptable

\footnotetext{
${ }^{121}$ Vermeule, 'Reparations' 2005 (n 8), 8.

${ }^{122}$ Ibid.
} 
if certain safeguards were implemented. One such safeguard concerns the eligibility of heirs: Italian victims are either dead or elderly. Without a specific mechanism to avoid delays frustrating its goal, the whole exercise would be emptied of meaning. If anything, this scenario would exacerbate rather than remedy the injustice. Reduced payments to victims' heirs and assigns are common (for instance, consider the calculation used in the liquidation of US/French Railroad Deportees' claims and the pay-outs to the families of Korean comfort women) and might represent an acceptable compromise. Another solution might be to establish a cut-off date (for instance, February 1999, on the model of the RRF scheme) and allow the heirs to claim reparation on behalf of eligible persons deceased thereafter.

\section{The Standard and Burden of Proof}

One recurring feature of the payment schemes described above is the bestowment upon the claimants of evidentiary duties that are softer than normally expected in litigation (see, eg, the UNCC, the DART, the Eritrea/Ethiopia scheme and the US Banks and Railroads schemes). This staple of reparation processes is certainly fit for the Joint Scheme. More to the point, Germany could pledge to retrieve the applications filed with the RRF competent organizations by IMIs and process their claims automatically. In any event, applicants shall be expected to provide evidence of their identity and nationality and a template form reporting their account of the relevant circumstances of internment and forced labour. The form might facilitate the task by providing some pre-determined choices as regards places and dates, relating to known historical patterns of wrongdoing and documented flows of IMIs and other forced laborers. Applicants should be warned of the sanctions attached to the making of false statements; conversely, their affidavits, if complete, plausible and not contradicted, should warrant reparation even in the absence of other supporting documentation.

\section{The Involvement of Victims}

The Joint Scheme should include specific safeguards for offering satisfaction to the Italian victims, besides and independently of any monetary payment. ${ }^{123}$ Specific means to do so could include: issuing official declarations and individual letters to

\footnotetext{
${ }^{123}$ Satisfaction is listed among the basic forms of reparation that states should warrant in the UN Basic Principles and Guidelines on the Right to a Remedy and Reparation for Victims of Gross Violations of International Human Rights Law and Serious Violations of International Humanitarian Law, adopted and proclaimed by General Assembly Resolution, A/RES/60/147, 16 December 2005; see, in particular, principle 22. See also Andreas von Arnauld, chapter 'Deadlocked in Dualism', in this volume.
} 
restore the victims' dignity and assume responsibility (possibly, and when appropriate, on the part of both states), establishing commemorations and tributes to the victims, and including an account of the injustices in educational materials. ${ }^{124}$ It is equally important that the victims - possibly through the representative associations - are consulted during the negotiation stage and subsequently involved in the governance of the scheme. Involvement of victims might be the critical element making an otherwise unpalatable payment acceptable. ${ }^{125}$ The offer of multiple non-monetary remedies proved beneficial in the DART scheme and catered effectively to the victims' fundamental need for closure and reconciliation. ${ }^{126}$ The opposite might be said of the comfort women scheme, in which monetary reparations were perceived to be unsatisfactory by some of the victims and a large share of South Korean public opinion. As Korea and Japan have learnt the hard way, memory and respect for victims might save the day when reparation cannot make the victims whole. $^{127}$

\section{Legal Peace}

Germany will likely insist on the insertion of language specifying that any payment under the Joint Scheme would be made out of comity and a sense of moral and historical justice, rather than under any legal obligation. Moreover, in the current scenario Germany is satisfactorily shielded from individual actions by the law of sovereign immunity. Nonetheless, it would be reasonable to consider the Joint Scheme an adequate opportunity to provide legal peace to Germany from the claims of Italian victims brought before any alternative forum. ${ }^{128}$ The system of individual waivers, state commitment to redirect court actions and express relinquishment, common to some of the schemes described above (check, in particular, the language of the two US/French agreements), would serve as an appropriate model for the Joint Scheme.

\footnotetext{
${ }^{124}$ See ibid, lets d), e), g), h).

${ }^{125}$ Vermeule, 'Reparations' 2005 (n 8), 11: '[W]hether partial payment is better than nothing should depend on the political process by which the payment is accomplished, on the perceived alternatives, and on the accompanying symbolism.'

${ }^{126}$ Vernon, 'The Ethics' 2017 (n 35), 147, recorded the beneficial effects of the engaging conferencing sessions offered by the DART programme: '[C]omplainants reported immediate therapeutic benefits and a high level of satisfaction that their concerns had been thoroughly acknowledged and addressed.' These effects were recorded in the Defence Abuse Response Taskforce, Seventh Interim Report; see n 50.

${ }^{127}$ Christopher Kutz, 'Justice in Reparations: The Cost of Memory and the Value of Talk', Philosophy \& Public Affairs 32 (2004), 277-312, at 312.

${ }^{128}$ See also Riccardo Pavoni, chapter 'A Plea for Legal Peace', in this volume.
} 


\section{Speed}

This element explains itself. Beating around the bush is an indecent strategy given the age of the victims who are still alive.

\section{References}

Adler, Libby/Peer Zumbansen, 'The Forgetfulness of Noblesse: A Critique of the German Foundation Law Compensating Slave and Forced Laborers of the Third Reich', Harvard Journal on Legislation 39 (2002), 1-62

Arnauld, Andreas von, 'Damages for the Infringement of Human Rights in Germany', in Ewa Bagińska (ed), Damages for Violations of Human Rights (Heidelberg: Springer 2016), 101-136

Bazyler, Michael J, 'The Holocaust Restitution Movement in Comparative Perspective', Berkeley Journal of International Law 22 (2002), 11-44

Bettauer, Ronald, 'A Measure of Justice for Uncompensated French Railroad Deportees during the Holocaust', ASIL Insights, (1 March 2016), available at https://www.asil.org/insights/volume/ 20/issue/5/measure-justice-uncompensated-french-railroad-deportees-during-holocaust

Cowen, Tyler, 'How Far Back Should We Go? Why Restitution Should Be Small', in Jon Elster (ed), Retribution and Reparation in the Transition to Democracy (Cambridge: CUP 2006)

Degeling, Simone/Kit Barker, 'Private Law and Grave Historical Injustice: The Role of the Common Law', Monash University Law Review 41 (2015), 377-413

Dybnis, Ari, 'Was the Eritrea-Ethiopia Claims Commission Merely a Zero-Sum Game: Exposing the Limits of Arbitration in Resolving Violent Transnational Conflict', Loyola of Los Angeles International and Comparative Law Review 33 (2010), 255-286

Fassbender, Bardo, 'Compensation for Forced Labour in World War II: The German Compensation Law of 2 August 2000', Journal of International Criminal Justice 3 (2005), 243-252

Gray, Christine, 'The Eritrea/Ethiopia Claims Commission Oversteps Its Boundaries: A Partial Award?', European Journal of International Law 17 (2006), 699-721

Kutz, Christopher, 'Justice in Reparations: The Cost of Memory and the Value of Talk', Philosophy \& Public Affairs 32 (2004), 277-312

Lee, Benjamin, 'South Korea-Japan Comfort Women Agreement: Where Do We Go From Here?', The Diplomat, (6 September 2016), available at https://thediplomat.com/2016/09/south-koreajapan-comfort-women-agreement-where-do-we-go-from-here/

Luck, Annemarie, 'No Comfort in the Truth: It's the Episode of History Japan Would Rather Forget. Instead Comfort Women Are Back in the News', Index on Censorship 47(1) (2018), 19-21

Palchetti, Paolo, 'Italian Concerns after Sentenza 238/2014: Possible Reactions, Possible Solutions', VerfBlog, (11 May 2017), available at https://verfassungsblog.de/italian-concerns-aftersentenza-2382014-possible-reactions-possible-solutions/

Roht-Arriaza, Naome, 'Reparations in the Aftermath of Repression and Mass Violence', in Eric Stover/Harvey M Weinstein (eds), My Neighbour, My Enemy: Justice and Community in the Aftermath of Mass Atrocity (Cambridge: CUP 2010), 121-140

Rumble, Garry A/Melanie McKean/Dennis Pearce, Report of the Review of Allegations of Sexual and Other Abuse in Defence: Facing the Problems of the Past, Volume-General Findings and Recommendations (Canberra: DLA Piper 2011)

Sala, Ilaria Maria, 'Why Is the Plight of "Comfort Women” Still So Controversial?', The New York Times, (14 August 2017), available at www.nytimes.com/2017/08/14/opinion/comfort-womenjapan-south-korea.html

Shelton, Dinah, Remedies in International Human Rights Law (Oxford: OUP 2005) 
Shin, Hyonhee, 'South Korea Not Seeking to Re-negotiate "Comfort Women" Deal with Japan', Business Insider, (9 January 2018), available at www.businessinsider.com/r-south-korea-notseeking-to-renegotiate-comfort-women-deal-with-japan-foreign-minister-2018-1?IR =T

Vermeule, Adrian, 'Reparations as Rough Justice', University of Chicago Public Law \& Legal Theory Working Paper 105 (2005), 1-18

Vernon, Alikki, 'The Ethics of Appropriate Justice Approaches: Lessons from a Restorative Response to Institutional Abuse', Law in Context 35 (2017), 139-158

Weber, Torsten, 'Apology Failures: Japan's Strategies Towards China and Korea in Dealing with Its Imperialist Past', in Berber Bevernage/Nico Wouters (eds), The Palgrave Handbook of StateSponsored History After 1945 (London: Palgrave Macmillan 2018), 801-816

Wolfe, Stephanie, The Politics of Reparations and Apologies (Heidelberg: Springer 2014)

Wui Ling, Cheah, 'Walking the Long Road in Solidarity and Hope: A Case Study of the Comfort Women Movement's Deployment of Human Rights Discourse', Harvard Human Rights Journal 22 (2009), 63-107

Zumbansen, Peer (ed), Zwangsarbeit im Dritten Reich: Erinnerung und Verantwortung-NSForced Labor: Remembrance and Responsibility (Baden Baden: Nomos 2002)

Open Access This chapter is licensed under the terms of the Creative Commons Attribution 4.0 International License (http://creativecommons.org/licenses/by/4.0/), which permits use, sharing, adaptation, distribution and reproduction in any medium or format, as long as you give appropriate credit to the original author(s) and the source, provide a link to the Creative Commons license and indicate if changes were made.

The images or other third party material in this chapter are included in the chapter's Creative Commons license, unless indicated otherwise in a credit line to the material. If material is not included in the chapter's Creative Commons license and your intended use is not permitted by statutory regulation or exceeds the permitted use, you will need to obtain permission directly from the copyright holder.

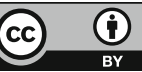




\section{Part IV \\ European Perspectives}




\title{
Waiting for Negotiations: An Italian Way to Get Out of the Deadlock
}

\author{
Alessandro Bufalini
}

Abstract The outcome of Judgment 238/2014 does not directly rely on the fact that the international dispute on state immunity involves two member states of the EU. Also, it is difficult to envisage at the European level any normative development on the international rules on state immunity. It seems, however, that some useful lessons can be learnt from the judicial dialogue between the European Court of Justice, the European Court of Human Rights, and constitutional courts. In very general terms and for many reasons, the relationship between constitutional courts and the International Court of Justice (ICJ) cannot rely on particularly sophisticated techniques of judicial dialogue.

This encourages us to consider the importance of involving state-level political organs as one of the counterparts to the dialogue. The potential power of judges to address these political organs in order to find a diplomatic solution raises the thorny question of whether this availability of alternative means of dispute settlement at the international level might impact on (or somehow restrict) the right of access to justice for Italian victims. Since both ICJ and the Italian Constitutional Court (ItCC) seem to agree that negotiation is the alternative dispute settlement par excellence (and the only means available to settle the present dispute at the international level), the ItCC might have given more importance to the availability of alternative means of redress - in the form of negotiations between the two states-in order to wear down the absolute character of the principle of judicial protection enshrined in Article 24 of the Italian Constitution.

Of course, a negotiated solution depends upon the willingness of both parties, whereas an Italian political initiative aimed at unilaterally granting reparation to the victims is always possible. Moreover, the latter solution may stop the enforcement of Judgment 238/2014 and reduce Italy's exposure to international responsibility for non-compliance with the 2012 ICJ Judgment. So long as Italian victims and their

\footnotetext{
A. Bufalini $(\bowtie)$

Tuscia University, Department of Linguistic, Literary, Historical, Philosophical and Legal Studies, Viterbo, Italy

e-mail: alessandro.bufalini@unitus.it

(C) The Author(s) 2021 
heirs are compensated, the restriction on their right to seek justice through the courts might become more tolerable for the Italian tribunals.

\section{The EU Membership of Italy and Germany: Is It Relevant?}

In its order of 21 January 2014, which raised questions about the constitutionality of the international rule on state immunity, the Tribunal of Florence emphasized the supranational and universal character of the principle of the absolute guarantee of judicial protection. According to the Tribunal of Florence, the importance of this common and collective value should be considered even more essential between member states of the EU ('tanto più (...) tra Stati dell'Unione Europea') than in a universal dimension. ${ }^{1}$ The same Tribunal, when enforcing the effects of Judgment $238 / 2014,{ }^{2}$ was even more categorical. In its judgment of 6 July 2015, the Tribunal of Florence considered a customary international rule that precludes not only Italian judges but all 'European' judges from determining state responsibility for the commission of war crimes and crimes against humanity to be incompatible with fundamental human rights protections, as enshrined in the Italian Constitution and in the Charter of Fundamental Rights of the European Union (EU Charter). ${ }^{3}$ In a more recent Judgment of 22 February 2016, the Tribunal, recalling the centrality of human dignity in the EU Charter, concluded that, at least in the relationships between EU member states, the restriction on state immunity envisaged by the Italian Constitutional Court (ItCC) is reasonable. This conclusion is supported by the fact that, although the EU Charter 'shall not extend in any way the competences of the Union as defined in the Treaties' (Article 6 of the Treaty on European Union), the high degree of human rights protection provided therein cannot but distinguish the very essence of the EU. ${ }^{4}$

The EU membership of Italy and Germany obviously does not affect the content of international norms. However, according to Tribunal of Florence, the fact that Italy and Germany built, together with many other states, a new and different legal order - the EU-cannot be irrelevant from an international law perspective. ${ }^{5}$ This conclusion raises the question of whether the EU membership of both states is relevant at all in an assessment of the current dispute raised after Judgment

\footnotetext{
${ }^{1}$ Tribunale di Firenze, Order of 21 January 2014, No 84/2014, 6.

${ }^{2}$ Corte Costituzionale, Judgment of 22 October 2014, No 238/2014.

${ }^{3}$ Tribunale di Firenze, Judgment of 6 July 2015, No 2468/2015, 13. For an account on these decisions, see Elena Sciso, 'Brevi considerazioni sui primi seguiti della sentenza della Corte costituzionale 238/2014', Rivista di diritto internazionale 98 (2015), 887-897, at 895-897.

${ }^{4}$ Tribunale di Firenze, Judgment of 22 February 2016, No 14740/2009, 12 et seq.

${ }^{5}$ Ibid, 12: 'It cannot be irrelevant, also from an international law perspective, the fact that Germany and Italy - while in force an international customary rule on state immunity, as the one identified by the ICJ-have contributed, together with an increasing number of other states, to the creation of a new supranational legal order' (translated by the author).
} 
238/2014, as suggested by the Tribunal of Florence. And if so, why should it be so? In the reasoning of the Italian tribunal, the reference to a European dimension serves the purpose of emphasizing the absolute centrality of human rights protections both in the constitutional traditions of EU member states and in the EU legal order itself. From this perspective, the existence of a common European dimension-characterized by the importance attached to human rights protections - may have the effect of strengthening the legitimacy, and eventually the acceptability, of the solution spelt out in Judgment 238/2014. From a strictly international law perspective, however, it is difficult to see how EU membership could affect the application of the international rule on state immunity.

The European dimension of the dispute has also been invoked from a different viewpoint. The argument goes that Italy and Germany's EU membership may play a role at the political level by facilitating the possibility of reaching a negotiated settlement. In other words, this context of regional integration 'should (...) help to settle a dispute which keeps alive conflictual relations originating from the Second World War'.

The outcome of Judgment 238/2014 does not directly rely on the fact that the international dispute on state immunity involves two member states of the EU, and nor did the ItCC place any relevance on this aspect. Still, a European perspective may add some food for thought to the present debate. With this in mind, this chapter focuses on two different issues. In the first part, I will assess possible European normative developments in the field of state immunity (section II). I will evaluate whether Judgment 238/2014 may be seen as a contribution to the formation or consolidation of a European judicial practice on state immunity in the case of human rights violations. At the same time, I will try to assess whether the creation of a regional exception to the international rule on state immunity would or indeed should be desirable. Moreover, I will endeavour to verify whether, and to what extent, it is possible to envisage an EU legislative intervention on the scope or the application of the international customary rule on the jurisdictional immunity of the state. The second part of the chapter will appraise what we can learn from the dialogue between judges at the European level. In particular, I will try to shed some light on some of the drawbacks to the application of both the counterlimits doctrine and the equivalent protection technique in the relationship between constitutional courts and the International Court of Justice (ICJ) (section III). I will then explore how the availability of alternative means of dispute settlement at the international level may impact on the need to award redress for Italian victims (section IV). In the last paragraph, I will offer some concluding remarks (section V).

\footnotetext{
${ }^{6}$ Karin Oellers-Frahm, 'A Never-Ending Story: The International Court of Justice-The Italian Constitutional Court-Italian Tribunals and the Question of Immunity', Heidelberg Journal of International Law 76 (2016), 193-202, at 202.
} 


\section{At What Stage of Development is the EU's Law on State Immunity?}

Judgment 238/2014 does not make any reference to the possible existence or development of a 'European' customary law on state immunity. The ItCC does not even examine the ICJ's qualified interpretation of the customary international law on state immunity from the civil jurisdiction of other states for acts considered iure imperii.

Nevertheless, one may consider the idea of an evolution to the rule on state immunity at the European level. For example, Pasquale De Sena has wondered whether Judgment 238/2014 could contribute to the formation of a 'regional customary rule, according to which European States may invoke constitutional provisions on access to justice, as a circumstance capable of precluding the wrongfulness of their failure to comply with conflicting international legal duties'. Following this line of reasoning, Judgment 238/2014 could be seen as an invitation for all EU member state judges to give prevalence to their own constitutional norms on human rights protections even when this implies a violation of international obligations. The Tribunal of Florence has also referred to the idea that supreme principles on human rights protections enshrined in the Italian Constitution (and common to both Germany and Italy as members of the EU) would represent an exception to the inability to invoke national law as a justification for non-observance of international obligations (Article 27 of the Vienna Convention on the Law of Treaties, and Article 32 of the Draft Articles on State Responsibility ${ }^{8}$ ). ${ }^{9}$ However, the Italian Tribunal did not allude to the existence or development of a regional custom of this kind.

The possible existence of regional customary international rules has been recently reasserted by the International Law Commission (ILC). ${ }^{10}$ The practice in this area, however, is scarce. One may only note the well-known case related to the particular practice of diplomatic asylum in Latin America, although the very existence of that regional custom was eventually denied. ${ }^{11}$ Apart from that, any exception to the irrelevance of domestic law as a justification for non-compliance with international

\footnotetext{
${ }^{7}$ Pasquale De Sena, 'The Judgment of the Italian Constitutional Court on State Immunity in Cases of Serious Violations of Human Rights and Humanitarian Law: A Tentative Analysis under International Law', Question of International Law: Zoom-Out 2 (2014), 17-31, at 31.

${ }^{8}$ ILC, Draft Articles on Responsibility of States for Internationally Wrongful Acts, adopted by the Commission at its fifty-third session in 2001 (Final Outcome), UN Doc A/56/10, 43, UN Doc A/RES/56/83, Annex, UN Doc A/CN.4/L.602/Rev.1, GAOR 56 ${ }^{\text {th }}$ Session Supp 10, 43.

${ }^{9}$ Tribunale di Firenze, Judgment No 14740/2009 (n 4), 25.

${ }^{10}$ ILC, Draft Conclusions on identification of customary international law with commentaries, adopted by the ILC at its seventieth session, in 2018, and submitted to the General Assembly as a part of the Commission's report covering the work of that session (A/73/10) (see, in particular, draft conclusion 16).

${ }^{11}$ ICJ, Haya de la Torre (Colombia v Peru), Judgment of 20 November 1950, ICJ Reports 1950, 266.
} 
law is also not supported by state practice or any international decision. ${ }^{12}$ This appears to be true also for constitutional provisions. In particular, it is still difficult to counter the opinion of the Permanent Court of International Justice that 'a State cannot adduce as against another State its own Constitution with a view to evading obligations incumbent upon it under international law or treaties in force'. ${ }^{13}$

Moreover, compared to general customary law, 'stricter criteria apply' to the formation of regional customs: the relevant practice has to be accepted as law by each state concerned. In addition, particular customs require clearly established practice and greater evidence of the acceptance of that practice as law. ${ }^{14}$ As things stand, these elements are far from being in existence, and even the Italian position on the emergence of an exception to the general rule remains unclear. ${ }^{15}$

More generally, customary international law has not only an elusive nature but it is typical of primitive legal systems, where there is no formal legislature. As a highly developed regional legal order, the EU can rely on more sophisticated modes of law-making. In the EU's legal order, a crucial choice-such as reconciling the traditional rule on state immunity and the scope of the individual's right of access to court-should be the result of a legislative process rather than based on the initiative of national judges. No doubts, judicial decisions often encourage legislative intervention. In the context of state immunity, however, (national) judicial activism may more likely increase legal uncertainty and raise diplomatic tensions.

The issue has in fact already been discussed, at least in relation to the adoption of a European regulation on the enforcement of judgments between member states. In its application to the ICJ, Germany recalled that recognition and enforcement of judgments between EU member states 'does not comprise legal actions claiming compensation for loss or damage suffered as a consequence of acts of warfare'. ${ }^{16}$ This would be a consequence of the European Court of Justice (ECJ)'s interpretation of the Brussels Regulation on the jurisdiction of courts and the recognition and enforcement of judgments in civil and commercial matters in EU countries. ${ }^{17}$ In the Lechouritou case, ${ }^{18}$ the ECJ clarified that the 'civil matters', referred to in Article 1 of the Brussels Convention on Jurisdiction and the Enforcement of Judgments in

\footnotetext{
${ }^{12}$ The commentary to Article 32 of the Draft Articles on State Responsibility does not refer to any exception to the rule; cf ILC, Draft Articles on State Responsibility 2001 (n 8), 94.

${ }^{13}$ PCIJ, Treatment of Polish Nationals and Other Persons of Polish Origin or Speech in Danzig Territory, Advisory Opinion of 4 February 1932, PCIJ series A/B No 44, 24.

${ }^{14} \mathrm{ILC}$, Draft Conclusions (n 10), 35.

${ }^{15}$ See Paolo Palchetti, chapter 'Right of Access to (Italian) Courts über alles?', and Andreas Zimmermann, chapter 'Would the World Be a Better Place If One Were to Adopt a European Approach to State Immunity?', in this volume.

${ }^{16} \mathrm{ICJ}$, Jurisdictional Immunities of the State (Germany v Italy), Application Instituting Proceedings Filed in the Registry of the Court on 23 December 2008, para 6.

${ }^{17}$ Council Regulation (EC) No 44/2001 of 22 December 2000 on Jurisdiction and the Recognition and Enforcement of Judgments in Civil and Commercial Matters [2001] OJ L12.

${ }^{18}$ ECJ, Lechouritou and Others $v$ the Federal Republic of Germany, Judgment of 15 February 2007, Case No C-292/05, I-1540, paras 17-19.
} 
Civil and Commercial Matters of $1968,{ }^{19}$ do not include legal actions 'for compensation in respect of the loss or damage suffered by the successors of the victims of acts perpetrated by armed forces in the course of warfare' in the territory of another state. $^{20}$ The reference to the sole 'successors' may suggest that civil actions brought by direct victims may have a chance to succeed. However, the ECJ also referred to Regulation No 805/2004, which creates a European Enforcement Order for uncontested claims, ${ }^{21}$ and to Regulation No 1896/2006, which establishes a European order for payment procedures. ${ }^{22}$ These regulations confirm, more generally, the idea of an exclusion of acta iure imperii from the 'civil and commercial' scope of the regulations, regardless of 'whether or not the acts or omissions are lawful' (Article 2(1) of both regulations).

Indeed, the creation of the European Enforcement Order was originally aimed at completely abolishing the exequatur procedure whereby national judges could decide to grant leave to any enforceable judgment obtained in another member state. A European Enforcement Order would have been automatically enforceable, without any kind of new examination of the case, as if the judgment was issued by another judge belonging to the member state where the execution is pursued. The explicit exclusion of acta iure imperii from the civil and commercial scope of Regulation No 805/2004 was actually due to the will of the German delegation within the Council of the EU. The initiative of the German delegation overtly aimed at ensuring that 'titles on the liability of the Federal Republic of Germany for war crimes committed during World War II should not be certified as a European Enforcement Order'. ${ }^{23}$

The German proposal was not opposed by other EU member states. This may be a sign of a common understanding between EU member states regarding all claims for compensation related to the acta iure imperii, including crimes committed in the course of World War II. Certainly, this does not preclude a different regulation intended to recognize a right to enforcement of any judgment granting compensation

\footnotetext{
${ }^{19}$ Brussels Convention on Jurisdiction and the Enforcement of Judgments in Civil and Commercial Matters, 27 September 1968, OJ L 299, 31 December 1972.

${ }^{20}$ Ibid, para 46. On this point, see Giovanni Boggero, 'The Legal Implications of Sentenza No. 238/2014 by Italy's Constitutional Court for Italian Municipal Judges: Is Overcoming the “Triepelian Approach" Possible?', Heidelberg Journal of International Law 1 (2016), 203-224, at 222-223.

${ }^{21}$ Regulation of the European Parliament and of the Council (EC) No 805/2004 of 21 April 2004 creating a European Enforcement Order for uncontested claims [2004] OJ L 143.

${ }^{22}$ Regulation of the European Parliament and of the Council (EC) No 1896/2006 of 12 December 2006 creating a European order for payment procedure [2006] OJ L 399.

${ }^{23}$ On this aspect see, eg, Veronika Gärtner, 'The Brussels Convention and Reparations-Remarks on the Judgment of the European Court of Justice in Lechouritou and others v. the State of the Federal Republic of Germany', German Law Journal 8 (2007) 417-442, at 439; Nerina Boschiero, 'Jurisdictional Immunities of the State and Exequatur of Foreign Judgments: A Private International Law Evaluation of the Recent ICJ Judgment in Germany v. Italy', in Nerina Boschiero/Tullio Scovazzi/ Cesare Pitea et al (eds), International Courts and the Development of International Law: Essays in Honour of Tullio Treves (The Hague: Asser Press 2013), 781-824, especially at 798 et seq.
} 
for victims of human rights violations. Despite being technically possible, such a normative development seems at the moment to be far from reach. So, is there still something we can learn from the European legal order?

\section{Techniques of Dialogue Between Judges at the European Level: What Lessons Can We Learn?}

The relationship between EU law and national legal orders relies significantly on a continuous dialogue between judges. In this sometimes complicated interaction, constitutional courts play an essential role. Of course, this dialectical relationship between judicial organs takes place using a number of means. For our purposes, two techniques of judicial dialogue deserve particular attention: the counterlimits doctrine (dottrina dei controlimiti), applied by the ItCC, and the test of equivalent protection, often employed by national and European judges to ensure respect for fundamental rights. The key issue here is to evaluate the effects of using these techniques in the relationship between the ItCC and the ICJ.

Admittedly, the counterlimits doctrine presents an intrinsic contradiction. The contradiction stems from the recognition of a constitutional judicial power that prevents the entrance of international norms into the national system, for the purposes of safeguarding the supreme principles of the Italian Constitution. This power would be in conflict with the openess to international law granted by the Constitution itself (especially by those rules aimed at granting compliance with international obligations, for example Articles 10, 11, and 117 of the Italian Constitution).

It may be the existence of this contradiction that has seen the counterlimits doctrine often invoked in the past but never concretely applied, at least until Judgment 238/2014. What is more interesting here, however, is a more latent aspect to this technique. As pointed out by Stefano Battini, so long as the application of the counterlimits doctrine remains a mere threat, the collision of legal orders continues to be an abstract scenario. ${ }^{24}$ The effects of the potential application of the counterlimits doctrine may even be seen as a constructive one. First, the non-application of the counterlimits doctrine confirms the existence of common, or at least compatible, values between legal systems: if the counterlimits are not applied, it means that the 'external rule' is in compliance with national legal principles. Secondly, the possibility that the counterlimits doctrine can be applied may provide a warning to judges of other legal orders about the existence of a potential systemic collision. The threat of this clash may force them to take into account the interests that are conflicting and to look for acceptable, balanced

\footnotetext{
${ }^{24}$ Stefano Battini, 'È costituzionale il diritto internazionale?', Giornale di diritto amministrativo 3 (2015), 367-377, at 372-373.
} 
solutions. The problem is that when the doctrine is in fact concretely applied, as in Judgment 238/2014, the contrast between legal orders becomes irreconcileable.

Admittedly, the judicial dialogue between constitutional courts (or the European Court of Human Rights (ECtHR)) and the ECJ has often relied on a different technique, one that favours a more dialectial interaction between legal systems: the test of equivalent protection. ${ }^{25}$ In the application of this technique, the degree of judicial control over the 'external law' is loosened by the fact that the protection does not need to be exactly the same but comparatively adequate or generally acceptable. $^{26}$ It is the admissibility of an imperfect accordance between the two systems that specifically enhances 'the potentialities of equivalent protection as a technique for the balancing of interests'. ${ }^{27}$ The counterlimits doctrine instead precludes this adaptability, since it rests on a purely hierarchical logic. In Judgment 238/2014, the ItCC has created an irremovable barrier to safeguard the supreme and non-derogable principles of the Italian Constitution. As a consequence, the balance between competing interests can be done only in light of national parameters. One may argue that the resulting and contested absence of a real balancing in Judgment $238 / 2014$ is a consequence of the particular (national) perspective assumed by the ItCC, ${ }^{28}$ although the above-mentioned constitutional provisions may have led to a different result.

A further distinction between the counterlimits doctrine and the equivalent protection test concerns the absence in the former of any presumption of conformity between the international rule or decision and national law. ${ }^{29}$ The main idea behind

\footnotetext{
${ }^{25}$ Judgment 238/2014 is indeed often compared to other decisions that allowed constitutional courts (Frontini and Solange I and II concerning the Italian and German Constitutional Courts respectively) and the European Court of Human Rights (Bosphorus) to somehow limit the impact of EU law within their own systems. See Corte Costituzionale, Judgment of 18 December 1973, No 183/1973; Bundesverfassungsgericht, Order of 29 May 1974, 2 BvL 52/71, BVerfGE 37, 271 (Solange I), and Order of 22 October 1986, 2 BvR 197/83, BVerfGE 73, 339 (Solange II); ECtHR, Bosphorus v Ireland, Grand Chamber Judgment of 30 June 2005, Application No 45036/98.

${ }^{26}$ See, generally, Veronika Bílková, 'The Standard of Equivalent Protection as a Standard of Review', in Lukasz Gruszczynski/Wouter Werner (eds), Deference in International Courts and Tribunals: Standard of Review and Margin of Appreciation (Oxford: OUP 2014), 272-288; Maura Marchegiani, Il principio della protezione equivalente come meccanismo di coordinamento tra sistemi giuridici nell'ordinamento internazionale (Naples: Editoriale Scientifica 2018).

${ }^{27}$ Maurizio Arcari, 'Forgetting Article 103 of the UN Charter?: Some perplexities on "equivalent protection" after Al-Dulimi', Questions of International Law: Zoom-In 6 (2014), 31-41, at 37: Arcari criticizes the excessively demanding level of protection required in the more recent jurisprudence of the ECtHR on UN Security Council targeted sanctions (see, in particular, 39 et seq).

${ }^{28}$ On the absence of a real balancing in Judgment 238/2014, see Pasquale De Sena, 'Spunti di riflessione sulla sentenza 238/2014 della Corte Costituzionale', SIDIBlog, (30 October 2014), available at www.sidiblog.org/2014/10/30/spunti-di-riflessione-sulla-sentenza-2382014-dellacorte-costituzionale/.

${ }^{29}$ On this point see Anne Peters, 'Let Not Triepel Triumph: How To Make the Best Out of Sentenza No. 238 of the Italian Constitutional Court for a Global Legal Order', EJIL:Talk!, (22 December 2014), available at www.ejiltalk.org/let-not-triepel-triumph-how-to-make-the-best-out-of-sentenzano-238-of-the-italian-constitutional-court-for-a-global-legal-order-part-i/.
} 
the equivalent protection technique lies precisely in the general assumption that safeguarding fundamental rights is normally considered a cornerstone of both the legal order making the norm or decision to be implemented and the system that should give effect to that norm or decision. This presumption is not supposed to be easily rebuttable, although judges have used the equivalent protection test in order to assess the degree of human rights protections provided by international organizations. ${ }^{30}$ In this respect, one can note that this more dialogical technique has proved to be useful in the context of highly integrated and institutionalized systems, whereas it may be difficult to conceive of a judicial recourse to this method by constitutional courts in their relationship with the ICJ.

Despite these criticisms regarding the application of the counterlimits doctrine, Judgment 238/2014 may be seen as an 'episode in a more general tendency to return to dualistically colored practices in the relationship between the legal orders'. 31 However, Jugdment 238/2014 and the counterlimits doctrine therein applied display some specific features. One cannot ignore the particular context in which Judgment $238 / 2014$ operates. In this regard, some scholars have highlighted that it is one thing to apply a national 'filter to a European supranational organization, such as the EU, and quite another to use it to scrutinize global institutions and universal rules'. ${ }^{32}$ The difference would lie in the lower level of integration and the more varied array of legal values, principles, and intepretations characterizing international rules compared to the high degree of integration and sophistication reached by the EU. The application of a national filter may also cause tension within the EU system. But any claim for a protection of national identity has a wider and more dangerous impact at the international level, namely heavily weakening the application and enforcement of international law and decisions. ${ }^{33}$

Admittedly, an assessment of states' compliance with human rights has recently occurred in the case law related to the implementation of other international legal acts, that is the UN Security Council's targeted sanctions. The ItCC itself recalled, albeit in very general terms, the Kadi jurisprudence of the EU courts. ${ }^{34}$ As for the

\footnotetext{
${ }^{30}$ See, eg, ECtHR, Michaud v France, Judgment of 6 December 2012, Application No 12323/11; Al-Dulimi and Montana Management Inc. v Switzerland, Judgment of 26 November 2013, Application No 5809/08; AL v Italy, Decision of 11 May 2000, Application No 41387/98.

${ }^{31}$ Robert Kolb, 'The Relationship between the International and the Municipal Legal Order: Reflections on the Decision no 238/2014 of the Italian Constitutional Court', Questions of International Law: Zoom-Out 2 (2014), 5-16, at 6.

${ }^{32}$ Nico Krisch, 'The Backlash against International Courts', VerfBlog, (16 December 2014), available at http://verfassungsblog.de/backlash-international-courts-2/.

${ }^{33}$ See also Raffaela Kunz, chapter 'Teaching the World Court Makes a Bad Case', in this volume.

${ }^{34}$ ItCC, Judgment 238/2014 (n 2), para 3.4.
} 
Strasbourg Court, one could refer to the $N a d a^{35}$ and Al-Dulimi ${ }^{36}$ cases. However, in this case-law, the courts were essentially talking to the political organs of the UN in order to improve the level of human rights protection of that legal system. Intersystemic dialogues do not always involve judicial organs only. If one takes into account the different counterparts of the dialogue, a clear consequence of Judgment $238 / 2014$ is the 'more serious damage to the normativity of the international legal system'. ${ }^{37}$ The judgment of the ItCC, in fact, questions the decision of another judicial organ and does not react-as in Kadi, Al-Dulimi, and similar cases - to the potential arbitrariness of political organs, whose acts directly impinge on individual rights.

All in all, both the counterlimits doctrine and the equivalent protection test suffer from additional inherent limitations, if applied to the relationship between constitutional courts and the ICJ. For example, in the thoroughly debated Taricco saga, the ItCC envisaged an application of the counterlimits doctrine against the ECJ without causing an insurmountable conflict or stalemate. ${ }^{38}$ The ItCC, in fact, did not clarify the exact scope of the supreme principle (of legality in criminal law) endangered by a previous ECJ decision. This was likely a 'pure strategic choice', aimed at leaving some leeway to the ECJ in its eventual attempt to reconcile EU law with the Italian

\footnotetext{
${ }^{35}$ ECtHR, Nada v Switzerland, Grand Chamber Judgment of 12 September 2012, Application No 10593/08. For comments, see Nicolas Hervieu, 'La délicate articulation des engagements onusiens et européens au prisme de la lutte contre le terrorisme', (21 September 2012), available at https:// revdh.files.wordpress.com/2012/09/lettre-adl-du-credof-21-septembre-2012.pdf, 1-11; Marko Milanovic, 'European Court Decides Nada v. Switzerland', EJIL:Talk!, (14 September 2012), available at www.ejiltalk.org/european-court-decides-nada-v-switzerland/; Maria E Gennusa, 'Nada c. Svizzera: sulle orme di Kadi?', Quaderni costituzionali 1 (2013), 164-167, at 164 et seq. ${ }^{36}$ ECtHR, Al-Dulimi v Switzerland (n 30). See, among others, Anne Peters, 'Targeted Sanctions after Affaire Al-Dulimi et Montana Management Inc. c. Suisse: Is There a Way Out of the Catch-22 for UN Members?', EJIL:Talk!, (4 December 2013), available at www.ejiltalk.org/targetedsanctions-after-affaire-al-dulimi-et-montana-management-inc-c-suisse-is-there-a-way-out-of-thecatch-22-for-un-members/; Maura Marchegiani, 'Le principe de la protection équivalente dans l'articulation des rapports entre ordre juridique des NU et CED après l'arrêt Al-Dulimi', Questions of International Law: Zoom-In 6 (2014), 3-14, at 3 et seq.

${ }^{37}$ See Peters, 'Let Not Triepel Triumph' 2014 (n 29); see also Raffaela Kunz, 'The Italian Constitutional Court and "Constructive Contestation": A Miscarried Attempt?', Journal of International Criminal Justice 14 (2016), 621-627, at 626.

${ }^{38}$ Corte Costituzionale, Order of 26 January 2017, No 24/2017; in its request for a preliminary ruling, the ItCC explained both reasons for the contrast between a previous ECJ's decision and a supreme constitutional principle and the consequences in the event that the conflict persists: the non-application of the ECJ's decision (ECJ, Taricco and Others, Judgment of 8 September 2015, Case No C-105/14). For an account on the extensive doctrinal debate over this Order, see Alessandro Bernardi/Cristiano Cupelli (eds), Il caso Taricco e il dialogo tra le Corti: L'ordinanza 24/2017 della Corte costituzionale (Naples: Jovene Editore 2017).
} 
Constitution. ${ }^{39}$ And the ECJ took the chance ${ }^{40}$ 'by emphasizing (...) the language of common constitutional [traditions] rather than one of constitutional identity, ${ }^{41}$ thereby finding a way to accommodate both domestic and EU law. This case shows that the relationship between national courts and the ECJ is both sophisticated and highly developed, and provides judges with several 'means of dialogue' to solve normative conflicts. A wise use of the preliminary reference procedure may be one of these means and methods. The judicial dialogue within the EU's judicial order is built on these strategic, refined, and subtle choices.

The relationship between constitutional courts and the ICJ cannot rely on these kinds of means and subtleties. There is no preliminary reference procedure on which constitutional courts may rely upon. More generally - as the ItCC itself has actually recognized in Judgment 238/2014 - the ICJ should have the last word on international law matters. As far as this word might be wrong, a purely confrontational attitude from national courts will likely only have the effect of undermining respect for international law, especially if one takes into account the infrequent opportunities for dialogue between constitutional courts and the ICJ.

There is another element that might be worth briefly recalling here. In the cases of $\mathrm{Nada}$ and Al-Dulimi ${ }^{42}$ the Strasbourg Court partly departed from the test of equivalent protection and relied on the idea that states enjoy a degree of discretion in the implementation of United Nations Security Council resolutions. In practice, states can decide how to give effect to Security Council resolutions, provided that they comply with their obligations under the European Convention on Human Rights (ECHR). This approach can also be problematic, since it might be difficult to assess if and to what extent there is any real discretion left to the state by a Security Council decision. What matters more here, however, is that the ECtHR not only assumes that it is possibile to comply with the Security Council decisions while protecting human rights but leaves states free to decide how to achieve this goal. For our purposes, a remarkable aspect of this approach is that it transfers the burden of solving potential conflicts between legal orders to state-level political organs.

At the end of the day, even in the undesirable scenario of an application of the counterlimits doctrine, the ItCC should try to leave some leeway for other actors-

\footnotetext{
${ }^{39}$ See Davide Paris, 'Carrot and Stick: The Italian Constitutional Court's Preliminary Reference in the Case Taricco', Questions of International Law: Zoom-In 5 (2017), 5-20, at 10-11. See also Giacomo Rugge, 'The Italian Constitutional Court on Taricco: Unleashing the Normative Potential of National Identity?, Questions of International Law: Zoom-In 5 (2017), 21-29.

${ }^{40}$ ECJ, M.A.S. and M.B. (Taricco II), Judgment of 5 December 2017, Case No C-42/17. For a critical analysis, see Francesco Viganò, 'Melloni Overruled?: Considerations on the Taricco II Judgment of the Court of Justice', New Journal of European Criminal Law 9 (2018), 18-23.

${ }^{41}$ See Marco Bassini/Oreste Pollicino, 'Defusing the Taricco Bomb through Fostering Constitutional Tolerance: All Roads Lead to Rome', VerfBlog, (5 December 2017), available at https:// verfassungsblog.de/defusing-the-taricco-bomb-through-fostering-constitutional-tolerance-allroads-lead-to-rome/.

${ }^{42}$ ECtHR, Nada v Switerzland (n 35); ECtHR, Al-Dulimi v Switzerland (n 30).
} 
particularly political organs of the Italian state-to find alternative solutions. ${ }^{43}$ In more general terms, the ItCC should not jeopardize the quest for alternative and perhaps political solutions and could even suggest ways to resolve the deadlock. In Judgment 238/2014, the ItCC appears to have neglected this promising facet of its role. As we shall see, however, Sentenza does not preclude the viability of alternative means of dispute settlement and redress.

\section{The Existence of Alternative Means of Dispute Settlement and a Reasonable Way to Award Redress to the Victims}

In reconciling human rights protections with immunity from jurisdiction, the interaction between legal systems may take different forms. As for state immunity, the ECtHR heavily relied on the importance of the principle par in parem non habet iurisdictionem, that is, equals have no jurisdiction over each other. As a consequence, restrictions on access to a judge (Article 6(1) ECHR) have often been considered legitimate and proportionate to the aim of complying with international law and respecting state sovereignty. ${ }^{44}$ In light of the 'principled approach' adopted by the Court of Strasbourg, recognition of state immunity would not require any assessment on the protection granted to individuals in other legal systems and, particularly, on the very existence of alternative means of protection. In practice, as Luigi Condorelli has critically pointed out, the international law of state immunity is in no way connected, balanced or reconciled with human rights law, so far. ${ }^{45}$

By contrast, the existence of alternative means of protection has played an important role in relation to the jurisdictional immunities of international organizations. According to the ECtHR, in order to establish whether an international organization enjoys immunity from municipal jurisdiction, a relevant factor relates to the availability to the applicants of 'reasonable alternative means to protect their rights under the Convention' ${ }^{46}$ Rare exceptions to this test, as in the well-known

\footnotetext{
${ }^{43}$ In this sense, see Paolo Palchetti, 'Judgment 238/2014 of the Italian Constitutional Court: In search of a way out', Questions of International Law: Zoom-Out 2 (2014), 44-47.

${ }^{44}$ ECtHR, Fogarty $v$ The United Kingdom, Grand Chamber Judgment of 21 November 2001, Application No 37112/97, para 34; ECtHR, McElhinney v Ireland, Grand Chamber Judgment of 21 November 2001, Application No 31253/96, para 35; ECtHR, Al-Adsani v The United Kingdom, Grand Chamber Judgment of 21 November 2001, Application No 35763/97, para 52.

${ }^{45}$ Luigi Condorelli, 'Conclusions générales', in Hervé Ascensio/Jean-François Flauss (eds), La soumission des organisations internationales aux normes internationales relatives aux droits de l'homme (Paris: Pedone 2009), 127-142, at 132 (translated by the author).

${ }^{46}$ ECtHR, Waite and Kennedy v Germany, Grand Chamber Judgment of 18 February 1999, Application No 26083/94, para 68; ECtHR, Beer and Regan v Germany, Grand Chamber Judgment of 18 February 1999, Application No 28934/95; ECtHR, Naletilić v Croatia, Decision of 4 May 2000, Application No 51891/99; ECtHR, Gasparini v Italy and Belgium, Decision of 12 May 2009, Application No 10750/03.
} 
Mothers of Srebrenica case, ${ }^{47}$ are normally justified by the unique and imperative nature of the functions of the United Nations Security Council in mantaining or restoring international peace and security. ${ }^{48}$

The issue of the availibility of alternative means of protection was also addressed before the ICJ. Italy argued that the denial of immunity to Germany was justified by the failure of all other attempts to obtain reparation for the victims involved. The Italian argument however, was rejected, since the ICJ was unable to determine the existence of a customary international rule that 'makes the entitlement of a State to immunity dependent upon the existence of effective alternative means of securing redress. 49

From its side, the ItCC, in Judgment 238/2014, rested on the assumption that no access to justice was granted to Italian victims. This impression is discernable, for example, in the statement that it 'would indeed be difficult to identify how much is left of a right if it cannot be invoked before a judge in order to obtain effective protection'. ${ }^{50}$ Later on, the ItCC also affirmed that 'the completely disproportionate sacrifice of two supreme principles of the Constitution' (Articles 2 and 24) stems from 'the denial of judicial protection'. 51

Italian military internees indeed tried to bring their case before German judges, going all the way up to the German Constitutional Court. ${ }^{52}$ Their legal action did not meet with success. According to some scholars, however, the individuals did not lack access to justice but to a judge who could grant them compensation. ${ }^{53}$ Be that as it may, the ItCC should have scrutinized whether access to justice was effectively granted to victims instead of assuming, as an automatic consequence of the unachieved reparation, the denial of judicial protection. After all, one of Italy's

\footnotetext{
${ }^{47}$ Supreme Court of The Netherlands, Mothers of Srebrenica et al $v$ State of The Netherlands and the United Nations, Judgment of 13 April 2012, Case No10/04437.

${ }^{48}$ See Beatrice Ilaria Bonafé, 'L'esistenza di rimedi alternativi ai fini del riconoscimento dell'immunità delle organizzazioni internazionali: la sentenza della Corte suprema olandese nel caso Madri di Srebrenica', Rivista di diritto internazionale 95 (2012), 826-828.

${ }^{49} \mathrm{ICJ}$, Jurisdictional Immunities of the State (Germany v Italy: Greece intervening), Judgment of 3 February 2012, ICJ Reports 2012, 99, para 101.

${ }^{50}$ ItCC, Judgment 238/2014 (n 2), para 3.4.

${ }^{51}$ Ibid.

${ }^{52}$ Bundesverfassungsgericht, Order of 28 June 2004, 2 BvR 1379/01, BVerfGK 3, 277; Verwaltungsgericht Berlin, Judgment of 9 September 2004, 9 A 336.02. In this context see also the Distomo cases where German courts dismissed claims brought by Greek victims of WWII massacres: Bundesverfassungsgericht, Order of 15 February 2006, 2 BvR 1476/03, BVerfGK 7, 303 .

${ }^{53}$ Battini, 'È costituzionale il diritto internazionale?' 2015 (n 24), 375. See also Christian Tomuschat, 'The National Constitution Trumps International Law', Italian Journal of Public Law 2 (2014), 189-196, at 191-192; Sabino Cassese, Dentro la Corte: Diario di un giudice costituzionale (Bologna: Il Mulino 2015), at 260-261; see also Christian Tomuschat, chapter 'The Illusion of Perfect Justice', and Sabino Cassese, chapter 'Recollections of a Judge', in this volume. For a different perspective, see Valerio Onida, chapter 'Moving beyond Judicial Conflict in the Name of the Pre-Eminence of Fundamental Human Rights', in this volume.
} 
arguments before the ICJ was specifically aimed at demonstrating that many Italian victims "were not included in any postwar reparation scheme agreed upon between Italy and Germany nor were they included in the reparation schemes set up unilaterally by Germany'. 54 This would lead to the conclusion that 'the remedies available under German law provided no reasonable possibility of obtaining effective redress'. 55

Yet, in the event that judicial means were considered unsatisfactory or unavailable, the ItCC's evaluation could then have dwelt upon the existence of interstate negotations as a possible alternative means of redress. The Tribunal of Florence, for example, in evaluating the effectiveness of the protection granted to Italian victims, gave decisive relevance to the fact that Germany did not attempt to undertake negotiations with Italy. ${ }^{56}$ In other words, besides an assessment of the effectiveness of the right to a judge granted to Italian victims, the ItCC may have inquired as to the viability of other (diplomatic) means of protecting the rights of the victims. This would have implied that political organs, and especially the Italian government, could have become a counterpart of the dialogue.

As is well-known, the ICJ was 'not unaware' that the customary rule on state immunity 'may preclude judicial redress for the Italian nationals concerned', and, on this basis, the international judge envisaged 'further negotation involving the two States concerned, with a view of resolving the issue'. ${ }^{57}$ The ICJ seems therefore to suggest that negotiation is the alternative dispute settlement par excellence. Even the ItCC interpreted this paragraph as indicative of the fact that the 'opening of new negotiations is the only means available to settle the dispute in international law'. ${ }^{5}$ More generally, Judgment 238/2014 on no less than three occasions recalls the fact that the ICJ referred to the opening of new negotiations as the only appropriate method of finding a solution on the international plane.

If this is the only path to a solution at the international level, then the ItCC could have given more importance to the availability of alternative means of redress-in the form of negotiations between the two states - in order to wear down the absolute character of the principle of judicial protection enshrined in Article 24 of the Italian Constitution. In its jurisprudence, after all, the ItCC itself considers the promotion of

\footnotetext{
${ }^{54} \mathrm{ICJ}$, Jurisdictional Immunities of the State (Germany v Italy), Rejoinder of Italy, 10 January 2011, para 4.22.

${ }^{55}$ Ibid.

${ }^{56}$ Tribunale di Firenze, Judgment No 14740/2009 (n 4), 13: '[I]n order to find a proper balance, in the present case, between the rationale behind the customary rule on State immunity with the effectiveness of human rights protection, one must consider that the radical choice of the Italian Constitutional Court was determined by the conduct of the Federal Republic of Germany. The latter, although admitting to be responsible for the crimes committed by the Third Reich, has not only invoked its jurisdictional immunity before Italian judges, but it did not undertake any negotiations with the victims and their heirs, or with Italy' (translated by the author).

${ }^{57} \mathrm{ICJ}$, Jurisdictional Immunities (n 49), para 104.

${ }^{58}$ ItCC, Judgment 238/2014 (n 2), para 3.1.
} 
alternative means of dispute settlement as a public interest apt to temporarily restrict the right of access to a judge. ${ }^{59}$

Notwithstanding the ICJ's auspices, it is unclear whether the two states genuninely attempted to find a negotiated solution to the dispute. In that light, the ItCC may have scrutinized adverse human rights impacts resulting from a reluctance of the Italian government to pursue diplomatic initiatives. Scrutiny of Italy's behaviour in granting human rights protection to its citizens may have encouraged the government to look either for a diplomatic settlement or for any other internal solution capable of addressing the unanswered claims of the victims.

An interesting example in this regard comes from the South Korean Constitutional Court. In light of a duty to protect citizens abroad (Article 2 of the Korean Constitution) and to respect the dignity of the victims of human rights violations, the Korean government was deemed liable for the negative consequences affecting Korean comfort women as a result of both the content of the bilateral agreement concluded with Japan in 1965 and the failure to pursue economic compensation from Japan through diplomatic channels. ${ }^{60}$ More pointedly, the Constitutional Court decided that the Korean government had not done enough to obtain reparations for the violence suffered by its own citizens, and that this inaction represented a breach of constitutionally enshrined individual rights. Eventually, the Korean Constitutional Court asked the government to activate all diplomatic means at its disposal in order to solve the interpretive disputes concerning the content of the peace treaty signed in 1965 by the two states. ${ }^{61}$ While the ItCC cannot impose such an obligation on the Italian government, the consequences of the enforcement of Judgment 238/2014 might still exert a certain pressure on Italian political organs to either find a means to settle the dispute at the international level or to directly award some means of redress to the victims. The point is that a negotiated solution depends of course upon the willingness of both parties, whereas an Italian political initiative aimed at unilaterally granting reparation to the victims is always (and immediately) possible.

My suggestion is that, while waiting for a negotiated solution, Italy should compensate its own nationals. From a legal viewpoint, such a political choice

\footnotetext{
${ }^{59}$ Remo Caponi, 'A Fresh Start: How to Resolve the Conflict between the ICJ and the Italian Constitutional Court', VerfBlog, (28 January 2015), available at http://verfassungsblog.de/freshstart-resolve-conflict-icj-italian-constitutional-court/. See especially the reference to the Constitutional Court's decision No 276/2000, para 3.4.

${ }^{60}$ Korean Constitutional Court, Determination of the constitutionality of the inaction with respect to Article 3 of the Agreement on the Settlement of Problems concerning Property and Claims and the Economic Cooperation between the Republic of Korea and Japan, Anonymous (64 former Japanese military sex slaves) v Minister of Foreign Affairs and Trade, Individual constitutional complaint, 23-2(A) KCCR 366, ILDC 1880 (KR 2011), 2006 Hun-Ma 788, 30 August 2011. See also Filippo Fontanelli, chapter 'Sketches for a Reparation Scheme', in this volume.

${ }^{61}$ The Korean Constitutional Court reached this conclusion despite the fact that the Korean government had provided for economic compensation to Korean victims and had made the decision to focus its diplomatic efforts 'only' on obtaining Japanese apologies and a recognition of all committed violations.
} 
would confine the question of compensation within the Italian legal order. It would possibly arrest the enforcement of Judgment 238/2014 and reduce Italy's exposure to international responsibility for non-compliance with the 2012 ICJ Judgment. From a diplomatic perspective, Italy's engagment in compensatation-even if not full compensation-would be a gesture of goodwill toward Germany. This gesture-while stopping domestic proceedings against Germany-could potentially foster the resumption of negotiations. From a humanitarian point of view, compensation may partially restore the victims' dignity, many of whom have been waiting too long and might yet die while waiting.

Finally, the risks of failing to find a settlement at the international level and the costs of a lack of protection for its nationals should be temporarily borne by Italy. As long as Italian victims and their heirs are compensated, a restriction on their right to seek justice through the courts might become more tolerable for the Italian tribunals.

\section{Conclusions}

To date, it is hard to envisage any rapid development regarding the evolution of international rules on the jurisdicitional immunity of the state. Despite all the attention paid to the rights of the individuals, the European legal order does not seem to be an exception to the actual state of affairs. However, judicial dialogue at the European level shows many different ways to solve normative conflicts. In particular, the need to reconcile the international rules on state immunity with the norms for the protection of human rights seems to make it necessary to involve statelevel political organs and to look at the existence of alternative non-judicial means of dispute settlment.

Maybe it is no accident that both the ICJ and the ItCC suggest that the best option to solve the conflict lies in negotiation. But however trite it may be to say, a negotiated solution might never materialize. Thus, in order to get out of the actual deadlock - and to avoid the consequences of an inability to reach a political solution at the international level falling back onto the victims-Italy should grant its own citizens compensation and thereby restore their dignity.

\section{References}

Arcari, Maurizio, 'Forgetting Article 103 of the UN Charter?: Some perplexities on "equivalent protection" after Al-Dulimi', Questions of International Law: Zoom-In 6 (2014), 31-41

Bassini, Marco/Oreste Pollicino, 'Defusing the Taricco Bomb through Fostering Constitutional Tolerance: All Roads Lead to Rome', VerfBlog, (5 December 2017), available at https:// verfassungsblog.de/defusing-the-taricco-bomb-through-fostering-constitutional-tolerance-allroads-lead-to-rome/

Battini, Stefano, 'È costituzionale il diritto internazionale?', Giornale di diritto amministrativo 3 (2015), 367-377 
Bernardi, Alessandro/Cristiano Cupelli (eds), Il caso Taricco e il dialogo tra le Corti: L'ordinanza 24/2017 della Corte costituzionale (Naples: Jovene Editore 2017)

Bílková, Veronika, 'The Standard of Equivalent Protection as a Standard of Review', in Lukasz Gruszczynski/Wouter Werner (eds), Deference in International Courts and Tribunals: Standard of Review and Margin of Appreciation (Oxford: OUP 2014), 272-288

Boggero, Giovanni, 'The Legal Implications of Sentenza No. 238/2014 by Italy's Constitutional Court for Italian Municipal Judges: Is Overcoming the "Triepelian Approach" Possible?", Heidelberg Journal of International Law 1 (2016), 203-224

Bonafé, Beatrice Ilaria, 'L'esistenza di rimedi alternativi ai fini del riconoscimento dell'immunità delle organizzazioni internazionali: la sentenza della Corte suprema olandese nel caso Madri di Srebrenica', Rivista di diritto internazionale 95 (2012), 826-828

Boschiero, Nerina, 'Jurisdictional Immunities of the State and Exequatur of Foreign Judgments: A Private International Law Evaluation of the Recent ICJ Judgment in Germany v. Italy', in Nerina Boschiero/Tullio Scovazzi/Cesare Pitea et al (eds), International Courts and the Development of International Law: Essays in Honour of Tullio Treves (The Hague: Asser Press 2013), 781-824

Caponi, Remo, 'A Fresh Start: How to Resolve the Conflict between the ICJ and the Italian Constitutional Court', VerfBlog, (28 January 2015), available at http://verfassungsblog.de/ fresh-start-resolve-conflict-icj-italian-constitutional-court/

Cassese, Sabino, Dentro la Corte: Diario di un giudice costituzionale (Bologna: Il Mulino 2015)

Condorelli, Luigi, 'Conclusions générales', in Hervé Ascensio/Jean-François Flauss (eds), La soumission des organisations internationales aux normes internationales relatives aux droits de l'homme (Paris: Pedone 2009), 127-142

De Sena, Pasquale, 'Spunti di riflessione sulla sentenza 238/2014 della Corte Costituzionale', SIDIBlog, (30 October 2014a), available at www.sidiblog.org/2014/10/30/spunti-diriflessione-sulla-sentenza-2382014-della-corte-costituzionale/

De Sena, Pasquale, 'The Judgment of the Italian Constitutional Court on State Immunity in Cases of Serious Violations of Human Rights and Humanitarian Law: A Tentative Analysis under International Law', Question of International Law: Zoom-Out 2 (2014b), 17-31

Gärtner, Veronika, 'The Brussels Convention and Reparations-Remarks on the Judgment of the European Court of Justice in Lechouritou and others v. the State of the Federal Republic of Germany', German Law Journal 8 (2007) 417-442

Gennusa, Maria E, 'Nada c. Svizzera: sulle orme di Kadi?', Quaderni costituzionali 1 (2013), $164-167$

Hervieu, Nicolas, 'La délicate articulation des engagements onusiens et européens au prisme de la lutte contre le terrorisme', (21 September 2012), available at https://revdh.files.wordpress.com/ 2012/09/lettre-adl-du-credof-21-septembre-2012.pdf, 1-11

Kolb, Robert, 'The Relationship between the International and the Municipal Legal Order: Reflections on the Decision no 238/2014 of the Italian Constitutional Court', Questions of International Law: Zoom-Out 2 (2014), 5-16

Krisch, Nico, 'The Backlash against International Courts', VerfBlog, (16 December 2014), available at http://verfassungsblog.de/backlash-international-courts-2/

Kunz, Raffaela, "The Italian Constitutional Court and "Constructive Contestation": A Miscarried Attempt?', Journal of International Criminal Justice 14 (2016), 621-627

Marchegiani, Maura, 'Le principe de la protection équivalente dans l'articulation des rapports entre ordre juridique des NU et CED après l'arrêt Al-Dulimi', Questions of International Law: ZoomIn 6 (2014), 3-14

Marchegiani, Maura, Il principio della protezione equivalente come meccanismo di coordinamento tra sistemi giuridici nell'ordinamento internazionale (Naples: Editoriale Scientifica 2018)

Milanovic, Marko, 'European Court Decides Nada v. Switzerland', EJIL:Talk!, (14 September 2012), available at www.ejiltalk.org/european-court-decides-nada-v-switzerland/ 
Oellers-Frahm, Karin, 'A Never-Ending Story: The International Court of Justice-The Italian Constitutional Court-Italian Tribunals and the Question of Immunity', Heidelberg Journal of International Law 76 (2016), 193-202

Palchetti, Paolo, 'Judgment 238/2014 of the Italian Constitutional Court: In search of a way out', Questions of International Law: Zoom-Out 2 (2014), 44-47

Paris, Davide, 'Carrot and Stick: The Italian Constitutional Court's Preliminary Reference in the Case Taricco', Questions of International Law: Zoom-In 5 (2017), 5-20

Peters, Anne, 'Let Not Triepel Triumph: How To Make the Best Out of Sentenza No. 238 of the Italian Constitutional Court for a Global Legal Order', EJIL:Talk!, (22 December 2014), available at www.ejiltalk.org/let-not-triepel-triumph-how-to-make-the-best-out-of-sentenzano-238-of-the-italian-constitutional-court-for-a-global-legal-order-part-i/

Peters, Anne, 'Targeted Sanctions after Affaire Al-Dulimi et Montana Management Inc. c. Suisse: Is There a Way Out of the Catch-22 for UN Members?', EJIL:Talk!, (4 December 2013), available at www.ejiltalk.org/targeted-sanctions-after-affaire-al-dulimi-et-montana-manage ment-inc-c-suisse-is-there-a-way-out-of-the-catch-22-for-un-members/

Rugge, Giacomo, 'The Italian Constitutional Court on Taricco: Unleashing the Normative Potential of National Identity?, Questions of International Law: Zoom-In 5 (2017), 21-29

Sciso, Elena, 'Brevi considerazioni sui primi seguiti della sentenza della Corte costituzionale 238/2014', Rivista di diritto internazionale 98 (2015), 887-897

Tomuschat, Christian, 'The National Constitution Trumps International Law', Italian Journal of Public Law 2 (2014), 189-196

Viganò, Francesco, 'Melloni Overruled?: Considerations on the Taricco II Judgment of the Court of Justice', New Journal of European Criminal Law 9 (2018), 18-23

Open Access This chapter is licensed under the terms of the Creative Commons Attribution 4.0 International License (http://creativecommons.org/licenses/by/4.0/), which permits use, sharing, adaptation, distribution and reproduction in any medium or format, as long as you give appropriate credit to the original author(s) and the source, provide a link to the Creative Commons license and indicate if changes were made.

The images or other third party material in this chapter are included in the chapter's Creative Commons license, unless indicated otherwise in a credit line to the material. If material is not included in the chapter's Creative Commons license and your intended use is not permitted by statutory regulation or exceeds the permitted use, you will need to obtain permission directly from the copyright holder.

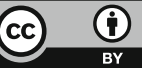




\title{
Sentenza 238/2014: EU Law and EU Values
}

\author{
Bernardo Giorgio Mattarella
}

\begin{abstract}
The relationship between Judgment 238/2014 of the Italian Constitutional Court and EU law is, at first glance, apparently weak, as the subject matter of the former is not governed by the latter, nor there have been any judgments from EU courts regarding the case. However, if one considers the origin and purpose of the EU itself and the state of relations between Italy and Germany, one cannot help but examine the case from a European law perspective. Judgment 238/2014 is relevant to European law in several ways, all of which concern not only military cooperation in the EU but also the protection of human rights, the risk of forum shopping and, above all, how reliable member states are in their mutual relations. European law in turn is relevant to the present case not so much because it offers solutions but because it shows a method for settling clashes between legal systems and illustrates its inherent difficulties. Sentenza 238/2014 is an unpersuasive judgment and can be criticized from different angles: the legal one (international and constitutional law), the factual reconstruction and the judgment's likely effects. There are, however, two possibilities of resolving the situation that Sentenza has produced: firstly the legal one, which involves the use of all possible tools to limit its effects; and secondly the diplomatic one, which implies further negotiations. European law does not provide a ground for a preference between these two options, but it suggests that none of these ways is neglected.
\end{abstract}

\section{Introduction}

Neither the protection nor reparations for the victims of Nazi crimes committed during World War II (WWII) are governed by European law, nor are there EU courts' decisions regarding them. Therefore, one could simply give a negative answer to the four key questions raised by the editors: that Judgment 238/2014 does not have legal implications for European military operations, that it is not an

\footnotetext{
B. G. Mattarella ( $\square)$

LUISS Guido Carli University, Department of Law, Rome, Italy

e-mail: bmattarella@luiss.it 
application of a particular national approach to European issues, that there is not a European special way to state immunity, and that European law is of little help in the issues related to this Judgment.

Nevertheless, it would be a mistake to believe that European law is irrelevant to Judgment 238/2014, and vice versa. Indeed, some background facts need to be taken into consideration: the European integration process started after WWII precisely to ensure peace in Europe by creating ties, not only economic in nature, between European countries. More than 70 years after the end of the war and 60 years after the foundation of the European Communities, we are still discussing reparations for war crimes. Is this a failure for the EU?

Maybe not. The fact that such issues are peacefully negotiated between governments, with legal proceedings before courts and with friendly discussions among scholars, seems to me a success. One reason for optimism is that what has been said so far shows the high standard of human rights protection in the EU. Italian courts, in the cases that we are discussing, have broadly, though possibly improperly, applied the principles of human rights protection that are part of the common legal heritage of all EU member states. Judgment 238/2014 undoubtedly demonstrates that there is a problem between two founding member states of the Union. This is certainly a cause for concern, which should not, however, overshadow the otherwise excellent relations between Germany and Italy. It is in this context that we can reflect both on the implications of Sentenza for EU law and on the indications that EU law can provide for the issues that we are discussing.

\section{Implications for EU Law}

As for the implications of Judgment 238/2014 for EU law, it can easily be affirmed that there is no regional customary policy on state immunity cases in which EU member states are involved. Nor is Sentenza likely to have specific legal implications, for instance concerning European military operations. ${ }^{1}$ There are, however, broader legal implications, both substantive and procedural, that inter alia concern respect for human rights in the EU. On the one hand, the way in which the issue of reparations for war crimes is dealt with in this case could become an important precedent for other violations of human rights, for example concerning immigration and asylum. A violation of human rights, for example, could be found by a national court in the rejection or expulsion of migrants, who could therefore be entitled to compensation. On the other hand, Judgment 238/2014 raises the issue of universal jurisdiction, which could give rise to forms of forum shopping. ${ }^{2}$

\footnotetext{
${ }^{1}$ See also Andreas Zimmermann, chapter 'Would the World Be a Better Place If One Were to Adopt a European Approach to State Immunity?', in this volume.

${ }^{2}$ See also Giovanni Boggero/Karin Oellers-Frahm, chapter 'Between Cynicism and Idealism', in this volume.
} 
In theory, one consequence of this ruling could be the attraction of multiple human rights cases directed towards Italian courts. Such a prospect would be terrible for Italy, whose courts are already heavily engaged in too much litigation. It would be even worse for Europe if a jurisdiction not recognizing state immunity were to be established within its borders, with unforeseeable effects, for example, on the free movement of capital (if the courts of a member state become particularly keen in granting compensation for offenses related to human rights, potential defendants could move their assets out of that state). Nevertheless, these risks should not be overestimated. We must consider the peculiarities of the case, influenced as it is by the special perception in Europe of WWII and Nazi crimes. It is also necessary to take into account the circumstances of this particular case and of this Judgment, which was decided by the Italian Constitutional Court (ItCC) with a difficult and not unanimous deliberation. ${ }^{3}$

The risks, in fact, are not the worst consequence of the Judgment. More worrying is its effect on the predictability of negotiations on this matter and on the reliability of the negotiating parties. In any negotiation there is always the risk that one of the parties plays according to the rules for as long as it finds it convenient. Such an attitude would be particularly harmful for the EU, where the very idea of the unreliability of a founding member state is unacceptable. Even in this respect, however, the risk should not be overestimated. We must consider, once again, the peculiarities of the case. It is necessary to take into account, above all, the experience of more than 60 years of fruitful negotiations and fair implementation of European law. Overall, we should not overrate the implications of Judgment 238/2014 for European law.

\section{The Suggestions Provided by EU Law}

What indications can European law provide for the case at hand? First of all, customary law does not offer clear indications for this case and a legislative solution is at present quite difficult. Hence, there are a few alternatives to further negotiations. Secondly, there is the theme of the dialogue between courts and of the conditional approach; in this respect, European law provides important indications that demonstrate the complexity of the matter.

European law implies a certain degree of mutual trust between national courts and between these national courts and European courts; trust is necessary for the implementation of European law, which requires coordination and responsibility. However, coordination is more difficult to achieve between courts than between governments because courts cannot negotiate and agree on individual cases. Consequently, the possibility that government decisions are ruled out by court decisions is a risk that needs to be eliminated.

\footnotetext{
${ }^{3}$ See Sabino Cassese, chapter 'Recollections of a Judge', in this volume.
} 
Coordination and accountability in the EU are necessary for all actors, including courts, which, in turn, must safeguard the rule of law and protect individual rights without infringements or compromises. Within this framework, we can deal with the 'barking or biting' issue, which is raised by the 'Solange approach', by the counterlimits doctrine, and by the theory of equivalent protection. Barking is useful as long as a court does not need to bite, but is effective only if everyone knows that the court has teeth enough to bite. One bite, from time to time and in exceptional circumstances, can be appropriate and necessary. Of course, an inappropriate bite would be harmful. ${ }^{4}$

\section{Law and Negotiations}

An evaluation of whether Judgment 238/2014 is right or wrong is necessary in order to outline the future path to follow. There are many arguments suggesting that the ItCC's Sentenza is wrong from the point of view of both international law and constitutional law. The Judgment seems to be based on a questionable contrast between the international law principle of immunity and the protection of the rights of the individual granted by national law. It also seems incorrect on the merits because the right to a judge had actually been granted by Germany. ${ }^{5}$ In this respect, though we may have doubts about German legislative and judicial decisions, we must consider Germany's efforts to compensate the victims. We must also acknowledge that the ItCC acted beyond its remit by syndicating those decisions: it did not share the views of German courts and thus stated that there had been no judgments. The ItCC may also have sinned by vanity, searching the 'great judgment', ${ }^{6}$ and may have underestimated or overlooked the effects of its decision, doing little good to constitutional adjudication. $^{7}$

It seems to me, however, that the main task ahead is to identify possible solutions in order to limit the negative effects of Sentenza 238/2014 and to highlight the positive elements of the case. The Judgment must be circumscribed as a unique decision: it is unlikely that a similar judgment will be adopted in the future, but it is equally unlikely a revision of the Constitutional Court's position. We cannot realistically expect an overruling, but we can expect a different decision in the future, when based on different facts. There are two different ways out of the current deadlock: legal and diplomatic.

\footnotetext{
${ }^{4}$ See also Raffaela Kunz, chapter 'Teaching the World Court Makes a Bad Case', in this volume.

${ }^{5}$ For a different perspective, see Valerio Onida, chapter 'Moving beyond Judicial Conflict in the Name of the Pre-Eminence of Fundamental Human Rights', in this volume.

${ }^{6}$ Guido Calabresi, Il mestiere di giudice: Pensieri di un accademico americano (Bologna: Il Mulino 2014).

${ }^{7}$ See Sabino Cassese, chapter 'Recollections of a Judge', in this volume.
} 
The legal route is to wait and use all possible legal means to limit the effects of the Sentenza, counting on non-execution of any further judiciary decisions. It seems to me that exclusively choosing this route would be offensive to the dignity of the victims and also to the dignity of constitutional adjudication: Judgment 238/2014 may be criticized, but it is a judgment of a constitutional court and must be executed.

The diplomatic route involves new negotiations, which could be carried out by exploiting the peculiarities of this case, in which there was a certain lack of negotiation - the International Court of Justice had called for 'further negotiations' and the ItCC complained of their absence. The case poses a relatively small issue in financial terms, which could also be addressed by involving the Italian government: Judgment 238/2014, in fact, is rigid on the side of the victims, not on that of the possible payers, so it should not prevent the Italian government from allocating resources in an effort to resolve the case. ${ }^{8}$ Of course, money is not the most important thing in this case; more important is the recognition due to the victims. However, allocating financial resources could be a form of recognition of their suffering and of their rights.

European law does not provide clear indications for either the legal or the diplomatic route: the EU is a community of law, but it is also a community of values. Both ways are eligible, both can be loyally and legally taken.

\section{Reference}

Calabresi, Guido, Il mestiere di giudice: Pensieri di un accademico americano (Bologna: Il Mulino 2014)

Open Access This chapter is licensed under the terms of the Creative Commons Attribution 4.0 International License (http://creativecommons.org/licenses/by/4.0/), which permits use, sharing, adaptation, distribution and reproduction in any medium or format, as long as you give appropriate credit to the original author(s) and the source, provide a link to the Creative Commons license and indicate if changes were made.

The images or other third party material in this chapter are included in the chapter's Creative Commons license, unless indicated otherwise in a credit line to the material. If material is not included in the chapter's Creative Commons license and your intended use is not permitted by statutory regulation or exceeds the permitted use, you will need to obtain permission directly from the copyright holder.

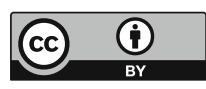

\footnotetext{
${ }^{8}$ See also Francesco Francioni, chapter 'Overcoming the Judicial Conundrum', in this volume.
} 


\title{
The Consequences of Sentenza 238/2014: What to Do Now?
}

\author{
Doris König
}

\begin{abstract}
This chapter illustrates the two ways in which national constitutional courts can deal with a conflict between international or European law on the one hand and national constitutional law on the other hand. The dualist approach of not complying with international or European law comes at the risk of undermining respect for an external legal order and in the author's view should thus be used in exceptional cases only. The chapter argues that the test of equivalent protection is more constructive but requires a close relationship between the legal orders involved. Therefore, this option is difficult to apply in cases which are about conflicts with international and not with European law. In Sentenza 238/2014, the Italian Constitutional Court chose a dualist approach. Although the legal path has not been exhausted yet (Germany could bring another case before the International Court of Justice), the author advocates negotiations with the aim of achieving a political solution which takes into account the interests of all parties involved.
\end{abstract}

\section{Introduction}

This concise chapter elaborates on two issues: it firstly focuses on the techniques national constitutional courts have to tackle a conflict between international or European Union law on the one hand, and national constitutional law on the other hand. It then offers some thoughts on the way forward to solve the conflict between Italy and Germany after Sentenza 238/2014.

\footnotetext{
D. König $(\bowtie)$

German Federal Constitutional Court, Karlsruhe, Germany

e-mail: doris.koenig@law-school.de 


\section{Techniques of Judicial Dialogue}

As Alessandro Bufalini states in his chapter, there are basically two techniques of judicial dialogue between national constitutional courts and international or European courts - the Court of Justice of the European Union and the European Court of Human Rights - in case of a conflict between national, constitutional and international or European law. ${ }^{1}$ The first technique is the more confrontational one, namely the decision not to apply or comply with international or European law in the national legal order due to constitutional reasons. The Italian Constitutional Court uses the counterlimits doctrine (dottrina dei controlimiti), ${ }^{2}$ and the German Federal Constitutional Court uses the identity review (Identitätskontrolle) ${ }^{3}$ to examine whether international or European law is compatible with fundamental principles and inalienable human rights of the national constitutional order. This approach led to the conflict at hand, and triggered numerous legal proceedings before Italian courts which make it extremely difficult to come to a satisfactory solution of the problems raised. Nevertheless, from a constitutional law perspective based on the dualist theory, this technique is sometimes necessary for national constitutional courts to protect the very essence or the 'identity' of the national constitutional order they are the guardians of.

The more constructive technique is the test of equivalent protection which is often applied in cases where the protection of human rights at different legal levels is at stake. In these cases, constitutional courts do not control the compliance with human rights guarantees themselves as long as exists an equivalent human rights protection including judicial review at the international or European law level. ${ }^{4}$ In Germany, this technique is called Solange-Rechtsprechung ('as long as' jurisprudence). ${ }^{5}$ Bufalini rightly points out that this more dialogical second technique usually requires a close relationship and similarity of the two legal orders concerned and also a sophisticated relationship between the courts involved to develop the pertinent means and methods of the necessary 'judicial dialogue'. 6 This is the reason why this technique is often used in the context of European Union law and human rights protection guaranteed in the European Convention on Human Rights. ${ }^{7}$ This also

\footnotetext{
${ }^{1}$ See Alessandro Bufalini, chapter 'Waiting for Negotiations', in this volume.

${ }^{2}$ See eg Corte Costituzionale, Judgment of 27 December 1973, No 183/1973 (Frontini).

${ }^{3}$ See Bundesverfassungsgericht, Order of 15 December 2015, 2 BvR 2735/14, BVerfGE 140, 317.

${ }^{4}$ See, generally, Veronika Bílková, 'The Standard of Equivalent Protection as a Standard of Review', in Lukasz Gruszczynski/Wouter Werner (eds), Deference in International Courts and Tribunals: Standard of Review and Margin of Appreciation (Oxford: OUP 2014).

${ }^{5}$ See FCC, Order of 22 October 1986, 2 BvR 197/83, BVerfGE 73, 339 (Solange II).

${ }^{6}$ See Alessandro Bufalini, chapter 'Waiting for Negotiations', in this volume.

${ }^{7}$ For a thorough analysis of the principle of equivalent protection, see Elisa Ravasi, Human Rights Protection by the ECtHR and the ECJ-A Comparative Analysis in Light of the Equivalency Doctrine (Leiden/Boston: Brill Nijhoff 2017).
} 
explains why it is not used very often in genuine international law cases such as the one at hand.

If constitutional courts make use of the more confrontational technique, mentioned above, thereby blocking off the applicability or enforcement of international or European law in the national legal order, they should do so in a very cautious and responsible way. This technique should only be used rarely in exceptional cases, and - if possible - the language used in such judgments should not be too rigid and confrontational in order to leave some room for the political actors to find a solution to the conflict afterwards. National courts should take into account that decisions to openly disobey international or European law are always apt to undermine respect for the external legal order and also for the rule of law in general.

\section{Possible Ways to Solve the Conflict Between Germany and Italy}

The case at hand is an illustrative example for the difficulties that arise from judgments that apply the counterlimits doctrine, thus preventing the enforcement of the Jurisdictional Immunities Judgment of the International Court of Justice (ICJ) in Italy. ${ }^{8}$ When it comes to finding a solution to the conflict between Germany and Italy, there are, as Bernardo Giorgio Mattarella points out in his chapter, basically two paths to follow, namely the legal path and the political opportunity (and diplomatic) path. ${ }^{9}$ The legal path has not yet been exhausted completely; several options are left, especially with a view to the question of the execution of the judgments now rendered by Italian courts against Germany. ${ }^{10}$ If bad comes to worst, Germany could once again bring the case before the ICJ asking for compensation for reparation payments she was forced to make. In my view, to follow that path would not lead to a sensible solution of a conflict between two countries which are both members of the European Union and work together closely in many ways.

Therefore, both states should choose the preferable option to once again take up negotiations and find a political solution which is apt to close the wounds of the past and takes into account the position and the feelings of the victims. There are many different options concerning how such negotiations could be made, what the aims could be, who should initiate them and who should participate. It is not for me to give advice in this regard. These negotiations do not have to start from scratch; much has been done already. It is clear, however, that such negotiations and their success are dependent on the mutual political will and a certain sense of generosity on both

\footnotetext{
${ }^{8} \mathrm{ICJ}$, Jurisdictional Immunities of the State (Germany v Italy: Greece intervening), Judgment of 3 February 2012, ICJ Reports 2012, 99; ItCC, Judgment of 22 October 2014. No 238/2014.

${ }^{9}$ See Bernardo Giorgio Mattarella, chapter 'Sentenza 238/2014', in this volume.

${ }^{10}$ See Paolo Palchetti, chapter 'Right of Access to (Italian) Courts über alles?', in this volume. See also recently, Corte di Cassazione, Judgment of 25 June 2019, No 21995/2019.
} 
sides. In my view this would be the most sensible way to finally solve the problem in the best interests of both states and the victims.

\section{References}

Bílková, Veronika, 'The Standard of Equivalent Protection as a Standard of Review', in Lukasz Gruszczynski/Wouter Werner (eds), Deference in International Courts and Tribunals: Standard of Review and Margin of Appreciation (Oxford: OUP 2014)

Ravasi, Elisa, Human Rights Protection by the ECtHR and the ECJ-A Comparative Analysis in Light of the Equivalency Doctrine (Leiden/Boston: Brill Nijhoff 2017)

Open Access This chapter is licensed under the terms of the Creative Commons Attribution 4.0 International License (http://creativecommons.org/licenses/by/4.0/), which permits use, sharing, adaptation, distribution and reproduction in any medium or format, as long as you give appropriate credit to the original author(s) and the source, provide a link to the Creative Commons license and indicate if changes were made.

The images or other third party material in this chapter are included in the chapter's Creative Commons license, unless indicated otherwise in a credit line to the material. If material is not included in the chapter's Creative Commons license and your intended use is not permitted by statutory regulation or exceeds the permitted use, you will need to obtain permission directly from the copyright holder. 


\title{
Would the World Be a Better Place If One Were to Adopt a European Approach to State Immunity? Or, 'Soll am Europäischen Wesen die Staatenimmunität Genesen'?
}

\section{Andreas Zimmermann}

\begin{abstract}
This chapter argues not only that there is no European Sonderweg (or 'special way') when it comes to the law of state immunity but that there ought not to be one. Debates within The Hague Conference on Private International Law in the late 1990s and those leading to the adoption of the 2002 UN Convention on Jurisdictional Immunities of States, as well as the development of the EU Brussels Regulation on Jurisdiction and Enforcement, as amended in 2015, all demonstrate that state immunity was not meant to be limited by such treaties but 'safeguarded'. Likewise, there is no proof that regional European customary law limits state immunity when it comes to ius cogens violations, as Italy and (partly) Greece are the only European states denying state immunity in such cases while the European Court of Human Rights has, time and again, upheld a broad concept of state immunity. It therefore seems unlikely that in the foreseeable future a specific European customary law norm on state immunity will develop, especially given the lack of participation in such practice by those states most concerned by the matter, including Germany. This chapter considers the possible legal implications of the jurisprudence of the Italian Constitutional Court for European military operations (if such operations went beyond peacekeeping). These implications would mainly depend on the question of attribution: if one where to assume that acts undertaken within the framework of military operations led by the EU were to be, at least also, attributable to the troopcontributing member states, the respective troop-contributing state would be entitled to enjoy state immunity exactly to the same degree as in any kind of unilateral military operations. Additionally, some possible perspectives beyond Sentenza 238/2014 are examined, in particular concerning the redress awarded by domestic courts 'as long as' neither the German nor the international system grant equivalent protection to the victims of serious violations of international humanitarian law committed during
\end{abstract}

\footnotetext{
A. Zimmermann ( $\square)$

University of Potsdam, Faculty of Law, Potsdam, Germany

e-mail: andreas.zimmermann@uni-potsdam.de 
World War II. In the author's opinion, strengthening the jurisdiction of international courts and tribunals, bringing interstate cases for damages before the International Court of Justice, as well as providing for claims commissions where individual compensation might be sought for violations of international humanitarian law would be more useful and appropriate mechanisms than denying state immunity.

\section{Introduction}

Although this chapter addresses a somewhat colourful bundle of questions, all of them, one way or the other, relate to one overarching question: do specific European perspectives exist de lege lata-or at least should such perspectives exist de lege ferenda-when it comes to the law of state immunity in situations where serious violations of international law have been committed or where, more realistically in current circumstances, such violations are being alleged by the claimant? To get straight to the point, the blunt answer is a clear and simple 'no'. There is no European Sonderweg (or 'special way') when it comes to the law of state immunity, and there ought not to be one either. Rather, member states of the EU, and contracting parties to the European Convention on Human Rights (ECHR) more broadly, should continue to abide by universally recognized principles of state immunity, as having been confirmed by the International Court of Justice (ICJ) in its Jurisdictional Immunities Judgment on the matter. ${ }^{1}$ Accordingly, relevant treaty norms, including the ECHR and applicable secondary legislation of the EU, ${ }^{2}$ should continue to be interpreted and applied in line with currently applicable norms of customary and treaty law on the matter.

Having thus set the scene for the perspective adopted in this chapter, the following sections will delve into more specific issues surrounding the topic. First, a somewhat technical aspect will be addressed: the enforcement, in individual European states, of domestic judgments rendered contrary to traditional concepts of state immunity (section II). In particular, the debate within the Hague Conference on Private International Law in the late 1990s will be summarized since it was also of relevance for the debate on the 2004 UN Convention on Jurisdictional Immunities of States and Their Property (UN Convention on State Immunity) ${ }^{3}$ and the

\footnotetext{
${ }^{1}$ ICJ, Jurisdictional Immunities of the State (Germany v Italy: Greece intervening), Judgment of 3 February 2012, ICJ Reports 2012, 99, para 56 et seq.

${ }^{2}$ Cf Regulation (EC) No 805/2004 of the European Parliament and of the Council of 21 April 2004 creating a European Enforcement Order for Uncontested Claims, OJ vol 47, L143; Regulation (EC) No 1896/2006 of the European Parliament and of the Council of 12 December 2006 creating a European Order for Payment Procedures, OJ vol 49, L399; Regulation (EU) No 1215/2012 of the European Parliament and of the Council of 12 December 2012 on Jurisdiction and the Recognition and Enforcement of Judgments in Civil and Commercial Matters, OJ vol 55, L 351. For details on the latter, cf section II.2.

${ }^{3}$ UN Convention on Jurisdictional Immunities of States and Their Property (2 December 2004), UN Doc A/RES/59/38, UN Doc A/59/49, 486 (not yet in force).
} 
development of the Brussels Regulation. Second, the possible development of specific rules of regional customary law on the matter will be discussed (section III). Third, the legal implications of the jurisprudence of the Italian Constitutional Court (ItCC) for European military operations, and in particular for military operations under the auspices of the EU, will be analyzed (section IV). Finally, the chapter will conclude with some remarks on possible European perspectives beyond Sentenza 238/2014 (section V).

\section{Enforcing Foreign Judgments That Have Not Respected State Immunity}

\section{The Hague Conference on Private International Law $^{4}$}

It was in 1996 that the Hague Conference on Private International Law, with important input from European states and from the EU, decided to 'include in the agenda of the $19^{\text {th }}$ session the question of (..) recognition and enforcement of foreign judgments in civil and commercial matters'. 5 This led to the creation of a Special Commission to come up with a first draft for a convention. The Special Commission's 1999 draft included Article 18(3) that, if adopted, would have provided, as one option, for the possibility of exercising universal jurisdiction in civil matters with respect to conduct constituting genocide, crimes against humanity, war crimes, or other serious crimes against a natural person under international law, respectively with regard to ius cogens violations. ${ }^{6}$ It is worth recalling that the draft provision had also provided that the envisaged broad acceptance of jurisdiction would only apply, at least as far as the two latter categories of violations of international law are concerned (namely serious crimes under international law and ius cogens violations other than genocide, war crimes and crimes against humanity), 'if the party seeking relief is exposed to a risk of a denial of justice

\footnotetext{
${ }^{4} \mathrm{Cf}$, generally on the conference, www.hcch.net/en/home.

${ }^{5} \mathrm{Cf}$ Catherine Kessedjian, 'International Jurisdiction and Foreign Judgments in Civil and Commercial Matters', Preliminary Document No 7 (April 1997), para 26, available at https://assets.hcch.net/ docs/76852ce3-a967-42e4-94f5-24be4289d1e5.pdf.

${ }^{6}$ Hague Conference on Private International Law, Preliminary Draft Convention on Jurisdiction and Foreign Judgments in Civil and Commercial Matters, 30 October 1999, text to be found in Stefan Rinke, Schadensersatzklagen gegen Staaten wegen schwerer Menschenrechtsverletzungen im Europäischen Zivilprozessrecht, (Berlin: BWV Verlag 2016), 128 or the Report by Peter Nygh/ Fausto Pocar concerning the Preliminary Draft Convention on Jurisdiction and Foreign Judgments in Civil and Commercial Matters, adopted by the Special Commission, Preliminary Document No 11 (August 2000), available at https://assets.hcch.net/upload/wop/jdgmpd11.pdf, 10.
} 
because proceedings in another state are not possible or cannot reasonably be required'?

This draft provision thus foreshadowed the last-resort argument made later by Italy during the ICJ proceedings brought by Germany for alleged violations of Germany's state immunity. ${ }^{8}$ It ought to be noted, however, that this provision, as Peter Nygh and Fausto Pocar's underlying explanatory report had made clear, ${ }^{9}$ was only meant to govern jurisdictional issues while state immunity was not meant to be limited by the envisaged treaty. This was confirmed by its draft Article 1(4), which in broad terms had provided that '[n]othing in this Convention affects the privileges and immunities of sovereign States or of entities of sovereign States, or of international organizations'. ${ }^{10}$ It also ought to be noted that the International Law Commission (ILC) was, during the very same period, working on a draft convention on the jurisdictional immunities of states, ${ }^{11}$ which, as is well known, later led to the adoption of the UN Convention on the matter. ${ }^{12}$ The ILC's draft convention similarly did not include any reference to a possible limitation on state immunity in cases of serious violations of international law. ${ }^{13}$ Notwithstanding this development within the ILC, the 2001 draft Hague convention, as submitted to and discussed by The Hague diplomatic conference, had retained, mutatis mutandis, identical language to the same effect as the 1999 draft by the then Special Commission. In other words, it had retained the concept of state immunity even when it comes to instances of genocide, war crimes, and other violations of ius cogens.

What is brought to light by this development is that even a possible acceptance of the exercise of universal jurisdiction in matters such as genocide, crimes against humanity or war crimes, in the envisaged future convention on the recognition and enforcement of foreign judgments, would not have been meant to curtail traditional concepts of state immunity even when it comes to serious violations of international law. What is more, as is evident from the fate of the draft, is that even on those issues no consensus could be reached which led in 2005 to the adoption of a mere convention on choice of court agreements. ${ }^{14}$

\footnotetext{
${ }^{7}$ Ibid.

${ }^{8} \mathrm{ICJ}$, Jurisdictional Immunities (Germany v Italy: Greece intervening) (n 1), para 98 et seq.

${ }^{9} \mathrm{Cf}$ Nygh/Pocar, 'Report concerning the Preliminary Draft Convention' 2000 (n 6).

${ }^{10}$ Ibid, 4.

${ }^{11}$ Yearbook of the International Law Commission II, part 2 (1999), chapter VII, 127 et seq.

${ }^{12} \mathrm{UN}$ Convention on Jurisdictional Immunities, 2004 (n 3).

${ }^{13} \mathrm{Cf}$ Rinke, Schadensersatzklagen 2016 (n 6), 128 et seq; see also Gerhard Hafner, 'Das Übereinkommen der Vereinten Nationen über die Immunität der Staaten und ihres Vermögens von der Gerichtsbarkeit', Zeitschrift für öffentliches Recht 61 (2006), 381-395, at 394.

${ }^{14}$ Convention on Choice of Court Agreements, The Hague Conference on Private International Law, 30 June 2005, available at www.hcch.net/en/instruments/conventions/full-text/?cid=98.
} 


\section{Brussels Ia Regulation}

Turning now to developments within the framework of the EU more specifically, as is well known, the Brussels Regulation was amended in 2015. Commonly referred to as the Brussels Ia Regulation, it built on the Brussels and Lugano Conventions, ${ }^{15}$ as well as earlier versions of the Brussels Regulation itself, ${ }^{16}$ and significantly facilitates the enforcement of judgments on civil and commercial matters rendered in another EU member state by providing for a quasi-automatic system of enforcement of such judgments. ${ }^{17}$ This raises the question of whether under the Brussels Ia Regulation a judgment by a domestic court of one member state denying state immunity when it comes to alleged violations of ius cogens committed by a foreign armed force is enforceable in other EU member states. If that were the case, this would clearly be indicative of an acceptance by the EU of a special regime of a more limited concept of state immunity.

Before entering into details, it should be noted that the preambular paragraph 38 of said Regulation confirms - in the view of its drafters-that it 'respects fundamental rights and observes the principles recognised in the Charter of Fundamental Rights of the European Union, in particular the right to an effective remedy and to a fair trial guaranteed in Article 47 of the Charter'. After having thus confirmed that the Regulation stands in line with the right to an effective remedy, the Regulation, as amended in 2015, now expressis verbis settles that it 'shall not extend, in particular, to (...) the liability of the State for acts and omissions in the exercise of State authority (acta iure imperii), ${ }^{18}$

The amended version, therefore, now also expressis verbis reiterates what the European Court of Justice (ECJ) had already decided in 2007 under the then applicable (older) version of the Brussels Regulation in the Kalavryta case brought by Ms Lechouritou against Germany, and involving a claim for damages related to a massacre committed by the German army in 1943 against Greek civilians. ${ }^{19}$ The ECJ had then decided that such claims do not amount to civil and commercial claims within the meaning of the Brussels system providing for the intra-Union enforcement of judgments.

However, what is brought out by the interplay between the preamble of the amended Regulation and the exclusion from its scope of acta jure imperii-such

\footnotetext{
${ }^{15}$ Brussels Convention on Jurisdiction and the Enforcement of Judgments in Civil and Commercial Matters, 27 September 1968, Official Journal of the European Communities L 299, 31 December 1972; Convention on Jurisdiction and the Enforcement of Judgments in Civil and Commercial Matters, 16 September 1988, Official Journal of the European Communities, vol 31, L 319, 25 November 1988.

${ }^{16}$ Council Regulation (EC) No 44/2001 of 22 December 2000 on Jurisdiction and the Recognition and Enforcement of Judgments in Civil and Commercial Matters [2001] OJ L12.

${ }^{17} \mathrm{Cf}$, for details, preambular para 2, Arts 36(1), 39, and 40 of Regulation (EU) 1215/2012 on Judgments in Civil and Commercial Matters (n 2).

${ }^{18}$ Art 1 of Regulation (EU) 1215/2012 on Judgments in Civil and Commercial Matters (n 2).

${ }^{19}$ ECJ, Lechouritou and Others, Judgment of 15 February 2007, Case No C-292/05, I-1540.
} 
as acts of armed forces, in particular when they take place within the framework of armed conflicts ${ }^{20}$ - is that the Brussels Regulation, as amended, wanted to 'safeguard' traditional rules of state immunity. What is more, the drafters of the amended Regulation were obviously aware of the then recent judgment of the ICJ in the Jurisdictional Immunities (Germany $v$ Italy) case. They were also aware of the previously unsuccessful attempts to use the Brussels Regulation to enforce Greek court decisions in Italy, ${ }^{21}$ which had set aside Germany's state immunity in cases involving war crimes but which could not be enforced in Greece itself for lack of consent by the Greek Minister of Justice. ${ }^{22}$ Accordingly, the amendment of the Brussels Regulation in 2015, when read in conjunction with the above-mentioned preamble to the Regulation, must be seen as evidence of the conviction of EU member states that the traditional rules of state immunity, including when it comes to ius cogens violations, are indeed compatible with the international and European rule of law.

\section{Regional European Customary Law on State Immunity?}

International law since the judgment of the ICJ in the Asylum (Colombia v Peru) case recognizes - be it only as a matter of principle - the concept, the notion, and the possibility of regional customary law. ${ }^{23}$ Yet, as the Court stated, the existence of any such rule presupposes that ' $[\mathrm{t}]$ he Party which relies on a custom of this kind must prove (...) that the rule invoked by it is in accordance with a constant and uniform usage practised by the States in question', and that this statement, the Court confirmed, 'follow[ed] from Article 38 of the Statute of the Court, which refers to international custom "as evidence of a general practice accepted as law". 24

Accordingly, in the case at hand, in order to argue in favour of a rule of regional customary law limiting state immunity when it comes to ius cogens violations, one would have to show coherent and consistent state practice by European states and thus confirming the existence of such a rule (or the emergence thereof). Yet, even if one were to limit oneself to the practice of EU member states, which in itself would be problematic since EU member states presumably do not even constitute a 'region' for purposes of general international law, there are only singular cases where no state immunity has been granted even where the underlying issues related to serious

\footnotetext{
${ }^{20}$ During the ICJ proceedings leading to the Jurisdictional Immunities Judgment, neither of the two parties argued that such acts did not amount to acta iure imperii; see ICJ, Jurisdictional Immunities (n 1), 99, para 60 et seq.

${ }^{21} \mathrm{Cf}$ ICJ, Jurisdictional Immunities (n 1), 99, para 33 et seq.

${ }^{22}$ Enforcement against a foreign state requires the consent of the Minister of Justice under Art 923 of the Greek Code of Civil Procedure, which was not granted.

${ }^{23}$ ICJ, Asylum Case (Colombia v Peru), Judgment of 20 November 1950, ICJ Reports 1950, 266, 276 et seq.

${ }^{24}$ Ibid.
} 
violations of either international humanitarian law or human rights law. Even in the case of Italy, the Italian government and Italian courts continue to take the position that Germany enjoys immunity when it comes to the execution of the underlying judgments, ${ }^{25}$ while the judgment of the $\mathrm{ItCC}^{26}$ did not base its decision on international law but rather exclusively on domestic Italian law. ${ }^{27}$

Moreover, the 2012 ICJ Judgment in turn had made frequent reference specifically to decisions of European courts, including judgments by Polish, ${ }^{28}$ Slovenian, ${ }^{29}$ Belgian $^{30}$ and Serbian courts, ${ }^{31}$ and on that basis had upheld Germany's state immunity even in the face of serious violations of the laws and customs of war. ${ }^{32}$ Hence, at most there is practice by only two European states denying state immunity in cases of ius cogens violations, namely Italy and possibly Greece (notwithstanding the Greek government not granting the necessary permission to enforce a judgment of Greek courts against Germany, which then led to an attempt to have the said judgment enforced in Italy). Even in those instances, this practice is limited to the practice of national courts, rather than that of either the executive or the legislative branch, which in and of itself raises fundamental questions as to the notion and concept of state practice within the meaning of Article 38 of the ICJ Statute. ${ }^{33}$

Furthermore, four European states-Finland, Sweden, Norway, and Italy-also made it clear when ratifying the 2004 UN Convention on State Immunity that in their respective understanding the foreign tort exception to state immunity under the Convention does not apply when it comes to activities of armed forces during an

\footnotetext{
${ }^{25}$ ICJ, Jurisdictional Immunities (n 1), 99, para 112; Cf also Karin Oellers-Frahm, ‘A Never-Ending Story: The International Court of Justice-The Italian Constitutional Court-Italian Tribunals and the Question of Immunity', Heidelberg Journal of International Law 76 (2016), 193-202, at 195 et seq. ${ }^{26}$ Corte Costituzionale, Judgment of 22 October 2014, No 238/2014.

${ }^{27} \mathrm{Ibid}$, Conclusions in Point of Law, para 3. For details on the approach taken by the Constitutional Court cf, eg, Raffaela Kunz, 'The Italian Constitutional Court and "Constructive Contestation": A Miscarried Attempt?', Journal of International Criminal Justice 14 (2016), 621-627, at 623 et seq.

${ }^{28}$ Supreme Court of Poland, Natoniewski v Federal Republic of Germany, Judgment of 29 October 2010, Polish Yearbook of International Law, vol XXX, 2010, 299.

${ }^{29}$ Constitutional Court of Slovenia, Decision of 8 March 2001, Case No Up-13/99, Constitutional Court, para 13.

${ }^{30}$ Court of First Instance of Ghent, Botelberghe v German State, Judgment of 18 February 2000.

${ }^{31}$ Court of First Instance of Leskovac, Judgment of 1 November 2001.

${ }^{32}$ ICJ, Jurisdictional Immunities (n 1), 99, cites: ECtHR, McElhinney v Ireland, Grand Chamber Judgment of 21 November 2001, Application No 31253/96; ECtHR, Grosz v France, Decision of 16 June 2009, Application No 14717/06; and Kalogeropoulou and Others v Greece and Germany, Decision of 12 December 2002, Application No 59021/00. Cf also the ICJ's conclusion in para 78.

${ }^{33}$ The implications of inconsistent state practice in the identification of customary international law are also addressed in Draft Conclusion 7 and the accompanying commentary adopted by the ILC in its sixty-eighth session in the framework of its on-going project on the 'Identification of customary international law', cf Report of the International Law Commission, Sixty-Eighth Session (2 May-10 June and 4 July-12 August 2016), General Assembly Official Records, Seventy-First Session Supplement No 10 (A/71/10), 92 et seq. See also Paolo Palchetti, chapter 'Right of Access to (Italian) Courts über alles?', in this volume.
} 
armed conflict, and indeed even beyond as far as 'activities undertaken by military forces of a State in the exercise of their official duties' are concerned. ${ }^{34}$ Besides, one might also recall the well-known Article 31 of the European Convention on the matter ${ }^{35}$ which expressis verbis contains the very same idea. ${ }^{36}$ Finally, the regional European human rights institution, namely the European Court of Human Rights (ECtHR), has also time and again upheld a broad concept of state immunity. As a matter of fact, it did so even in the face of ius cogens violations like torture. ${ }^{37}$

Put otherwise, one might be tempted to say that if there is one region in the world where the traditional concept of state immunity has been upheld the most, it is Europe. If one were to take a different position, be it only arguendo, namely that there indeed was a European tendency to restrict state immunity when it comes to violations of international humanitarian law or human rights law, the necessary requirements for the creation of a new and more limited rule of customary international law on the matter within both a short period of time and the parameters of the ICJ's North Sea Continental Shelf (Germany/Netherlands) case are clearly not fulfilled. ${ }^{38}$ Indeed, this is true not only for lack of a virtually uniform practice but also for lack of participation in such practice by those states most concerned by the matter, which in the case at hand would have to include Germany as being particularly concerned by issues of state immunity relating to war crimes and other similar violations of international law committed during World War II (WWII).

Given this situation, it seems barely imaginable that in the foreseeable future a specific European customary law norm on state immunity could develop. Rather, it seems that the EU and its member states, as well as other member states of the Council of Europe, like Norway, Turkey, or the Russian Federation, continue to rely on a broad concept of state immunity. This is also brought out, inter alia, by the recent démarches of the EU against the so-called US Justice Against Sponsors of

\footnotetext{
${ }^{34} \mathrm{Cf}$ UN Convention on Jurisdictional Immunities, 2004 (n 3), Declarations and Reservations available at https://treaties.un.org/doc/Publication/MTDSG/Volume\%20I/Chapter\%20III/III-13. en.pdf.

${ }^{35}$ Art 31 of the European Convention on State Immunity, 16 May 1972, ETS No 074, reads: 'Nothing in this Convention shall affect any immunities or privileges enjoyed by a Contracting State in respect of anything done or omitted to be done by, or in relation to, its armed forces when on the territory of another Contracting State.'

${ }^{36}$ It should also be mentioned that, as noted by the ICJ in its Jurisdictional Immunities Judgment, courts in Belgium (Court of First Instance of Ghent, Botelberghe v German State, Judgment of 18 February 2000), Ireland (Supreme Court, McElhinney $v$ Williams, Judgment of 15 December 1995, 3 Irish Reports 382), Slovenia (Constitutional Court, Case No Up-13/99, para 13), Greece (Margellos v Federal Republic of Germany, Case No 6/2002, ILR, vol 129, 529) and Poland (Supreme Court of Poland, Natoniewski v Federal Republic of Germany, Polish Yearbook of International Law, vol XXX, 2010,299) all held that that the immunity of a state for torts committed by its armed forces is unaffected by Art 11 of the Convention by virtue of its Art 31; cf ICJ, Jurisdictional Immunities (n 1), 99, at para 68.

${ }^{37}$ ECtHR, Jones and Others $v$ The United Kingdom, Judgment of 14 January 2014, Applications Nos 34356/06 and 40528/06, para 93.

${ }^{38}$ ICJ, North Sea Continental Shelf (Federal Republic of Germany/Netherlands), Judgment of 20 February 1969, ICJ Reports 1969, 3, at para 74.
} 
Terrorism Act (JASTA), ${ }^{39}$ which, by way of amending the US Foreign Sovereign Immunities Act, significantly narrows the scope of foreign sovereign immunity under domestic US law- and it does so in violation of international law. ${ }^{40}$

As a matter of fact, out of the 14 European states having so far ratified UN Convention on State Immunity, ${ }^{41}$ only Switzerland has formally taken the position that the said treaty is without prejudice to developments in international law regarding pecuniary compensation for human rights violations; ${ }^{42}$ while Italy, when ratifying the Convention, merely referred to the necessity to interpret the treaty in line with human rights law. ${ }^{43}$ This acceptance by the vast majority of ratifying European states of the 2004 UN Convention, which does not contain an ius cogens or some other form of human rights exception, once again confirms the general European perspective on the matter, as outlined above. It is even more telling that six of those ratifying European states have done so after the Jurisdictional Immunities Judgment between Germany and Italy had been rendered ${ }^{44}$ —and they did so without entering any reservation or formal declaration as to the 'conservative' interpretation of the current status of the rules of state immunity by the ICJ.

\section{Possible Legal Implications of the Jurisprudence of the Italian Constitutional Court for European Military Operations}

The jurisprudence of the ItCC might have particular implications for European military operations, namely for military operations under the auspices of the EU, given that EU states might face a denial of their state immunity when their troops

\footnotetext{
${ }^{39}$ US, Justice Against Sponsors of Terrorism Act, 28 September 2016, Public Law No 114-222, available at www.gpo.gov/fdsys/pkg/BILLS-114s2040enr/html/BILLS-114s2040enr.htm.

${ }^{40} \mathrm{EU}$, Delegation to the United States of America, note to the US Department of State of 9 September 2016, available at www.washingtonpost.com/news/powerpost/wp-content/uploads/ sites/47/2016/09/EU-on-JASTA.pdf. See also Riccardo Pavoni, chapter 'A Plea for Legal Peace', in this volume.

${ }^{41}$ Those are: Austria, Czech Republic, Finland, France, Italy, Latvia, Liechtenstein, Norway, Portugal, Romania, Slovakia, Spain, Sweden and Switzerland. Cf UN Convention on Jurisdictional Immunities, 2004 (n 3).

${ }^{42}$ Ibid, upon ratification on 16 April 2010, Switzerland declared: 'Switzerland considers that article 12 does not govern the question of pecuniary compensation for serious human rights violations which are alleged to be attributable to a state and are committed outside the state of the forum. Consequently, this Convention is without prejudice to developments in international law in this regard.'

${ }^{43}$ Ibid, upon ratification on 6 May 2013, Italy declared: '[T]he Italian Republic wishes to underline that Italy understands that the Convention will be interpreted and applied in accordance with the principles of international law and, in particular, with the principles concerning the protection of human rights from serious violations.'

${ }^{44}$ Ibid, those are Czech Republic, Finland, Italy, Latvia, Liechtenstein and Slovakia.
} 
allegedly commit violations of international humanitarian law during such operations. It should first be noted, however, that it is highly unlikely that European armed forces and their member states will commit violations of international humanitarian law amounting to ius cogens violations akin to the war crimes that gave rise to the jurisprudence of the Italian courts in the first place. Hence, most probably, the issue of a possible ius cogens exception will hopefully remain a mere academic issue when it comes to the realities of current European military operations.

Secondly, and this is a somewhat more difficult question to answer, it is doubtful whether the result reached by the ICJ in its Jurisdictional Immunities Judgment confirming state immunity for belligerent acts ${ }^{45}$ would also apply to activities of armed forces not amounting to participation in an armed conflict as a belligerent party but rather, for example, to acts forming part of a peacekeeping operation. This would then bring back the issue of the scope and status under customary law of the foreign tort exception. Again, it ought to be noted that several European states, including Italy, have taken the position that the counter-exception to the foreign tort exception should be broadly defined as covering all forms of military activities and even those beyond the scope of armed conflicts. ${ }^{46}$

In any case, any debate about the extent of state immunity when it comes to European military operations would first and foremost, and as a preliminary matter, have to tackle the issue of attribution. ${ }^{47}$ If European military operations, conducted under the auspices of the EU, were to be attributed to either the EU or, in the case of an underlying mandate by the Security Council, to the $\mathrm{UN}^{48}$ in line with the somewhat problematic jurisprudence of the ECtHR in the Behrami and Behrami $v$ France and Saramati v France, Germany and Norway cases, ${ }^{49}$ the question of state responsibility would obviously not arise. Yet, as the domestic proceedings in the Netherlands concerning the UN peacekeeping operation in Bosnia and Herzegovina have confirmed, mutatis mutandis, parallel issues to the immunity of international organizations might nevertheless come to light. ${ }^{50}$ It ought to be noted, however, that the Protocol on the Privileges and Immunities of the European Union, annexed to the

\footnotetext{
${ }^{45}$ ICJ, Jurisdictional Immunities (n 1), 99, at para 139, findings (1) and (3).

${ }^{46}$ Those are Finland, Italy, Norway and Sweden. See Convention on Jurisdictional Immunities, 2004 (n 3).

${ }^{47} \mathrm{Cf}$ Aurel Sari/Ramses A Wessel, 'International Responsibility for EU Military Operations: Finding the EU's Place in the Global Accountability Regime', in Bart Van Vooren/Steven Blockmans/Jan Wouters (eds), The EU's Role in Global Governance: The Legal Dimension (Oxford: OUP 2013), 126-141.

${ }^{48} \mathrm{Cf}$ Terry D Gill, 'Legal Aspects of the Transfer of Authority in UN Peace Operations', Netherlands Yearbook of International Law 42 (2011), 37-68, at 53 et seq.

${ }^{49}$ ECtHR, Behrami and Behrami v France, Grand Chamber Decision of 31 May 2007, Application No 71412/01 and ECtHR, Saramati v France, Germany and Norway, Grand Chamber Decision of 2 May 2007, Application No 78166/01.

${ }^{50}$ ECtHR Behrami and Behrami v France (n 49) and ECtHR, Saramati v France, Germany and Norway, (n 49). Cf Gill, 'Legal Aspects of the Transfer of Authority in UN Peace Operations' 2011 (n 48), 39.
} 
Treaty of Nice, ${ }^{51}$ does not as such provide for a general immunity of the EU at least when it comes to civil proceedings for damages brought before civil courts of an EU member state.

If one were to assume, however, that acts as part of military operations led by the EU were to be at least also attributable to the troop-contributing member states, as was the position taken by German courts concerning military operations conducted off the coast of Somalia within the framework of the European Union Naval Force (EU NAVFOR) ${ }^{52}$ no specific issues of state immunity would arise. Rather, the respective troop-contributing state would be entitled to enjoy state immunity to the same degree as in any kind of unilateral military operation. It is again interesting to note that Italy, when ratifying the 2004 UN Convention on State Immunity, expressly reiterated that-in its view-the Convention does not set aside 'special immunity regimes, including the ones concerning the status of armed forces and associated personnel following the armed forces, ${ }^{53}$ and it is submitted that this is completely in line with customary law. Accordingly, given that European armed forces would in most cases and including those like Afghanistan, where they are involved in actual fighting, act within the framework of a status of forces agreement concluded with the relevant territorial state specifically providing for the immunity of the respective European state, the issue would be moot since any such European state involved in a military operation would then continue to be entitled to fullyfledged immunity as a matter of treaty law.

Besides, to the extent that a domestic court of the territorial state with which a status of forces agreement providing for immunity has been concluded would have to decide the matter, setting aside such treaty-based immunity would not only require arguing that there is no state immunity in such cases but would have to argue that the alleged customary rule setting aside state immunity in case of alleged war crimes was in and of itself also of an ius cogens character. Such an argument, while being in line with the general thrust of the judgment of the ItCC, ${ }^{54}$ would, however, necessarily assume another bold step not supported by actual state practice.

In any case, it is worth noting that at least when it comes to European military operations in the strict sense, namely those undertaken under the auspices of the EU rather than operations within the framework of NATO but involving European states, the respective status of forces agreements concluded by the EU provide as a matter of routine for an individual right to seize a claims commission, followed by some form of arbitration. For example, the Agreement between the European Union

\footnotetext{
${ }^{51}$ Protocol (No 7) on the Privileges and Immunities of the European Union, annexed to the Treaty on European Union ('Treaty of Nice'), 13 December 2007, Official Journal of the European Union, vol 55, C 326/266.

${ }^{52} \mathrm{Cf}$, inter alia, Higher Administrative Court of Nordrhein-Westfalen, Judgment of 18 September 2014, 4 A 2948/11, DVB1 2015, 375-379, findings (Leitsätze) (1), (2) and (3).

${ }^{53}$ Declaration by the Italian Republic concerning the UN Convention on Jurisdictional Immunities, 2004 (n 3), made upon ratification in date of 6 May 2013, available at https://treaties.un.org/doc/ Publication/MTDSG/Volume\%20I/Chapter\%20III/III-13.en.pdf.

${ }^{54}$ ItCC, Judgment 238/2014 (n 26).
} 
and the Republic of Uganda on the Status of the European Union-led Mission in Uganda, ${ }^{55}$ regulating the legal status of the European Union Training Mission Somalia (EUTM) in Uganda, while confirming in its Article 5(3) that EUTM Somalia 'shall enjoy immunity from every form of legal process' at the same time provides in its Article 15 for the setting up of a claims commission, where claims by individuals can be brought, as well as for the creation of an arbitral tribunal, should the claims process fail to adequately address alleged individual damages. In such a scenario the last resort argument, as submitted by Italy in the ICJ proceedings brought by Germany, ${ }^{56}$ and somewhat also reflected in the judgment of the ItCC here under consideration, ${ }^{57}$ would no longer be of relevance, given the alternative to setting aside state immunity. In most situations with a deployment of troops under the auspices of the EU, the issue underlying Sentenza 238/2014 is thus somewhat academic in nature.

\section{Further Perspectives Beyond Sentenza 238/2014}

Obviously, the unfortunate approach chosen by the ItCC of disregarding the international legal obligations of Italy to implement a binding judgment of an international court or tribunal is not unique. It suffices to refer to the examples of the 2008 judgment of the US Supreme Court in Medellin v Texas ${ }^{58}$ (setting aside the effects of the ICJ judgment in Avena and Other Mexican Nationals, Mexico $v$ United States of America), ${ }^{59}$ or the more recent decision of the Russian Constitutional Court in the Yukos case. ${ }^{60}$ Just like the German Federal Constitutional Court, which had unfortunately in the past-albeit as a matter of principled approach only-mutatis mutandis chosen the collision course with the $\mathrm{ECJ}^{61}$ and later the

\footnotetext{
${ }^{55}$ Agreement between the European Union and the Republic of Uganda on the Status of the European Union-led Mission in Uganda, entered into force 12 August 2010, OJ L221/2, available at http://ec.europa.eu/world/agreements/prepareCreateTreatiesWorkspace/treatiesGeneralData.do? step $=0 \&$ redirect $=$ true $\&$ treaty $I d=9781$.

${ }^{56} \mathrm{ICJ}$, Jurisdictional Immunities (n 1), 99, at paras 98-104.

${ }^{57}$ ItCC, Judgment 238/2014 (n 26), Conclusions in Point of Law, para 3.4.

${ }^{58}$ US Supreme Court, Medellín v Texas, Judgment of 25 March 2008, No 06-984, available at https://supreme.justia.com/cases/federal/us/552/491/.

${ }^{59} \mathrm{ICJ}$, Avena and Other Mexican Nationals (Mexico v United States of America), Judgment of 31 March 2004, ICJ Reports 2004, 12.

${ }^{60}$ Russian Constitutional Court, Judgment of 19 January 2017, No 1-П/2017. See also, on the decision, Matthias Hartwig, 'Vom Dialog zum Disput? Verfassungsrecht vs. Europäische Menschenrechtskonvention-Der Fall der Russländischen Föderation', Europäische GrundrechteZeitschrift 44 (2017), 1-23.

${ }^{61}$ Bundesverfassungsgericht, Order of 22 October 1986, 2 BvR 197/83, BVerfGE 73, 339 (Solange II), English version: (1984) Case 345/82, [1987] 3 CMLR 225; Bundesverfassungsgericht, Judgment of 12 October 1993, 2 BvR 2134/92, BVerfGE 89, 155 (Maastricht Judgment).
} 
ECtHR, ${ }^{62}$ the course chosen by the ItCC has similarly not (yet) led to a concrete collision with the principal judicial organ of the UN. Such a collision would only occur if concrete steps were now taken to execute judgments for damages against German state property located in Italy and if Germany were to then start renewed proceedings before the ICJ, which could possibly lead to another ICJ judgment most probably reconfirming the 2012 ICJ Judgment. Hopefully such a collision can be avoided.

This leads to the question of whether the redress awarded by domestic (Italian) courts 'as long as' neither the German nor the international system grant equivalent protection to the victims of serious violations of international humanitarian law committed during WWII is necessary or at least tolerable. For instance, this raises the issue of whether indeed such individual claims do exist in the first place as a matter of the current international lex lata, which one might say is doubtful. Even if this were the case, such individual claims might have already been satisfied under previous interstate agreements or in the meantime might have been subject to some other form of prescription one way or the other.

While these questions would go beyond the scope of this chapter, one has to ask more broadly whether it truly makes sense at the current stage of international law and currently prevailing political developments to take bold steps like recognizing an individual right to compensation for such violations (and even where such violations have been committed more than 70 years ago) combined with denying immunity to the state concerned. The Pandora's box argument, while having been repeated time and again, ${ }^{63}$ is obvious: does it really make sense, for example, to have Georgian courts decide cases against the Russian Federation for alleged violations of international humanitarian law during the 2008 armed conflict — and then obviously also vice-versa-with almost 'automatic', yet completely contrary, results on the merits? Would this constitute an improvement of the international legal order, and would such a development truly foster the international rule of law?

Rather, the way forward-be it only for future cases-should be to enlarge and strengthen the jurisdiction of international courts and tribunals, either those that provide access to individuals or that have some form of compulsory jurisdiction. The European Convention for the Peaceful Settlement of Disputes certainly forms part of such an attempt, which could not be invoked by Italy as a jurisdictional basis for its counter-claim for reasons ratione temporis. ${ }^{64}$ That is to say: if a similar scenario of violations of international humanitarian law was to arise again today between two or more of the contracting parties of the said Convention, and it is hoped that this will

\footnotetext{
${ }^{62}$ Bundesverfassungsgericht, Order of 14 October 2004, 2 BvR 1481/04, BVerfGE 111, 307 (Görgülü); English translation by the Court, available at www.bverfg.de/entscheidungen/ rs20041014_2bvr148104en.html.

${ }^{63}$ Andreas Zimmermann, 'Das Völkerrecht stärken!', Die Tageszeitung (13 September 2011), available at http://www.taz.de/!5112119/.

${ }^{64} \mathrm{ICJ}$, Jurisdictional Immunities (n 1), 99, para 44.
} 
not happen, the underlying interstate case for damages could be brought, and rightly so, before the ICJ. It is submitted that this might be the right way forward.

In the same vein, providing for claims commissions might also be a useful and an appropriate mechanism provided the parties involved are indeed able and willing to follow up on such a process. ${ }^{65}$

This leads to a final question: what lessons ought to be learned when it comes to a possible dialogue between domestic and constitutional courts on the one hand, and international courts on the other? In the author's understanding, international courts not only constitute a capstone but also a cornerstone of the construction of international law. Once such a cornerstone is removed or damaged-and unfortunately, we currently see many instances, benevolent or not, to that effect throughout the world - the danger arises that the whole edifice if not collapses then at least begins to crack. Hence, every attempt should be made not to question their authority even more so since such international judicial institutions by their very nature have the clear advantage of being by far furthest away from domestic political pressures and sentiments.

In summary, one might say that European states, as well as European (constitutional) courts, should not straightforwardly follow Frank Sinatra's tempting example, who in his 1969 song 'My Way' told us that he had not acted 'in a shy way', that he 'had to say the things he truly felt' and not 'the words of one who kneels', and that 'the record therefore showed that he had to take the blows' in order to 'do it my way' ${ }^{66}$ Domestic courts, and even more so the highest courts of democratic and rule-based countries, do not only have a responsibility to their own constitutional order but also more broadly to the international legal order. Hence, such courts, but also Europe more generally, should try to avoid deciding matters of state immunity 'their own way' because it is not only them that would have to take the blow, but such blows could threaten to undermine international law and the international rule of law at large.

\section{References}

Gill, Terry D, 'Legal Aspects of the Transfer of Authority in UN Peace Operations', Netherlands Yearbook of International Law 42 (2011), 37-68

Hafner, Gerhard, 'Das Übereinkommen der Vereinten Nationen über die Immunität der Staaten und ihres Vermögens von der Gerichtsbarkeit', Zeitschrift für öffentliches Recht 61 (2006), 381-395

Hartwig, Matthias, 'Vom Dialog zum Disput? Verfassungsrecht vs. Europäische Menschenrechtskonvention-Der Fall der Russländischen Föderation', Europäische Grundrechte-Zeitschrift 44 (2017), 1-23.

Kunz, Raffaela, 'The Italian Constitutional Court and "Constructive Contestation": A Miscarried Attempt?', Journal of International Criminal Justice 14 (2016), 621-627

\footnotetext{
${ }^{65}$ Eritrea-Ethiopia Claims Commission, Eritrea/Ethiopia, Partial Award of 19 December 2005, Ius Ad Bellum-Ethiopia's Claims 1-8, available at https://pcacases.com/web/sendAttach/763.

${ }^{66}$ Frank Sinatra, 'My Way', available at https://www.youtube.com/watch?v=qQzdAsjWGPg.
} 
Oellers-Frahm, Karin, 'A Never-Ending Story: The International Court of Justice-The Italian Constitutional Court-Italian Tribunals and the Question of Immunity', Heidelberg Journal of International Law 76 (2016), 193-202

Rinke, Stefan, Schadensersatzklagen gegen Staaten wegen schwerer Menschenrechtsverletzungen im Europäischen Zivilprozessrecht (Berlin: BWV Verlag 2016)

Sari, Aurel/Ramses A Wessel, 'International Responsibility for EU Military Operations: Finding the EU's Place in the Global Accountability Regime', in Bart Van Vooren/Steven Blockmans/ Jan Wouters (eds), The EU's Role in Global Governance: The Legal Dimension (Oxford: OUP 2013), 126-141

Zimmermann, Andreas, 'Das Völkerrecht stärken!', Die Tageszeitung (13 September 2011), available at http://www.taz.de/!5112119/

Open Access This chapter is licensed under the terms of the Creative Commons Attribution 4.0 International License (http://creativecommons.org/licenses/by/4.0/), which permits use, sharing, adaptation, distribution and reproduction in any medium or format, as long as you give appropriate credit to the original author(s) and the source, provide a link to the Creative Commons license and indicate if changes were made.

The images or other third party material in this chapter are included in the chapter's Creative Commons license, unless indicated otherwise in a credit line to the material. If material is not included in the chapter's Creative Commons license and your intended use is not permitted by statutory regulation or exceeds the permitted use, you will need to obtain permission directly from the copyright holder. 
Part V

Courts 


\title{
A Dangerous Last Line of Defence: Or, A Roman Court Goes Lutheran
}

\author{
Christian J. Tams
}

\begin{abstract}
The chapter addresses questions of international law implicated by Sentenza 238/2014. It begins by revisiting the longstanding debate about state immunity and its limits, arguing that notwithstanding decades of discussion, a 'grave breaches' exception has never had more than marginal support in positive international law. Against that background, it comes as no surprise that the Italian Constitutional Court (ItCC), in Judgment 238/2014, did not assert the existence of a grave breaches exception as a matter of international law. Instead, the ItCC relied on what might be termed a 'foreign relations law' approach, holding that Italian constitutional law required it not to give domestic effect to the international law of state immunity. This 'foreign relations law' approach offers a last line of defence for those seeking to limit the reach of rules of state immunity. As is set out in this chapter, it is an effective line of defence because international law does not 'by itself, possess the force to amend or repeal internationally unlawful domestic (...) acts' (Antonio Cassese). At the same time it is a dangerous line, as it risks weakening international law generally and not just in the area of immunity. This chapter suggests that, when read as a foreign relations law decision, Sentenza 238/2014 is not as such unusual: it is one of many decisions accepting some form of 'constitutional override' that limits the effects of international law within domestic legal orders. However, Sentenza 238/2014 stands out because - unlike other decisions-it seems to refuse international law any place in the construction of constitutional law: in the ItCC's 'separatist treatment' (Kolb) international law is denied a directive function ('Orientierungswirkung'); it is not factored into the equation. Seen in that light, Sentenza 238/2014 (counter-intuitively, for a 'Roman' decision) has a 'Lutheran' quality; it is informed by a stubborn 'here I stand, I can do no other'
\end{abstract}

I am grateful to Eleni Methymaki for her competent research assistance and insightful comments on the initial draft.

C. J. Tams (ه)

University of Glasgow, School of Law, Glasgow, UK

e-mail: christian.tams@glasgow.ac.uk 
aspect, which limits the potential for a constructive dialogue between domestic and international judiciaries.

\section{Introduction}

This chapter situates Judgment $238 / 2014^{1}$ in the wider debate on immunity and human rights. It does so by analysing the argumentative strategy adopted by the Italian Constitutional Court (ItCC) and assessing how it could influence the development of international law. My key argument is that the judgment's influence is likely to be limited, and that this is largely for the better. More specifically, Judgment 238/2014 contributes fairly little to the long-standing debates about the scope of immunities enjoyed, under international law, by states responsible for grave breaches of international law.

To set the stage, I begin by revisiting those long-standing debates and argue that notwithstanding decades of discussion and fervent support among some commentators, a 'grave breaches' exception has only ever been endorsed by a small number of states and international organizations (section II). Against that background, it comes as no surprise that the ItCC, in Judgment 238/2014, did not assert the existence of a grave breaches exception as a matter of international law. Instead, the ItCC relied on what might be termed a 'foreign relations law' approach, ${ }^{2}$ holding that Italian constitutional law required it not to give domestic effect to the international law of state immunity (section III). This foreign relations law approach offers a last line of defence for those seeking to limit the reach of rules of state immunity. As is set out in section IV, this approach is an effective line of defence, as international law does not 'by itself, possess the force to amend or repeal internationally unlawful domestic (...) acts'. ${ }^{3}$ At the same time, it is a dangerous line, as it risks weakening international law generally and not just in the area of immunity. The chapter suggests that, when read as a foreign relations law decision, Judgment 238/2014 is not as such unusual: it is one of many decisions accepting some form of 'constitutional override' that limits the effects of international law within domestic legal orders. However, it stands out because - unlike decisions of other domestic courts preserving the possibility of a constitutional override - it seems to refuse international law any place in the construction of constitutional law: in the ItCC's 'separatist treatment',

\footnotetext{
${ }^{1}$ Corte Costituzionale, Judgment of 22 October 2014, No 238/2014.

${ }^{2}$ Put simply the term 'foreign relations law' is used to denote 'the domestic law of each nation that governs how this nation interacts with the rest of the world' without, however, itself making a determination of the state's international rights and obligations, Curtis A Bradley, 'What is Foreign Relations Law?' in Curtis A Bradley (ed), The Oxford Handbook of Comparative Foreign Relations Law (Oxford: OUP 2018).

${ }^{3}$ Antonio Cassese, 'Towards a Moderate Monism', in Antonio Cassese (ed), Realizing Utopia: The Future of International Law (Oxford: OUP 2012), 187-199, 199.

${ }^{4}$ Robert Kolb, The Law of Treaties: An Introduction (Cheltenham: Edward Elgar 2016), 180.
} 
international law is denied any 'directive function' ('Orientierungswirkung'); it is not factored into the equation. ${ }^{5}$ Seen in that light, Judgment 238/2014 (perhaps counter-intuitively, for a 'Roman' decision) has a 'Lutheran' quality; it is informed by a stubborn 'here I stand, I can do no other' mindset, which limits the potential for constructive dialogue between domestic and international judiciaries (section V). ${ }^{6}$ Section VI briefly comments on the implications of this 'Roman-Lutheran' approach to international law.

\section{Immunity and Grave Breaches of International Law: The State of Play in Late 2014}

Much of the initial reaction to Judgment 238/2014 viewed it as yet another contribution to the debate about immunity and grave breaches of international law affecting the rights of individuals. ${ }^{7}$ That, no doubt, is the substantive focus of the

\footnotetext{
${ }^{5}$ According to Kolb, Judgment 238/2014 adopts a stance of 'robust dualism' (ibid); see also Filippo Fontanelli, 'The Italian Constitutional Court's Challenge to the Implementation of the ICJ's Germany v Italy Judgment', iLawyer, (30 October 2014), available at http://ilawyerblog.com/ italian-constitutional-courts-challenge-implementation-icjs-germany-v-italy-judgment/, asserting that the judgment 'produced the most spectacular display of dualism this side of Medellin'.

${ }^{6}$ On this 'multi-level' judicial dialogue and its benefits for both the international and the domestic legal orders, see Antonios Tzanakopoulos, 'Judicial Dialogue in Multi-level Governance: The Impact of the Solange Argument', in Ole K Fauchald/André Nollkaemper (eds), The Practice of International and National Courts and the (De-)Fragmentation of International Law (Oxford: Hart 2012), 185-215; ILA, 'Mapping the Engagement of Domestic Courts with International Law', Final Report of the Study Group on Principles on the Engagement of Domestic Courts with International Law, (Johannesburg, 2016), available at http://www.ila-hq.org/index.php/study-groups?studygroups $\mathrm{ID}=57$; see also the collection of essays in Christian $\mathrm{J}$ Tams/Antonios Tzanakopoulos, 'International Law and Practice: Symposium on Domestic Courts as Agents of Development of International Law', Leiden Journal of International Law 26 (2013), 531-540; Alessandro Bufalini, 'Judgment 238/2014 and the Importance of a Constructive Dialogue', VerfBlog, (12 May 2017), available at http://verfassungsblog.de/judgment-2382014-and-the-importance-of-a-constructivedialogue/.

${ }^{7}$ See, eg, Theodor Schilling, 'The Dust Has Not Yet Settled: The Italian Constitutional Court Disagrees with the International Court of Justice, Sort of', EJIL:Talk!, (12 November 2014), available at https://www.ejiltalk.org/the-dust-has-not-yet-settled-the-italian-constitutional-courtdisagrees-with-the-international-court-of-justice-sort-of/; Andrea Pin, 'Tearing Down Sovereign Immunity's Fence: The Italian Constitutional Court, the International Court of Justice, and the German War Crimes', OpinioJuris, (19 November 2014), available at http://opiniojuris.org/2014/ 11/19/guest-post-tearing-sovereign-immunitys-fence-italian-constitutional-court-internationalcourt-justice-german-war-crimes/; Felix Würkert, 'No Custom Restricting State Immunity for Grave Breaches: Well Why Not?', VerfBlog, (11 December 2014), available at http:// verfassungsblog.de/no-custom-restricting-state-immunity-grave-breaches-\%E2\% $80 \% 92$-wellnot-2/; Anne Peters, 'Let Not Triepel Triumph: How to Make the Best Out of Sentenza No 238 of the Italian Constitutional Court for a Global Legal Order', EJIL:Talk!, (22 December 2014), available at https://www.ejiltalk.org/let-not-triepel-triumph-how-to-make-the-best-out-ofsentenza-no-238-of-the-italian-constitutional-court-for-a-global-legal-order-part-i/; Remo Caponi,
} 
decision: the ItCC declared unconstitutional domestic rules intending to give effect to international law principles of immunity, insofar as they covered certain grave breaches of international law, and to the decisions of the International Court of Justice (ICJ), insofar as they concerned the application of the Jurisdictional Iтmиnities Judgment of 3 February 2012. In taking a stand on these matters, the ItCC joined a major, decades-long debate that had, in fact, been one of international law's grands débats of the 1990s and 2000s: whether sovereign immunity should shield a state, and its representatives, from civil claims in foreign courts with respect to conducts that (if established) would amount to grave breaches of international law, notably violations of fundamental human rights. ${ }^{8}$

Many contributions to this controversy, until recently, followed a fairly predictable script. Those arguing that sovereign immunity could not—or no longer-be invoked, argued for a reform of international law that should recognize an immunity exception for grave breaches. ${ }^{9}$ Those defending immunity, even for grave breaches,

\footnotetext{
'A Fresh Start: How To Resolve the Conflict between the ICJ and the Italian Constitutional Court', VerfBlog, (28 January 2015), available at http://verfassungsblog.de/fresh-start-resolve-conflict-icjitalian-constitutional-court/.

${ }^{8}$ See, eg, Adam C Belsky/Mark Merva/Naomi Roht-Arriaza, 'Implied Waiver under the FSIA: A Proposed Exception to Immunity for Violations of Peremptory Norms of International Law', California Law Review 77 (1989), 365-415; Andrea Bianchi, 'Denying State Immunity to Violators of Human Rights', Austrian Journal of Public and International Law 45 (1994), 195-229; Mathias Reimann, 'A Human Rights Exception to Sovereign Immunity: Some Thoughts on Princz v Federal Republic of Germany', Michigan Journal of International Law 16 (1995), 403-432; Andreas Zimmermann, 'Sovereign Immunity and Violations of Jus Cogens: Some Critical Remarks', Michigan Journal of International Law 16 (1995), 433-440; Richard Garnett, 'The Defence of State Immunity for Acts of Torture', Australian Year Book of International Law 18 (1997), 97-126; Susan Marks, 'Torture and the Jurisdictional Immunities of Foreign States', Cambridge Law Journal 56 (1997), 8-11; Andrea Bianchi, 'Immunity versus Human Rights: The Pinochet Case', European Journal of International Law 10 (1999), 237-277; Alexander Orakhelashvili, 'State Immunity and International Public Order', German Year Book of International Law 45 (2002), 227-268; Lee M Caplan, 'State Immunity, Human Rights, and Jus Cogens: A Critique of the Normative Hierarchy Theory', American Journal of International Law 97 (2003), 741-781; Thomas Giegerich, 'Do Damages Claims Arising from Jus Cogens Violations Override State Immunity for the Jurisdiction of Foreign Courts?', in Christian Tomuschat/Jean-Marc Thouvenin (eds), The Fundamental Rules of the International Legal Order (Leiden: Brill 2006), 203-238; Lorna McGregor, 'State Immunity and Jus Cogens', International and Comparative Law Quarterly 55 (2006), 437-446; Alexander Orakhelashvili, 'State Immunity and Hierarchy of Norms: Why the House of Lords Got it Wrong', European of Journal International Law 18 (2008), 955-970; Sevrine Knuchel, 'State Immunity and the Promise of Jus Cogens', Northwestern Journal of International Human Rights 9 (2011), 149-183.

${ }^{9}$ See, eg, Reimann, ‘A Human Rights Exception' 1995 (n 8); Knuchel, ‘State Immunity’ 2011 (n 8); Lorna McGregor, 'Torture and State Immunity: Distorting Sovereignty', European Journal of International Law 18 (2008), 903-919; Andrew Clapham, 'The Jus Cogens Prohibition of Torture and the Importance of Sovereign State Immunity', in Marcelo Cohen (ed), Promoting Justice, Human Rights and Conflict Resolution Through International Law: Liber Amicorum Lucius Caflisch (Leiden: Brill 2007), 151-169.
} 
claimed that no such exception was recognized in international law-that the case for it had not been made out. ${ }^{10}$ Just as the script was predictable, so too were the roles assigned to the discussants: the call for reform was one of progress and optimism that emphasized the centrality of human rights; ${ }^{11}$ to this the sceptics typically responded by insisting on the careful application of the sources of law and by warning against overzealousness. Less predictable were the manifold arguments advanced in support of an immunity exception; these were diverse and at times both ingenious and creative. They were also frequently used in combination with one another in order to present as far as possible a strong case against the granting of state immunity.

For the sake of simplicity, they can be grouped into five broad and overlapping categories:

1. Normative hierarchy/ius cogens: sovereign immunity would have to yield to superior rules of international law recognized as peremptory from which no derogation is permitted (such as rules prohibiting torture or war crimes); ${ }^{12}$

2. A duty to exercise jurisdiction deriving from other fields of international law, such as international conventions to which the state is party: immunity would be superseded by state obligations to exercise jurisdiction, or to give effect to the human right to an effective remedy; ${ }^{13}$

3. Refusal to extend immunity to egregious acts: state conduct amounting to grave breaches could not be qualified as an 'official' or 'sovereign act' benefiting from immunity, or in any case such behaviour would constitute an 'implied waiver' on behalf of the state; alternatively, reliance on immunity would be considered abusive and ineffective, ${ }^{14}$

\footnotetext{
${ }^{10}$ For example, Zimmermann, 'Sovereign Immunity and Violations' 1995 (n 8); cf Giegerich, 'Damages Claims Arising from Jus Cogens' 2006 (n 8).

${ }^{11}$ Judge Cançado Trindade's dissenting opinion in the Jurisdictional Immunities case before the ICJ is a powerful example in point: 'Individuals are indeed subjects of international law (not merely "actors") and whenever legal doctrine departed from this, the consequences and results were catastrophic. Individuals are titulaires of rights and bearers of duties which emanate directly from international law (the ius gentium). Converging development, in recent decades, of the international law of human rights, of international humanitarian law, and of the international law of refugees, followed by those of international criminal law, give unequivocal testimony to this (...). The doctrine of sovereign immunities (...) unduly underestimated and irresponsibly neglected the position of the human person in international law' (paras 180-181).

${ }^{12}$ For academic claims to this effect, see Orakhelashvili, 'State Immunity and International Public Order' 2002 (n 8); Orakhelashvili, 'State Immunity and the Hierarchy of Norms' 2008 (n 8); Bianchi, 'Immunity versus Human Rights' 1999 (n 8).

${ }^{13}$ Orakhelashvili, 'State Immunity and the Hierarchy of Norms' 2008 (n 8); McGregor, 'State Immunity and Jus Cogens' 2006 (n 8), 439.

${ }^{14}$ Caplan, 'State Immunity’ 2003 (n 8); Belsky/Merva/Roht-Arriaza, 'Implied Waiver' 1989 (n 8); Bianchi, 'Immunity versus Human Rights' 1999 (n 8).
} 
4. A justified response: the denial of immunity could be considered lawful as a reprisal or countermeasure to the previously unlawful conduct of the defendant state ${ }^{15}$

5. Acceptance of an exception in international practice: cutting across these substantive considerations, the simplest argument has always been that international practice had come to accept an immunity exception, either for all grave breaches or at least for those qualifying as territorial torts. ${ }^{16}$

By October 2014, when the ItCC rendered its decision, all of these arguments were well known and had been tried out, mostly unsuccessfully, dozens of times. ${ }^{17}$ They did not, of course, go away. But it is probably fair to say that they showed significant signs of wear and tear. ${ }^{18}$ No doubt, "the cause endured, the hope still lived, the dream would never die',; ${ }^{19}$ but in seeking to translate their claims into winning legal arguments, supporters had made limited headway. So rare had been their successes, and so frequent and resounding their defeats, that the project of a grave breaches exception seemed to have either lost steam or stalled altogether. To illustrate:

1. The concept of an immunity exception for grave breaches of international law had not been, by 2014, recognized in an international treaty. In the course of the international community's most significant law-making project on jurisdictional

\footnotetext{
${ }^{15}$ Giegerich, 'Damages Claims Arising from Jus Cogens' 2006 (n 8); Antonios Tzanakopoulos, Disobeying the Security Council: Countermeasures Against Wrongful Sanctions (Oxford: OUP 2011), 194; Antonios Tzanakopoulos, 'Domestic Courts in International Law: The International Judicial Function of National Courts', Loyola of Los Angeles International and Comparative Law Review 34 (2012), 133-168, at 149 and note 53 therein.

${ }^{16}$ McGregor, 'State Immunity and Jus Cogens' 2006 (n 8), 438.

${ }^{17}$ For example, in Princz v Germany, 26 F 3d 1166 (DC Cir, 1 July 1994); ECtHR, Al-Adsani v The United Kingdom, Judgment of 21 November 2001, Application No 35763/97; ICJ, Arrest Warrant of 11 April 2000 (DRC v Belgium), Judgment of 14 February 2002, ICJ Reports 2002, 3; Court of Appeal of Ontario, Bouzari v Islamic Republic of Iran, (2004) 71 OR (3d) 675; Al-Adsani $v$ The Government of Kuwait and Others (No 2), CA 29 March 1996, (1996) 107 ILR 536; Corte di Cassazione, Judgment of 11 March 2004, No 5044/04 (Ferrini); Maria Gavouneli/Ilias Bantekas, 'Prefecture of Voiotia v Federal Republic of Germany, Case no 11/2000', American Journal of International Law 95 (2001), 198-204; Jones v Ministry of Interior Al-Mamlaka Al-Arabiya AS Saudiya (the Kingdom of Saudi Arabia) [2006] UKHL 26; ICJ, Jurisdictional Immunities of the State (Germany v Italy: Greece intervening), Judgment of 3 February 2012, ICJ Reports 2012, 99.

${ }^{18}$ To my surprise, this is often not recognized, at least not expressly. In response to this, the following section sets out my view in rather blunt terms. It draws on points made forcefully by Roger O'Keefe in 'State Immunity and Human Rights: Heads and Walls, Hearts and Minds', Vanderbilt Journal of Transnational Law 44 (2011), 999-1045; see also Andrea Bianchi, 'On Certainty', EJIL:Talk!, (16 February 2012), available at https://www.ejiltalk.org/on-certainty/.

${ }^{19}$ To adapt the terms of a brave, defiant concession speech: see Ted Kennedy, Concession Speech at the Democratic National Convention in New York City, 12 August 1980, available at www. americanrhetoric.com/speeches/tedkennedy1980dnc.htm.
} 
immunities, the UN Convention on Jurisdictional Immunities of States and Their Property (UN Convention), ${ }^{20}$ the drafters considered the introduction of a limited immunity exception for grave breaches affecting peremptory norms, ${ }^{21}$ but decided the time was not 'ripe' enough to do so. ${ }^{22}$

2. Regional human rights courts, like the European Court of Human Rights (ECtHR), faced with claims by victims alleging grave breaches amounting to, inter alia, torture and war crimes, as well as an impairment of their right of access to justice, repeatedly accepted the right of contracting states to uphold immunity. This was neither affected by the peremptory character of the norms allegedly breached nor by the victims' right of access to justice and an effective remedy. In particular, the ECtHR construed Article 6 of the European Convention on Human Rights and Fundamental Freedoms in light of (and limited by) the principles of sovereign immunity, therefore not requiring the recognition of a grave breaches exception. In a series of cases, the ECtHR accepted that Article 6 was not disproportionally restricted by the grant of sovereign immunity and largely deferred to the judgment of the contracting states. ${ }^{23}$

3. Relatively little pressure towards admitting a 'grave breaches' exception came from domestic legislation; state immunity statutes on balance do not offer much support for a 'grave breaches exception'. ${ }^{24}$ Reforms at the domestic level mainly aimed to align national law with the UN Convention and in some instances to

\footnotetext{
${ }^{20}$ UN Convention on Jurisdictional Immunity of States and Their Property (2 December 2004), UN Doc A/RES/59/38, UN Doc A/59/49, 486 (not yet in force).

${ }^{21}$ ILC, Report of the Working Group on Jurisdictional Immunities of States and Their Property, Report on the Work of the Fifty-first Session (1999), UN Doc A/54/10, paras 471-484.

${ }^{22}$ The proposal was not taken up by the Ad Hoc Committee on Jurisdictional Immunities of States and Their Property in its reports. See, Report of the Ad Hoc Committee on Jurisdictional Immunities of States and Their Property (GAOR 57 ${ }^{\text {th }}$ session, Suppl No 22, A/57/22, 4-15 February 2002); Report of the Ad Hoc Committee on Jurisdictional Immunities of States and Their Property (GAOR 58 ${ }^{\text {th }}$ session, Suppl No 22, A/58/22, 24-28 February 2003); Report of the Ad Hoc Committee on Jurisdictional Immunities of States and Their Property (GAOR $59^{\text {th }}$ session, Suppl No 22, A/59/22, 1-5 March 2004). See also, Convention on Jurisdictional Immunities of States and Their Property, Report of the Chairman of the Working Group, UN Doc A/C.6/54/L.12 (12 November 1999), para 47; cf McGregor, 'State Immunity and Jus Cogens' 2006 (n 8); see also Andreas Zimmermann, chapter 'Would the World Be a Better Place If One Were to Adopt a European Approach to State Immunity?', in this volume.

${ }^{23}$ ECtHR, Al-Adsani $v$ The United Kingdom (n 17), paras 53-67; ECtHR, Fogarty $v$ The United Kingdom, Grand Chamber Judgment of 21 November 2001, Application No 37112/97, paras 33-39; ECtHR, McElhinney v Ireland, Grand Chamber Judgment of 21 November 2001, Application No 31253/96, paras 34-38; ECtHR, Kalogeropoulou and Others v Greece and Germany, Judgment of 12 December 2002, Application No 59021/00.

${ }^{24}$ See, eg, Foreign Sovereign Immunities Act, 28 USC $§ § 1330,1602-1611$; UK, State Immunity Act 1978, 17 ILM (1978) 1123; Canada, State Immunity Act 1982, 21 ILM (1982) 798; Australia, Foreign States Immunity Act 1985, 25 ILM (1986) 715.
} 
facilitate judicial proceedings against states accused of supporting terrorism. ${ }^{25}$ Yet, to my knowledge, there was not in the years prior to 2014 any concerted attempt by states to enshrine a grave breaches exception via domestic law. This is worth noting because it sets apart the controversies about immunity from, for example, debates about universal jurisdiction, where claims towards effective remedies have resulted in law reforms at the national level-the gradual assertion, by states, of extraterritorial jurisdiction over international crimes being the most prominent example. ${ }^{26}$

4. Domestic courts asked to adjudicate on claims brought in response to grave breaches by a foreign state upheld in their overwhelming majority that foreign state's immunity: in so doing they rejected arguments based on ius cogens, on the right to an effective remedy, on abuse of rights, or on the nature (official or otherwise) of the impugned conduct. As for ius cogens in particular, the overwhelming majority of courts across jurisdictions accepted the superiority argument in principle but did not think it relevant. In line with the ECtHR's jurisprudence, courts in $\mathrm{Canada}^{27}{ }^{27}$ Australia, ${ }^{28}$ England, ${ }^{29}$ New Zealand, ${ }^{30}$ France, ${ }^{31}$ and the US, ${ }^{32}$ among others, did not consider there to be a clash, in the main because in their view, despite the presumably peremptory nature of the rules violated, the remedial rights of victims did not qualify as peremptory themselves. Domestic courts in Greece and, notably, Italy took a different

\footnotetext{
${ }^{25}$ That was the case with the 'Flatow' amendment to the US FSIA, which was introduced to allow suits against state sponsors of terrorism in US courts. See FSIA, 28 USC §1605A.

${ }^{26}$ In a survey published in 2012, Amnesty International concluded that '147 (approximately $76.2 \%$ ) out of 193 states [whose legislation was assessed] have provided for universal jurisdiction over one or more of [the] crimes' recognized under international law (which Amnesty took to mean war crimes, crimes against humanity, genocide, torture); see Amnesty International, Universal jurisdiction: A Preliminary Survey of Legislation Around the World: 2012 Update, available at https:// www.amnesty.org/en/documents/ior53/019/2012/en/.

${ }^{27}$ Court of Appeal of Ontario, Bouzari v Islamic Republic of Iran, (2004) 71 OR (3d) 675; Supreme Court of Canada, Kazemi Estate v Islamic Republic of Iran, 2014 SCC 62, [2014] 3 SCR 176.

${ }^{28}$ New South Wales Court of Appeal, Zhang $v$ Zemin [2010] NSWCA 255.

${ }^{29}$ UK Court of Appeal, Al-Adsani v The Government of Kuwait and Others (No 2), CA 29 March 1996, (1996) 107 ILR 536; UK House of Lords, Jones v Ministry of Interior Al-Mamlaka Al-Arabiya AS Saudiya (The Kingdom of Saudi Arabia) [2006] UKHL 26.

${ }^{30}$ New Zealand, High Court, Fang and Others v Jiang Zemin and Others, (21 December 2006), 141 ILR 702.

${ }^{31}$ Court of Cassation, Réunion Aérienne v Socialist People's Libyan Arab Jamahiriya, (Civil Chamber I, 9 March 2011), Case no 09-14743 150 ILR 630.

${ }^{32}$ Princz v Germany, Judgment of 1 July 1994 (n 17).
} 
(heretical or progressive-depending on one's perspective) view, ${ }^{33}$ but they too faced domestic opposition. ${ }^{34}$

5. Finally, in its Jurisdictional Immunities Judgment, the ICJ rejected arguments advanced in support of an immunity exception for grave breaches. It did so after a rather detailed perusal of international practice (which, in view of the Court, did not support an immunity exception, not even for territorial torts) and following a full analysis of the various arguments set out above. ${ }^{35}$

None of this, however, settled the debate (what debate is ever settled in international law?). And of course, the largely negative response did not invalidate the arguments set out in support of an immunity exception: they remain plausible, and who knows, they might one day find greater acceptance. ${ }^{36}$ However, even from the briefest summary just offered, it should be clear that to argue for an immunity exception as a matter of existing international law-at the time of the ItCC's decision in October 2014-was the argumentative equivalent of embarking on a very steep, and very long, uphill struggle. The argument had been made in dozens of settings, and almost invariably rejected - by states, by international courts, and by a large majority of domestic courts and tribunals called upon to address claims. What is more, the argument had been rebuffed comprehensively in its different manifestations, from the ius cogens variant to the 'abuse of rights' doctrine. Support for it was never more than marginal. Decisions such as Ferrini or Prefecture of Voiotia met with approval in some sectors but clearly deviated from a fairly solid mainstream approach. Viewed from that perspective, the 2012 ICJ Judgment could plausibly be described at the time as the 'final nail in the coffin of attempts to circumvent state immunity in domestic civil proceedings' 37

\section{Judgment 238/2014 of 22 October 2014: Changing Tack}

Several years after the Jurisdictional Immunities Judgment, we know that it was not the 'final nail'. But the grand controversy of the past two decades does yield important lessons. It testifies to the resilience of traditional concepts of international

\footnotetext{
${ }^{33}$ Corte di Cassazione, Ferrini (n 17); Maria Gavouneli/Ilias Bantekas, 'Prefecture of Voiotia v Federal Republic of Germany' 2001 (n 17), 198-204; Corte di Cassazione, Judgment of 24 July 2008, No 31171/2008 (Lozano); Corte di Cassazione, Judgment of 21 October 2008, No 1072/2008 (Milde).

${ }^{34}$ Greek Special Supreme Court (Anotato Eidiko Dikastirio), Margellos and Others v Federal Republic of Germany, Decision of 17 September 2002, Case No 6/2002.

${ }^{35} \mathrm{ICJ}$, Jurisdictional Immunities (n 17), 99, paras 52 et seq, especially paras 60-61, 65-79 for the rejection of the territorial tort exception; paras 81-106 for the rejection of the grave breaches exception and the normative conflict between ius cogens and state immunity argument.

${ }^{36}$ See, in that respect, 'Debate: "Remedies against Immunity?"”, Verfblog, (11 May 2017), available at http://verfassungsblog.de/category/debates/remedy-against-immunity/.

${ }^{37}$ O’Keefe, 'State Immunity’ 2011 (n 18), 1032.
} 
law (such as immunity) and to the difficulty of seeking to rewrite international law through domestic judicial activism and academic commentary. As regards the former, in particular, domestic courts can be powerful agents of legal developments, ${ }^{38}$ and have been so in the field of immunity. ${ }^{39}$ But as regards the debate about immunity and human rights, few domestic courts have embraced that role, and their arguments persuaded few others.

Perhaps more than anything else, the debate about an immunity exception illustrates the weakness of deducing concrete legal consequences from abstract concepts such as ius cogens, abuse of rights, the right to a remedy, or even the international rule of law. While all of these concepts have a sound foundation in international law, deductions from them simply do not take us far; the specific legal consequences are a matter of balancing and debate.

As regards the ius cogens argument, years of debate have demonstrated the fragility of deductive reasoning. Yes, torture and war crimes are prohibited by peremptory norms - and perhaps, in litigation about war crimes committed during World War II, one could even (somehow) argue that they were prohibited with peremptory force in the 1940s. But from this it in no way necessarily follows that the right of victims to seek damages was peremptory in nature too, and less still that the right to seek damages before foreign domestic courts was peremptory. To be sure, such an argument can be made-but it actually has to be made, as this is not a mere matter of deduction from an abstract legal principle. The experience of the last two decades suggests that when the argument was made, it only ever convinced a minority of listeners: perhaps because its implications were undesirable; perhaps because, once admitted, the argument was so difficult to reign in; perhaps because the time was not 'ripe'. Many might have preferred a different result and would have been happier had a more ambitious construction of ius cogens been endorsed by more than a small minority. ('What a pity!', began one of the dissents appended to the ECtHR's Al-Adsani judgment). Whatever the reasons for its inability to convince more than a minority, Roger O'Keefe, commenting on decades of legal argument, had a strong point when encouraging proponents of the reform movement to take stock and accept (or at least entertain the possibility) that their initial arguments had been 'heading nowhere'. ${ }^{40}$

Perhaps the ItCC, in Judgment 238/2014, accepted as much. While continuing the struggle against immunity, it opted for a new approach. The Court now sidestepped debates about the scope of immunity under international law; in fact, it accepted (albeit grudgingly, one can assume) the ICJ's construction of international law as set out in Jurisdictional Immunities: 'It has to be recognized that, at the international level, the interpretation by the ICJ (...) is particularly qualified and does not allow further examination by national governments and/or judicial authorities, including

\footnotetext{
${ }^{38}$ See the collection of essays in Tams/Tzanakopoulos, 'International Law and Practice' 2013 (n 6).

${ }^{39}$ Rosanne van Alebeek, 'Domestic Courts as Agents of Development of International Immunity Rules', Leiden Journal of International Law 26 (2013), 559-578.

${ }^{40}$ O'Keefe, 'State Immunity' 2011 (n 18), 1012.
} 
this Court'. ${ }^{41}$ The claim that international law should recognize an immunity exception for grave breaches is all but abandoned: the international rules of immunity have been 'defined by the ICJ', and as rules of international law they reach into the Italian legal order (as the ItCC observes in a remarkable passage) 'as interpreted in the international legal order'. ${ }^{42}$ Not even an echo, then, in Judgment 238/2014, of the clarion calls of Ferrini, in which the Italian Supreme Court had boldly refused to give effect to immunity rules if these 'would hinder the protection of values whose safeguard is to be considered (...) essential to the whole international community'. ${ }^{43}$ And no serious attempt, unlike in Prefecture of Voiotia, to apply the 'territorial tort' exception to the conduct of armed forces (and to free it from the shackles of the ICJ's restrictive reasoning). The ItCC, while persisting in its struggle for an immunity exception, displays a remarkable argumentative flexibility.

Instead of rehearsing the international law debates, the ItCC approached the matter from the perspective of (Italian) foreign relations law: in its words, it was 'clear that another issue has to be examined and resolved, namely the envisaged conflict between the norm of international law (...) incorporated and applied in the domestic legal order, as interpreted in the international legal order, and norms and principles of the [Italian] Constitution' ${ }^{44}$ This is a significant change of tack. As noted by Filippo Fontanelli, the ItCC 'deploy[s] its judicial authority in foro domestico'. ${ }^{45}$ In rather plainer terms, one might state that the ItCC prefers home games to away games; and on Italian home ground, the 'human rights cause' (battered in The Hague, Strasbourg, London, and elsewhere) triumphed. The Italian constitutional right to an effective remedy in case of infringements of 'the inviolable rights of the person', said the ItCC, was not to be construed in light of immunities 'as interpreted in the international legal order'; it had an autonomous existence and is limited by competing constitutional principles only. ${ }^{46}$

Whether or not that construction is convincing as a matter of Italian law is for others to judge. ${ }^{47}$ From an international law perspective, the ItCC's approach calls

\footnotetext{
${ }^{41}$ ItCC, Judgment 238/2014 (n 1), section 3.1.

${ }^{42}$ Ibid.

${ }^{43}$ See Corte di Cassazione, Ferrini (n 17), section 9.1.

${ }^{44}$ ItCC, Judgment 238/2014 (n 1), section 3.1.

${ }^{45}$ Filippo Fontanelli, 'Damage Assessment on the Building of International Law after the Italian Constitutional Court's Decision no. 238 of 2014: No Structure Damage, Just Wear and Tear', VerfBlog, (15 December 2014), available at http://verfassungsblog.de/damage-assessmentbuilding-international-law-italian-constitutional-courts-decision-no-238-2014-no-structural-dam age-just-wear-tear- $2 /$.

${ }^{46} \mathrm{As}$ far as competing constitutional principles are concerned, the ItCC briefly mentions immunity but holds that it could only justify restrictions that are 'connected-substantially and not just formally - to the sovereign function of the State'; see ItCC, Judgment 238/2014 (n 1), section 3.4.

${ }^{47}$ Alessandro Bufalini, 'Judgment 238/2014 and the Importance of a Constructive Dialogue' 2017 (n 6); see also Alessandro Bufalini, chapter 'Waiting for Negotiations', in this volume. Christian Tomuschat, 'No Consensus—but Hope at Villa Vigoni', VerfBlog, (18 May 2017), available at http://verfassungsblog.de/no-consensus-but-hope-at-villa-vigoni/.
} 
for two comments. The first is fairly obvious and taken up in many chapters in this volume: by refusing to give effect to sovereign immunity as construed by the ICJ, the Constitutional Court puts Italy on a collision course with international law. ${ }^{48}$ Judgment 238/2014 may not itself amount to a breach of international law, but with the highest judicial authority directs Italian state organs towards such a breach, and towards non-compliance with the 2012 ICJ Judgment. The second comment concerns the implications of the ItCC's reasoning for future debates about immunity and human rights. In this respect, the Court's argumentative change of tack is seemingly clever (as it takes the argument to a different level), but also potentially dangerous (as it is based on a problematic understanding of the relationship between domestic and international legal orders). The remainder of this chapter addresses these aspects in turn.

\section{A Clever Move and Its Implications}

On the face of it, the Italian Constitutional Court's change of tack is indeed rather clever. It shields Judgment 238/2014 from the obvious criticism: that the ItCC thought it knew international law better than the ICJ, the ECtHR, and the majority of states and other domestic courts. The ItCC does not make such a claim. Rather, it claims to know Italian constitutional law better. And who would fault it for that? Put differently, on the 'home turf' of the Italian Constitution, the scope of immunities depends on the status of international law within the Italian constitutional order. Unless one ignores the ItCC's reasoning, ${ }^{49}$ this argumentative move limits the significance of Judgment 238/2014 to the long-standing debate about immunity and grave breaches sketched out above-with two related consequences.

First, based on Italian constitutional law, Judgment 238/2014 is (dare one say) 'immune' from the usual arguments developed in the long-standing international law debates. There is little point in a further round of discussion about the impact of ius cogens, or the scope of the territorial tort exception, or the proper way of characterizing egregious conduct - the ItCC has conceded the international law argument. Second, and conversely, based on constitutional law, Judgment 238/2014 has relatively little to contribute to the international law debate about immunity and

\footnotetext{
${ }^{48} \mathrm{Cf}$, inter alia, Christian Tomuschat, chapter 'The Illusion of Perfect Justice', Heike Krieger, chapter 'Sentenza 238/2014: A Good Case for Law-Reform?', and Andreas Zimmermann, chapter 'Would the World Be a Better Place If One Were to Adopt a European Approach to State Immunity?', in this volume.

${ }^{49}$ Some have suggested that where constitutional and international rules are 'con-substantial', domestic decisions addressing questions of foreign relations law should be viewed as international law decisions cloaked in constitutional law language - and treated as contributions to international legal debate: see Tzanakopoulos, 'Domestic Courts in International Law' 2012 (n 15), 143. But this risks to overlook the strategic choice of 'going domestic', which at least in the proceedings before the ItCC seemed a conscious one.
} 
grave breaches. In order to do that it would have had to play the 'away game'. Or rather, in the words of Filippo Fontanelli:

[T]he Italian ruling cannot possibly hope to persuade the international community about the correctness of its conclusion under international law, because it expressly avoided a re-consideration of the international legal custom. Unlike the previous Ferrini judgment, the Constitutional Court's decision confined itself to deploy judicial authority in foro domestico. There is ample literature of how effective national courts can be in shaping international law through interpretation. This judgment did not try to do that, thus it cannot succeed. ${ }^{50}$

It might still be argued that, irrespective of its (international or constitutional) reasoning, Judgment 238/2014 should matter as international practice: it stands, after all, for the proposition that domestic courts in fact are prepared to accept an immunity exception. ${ }^{51}$ Yet that argument only goes so far. The judgment indeed is relevant for the assessment of customary international law; but in an assessment of international practice, it should not carry much weight. It helps assess the practice of precisely one state, and one state that had previously deviated from the international law mainstream at that: Italy. ${ }^{52}$ What is more, Sentenza $238 / 2014$ is not really a reliable guide to the approach of Italy as such. Over the past decades, Italian practice has been anything but uniform-with parliament and the executive leaning more towards the international law mainstream and the courts remaining divided. ${ }^{53}$ In line with recent attempts to clarify the process of custom formation, such domestic discord affects the weight to be accorded to Italy's practice: as noted in the ILC's recent work on custom, 'where different organs or branches within the State adopt different courses of conduct on the same matter or where the practice of one organ varies over time (...), that State's contribution to "a general practice" may be reduced'. 54

That still leaves open the possibility that Judgment 238/2014 is followed by other actors of international law, whose practice would then matter. In this respect, Fontanelli's aforementioned statement needs to be qualified. Perhaps in retrospect Judgment 238/2014 will come to be seen as the beginning of a trend: perhaps we will see a wave of domestic court decisions all relying on constitutional law guarantees, as their 'last line of defence', to keep immunity at bay. While such a possibility cannot be excluded, trends in international practice sketched out above suggest this to be remote. Remote not only because (so far) a clear majority of domestic courts have been inclined to uphold immunity for grave breaches ${ }^{55}$ but also because the

\footnotetext{
${ }^{50}$ Fontanelli, 'Damage Assessment' 2014 (n 45).

${ }^{51}$ Cf ILA, 'Mapping the Engagement of Domestic Courts' 2016 (n 6), paras 5-6.

${ }^{52} \mathrm{Ibid}$, paras 5, 6, and 8 .

${ }^{53} \mathrm{Cf}$ Paolo Palchetti, chapter 'Right of Access to (Italian) Courts über alles?', and Riccardo Pavoni, chapter 'A Plea for Legal Peace', in this volume.

${ }^{54}$ ILC, Report of the International Law Commission on the work of its $70^{\text {th }}$ session (2016), UN Doc A/73/10, 'Identification of Customary International Law', Conclusion 7, para 4 of the commentary; see also ILA, 'Mapping the Engagement of Domestic Courts' 2016 (n 6), para 7.

${ }^{55}$ See n 27 and n 32.
} 
ItCC's reasoning in Judgment 238/2014 is firmly based on Italian constitutional law, and depends on so many premises: the acceptance of a robust constitutional right to a remedy, a refusal to construe that remedial right in light of competing principles such as those protecting immunity, and not least (to foreshadow a point addressed in section V) a preparedness to play havoc with international law. Thus, Italian constitutional law both enables the clever change of tack and limits the probable impact of the decision. In short, whether one looks at its reasoning or its outcome, it seems that precisely because the ItCC opted to 'go constitutional', Judgment $238 / 2014$ will have a limited impact on the international law debate on sovereign immunities.

\section{V. 'Here I Stand, I Can Do No Other': A Problematic Last Line of Defence}

The relative loss of influence on future international law debates is not the only price of 'going constitutional'. Judgment 238/2014 also - and the point has been hinted at already_plays havoc with international law. It does so in two respects: its outcome, and the process by which that outcome is reached. Regarding the former, by refusing to give effect to the duty to respect the immunity of foreign states, as concretized in a binding ICJ judgment, the ItCC pushes Italy towards breaching international law, ${ }^{56}$ and this in a setting where the international law dispute had been referred to court in an attempt (in the words of the two governments) 'to clarify a complex question'.57 The fact that many will sympathize with the ItCC's conduct does not make that breach any less blatant.

The second point is less obvious, but systemically more relevant. By construing constitutional law in splendid isolation from international law, and by giving it primacy, the ItCC displays an inward-looking mindset that shields constitutional guarantees from international law. This of course has not escaped commentators, including those who might have looked favourably on the outcome of Judgment 238/2014: Anne Peters has criticized the ItCC's 'Triepelian understanding', 58 and

\footnotetext{
${ }^{56}$ Under Art 94 (1) of the UN Charter, 24 October 1945, 1 UNTS XVI, member states of the UN have to comply with the decisions of the ICJ in a case to which they are party; See also Art 4 of the ILC Draft Articles on the Responsibility of States for Internationally Wrongful Acts, adopted by the Commission at its fifty-third session in 2001 (Final Outcome), UN Doc A/56/10, 43, UN Doc A/RES/56/83, Annex, UN Doc A/CN.4/L.602/Rev.1, GAOR 56 ${ }^{\text {th }}$ Session Supp 10, 43; cf Constantin Eustathiadès, La responsabilité internationale de l'État pour les actes des organes judiciaires et le problème du déni de justice en droit international, Vol 1 (Paris: Pedone 1936).

${ }^{57}$ Italy-Germany Summit, Trieste, 18 November 2008, Joint Declaration, available at www.esteri.it/ mae/en/sala_stampa/archivionotizie/approfondimenti/2008/11/20081119_dichiarazionecongiunta. html.

${ }^{58}$ Peters, 'Let Not Triepel Triumph' 2014 (n 7).
} 
Robert Kolb seems to go further when warning of a 'shattering schism between internal and international law'. ${ }^{59}$ Underlying these and similar statements is a feeling that by opting to decide the case on constitutional grounds, the ItCC has taken a new, and highly dangerous argumentative path, which other domestic actors engaging with international law will happily take to avoid international legal constraints.

Upon reflection, the stark language warning of 'schisms' and 'Triepel's triumph' seems unduly dramatic. For a domestic court to emphasize the primacy of constitutional law over international law is not as such unusual. Most domestic legal systems, even those that profess an openness towards the international or supranational level, preserve the option of some constitutional override. ${ }^{60}$ To mention but the most obvious override strategies, within many domestic legal orders parts of international law have some status but are ranked below constitutional law (so that they yield in the event of a clash); in others, domestic law (including constitutional law) may have to be construed in light of international law principles but with the caveat that such enlightened interpretations should not fall foul of overarching constitutional principles; still elsewhere, domestic legal systems limit the number of international law rules that can be invoked before domestic courts (for example by requiring them to be recognized by domestic law as 'self-executing'). High-profile decisions from the Solange jurisprudence and its follow-up, ${ }^{61}$ to Görgülü, ${ }^{62}$ Medellin, ${ }^{63}$ and $\mathrm{Kadi}^{64}$ (to name but a few) are attempts to strike the right balance, but they all insist on the possibility of some constitutional overrides. All of them, even the internationally-minded ones, assume that constitutional law determines just how intrusive international law should be, and that, where domestic and international

\footnotetext{
${ }^{59}$ Robert Kolb, 'The Relationship between the International and the Municipal Legal Order: Reflections on the Decision 238/2014 of the Italian Constitutional Court', Questions of International Law: Zoom-Out 2 (2014), 5-16.

${ }^{60}$ In this respect, Anne Peters rightly characterizes 'Sentenza No. 238 [as] just one more building block in the wall of "protection" built up by domestic courts against "intrusion" of international law, relying on the precepts of their national constitution', Peters, 'Let Not Triepel Triumph' 2014 (n 7). For a detailed comparative account, see the contributions to Dinah Shelton, International Law and Domestic Legal Systems: Incorporation, Transformation and Persuasion (Oxford: OUP 2011). Antonio Cassese's Hague lectures remain highly instructive, 'Modern Constitutions and International Law', Recueil des Cours 192 (1989), 331-476. The different 'avoidance techniques' employed by domestic legal orders are summarized in ILA, 'Mapping the Engagement of Domestic Courts' 2016 (n 6), paras 38-40; See also Raffaela Kunz, chapter 'Teaching the World Court Makes a Bad Case', in this volume.

${ }^{61}$ Bundesverfassungsgericht, Order of 29 May 1974, 2 BvL 52/71, BVerfGE 37, 271 (Solange I); Bundesverfassungsgericht, Order of 22 October 1986, 2 BvR 197/83, BVerfGE 73, 339 (Solange II).

${ }^{62}$ ECtHR, Görgülü v Germany, Judgment of 26 May 2004, Application No 74969/01.

${ }^{63}$ US Supreme Court, Medellín v Texas, 552 U.S. 491 (2008).

${ }^{64} \mathrm{CJEU}$, European Commission, Council of the European Union, and United Kingdom of Great Britain and Northern Ireland $v$ Yassin Abdullah Kadi and French Republic, Judgment of 18 July 2013, Joined Cases No C-584/10 P, C-593/10 P, and C-595/10 P, [2013] ECR I-0000 (Kadi II CJEU).
} 
law clash, 'any change in national laws still remains contingent upon the will of the failing state'. ${ }^{65}$ Perhaps this is international law's real Achilles heel in the era of inward-looking obligations: ${ }^{66}$ outside niche areas, international law does not 'by itself, possess the force to amend or repeal internationally unlawful domestic (...) acts' ${ }^{67}$ But cases like Kadi and perhaps now Judgment 238/2014 should give even some die-hard internationalists pause: it is easy to call for international law to be strong, robust, and intrusive when one likes its prescriptions, and rather more difficult when it prescribes outcomes that are unpopular. In areas such as immunities and draconian sanctions, but also in investment protection, international law has recently appeared on a collision course with constitutionally protected values. In these and other fields, international law deserves engagement rather than 'blind faith'. Constitutional overrides may every now and then serve as a necessary safety valve, ${ }^{68}$ and it is certainly a very common technique for protecting international law from itself.

If few domestic courts or domestic legal orders are free from protectionist leanings, Judgment 238/2014 stands out for its bluntness. The constitutional override comes without niceties, with an almost 'Lutheran' directness to it. 'Here I stand, I can do no other' seems to be the motto: international law is refused effect without regrets, and without any balancing or the pretence of a constructive dialogue. International law and constitutional law are neatly separated, and in the ItCC's 'separatist treatment' ${ }^{69}$ the former plays no role in the construction of the latter. (In fact, international legal rules are denied any 'directive function' ['Orientierungswirkung ${ }^{70}$ ], even though they were authoritatively 'defined by the ICJ $^{71}$ in a case directed against Italy). In the discussion of constitutional law, international law no longer features, at least not expressly: neither as part of a balancing exercise (weighing the need to grant an effective remedy against the need to comply with international law), nor as part of a 'Solange II construction' in which non-compliance with international law remains an option but is the exception to the default position.

\footnotetext{
${ }^{65}$ Cassese, 'Towards a Moderate Monism' 2012 (n 3), 191.

${ }^{66}$ The term 'inward looking' is used here to denote international obligations that 'specifically enjoin States to undertake certain conduct within their own domestic legal order: to adopt a specific legal framework, to accord individual rights, to abstain from taking specific actions', ILA, 'Mapping the Engagement of Domestic Courts' 2016 (n 6), para 12.

${ }^{67}$ Cassese, 'Towards a Moderate Monism' 2012 (n 3), 199.

${ }^{68}$ For a cautious (and important) German perspective on these themes, see Stefan Talmon, 'Die Grenzen der Anwendung des Völkerrechts im deutschen Recht', Juristenzeitung 68 (2013), 12-21. As Talmon notes on page 21, referring to Security Council sanctions in particular, 'blind faith in international law ignores the realities' (translated by the author).

${ }^{69}$ Kolb, 'International and Municipal Legal Order' 2014 (n 59).

${ }^{70} \mathrm{Cf}$ Bundesverfassungsgericht, Order of 19 September 2006, 2 BvR 2115/01, BVerfGK 9, 174 (Wiener Konsularrechtsübereinkommen), para 61.

${ }^{71}$ ItCC, Judgment 238/2014 (n 1), section 3.1.
} 
The problem with Judgment 238/2014, then, is not that it insists on the primacy of constitutional law over international law but that it refuses to factor international law into its constitutional law reasoning. ${ }^{72}$ The principle of a constitutional override may be fine (though it is international law's Achilles heel), but the process by which the ItCC overrides international law is highly problematic. To speak of high peak dualism, ${ }^{, 73}$ may be one way of looking at it. More than anything else, however, it is the refusal of balance-the 'here I stand, I can do no other'-that disturbs and disappoints.

\section{Concluding Thoughts}

Judgment 238/2014 is an interesting case because it forces us to question some easy and cheap 'truths' in the way that earlier foreign relations decisions did not. To illustrate, it was easy (and perhaps a bit cheap) to chide the US Supreme Court for its Medellin judgment, in which constitutional law trumped an ICJ judgment and resulted in the execution of José Medellin: international law was on the side of progress after all, and so — of course! — it should be robust and intrusive.

Judgment $238 / 2014$ is trickier because opinion is at best mixed on whether international law-as presented in section II-is on the side of progress. Many would say it is not (or, in fact, that it impedes progress), hence the constant incantations that immunity were 'archaic'. But then again, only very stubborn progressivists will be able to ignore the resilience of that archaic notion, and there is no way of denying that in this particular case the archaic notion was confirmed and crystallized in a binding ICJ judgment.

In Judgment 238/2014, as noted in the preceding sections, the ItCC adopted a straightforward approach. Faced with an international legal rule that it considered regressive, it took the debate to its 'home turf'. It conceded the international law arguments and opted to stop international law at the last, constitutional, line of defence, and all this without giving it the benefit of any constructive engagement. All this, as noted above, it did with a stubborn determination: like Martin Luther at the Diet of Worms, it ,'could do no other'.

So, what should be done about Judgment 238/2014? Criticism, protest and scandalization are all obvious responses, and of course they are trusted strategies for dealing with non-compliance and of keeping up the pressure. Since 2014 they

\footnotetext{
${ }^{72}$ See also Sabino Cassese, chapter 'Recollections of a Judge', in this volume. After all, international law does not contain a rule prescribing its superiority over domestic law in the domestic legal orders of the states. See André Nollkaemper, 'The Effects of Treaties in Domestic Law' in Christian $\mathrm{J}$ Tams/Antonios Tzanakopoulos/Andreas Zimmermann (eds), Research Handbook on the Law of Treaties (Cheltenham: Edward Elgar 2014), 123-150, at 130.

${ }^{73}$ Kolb, 'International and Municipal Legal Order' 2014 (n 59).
} 
have informed many responses to the judgment and are still being articulated.$^{74}$ The preceding sections suggest that criticism and protest remain crucial: the judgment is a fairly blatant case of ignoring the demands of a clearly worded international decision, not an instance of minimalist compliance or muddling through. At the same time, the preceding sections also yield a number of insights that argue for a more nuanced, perhaps cautious, approach. Three of these stand out.

First, while refusing to give effect to international law, Judgment 238/2014 employs a last line of defence that is prima facie effective. International law has no means of compelling 'rogue' domestic courts to fall back in line, not least because it values the judicial independence that makes decisions like this possible. And Judgment 238/2014 is not the only domestic court decision that ignores international law. Domestic disobedience is a fact of international legal life: not welcome but common. This does not mean international lawyers should 'keep calm and carry on' - but suggests that Judgment 238/2014 has to be engaged with, not just scandalized.

Second, while the judgment's 'Lutheran' refusal to engage with international law is unfortunate, it is difficult to take issue with the ItCC's starting-point: domestic legal actors (governments, parliaments, courts) in most countries insist on some form of constitutional override, and in an era of inward-looking international law ${ }^{75}$ this is plausible. The difference between Kadi, Medellin, the various Solanges, and Judgment 238/2014 is one of degree, not of principle. In this sense, most domestic and regional courts have some 'Triepelian' leanings; some occasionally choose to be more openly 'Triepelian' than others. Again, this is not a plea for a non-committal 'anything goes' but an attempt to more clearly define the focus of debate.

Third, as international lawyers reflect on their strategy of engaging with the rogue decision, they (we) should be mindful of the character of the particular legal rule that is being defended. In section II, I have offered a purposefully robust dismissal of the grave breaches exception to immunities, which in my view has never enjoyed much support among states and international organizations. But of course, whatever its status in international law, the grave breaches exception has wide appeal among groups on whose support international law regularly counts in its pursuit of progressive causes. In Judgment 238/2014, the ItCC failed to give effect to state immunity, but in so doing disregarded a fairly unpopular rule of international law-a discipline that often reflects the hopes of many, and that typically benefits from being a projection of hopes. Perhaps, in fact, it should give international lawyers pause that in Judgment 238/2014 the ItCC effectively gives up on international law as a means of protecting remedial rights of victims.

\footnotetext{
${ }^{74}$ For examples of primarily critical perspectives, see Christian Tomuschat, chapter 'The Illusion of Perfect Justice', Andreas Zimmermann, chapter 'Would the World Be a Better Place If One Were to Adopt a European Approach to State Immunity?', and Giovanni Boggero/Karin Oellers-Frahm, chapter 'Between Cynicism and Idealism', in this volume.

${ }^{75}$ See n 66.
} 
In offering these three considerations, I do not mean to undermine the international law argument set out in sections II-V of this chapter. But there is some scope for argumentative disarmament, and for moving away from the 'holier than thou' attitude that continues to characterize much of the debate.

\section{References}

Alebeek, Rosanne van, 'Domestic Courts as Agents of Development of International Immunity Rules', Leiden Journal of International Law 26 (2013), 559-578

Belsky, Adam C/Mark Merva/Naomi Roht-Arriaza, 'Implied Waiver under the FSIA: A Proposed Exception to Immunity for Violations of Peremptory Norms of International Law', California Law Review 77 (1989), 365-415

Bianchi, Andrea, 'Denying State Immunity to Violators of Human Rights', Austrian Journal of Public and International Law 45 (1994), 195-229

Bianchi, Andrea, 'Immunity versus Human Rights: The Pinochet Case', European Journal of International Law 10 (1999), 237-277

Bianchi, Andrea, 'On Certainty', EJIL:Talk!, (16 February 2012), available at https://www.ejiltalk. org/on-certainty/

Bradley, Curtis A, 'What is Foreign Relations Law?' in Curtis A Bradley (ed), The Oxford Handbook of Comparative Foreign Relations Law (Oxford: OUP 2018)

Bufalini, Alessandro, 'Judgment 238/2014 and the Importance of a Constructive Dialogue', VerfBlog, (12 May 2017), available at http://verfassungsblog.de/judgment-2382014-and-theimportance-of-a-constructive-dialogue/

Caplan, Lee M, 'State Immunity, Human Rights, and Jus Cogens: A Critique of the Normative Hierarchy Theory', American Journal of International Law 97 (2003), 741-781

Caponi, Remo, 'A Fresh Start: How To Resolve the Conflict between the ICJ and the Italian Constitutional Court', VerfBlog, (28 January 2015), available at http://verfassungsblog.de/freshstart-resolve-conflict-icj-italian-constitutional-court/

Cassese, Antonio, 'Modern Constitutions and International Law', Recueil des Cours 192 (1989), $331-476$

Cassese, Antonio, 'Towards a Moderate Monism' in Antonio Cassese (ed), Realizing Utopia: The Future of International Law (Oxford: OUP 2012), 187-199

Clapham, Andrew, 'The Jus Cogens Prohibition of Torture and the Importance of Sovereign State Immunity', in Marcelo Cohen (ed), Promoting Justice, Human Rights and Conflict Resolution Through International Law: Liber Amicorum Lucius Caflisch (Leiden: Brill 2007), 151-169

Eustathiadès, Constantin, La responsabilité internationale de l'État pour les actes des organes judiciaires et le problème du déni de justice en droit international, vol 1 (Paris: Pedone 1936)

Fontanelli, Filippo, 'Damage Assessment on the Building of International Law after the Italian Constitutional Court's Decision no. 238 of 2014: No Structure Damage, Just Wear and Tear', VerfBlog, (15 December 2014), available at http://verfassungsblog.de/damage-assessmentbuilding-international-law-italian-constitutional-courts-decision-no-238-2014-no-structuraldamage-just-wear-tear-2/

Fontanelli, Filippo, 'The Italian Constitutional Court's Challenge to the Implementation of the ICJ's Germany v Italy Judgment', iLawyer, (30 October 2014), available at http://ilawyerblog.com/ italian-constitutional-courts-challenge-implementation-icjs-germany-v-italy-judgment/

Garnett, Richard, 'The Defence of State Immunity for Acts of Torture', Australian Year Book of International Law 18 (1997), 97-126

Gavouneli, Maria/llias Bantekas, 'Prefecture of Voiotia v Federal Republic of Germany, Case no 11/2000', American Journal of International Law 95 (2001), 198-204 
Giegerich, Thomas, 'Do Damages Claims Arising from Jus Cogens Violations Override State Immunity for the Jurisdiction of Foreign Courts?', in Christian Tomuschat/Jean-Marc Thouvenin (eds), The Fundamental Rules of the International Legal Order (Leiden: Brill 2006), 203-238

Knuchel, Sevrine, 'State Immunity and the Promise of Jus Cogens', Northwestern Journal of International Human Rights 9 (2011), 149-183

Kolb, Robert, The Relationship between the International and the Municipal Legal Order: Reflections on the Decision 238/2014 of the Italian Constitutional Court', Questions of International Law: Zoom-Out 2 (2014), 5-16

Kolb, Robert, The Law of Treaties: An Introduction (Cheltenham: Edward Elgar 2016)

Marks, Susan, 'Torture and the Jurisdictional Immunities of Foreign States', Cambridge Law Journal 56 (1997), 8-11

McGregor, Lorna, 'State Immunity and Jus Cogens', International and Comparative Law Quarterly 55 (2006), 437-446

McGregor, Lorna, 'Torture and State Immunity: Distorting Sovereignty', European Journal of International Law 18 (2008), 903-919

Nollkaemper, André, 'The Effects of Treaties in Domestic Law' in Christian J Tams/Antonios Tzanakopoulos/Andreas Zimmermann (eds), Research Handbook on the Law of Treaties (Cheltenham: Edward Elgar 2014), 123-150

O'Keefe, Roger in 'State Immunity and Human Rights: Heads and Walls, Hearts and Minds', Vanderbilt Journal of Transnational Law 44 (2011), 999-1045

Orakhelashvili, Alexander, 'State Immunity and International Public Order', German Year Book of International Law 45 (2002), 227-268

Orakhelshvili, Alexander, 'State Immunity and Hierarchy of Norms: Why the House of Lords Got it Wrong', European of Journal International Law 18 (2008), 955-970

Peters, Anne, 'Let Not Triepel Triumph: How to Make the Best Out of Sentenza No 238 of the Italian Constitutional Court for a Global Legal Order', EJIL:Talk!, (22 December 2014), available at https://www.ejiltalk.org/let-not-triepel-triumph-how-to-make-the-best-out-ofsentenza-no-238-of-the-italian-constitutional-court-for-a-global-legal-order-part-i/

Pin, Andrea, 'Tearing Down Sovereign Immunity's Fence: The Italian Constitutional Court, the International Court of Justice, and the German War Crimes', OpinioJuris, (19 November 2014), available at http://opiniojuris.org/2014/11/19/guest-post-tearing-sovereign-immunitys-fenceitalian-constitutional-court-international-court-justice-german-war-crimes/

Reimann, Mathias, 'A Human Rights Exception to Sovereign Immunity: Some Thoughts on Princz v Federal Republic of Germany', Michigan Journal of International Law 16 (1995), 403-432

Schilling, Theodor, 'The Dust Has Not Yet Settled: The Italian Constitutional Court Disagrees with the International Court of Justice, Sort of', EJIL:Talk!, (12 November 2014), available at https:// www.ejiltalk.org/the-dust-has-not-yet-settled-the-italian-constitutional-court-disagrees-withthe-international-court-of-justice-sort-of/

Shelton, Dinah, International Law and Domestic Legal Systems: Incorporation, Transformation and Persuasion (Oxford: OUP 2011)

Talmon, Stefan, 'Die Grenzen der Anwendung des Völkerrechts im deutschen Recht', Juristenzeitung 68 (2013), 12-21

Tams, Christian J/Antonios Tzanakopoulos, 'International Law and Practice: Symposium on Domestic Courts as Agents of Development of International Law', Leiden Journal of International Law 26 (2013), 531-540

Tomuschat, Christian, 'No Consensus_but Hope at Villa Vigoni', VerfBlog, (18 May 2017), available at http://verfassungsblog.de/no-consensus-but-hope-at-villa-vigoni/

Tzanakopoulos, Antonios, 'Domestic Courts in International Law: The International Judicial Function of National Courts', Loyola of Los Angeles International and Comparative Law Review 34 (2012), 133-168

Tzanakopoulos, Antonios, 'Judicial Dialogue in Multi-level Governance: The Impact of the Solange Argument', in Ole K Fauchald/André Nollkaemper (eds), The Practice of International 
and National Courts and the (De-)Fragmentation of International Law (Oxford: Hart 2012), $185-215$

Tzanakopoulos, Antonios, Disobeying the Security Council: Countermeasures Against Wrongful Sanctions (Oxford: OUP 2011)

Würkert, Felix, 'No Custom Restricting State Immunity for Grave Breaches: Well Why Not?', VerfBlog, (11 December 2014), available at http://verfassungsblog.de/no-custom-restrictingstate-immunity-grave-breaches-\%E2\%80\%92-well-not-2/

Zimmermann, Andreas, 'Sovereign Immunity and Violations of Jus Cogens: Some Critical Remarks', Michigan Journal of International Law 16 (1995), 433-440

Open Access This chapter is licensed under the terms of the Creative Commons Attribution 4.0 International License (http://creativecommons.org/licenses/by/4.0/), which permits use, sharing, adaptation, distribution and reproduction in any medium or format, as long as you give appropriate credit to the original author(s) and the source, provide a link to the Creative Commons license and indicate if changes were made.

The images or other third party material in this chapter are included in the chapter's Creative Commons license, unless indicated otherwise in a credit line to the material. If material is not included in the chapter's Creative Commons license and your intended use is not permitted by statutory regulation or exceeds the permitted use, you will need to obtain permission directly from the copyright holder. 


\title{
Teaching the World Court Makes a Bad Case: Revisiting the Relationship Between Domestic Courts and the ICJ
}

\author{
Raffaela Kunz
}

\begin{abstract}
Sentenza 238/2014 once more highlights the important role domestic courts play in international law. More than prior examples, it illustrates the ever more autonomous and self-confident stance of domestic courts on the international plane. But the ruling of the Italian Constitutional Court (ItCC) also shows that more engagement with international law does not necessarily mean that domestic courts enhance the effectiveness of international law and become 'compliance partners' of international courts. Sentenza 238/2014 suggests that domestic courts, in times of global governance and increased activity of international courts, see the role they play at the intersection of legal orders also as 'gate-keepers', ready to cushion the domestic impact of international law if deemed necessary. The judgment of the ItCC thus offers a new opportunity to examine the multifaceted and complex role of these important actors that apply and shape international law, while always remaining bound by domestic (constitutional) law. This chapter does so by exploring how domestic courts deal with rulings of the World Court. It shows that despite the fact that in numerous situations domestic courts could act as compliance partners of the International Court of Justice, in reality, more often than not, they have refused to do so, arguing that its judgments are not self-executing and thus deferring the implementation to the political branches. Assessing this practice, the chapter argues that domestic courts should take a more active stance and overcome the purely interstate view that seems at odds with present-day international law. While it seems too far-reaching to expect domestic courts to follow international courts unconditionally, the chapter cautions that there is a considerable risk of setting dangerous precedents by openly defying international judgments. Domestic courts should carefully balance the different interests at stake, namely an effective system of international adjudication on the one hand and the protection of fundamental domestic principles on the other hand. The chapter finds that the ItCC's attempt to reintroduce clear
\end{abstract}

\footnotetext{
R. Kunz $(\bowtie)$

Max Planck Institute for Comparative Public Law and International Law, Heidelberg, Germany e-mail:kunz@mpil.de 
boundaries between legal orders lacks the openness and flexibility needed to effectively cope with today's complex and plural legal reality.

\section{Introduction}

Judgment $238 / 2014$ of the Italian Constitutional Court (ItCC) ${ }^{1}$ is worth exploring from an international law perspective. Besides the obvious questions it raises in relation to state immunity, it also touches upon the role of domestic courts in international law. Sentenza 238/2014 is yet another illustration of how domestic courts in recent years increasingly became important actors on the international plane. $^{2}$ Not only do they contribute to the creation of new rules of customary international law; ${ }^{3}$ they also fill certain gaps in the existing international legal order by applying and giving effect to international law. In this sense, and in line with Scelle's theory of dédoublement fonctionnel, ${ }^{4}$ domestic judges also fulfil an international judicial function, ${ }^{5}$ and by doing so not only serve the domestic but the international rule of law as well. ${ }^{6}$ The ruling of the ItCC, more than prior examples of domestic court engagement with international law, illustrates the ever more autonomous and self-confident role domestic courts play on the international plane-they do not even seem anymore to shy away from contradicting their governments, a development that seemed nearly impossible only years ago. ${ }^{7}$ In this sense, Sentenza appears to suggest that the quest of the Institut de Droit

\footnotetext{
${ }^{1}$ Corte Costituzionale, Judgment of 22 October 2014, No 238/2014.

${ }^{2}$ See ILA, Study Group on Principles on the Engagement of Domestic Courts with International Law, Conference Study Group Report Johannesburg: 'Mapping the Engagement of Domestic Courts with International Law', 2016, available at http://www.ila-hq.org/index.php/study-groups? study-groupsID $=57$.

${ }^{3}$ See Antonios Tzanakopoulos/Christian J Tams, 'Introduction: Domestic Courts as Agents of Development of International Law', Leiden Journal of International Law 26 (2013), 531-540, as well as the other contributions in the same issue.

${ }^{4}$ Georges Scelle, 'Le phénomène juridique du dédoublement fonctionnel', in Walter Schätzel/HansJürgen Schlochauer (eds), Rechtsfragen der Internationalen Organisation. Festschrift für Hans Wehberg (Frankfurt am Main: Verlag Klostermann 1956), 324-342.

${ }^{5}$ Yuval Shany, 'Dédoublement fonctionnel and the Mixed Loyalities of National and International Judges', in Filippo Fontanelli/Giuseppe Martinico/Paolo Carrozza (eds), Shaping Rule of Law Trough Dialogue: International and Supranational Experiences (Groningen: Europa Law Publishing 2010), 29-42.

${ }^{6}$ André Nollkaemper, National Courts and the International Rule of Law (Oxford: OUP 2011).

${ }^{7}$ The Italian government intended to comply with the judgment and passed a law implementing it. It was this law, among others, that the ItCC declared unconstitutional. See Art 3 of the Italian Law No 5 of 14 January 2013, Accession of the Republic of Italy to the UN Convention on Jurisdictional Immunities of States and Their Property. On the traditional deference of domestic courts towards the executive on the international plane, see Eyal Benvenisti, 'Reclaiming Democracy: The Strategic Uses of Foreign and International Law by National Courts', American Journal of International Law 102 (2008), 241-274, at 241; Eyal Benvenisti/George W Downs, Between
} 
International, which claimed in 1993 'to strengthen the independence of national courts in relation to the Executive and to promote better knowledge of international law by such courts,, 8 is becoming reality.

But Judgment 238/2014 also illustrates that greater engagement with international law does not necessarily mean that domestic courts enhance the effectiveness of international law. In the same vein, they are not automatically 'partners' of international courts and contribute to compliance with their judgments, as has been suggested. ${ }^{9}$ To the contrary, the ruling of the ItCC shows that domestic courts - maybe increasingly — see the role they play at the intersection of legal orders also as one of 'gate-keepers', controlling the effects of international law at the domestic level and ready to cushion its impact if deemed necessary. ${ }^{10}$ And whereas compliance has always been considered the Achilles' heel of international adjudication, ${ }^{11}$ Judgment 238/2014 stands out for yet another feature. It is an example of what has been termed 'principled resistance, ${ }^{12}$ that is an instance of a case where a domestic court deals with an international judgment and deliberately decides to reject it. ${ }^{13}$

Sentenza is thus yet another illustration of the dual—and often delicate-role domestic courts perform at the intersection of legal orders. ${ }^{14}$ They are 'servants' to international law within the domestic realm and act as pivotal safeguards for its effectiveness. At the same time, they of course remain 'answerable to the dictates of

Fragementation and Democracy: The Role of National and International Courts (Cambridge: CUP 2017), at 105.

${ }^{8}$ Institut de droit international, 'The Activities of National Judges and the International Relations of their State', 7 September 1993, available at www.idi-iil.org/app/uploads/2017/06/1993_mil_01_en. pdf.

${ }^{9}$ Cf Eyal Benvenisti/George W Downs, 'National Courts, Domestic Democracy, and the Evolution of International Law', European Journal of International Law 20 (2009), 59-72.

${ }^{10}$ Nollkaemper calls this the 'shield' function. See André Nollkaemper, 'The Duality of Direct Effect of International Law', European Journal of International Law 25 (2014), 105-125, at $115-117$.

${ }^{11}$ Andrea Gattini, 'Domestic Judicial Compliance with International Judicial Decisions: Some Paradoxes', in Ulrich Fastenrath/Rudolf Geiger/Daniel-Erasmus Khan et al (eds), From Bilateralism to Community Interest: Essays in Honour of Bruno Simma (Oxford: OUP 2011), 1168-1188, at 1168 .

${ }^{12}$ This term has been used in the context of the European Court of Human Rights. See Fiona de Londras/Kanstantsin Dzehtsiarou, 'Mission Impossible? Addressing Non-Execution through Infringement Proceedings in the European Court of Human Rights', International and Comparative Law Quarterly 66 (2017), 467-490. For a critical answer, see Alice Donald, 'Tackling Non-Implementation in the Strasbourg System: The Art of the Possible?', EJIL:Talk!, (28 April 2017), available at www.ejiltalk.org/tackling-non-implementation-in-the-strasbourg-system-theart-of-the-possible/. In June 2017, the University of Konstanz held a conference on the topic of 'Principled Resistance against ECtHR Judgments—a New Paradigm?'.

${ }^{13}$ Formally speaking, the ItCC did not 'reject' the ICJ judgment and only decided on the domestic legislation implementing the relevant treaties. Nonetheless, the ruling might entail the responsibility of Italy under international law.

${ }^{14} \mathrm{Cf}$, Nollkaemper, 'The Duality' 2014 (n 10). 
applicable domestic law' ${ }^{15}$ Domestic courts are, and in times of global governance probably increasingly will be, torn between the sometimes not easily reconcilable commands of domestic and international law: between an effective system of international adjudication on the one hand and key values of pluralism and constitutionalism on the other hand. Against this backdrop, Judgment 238/2014 offers a new opportunity to examine the role of domestic courts in international law, and, more concretely, in the implementation of the rulings of the International Court of Justice (ICJ/World Court). Recalling some famous instances in which domestic courts have been confronted with judgments of the ICJ, this chapter shows that despite the fact that in numerous situations domestic courts could act as compliance partners and help the ICJ to give effects to its rulings in the domestic sphere, in reality, more often than not, they have refused to do so (section II). After offering some possible explanations for this practice, the chapter moves to the normative level and tries to contribute to the important debate on what role domestic courts should play at the intersection of legal orders and vis-à-vis their international counterparts (section III). It first argues that, given the development of international law, the very state-centred view many domestic courts take is no longer adequate and that domestic courts should take a more active role in the implementation of ICJ judgments. On the other hand, even though good reasons can be brought forward to allow domestic courts to disobey the ICJ in extreme cases where a conflict with core principles of the domestic order seems unavoidable, the risk of setting dangerous precedents that may damage the authority of the World Court demands a careful balancing of the different interests at stake. The chapter concludes by finding that the ItCC's attempt to reintroduce clear boundaries between legal orders lacks the openness and flexibility needed to effectively cope with today's complex and plural legal reality (section IV).

\section{The Dual Role of Domestic Courts at the Intersection of Legal Orders}

\section{Domestic Courts as Law Enforcers}

Although international adjudication is often seen as a form of law enforcement, international judgments also need to pass the 'acid test of inforcement [sic]'. ${ }^{16}$ In fact, given that international courts lack the capability to take action within the

\footnotetext{
${ }^{15}$ Rosalyn Higgins, 'National Courts and the International Court of Justice', in Mads Andenas/ Duncan Fairgrieve (eds), Tom Bingham and the Transformation of the Law: A Liber Amicorum (Oxford: OUP 2009), 405-418, at 417.

${ }^{16}$ Robert Jennings, 'The Judicial Enforcement of International Obligations', Heidelberg Journal of International Law 47 (1987), 3-16, at 3; Alexandra Huneeus, 'Compliance with Judgments and Decisions', in Cesare Romano/Karen J Alter/Yuval Shany (eds), The Oxford Handbook of International Adjudication (Oxford: OUP 2014), 437-463, at 437.
} 
domestic realm, the question of the enforcement of international judgments is as old as international courts themselves. ${ }^{17}$ Whereas the enforcement of international judgments has traditionally been considered to be a political matter, best confined to the executive, ${ }^{18}$ some have long suggested that domestic courts could fill the enforcement gap at the domestic level and play a role in giving effect to international judgments. $^{19}$

With regard to the World Court, domestic courts can play a role as 'enforcers' in two constellations. ${ }^{20}$ First of all, a victorious state can bring an ICJ ruling before a domestic court to oblige the debtor state to comply. So far, however, it seems that no state has ever attempted to enforce an ICJ judgment against another state before a domestic court. ${ }^{21}$ Not so, however, with regard to actions brought by private parties. In several instances private parties have called on domestic courts in order to bring a state to comply with an ICJ judgment. ${ }^{22}$ That this constellation has been more relevant in practice is unsurprising despite the interstate nature of the procedure before the World Court, given that non-state actors and particularly individuals can have a strong interest in the effective enforcement of international judgments affecting their interests, which has often been the case even before the ICJ. ${ }^{23}$ Driven by their interest, individuals operate in a 'private attorney-general' fashion and enhance the effectiveness of international law. ${ }^{24}$

However, most of the attempts by private parties to enforce ICJ judgments before domestic courts have hitherto failed. The following examples suggest that domestic courts are reluctant to assume a role in the direct enforcement of judgments of the ICJ, and that they adhere to the old paradigm according to which domestic and international courts are 'courts of a different legal order' ${ }^{25}$ In this dualist view, the obligations from international judgments remain purely international obligations. Either they are not self-executing - that is they are directed at the state as a whole,

\footnotetext{
${ }^{17}$ Richard Frimpong Oppong/Angela M Barreto, 'Enforcement', in William A Schabas/ Shannonbrooke Murphy (eds), Research Handbook on International Courts and Tribunals (Cheltenham: Edward Elgar 2017), 273-298, at 273.

${ }^{18}$ Ibid, at 276; 286.

${ }^{19}$ Wilfred C Jenks, The Prospects of International Adjudication (London/New York: Stevens\&Sons/Oceana Publications 1964), at 706-715; Jennings, 'Judicial Enforcement' 1987 (n 16), 8-9.

${ }^{20}$ For an overview, see Sarita Ordonez/David Reilly, 'Effect of the Jurisprudence of the International Court of Justice on National Courts', in Thomas M Franck/Gregory H Fox (eds), International Law Decisions in National Courts (New York: Transnational Publishers 1996), 335-371. See also Gattini, 'Domestic Judicial Compliance' 2011 (n 11), 1171-1178.

${ }^{21}$ Ordonez/Reilly, 'Effect of the Jurisprudence' 1996 (n 20), 349.

${ }^{22}$ For an overview, see ibid, 351-353.

${ }^{23}$ Gattini, 'Domestic Judicial Compliance' 2011 (n 11), 1173.

${ }^{24}$ Yuval Shany, 'No Longer a Weak Department of Power? Reflections on the Emergence of a New International Judiciary', The European Journal of International Law 20 (2009), 73-91, at 79.

${ }^{25}$ PCIJ, Certain German Interests in Polish Upper Silesia (Germany v Poland), Judgment of 25 August 1925, PCIJ Reports Series A No 6, 3, at 20.
} 
and it is not up to the judiciary to directly give effect to them ${ }^{26}$ —or individuals simply have no standing to enforce them.

An early example of a private party unsuccessfully seeking to enforce a judgment of the World Court - in this case the predecessor to the ICJ-is the case of Socobel v Greece. In this case the Permanent Court of International Justice (PCIJ) had confirmed the validity of a previously rendered arbitral award. ${ }^{27}$ Based on the finding of the PCIJ, the Société Commerciale de Belgique sought to enforce the award and filed a claim to attach Greek assets before a Belgian court. The Tribunal Civil de Bruxelles, however, denied the possibility of giving effect to the findings of the PCIJ. It concluded that the plaintiffs needed an exequatur to enforce the judgment and held that 'in the absence of an independent power of execution belonging to that Court [the PCIJ], which would enable litigants before it to execute its decisions de plano, these decisions are not exempt from the servitude imposed on Belgian territory on decisions of other than Belgian tribunals'. Furthermore, it concluded that the judgment of the PCIJ could not be considered a judgment in favour of the plaintiff because it was 'inconceivable that a party which, by definition, is not admitted to the bar of an international court should be able to rely on a judicial decision in a case to which it was not a party'. ${ }^{28}$

Another well-known example where a higher court was confronted with an enforcement action occurred in the course of the Nicaragua case. In its judgment the ICJ had found that the support of the Contra rebels by the US government had violated international law and ordered both the cessation of the illegal actions and the payment of reparations. ${ }^{29}$ The US had vehemently opposed the bringing of the case before the ICJ and subsequently boycotted the proceedings on the merits stage. This was not a good basis for compliance. Not surprisingly, the US for several years continued its actions and openly defied the judgment of the World Court. ${ }^{30}$ Against this backdrop, a group of private individuals tried to bring the US to comply with the judgment via domestic litigation. The domestic court they addressed, however, found that "neither individuals nor organizations have a cause of action in an American court to enforce ICJ judgments. The ICJ is a creation of national governments, working through the UN; its decisions operate between and among such governments and are not enforceable by individuals having no relation to the claim that the ICJ has adjudicated. ${ }^{, 31}$ More recently, the Constitutional Court of Colombia

\footnotetext{
${ }^{26}$ For terminology, see Yuvji Iwasawa, 'Domestic Application of International Law', Recueil des Cours 378 (2016), 9-261.

${ }^{27}$ PCIJ, The 'Société Commerciale de Belgique' (Belgium v Greece), Judgment of 15 June 1939, PCIJ Series A/B No 78.

${ }^{28}$ Tribunal Civil de Bruxelles, Socobel v Greek State, ILR 18 (1951), 3, at 4-5.

${ }^{29} \mathrm{ICJ}$, Military and Paramilitary Activities in and against Nicaragua (Nicaragua $v$ United States of America), Judgment of 27 June 1986, ICJ Reports 1986, 14.

${ }^{30}$ See, for an overview of the US reaction to the proceedings, Constanze Schulte, Compliance with Decisions of the International Court of Justice (Oxford: OUP 2004), 190-192.

${ }^{31}$ United States Court of Appeals, District of Columbia Circuit, Committee of United States Citizens Living in Nicaragua $v$ Reagan, 859 F.2d 929 (1988), 932.
} 
decided that a judgment of the ICJ concerning the territorial limits between Nicaragua and Colombia in the Caribbean $\mathrm{Sea}^{32}$ needed to be implemented, in this case through the executive, by means of a treaty. ${ }^{33}$

This reluctance and the underlying dualist view of these courts to a certain extent find their basis in international law itself. ${ }^{34}$ Traditionally, international judgments are treated no differently than other international obligations and are formulated as 'obligations of result', stopping 'short at the outer boundaries of the State machinery'. ${ }^{35}$ The UN Charter states that '[e]ach Member of the United Nations undertakes to comply with the decision of the International Court of Justice in any case to which it is a party' (Article 94(1)), from which it is generally concluded that the judgments of the World Court address the state as a whole and do not require a direct effect as a matter of international law. ${ }^{36}$ For a long time, this was also the line followed by the ICJ, which limited itself to stating whether or not there was a violation of international law, without giving any indication about concrete steps to be undertaken as a consequence thereof. More recently, however, the ICJ cautiously began formulating more concrete obligations in its judgments, which led some observers to conclude that the Court might soon 'pierce the veil' and ask states to give direct effect to its judgments. ${ }^{37}$ Unsurprisingly, several of these cases directly dealt with rights of individuals, and even less surprisingly some of these judgments subsequently ended up before domestic judges.

A milestone in this development was undoubtedly the LaGrand judgment, in which the ICJ famously stated that the Vienna Convention on Consular Relations ${ }^{38}$ also contained individual rights. It decided that the US had infringed upon these rights by not informing two German nationals, the LaGrand brothers - who had each

\footnotetext{
${ }^{32}$ ICJ, Territorial and Maritime Dispute (Nicaragua v Colombia), Judgment of 19 November 2012, ICJ Reports 2012, 624.

${ }^{33}$ Constitutional Court of Colombia, Judgment of 2 May 2014, No C-269/14.

${ }^{34}$ See also Gattini, 'Domestic Judicial Compliance' 2011 (n 11).

${ }^{35} \mathrm{ILC}$, Report of the Commission to the General Assembly on the Work of Its Twenty-Ninth Session, Commentary to the Draft Articles on State Responsibility, 'Breach of an International Obligation Requiring the Achievement of a Special Result', 9 May-29 July 1977, ILC YB 1977 (II), Art 21, para 1. Cf Ward Ferdinandusse, 'Out of the Black Box? The International Obligation of State Organs', Brooklyn Journal of International Law 29 (2003), 45-127.

${ }^{36}$ Karin Oellers-Frahm, 'Article 94', in Bruno Simma/Daniel-Erasmus Khan/Georg Note et al (eds), The Charter of the United Nations: A Commentary (Oxford: OUP 2012), para 12; Fulvio Palombino, 'Les arrêts de la Cour internationale de Justice devant le juge interne', Annuaire français de droit international 51 (2005), 121-139, at 122; Giuseppe Cataldi, 'La mise en oeuvre des décisions des tribunaux internationaux dans l'ordre interne', Recueil des Cours 386 (2017), 267-428, at 361-362.

${ }^{37}$ Vladen Vereshchetin, 'On the Expanding Reach of the Rulings of the International Court of Justice', in Pierre-Marie Dupuy (ed), Völkerrecht als Wertordnung. Festschrift für Christian Tomuschat (Kehl: Engel Verlag 2006), 621-633.

${ }^{38}$ Vienna Convention on Consular Relations, 24 April 1963, UNTC 596261.
} 
received the death penalty in the US - of their rights under the Convention. ${ }^{39}$ But the case that provoked a flurry of subsequent domestic proceedings was Avena, which involved 54 Mexican nationals on death row. In this instance, the ICJ had found that the US had violated the Vienna Convention on Consular Relations by having not properly informed the concerned Mexican nationals of their rights. Whereas in the operative part of the judgment, the Court limited itself to state that the appropriate reparation would consist in the 'review and reconsideration' of the convictions by means of the US's choosing, ${ }^{40}$ in the ratio decidendi the ICJ specified that it considered that 'it is the judicial process that is suited to this task' ${ }^{41}$

Following this ruling, an individual petitioner not explicitly listed in Avena but in a situation similar to the one dealt with in the judgment, relied on the ICJ to have his sentence reconsidered. The US Supreme Court found that the ICJ deserved 'respectful consideration'; this, however, did not mean that 'its interpretations were intended to be binding on US courts'. ${ }^{42}$ The Supreme Court thus considered itself incapable of giving effect to the conclusions of the ICJ in this case. It was only in Medellin that the US Supreme Court was confronted with a claim by an individual directly benefitting from the ruling in Avena. The petitioner, José Ernesto Medellín, was backed with a memorandum by the then president George W Bush, which ordered the courts of the US to give effect to the ruling of the ICJ. ${ }^{43}$ However, the Supreme Court concluded that 'neither Avena nor the President's Memorandum constitutes directly enforceable federal law that pre-empts state limitations on the filing of successive habeas petitions'. ${ }^{44}$ It interpreted the phrase 'undertake to comply' in Article 94(1) of the UN Charter as a 'commitment by member states to take future action through their political branches (...)'. ${ }^{45}$ The consequence of the lack of direct effect in this case is well known. José Ernesto Medellín was executed shortly thereafter.

\footnotetext{
${ }^{39}$ ICJ, LaGrand (Germany v United States of America), Judgment of 27 June 2001, ICJ Reports 2001, 466, para 77: 'Based on the text of these provisions, the Court concludes that Art 36, para 1 , creates individual rights, which, by virtue of Art 1 of the Optional Protocol, may be invoked in this Court by the national State of the detained person. These rights were violated in the present case.' Cf, Anne Peters, Beyond Human Rights: The Legal Status of the Individual in International Law (Cambridge: CUP 2016), 348-387.

${ }^{40} \mathrm{ICJ}$, Avena and Other Mexican Nationals (Mexico v United States of America), Judgment of 31 March 2004, ICJ Reports 2004, operative para 153, No 9.

${ }^{41}$ Ibid, para 140.

${ }^{42}$ US Supreme Court, Sanchez-Llamas v Oregon, 548 US 331 (2006), 4.

${ }^{43}$ ' I have determined, pursuant to the authority vested in me as President by the Constitution and the laws of the United States of America, that the United States will discharge its international obligations under the decision of the International Court of Justice in [Avena], by having State courts give effect to the decision in accordance with general principles of comity in cases filed by the 51 Mexican nationals addressed in that decision.' See US Supreme Court, José Ernesto Medellín v Texas, 552 US (2008), 7.

${ }^{44}$ Ibid, 2.

${ }^{45}$ Ibid, 12 .
} 
A very different stance has been taken by the German Federal Constitutional Court (FCC). This court affirmed a certain direct effect of international judgments before German courts. Equally confronted with claims by foreign individuals - in this case Turkish nationals - that the Vienna Convention on Consular Relations had been violated, it extensively relied on LaGrand and Avena. It declared that German courts were in principle bound by the findings of the ICJ also in the absence of a formal act of 'execution' by the political branches. Building upon its jurisprudence on the effects of judgments of the European Court of Human Rights (ECtHR) and the constitutional principle of openness towards international law, the FCC stated that German courts had a duty to take into account ICJ judgments. ${ }^{46}$ It came to this conclusion even though Germany had not been a party to the proceedings before the ICJ in this case and was therefore not legally bound by the judgments' inter partes binding effect. The FCC thus accepted that any judgment of the ICJ (or any other international court) issued against another state deploys a "normative directing function'. 47

Called upon to clarify the obligations flowing from Avena in light of the different possible solutions, the ICJ subsequently had the chance to give its view on the matter. However, the World Court did not accept Mexico's invitation to unequivocally 'lift the veil' and directly address state organs. Instead, it took a classical 'black box' stance, making clear that it does not require domestic courts to give effect to its judgments directly as a matter of international law. ${ }^{48}$

\section{Domestic Courts as 'Gate-Keepers'}

In most of the examples described above, domestic courts have thus denied the possibility to directly give effect to judgments of the ICJ and considered the political branches to be the organ most suited for their implementation. By contrast, in the judgment of the ItCC, the 'self-executingness' of the ICJ judgment was not at stake-the Italian parliament had enacted legislation implementing the 2012 ruling. ${ }^{49}$ The reasons the ItCC brought forward were rather substantive. It argued

\footnotetext{
${ }^{46}$ Bundesverfassungsgericht, Order of 19 September 2006, 2 BvR 2115/01.

${ }^{47}$ Ibid, para 62.

${ }^{48} \mathrm{ICJ}$, Request for Interpretation of the Judgment of 31 March 2004 in the Case concerning Avena and Other Mexican Nationals (Mexico v United States of America), Judgment of 19 January 2009, ICJ Reports 2009, 3, para 44: 'The Avena judgment nowhere lays down or implies that the Courts in the United States are required to give direct effect to par. 153 (9). (...) [T] he judgment leaves it to the United States to choose the means of implementation, not excluding the introduction within a reasonable time of appropriate legislation, if deemed necessary under constitutional law. Nor moreover does the Avena judgment prevent direct enforceability of the obligation in question, if such an effect is permitted by domestic law.'

${ }^{49}$ Italian Law No 5/2013 (n 7).
} 
that the enforcement of the ICJ judgment, obliging Italian courts to uphold state immunity - and deny jurisdiction - in cases of war crimes and crimes against humanity, would violate core principles of the Italian Constitution, namely the guarantee of judicial protection under Articles 2 and 24. Another difference between Judgment 238/2014 and the abovementioned examples is that the Italian Constitutional Court did not argue that implementation would still occure and that it is merely up to another state organ to give effect to the ICJ judgment. The ItCC rather held that the enforcement of the Jurisdictional Immunities Judgment would altogether be contrary to the Italian Constitution, and therefore that no state organ should give effect to it. It therefore declared, inter alia, the law implementing the ICJ judgment unconstitutional. $^{50}$

Sentenza 238/2014 is a telling example of how the Italian Constitutional Court perceives its role at the intersection of legal orders, and vis-à-vis its international counterparts. In other cases, it took a similar position. Towards the ECtHR, the ItCC stated in 2015 that it did not consider itself a 'passive recipient of an interpretative command issued elsewhere in the form of a court ruling (...) ${ }^{51}$ In this judgment, it restricted its hitherto open and friendly position towards the ECtHR ${ }^{52}$ and made clear that it is keeping an active eye on Strasbourg, reserving the option not to follow the jurisprudence beyond what is strictly required under Article 46 of the European Convention on Human Rights (ECHR). ${ }^{53}$ Most recently, the ItCC even spoke up against the European Court of Justice (ECJ). In a preliminary reference ruling, it argued that the application of the Taricco jurisprudence of the ECJ would violate fundamental rights under the Italian Constitution as well as the EU Charter of Fundamental Rights and threatened the ECJ to raise the controlimiti bar in case the latter insisted on its position. ${ }^{54}$ To widespread astonishment, the ECJ yielded and adjusted its position, ${ }^{55}$ a move that has been read by some as a successful example of judicial dialogue ${ }^{56}$ and by others as 'the first of many other humiliating and inevitable concessions to national constitutional courts in the near future. ${ }^{57}$

\footnotetext{
${ }^{50}$ ItCC, Judgment 238/2014 (n 1), operative paras.

${ }^{51}$ Corte Costituzionale, Judgment of 26 March 2015, No 49/2015, para 7.

${ }^{52}$ Corte Costituzionale, Judgments of 22 October 2007, Nos 348 and 349/2007.

${ }^{53} \mathrm{See}$, for a good summary, Andrea Pin, 'A Jurisprudence to Handle with Care: The European Court of Human Rights' Unsettled Case Law, its Authority, and its Future, According to the Italian Constitutional Court', I-CONnect. Blog, (30 April 2015), available at www.iconnectblog.com/ 2015/04/mini-symposium-on-cc-judgment-49-2015.

${ }^{54}$ Corte Costituzionale, Order of 23 November 2016, No 24/2017.

${ }^{55}$ CJEU, Taricco II (M.A.S. and M.B.), Judgment of 5 December 2017, Case No C-42/17.

${ }^{56}$ Giacomo Rugge, 'The Italian Constitutional Court on Taricco: Unleashing the normative potential of "national identity"?', QIL, Zoom-In 37 (2017), 21-29.

${ }^{57}$ Daniel Sarmiento, 'To Bow at the Rhythm of an Italian Tune', Despite our Differences, (5 December 2017), available at https://despiteourdifferencesblog.wordpress.com/2017/12/05/tobow-at-the-rhythm-of-an-italian-tune/. For a good analysis of the case, see Dana Burchardt, 'Belittling the Primacy of EU Law in Taricco II', VerfBlog, (7 December 2017), available at https://doi. org/10.17176/20171207-180534.
} 
These examples illustrate that the ItCC sees itself as an active player on the international plane, willing to participate in the shaping of international law. In the Sentenza this also becomes clear by the fact that the ItCC refers to the Kadi decision of the ECJ, ${ }^{58}$ explicitly expressing the ambition that its judgment, like Kadi, ${ }^{59}$ may contribute to a development of international law in a direction more attentive to fundamental rights. ${ }^{60}$

But these examples also show that the ItCC increasingly sees itself as a gatekeeper positioned at the intersection of legal orders, ready to step in and 'shield' the domestic order from effects of international law it considers negative. Of course, compliance with international law has always been an issue and a certain resistance against the World Court is nothing new. Even though the overall compliance rate of the ICJ is quite good $^{61}$ and the enforcement mechanism of Article 94(2) of the UN Charter has been activated only once, ${ }^{62}$ there are several well-known examples where compliance with a judgment on the merits has posed problems. One recurring issue is late compliance, ${ }^{63}$ another cases in which states boycott the whole proceeding before the ICJ, or openly defy a ruling by other means. ${ }^{64}$ It is, however, a different matter if domestic courts start to control international judgments and verify their constitutionality as a matter of principle, and therefore systematically 'judge' them anew, as the ItCC has started to do. ${ }^{65}$ Despite the fact that a certain reservation

\footnotetext{
${ }^{58} \mathrm{CJEU}$, Kadi and Al Barakaat International Foundation $v$ Council of the European Union and Commission of the European Communities, Judgment of 3 September 2008, Joined Cases C-402/05 $\mathrm{P}$ and $\mathrm{C}-415 / 05 \mathrm{P}$.

${ }^{59}$ In Kadi, the CJEU engaged the fundamental rights standards of the European Union to scrutinize measures implementing anti-terrorist sanctions ordered by the UN Security Council. This decision eventually led to an improvement of the fundamental rights protections within the United Nations sanctioning regime. See, eg, Katja S Ziegler, 'Strengthening the Rule of Law, but Fragmenting International Law: The Kadi Decision of the ECJ from the Perspective of Human Rights', Human Rights Law Review 9 (2009), 288-305.

${ }^{60}$ ItCC, Judgment 238/2014 (n 1), para 3.3.

${ }^{61}$ Schulte, Compliance 2004 (n 30), 271-276.

${ }^{62}$ Irène Couzigou, 'Enforcement of UN Security Council Resolutions and ICJ Judgments: The Unreliability of Political Enforcement Mechanisms', in András Jakab/Dimitry Kochenov (eds), The Enforcement of EU Law and Values: Ensuring Member States' Compliance (Oxford: OUP 2017), $363-378$, at 374.

${ }^{63}$ An example for this is the Haya de la Torres case. This dispute between Peru and Colombia gave rise to three ICJ judgments: Asylum case (Colombia v Peru), Judgment of 20 November 1950; Request for Interpretation of the Judgment of November 20th, in the Asylum Case (Colombia v Peru), Judgment of 27 November 1950; Haya de la Torre case (Colombia v Peru), Judgment of 13 June 1951. For an overview, see Schulte, Compliance 2004 (n 30), 99-108.

${ }^{64}$ According to Schulte, this has happened in at least four instances, namely in the Corfu Channel, Fisheries Jurisdiction, Teheran Hostages and Nicaragua cases. See Schulte, Compliance 2004 (n 30), 271. For more examples, see Aloysius P Llamazon, 'Jurisdiction and Compliance in Recent Decisions of the International Court of Justice', European Journal of International Law 18 (2007), $815-852$, at 825-840.

${ }^{65}$ Cf Fulvio Palombino, 'Compliance with International Judgments: Between Supremacy of International Law and National Fundamental Principles', Heidelberg Journal of International Law
} 
towards international law and institutions as such is nothing new and that other constitutional courts have always reserved the right to step in and protect their constitutional orders, especially in more integrated orders such as the EU-the FCC possibly representing the most famous example ${ }^{66}$ - the important difference is that the ItCC no longer limits itself to issuing warning shots. This recent development clearly shows that it has started to actually apply the constitutional barriers and that it accepts the price of Italian responsibility under international law.

\section{Which Role for Courts at the Intersection of Legal Orders?}

How can this development be explained? It is argued here that it is neither surprising that clashes between international and domestic (constitutional) law seem to happen more frequently in recent times, nor that they often emerge with regard to judgments of international courts. This has not only to do with a quantitative change of international law, the proliferation of international courts and tribunals, and more generally the growing importance of international regulation in times of global governance, but also with a qualitative change of the norms. Whereas in the past, international law often remained vague and gave states considerable leeway for its implementation, the concrete orders of international courts reduce this leeway and make tensions or even frictions more likely. ${ }^{67}$ Chances remain high that this development continues. The consequence is that domestic courts in the near future might be confronted more often with international judgments. This is also true for the ICJ which has started to formulate more concrete obligations. ${ }^{68}$

This brief analysis thus shows once more the difficult-and arguably highly political $^{69}$ - role domestic courts assume at the intersection of legal orders. The examples illustrate that the question of whether and how to give effect to

\footnotetext{
75 (2015), 503-529; Stefano Battini, ‘È costituzionale il diritto internazionale?', Giornale di diritto amministrativo 3 (2015), 367-377.

${ }^{66}$ Bundesverfassungsgericht, Order of 29 May 1974, BvL 52/71, BVerfGE 37, 271. See, for more examples, Anne Peters, 'The Globalization of State Constitutions', in Janne E Nijman/André Nollkaemper (eds), New Perspectives on the Divide Between National and International Law (Oxford: OUP 2007), 251-308, at 266-267; Anne Peters, 'Supremacy Lost: International Law Meets Domestic Constitutional Law', Vienna Online Journal on International Constitutional Law 3 (2009), 170-198.

${ }^{67}$ See also Nico Krisch, 'Pluralism in International Law and Beyond', (3 June 2015), available at https://papers.ssrn.com/sol3/papers.cfm?abstract_id=2613930,1-18, at 3.

${ }^{68}$ See section II. 1 of this chapter.

${ }^{69}$ Nollkaemper, 'The Duality’ 2014 (n 10), 121.
} 
international law is far from being a technical question. ${ }^{70}$ Giving effect to international judgments rather involves complex constitutional questions and requires the balancing of sometimes conflicting but equally important interests like the effectiveness of international adjudication and the protection of fundamental constitutional principles, both of which can be considered aspects of the rule of law in a general sense. When asked to give effect to international judgments, domestic courts may even face the dilemma of, on the one hand, abiding by judicial decisions based on international law, which contradict fundamental protections in the domestic legal system, or, on the other hand, adhering to national (constitutional) law, which risks defying international law. More than as instances of backlash, much of the resistance to international courts by their domestic counterparts can thus be seen as an illustration of today's complex and plural legal reality. ${ }^{71}$

This raises the question of how domestic courts should deal with international judgments. It is submitted here that good reasons support a solid place for domestic courts in the enforcement of the judgments of the ICJ. First of all, the practice of the ICJ—hitherto considered the archetype of an 'old style' international court ${ }^{72}$-is changing. To be sure, the ICJ refrained from claiming that its judgments enjoy a direct effect in the domestic legal orders, as seen above. ${ }^{73}$ Nonetheless, the position of the World Court has undeniably evolved: it is no longer exclusively a 'Court of sovereign States', becoming 'also a court concerned with human rights, as human rights law has finally found its proper place within international law'. ${ }^{74}$ The ICJ is now even said to contribute to a 'humanisation in international adjudication'. ${ }^{75}$

The purely state-centred view that some domestic courts still adopt seems to be at odds with this development. Whereas it might have made sense with regard to the

\footnotetext{
${ }^{70}$ Peters, Beyond Human Rights 2016 (n 39), 495; Armin von Bogdandy, 'Pluralism, Direct Effect, and the Ultimate Say: On the Relationship Between International and Domestic Constitutional Law', International Journal of Constitutional Law 6 (2008), 397-413, at 398.

${ }^{71}$ See for a differentiated view on the phenomenon of backlash Mikael Rask Madsen/Pola Cebulak/ Micha Wiebusch, 'Backlash against International Courts: Explaining the Forms and Patterns of Resistance to International Courts', International Journal of Law in Context 14 (2018), 197-220.

${ }^{72}$ Karen J Alter, The New Terrain of International Law: Courts, Politics, Rights (Princeton: Princeton University Press 2014), 81.

${ }^{73}$ See section II. 1 of this chapter.

${ }^{74}$ Rosalyn Higgins, 'Human Rights in the International Court of Justice', Leiden Journal of International Law 20 (2007), 745-751, at 746. Cf Gentian Zyberi, The Humanitarian Face of the International Court of Justice: Its Contribution to Interpreting and Developing International Human Rights and Humanitarian Law Rules and Principles (Antwerpen: Intersentia 2008); Bruno Simma, 'Mainstreaming Human Rights: The Contribution of the ICJ', Journal of International Dispute Settlement 3 (2012), 7-29.

${ }^{75}$ International Law Association, Committee on International Human Rights Law, Conference Report Washington: 'International Human Rights Law and the International Court of Justice (ICJ)', 2014, available at www.ila-hq.org/index.php/committees, para 86.
} 
'traditional' international law which treated mainly interstate issues, ${ }^{76}$ this is no longer the case for the 'inward-looking' international law of today. ${ }^{77}$ Accordingly, the 'fiction' of the unitary state is increasingly being considered an obstacle to compliance with international requirements. In the words of Rosalyn Higgins, 'compliance with the findings of international tribunals is made the more difficult exactly because while "the state" carries the international obligation to comply, the necessary action to achieve that must internally be performed by organs of state (...). ${ }^{78}$ This is even more so if the judgments directly touch upon rights or interests of individuals. Both the ECtHR and the Inter-American Court of Human Rights have stated that effective compliance with judgments is the materialization of justice for the concrete case, ${ }^{79}$ and represents an important aspect of the right to have access to justice and the rule of law. ${ }^{80}$ For individuals benefitting from a judgment of the ICJ, domestic courts are likely to be the only avenue open to reach compliance. ${ }^{81}$ The use of classical 'avoidance techniques ${ }^{, 82}$ seems inadequate in such situations.

However, this does not mean that domestic courts should follow the ICJ blindly. Given the increasing impact of international law on domestic systems and its persisting deficits, the claim for its absolute supremacy, and thus a rigid rule favouring the precedence of international law, seems neither normatively desirable nor to correspond to legal reality. ${ }^{83}$ A growing body of scholarship argues that, given the lack of democratic legitimacy and effective safeguards for fundamental rights in certain areas of international law, at least the highest domestic courts should in exceptional cases have a 'constitutional right to resist' international law. ${ }^{84}$ This means that they may exceptionally disregard international law where its application in the specific circumstances would result in a violation of core principles of the

\footnotetext{
${ }^{76}$ Allot speaks of 'structural duality'. See Philip Allot, 'The Emerging Universal Legal System', in Janne E Nijman/André Nollkaemper (eds), New Perspectives on the Divide Between National and International Law (Oxford: OUP 2007), 63-83, at 82.

${ }^{77} \mathrm{Cf}$, Ferdinandusse, 'Out of the Black Box' 2003 (n 35); Mohammed Bedjaoui, 'The Reception by National Courts of Decisions of International Tribunals', in Thomas M Franck/Gregory H Fox (eds), International Law Decisions in National Courts (New York: Transnational Publishers 1996), $21-35$, at 23 .

${ }^{78}$ Rosalyn Higgins, 'The Concept of "the State": Variable Geometry and Dualist Perceptions', in Laurence Boisson de Chazournes/Vera Gowlland-Debbas (eds), The International Legal System in Quest of Equity and Universality: Liber Amicorum Georges Abi-Saab (The Hague: Martinus Nijhoff 2001), 547-561, at 547.

${ }^{79}$ IACtHR, Case of Baena Ricardo et al v Panama, Judgment of 28 November 2003, Series C No 104, para 72.

${ }^{80}$ ECtHR, Hornsby v Greece, Judgment of 19 March 1997, Application No 18357/91, para 40.

${ }^{81} \mathrm{Cf}$ Oppong/Barreto, 'Enforcement' 2016 (n 17), 286.

${ }^{82}$ ILA, 'Engagement of Domestic Courts' (n 2), para 21.

${ }^{83} \mathrm{Cf}$ André Nollkaemper, 'Rethinking the Supremacy of International Law', Zeitschrift für öffentliches Recht 65 (2010), 65-85.

${ }^{84}$ Thomas Cottier/Daniel Wüger, 'Auswirkungen der Globalisierung auf das Verfassungsrecht: Eine Diskussionsgrundlage', in Beat Sitter-Liver (ed), Herausgeforderte Verfassung: Die Schweiz im globalen Kontext (Freiburg: Universitätsverlag Freiburg 1999), 241-281, at 263.
} 
domestic constitutional order or the 'constitutional identity ${ }^{85}$ Under these narrow circumstances, disobedience is a tool that helps to moderate the negative side-effects of multilevel governance and to facilitate - and not disrupt- the interplay between different legal orders. In this vein, it might, in the long run, foster rather than weaken the ideal of the rule of law also at the international level. ${ }^{86}$

This shows that seeing domestic courts in a binary fashion as either 'gatekeepers' or 'compliance partners' does not capture the complex role they play today at the intersection of legal orders. It has thus been suggested that it is at the same time more accurate descriptively and normatively preferable to view courts as bearers of 'multiple identities, ${ }^{87}$ In this sense, domestic courts are now part of a wider network, a 'global community of courts', ${ }^{88}$ and should have in mind the 'overall systemic interest in creating an interlocking system of adjudication. ${ }^{, 89}$ Domestic courts should take into account that to abide by judgments resulting from disputes that the parties voluntarily submitted to an international court belongs to the very foundations upon which the system of binding international adjudication is built. ${ }^{90}$ Non-compliance imperils 'the raison d'être for the functioning' ${ }^{91}$ of international courts, and arguably the (rather fragile) international rule of law. Rather than as guardians of one particular order, in today's complex legal reality courts should thus see themselves as mediators between orders. ${ }^{92}$ More than strict conflict rules and hierarchies, what better fits to the complex reality is an approach that allows to take into account the different interests at stake and to balance them. This again does not require to follow international courts at any prize, but at least to seriously engage with them and consider their rulings. This flexible, procedural solution thus reflects the fact that many different interests and claims are at play and to a certain extent allows to reconcile the multiple roles played by domestic courts.

The middle-ground position some courts such as the FCC take, requiring to take into account international judgments, seems most suited to reconcile those multiple

\footnotetext{
${ }^{85}$ Anne Peters, 'Rechtsordnungen und Konstitutionalisierung: Zur Neubestimmung der Verhältnisse', Zeitschrift für öffentliches Recht 65 (2010), 3-63, at 61; von Bogdandy, 'Pluralism, Direct Effect' (n 70), 398.

${ }^{86}$ See, on these 'feedback loops', Machiko Kanetake/André Nollkaemper, 'The International Rule of Law in the Cycle of Contestations and Deference', in Machiko Kanetake/André Nollkaemper (eds), The Rule of Law at the National and International Levels: Contestation and Deference (Oxford: Hart 2016), 445-460.

${ }^{87}$ Nico Krisch, Beyond Constitutionalism: The Pluralist Structure of Postnational Law (Oxford: OUP 2010), at 291-294.

${ }^{88}$ Anne-Marie Slaughter, 'A Global Community of Courts', Harvard International Law Journal 44 (2003) 191-219.

${ }^{89}$ Paul S Berman, Global Legal Pluralism: A Jurisprudence of Law Beyond Borders (Cambridge: CUP 2012), 294.

${ }^{90}$ Karin Oellers-Frahm, 'Article 94 UN Charter', in Andreas Zimmermann/Karin Oellers-Frahm/ Christian Tomuschat et al (eds), The Statute of the International Court of Justice: A Commentary (Oxford: OUP $2^{\text {nd }}$ ed 2012), para 1.

${ }^{91}$ IACtHR, Baena Ricardo v Panama (n 79), para 72.

${ }^{92}$ Krisch, Beyond Constitutionalism 2010 (n 87), 294.
} 
roles of courts. ${ }^{93}$ Certainly, this jurisprudence has been extensively criticized, especially in the context of the European human rights system, precisely because it widens the scope of possibilities to disregard binding judgments. ${ }^{94}$ The Russian Constitutional Court even called it an 'emblematic' example of deviation from judgments of the ECtHR. ${ }^{95}$ However, this line has thus far allowed German courts to reconcile claims of the different legal orders with few frictions. The reason is that the FCC reads this requirement generally in a result-oriented and international law friendly way, seriously engaging with its international counterparts. ${ }^{96}$ By contrast, for the US Supreme Court in order to satisfy the requirement of taking into account international judgments, a mere reference to the relevant judgment seems to suffice. ${ }^{97}$ Such merely formal cross-referencing certainly does not allow a serious engagement and lacks the openness needed to effectively cope with today's complex legal reality.

How is Judgment 238/2014 to be read against this backdrop? Two aspects of the judgment deserve to be highlighted in this regard. First of all, and despite the fact that the ItCC stresses that the effect of its judgment remain limited to the Italian legal order, ${ }^{98}$ its aim is not only to avoid legal consequences it deems intolerable, but furthermore to contribute to the evolution of the law of immunities in a way more considerate of human rights. ${ }^{99}$ It thus considers that it enters into a form of judicial dialogue with the ICJ with the aim to push for a change it deems necessary. ${ }^{100}$

\footnotetext{
${ }^{93}$ See section II. 1 of this chapter. See also ILA, Committee on International Human Rights Law, Resolution No 2/2016: 'The impact of international human rights law on the International Court of Justice', 2016, No 9 a): 'They [Constitutional and supreme courts] take the pertinent judgments and decisions of courts and quasi-judicial bodies, also in those cases to which the state was not a party, fully into account and integrate them in their reasoning in good faith', available at http://www.ilahq.org/index.php/committees.

${ }^{94}$ For an overview, see Matthias Hartwig, 'Much Ado about Human Rights: The Federal Constitutional Court Confronts the European Court of Human Rights', German Law Journal 5 (2005), 869-894.

${ }^{95}$ Russian Constitutional Court, Judgment of 14 July 2015, No 21-П/2015, para 4.

${ }^{96} \mathrm{See}$, for a paradigmatic example of adjustment to the ECtHR, Bundesverfassungsgericht, Order of 4 May 2011, 2 BvR 2365/09, BVerfGE 128, 326 (Sicherungsverwahrung). See, on the stance of the FCC towards the ECtHR, Eckart Klein, 'Germany', in Janneke Gerards/Joseph Fleuren (eds), Implementation of the European Convention on Human Rights and of the Judgments of the ECtHR in National Case Law (Cambridge: Intersentia 2014), 185-216; Elisabeth LambertAbdelgawad/Anne Weber, 'The Reception Process in France and Germany', in Helen Keller/ Alec Stone Sweet (eds), A Europe of Rights: The Impact of the ECHR on National Legal Systems (Oxford: OUP 2008), 107-164. Cf Krisch, Beyond Constitutionalism 2010 (n 87), 109-152.

${ }^{97}$ US Supreme Court, Sanchez-Llamas v Oregon (n 42).

${ }^{98}$ ItCC, Judgment 238/2014 (n 1), para 3.3.

${ }^{99}$ Ibid.

${ }^{100}$ See on judicial dialogue Anne-Marie Slaughter, 'A Global Community of Courts', Harvard International Law Journal 44 (2003) 191; Christopher McCrudden, 'A Common Law of Human Rights?: Transnational Judicial Conversations on Constitutional Rights', Oxford Journal of Legal Studies 20 (2000), 499-532; Sujit Choudry, 'Globalization in Search of Justification: Toward a Theory of Comparative Constitutional Interpretation', Indiana Law Journal 74 (1999), 819-892.
} 
Especially in the European human rights system, domestic courts have sometimes successfully entered into such a dialogue, ${ }^{101}$ which enhances the 'shared responsibility' for the standards of the ECHR ${ }^{102}$ and provides 'a constructive way for channeling substantive disagreement or criticism (...) ${ }^{103}$ However, it is submitted here that to enter into a 'dialogue' with the ICJ seems less fruitful from the outset. Other than the human rights courts, the World Court is much less flexible and does not have the same possibilities to react. ${ }^{104}$ In the case of the ECtHR, for instance, the Grand Chamber can correct a judgment. Furthermore, in the European system a change of jurisprudence is much easier to undertake due to the rich case-law of the ECtHR. This is different for the World Court, which only deals with a handful of cases per year. The risk of damaging its authority seems thus even bigger. ${ }^{105}$ In fact, in cases of legal conflict such as in the one at hand, where a domestic court (at least de facto) contests a final and binding international judgment with the consequence that enforcement of this judgment becomes difficult or even impossible, the term 'dialectical review' seems to fit better than 'judicial dialogue'. ${ }^{106}$

The second point relevant from the viewpoint of the interaction of different legal orders is that Sentenza 238/2014 indicates a move towards a more national and 'gatekeeper' type of understanding of the ItCC's role at the intersection of legal orders. Even though it would be too far-fetched to read Sentenza as an instance of nationalism trumping multilateralism and as an inevitable sign of crisis and decline of the international judiciary, the judgment clearly indicates a certain shift of the ItCC to a more dualist vision of the relationship between legal orders. Whereas several of the recent judgments of the ItCC touching upon the relationship of the Italian legal order with international or European law show that the Corte pursues a

\footnotetext{
${ }^{101}$ In the European system, several cases are known where the ECtHR adjusted its position. See, eg, ECtHR, Case of Al-Khawaja and Tahery $v$ The United Kingdom, Grand Chamber Judgment of 15 December 2011, Applications Nos 26766/05 and 22228/06.

${ }^{102} \mathrm{On}$ the notion of shared responsibility, see ECtHR, 'Implementation of the Judgments of the European Court of Human Rights: a Shared Judicial Responsibility?', (31 January 2014), available at www.echr.coe.int/Documents/Seminar_background_paper_2014_ENG.pdf. See also High Level Conference on the Future of the European Court of Human Rights, 'Copenhagen Declaration', 12-13 April 2018, available at https://rm.coe.int/copenhagen-declaration/16807b915c, paras 6-11. See, for the legitimizing effect of court interaction, Armin von Bogdandy/Ingo Venzke, In Whose Name? A Public Law Theory of International Adjudication (Oxford: OUP 2014), 196.

${ }^{103}$ Sarah Lambrecht, 'Assessing the Existence of Criticism of the European Court of Human Rights', in Patricia Popelier/Sarah Lambrecht/Koen Lemmens (eds), Criticism of the European Court of Human Rights. Shifting the Convention System: Counter-Dynamics and the National and EU Level (Cambridge: Intersentia 2016), 505-554, at 549.

${ }^{104}$ See also Alessandro Bufalini, chapter 'Waiting for Negotiations', in this volume.

${ }^{105}$ See, in more detail, Raffaela Kunz, 'The Italian Constitutional Court and "Constructive Contestation”: A Miscarried Attempt?', Journal of International Criminal Justice 14 (2016), 621-627.

${ }^{106} \mathrm{Cf}$ Robert B Ahdieh, 'Between Dialogue and Decree: International Review of National Courts', New York University Law Review 79 (2004), 2029-2163.
} 
more substantive check and makes the application and enforcement of legal norms from other orders dependent on their compatibility with Italian law, ${ }^{107}$ in the Sentenza it becomes particularly clear that by neatly distinguishing the 'inside' from the 'outside', the ItCC attempts to reintroduce clear boundaries between legal orders. And while this might be seen as a reaction to some of the problems and controversies surrounding global governance, it is submitted that such a stance lacks the openness and flexibility needed to effectively cope with the challenges of today's complex and plural legal reality. Rather than shielding off their legal orders, domestic courts should acknowledge that they are important actors at the intersection of legal orders, and that the functioning of the overall system in the long run to large extents will depend on them. ${ }^{108}$ Moreover, they should be aware that their judgments are indeed read and that nowadays their audience is global. The danger of setting dangerous precedents is thus a real one. The fact that the Russian Constitutional Court justified its disregard for judgments of the ECtHR explicitly relying, among others, on the $\mathrm{ItCC}^{109}$ indicates that Pandora's box is already wide open.

\section{Conclusion}

Judgment 238/2014 is a good occasion to explore once more the role of domestic courts in international law. This chapter has done so with regard to the particular question of the relationship between domestic courts and international courts, and more concretely the ICJ. As the case studies show, though domestic courts could act as enforcers of judgments of the World Court, in many instances they have not assumed such a role and deferred implementation to the political branches. This chapter argues that in light of the current state of international law and the important role the individual now plays - however indirectly-before the ICJ, the very dualist stance many domestic courts take is inadequate. Often, domestic courts can be the only avenue available for individuals to enforce judgments rendered in their favour. That this can be a matter of life or death is highlighted by the Avena saga. On the other hand, in light of the growing impact of international law and its persistent deficits, it seems too far-reaching to expect domestic courts to follow international courts blindly. A certain control undertaken by domestic courts might compensate for these deficits and in the long run even contribute to the international rule of law. However, in the face of today's plural legal reality, domestic courts should take into account and carefully balance the different interests at stake, namely an effective system of international adjudication and the protection of fundamental constitutional

\footnotetext{
${ }^{107}$ Section II.2. of this chapter.

${ }^{108}$ See also Paul S Berman, 'Jurisgenerative Constitutionalism: Procedural Principles for Managing Global Legal Pluralism', Indiana Journal of Global Legal Studies 20 (2013), 665-695.

${ }^{109}$ Russian Constitutional Court, Judgment No 21-П/2015 (n 95), para 4. See also Heike Krieger, chapter 'Sentenza 238/2014: A Good Case for Law-Reform?', in this volume.
} 
principles. Only in very exceptional circumstances should they contradict their international counterparts. This is even more so in the case of the ICJ, which after all barely has a chance to react. The danger of damaging its authority seems significant. Domestic courts should recognize that they are crucial actors at the intersection of legal orders, and that a functioning system of adjudication across levels and orders at the end of the day will to large extents depend on them.

\section{References}

Ahdieh, Robert B, 'Between Dialogue and Decree: International Review of National Courts', New York University Law Review 79 (2004), 2029-2163

Allot, Philip, 'The Emerging Universal Legal System', in Janne E Nijman/André Nollkaemper (eds), New Perspectives on the Divide Between National and International Law (Oxford: OUP 2007), 63-83

Alter, Karen J, The New Terrain of International Law: Courts, Politics, Rights (Princeton: Princeton University Press 2014)

Battini, Stefano, 'È costituzionale il diritto internazionale?', Giornale di diritto amministrativo 3 (2015), 367-377

Bedjaoui, Mohammed, 'The Reception by National Courts of Decisions of International Tribunals', in Thomas M Franck/Gregory H Fox (eds), International Law Decisions in National Courts (New York: Transnational Publishers 1996), 21-35

Benvenisti, Eyal, 'Reclaiming Democracy: The Strategic Uses of Foreign and International Law by National Courts', American Journal of International Law 102 (2008), 241-274

Benvenisti, Eyal/George W Downs, 'National Courts, Domestic Democracy, and the Evolution of International Law', European Journal of International Law 20 (2009), 59-72

Benvenisti, Eyal/George W Downs, Between Fragementation and Democracy: The Role of National and International Courts (Cambridge: CUP 2017)

Berman, Paul S, 'Jurisgenerative Constitutionalism: Procedural Principles for Managing Global Legal Pluralism', Indiana Journal of Global Legal Studies 20 (2013), 665-695

Berman, Paul S, Global Legal Pluralism: A Jurisprudence of Law Beyond Borders (Cambridge: CUP 2012)

Bogdandy, Armin von/Ingo Venzke, In Whose Name? A Public Law Theory of International Adjudication (Oxford: OUP 2014)

Bogdandy, Armin von, 'Pluralism, Direct Effect, and the Ultimate Say: On the Relationship Between International and Domestic Constitutional Law', International Journal of Constitutional Law 6 (2008), 397-413

Burchardt, Dana, 'Belittling the Primacy of EU Law in Taricco II', VerfBlog, (7 December 2017), available at https://doi.org/10.17176/20171207-180534

Cataldi, Giuseppe, 'La mise en oeuvre des décisions des tribunaux internationaux dans l'ordre interne', Recueil des Cours 386 (2017), 267-428

Choudry, Sujit, 'Globalization in Search of Justification: Toward a Theory of Comparative Constitutional Interpretation', Indiana Law Journal 74 (1999), 819-892

Cottier, Thomas/Daniel Wüger, 'Auswirkungen der Globalisierung auf das Verfassungsrecht: Eine Diskussionsgrundlage', in Beat Sitter-Liver (ed), Herausgeforderte Verfassung: Die Schweiz im globalen Kontext (Freiburg: Universitätsverlag Freiburg 1999), 241-281

Couzigou, Irène, 'Enforcement of UN Security Council Resolutions and ICJ Judgments: The Unreliability of Political Enforcement Mechanisms', in András Jakab/Dimitry Kochenov (eds), The Enforcement of EU Law and Values: Ensuring Member States' Compliance (Oxford: OUP 2017), 363-378 
De Londras, Fiona/Kanstantsin Dzehtsiarou, 'Mission Impossible? Addressing Non-Execution through Infringement Proceedings in the European Court of Human Rights', International and Comparative Law Quarterly 66 (2017), 467-490

Donald, Alice, 'Tackling Non-Implementation in the Strasbourg System: The Art of the Possible?', EJIL:Talk!, (28 April 2017), available at www.ejiltalk.org/tackling-non-implementation-in-thestrasbourg-system-the-art-of-the-possible/

Ferdinandusse, Ward, 'Out of the Black Box? The International Obligation of State Organs', Brooklyn Journal of International Law 29 (2003), 45-127

Gattini, Andrea, 'Domestic Judicial Compliance with International Judicial Decisions: Some Paradoxes', in Ulrich Fastenrath/Rudolf Geiger/Daniel-Erasmus Khan et al (eds), From Bilateralism to Community Interest: Essays in Honour of Bruno Simma (Oxford: OUP 2011), $1168-1188$

Hartwig, Matthias, 'Much Ado about Human Rights: The Federal Constitutional Court Confronts the European Court of Human Rights', German Law Journal 5 (2005), 869-894

Higgins, Rosalyn, 'Human Rights in the International Court of Justice', Leiden Journal of International Law 20 (2007), 745-751

Higgins, Rosalyn, 'National Courts and the International Court of Justice', in Mads Andenas/ Duncan Fairgrieve (eds), Tom Bingham and the Trasnsformation of the Law: A Liber Amicorum (Oxford: OUP 2009), 405-418

Higgins, Rosalyn, 'The Concept of "the State": Variable Geometry and Dualist Perceptions', in Laurence Boisson de Chazournes/Vera Gowlland-Debbas (eds), The International Legal System in Quest of Equity and Universality: Liber Amicorum Georges Abi-Saab (The Hague: Martinus Nijhoff 2001), 547-561

Huneeus, Alexandra, 'Compliance with Judgments and Decisions', in Cesare Romano/Karen J Alter/Yuval Shany (eds), The Oxford Handbook of International Adjudication (Oxford: OUP 2014), 437-463

Iwasawa, Yuvji, 'Domestic Application of International Law', Recueil des Cours 378 (2016), 9-261

Jenks, Wilfred C, The Prospects of International Adjudication (London/New York: Stevens\&Sons/ Oceana Publications 1964), 706-715

Jennings, Robert, 'The Judicial Enforcement of International Obligations', Heidelberg Journal of International Law 47 (1987), 3-16

Kanetake, Machiko/André Nollkaemper, 'The International Rule of Law in the Cycle of Contestations and Deference', in Machiko Kanetake/André Nollkaemper (eds), The Rule of Law at the National and International Levels: Contestation and Deference (Oxford: Hart 2016), 445-460

Klein, Eckart, 'Germany', in Janneke Gerards/Joseph Fleuren (eds), Implementation of the European Convention on Human Rights and of the Judgments of the ECtHR in National Case Law (Cambridge: Intersentia 2014), 185-216

Krisch, Nico, 'Pluralism in International Law and Beyond', (3 June 2015), available at https:// papers.ssrn.com/sol3/papers.cfm?abstract_id $=2613930,1-18$

Krisch, Nico, Beyond Constitutionalism: The Pluralist Structure of Postnational Law (Oxford: OUP 2010)

Kunz, Raffaela, 'The Italian Constitutional Court and "Constructive Contestation": A Miscarried Attempt?', Journal of International Criminal Justice 14 (2016), 621-627

Lambert-Abdelgawad, Elisabeth/Anne Weber, 'The Reception Process in France and Germany', in Helen Keller/Alec Stone Sweet (eds), A Europe of Rights: The Impact of the ECHR on National Legal Systems (Oxford: OUP 2008), 107-164

Lambrecht, Sarah, 'Assessing the Existence of Criticism of the European Court of Human Rights', in Patricia Popelier/Sarah Lambrecht/Koen Lemmens (eds), Criticism of the European Court of Human Rights. Shifting the Convention System: Counter-Dynamics and the National and EU Level (Cambridge: Intersentia 2016), 505-554

Llamazon, Aloysius P, 'Jurisdiction and Compliance in Recent Decisions of the International Court of Justice', European Journal of International Law 18 (2007), 815-852 
Madsen, Mikael Rask/Pola Cebulak/Micha Wiebusch, 'Backlash against International Courts: Explaining the Forms and Patterns of Resistance to International Courts', International Journal of Law in Context 14 (2018), 197-220

McCrudden, Christopher, 'A Common Law of Human Rights?: Transnational Judicial Conversations on Constitutional Rights', Oxford Journal of Legal Studies 20 (2000), 499-532

Nollkaemper, André, 'Rethinking the Supremacy of International Law', Zeitschrift für öffentliches Recht 65 (2010), 65-85

Nollkaemper, André, 'The Duality of Direct Effect of International Law', European Journal of International Law 25 (2014), 105-125

Nollkaemper, André, National Courts and the International Rule of Law (Oxford: OUP 2011)

Oellers-Frahm, Karin, 'Article 94 UN Charter', in Andreas Zimmermann/Karin Oellers-Frahm/ Christian Tomuschat et al (eds), The Statute of the International Court of Justice: A Commentary (Oxford: OUP $2^{\text {nd }}$ ed 2012)

Oellers-Frahm, Karin, 'Article 94', in Bruno Simma/Daniel-Erasmus Khan/Georg Note et al (eds), The Charter of the United Nations: A Commentary (Oxford: OUP 2012)

Oppong, Richard Frimpong/Angela M Barreto, 'Enforcement', in William A Schabas/ Shannonbrooke Murphy (eds), Research Handbook on International Courts and Tribunals (Cheltenham: Edward Elgar 2017), 273-298

Ordonez, Sarita/David Reilly, 'Effect of the Jurisprudence of the International Court of Justice on National Courts', in Thomas M Franck/Gregory H Fox (eds), International Law Decisions in National Courts (New York: Transnational Publishers 1996), 335-371

Palombino, Fulvio, 'Compliance with International Judgments: Between Supremacy of International Law and National Fundamental Principles', Heidelberg Journal of International Law 75 (2015), 503-529

Palombino, Fulvio, 'Les arrêts de la Cour internationale de Justice devant le juge interne', Annuaire français de droit international 51 (2005), 121-139

Peters, Anne, 'Rechtsordnungen und Konstitutionalisierung: Zur Neubestimmung der Verhältnisse', Zeitschrift für öffentliches Recht 65 (2010), 3-63

Peters, Anne, 'Supremacy Lost: International Law Meets Domestic Constitutional Law', Vienna Online Journal on International Constitutional Law 3 (2009), 170-198

Peters, Anne, 'The Globalization of State Constitutions', in Janne E Nijman/André Nollkaemper (eds), New Perspectives on the Divide Between National and International Law (Oxford: OUP 2007), 251-308

Peters, Anne, Beyond Human Rights: The Legal Status of the Individual in International Law (Cambridge: CUP 2016)

Pin, Andrea, 'A Jurisprudence to Handle with Care: The European Court of Human Rights' Unsettled Case Law, its Authority, and its Future, According to the Italian Constitutional Court', I-CONnect. Blog, (30 April 2015), available at www.iconnectblog.com/2015/04/minisymposium-on-cc-judgment-49-2015

Rugge, Giacomo, 'The Italian Constitutional Court on Taricco: Unleashing the normative potential of "national identity"?', QIL, Zoom-In 37 (2017), 21-29

Sarmiento, Daniel, 'To Bow at the Rhythm of an Italian Tune', Despite our Differences, (5 December 2017), available at https://despiteourdifferencesblog.wordpress.com/2017/12/05/ to-bow-at-the-rhythm-of-an-italian-tune/

Scelle, Georges, 'Le phénomène juridique du dédoublement fonctionnel', in Walter Schätzel/HansJürgen Schlochauer (eds), Rechtsfragen der Internationalen Organisation. Festschrift für Hans Wehberg (Frankfurt am Main: Verlag Klostermann 1956), 324-342

Schulte, Constanze, Compliance with Decisions of the International Court of Justice (Oxford: OUP 2004)

Shany, Yuval, 'Dédoublement Fonctionnel and the Mixed Loyalities of National and International Judges', in Filippo Fontanelli/Giuseppe Martinico/Paolo Carrozza (eds), Shaping Rule of Law Trough Dialogue: International and Supranational Experiences (Groningen: Europa Law Publishing 2010), 29-42 
Shany, Yuval, 'No Longer a Weak Department of Power? Reflections on the Emergence of a New International Judiciary', The European Journal of International Law 20 (2009), 73-91

Simma, Bruno, 'Mainstreaming Human Rights: The Contribution of the ICJ', Journal of International Dispute Settlement 3 (2012), 7-29

Slaughter, Anne-Marie, 'A Global Community of Courts', Harvard International Law Journal 44 (2003), 191-219

Tzanakopoulos, Antonios/Christian J Tams, 'Introduction: Domestic Courts as Agents of Development of International Law', Leiden Journal of International Law 26 (2013), 531-540

Vereshchetin, Vladen, 'On the Expanding Reach of the Rulings of the International Court of Justice', in Pierre-Marie Dupuy (ed), Völkerrecht als Wertordnung: Festschrift für Christian Tomuschat (Kehl: Engel Verlag 2006), 621-633

Ziegler, Katja S, 'Strengthening the Rule of Law, but Fragmenting International Law: The Kadi Decision of the ECJ from the Perspective of Human Rights', Human Rights Law Review 9 (2009), 288-305

Zyberi, Gentian, The Humanitarian Face of the International Court of Justice: Its Contribution to Interpreting and Developing International Human Rights and Humanitarian Law Rules and Principles (Antwerpen: Intersentia 2008)

Open Access This chapter is licensed under the terms of the Creative Commons Attribution 4.0 International License (http://creativecommons.org/licenses/by/4.0/), which permits use, sharing, adaptation, distribution and reproduction in any medium or format, as long as you give appropriate credit to the original author(s) and the source, provide a link to the Creative Commons license and indicate if changes were made.

The images or other third party material in this chapter are included in the chapter's Creative Commons license, unless indicated otherwise in a credit line to the material. If material is not included in the chapter's Creative Commons license and your intended use is not permitted by statutory regulation or exceeds the permitted use, you will need to obtain permission directly from the copyright holder. 


\title{
Between Cynicism and Idealism: Is the Italian Constitutional Court Passing the Buck to the Italian Judiciary?
}

\author{
Giovanni Boggero and Karin Oellers-Frahm
}

\begin{abstract}
In this chapter we focus on the consequences of Sentenza 238/2014 for the Italian judiciary. The judgment of the Corte Costituzionale obliges the Italian tribunals to admit claims for the reparation of victims or the heirs of victims and to decide on the merits. In this context, a series of difficult legal questions arise that require consistent answers. The practice shows, however, that consistent answers cannot be taken for granted as long as the decision is in the hands of lower-level tribunals. The questions to be solved concern, firstly, who can bring a claim: the victims only or-in cases where they are no longer alive-also their spouses, children, or even grandchildren and other family members? This raises a second question namely whether there is any time limit for bringing claims, which of course touches upon more general concerns, such as intertemporal law, statutory limitations, prescriptions, forfeiture and inadmissibility due to reparation agreements. Thirdly, there is the question as to the specific nature of the reparations: for example, financial reparations and their calculation standards, or satisfaction only? A further question arising from all decisions granting reparation relates to the execution of the judgments, as it seems rather illusory that Germany will comply voluntarily with such judgments. An additional aspect the chapter addresses is the broader impact of the decisions of the Italian judiciary: the non-recognition of state immunity before Italian tribunals will make Italy an attractive forum for similar claims, evidence of which has already emerged. Furthermore, the decisions of the tribunals will servealthough certainly involuntarily_as precedents in similar cases not only in Italy.
\end{abstract}

\footnotetext{
The chapter is the result of a common reflection; nevertheless, sections II and III are attributable to Karin Oellers-Frahm, while sections IV and V to Giovanni Boggero. The introduction (I) and the concluding remarks (VI) were written four hands.
}

G. Boggero $(\square)$

University of Turin, Department of Law, Turin, Italy

e-mail: giovanni.boggero@unito.it

K. Oellers-Frahm

Max Planck Institute for Comparative Public Law and International Law, Heidelberg, Germany

e-mail: oellers.affiliate@mpil.de 
Such effects will concern issues such as (a) the reparation of war-related claims on an individual basis and (b) their consequences for the readiness of states to terminate armed activities by concluding peace treaties and reparation agreements on a lump sum basis. With a view to actual armed conflicts that are mostly not international armed conflicts the question has then to be asked (c) whether individual reparation claims will lead to discriminatory consequences as reparation will probably only be realizable for victims of war crimes committed by state organs and not those committed by non-state actors. The chapter will then conclude by trying to assess more in general the task of constitutional and/or supreme courts to balance the consequences flowing from their decisions against their power or intent to enhance the development of (international) law.

\section{Introduction}

Sentenza $238 / 2014^{1}$ resulted in a grave dilemma for the Italian judiciary, which is expected to comply with the judgment. In particular, cases already pending-or cases that will be brought in the future before a court concerning reparation for war crimes committed by Germany during World War II (WWII) against Italian citizens-will no longer be dismissed on the basis of jurisdictional immunity of Germany. As a matter of principle, ${ }^{2}$ they have to be decided on the merits.

This implies that courts have to decide on a series of complicated issues that have hitherto remained unanswered, such as who may bring a claim, whether there is a time limit for bringing claims and what the specific reparation scheme might look like. A further and highly delicate question relates to the execution of those judgments awarding compensation or reparation. Under general international law states do not only enjoy immunity from adjudication but also immunity from execution ${ }^{3}$ and Sentenza 238/2014 only explicitly denies in the Italian legal order the existence

\footnotetext{
${ }^{1} \mathrm{Cf}$ Karin Oellers-Frahm, 'Das italienische Verfassungsgericht und das Völkerrecht-eine unerfreuliche Beziehung, Anmerkung zur Entscheidung des italienischen Verfassungsgerichts vom 22. Oktober 2014', Europäische Grundrechte-Zeitschrift 42 (2015), 8-16; Stefan Raffeiner, 'Jenseits der Staatenimmunität im deutsch-italienischen Staatenimmunitäten-Fall: Wege und Hürden nach dem Urteil der Corte Costituzionale', Heidelberg Journal of International Law 76 (2016), 451-473; Marco Longobardo, 'The Italian Constitutional Court's Ruling Against State Immunity When International Crimes Occur: Thoughts on Decision No. 238 of 2014', Melbourne Journal of International Law 16 (2015), 255-269; Giuseppe Cataldi, 'La Corte costituzionale e il ricorso ai "contro-limiti" nel rapporto tra consuetudini internazionali e diritti fondamentali', Diritti umani e diritto internazionale 9 (2015), 41-50.

${ }^{2}$ Giovanni Boggero, 'The Legal Implications of Sentenza No. 238/2014 by Italy's Constitutional Court for Italian Municipal Judges: Is Overcoming the 'Triepelian Approach' Possible?', Heidelberg Journal of International Law 76 (2016), 203-224, at 215 et seq, where the author refers to the means available for Italian judges to decide not in conformity with the Constitutional Court's judgment.

${ }^{3}$ Xiaodang Yang, 'Immunity from Execution', in Alexander Orakhelashvili (ed), Research Handbook on Jurisdiction and Immunities in International Law (Cheltenham: Edward Elgar 2016), $372-422$.
} 
of the customary rule of state immunity from adjudication for acta iure imperii involving serious violations of human rights or humanitarian law. At the same time, the 2012 International Court of Justice (ICJ) Judgment remains binding upon Italy under international law, with the consequence that Italian tribunals disregarding that judgment commit a violation of international law that is attributable to the Italian state because the judiciary is an organ acting on behalf of the state (Article 4 of the Draft Articles on State Responsibility); ${ }^{4}$ such violations would occur, in particular, when acts of execution concerning the relevant adjudicatory judgments were adopted.

The following considerations will firstly concentrate on questions to be answered by Italian courts and tribunals and the effect that such decisions may have more generally under international law and, secondly, address the (problems related to) execution. This will lead to a number of reflections concerning potential political solutions, such as reparation agreements between Italy and Germany, and the question of the constitutionality of such solutions.

\section{Attempts by Italian Courts to Cope with the Contrasting Obligations Stemming from International and Domestic Law}

After the delivery of Sentenza 238/2014, the Italian tribunals had to decide on the cases suspended during the proceedings before the ICJ. It was the Tribunal of Florence ${ }^{5}$ - though not the same judge that had referred the question of constitutionality to the Italian Constitutional Court (ItCC) leading to Judgment 238/2014 ${ }^{6}$ that took the first decision following Sentenza. ${ }^{7}$ That decision is clearly characterized by the Tribunal's attempt to find a way between Scylla and Charybdis, namely to comply at the same time with the ICJ Judgment and the Judgment of the ItCC. In its Order of 23 March $2015,{ }^{8}$ the Tribunal explicitly mentioned the risk that the Italian

\footnotetext{
${ }^{4}$ ILC, Draft Articles on Responsibility of States for Internationally Wrongful Acts, adopted by the Commission at its fifty-third session in 2001 (Final Outcome), UN Doc A/56/10, 43, UN Doc A/RES/56/83, Annex, UN Doc A/CN.4/L.602/Rev.1, GAOR 56 ${ }^{\text {th }}$ Session Supp 10, 43.

5'Tribunal' is used as translation for 'Tribunale', which generally is a court of first instance in the Italian civil judiciary system. A 'Corte d'Appello' generally reviews the judgment made by the courts of first instance.

${ }^{6}$ It was the Tribunal of Florence that in 2014 referred three questions to the Constitutional Court, leading to Sentenza 238/2014: (1) whether the rule of jurisdictional state immunity applies also in cases of grave human rights violations; (2) whether the law ratifying the UN Charter is constitutional with regard to Art 94 of the Charter concerning the obligation to comply with decisions of the ICJ; and (3) whether the Italian Law No 5 of 14 January 2013 concerning the implementation of the 2012 ICJ Judgment was constitutional.

${ }^{7}$ Corte Costituzionale, Judgment of 22 October 2014, No 238/2014.

${ }^{8}$ Tribunale di Firenze, Order of 23 March 2015, No 2012/1300, where not the victim himself but family members of the victim had brought the claim. Cf Karin Oellers-Frahm, 'A Never-Ending Story: The International Court of Justice-The Italian Constitutional Court-Italian Tribunals and
} 
state would violate international law if it were to disregard the customary rule on state immunity, and the Tribunal thus attempted to find a subtler solution. This solution was linked to paragraph 104 of the ICJ Judgment in which the Court mentioned the advantage, or rather desirability, of renegotiations between Italy and Germany. ${ }^{9}$ On the basis of this approach the Tribunal found that in the case at stake it should proceed by seeking a conciliatory solution. However, as paragraph 104 of the ICJ Judgment could not serve as a legal basis for imposing conciliation, the Tribunal found that "considering that the dispute at hand implies the risk for Italy of committing an international wrongful act (...), an attempt of conciliation between the applicants and the Federal Republic of Germany but also between Italy and Germany (...) should be made in accordance with Article 185 of the Code of Civil Procedure'. ${ }^{10}$ At the same time, the Tribunal itself presented a concrete proposal of conciliation. This proposal provided that Germany grants financial support amounting to $€ 15,000$ to the family members of the victims to enable them to temporarily live in Germany for educational or other cultural purposes and that the plaintiffs in return withdraw their claim. Failing the adoption of this conciliation proposal, formal mediation before a special body would occur. ${ }^{11}$ This approach was followed by the Tribunal of Piacenza in its sentenza non definitiva ("non-final judgment') of 25 September $2015,{ }^{12}$ which was somewhat more cautious as it did not itself present a proposal for conciliation but only 'invited' Italy and Germany to consider the opportunity of depositing a note containing a proposal for an amicable solution. The Tribunal mentioned, however, that the attitude of the parties would be a decisive factor in the regulation of the costs of the procedure-thus trying to put some pressure on the parties to follow the 'invitation' for conciliation. The conciliation solution would in fact have presented an elegant way out of the dilemma with

the Question of Immunity', Heidelberg Journal of International Law 76 (2016), 193-202; Boggero, 'Legal Implications of Sentenza No. 238' 2016 (n 2).

${ }^{9} \mathrm{ICJ}$, Jurisdictional Immunities of the State (Germany v Italy: Greece Intervening), Judgment of 3 February 2012, ICJ Reports 2012, 99, para 104, where the ICJ stated 'the claims arising from the treatment of the Italian military internees (...) together with other claims of Italian nationals which have allegedly not been settled - and which formed the basis for the Italian proceedings—could be the subject of further negotiations involving the two States concerned, with a view to resolving this issue.'

${ }^{10}$ Tribunale di Firenze, Order No 2012/1300 (n 8), 2-3, (translated by the authors).

${ }^{11}$ Ibid, 3.

${ }^{12}$ Tribunale di Piacenza, Decision of 28 September 2015, No 1462/2015. See also, however, Tribunale di Sulmona, Order of 2 November 2017, No 20/2015, 8. Here judge Giovanna Bilò states that 'five years after the judgment of the Court of The Hague the existence of such a far reaching customary law (eg immunity from jurisdiction without any exception) in the international legal order may be doubted' (translated by the authors). Cf in this context, Giovanni Boggero, 'Ancora sul seguito della sentenza n. 238/2014: una recente pronuncia del Tribunale di Sulmona', (20 November 2017), available at www.diritticomparati.it/ancora-sul-seguito-della-sentenza-n2382014-una-recente-pronuncia-del-tribunale-di-sulmona/ and also: Maria Irene Papa/Alessandra Zanobetti, 'Eccidio di Roccaraso: giurisdizione italiana e immunità degli Stati dalla giurisdizione civile', in Il Corriere giuridico 6 (2018), 788-798. 
which the Italian tribunals were confronted, namely that of disregarding neither the decision of the ItCC nor international law as stated by the ICJ. But this attempt failed for two reasons: first, Article 185 of the Italian Code of Civil Procedure was not the proper legal basis, as it provides for negotiations between the plaintiff and the defendant - that is, the individual claimant and Germany - and not between the defendant and a third party - that is, Germany and Italy. ${ }^{13}$ Secondly, Germany unsurprisingly did not react to the decision.

\section{Issues to Be Decided by the Italian Courts}

\section{Who Can Bring a Claim and Who Is a Victim?}

The first question that had to be answered following the failure to find a conciliatory solution concerned the issue of who can bring a claim. The war crimes committed against Italian nationals that represent the origin of the claims were committed by Germany between 1943 and 1945, a time frame that already indicated that a large number of the directly affected persons would not be in a situation to bring their claims personally. Thus, the question arose as to who could bring a claim besides the victims themselves: whether family members, spouses, children, grandchildren or even nieces, nephews and cousins were entitled to claim compensation for the suffering inflicted upon them due to the loss of the family member. As already mentioned, the Italian tribunals did not address this topic at all in a first approach following Sentenza 238/2014, but admitted without further discussion claims brought by any family member and tried to circumvent a decision on the merits by referring the parties to conciliation. ${ }^{14}$ When this attempt failed, the Italian tribunals were bound to decide on the merits, namely to award or decline compensation, and in this context they had to define in more detail who is entitled to bring a claim and receive compensation.

Today there is no question that direct victims are entitled to bring a claim. However, most of the cases were brought by family members as the victims themselves were no longer alive. And as the practice of the Italian courts was unanimous in finding that claims cannot lead to reparation of material damages but only to compensation of immaterial (moral) damages, even where victims themselves brought a case ${ }^{15}$ the way was open to admitting claims from secondary or indirect victims. Such damage resulting from family links/family solidarity was

\footnotetext{
${ }^{13}$ Oellers-Frahm, ‘A Never-Ending Story’ 2016 (n 8), 198.

${ }^{14}$ See section II.

${ }^{15}$ Corte di Cassazione, Judgment of 9 May 2011, No 10107/2011.
} 
defined as danno parentale, and could in principle be claimed whenever a family link existed with regard to the victim. ${ }^{16}$ This very general definition of the danno parentale seemed to give leeway for claims brought by any family member without any further requirement. In 2017, however, it was again the Tribunal of Ascoli Piceno, although in a different but similar case decided on by a different judge than the one that delivered the Order of 8 March 2016, ${ }^{17}$ examining in more detail the issue of who is entitled to compensation for danno parentale. Following the Order of 8 March 2016 it was confirmed in general terms that the danno parentale is, in principle, not submitted to prefixed limits, but that having a family link in itself is an insufficient justification for a claim to compensation. Rather, it is incumbent on the claimants to prove that the loss of the family member had a relevant impact on them personally. In the case before it, the Tribunal of Ascoli Piceno found that neither the brothers nor a nephew of the victim could prove any personal damage and thus dismissed their compensation claim. As other aspects had been dismissed as inadmissible by the Italian tribunals (such as a statutory limitation, forfeiture or limiting claims for compensation), ${ }^{18}$ the requirement of proving substantive personal damage constitutes a necessary and welcome limitation for future claims. This also means, however, that the tribunals will have to investigate the claimants family life and personal relationships dating back, potentially, more than 70 years, which is not only a difficult task but leaves much room for discretion and-as the Tribunal of Ascoli Piceno explicitly stated-for the 'skill of the advocates'. ${ }^{19}$ Nevertheless, this caselaw is promising in the sense that there will be some personal limits for bringing claims whereof the Court of Cassation will have to ensure a uniform interpretation.

In this context it is worth mentioning that the Tribunal of Ascoli Piceno in the same Order of 24 February 2017 awarded a financial reparation of $€ 30,000$ to the Comune di Castignano - the municipality where the crimes were committed-for the moral damage produced and inflicted on the public life of the Comune, and this claim was not subjected to any limiting considerations. In particular, this final section of the decision raises the fundamental question of the kind of reparation which comprises restitution, compensation and satisfaction, ${ }^{20}$ what seems especially significant with regard to the reparation accorded to a collective entity, in this case a municipality, rather than individual family members.

\footnotetext{
${ }^{16} \mathrm{Cf}$ Tribunale di Ascoli Piceno, Order of 8 March 2016, No 112/2015 (partial admittance), 22, Judge Foti relying on Corte di Cassazione, Judgment of 12 July 2006, No 15760/2006; Corte Costituzionale, Judgment of 6 May 1985, No 132/1985; Corte Costituzionale, Judgment of 14 July 1984, No 184/1984.

${ }^{17}$ Tribunale di Ascoli Piceno, Order of 24 February 2017, No 523/2015 (final admittance).

${ }^{18}$ See section III.2.

${ }^{19}$ Tribunale di Ascoli Piceno, Order No 523/2015 (n 17), 51, referring to Corte di Cassazione, Judgment of 8 October 2007, No 20987/2007. The original terms used by the Tribunal read: '[S]petta alle vittime ed alla intelligenza dei loro difensori, apprestare una difesa adeguata'. ('[I]t lies with the victims and the skill of their advocates to present an adequate defence' (translated by the authors)).

${ }^{20}$ See sections III.3. and V; Cf ILC, Draft Articles on State Responsibility, 2001 (n 4), Art 34.
} 


\section{Time Frame for Reparation Obligations}

The question of who can bring a claim involves the more general issue of the time frame for compensation claims. There are rules in national and international law reflecting the idea that legal peace can only be assured if after a certain lapse of time claims can no longer be raised. ${ }^{21}$ Such rules concern intertemporal law, statutory limitation, and forfeiture; each one was tackled by the Italian tribunals, but they were all dismissed as not applicable.

According to the principle of intertemporal law, ${ }^{22}$ only the law in force at the time when the controversial action occurred is applicable. This principle guarantees the certainty and stability of law, which is of utmost importance in both national and international law. It finds reflection in the idiom nullum crimen, nulla poena sine praevia lege poenali, which prohibits the retrospective application of criminal sanctions. In this context, the Italian tribunals rightly referred furthermore to the fact that 'since ever' international actors had tried to put limits to war crimes. ${ }^{23}$ They mention the International Geneva Conventions of 1864, 1906, 1929, and reaffirmed by those of 1949, which all substantially sanctioned crimes of war or what is now classified as crimes against humanity. While these arguments are plausible, the question remains whether criminal responsibility also implies civil responsibility: an obligation of individual reparation. In this context the Italian judges were categorical in stating that at the time the crimes were committed the "possibility of criminal-and even civil—sanctions was generally accepted'. ${ }^{24}$ This statement seems rather controversial as individual redress for war-related crimes was certainly

\footnotetext{
${ }^{21}$ Karin Oellers-Frahm, 'Judicial Redress of War-Related Claims by Individuals: The Example of the Italian Courts', in Ulrich Fastenrath et al (eds), From Bilateralism to Community Interest: Essays in Honour of Judge Bruno Simma (Oxford: OUP 2011), 1055-1078, at 1070; Carlo Focarelli, 'Diniego dell'immunità giurisdizionale degli Stati stranieri per crimini, jus cogens e dinamica del diritto internazionale', Rivista di diritto internazionale 91 (2008), 738-757; Alexander Orakhelashvili, 'State Immunity and International Public Order Revisited', German Yearbook of International Law 49 (2006), 327-365.

${ }^{22} \mathrm{Cf}$ Rosalyn Higgins, 'Some Observations on the Inter-Temporal Rule in International Law', in Jerzy Makarczyk (ed), Theory of International Law at the Threshold of the 21st Century (The Hague: Kluwer 1996), 173-181; Mieke van der Linden, 'The Inextricable Connection between Historical Consciousness and International Law', Select Proceedings of the ESIL 5 (2014), 447-460.

${ }^{23} \mathrm{Cf}$ Tribunale di Ascoli Piceno, Order No 523/2015 (n 17), 19 et seq; Tribunale di Ascoli Piceno, Order No 112/2015 (n 16); Tribunale di Piacenza, Judgment of 25 September 2015, No 723/2015.

${ }^{24}$ Tribunale di Ascoli Piceno, Order No 523/2015, (n 17), 25 stating that: ' $[L] a$ possibilità di sanzionare penalmente - e, ancor più, civilmente - fatti che (. . .) erano considerati criminosi (...) deve reputarsi norma internazionale comunemente accettata e riconosciuta' (translated by the authors).
} 
not an issue at the time at stake, namely before the adoption of the 1949 Geneva Conventions, and is under discussion, and thus not generally accepted, still today. ${ }^{25}$

With regard to prescription, the Italian judges are unanimous and refer, without further explanations, only to the Ferrini judgment of the Court of Cassation stating that there is no prescription for the 'credito risarcitorio da crimine di guerra', meaning that claims for reparation and compensation in such cases are, in principle, not submitted to time limitations. ${ }^{26}$ This follows from the fact that such claims 'reside in a principle of constitutional value, namely the right of the victims to complete compensation of damages, material or immaterial, resulting from the violation of fundamental human rights'. ${ }^{27}$ Although this statement seems to imply that there is no time limit for bringing reparation claims, it nevertheless refers to the right of 'victims', and this reference in combination with the more detailed interpretation of the 'danno parentale' given by the Tribunal of Ascoli Piceno sets a (biological) time limit, although not in the form of a prescription.

Furthermore, the objection concerning forfeiture of the claims ${ }^{28}$ was dismissed by the Italian judges. Forfeiture or 'implied waiver' of rights can be seen in the attitude of the Italian state after WWII, in particular in its renunciation to claim further reparation in the Peace Treaty of 1947 and later once more in the Bonn Agreements of 1961. This argument is, however, constantly dismissed by the Italian tribunals, arguing instead that the actual claims for reparation only concern immaterial damage and that such damage was not the subject matter of the Peace Treaty or the reparation agreements. $^{29}$

In sum it may be stated that 'legal peace', requiring, inter alia, respectively a definition of those who constitute the secondary victims of the crimes committed by Germany during WWII, will depend on the jurisdictional practice of the ordinary tribunals (in the last instance, the Court of Cassation) in interpreting what exactly amounts to 'danno parentale'. In this context the Tribunal of Ascoli Piceno's Order of 24 February 2017 sets a positive signal in the sense of requiring not only a mere

\footnotetext{
${ }^{25}$ Cf section III.1. See Christian Marxsen, 'What do Different Theories of Customary International Law Have to Say about the Individual Right to Reparation under International Humanitarian Law', Heidelberg Journal of International Law 78 (2018), 581-586, giving an introduction to the following 19 reports on that subject matter.

${ }^{26} \mathrm{Cf}$ Tribunale di Piacenza, Judgment No 723/2015 (n 23), para 4; Tribunale di Firenze, Judgment of 6 July 2015, No 2469/2015 (Furio Simoncioni) referring to Corte di Cassazione, Judgment of 11 March 2004, No 5044/04 (Ferrini); Cf for further decisions, Raffeiner, 'Jenseits der Staatenimmunität' (2016) (n 1), 468.

${ }^{27}$ Tribunale di Ascoli Piceno, Order No 523/2015 (n 17), 48, referring to Corte di Cassazione, Judgment No 15760/2006 (n 16); ItCC, Judgment No 132/1985 (n 16); ItCC, Judgment No 184/1984 (n 16).

${ }^{28} \mathrm{Cf}$ Burkhard Hess, 'Kriegsentschädigungen aus kollisionsrechtlicher und rechtsvergleichender Sicht', in Wolff Heintschel von Heinegg (ed), Entschädigung nach bewaffneten Konflikten: die Konstitutionalisierung der Welthandelsordnung (Heidelberg: Müller 2003), 107-205, at 146 et seq; Andrea Gattini, Le riparazioni di guerra nel diritto internazionale (Padua: CEDAM 2003), 247.

${ }^{29}$ Tribunale di Piacenza, Judgment No 723/2015 (n 23).
} 
family link, but also the proof of a concrete damage in order to have a claim admitted.

\section{Type of Reparation}

Finally, as a consequence of Sentenza 238/2014, the tribunals had to decide on the kind of reparation: either financial reparation or compensation-and the parameters of calculation - or mere satisfaction and/or a lump sum compensation to primary victims still alive or also to victims' family members. With a view to the first decisions of the Italian tribunals it has to be stated that no uniform scheme has been developed and that the decisions awarding monetary compensation raise serious concerns.

The cases where the victims themselves bring a claim may seem uncontroversial in justifying financial compensation. The few cases decided thus far demonstrate, however, that the amount of compensation awarded varies significantly. This raises questions not only with regard to the 'justice to be done' in the assessment of the suffering of the victim but also with regard to the lack of transparency concerning the calculation of the compensation amount. For example, two cases may be mentioned where the victims themselves brought a claim and where a compensation was awarded. ${ }^{30}$ In one of the cases an amount of $€ 50,000$ was awarded, in the other an amount of-only- $€ 30,000$ (plus interests of 4\% since 1945) was accorded without any explanation on how the amount was calculated. With a view to this opaque practice it might be preferable to award a prefixed amount of money as satisfaction or symbolic compensation because compensation is not only difficult to calculate but, as stated by the Italian tribunals, making good the suffering of the victims is impossible. Significant differences between the amounts of compensation awarded may raise further problems instead of leading to appeasement.

A second and rather more severe concern resulting from the first set of decisions following Sentenza 238/2014 relates to the proportionality of compensation awarded to the victims and the amount of compensation awarded to 'secondary victims', namely the heirs of victims. In this context a decision of the Tribunal of Florence is worth mentioning, which was delivered after the attempted conciliation solution under Article 185 of the Italian Code of Civil Procedure failed. ${ }^{31}$ In this case, the Tribunal of Florence fixed an amount of $€ 325,000$ (plus interests of $4 \%$ running from 1945 ) as compensation for each of the daughters of the victim. ${ }^{32}$ In another case,

\footnotetext{
${ }^{30}$ Tribunale di Firenze, Judgment of 6 July 2015, No 2468/2015 (Duilio Bergamini) and Judgment No 2469/2015 (Furio Simoncini) (n 26). Cf Oellers-Frahm, 'A Never-Ending Story' 2016 (n 8), 199. In the same vein, Corte di Cassazione, Judgment of 13 January 2017, No 762/2017 and Judgment of 29 July 2016, No 15812/2016.

${ }^{31}$ See section II.

${ }^{32}$ Tribunale di Firenze, Judgment of 22 February 2016, No 144740/2009 (Donati).
} 
decided by the Tribunal of Ascoli Piceno, the spouses and children of a victim were each awarded compensation of between $€ 130,000$ and $€ 150,000 .{ }^{33}$ Already these two examples raise the question of 'doing justice', in that it is extremely problematic and hardly tolerable that family members of a victim, more than 70 years after the underlying crime, were awarded a compensation amount significantly higher than that awarded to the victims themselves. It demonstrates that justice requires a fair balance between the compensation awarded to the primary and the secondary victims and that those who directly suffered the crime, and the compensation awarded to them, should set the standard for compensation awarded to family members.

These considerations support the proposals concerning a general limitation of financial compensation in two directions, first to award financial compensation to primary victims only, and second to provide for a prefixed amount, as has been done with regard to Russian prisoners of war. ${ }^{34}$ If, however, the next of kin should be accorded a right to compensation, the amount should in any case not exceed the sum fixed for a primary victim. As 'reparation', in the original sense of the term, cannot be made, satisfaction and a symbolic amount of financial compensation seems more adequate, not least when considering the length of time that has elapsed. From this perspective, the idea of a fund established by both Germany and Italy ${ }^{35}$ would probably best serve the aim of giving voice to the victims and their heirs without raising new problems by awarding financial compensation on grounds that lack sufficient transparency, ${ }^{36}$ as well as striking a fair balance between the compensation awarded to primary and secondary victims. The creation of a fund would, however, require the consent of Germany, which as things stand seems rather unlikely.

\section{Implications of the Italian Decisions}

\section{a) Precedential Effects}

The denial of immunity from jurisdiction resulting from Sentenza 238/2014 will have implications also beyond the Italian context since questions of reparation for war-related claims remain unsettled also with regard to other armed conflicts. ${ }^{37}$ Such cases are not only on the docket of national courts but of international courts as well,

\footnotetext{
${ }^{33}$ Tribunale di Ascoli Piceno, Order No 523/2015 (n 17).

${ }^{34}$ On 20 May 2015 the German government decided to pay a financial compensation of $€ 2,500$ to each of the approximately 4,000 Russian prisoners of war still alive, which is explicitly characterized as symbolic compensation. Cf section VI.

${ }^{35}$ See Stefan Kadelbach, chapter 'State Immunity, Individual Compensation for Victims of Human Rights Crimes, and Future Prospects', and Francesco Francioni, chapter 'Overcoming the Judicial Conundrum', in this volume.

${ }^{36}$ See section V.

${ }^{37}$ Cf Christian Tams, chapter 'A Dangerous Last Line of Defence', in this volume.
} 
in particular the European Court of Human Rights (ECtHR) and the Inter-American Court of Human Rights (IACrtHR). These issues can only summarily be addressed in the present context, but they are of high relevance not only on the national, but also on the international level because they gain significance as precedents particularly regarding the following issues. ${ }^{38}$

In the first place there is the fundamental question of whether individuals have at all a right to claim compensation or reparation for war-related crimes, a question that is not explicitly settled in international law. ${ }^{39}$ State practice resulting from the history of ending wars shows that peace treaties (usually) provided for reparation schemes covering all claims of any kind in order to foster peaceful future relations. There are only a few precedents where victims of war crimes were seeking or even accorded reparation for their personal suffering during war. ${ }^{40}$

Only recently can a development be observed concerning individual claims requiring reparation or compensation for war-related crimes brought before national courts, but also before international human rights courts, as there is no clearly defined demarcation between human rights and humanitarian law. ${ }^{41}$ Although these developments have some merit, because war-related crimes should not go unpunished, the fundamental question remains: whether this is an acceptable way to cope with war-related claims as thousands of claims originating from all sides of the

\footnotetext{
${ }^{38}$ Giuseppe Cataldi, 'Immunités juridictionnelles des Etats étrangers et droit de l'homme: quel équilibre entre les valeurs fondamentales de l'ordre national et le droit international coutumier?', in James Crawford et al (eds), The International Legal Order: Current Needs and Possible Responses (Leiden: Brill Nijhoff 2017), 571-590.

${ }^{39}$ Christian Tomuschat, 'Individual Reparation Claims in Instances of Grave Human Rights Violations: The Position under General International Law', in Albrecht Randelzhofer/Christian Tomuschat (eds), State Responsibility and the Individuals (The Hague: Martinus Nijhoff 1999), 1-25; Alessandro Bufalini, 'La riparazione per gravi violazioni dei diritti umani e del diritto umanitario tra rinuncia dello stato e diritto individuale', in Andrea Spagnolo/Stefano Saluzzo (eds), La responsabilità degli stati e delle organizzazioni internazionali (Milan: Ledizioni 2017), 375-391; Enzo Cannizzaro, 'Is There an Individual Right to Compensation?', in Denis Alland et al (eds), Unité et diversité du droit international (Leiden: Brill Nijhoff 2014), 495-502. See also Christian Tomuschat, chapter 'The Illusion of Perfect Justice', in this volume; Marxsen, 'Different Theories of Customary International Law' 2018 (n 25) and the other reports referred to in n 25.

${ }^{40}$ See Roland Bank/Elke Schwager, 'Is There a Substantive Right to Compensation for Individual Victims of Armed Conflict against a State under International Law' German Yearbook of International Law 49 (2006), 367-411, who propose to combine the conclusion of reparation agreements between the states concerned with a waiver of individual claims what seems to indicate a feasible solution; the individual claims were thus merged with the reparation provisions in the peace treaties and the individuals were then compensated by the state which received the reparation payments.

${ }^{41}$ In its Advisory Opinion concerning Legal Consequences of the Construction of Wall in the Occupied Palestinian Territory, the ICJ had stated in this context: 'As regards the relationship between international humanitarian law und human rights law, there are thus three possible situations: some rights may be exclusively matters of international humanitarian law; others may be exclusively matters of human rights law; yet others may be matters of both these branches of international law', (ICJ, Legal Consequences of the Construction of Wall in the Occupied Palestinian Territory, Advisory Opinion of 9 July 2004, ICJ Reports 2004, 13, para 106).
} 
involved actors may put at risk peaceful relations between former enemies. ${ }^{42}$ This question, which is still pending before the ECtHR, ${ }^{43}$ was met with silence by the Italian tribunals as they merely referred to the Ferrini Judgment of the Court of Cassation, which did however, not concern this issue as such but only the question of statutory limitation. ${ }^{44}$ A further consequence of admitting individual redress of war-related violations of human rights may be that states involved in a war or armed conflict would abstain from accepting lump sum agreements when facing additional individual claims.

The fact that the Italian tribunals did not address the issue of admissibility of individual claims at all may be understood in the sense that this question is not controversial and will not play a role in Italian courts and tribunals inviting thus victims of war crimes to claim reparation, particularly because Italy admits such claims as it does not feel bound by the rule of state immunity or other relevant issues, such as intertemporal law, statutory limitation, forfeiture or waiver. These principles have not been admitted as limiting factors to individual claims, so that Italy may appear as an El Dorado for individuals seeking redress for war-related reparation claims and will not only serve as a precedent setter but also as the preferred forum for cases concerning reparations and compensation for war crimes that are allegedly unsettled and neither concern Italian nationals nor acts committed on Italian territory. ${ }^{45}$

\section{b) Forum Shopping (Universal Jurisdiction)}

The concern of forum shopping is in fact not only a theoretical one; there are cases in which Italian courts and tribunals were seized with cases lacking any relation to Italy. One of the most prominent and to a degree 'leading' cases in this context is the Distomo case, ${ }^{46}$ which concerned a claim for execution of a decision delivered by

\footnotetext{
${ }^{42} \mathrm{Cf}$ in this context, Karin Oellers-Frahm, 'A Regional Perspective on the Convergence and Conflicts of Human Rights and International Humanitarian Law in Military Operations: The European Court of Human Rights', in Erika de Wet/Jann Kleffner (eds), Convergence and Conflicts of Human Rights and International Humanitarian Law in Military Operations (Pretoria: Pretoria University Law Press 2014), 333-363; and Dinah Shelton, 'Humanitarian Law in the InterAmerican Human Rights System', ibid, 365-393.

${ }^{43}$ Cf ECtHR, Georgia v Russia II, Application No 38263/08 of 11 August 2008, where the ECtHR will have to decide whether international humanitarian law is exclusively applicable so that the case cannot be decided by the ECtHR in the context of an individual complaint.

${ }^{44}$ See section III.2.

${ }^{45}$ See also Bernardo Giorgio Mattarella, chapter 'Sentenza 238/2014', in this volume.

${ }^{46}$ Corte di Cassazione, Judgments of 29 May 2008, No 14199/2008 and of 20 May 2011, No 11163/2011, on which see: Micaela Frulli, “"The Times they are A-Changing”- - the Italian Court of Cassation Denies Germany Immunity from Execution to Allow Compensation to War Crimes' Victims', Journal of International Criminal Justice 9 (2011), 1129-1142. The execution proceedings concerned the implementation of the Tribunal of Livadia (Greece) of 30 October 1997 against Germany and Deutsche Bahn AG awarding reparation for war crimes committed by German
} 
Greek courts for German war-related crimes committed in Greece. Although this case concerned only the execution of the decision on the costs of the proceedings before Greek tribunals, the fact that the Italian Court of Cassation admitted execution on German property located in Italy set a new trend. The Court of Cassation did not at all tackle questions of state immunity or more generally questions of jurisdiction with regard to the execution of foreign judgments in Italy but merely referred to Article 64 of the Law No 218 of 31 May 1995 concerning the Italian international private law system, which inter alia requires that the foreign judgment does not run contrary to the national 'ordre public' for giving leeway for execution.

Italian tribunals were also confronted with individual reparation claims resulting from armed conflicts, such as the one that occurred between 1991 and 1995 in the former Yugoslavia. Thus, the criminal division of the Court of Cassation, for example, denied immunity to Serbia in relation to a request for compensation brought by the heirs of Italian victims of war crimes committed in the Yugoslav armed conflict. ${ }^{47}$ In two further decisions, the Court of Cassation recognized that Iran was not entitled to immunity for acts amounting to crimes against humanity, ${ }^{48}$ although in the cases before it the court denied exequatur to the judgments of US courts that had awarded damages against Iran for reasons concerning the requirements for exercising civil jurisdiction under the relevant Italian law. ${ }^{49}$

What is interesting in these cases is the fact that the Italian courts and tribunals do not refer to principles such as universal jurisdiction, which in particular in cases concerning war crimes is often referred to, but only rely on national law, namely Law No 218/1995, which regulates the Italian system of international private law. In the cases concerning civil claims, reference to the principle of universal jurisdiction would in fact not have been appropriate. Indeed, universal jurisdiction empowers states to exercise criminal jurisdiction regardless of where the alleged crime was

troops at Distomo which was the starting point of the controversy on the existence of state immunity in cases of serious violations of human rights. This decision was upheld by the Greek Supreme Court on 4 May 2000, but it was eventually not enforced because of the refusal by the Greek Ministry of Justice to authorize execution. For an overview over the controversy see Andrea Gattini, 'The Dispute on Jurisdictional Immunities of the State before the ICJ: Is the Time Ripe for a Change in the Law?', Leiden Journal of International Law 24 (2011), 173-200, with bibliographical references.

${ }^{47}$ Corte di Cassazione, Judgment of 29 October 2015, No 43696/2015 (Opačić); cf, in this context, Riccardo Pavoni, 'How Broad is the Principle Upheld by the Italian Constitutional Court in Judgment No. 238?', Journal of International Criminal Justice 14 (2016), 573-585, at 577. See also Paolo Palchetti, chapter 'Right of Access to (Italian) Courts über alles?', in this volume.

${ }^{48}$ Corte di Cassazione, Judgment of 28 October 2015, No 21946/2015 (Flatow); Corte di Cassazione, Judgment of 28 October 2015, No 21947/2015 (Eisenfeld). See also Riccardo Pavoni, chapter 'A Plea for Legal Peace', in this volume.

${ }^{49}$ Italian Law 31 May 1995, No 218. Art 64 and Art 3(1-2) require that (1) the foreign judge was competent according to the Italian legal order (which was not the case with regard to the US Foreign Immunities Act); (2) that the foreign state was represented in the forum state (which was not the case because the diplomatic relations between the US and Iran were interrupted since 1979); and finally that (3) the illegal act, which did not occur in the US but in Israel, had been the subject matter of criminal proceedings in the US (which was also not the case). 
committed and regardless of the accused's nationality, country of residence or any other relation with the prosecuting entity. ${ }^{50}$ Whether criminal jurisdiction would include civil jurisdiction, as was stated by the Tribunal of Ascoli Piceno, is not generally admitted ${ }^{51}$ and was explicitly contradicted by the Court of Cassation in the two aforementioned cases concerning the execution of US decisions against Iran. ${ }^{52}$ In these cases, the Court of Cassation stated that 'what follows from Sentenza $238 / 2014$ is not the recognition of a principle of universal civil jurisdiction in cases for compensation of delicta imperii, but only the inapplicability of the customary rule of immunity from civil jurisdiction in cases concerning compensation for damages deriving from the commission on the territory of the forum state of crimes against humanity' (paragraph 5, 'considerato in diritto' of both decisions (translated by the author)). Accordingly, universal jurisdiction would not constitute a legal basis for the competence of Italian courts and tribunals to admit compensation cases, as such competence derives only from Italian international private law rules. ${ }^{53}$ As, however, the primary hurdle for admitting civil cases against foreign states has been lifted by Sentenza 238/2014, namely immunity from jurisdiction, exequatur of foreign decisions is governed primarily by Articles 3 and 64 of Law No 218/1995 or, in cases involving EU member states, the Brussels Ia Regulation as amended in 2015. The application of this regulation would, however, require that the acts concerned do not constitute acts of state authority, namely acta iure imperii. ${ }^{54}$ Thus, the Italian courts and tribunals, by removing the hurdle of state immunity,

\footnotetext{
${ }^{50} \mathrm{Cf}$ Gerhard Werle/Florian Jeßberger, Principles of International Criminal Law (Oxford: OUP $3^{\text {rd }}$ ed 2014).

${ }^{51}$ In Tribunale di Ascoli Piceno, Order No 523/2015 (n 17), the Tribunal referred to Art 7 of the European Convention on Human Rights in the context of non-retroactivity of criminal law and the exception in para 2 of Art 7 concerning punishment for acts considered as criminal 'according to the general principles of law recognised by civilised nations'. The Tribunal of Ascoli Piceno stated in a categorical manner that this provision 'offered the possibility of criminal-and even civilsanctions of the war crimes' at stake (Judgment of 24 February 2017, at 25).

${ }^{52}$ Corte di Cassazione, Judgments Flatow and Eisenfeld (n 48).

${ }^{53}$ These rules are similar to the rules on recognition of foreign judgments in many states, eg section 238 of the German Code on Civil Procedure. The main prerequisites concern, on the one hand, some territorial link, namely that the defendant has at least a representation authorized to appear before Italian courts according to Art 77 of the Italian Code on Civil Procedure (Art 3 of Italian Law, 218/1995 (n 49)). On the other hand, the recognition of the foreign judgment depends on the following requirements: (1) that the judge delivering the judgment was competent to decide on the case according to the jurisdictional principles of the Italian legal order; (2) that the defendant was informed of the claim brought against him according to the forum law; (3) that the parties appeared before the court according to the forum law or non-appearance was officially stated; (4) that the decision has become binding under the forum law; (5) that the decision is not contrary to a binding decision of an Italian court; (6) that no proceedings are pending before an Italian judge concerning the same subject matter and the same parties and brought before the court prior to the foreign proceedings; and (7) that the decision does not produce effects contrary to the ordre public (Art 64 of Italian Law 218/1995 (n 49)).

${ }^{54}$ See Andreas Zimmermann, chapter 'Would the World Be a Better Place If One Were to Adopt a European Approach to State Immunity?', in this volume.
} 
offer an attractive forum for cases claiming compensation from foreign states or recognition of foreign judgments against states.

Although Italian courts and tribunals are thus a promising forum for cases concerning claims against states, the fact remains that plaintiffs before Italian courts have only succeeded in achieving a partial, or maybe even only a symbolic, victory. This is due to the fact that the question of execution of a judgment after a decision awarding compensation or a decision on recognition of a foreign judgment awarding compensation is still unsettled and poses even higher barriers than the one concerning the issue of jurisdiction. In this context the question of state immunity re-appears with regard to execution of the judgments, and a development with regard to practice for denying immunity from execution comparable to that concerning jurisdictional immunity has not occurred yet.

\section{Enforcing a Successful Adjudication: The Constitutional Court Versus 'the Last Bastion of State Immunity'?}

It remains to be seen whether, and if so when, all of the judgments by Italian courts considered so far will be enforced, thus making reparations to the victims effective. After adjudication on one's claim becomes final, enforcement traditionally occurs either willingly by the respondent or by way of specific execution proceedings established under domestic law. However, if the respondent is a foreign state, general international law provides for a procedural bar preventing the judiciary of the forum state from enabling enforcement. In the absence of an express waiver of immunity by the foreign state, this guarantee is generally accorded to every sovereign state and is called 'immunity from execution'. Unlike 'immunity from adjudication', the approach towards lifting immunity from execution has been far more restrictive in state practice. This brings up the question of whether, following Sentenza 238/2014, Italian ordinary courts are under obligation to deny Germany immunity from execution or, conversely, whether they still ought to abide by it and, if so, on what basis.

For the time being, this question has been dealt with by the Court of Appeal of Milan and by the Tribunal of Rome. More recently, the Court of Cassation delivered the final judgment on the question previously decided by the Court of Appeal of Milan, thereby apparently setting a point in favour of the doctrine whereby immunity from execution should be upheld even after denial of immunity from adjudication. Before these pronouncements, however, other courts adjudicating on the merits of the actions for damages related to crimes committed by Germany on Italian soil already suggested a different nature existing between immunity from adjudication and immunity from execution. In particular, in its Judgment No 2468 of 6 July $2015,{ }^{55}$ the Tribunal of Florence maintained that the exercise of civil jurisdiction did

${ }^{55}$ Tribunale di Firenze, Judgment No 2468/2015 (n 30). 
not per se pose a risk to the sovereignty of the German state since it merely implied a judgment having a declaratory nature ('sentenza di mero accertamento e condanna') and not necessarily entailing execution.

In this respect, however, the judgments mentioned above provided for more nuanced solutions. In its ruling of 27 January 2015, ${ }^{56}$ the Court of Appeal of Milan refused to take measures of constraint on Villa Vigoni-a cultural property belonging to Germany and located in Italy_-being conscious of the risk of infringing upon the right to state immunity from enforcement. In fact, as already acknowledged by the ICJ in its Jurisdictional Immunities Judgment (paragraphs 113-120), immunity from adjudication and immunity from execution are subjected to different legal regimes under customary international law. ${ }^{57}$ While in the field of jurisdictional immunity courts ought to scrutinize the nature of an act as iure imperii or iure gestionis, when applying immunity from execution, judges ought to check whether the property against which enforcement measures should be taken is being used for governmental or commercial purposes. Therefore, insofar as used for non-commercial governmental purposes, Villa Vigoni could not be seized or subjected to provisional measures even after Sentenza 238/2014. ${ }^{58}$ The judgment of the ItCC, in fact, concerned a question on the application of immunity from adjudication only. ${ }^{59}$ Therefore, Article 24 of the Italian Constitution could not extensively be interpreted as providing for a right to a judge as including also effective enforcement, otherwise such a right would have encroached upon assets devoted to a public service (publicis usibus destinata). Yet, the ground for declaring the invalidity of the judicial mortgage over Villa Vigoni by the Court of Appeal of Milan was the ineffectiveness of the instrument permitting enforcement ('titolo esecutivo'), that is, the non-enforceability of Greek judgments in Italy after the ICJ

\footnotetext{
${ }^{56}$ Corte d'Appello di Milano, Judgment of 27 January 2015, No 1278/2015.

${ }^{57}$ See Michael Wood, 'Immunity from Jurisdiction and Immunity from Measures of Constraint'; Chester Brown/Roger O'Keefe, 'Part IV State Immunity from Measures of Constraint in Connection with Proceedings Before a Court, Preliminary Material', both in Roger O'Keefe et al (eds), The United Nations Convention on Jurisdictional Immunities of States and Their Property (Oxford: OUP 2013), 13-18 and 288-293. Cf also, ILC, Report on the Work of the thirtieth session (1978), UN Doc A/33/10, 154, para 23. See, in particular, 'Concurring Opinion of Judge Pellonpää joined by Judge Bratza in Al Adsani v United Kingdom', in Elihu Lauterpacht et al (eds), International Law Reports 123 (Cambridge: CUP 2003), 45-49, arguing that even in the US, where the Foreign Sovereign Immunities Act (FSIA) has been amended so as to allow US citizens to raise damage claims based, inter alia, on torture against specifically designated states, immunity from execution has ultimately not been removed.

${ }^{58}$ As regards other similar cases, it ought to be pointed out that execution or attachment measures against properties situated in the forum state and serving as cultural institutions were generally prohibited, as the practice of Swiss courts and of the Hellenic Republic shows. See August Reinisch, 'European Court Practice Concerning State Immunity from Enforcement Measures', The European Journal of International Law 17 (2006), 803-836, at 824; more recently see: Jean-Marc Thouvenin/Victor Grandaubert, 'The Material Scope of Immunity from Execution', in Tom Ruys et al (eds), The Cambridge Handbook of Immunities and International Law (Cambridge: CUP 2019), 245-265, at 260 mentioning also French case-law.

${ }^{59}$ ItCC, Judgment 238/2014 (n 7), para 1.2.
} 
Judgment. The opinion of the Court of Appeal was substantially confirmed in June 2018 by the Court of Cassation. However, the Italian Supreme Court overruled the reasons on the basis of which the lower judge declared the invalidity of the legal charge: the question was in fact not the ineffectiveness of the aforementioned instrument to permit enforceability, as would have been the case if the Italian judiciary would have abided by the ICJ Judgment (paragraphs 121-131); on the contrary, according to the Supreme Court, the instrument ('titolo esecutivo') remains effective, but allows for enforceability only against those assets of the Federal Republic of Germany that are not devoted to public purposes. This not being the case, the lower judge should have declined jurisdiction and the judicial mortgage should have been cancelled from the land register. ${ }^{60}$ Therefore, one should conclude that the Supreme Court reversed the lower judge decision to the extent to which the Court of Appeal, building upon the ICJ Judgment, had made the exequatur granted to Greek judgments null and void, even though it could only adjudicate upon the legality of the mortgage.

In this respect, the reasoning by the Court of Cassation is only partly consistent with a decision by the Tribunal of Rome, handed down on 20 May 2015 and upheld by the same Court of Cassation on 3 September 2019. In fact, the Tribunal overturned a 2012 order by the enforcement judge of the same Tribunal of Rome according to which an action for execution in Italy of Greek judgments against Germany could not be advanced or undertaken. For their execution Greek claimants had attempted to attach credits owed by the Italian Ferrovie dello Stato (the Italian state-owned railway company) to Deutsche Bahn $A G$, the German railway company and a private corporate body the shares of which are currently held by the Federal Republic. The Tribunal of Rome argued that, after Sentenza 238/2014, the order already issued by the enforcement judge on the basis of the ICJ Judgment was null and void and that execution proceedings of the underlying judgment on the merits, awarding the victims a sum of nearly $€ 50$ million, could be resumed. Objections brought forward by Deutsche Bahn AG before the Court of Cassation concerning the fact that it could not be held responsible for the crimes committed by Germany and that the underlying judgment had not considered this aspect were dismissed as inadmissible. The reason being that in a procedure on execution, questions of this kind could not be raised as they are part of the proceedings on the merits. Only in the case of a serious error in law that aspect could have been reviewed in the execution procedure. However, such an error did not exist in the case at stake as it is clear that the Italian legal order does not grant immunity from jurisdiction in cases concerning violations of human rights, pursuant to Sentenza 238/2014. Accordingly, not only the judge on the merits, but also the enforcement judge is obliged to dismiss

\footnotetext{
${ }^{60}$ Corte di Cassazione, Judgment of 8 June 2018, No 14885/2018, which goes back to Corte di Cassazione, Judgment of 12 January 1996, No 173/1996. See the case note by Olivia Lopes Pegna, "Giù le mani da Villa Vigoni: quale tutela "effettiva" per le vittime di gravi crimini compiuti da Stati esteri', Rivista di diritto internazionale 4 (2018), 1237-1244; Pierfrancesco Rossi, 'The Aftermath of the Italian Constitutional Court Judgment No. 238 of 2014 in Exequatur and Enforcement Proceedings', Italian Yearbook of International Law, 28 (2018), 455-459.
} 
objections based on state immunity and exercise jurisdiction. This implies, in essence, that the grant of exequatur of Greek judgments by Italian courts, being of an adjudicatory nature, was deemed legitimate and in line with Sentenza 238/2014. Nonetheless, the Supreme Court's judgment applies 'without prejudice to whether immunity from execution applies, a question which will potentially be dealt with once the very execution proceedings will be started'. ${ }^{61}$ In other words, from a domestic civil procedural point of view, the execution proceedings in which the unaffected question on whether Deutsche Bahn AG credit liabilities can legitimately be attached by the Italian state might be addressed, start in a later moment and not already when the enforcement judge declares a judgment enforceable. Therefore, the fact that the enforcement judge cannot decline jurisdiction on grounds of sovereign immunity does not yet say anything about whether or not the properties of the foreign state can legitimately be attached.

In this respect, however, from an international law perspective of immunity application, whereas Villa Vigoni is a German property serving sovereign purposes and in fact deserves enjoyment of immunity from execution, the credit liabilities of the German railway company towards the Italian railways could hardly be treated as fulfilling non-commercial purposes. In this respect, Italian ordinary courts are called upon to give a consistent interpretation of both the existing customary international law and the manifold case-law of the ItCC and to assess whether immunity from measures of constraint should be lifted. Before Sentenza 238/2014, the Corte Costituzionale already dealt with the question of the compatibility of immunity from execution with the right to effective judicial protection, ie to enforcement of a judgment as encompassed in Article 24 of the Italian Constitution. ${ }^{62}$ In particular, with its Judgment No 329/1992 the ItCC declared unconstitutional a legal provision dating back to 1926 that prevented the Italian judiciary from confiscating the goods of a foreign state without prior authorization from the Minister of Justice. ${ }^{63}$ By leaving it up to the discretion of the executive power, the legal provision at hand was deemed to be contrary to the (then) current state of customary international law and therefore contrary to Article 10(1) of the Italian Constitution since it might have

\footnotetext{
${ }^{61}$ Tribunale di Roma, Judgment of 20 May 2015, No 11069/2015, (translated by the authors). So also: Corte di Cassazione, Judgment of 3 September 2019, No 21995/2019. (para 19). Cf Cristina M Mariottini, 'Case Note: Deutsche Bahn AG v. Regione Stereá Ellada', American Journal of International Law 3 (2020), 486-493; Barbara De Santis, 'Profili di giurisdizione nell'esecuzione forzata sui beni dello Stato estero', Judicium-Il processo civile in Italia e in Europa, 30 April 2020; Luca Baiada, 'Ancora sull'esecuzione su beni di Stato estero', Questione Giustizia, 30 September 2019, according to whom the Court of Cassation's judgment consistently draws upon Sentenza 238/2014 to bring about the lifting of immunity from execution. Contra see: Giorgia Berrino, 'La Corte di Cassazione torna sul tema delle immunità giurisdizionali degli Stati stranieri e dei loro beni', Rivista di diritto internazionale, 3 (2020), 844-858, at 856-857.

${ }^{62}$ On Article 24 of the Italian Constitution and enforcement proceedings see: Luigi Paolo Comoglio, 'Principi costituzionali e processo d'esecuzione', Rivista di diritto processuale 2 (1994), 450-469.

${ }^{63}$ Corte Costituzionale, Judgment of 2 July 1992, No 329/1992.
} 
prevented ordinary courts from lifting immunity from execution also for acta iure gestionis. ${ }^{64}$ At the same time, the prior authorization of the Minister also encroached upon the individual right to a judge as protected by Article 24 of the Italian Constitution, since 'the right of the individual to a judicial remedy requires that the existence of the legal conditions to file a lawsuit before a court be ascertained by a judge according to the procedural guarantees set out by the law', and not by a member of the executive power. Having said that, the ItCC clarified:

[I]t does not deny that, within the context of international relations with foreign states, the fundamental right to judicial protection can be limited beyond what customary international law provides, as introduced through Article 10 of the Italian Constitution. However, this limitation ought to be justified by a public interest potentially outweighing the principle set out in Article 24 of the Italian Constitution, which is one of the supreme principles of the constitutional order (cf. Judgment No 18/1982). Moreover, the norm providing for a limitation to the individual right at hand shall undergo a rigorous assessment of this interest in the light of the specific aspects of the case. ${ }^{65}$

That Article 24 of the Italian Constitution does not provide for an absolute right and can be outweighed by a higher public interest has been further confirmed by the ItCC in its Sentenza 238/2014. However, the sacrificing of the right to a judge should not be deemed disproportionate to the interest pursued and the means employed. Such an interest could not be assessed in the case regarding immunity from adjudication, thus making the right to a judge prevail over state immunity. ${ }^{66}$ It remains to be seen whether a different balancing operation could be carried out if immunity from execution was at stake.

As we have seen, pursuant to Sentenza 238/2014, mere compliance with customary international law, as well as the promotion of comity and good relations with other states, might provide for a legitimate aim to restrict the right to a judge but cannot per se constitute a proportionate means for justifying such a restriction. ${ }^{67}$ Therefore, the decision adopted by the Court of Appeal of Milan would probably not be confirmed in the same way by the ItCC. On the contrary, the final decision by the Court of Cassation appears to be much more in conformity with Sentenza 238/2014, as it does not uphold immunity from execution as such but only to the extent to which the properties of the foreign state at stake truly serve a public interest. This leaves open the practical question of what properties different from Villa Vigoni do allow for measures of constraint to be taken and, in particular, whether the credit liabilities of Deutsche Bahn AG or other German government-owned companies may legitimately be attached as assets within the property of a foreign State.

\footnotetext{
${ }^{64}$ Similarly in the US, as pointed out by Reinisch, 'European Court' 2006 (n 58), 814.

${ }^{65}$ ItCC, Judgment No 329/1992 (n 63), (translated by the authors).

${ }^{66}$ ItCC, Judgment 238/2014 (n 7), para 3.4.

${ }^{67} \mathrm{The}$ ItCC's reasoning is radically different from that of the ECtHR adjudicating on the compatibility of immunity with Article 6 ECHR. The Strasbourg Court, in fact, did not hesitate to consider domestic decisions to accord immunity as pursuing a legitimate aim and as being proportionate. On these judgments see, inter alia, Matthias Kloth, Immunities and the Right of Access to Court under Article 6 ECHR, (Leiden/Boston: Martinus Nijhoff 2010), 21-158.
} 
In this respect, however, one should also keep in mind that a judicial mortgage over part of the property of Villa Vigoni was recorded again on 11 November 2019 after the Tribunal of Sulmona had issued its Order of 2 November 2017. Therefore, even though the ICJ Judgment qualified Villa Vigoni as fulfilling 'entirely' noncommercial purposes (para. 119), Italian enforcement tribunals may soon be required to decide otherwise, ie that execution can be carried out as regards part of the real property of the cultural centre, considering its various uses. ${ }^{68}$

The ItCC could also argue that immunity from execution as such does not bring about an absolute and therefore disproportionate sacrifice of the right to a judge, since adjudication on the merits ('la verifica giurisdizionale', as the ItCC literally called it) had already been enabled after denial of immunity from adjudicatory jurisdiction. ${ }^{69}$ Quite surprisingly, such an outcome is hinted at in the Order of the Tribunal of Florence No 85/2014, by means of which it referred the question of constitutionality to the ItCC. There the Tribunal maintained that immunity from execution might not be in breach of Article 24 of the Italian Constitution since one could have reasoned as follows: 'While Article 24 of the Italian Constitution requires an assessment on the merits and a conviction for such serious crimes, (...) the same provision sets a limit in terms of execution, [being] (...) only this portion of jurisdiction, if exercised, intrusive on State sovereignty. ${ }^{, 70}$ However, upholding the benefit of immunity from execution in these terms would display an utmost cynicism towards the victims' destiny, ${ }^{71}$ thus making Sentenza 238/2014 a Pyrrhic victory. ${ }^{72}$ A sounder approach appears to conform to the first solution, according to which immunity from execution should be treated no longer as a taboo, but only to the extent that assets used for commercial purposes are concerned.

On the other hand, the ItCC might deny altogether Germany immunity from execution either by entrusting itself with the power to reinterpret general international law differently from that of the ICJ or, alternatively, by following the path of Sentenza 238/2014 and thereby discarding international law in favour of domestic constitutional law.

As to the first option, for which the ItCC has no constitutional mandate, it could follow an approach not completely unknown under customary international law,

\footnotetext{
${ }^{68} \mathrm{Cf}$ for instance Pål Wrange, 'Case Note: Sedelmayer v. Russian Federation', American Journal of International Law 2 (2012), 347-353, in which the Swedish Supreme Court allowed enforcement over a Russian real property being the building at stake only to a limited extent and not in considerable part' used for official purposes.

${ }^{69}$ Cf Paolo Palchetti, chapter 'Right of Access to (Italian) Courts über alles?', in this volume.

${ }^{70}$ Tribunale di Firenze, Order of 21 January 2014, No 85/2014 (translated by the authors).

${ }^{71}$ So also Paolo Palchetti, 'Italian Concerns after Sentenza 238/2014: Possible Reactions, Possible Solutions', VerfBlog, (11 May 2017), available at http://verfassungsblog.de/italian-concerns-aftersentenza-2382014-possible-reactions-possible-solutions/.

${ }^{72}$ This epithet is owed to the US District Court Judge Royce C Lamberth in Eisenfeld v Iran, US, 172 F.Supp.2d 1, 9 (D.D.C. 2000).
} 
whereby enforcement is regarded as a 'logical consequence' of adjudication and therefore could deny Germany immunity from enforcement measures. ${ }^{73}$ This outcome could be justified also by means of an a contrario argument, taking into account recent Italian state practice. In fact, even if it is true that Italian courts have so far always complied with the rule of immunity from execution, legislation passed most recently shows that neither the executive nor the legislative powers were fully convinced of the deeply rooted nature of this customary rule on the matter. For this reason, immediately following Sentenza 238/2014, the Italian parliament introduced Article 19-bis into Law No 162 of 10 November $2014,{ }^{74}$ by virtue of which the bank and postal accounts of a foreign state's diplomatic mission or consular posts are exempt from attachment and execution, insofar as the head of the diplomatic mission of the foreign state unilaterally declares that the accounts are in use for the institutional purposes of the mission itself. ${ }^{75}$ In so doing, it appears that Italian political bodies were uncertain as to the very existence of a rule of customary international law providing foreign states with immunity from execution whenever their property serves a sovereign purpose; alternatively, they probably feared that the Italian judiciary would have been able to provide for a different interpretation of general international law, thus potentially engaging Italy's responsibility for an internationally wrongful act. However, similar to the case adjudicated by the ItCC in $1992,{ }^{76}$ in precluding the assessment by the judiciary regarding the correctness of the unilateral declaration by the ambassador, the right of access to justice as

\footnotetext{
${ }^{73}$ In particular, Swiss courts for a given period of time considered that execution should simply follow from adjudication on the merits so that once adjudication against a foreign state is undertaken, enforcement should also be possible. In the Netherlands one could recall a rather isolated and outdated pronouncement by the Dutch Supreme Court (1973), by means of which any measure of enforcement against foreign state properties situated in the territory of the forum state could be taken. In Turkey, a number of decisions have held that foreign property can be seized or attached. See, for a general survey of state practice on immunity from execution, Hazel Fox/Philippa Webb, The Law of State Immunity (Oxford: OUP $3^{\text {rd }}$ ed 2013), 482-490; Reinisch, 'European Court' 2006 (n 58), 809-811; 813.

${ }^{74}$ Similarly, while a decision was pending before the ICJ, the Italian government issued the Law-decree No 68/2010, which suspended the effectiveness of the enforcement order ('titolo esecutivo') upon assets belonging to foreign states until the judgment. See, on the nature of this law decree and its compatibility with the Italian Constitution, Francesco Salerno, 'Esecuzione in Italia su beni di Stati stranieri: il decreto-legge 28 aprile 2010, n. 63' and Andrea Atteritano, 'Il DL 63/2010 compromette il diritto dell'individuo a una effettiva tutela giurisdizionale', (22 September 2010), both available at http://www.sidi-isil.org/? $\mathrm{p}=7965$.

${ }^{75} \mathrm{Cf}$ Benedetto Conforti, 'Il legislatore torna indietro di circa novant'anni: la nuova norma sull'esecuzione sui conti correnti di Stati stranieri', Rivista di diritto internazionale 2 (2015), 558-561. See also: Antonio Chiusolo, 'Immunità giurisdizionale e diritti inviolabili: nuova frontiera per la "giuristocrazia"?', Forum di Quaderni Costituzionali, (14 July 2015), available at http://www.forumcostituzionale.it/wordpress/wp-content/uploads/2015/07/chiusolo-nota-2382014.pdf, at 9-10; Attila Tanzi, 'Sulla sentenza 238/2014: cui prodest?', Forum di Quaderni Costituzionali, (26 November 2014), available at http://www.forumcostituzionale.it/wordpress/ wp-content/uploads/2014/12/nota_238_2014_tanzi.pdf, at 3-4.

${ }^{76}$ ItCC, Judgment 329/1992 (n 63).
} 
enshrined in Article 24 of the Italian Constitution has been infringed because its limitation beyond what customary international law provides is neither sustained by a higher public interest nor proportionate. ${ }^{77}$

As to the second option, the ItCC may also stress the need of providing victims with an effective judicial remedy, since 'the right to a judge enshrined in the Italian Constitution requires an effective protection of the rights of the individual' and cannot be deemed sufficient whenever a private claimant is allowed to file a lawsuit against a foreign state. ${ }^{78}$ The effectiveness of the judicial remedy could be deemed existent only to the extent that an enforcement order can be issued. In doing so, however, the ItCC would overrule its own case-law, which unequivocally distinguished between immunity from adjudication and immunity from execution and thus relying on the case-law of those courts that tend to approximate adjudicatory and enforcement immunity. From this perspective the ItCC would probably have to activate once more the counterlimits so as to preclude customary international law governing immunity from execution to enter the Italian legal order. ${ }^{79}$ Whereas in the first scenario outlined above the ItCC would close the books with Germany but leave totally or partially unsettled the question of reparations, in the second scenario the Corte Costituzionale would coherently follow up Sentenza 238/2014 and tear down the 'last bastion of State immunity'. ${ }^{80}$ The consequences, however, would probably be severe for the bilateral relations between the two states, as Germany might bring a new lawsuit before the ICJ. Such proceedings would constitute an unwelcome development between member states of the EU. An agreed extra-judicial settlement of the already too long-lasting controversy would thus clearly be the best solution. ${ }^{81}$

\footnotetext{
${ }^{77} \mathrm{Cf}$ Fabrizio Marongiu Buonaiuti, 'State Immunity from Enforcement Measures between Respect for State Sovereignty and Access to Justice', in Ermanno Calzolaio/Pierre Serrand (eds), La contrainte en droit-The constraint in Law, (Zurich: LIT Verlag 2017), 167-186, at 181-182. Doubts were raised also by Riccardo Luzzatto/Ilaria Queirolo, 'Sovranità territoriale, "Jurisdiction" e Regole di Immunità', in Sergio M Carbone/Riccardo Luzzatto/Alberto Santa Maria (eds), Istituzioni di diritto internazionale (Turin: Giappichelli $5^{\text {th }}$ ed 2016), 203-241, at 206-207. See also Riccardo Pavoni, chapter 'A Plea for Legal Peace', in this volume.

${ }^{78}$ As pointed out in the case-law of the Italian Constitutional Court, Article 24 of the Italian Constitution protects also the right to enforcement. See, inter alia, Judgments of 11 June 2014, No 182/2014; of 3 June 2013, No 119/2013; of 7 July 2010, No 281/2010, and of 5 March 2007, No $77 / 2007$.

${ }^{79}$ See also Paolo Palchetti, chapter 'Right of Access to (Italian) Courts über alles?', in this volume. ${ }^{80}$ This expression belongs to Special Rapporteur Sompong Sucharitkul. Cf Eighth Report on Jurisdictional Immunities of States and Their Property. See in this respect, ILC, Report on the Work of the thirty-eighth session (1986), UN Doc A/CN.4/396, Draft Article 18 (para 2).

${ }^{81}$ For similar considerations, Karin Oellers-Frahm, 'Suggesting Solutions: What About Concessions to be Made by Both Sides', VerfBlog, (15 May 2017), available at https://verfassungsblog.de/ suggesting-solutions-what-about-concessions-to-be-made-by-both-sides/.
} 


\section{The Compatibility of a Reparation Scheme with the Italian Constitution}

A different attitude could be displayed by the ItCC if negotiations on a possible reparation scheme for the victims excluded by prior reparations were started, a constellation, however, that appears highly unlikely at the present stage. In this respect, it could be useful to answer the question on the extent to which Italian courts should afford immunity from enforcement if negotiations on a possible reparation scheme were started by Italy and Germany and to what extent this solution would be compatible with Article 24 of the Italian Constitution. The same question could be asked if a law decree suspending attachment and/or execution proceedings were passed after the start of negotiations.

The answers to these questions might differ depending on the terms upon which negotiations would be started, as well as on the content of such a reparation scheme. In the first place, one may consider the unusual reparation scheme outlined by the same Tribunal of Florence. As already mentioned (section II), in its Order of 23 March 2015, when resuming proceedings after the decision of the ItCC the judge attempted to combine domestic procedural law and passages of the ICJ Judgment promoting negotiations. ${ }^{82}$ On the basis of a combined reading of internal legal provisions and a recommendatory statement by an international court, the Tribunal of Florence suggested a sui generis conciliation proposal, whose acceptance by all parties to the proceedings was conditional upon both the withdrawal of the claim for reparation by the applicants and the financial compensation amounting to up to $€ 15,000$ by the Federal Republic of Germany specifically for a cultural study visit to Germany for the victim's families. This equitable settlement being reached on an individual basis, albeit not well-founded in positive law, ${ }^{83}$ would have had the merit of allowing the judge to do away with the question of whether immunity from execution ought to be lifted.

A different outcome would probably occur if Italy and Germany willingly decided to conduct negotiations on a compensation fund covering all the remaining victims and not only the plaintiffs of a single or a given number of proceedings. ${ }^{84} \mathrm{In}$ this respect, in entering into negotiations with Germany and upon condition of their successful conclusion, Italy would itself waive the damages claims in the name of its

\footnotetext{
${ }^{82}$ Tribunale di Firenze, Order No 2012/1300 (n 8), referring to ICJ, Jurisdictional Immunities (n 9), paras 99 and 104.

${ }^{83}$ As pointed out by Oellers-Frahm, 'A Never-Ending Story' 2016 (n 8), 198.

${ }^{84}$ As pointed out by Thomas Giegerich, 'Do Damages Claims Arising from Jus Cogens Violations Override State Immunity from the Jurisdiction of Foreign Courts?', in Christian Tomuschat/JeanMarc Thouvenin (eds), The Fundamental Rules of the International Legal Order: Jus Cogens and Obligations Erga Omnes (Leiden/Bosten: Martinus Nijhoff 2006), 203-238, at 221: '[D]iplomatic or other international mechanisms are arguably more appropriate, as allowing civil claims by individual victims would give some individuals large sums of money while the majority of the victims would come away empty-handed'.
} 
citizens, as traditionally occurs under international law. Would this waiver conform to Article 24 of the Italian Constitution?

The ItCC could seize the opportunity to explore whether the international customary rule-according to which claims to reparations arising from violations of the law of armed conflicts can be waived by states in virtue of their sovereigntyinfringes upon Article 24 of the Italian Constitution. Unlike a treaty by means of which two states entirely waive the damages claims of their citizens, the present bilateral arrangement would rather be aimed at providing a symbolic compensation to all victims excluded from prior reparation agreements and not, as such, at defeating the power of the victims to adjudicate upon claims lodged before domestic tribunals. By contrast, it would be difficult to imagine that such an agreement will still allow claims regarding the modalities and to the extent to which reparation by Germany should take place. $^{85}$

Therefore, it would be difficult for the ItCC to state that the right of access to justice as enshrined in Article 24 of the Italian Constitution has been violated: once adjudication on the merits has been allowed, the question as to how and to what extent the victims will receive satisfaction, as long as it will ultimately somehow be ensured, should not concern constitutional judges but rest within the discretion of the state on how to provide them with reparation. ${ }^{86}$

\section{Concluding Remarks}

The above considerations highlight a series of problems resulting from the attempt of a domestic court, rectius a constitutional court, to contribute to the development of international law. There is no question that issues of state immunity might need reconsideration as demonstrated by the adoption of the 2004 UN Convention on Jurisdictional Immunities of States and Their Property. ${ }^{87}$ The fate of this Convention as such is, however, revealing: that ratifications are sparse shows that states are reluctant to accept the rules. ${ }^{88}$ Moreover, the attempt to apply such desirable but not yet generally accepted new rules to situations dating back more than 70 years and resulting from war-related actions raises more problems than it resolves. The possibility of re-assessing war-related acts under currently accepted human rights law raises not only the question of the reasonableness but also the feasibility of such an undertaking.

\footnotetext{
${ }^{85} \mathrm{Cf}$ Chiusolo, 'Immunità giurisdizionale' 2015 (n 75), 23-24.

${ }^{86}$ See also Riccardo Pavoni, chapter 'A Plea for Legal Peace', in this volume. Cf Paolo Palchetti, chapter 'Right of Access to (Italian) Courts über alles?', in this volume.

${ }^{87}$ UN Convention on Jurisdictional Immunities of States and Their Property (2 December 2004), UN Doc A/RES/59/38, UN Doc A/59/49, 486 (not yet in force).

${ }^{88}$ Until November 2020 , there were only 22 ratifications and 28 signatories to the Convention.
} 
However, the activism of national courts relating to new developments in international law should reflect the overall consequences: denying state immunity with regard to jurisdiction only partially resolved the question-and the Corte Costituzionale was undoubtedly aware of this fact. The hope that might have propelled the ItCC towards its decision, that immunity from execution might be denied on the same reasons as jurisdictional immunity, could only be considered as equivocal at that time. To entrust the further development of this issue to national jurisdictions and not to the international community could only result in judicial activism to the detriment of the people concerned: the victims of war crimes and their heirs. To raise their hopes of being awarded reparations only for said reparations to be impossible to realize seems rather cynical indeed, as it disregards the expectations of individuals originating from an ambitious, but short-sighted, decision of the ItCC. As long as Germany is not ready to step back from its legally justified denial of awarding reparations ${ }^{89}$ and Italy maintains its disregard for binding international law, the question will remain open for an unforeseeable future, since Italian judges will continue awarding compensation to the victims that Germany will ultimately not provide.

In this regard, and in order to finally close the chapter of WWII, a possible solution might be found either in the creation of a fund mutually established by Italy and Germany ${ }^{90}$ or by a unilateral action by Germany following the example of the reparations awarded to Russian prisoners of war: ${ }^{91}$ In this instance, the German parliament formally recognized 'responsibility for that part of the terrible events of the Nazi period and World War II' and awarded 'as a symbolic financial recognition for their suffering' the payment of $€ 2,500$ to each of the some 4,000 Russian prisoners still alive. ${ }^{92}$ Jochen Abraham Frowein was right to consider the question of reparations as settled, but also that Germany was free to offer reparations through 'unilateral measures', adding, however, that the situation of Russian prisoners was unique and therefore should not be considered as a precedent to be extended to other cases. ${ }^{93}$ Consequently, there is no legal obligation to award reparations to Italian victims of German war crimes and replicate the solution reached for Russian

\footnotetext{
${ }^{89}$ The German attitude seems in particular understandable with a view to compensations claims from other sides, as eg the compensation recently claimed by Poland. In the opinion delivered by the German Bundestag, Germany confirms its position also with regard to Poland that all war-related claims have been waived; cf Deutscher Bundestag-Wissenschaftliche Dienste, 'Völkerrechtliche Grundlagen und Grenzen kriegsbedingter Reparationen unter besonderer Berücksichtigung der deutsch-polnischen Situation', (28 August 2017), available at www.bundestag.de/blob/525616/ 211fd144be8368672e98ecd6a834fe25/wd-2-071-17-pdf-data.pdf.

${ }^{90}$ See also Stefan Kadelbach, chapter 'State Immunity, Individual Compensation for Victims of Human Rights Crimes, and Future Prospects', and Francesco Francioni, chapter 'Overcoming the Judicial Conundrum', in this volume.

${ }^{91} \mathrm{Cf}$ section III.3 and $\mathrm{n} 34$.

${ }^{92} \mathrm{Cf}$ Deutscher Bundestag, 'Plädoyer für Entschädigungen', (19 May 2015), available at www. bundestag.de/presse/hib/2015_05/-/375140 (translated by the authors).

${ }^{93}$ Ibid.
} 
prisoners of war. But Germany remains free to act on a unilateral basis, in particular wherever victims exist who have hitherto been excluded from any reparation scheme, so as to finally close the dispute troubling the otherwise friendly relations between Italy and Germany.

\section{References}

Atteritano, Andrea, 'Il DL 63/2010 compromette il diritto dell'individuo a una effettiva tutela giurisdizionale', (22 September 2010), available at http://www.sidi-isil.org/wp-content/uploads/ 2010/02/Atteritano-DL-Immunit\%C3\%A0-definitivo1.pdf

Baiada, Luca, 'Ancora sull'esecuzione su beni di Stato estero', Questione Giustizia, 30 September 2019.

Bank, Roland/Elke Schwager, 'Is There a Substantive Right to Compensation for Individual Victims of Armed Conflict against a State under International Law', German Yearbook of International Law 49 (2006), 367-411

Berrino, Giorgia, 'La Corte di Cassazione torna sul tema delle immunità giurisdizionali degli Stati stranieri e dei loro beni', Rivista di diritto internazionale 3 (2020), 844-858

Boggero, Giovanni, 'Ancora sul seguito della sentenza n. 238/2014: una recente pronuncia del Tribunale di Sulmona', (20 November 2017), available at www.diritticomparati.it/ancora-sulseguito-della-sentenza-n-2382014-una-recente-pronuncia-del-tribunale-di-sulmona/

Boggero, Giovanni, 'The Legal Implications of Sentenza No. 238/2014 by Italy's Constitutional Court for Italian Municipal Judges: Is Overcoming the 'Triepelian Approach' Possible?', Heidelberg Journal of International Law 76 (2016), 203-224

Brown, Chester/Roger O'Keefe, 'Part IV State Immunity from Measures of Constraint in Connection with Proceedings Before a Court, Preliminary Material', in Roger O'Keefe et al (eds), The United Nations Convention on Jurisdictional Immunities of States and Their Property (Oxford: OUP 2013), 288-293

Bufalini, Alessandro, 'La riparazione per gravi violazioni dei diritti umani e del diritto umanitario tra rinuncia dello stato e diritto individuale', in Andrea Spagnolo/Stefano Saluzzo (eds), $\mathrm{La}$ responsabilità degli stati e delle organizzazioni internazionali (Milan: Ledizioni 2017), 375-391

Cannizzaro, Enzo, 'Is There an Individual Right to Compensation?', in Denis Alland et al (eds), Unité et diversité du droit international (Leiden: Brill Nijhoff 2014), 495-502

Cataldi, Giuseppe, 'Immunités juridictionnelles des Etats étrangers et droit de l'homme: quel équilibre entre les valeurs fondamentales de l'ordre national et le droit international coutumier?', in James Crawford et al (eds), The International Legal Order: Current Needs and Possible Responses (Leiden: Brill Nijhoff 2017), 571-590

Cataldi, Giuseppe, 'La Corte costituzionale e il ricorso ai "contro-limiti" nel rapporto tra consuetudini internazionali e diritti fondamentali', Diritti umani e diritto internazionale 9 (2015), 41-50

Chiusolo, Antonio, 'Immunità giurisdizionale e diritti inviolabili: nuova frontiera per la “giuristocrazia"?', Forum di Quaderni Costituzionali, (14 July 2015), available at http://www. forumcostituzionale.it/wordpress/wp-content/uploads/2015/07/chiusolo-nota-238-2014.pdf

Comoglio, Luigi Paolo, 'Principi costituzionali e processo di esecuzione', Rivista di diritto processuale 2 (1994), 450-469

Conforti, Benedetto, 'Il legislatore torna indietro di circa novant'anni: la nuova norma sull'esecuzione sui conti correnti di Stati stranieri', Rivista di diritto internazionale 2 (2015), $558-561$ 
De Santis, Barbara, 'Profili di giurisdizione nell'esecuzione forzata sui beni dello Stato estero', Judicium-Il processo civile in Italia e in Europa, 30 April 2020

Focarelli, Carlo, 'Diniego dell'immunità giurisdizionale degli Stati stranieri per crimini, jus cogens e dinamica del diritto internazionale', Rivista di diritto internazionale 91 (2008), 738-757

Fox, Hazel/Philippa Webb, The Law of State Immunity (Oxford: OUP $3^{\text {rd }}$ ed 2013)

Frulli, Micaela, "The Times they are A-Changing"- the Italian Court of Cassation Denies Germany Immunity from Execution to Allow Compensation to War Crimes' Victims', Journal of International Criminal Justice 9 (2011), 1129-1142

Gattini, Andrea, Le riparazioni di guerra nel diritto internazionale (Padua: CEDAM 2003)

Gattini, Andrea, 'The Dispute on Jurisdictional Immunities of the State before the ICJ: Is the Time Ripe for a Change in the Law?', Leiden Journal of International Law 24 (2011), 173-200

Giegerich, Thomas, 'Do Damages Claims Arising from Jus Cogens Violations Override State Immunity from the Jurisdiction of Foreign Courts?', in Christian Tomuschat/Jean-Marc Thouvenin (eds), The Fundamental Rules of the International Legal Order: Jus Cogens and Obligations Erga Omnes (Leiden/Bosten: Martinus Nijhoff 2006), 203-238

Hess, Burkhard, 'Kriegsentschädigungen aus kollisionsrechtlicher und rechtsvergleichender Sicht', in Wolff Heintschel von Heinegg (ed), Entschädigung nach bewaffneten Konflikten: die Konstitutionalisierung der Welthandelsordnung (Heidelberg: Müller 2003), 107-205

Higgins, Rosalyn, 'Some Observations on the Inter-Temporal Rule in International Law', in Jerzy Makarczyk (ed), Theory of International Law at the Threshold of the 21st Century (The Hague: Kluwer 1996), 173-181

Kloth, Matthias, Immunities and the Right of Access to Court under Article 6 ECHR, (Leiden/ Boston: Martinus Nijhoff 2010)

Linden, Mieke van der, 'The Inextricable Connection between Historical Consciousness and International Law', Select Proceedings of the ESIL 5 (2014), 447-460

Longobardo, Marco, 'The Italian Constitutional Court's Ruling Against State Immunity When International Crimes Occur: Thoughts on Decision No. 238 of 2014', Melbourne Journal of International Law 16 (2015), 255-269

Lopes Pegna, Olivia, 'Giù le mani da Villa Vigoni: quale tutela "effettiva" per le vittime di gravi crimini compiuti da Stati esteri?', Rivista di diritto internazionale 4 (2018), 1237-1244

Luzzatto, Riccardo/Ilaria Queirolo, 'Sovranità territoriale, "Jurisdiction" e Regole di Immunità', in Sergio M Carbone/Riccardo Luzzatto/Alberto Santa Maria (eds), Istituzioni di diritto internazionale (Turin: Giappichelli $5^{\text {th }}$ ed 2016), 203-241

Mariottini, Cristina M, 'Case Note: Deutsche Bahn AG v. Regione Stereá Ellada', American Journal of International Law 3 (2020), 486-493

Marongiu Buonaiuti, Fabrizio, 'State Immunity from Enforcement Measures between Respect for State Sovereignty and Access to Justice', in Ermanno Calzolaio/Pierre Serrand (eds), $\mathrm{La}$ contrainte en droit-The constraint in Law (Zurich: LIT Verlag 2017), 167-186

Marxsen, Christian, 'What do Different Theories of Customary International Law Have to Say about the Individual Right to Reparation under International Humanitarian Law', Heidelberg Journal of International Law 78 (2018), 581-586

Oellers-Frahm, Karin, 'A Never-Ending Story: The International Court of Justice-The Italian Constitutional Court-Italian Tribunals and the Question of Immunity', Heidelberg Journal of International Law 76 (2016), 193-202

Oellers-Frahm, Karin, 'A Regional Perspective on the Convergence and Conflicts of Human Rights and International Humanitarian Law in Military Operations: The European Court of Human Rights', in Erika de Wet/Jann Kleffner (eds), Convergence and Conflicts of Human Rights and International Humanitarian Law in Military Operations (Pretoria: Pretoria University Law Press 2014), 333-363 
Oellers-Frahm, Karin, 'Das italienische Verfassungsgericht und das Völkerrecht-eine unerfreuliche Beziehung, Anmerkung zur Entscheidung des italienischen Verfassungsgerichts vom 22. Oktober 2014', Europäische Grundrechte-Zeitschrift 42 (2015), 8-16

Oellers-Frahm, Karin, 'Judicial Redress of War-Related Claims by Individuals: The Example of the Italian Courts', in Ulrich Fastenrath et al (eds), From Bilateralism to Community Interest: Essays in Honour of Judge Bruno Simma (Oxford: OUP 2011), 1055-1078

Oellers-Frahm, Karin, 'Suggesting Solutions: What About Concessions to be Made by Both Sides', VerfBlog, (15 May 2017), available at https://verfassungsblog.de/suggesting-solutions-whatabout-concessions-to-be-made-by-both-sides/

Orakhelashvili, Alexander, 'State Immunity and International Public Order Revisited', German Yearbook of International Law 49 (2006), 327-365

Palchetti, Paolo, 'Italian Concerns after Sentenza 238/2014: Possible Reactions, Possible Solutions', VerfBlog, (11 May 2017), available at http://verfassungsblog.de/italian-concerns-aftersentenza-2382014-possible-reactions-possible-solutions/

Papa, Maria Irene/Monica Zanobetti, 'Eccidio di Roccaraso: giurisdizione italiana e immunità degli Stati dalla giurisdizione civile', in Il Corriere giuridico 6 (2018), 788-798

Pavoni, Riccardo, 'How Broad is the Principle Upheld by the Italian Constitutional Court in Judgment No. 238?', Journal of International Criminal Justice 14 (2016), 573-585

Raffeiner, Stefan, 'Jenseits der Staatenimmunität im deutsch-italienischen StaatenimmunitätenFall: Wege und Hürden nach dem Urteil der Corte Costituzionale', Heidelberg Journal of International Law 76 (2016), 451-473

Reinisch, August, 'European Court Practice Concerning State Immunity from Enforcement Measures', The European Journal of International Law 17 (2006), 803-836

Rossi, Pierfrancesco, 'The Aftermath of the Italian Constitutional Court Judgment No. 238 of 2014 in Exequatur and Enforcement Proceedings', Italian Yearbook of International Law 28 (2018), 455-459

Salerno, Francesco, 'Esecuzione in Italia su beni di Stati stranieri: il decreto-legge 28 aprile 2010, n. 63', (22 September 2010), available at http://www.sidi-isil.org/wp-content/uploads/2010/02/ Salerno-Decreto-legge-28-aprile-2010-_1_.pdf

Tanzi, Attila, 'Sulla sentenza 238/2014: cui prodest?', Forum di Quaderni Costituzionali, (26 November 2014), available at http://www.forumcostituzionale.it/wordpress/wp-content/ uploads/2014/12/nota_238_2014_tanzi.pdf

Thouvenin, Jean-Marc/Victor Grandaubert, 'The Material Scope of Immunity from Execution', in Tom Ruys et al (eds), The Cambridge Handbook of Immunities and International Law (Cambridge: CUP 2019), 245-265

Tomuschat, Christian, 'Individual Reparation Claims in Instances of Grave Human Rights Violations: The Position under General International Law', in Albrecht Randelzhofer/Christian Tomuschat (eds), State Responsibility and the Individuals (The Hague: Martinus Nijhoff 1999), 1-25

Werle, Gerhard /Florian Jeßberger, Principles of International Criminal Law (Oxford: OUP $3^{\text {rd }}$ ed 2014)

Wood, Michael, 'Immunity from Jurisdiction and Immunity from Measures of Constraint', in Roger O'Keefe et al (eds), The United Nations Convention on Jurisdictional Immunities of States and Their Property (Oxford: OUP 2013), 13-18

Yang, Xiaodang, 'Immunity from Execution', in Alexander Orakhelashvili (ed), Research Handbook on Jurisdiction and Immunities in International Law (Cheltenham: Edward Elgar 2016), $372-422$ 
Open Access This chapter is licensed under the terms of the Creative Commons Attribution 4.0 International License (http://creativecommons.org/licenses/by/4.0/), which permits use, sharing, adaptation, distribution and reproduction in any medium or format, as long as you give appropriate credit to the original author(s) and the source, provide a link to the Creative Commons license and indicate if changes were made.

The images or other third party material in this chapter are included in the chapter's Creative Commons license, unless indicated otherwise in a credit line to the material. If material is not included in the chapter's Creative Commons license and your intended use is not permitted by statutory regulation or exceeds the permitted use, you will need to obtain permission directly from the copyright holder. 
Part VI

Negotiations 


\title{
Deadlocked in Dualism: Negotiating for a Final Settlement
}

\author{
Andreas von Arnauld
}

\begin{abstract}
While on the international plane Germany has as strong a position as one could wish for, a second appeal to the ICJ does not seem advisable. Though not formally estopped from challenging Sentenza 238/2014, Germany would at least face a principled contradiction (Wertungswiderspruch). Like Italy, Germany takes the position that international obligations must be disregarded should they be found incompatible with fundamental rights enshrined in the national constitution. Concerning the underlying conflict, another formally strong German position proves to have inherent shortcomings. To argue that, as far as Italian citizens are concerned, all matters of compensation had been dealt with comprehensively in the GermanItalian lump sum agreement of 1961 carries some conviction. However, the limitations of that agreement, the erosion of the individual's strict mediatisation in international law, and recent German compensation schemes for other victims of World War II (WWII) have fuelled a growing discontent with this final settlement. Having been doubly denied recognition as victims by the injustices of non-retroactivity and of differentiation, the Italian WWII victims 'in oblivion' have pursued compensation claims for over a decade now. It would go too far to argue an individual claim for financial compensation under international law for historic wrongs. The principle of intertemporal law, however, has its merits as well as its defects. This chapter argues in favour of mildly piercing the veil of intertemporality by reliance on fundamental ethical principles as part of the law in force already at the time of the original violation. A breach in this kind of obligation should give rise to an obligatio de negotiando under the principle of just satisfaction. Such a legal construction takes up the idea that in most of the recent cases of 'history taken to court', compensation is but a secondary aim, the primary aim being to 'tell one's own story' as a counter-narrative to hegemonic discourse. By entering into negotiations with the victims 'in oblivion', Germany-and Italy-could and should attempt to finally solve what has been and remains a fundamentally unjust situation.
\end{abstract}

\footnotetext{
A. von Arnauld $(\bowtie)$

University of Kiel, Walther Schücking Institute for International Law, Kiel, Germany

e-mail: arnauld@wsi.uni-kiel.de

(C) The Author(s) 2021

V. Volpe et al. (eds.), Remedies against Immunity?, Beiträge zum ausländischen öffentlichen Recht und Völkerrecht 297, https://doi.org/10.1007/978-3-662-62304-6_16
} 


\section{Jurisdictional Immunities, or a Formally Strong German Position}

On the international plane, Germany has as strong a position as one could wish for. In its 2012 Jurisdictional Immunities Judgment, the International Court of Justice (ICJ) in unambiguous terms found Italy responsible for a threefold violation of the customary principles of state immunity vis-à-vis the Federal Republic of Germany: by allowing civil claims against Germany in the first place; by taking measures of constraint against Villa Vigoni, which serves a non-commercial government purpose; and by declaring enforceable in Italy decisions of Greek courts upholding civil claims against Germany. ${ }^{1}$ Nevertheless, in two of the judgment's 139 paragraphs the ICJ voiced 'surprise' and 'regret' that 'Germany decided to deny compensation' to the great majority of Italian World War II (WWII) Military Internees (IMIs) and pointed out that claims arising from their treatment 'could be the subject of further negotiation involving the two States concerned, with a view to resolving the issue'. Legally speaking, however, the position taken by the Court was so clear that several commentators saw a missed opportunity for allowing future developments of the law of state immunity in cases of grave breaches of human rights. ${ }^{3}$

The ICJ did not stop here. By fourteen votes to one it found that 'the Italian Republic must, by enacting appropriate legislation, or by resorting to other methods of its choosing, ensure that the decisions of its courts and those of other judicial authorities infringing the immunity which the Federal Republic of Germany enjoys under international law cease to have effect'. ${ }^{4}$ Neither under the ICJ Statute nor under general international law can Italy invoke provisions of its internal law as justification for its failure to conform with the judgment. This would run counter to

\footnotetext{
${ }^{1}$ ICJ, Jurisdictional Immunities of the State (Germany v Italy: Greece intervening), Judgment of 3 February 2012, ICJ Reports 2012, 99, para 139.

${ }^{2}$ Ibid, paras 99; 104.

${ }^{3}$ See, eg, Carlos Esposito, 'Jus Cogens and Jurisdictional Immunities of States at the International Court of Justice: "A Conflict Does Exist”, Italian Yearbook of International Law 21 (2011), 161-174; Marco Calisto, 'Jurisdictional Immunities of the State: Germany v Italy before the ICJ from an Italian Perspective', German Yearbook of International Law 55 (2012), 319-343; Francesco Francioni, 'From Utopia to Disenchantment: The Ill Fate of "Moderate Monism" in the ICJ Judgment on the Jurisdictional Immunities of the State', European Journal of International Law 23 (2012), 1125-1132; Sangeeta Shah, 'Jurisdictional Immunities of the State: Germany v Italy', Human Rights Law Review 12 (2012), 555-573; Kimberley Trapp/Alex Mills, 'Smooth Runs the Water where the Brook is Deep: The Obscured Complexities of Germany v Italy', Cambridge Journal of International and Comparative Law 1 (2012), 153-168; Michael Bothe, 'Remedies of Victims of War Crimes and Crimes against Humanities: Some Critical Remarks on the ICJ's Judgment on the Jurisdictional Immunity of States', in Anne Peters/Evelyne Lagrange/Stefan Oeter/Christian Tomuschat (eds), Immunities in the Age of Global Constitutionalism (Leiden: Brill 2015), 99-115. In a similar vein, Markus Krajewski/Christopher Singer, 'Should Judges be Front-Runners? The ICJ, State Immunity and the Protection of Fundamental Human Rights', Max Planck Yearbook of United Nations Law 16 (2012), 1-34.
}

${ }^{4}$ ICJ, Jurisdictional Immunities (n 1), para 139, sub 4. 
the customary rule codified in Article 27 of the Vienna Convention of the Law of Treaties, according to which a state 'may not invoke the provisions of its internal law as justification for its failure to perform a treaty'. Some scholarly creativity notwithstanding, there can be little doubt that Sentenza 238/2014 is in clear contradiction to Italy's obligations under the ICJ Statute, thus adding to the violation of the principle of state immunity itself. ${ }^{5}$

Theoretically, Germany could therefore appeal a second time to the ICJ in order to challenge the 2014 judgment by the Corte Costituzionale. ${ }^{6}$ While the ICJ in 2012 expressly rejected Germany's claim for a guarantee of non-repetition, as it saw no indication that Italy would not comply with the judgment, ${ }^{7}$ the Court could probably be less reluctant this time. Germany might even ask the ICJ for an 'equitable satisfaction'. Though unprecedented, it seems at least arguable that the Italian Constitutional Court's express order not to respect the 2012 judgment corresponds to the situation provided for in Article 30 of the European Convention on Dispute Settlement, namely that one party's municipal law does not fully permit the execution of an ICJ judgment. A point of conjecture is how the ICJ would assess the fact that there is less a dispute between the German and Italian governments than between both respective governments and the Italian judiciary. ${ }^{8}$ However, as long

\footnotetext{
${ }^{5}$ Filippo Fontanelli, 'I know it's wrong but I just can't do right: First impressions on judgment no. 238 of 2014 of the Italian Constitutional Court', VerfBlog, (27 October 2014), available at https://verfassungsblog.de/know-wrong-just-cant-right-first-impressions-judgment-238-2014-ital ian-constitutional-court/; Robert Kolb, 'The Relationship between the International and the Municipal Legal Order: Reflections on the Decision no 238/2014 of the Italian Constitutional Court', Questions of International Law: Zoom Out 2 (2014), 5-16; Anne Peters, 'Let Not Triepel Triumph-How To Make the Best Out of Sentenza No. 238 of the Italian Constitutional Court for a Global Legal Order', EJIL Talk!, (22 December 2014), available at www.ejiltalk.org/let-not-triepeltriumph-how-to-make-the-best-out-of-sentenza-no-238-of-the-italian-constitutional-court-for-aglobal-legal-order-part-i/; Karin Oellers-Frahm, 'Das italienische Verfassungsgericht und das Völkerrecht-eine unerfreuliche Beziehung', Europäische Grundrechte-Zeitschrift 42 (2015), 8-16. A more positive assessment 'as a contribution to a dialectic and normative learning process between a revolutionary and emancipatory Kantian constitutional mindset and a conservative and evolutionary managerial mindset' is offered by Felix Würkert, 'Historische Immunität?', Archiv des Völkerrechts 53 (2015), 90-120. Positive reception also by Riccardo Pisillo Mazzeschi, 'Access to Justice in Constitutional and International Law: The Recent Judgment of the Italian Constitutional Court', Italian Yearbook of International Law 24 (2015), 9-23, stressing the need to strengthen the international (!) human right of access to justice. Concurring, Gianluigi Palombella, 'German War Crimes and the Rule of International Law', Journal of International Criminal Justice 14 (2016), 607-613.

${ }^{6}$ Arguably, it is not the judgment in itself, but only its application by the Italian judiciary which constitutes a direct violation of international legal obligations: Massimo Iovane, 'The Italian Constitutional Court Judgment No. 238 and the Myth of the "Constitutionalization" of International Law', Journal of International Criminal Justice 14 (2016), 595-605.

${ }^{7}$ ICJ, Jurisdictional Immunities (n 1), para 138.

${ }^{8}$ Karin Oellers-Frahm, 'A Never-Ending Story: The International Court of Justice-The Italian Constitutional Court-Italian Tribunals and the Question of Immunity', Heidelberg Journal of International Law 76 (2016), 193-202; see also Paolo Palchetti, chapter 'Right of Access to (Italian) Courts über alles?', in this volume. Cf, in general, Ingrid Wuerth, 'International Law in Domestic
} 
as Germany's immunity from enforcement measures is still respected by Italian authorities, the lack of clear damage requiring 'equitable satisfaction' might turn this into a moot point altogether.

\section{Trapped in Contradictions, or the Ambivalence of Dualism}

Even if Germany could successfully claim satisfaction before the ICJ, and even if it were to distribute said satisfaction to the victims of German WWII atrocities as a sign that it does not oppose compensation as such, the question remains whether such a move seems at all advisable. Because of its own dualist stance towards international law, Germany is trapped in what one might call the 'ambivalence of dualism'.

The Corte Costituzionale based its act of disobedience on basic tenets of the Italian Constitution (the so-called dottrina dei controlimiti), especially its guarantee of human rights and access to justice. ${ }^{9}$ Both, however, are also foundational elements of the German constitutional order-protected by Article 79(3) of the Basic Law even against constitutional amendments. ${ }^{10}$ This has, in fact, been the legal basis for the Federal Constitutional Court's (FCC) Solange saga: since Germany could never transfer public authority to the EU in a manner violating the Constitution's core 'identity', the Bundesverfassungsgericht remains competent, in principle, to control Acts emanating from the EU on their compatibility with fundamental rights guarantees. ${ }^{11}$ That this might result in disregarding obligations from EU law is part and parcel.

While this conflict might have appeared solved since the Solange II armistice between the FCC and the European Court of Justice (ECJ), ${ }^{12}$ recent decisions clearly

Courts and the Jurisdictional Immunities of the State Case', Melbourne Journal of International Law 13 (2012), 819-837, at 829-835. Paolo Palchetti argues that the Constitutional Court should have deferred the matter to the political organs on the basis of an emerging international and constitutional obligation to exercise diplomatic protection, 'Can State Action on Behalf of Victims Be an Alternative to Individual Access to Justice in Case of Grave Breaches of Human Rights?', Italian Yearbook of International Law 24 (2015), 53-60. Taking a similar line, Enzo Cannizzaro, 'Jurisdictional Immunities and Judicial Protection: The Decision of the Italian Constitutional Court No. 238 of 2014', Rivista di diritto internazionale 98 (2015), 126-134, at 130-131; Francesco Francioni, 'Access to Justice and Its Pitfalls: Reparation for War Crimes and the Italian Constitutional Court', Journal of International Criminal Justice 14 (2016), 629-636.

${ }^{9}$ Corte Costituzionale, Judgment of 22 October 2014, No 238/2014, para 3.5.

${ }^{10}$ That the relevant provisions of the Italian Constitution also 'fall outside the scope of constitutional review' has been stated by the Corte Costituzionale, as well, (n 9), para 3.2.

${ }^{11}$ Bundesverfassungsgericht, Decision of 29 May 1974, 2 BvL 52/71, BVerfGE 37, 271 (Solange I).

${ }^{12}$ Bundesverfassungsgericht, Decision of 22 October 1986, 2 BvR 197/83, BVerfGE 73, 339 (Solange II). 
show that the Bundesverfassungsgericht is still prepared to disobey international and supranational obligations on the basis of internal constitutional principles. On 15 December 2015 the Court infamously accepted an unconditional 'treaty override' by the German Parliament, based on an 'absolute' interpretation of the democratic principle (an exception was made, however, for human rights treaties) ${ }^{13}$ even more pertinent is a decision, from the very same day, concerning the execution of a European arrest warrant. ${ }^{14}$ Here, the FCC amended its Solange jurisprudence. It argued a competence and even a duty of German courts to assess whether the accused will be inhumanely treated in the member state demanding extradition, according to the standard of Article 1(1) of the Basic Law. Should such treatment be reasonably expected, the extradition is not to be granted. As the case at hand concerned convictions in absentia, the FCC stressed that fundamental principles of due process directly derive from human dignity and could thus trump any supranational obligation to extradite. It makes no real difference that the FCC superficially avoided the conflict with the ECJ by stating that a correct application of EU law would lead to the same conclusion: $:^{15}$ the 'correct' application of EU law being in open contradiction to the ECJ's—admittedly flawed-Melloni judgment of $2013 .{ }^{16}$

Since the aforementioned case and that of Sentenza 238/2014 are unrelated, ${ }^{17}$ Germany would not be formally estopped from challenging before the ICJ a legal position it takes itself within the context of EU obligations; Germany would, however, be at least trapped in a principled contradiction (Wertungswiderspruch) should it attack on the international plane Sentenza 238/2014 as disregarding the

\footnotetext{
${ }^{13}$ Bundesverfassungsgericht, Decision of 15 December 2015, 2 BvL 1/12, BVerfGE 141, 1 (Treaty Override).

${ }^{14}$ Bundesverfassungsgericht, Decision of 15 December 2015, 2 BvR 2735/14, BVerfGE 140, 317 (European Arrest Warrant II/Identity Control).

${ }^{15}$ FCC, European Arrest Warrant II (n 14), 355-366. On a rhetorical level, however, the German court's approach might at least be seen as inviting judicial dialogue-what the Italian court's Sentenza did not; cf Kolb, 'The international and the municipal legal order' (2014) (n 5), at 6 ('a high peak of a new form of robust dualism'). Also critical towards Sentenza 238/2014 for this reason, Raffaela Kunz, 'The Italian Constitutional Court and "Constructive Contestation": A Miscarried Attempt?', Journal of International Criminal Justice 14 (2016), 621-627; see also, Raffaela Kunz, chapter 'Teaching the World Court Makes a Bad Case', in this volume. The ECJ has, in fact, taken up the 'invitation' in its judgment of 5 April 2016, C-404/15 and C-659/15 PPU (Aranyosi and Căldăraru), ECLI:EU:C:2016:198.

${ }^{16}$ ECJ, Melloni, Judgment of 26 February 2013, C-399/11, ECLI:EU:C:2013:107. As to the incompatibility of both decisions see, eg, Christopher Bilz, 'Konfrontation statt Kooperation? "Solange III" und die Melloni-Entscheidung des EuGH', Juwiss Blog, (15 March 2016), available at www.juwiss.de/26-2016/.

${ }^{17}$ It might be interesting to note that Nazi criminals who were convicted for civilian massacres in Italy during WWII were generally tried in absentia. Germany over the years constantly refused extradition or to execute these judgments in Germany. See Antonio Sabino, 'Anno Giudiziario 2018: Intervento del Procuratore Generale Militare della Repubblica presso la Corte Militare di Appello' (1 March 2018), available at https://www.difesa.it/Giustizia_Militare/rassegna/ Bimestrale/2018/Documents/2_2018/3\%20Relazione\%20dott.\%20SABINO\%20PGMCMA.pdf, $1-44$, at $43-44$.
} 
ICJ's judgment. ${ }^{18}$ Like Italy, Germany takes the position that international-and even supranational ${ }^{19}$ —obligations must be disregarded should they collide with basic constitutional principles of domestic law; like Italy, Germany takes the position that due process is one of the grounds that justifies this kind of disobedience. To make this contradiction even more palpable: the European arrest warrant under German scrutiny had been issued-ironically-by Italy. ${ }^{20}$

\section{Germany and the Law \& Politics of History}

Germany is trapped in yet another contradiction: while German foreign policy has traditionally favoured a mildly progressive path in international law, laying special emphasis on the importance of human rights, ${ }^{21}$ the Distomo and Ferrini cases forced Germany into the role of an advocate of old-school interstate law. ${ }^{22}$ For obvious

\footnotetext{
${ }^{18}$ Concurring with Giuseppe Cataldi, 'A Historic Decision of the Italian Constitutional Court on the Balance between the Italian Legal Order's Fundamental Values and Customary International Law', Italian Yearbook of International Law 24 (2015), 37-52. Similarities in both courts' approaches (and that of the ECJ) are also pointed to by Michael Bothe, 'The Decision of the Italian Constitutional Court Concerning the Jurisdictional Immunities of Germany', Italian Yearbook of International Law 24 (2015), 25-36.

${ }^{19}$ Since the FCC generally acknowledges the primacy of EU law, it would demand even more compelling reasons for disobedience here. From a different angle, Alessandro Bufalini, chapter 'Waiting for Negotiations', in this volume, points out that compared to supranational law, disobeying international law might have an even more dangerous impact given the fragility of a legal system with only limited institutions for law enforcement. While this certainly carries some conviction, the present state of the EU seems not as robust as one might wish for, looking particularly at the rise of illiberalism and authoritarian policies in central and eastern Europe: see, eg, Jacques Rupnik, 'Surging Illiberalism in the East', Journal of Democracy 27 (2016), 77-87; R Daniel Kelemen, 'Europe's Authoritarian Equilibrium: Invoking Article 7 Against Poland Won't Be Enough', Foreign Affairs (22 December 2017), available at https://www.foreignaffairs.com/ articles/hungary/2017-12-22/europes-authoritarian-equilibrium.

${ }^{20} \mathrm{Cf}$ FCC, European Arrest Warrant II, (n 14), 361-364, citing the extensive jurisprudence of the European Court of Human Rights concerning trials in absentia.

${ }^{21}$ For a closer analysis, see Thomas Jäger/Alexander Höse/Kai Oppermann (eds), Deutsche Außenpolitik (Wiesbaden: Springer VS $2^{\text {nd }}$ ed 2011); Philip Liste, Völkerrecht-Sprechen: Die Konstruktion demokratischer Völkerrechtspolitik in den USA und der Bundesrepublik Deutschland (Baden-Baden: Nomos 2012); Michael Staack, 'Die Außenpolitik der Bundesrepublik Deutschland', in Michael Staack (ed), Einführung in die Internationale Politik. Studienbuch (Munich: Oldenbourg $5^{\text {th }}$ ed 2012), 213-261.

${ }^{22}$ In parenthesis, it might be mentioned that Italy is faced with a comparable situation concerning its stand towards the functional immunity of state officials in the Enrica Lexie case; cf Douglas Guilfoyle, 'Shooting fishermen mistaken for pirates: Jurisdiction, immunity and State responsibility', EJIL Talk!, (2 March 2012), available at www.ejiltalk.org/shooting-fishermen-mistaken-forpirates-jurisdiction-immunity-and-state-responsibility/; Hari Sankar, 'Jurisdictional and Immunity Issues in the Story of Enrica Lexie: A Case of Shoot \& Scoot turns around!', EJIL Talk!, (25 March 2013), available at www.ejiltalk.org/jurisdictional-and-immunity-issues-in-the-story-of-enricalexie-a-case-of-shoot-scoot-turns-around/.
} 
reasons, Germany tries to keep its history out of foreign courtrooms. That the Federal Government, when declaring acceptance of the ICJ's compulsory jurisdiction according to Article 36(2) of the Statute in 2008, included the-admittedly widely used-limitation to 'disputes arising after the present declaration' does not therefore come as a surprise.

It would be a misrepresentation to see this as an unwillingness to bear responsibility for atrocities committed by Germans during the Nazi period. At a political level, Germany is generally prepared to accept that responsibility, not only symbolically but financially also. ${ }^{23}$ From 1956 to the end of 2013, Germany paid a total of $€ 71$ billion in reparations to surviving victims of National Socialism (NS). ${ }^{24}$ However, the patchwork of instruments set up soon after the foundation of the Federal Republic of Germany (which understood itself — contrary to the German Democratic Republic - as successor to the German Reich, and thus accepted legal responsibility) was very much characterized by selectivity. ${ }^{25}$ Lobbyists, pressure groups, or a lack thereof, and the rise of the Cold War left their mark on the outcome. ${ }^{26}$ The central element of the diverse set of reparation instruments, the Federal Compensation Act (Bundesentschädigungsgesetz) of 1956 and amended in 1965, excluded foreign NS victims (with a later exception for Jewish emigrants from eastern Europe). Their reparation was primarily left to the interstate level. Individual titles to reparation could be introduced by way of national legislation, but only if the Federal legislator chose to do so. This position has been upheld in recent years by the FCC when dealing with—eventually unsuccessful—claims of former forced labourers and war crime victims. $^{27}$

\footnotetext{
${ }^{23} \mathrm{Cf}$ the assessments by Dinah Shelton, Remedies in International Human Rights Law (Oxford: OUP $3^{\text {rd }}$ ed 2015), 181; Ariel Colonomos/Andrea Armstrong, 'German Reparations to the Jews after World War II: A Turning Point in the History of Reparations', in Pablo de Greiff (ed), The Handbook of Reparations (Oxford: OUP 2006), 391-417, at 411.

${ }^{24}$ Joachim Käppner, 'Summe der Schande', Süddeutsche Zeitung (17 March 2015); Christoph Schult, 'Stunde der Bewährung', Der Spiegel Geschichte 2 (2015), 120-123. For a detailed overview on all relevant compensatory measures, see Bericht der Bundesregierung über Wiedergutmachung und Entschädigung für nationalsozialistisches Unrecht sowie über die Lage der Sinti, Roma und verwandter Gruppen, Deutscher Bundestag, Drucksache 10/6287 (31 October 1986) and Federal Ministry of Finance, Compensation for National Socialist Injustice: Indemnification Provisions, May 2019, available at https://www.bundesfinanzministerium.de/Content/EN/ Standardartikel/Press_Room/Publications/Brochures/2018-08-15-entschaedigung-ns-unrecht-engl. html.

${ }^{25}$ For a closer analysis, see Andreas von Arnauld, 'Damages for the Infringement of Human Rights in Germany', in Ewa Bagińska (ed), Damages for Violations of Human Rights: A Comparative Study of Domestic Legal Systems (Berlin/Heidelberg/New York: Springer 2015), 101-135, at 121-124. See also Riccardo Pavoni, chapter 'A Plea for Legal Peace', and Francesco Francioni, chapter 'Overcoming the Judicial Conundrum', in this volume.

${ }^{26}$ Walter Schwarz, 'Das Recht der Wiedergutmachung und seine Geschichte', Juristische Schulung 26 (1986), 433-440; Hans Günter Hockerts, 'Wiedergutmachung in Deutschland: Eine historische Bilanz 1945-2000', Vierteljahrshefte für Zeitgeschichte 49 (2001), 167-214.

${ }^{27}$ Bundesverfassungsgericht, Decision of 13 May 1996, 2 BvL 33/93, BVerfGE 94, 315 (Forced Labourers); Chamber Decision of 28 June 2004, 2 BvR 1379/01, Neue Juristische Wochenschrift
} 
While this jurisprudence conforms well to the traditional and still prevailing view in public international law, ${ }^{28}$ reparation at the interstate level has had its flaws, too. ${ }^{29}$ In order to support the Federal Republic of Germany in its political and economic recovery, its western partners agreed in Article 5(2) of the London Agreement on German External Debts to defer the '[c]onsideration of claims arising out of the second World War by countries which were at war with or were occupied by Germany during that war, and by nationals of such countries, against the Reich and agencies of the Reich (...) until the final settlement of the problem of reparation'. ${ }^{30}$ This clause was widely understood as a moratorium on claims against Germany until the conclusion of a peace treaty. ${ }^{31}$ However, only some of the states that could have claimed reparation were represented in the negotiations. ${ }^{32}$

During the 1960s, Germany concluded lump sum agreements on reparations with 11 western European countries, among them Italy. Payments to Italian citizens who were subjected to NS persecution were covered by a bilateral treaty of 2 June $1961^{33}$ on the basis of which Germany paid at that time DM (Deutsche Mark) 40 million to

(2004), 3257; Chamber Decision of 15 February 2006, 2 BvR 1476/03, Neue Juristische Wochenschrift (2006), 2542, at 2543; Albrecht Randelzhofer/Oliver Dörr, Entschädigung für Zwangsarbeit? Zum Problem individueller Entschädigungsansprüche von ausländischen Zwangsarbeitern während des Zweiten Weltkrieges gegen die Bundesrepublik Deutschland (Berlin: Duncker \& Humblot 1994); Hugo J Hahn, 'Individualansprüche auf Wiedergutmachung von Zwangsarbeit im Zweiten Weltkrieg: Das Entschädigungsgesetz vom 2.8.2000', Neue Juristische Wochenschrift 53 (2000), 3521-3526.

${ }^{28} \mathrm{Cf}$, even for present-day violations of international humanitarian law, Emanuela-Chiara Gillard, 'Reparation for violations of international humanitarian law', International Review of the Red Cross 85 (2003), 529-554; Roland Bank, 'Is There a Substantive Right to Compensation for Individual Victims of Armed Conflicts against a State under International Law?', German Yearbook of International Law 49 (2006), 367-412; Philipp Stöckle, 'Victims Caught Between a Rock and a Hard Place: Individual Compensation Claims against Troop-Contributing States', Die FriedensWarte/Journal of International Peace and Organization 88 (2013), 119-141; Christian Tomuschat, 'State Responsibility and the Individual Right to Compensation Before National Courts', in Andrew Clapham/Paolo Gaeta (eds), Oxford Handbook of International Law in Armed Conflict (Oxford: OUP 2014), 811-839; Emily L Camins, 'Needs or Rights? Exploring the Limitations of Individual Reparations for Violations of International Humanitarian Law', International Journal of Transitional Justice 10 (2016), 126-145.

${ }^{29}$ Helmut Rumpf, 'Die deutsche Frage und die Reparationen', Heidelberg Journal of International Law 33 (1973), 344-371, at 354-355; Hans Günter Hockerts, 'Wiedergutmachung in Deutschland 1945-1990: Ein Überblick', Aus Politik und Zeitgeschichte 63(25/26) (2013), 15-20.

${ }^{30}$ Agreement on German External Debts, 27 February 1953, UNTC No 4764 (London Debt Agreement).

${ }^{31}$ That peace treaty never came into being. Functionally, the Treaty on the Final Settlement with Respect to Germany, 12 September 1990, 1696 UNTS 115 (Two-plus-Four Treaty), which paved the way for German reunification, is widely regarded as the equivalent of such a treaty.

${ }^{32}$ Though Italy was among the signatories of the London Agreement, the negotiations were mostly conducted by the Tripartite Commission on German Debts, ie France, the UK, and the US.

${ }^{33}$ Agreement between the Federal Republic of Germany and Italy on the Compensation for Italian Nationals Subjected to National-Socialist Measures of Persecution (Bonn, 2 June 1961), German and Italian version published in Bundesgesetzblatt II 5 July 1963 No 22, 791. 
Italy. It has been the position of the German government until today that this treaty was meant to cover all individual claims, even though hundreds of thousands ${ }^{34}$ of IMIs and other victims of German wartime action were by definition excluded from the notion of 'persecution'. ${ }^{35}$ Without going into detail, given the wide-reaching mediatisation of the individual in international law in 1961, it would be reasonable to argue that with this treaty both states agreed to limit the circle of beneficiaries, for whose suffering Italy would demand and receive compensation from Germany, to those groups covered by the 1961 treaty. It has to be borne in mind that in Article 77 (4) of the 1947 Peace Treaty with the Allied Powers, ${ }^{36}$ Italy -also on behalf of its citizens - had already waived all potential rights to compensation against Germany concerning 'claims for loss or damage arising during the war'. In another bilateral treaty of 2 June 1961, the so-called Globalabkommen, Italy agreed vis-à-vis the Federal Republic of Germany to waive all claims related to the period between 1 September 1939 and 8 May 1945 (Article 2) - against payment of a further DM40 million. ${ }^{37}$ On the surface, the situation seems settled between Germany and Italy.

\section{Unsettling Settlements: Growing Discontent}

Yet, over the last 15-20 years, there has been a growing discontent with this final settlement, or Schlussstrich approach, for three reasons. Firstly, there are the inherent limitations of the 1961 treaty that excluded IMIs from the notion of 'victim'. Though their treatment might not formally have been in violation of the laws applicable in the 1940s, their fate at least prompted — or even necessitated — a change to these laws in the 1949 Geneva Conventions: for example, Article 4A(3) of the Third Geneva Convention, in granting prisoner-of-war status for 'Members of regular armed forces who profess allegiance to a government or an authority not recognized by the

\footnotetext{
${ }^{34}$ While the exact number is not undisputed, most independent sources estimate that there were around 600,000 IMIs forced to work in Germany. See, eg, Bob Moore, 'Enforced Diaspora: The Fate of Italian Prisoners of War during the Second World War?', War in History 22 (2015), 174-190, at 184; and Deutsch-Italienische Historikerkommission, 'Bericht der von den Außenministern der Bundesrepublik Deutschland und der Italienischen Republik am 28.3.2009 eingesetzten Deutsch-Italienischen Historikerkommission', (July 2012), available at www. villavigoni.it/contents/files/Abschlussbericht.pdf, 1-180, at 33.

${ }^{35}$ Art 1(1) limits compensation to those 'persecuted on grounds of race, religion, or ideology' ('aus Gründen der Rasse, des Glaubens oder der Weltanschaung'/'per ragione di razza, fede o ideologia '). Arguably, one might view the IMIs as covered by persecution for ideological reasons; this, however, was presumably not how that clause was understood by the parties in 1961 or later. ${ }^{36}$ Treaty of Peace with Italy, 10 February 1947, 49 UNTS 3.

${ }^{37}$ Agreement between the Federal Republic of Germany and Italy on the Settlement of Certain Property-Related, Economic and Financial Questions (Bonn, 2 June 1961), German and Italian version published in Bundesgesetzblatt II 26 June 1963, 668.
} 
Detaining Power', was explicitly meant to address the situation of IMIs. ${ }^{38}$ So there is a strong moral claim by those victims to be included in any given compensation scheme, even though, legally, the principles of non-retroactivity of international legal obligations and of mediatisation of the individual through its national state prove to be gatekeepers to the sphere of law.

Secondly, there is a change to international law. The last 25 years have witnessed a shift in perspective: the formerly state-centred system has gradually opened up to include the individual and their rights. As a parallel development, the traditional concept of interstate responsibility has come under pressure to recognize the right of individuals to reparation for human rights violations. This has found expression in the 'Basic Principles and Guidelines on the Right to a Remedy and Reparation for Victims of Gross Violations of International Human Rights Law and Serious Violations of International Humanitarian Law', adopted by the UN General Assembly in December 2005. ${ }^{39}$ Claims for reparation do not only concern recent cases of human rights violations; on numerous occasions there have been attempts to redress historical injustices by way of compensation claims filed with national and international courts alike. ${ }^{40}$

This leads to the third reason for growing discontent. While, again, the principles of intertemporal law and the arguably 'soft' character of the UN Principles of 2005 shield Germany from claims based on international law, Germany has in some cases agreed to set up compensation schemes - though only for certain groups of victims, mostly due to political pressure. Before 1990, it had been only the Jewish Claims Conference, backed by Israel and the US, that had managed as early as 1952 to secure payments from the Federal Republic of Germany. After 1990, the victims of forced and slave labour in German companies during WWII managed to get their claims accepted. In order to avert the impending threat of judicial proceedings in the US, the Federal Government together with German trade and industry associations set up the Foundation 'Remembrance, Responsibility and Future' (Erinnerung, Verantwortung und Zukunft), with a funding figure of DM10 billion. ${ }^{41}$ However,

\footnotetext{
${ }^{38}$ For the historical background, see Jean de Preux et al, III Geneva Convention Relative to the Treatment of Prisoners of War: Commentary (Jean Pictet ed, Geneva: ICRC 1960), 61-64. Cf also Article 50 of the same Convention limiting the kind of work prisoners of war might be compelled to do by the detaining power.

${ }^{39}$ UN General Assembly, A/Res/60/147, 16 December 2005. See Theo van Boven, 'Victim's Right to a Remedy and Reparation: The New United Nations Principles and Guidelines', in Carla Ferstman/Mariana Goetz/Alan Stephens (eds), Reparations for Victims of Genocide, War Crimes and Crimes against Humanity: Systems in Place and Systems in the Making (Leiden: Nijhoff 2009), 19-40; José Brunner/Constantin Goschler/Norbert Frei, 'Die Globalisierung der Wiedergutmachung', Aus Politik und Zeitgeschichte (17 June 2013), 23-30.

${ }^{40}$ Shelton, Remedies 2015 (n 23), 263-278.

${ }^{41}$ Roland Bank, 'New Programs for Payments to Victims of National Socialist Injustice', German Yearbook of International Law 44 (2003), 307-352; Bardo Fassbender, 'Compensation for Forced Labour in WWII: The German Compensation Law of 2 August 2000', Journal of International Criminal Justice 3 (2005), 243-252. See also Riccardo Pavoni, chapter 'A Plea for Legal Peace', Stefan Kadelbach, chapter 'State Immunity, Individual Compensation for Victims of Human Rights
} 
on the basis of a controversial distinction, Italian forced labourers were by and large excluded from that scheme. Keeping this in mind, it must have come as another setback that in 2015 Germany agreed to a voluntary payment to surviving former Soviet prisoners of war. ${ }^{42}$ Though only symbolic in amount (a mere $€ 2,500$ per victim), this at least signals a willingness on Germany's part to accept responsibility and to recognize the recipient as a victim. Such a recognition was belatedly extended in 2016 to IMIs - in the form of a memorial site and an exhibition sponsored by the German government. ${ }^{43}$ Without wanting to criticize these well-designed and thoughtful mementos, other than their fellow sufferers, the IMIs still remain outside any financial compensation scheme, and crucially they have not been included in the process of deciding on the most adequate way to address the historical wrongs they experienced.

\section{Unmaking History: Possible Solutions}

In an answer to a parliamentary question, the German Federal Government stated in March 2016 that Italy remains obliged to observe the ICJ judgment of February 2012 and that it does not intend at the moment to institute further proceedings against Italy, while nonetheless reserving the right to do so. ${ }^{44}$ In substance, the German government repeated its position that, as far as Italian citizens are concerned, all matters of compensation had been dealt with comprehensively in the 1961 Treaties. Legally speaking, this position is sound. Sometimes, however, relying on law-or a certain legal framing of a problem-misses one of the law's central objectives: to settle disputes. Behind the legal concepts of state immunity, ius cogens, mediatisation, and intertemporality lies a yet unresolved conflict: that of the WWII victims 'in oblivion'. The IMIs and others that suffered from German wartime action have been doubly denied recognition as victims: diachronically, in that their suffering has been treated as lawful under the rules applicable during WWII while it would be illegal today under the amended Geneva rules-the injustices of non-retroactivity; synchronically, by excluding them from the notion of 'victims' in the 1961 treaty; and again, by not offering them a compensation scheme, which was done, for example, for other forced labourers and the former Soviet prisoners of war-the injustices of differentiation. While formally applied correctly, the rule of

\footnotetext{
Crimes, and Future Prospects', and Filippo Fontanelli, chapter 'Sketches for a Reparation Scheme', in this volume.

${ }^{42} \mathrm{Cf}$ Richtlinie über eine Anerkennungsleistung an ehemalige sowjetische Kriegsgefangene, 30 September 2015, Bundesanzeiger AT 14.10.2015 B1. Cf also Jörg Luther, chapter "A Story of "Trials and Errors" that Might Have No Happy End' and Giovanni Boggero/Karin Oellers-Frahm, chapter 'Between Cynicism and Idealism', in this volume.

${ }^{43}$ See, inter alia, Oellers-Frahm, 'A Never-Ending Story' 2016 (n 8), 202.

${ }^{44}$ Deutscher Bundestag, Drucksache 18/7852, 10 March 2016. See also Drucksache 18/3492, 9 December 2014.
} 
non-retroactivity of law(s) turns out to be too one-dimensional for legally assessing the historical past. While it certainly has a reasonable moral basis in cases of criminal accountability (namely, the principle nulla poena sine lege praevia), in cases of state responsibility it is unable to grasp that when raising historical claims, the claimants do not mean history but the present. They are not arguing for correcting a historic record for historiography's sake. The question is how today's law accommodates the needs of those who still suffer from historic legal discrimination-or even legal annihilation. Once these exclusionary rules have been overcome, they should no longer determine the legal position of those who suffered from them.

I do not intend to argue for the opening of Pandora's box by allowing individual claims for compensation based on historical wrongdoings. There are inherent dangers in such a concept. Judges are not historians; they are, to quote Robert Cover, 'people of violence' whose decrees on historical truth might turn out even more exclusionary and difficult to revise than historical narratives outside the courtroom. ${ }^{45}$ What is more, adjudicating history might prove bottomless once one goes further back, with claims relating to early colonialism and beyond. However, in most of the recent cases of 'history taken to court,' compensation is but a secondary aim, the primary aim being to make the voice of the victims heard, allowing space for them to 'tell their own story' as a counter-narrative to the hegemonic discourse of the former oppressors. ${ }^{46}$ Courts are turned into fora to make one's story heard-and this process is used as leverage to exert pressure on the political system to listen.

If the law is to solve conflicts and serve justice, it should provide means to address this need. Elsewhere, and in the context of German colonial history, I have suggested an obligatio de negotiando following from the breach of fundamental ethical principles of law in force already at the time of the original violation. ${ }^{47}$ In our case, this could be the Martens clause, with its appeal to the 'laws of humanity and the dictates of public conscience'. ${ }^{48}$ The treatment of 'military internees', the killing of members of resistance movements and of hostages has surely shaken the public conscience, paving the way for the amendments to the Geneva Conventions in

\footnotetext{
${ }^{45}$ Robert Cover, 'Nomos and Narrative', Harvard Law Review 97 (1983-1984), 4-68, at 53. David J Bederman, 'Foreign Office International Legal History', in Matthew Craven/Malgosia Fitzmaurice/ Maria Vogiatzi (eds), Time, History and International Law (Leiden: Brill 2007), 43-64, at 62-63, reminds us of the 'enduring truth', 'that legal history and legal truth are not always the same thing, and they certainly cannot be ascertained by the same means and modalities'.

${ }^{46} \mathrm{Cf}$ generally Richard Delgado, 'Storytelling for Oppositionists and Others', Michigan Law Review 87 (1989), 2411-2441; Milner S Ball, 'Stories of Origin and Constitutional Possibilities', Michigan Law Review 87 (1989), 2280-2319; Peter Fitzpatrick, The Mythology of Modern Law (London/New York: Routledge 1992); Andreas von Arnauld, 'Norms and Narrative', German Law Journal 18 (2017), 309-329, at 317-320.

${ }^{47}$ von Arnauld, 'Damages for Infringement' 2015 (n 25), 128.

${ }^{48}$ Hague Convention (IV) Respecting the Laws and Customs of War on Land, 18 October 1907, Preamble, para 8.
} 
$1949^{49}$ - a prime example of Durkheim's colère publique in action. ${ }^{50}$ Arguably, even if not formally violating specific provisions of the law of warfare in force at the time $^{51}$ (different from other atrocities committed by Germans during WWII), the treatment of IMIs at least constituted a violation of fundamental ethical principles incorporated through the Martens clause into the sphere of legal obligations. From these 'soft' obligations one might derive not a strict obligation to compensate but a procedural obligation to engage in negotiations as a means of satisfaction. These negotiations are open-ended, that is, they might not necessarily lead to financial compensation, but could also lead to setting up a commemorative scheme like the one introduced in 2016. This, however, should not be decided over the heads of the victims themselves.

If one takes this approach seriously, the victims have to be included in these negotiations, especially since Italy in 1947 and 1961 was prepared to waive their interests. ${ }^{52}$ That, generally, violations of humanitarian law and principles do not give rise to individual claims for reparation could be disregarded once the responsible state decides to lift the veil of mediatisation for some groups of victims by setting up reparation programmes for individual claimants (the above-mentioned 'injustice of differentiation'). That we are dealing with past wrongs and injustices does not alter the fact that the decision (not) to enter into serious talks about the most adequate form of compensation is to be taken in the present. This decision has to conform to today's moral and legal standards. ${ }^{53}$ Non-retroactivity of the law is one of those standards (standards of present-day justice, that is). However, that its undifferentiated use might undermine the law's capability of solving present-day

\footnotetext{
${ }^{49}$ See n 38 .

${ }^{50}$ Emile Durkheim, De la division du travail: Etude sur l'organisations des sociétés supérieures (Paris: Felix Alcan 1893), 109-112. On Durkheim's influence on the concept of solidarity in international law in the writings of Georges Scelle, see Andreas Fischer-Lescano, 'Global Constitutional Struggles: Human Rights between colère publique and colère politique', in Wolfgang Kaleck/Michael Ratner/Tobias Singelnstein/Peter Weiss (eds), International Prosecution of Human Rights Crimes (Berlin/Heidelberg/New York: Springer 2007), 13-27, at 24-27.

${ }^{51} \mathrm{Cf}$ de Preux, III Geneva Convention 1960 (n 38), 264-265, as to the different views of the belligerents under the 1929 Geneva Conventions.

${ }^{52}$ For a similar reason, Krajewski/Singer, 'Should Judges be Front-Runners?' 2012 (n 3), 31-33, argue de lege ferenda for an inclusion of victims in proceedings before the ICJ in cases of human rights abuses in order to include 'the missing voices'.

${ }^{53} \mathrm{Cf}$, mutatis mutandis, the-lesser known and received—second principle of intertemporal law as stated by Max Huber, in the Island of Palmas (Netherlands v US), Award of 4 April 1928, 2 UN Rep Intl Arb Awards, 829-871, at 845: 'As regards the question which of different legal systems prevailing at successive periods to be applied in a particular case (the so-called intertemporal law), a distinction must be made between the creation of rights and the existence of rights. The same principle which subjects the act creative of a right to the law in force at the time the right arises, demands that the existence of the right, in other words its continued manifestation, shall follow the conditions required by the evolution of law.' For a closer analysis, see Ulf Linderfalk, 'The Application of International Legal Norms Over Time: The Second Branch of Intertemporal Law', Netherlands International Law Review 58 (2011), 147-172.
} 
disputes, which_like practically all disputes_are rooted in the past, has hopefully been made plausible in this chapter.

Is Germany then legally obliged to open negotiations? Certainly not on the basis of a traditional reading of international and constitutional law. If one is prepared, however, to accept the idea of procedural rights and obligations following from violations of 'ethical-legal' norms and how they are being addressed today, Germany is, in fact and in law, obliged to offer serious talks to victims. For its participation in the historical wrongs - at this late point, merely mentioning Mussolini's Repubblica di Salò will have to suffice-and for its waiver of rights of Italian citizens, Italy ought to be included in the negotiations and in any compensation scheme. ${ }^{54}$ In following this path, the law would better live up to its claim of settling conflicts by addressing injustices.

\section{References}

Arnauld, Andreas von, 'Damages for the Infringement of Human Rights in Germany', in Ewa Bagińska (ed), Damages for Violations of Human Rights: A Comparative Study of Domestic Legal Systems (Berlin/Heidelberg/New York: Springer 2015), 101-135

Arnauld, Andreas von, 'Norms and Narrative', German Law Journal 18 (2017), 309-329

Ball, Milner S, 'Stories of Origin and Constitutional Possibilities', Michigan Law Review 87 (1989), 2280-2319

Bank, Roland, 'Is There a Substantive Right to Compensation for Individual Victims of Armed Conflicts against a State under International Law?', German Yearbook of International Law 49 (2006), 367-412

Bank, Roland, 'New Programs for Payments to Victims of National Socialist Injustice', German Yearbook of International Law 44 (2003), 307-352

Bederman, David J, 'Foreign Office International Legal History', in Matthew Craven/Malgosia Fitzmaurice/Maria Vogiatzi (eds), Time, History and International Law (Leiden: Brill 2007), 43-64

Bilz, Christopher, 'Konfrontation statt Kooperation? "Solange III" und die Melloni-Entscheidung des EuGH', Juwiss Blog, (15 March 2016), available at www.juwiss.de/26-2016/

Bothe, Michael, 'Remedies of Victims of War Crimes and Crimes against Humanities: Some Critical Remarks on the ICJ's Judgment on the Jurisdictional Immunity of States', in Anne Peters/Evelyne Lagrange/Stefan Oeter/Christian Tomuschat (eds), Immunities in the Age of Global Constitutionalism (Leiden: Brill 2015), 99-115

Bothe, Michael, 'The Decision of the Italian Constitutional Court Concerning the Jurisdictional Immunities of Germany', Italian Yearbook of International Law 24 (2015), 25-36

Boven, Theo van, 'Victim's Right to a Remedy and Reparation: The New United Nations Principles and Guidelines', in Carla Ferstman/Mariana Goetz/Alan Stephens (eds), Reparations for Victims of Genocide, War Crimes and Crimes against Humanity: Systems in Place and Systems in the Making (Leiden: Nijhoff 2009), 19-40

Brunner, José/Constantin Goschler/Norbert Frei, 'Die Globalisierung der Wiedergutmachung', Aus Politik und Zeitgeschichte (17 June 2013), 23-30

\footnotetext{
${ }^{54}$ See also Filippo Fontanelli, chapter 'Sketches for a Reparation Scheme', and Francesco Francioni, chapter 'Overcoming the Judicial Conundrum', in this volume.
} 
Calisto, Marco, 'Jurisdictional Immunities of the State: Germany v Italy before the ICJ from an Italian Perspective', German Yearbook of International Law 55 (2012), 319-343

Camins, Emily L, 'Needs or Rights? Exploring the Limitations of Individual Reparations for Violations of International Humanitarian Law', International Journal of Transitional Justice 10 (2016), 126-145

Cannizzaro, Enzo, 'Jurisdictional Immunities and Judicial Protection: The Decision of the Italian Constitutional Court No. 238 of 2014', Rivista di diritto internazionale 98 (2015), 126-134

Cataldi, Giuseppe, 'A Historic Decision of the Italian Constitutional Court on the Balance Between the Italian Legal Order's Fundamental Values and Customary International Law', Italian Yearbook of International Law 24 (2015), 37-52

Colonomos, Ariel/Andrea Armstrong, 'German Reparations to the Jews after World War II: A Turning Point in the History of Reparations', in Pablo de Greiff (ed), The Handbook of Reparations (Oxford: OUP 2006), 391-417

Cover, Robert, 'Nomos and Narrative', Harvard Law Review 97 (1983-1984), 4-68

Delgado, Richard, 'Storytelling for Oppositionists and Others', Michigan Law Review 87 (1989), 2411-2441

Durkheim, Emile, De la division du travail: Etude sur l'organisations des sociétés supérieures (Paris: Felix Alcan 1893)

Esposito, Carlos, 'Jus Cogens and Jurisdictional Immunities of States at the International Court of Justice: “A Conflict Does Exist”, Italian Yearbook of International Law 21 (2011), 161-174

Fassbender, Bardo, 'Compensation for Forced Labour in WWII: The German Compensation Law of 2 August 2000', Journal of International Criminal Justice 3 (2005), 243-252

Fischer-Lescano, Andreas, 'Global Constitutional Struggles: Human Rights between colère publique and colère politique', in Wolfgang Kaleck/Michael Ratner/Tobias Singelnstein/Peter Weiss (eds), International Prosecution of Human Rights Crimes (Berlin/Heidelberg/New York: Springer 2007), 13-27

Fitzpatrick, Peter, The Mythology of Modern Law (London/New York: Routledge 1992)

Fontanelli, Filippo, 'I know it's wrong but I just can't do right: First impressions on judgment no. 238 of 2014 of the Italian Constitutional Court', VerfBlog, (27 October 2014), available at https://verfassungsblog.de/know-wrong-just-cant-right-first-impressions-judgment-238-2014italian-constitutional-court/

Francioni, Francesco, 'Access to Justice and Its Pitfalls: Reparation for War Crimes and the Italian Constitutional Court', Journal of International Criminal Justice 14 (2016), 629-636

Francioni, Francesco, 'From Utopia to Disenchantment: The Ill Fate of "Moderate Monism" in the ICJ Judgment on The Jurisdictional Immunities of the State', European Journal of International Law 23 (2012), 1125-1132

Gillard, Emanuela-Chiara, 'Reparation for violations of international humanitarian law', International Review of the Red Cross 85 (2003), 529-554

Guilfoyle, Douglas, 'Shooting fishermen mistaken for pirates: Jurisdiction, immunity and State responsibility', EJIL Talk!, (2 March 2012), available at www.ejiltalk.org/shooting-fishermenmistaken-for-pirates-jurisdiction-immunity-and-state-responsibility/

Hahn, Hugo J, 'Individualansprüche auf Wiedergutmachung von Zwangsarbeit im Zweiten Weltkrieg: Das Entschädigungsgesetz vom 2.8.2000', Neue Juristische Wochenschrift 53 (2000), 3521-3526

Hockerts, Hans Günter, 'Wiedergutmachung in Deutschland 1945-1990: Ein Überblick', Aus Politik und Zeitgeschichte 63(25/26) (2013), 15-20

Hockerts, Hans Günter, 'Wiedergutmachung in Deutschland: Eine historische Bilanz 1945-2000', Vierteljahrshefte für Zeitgeschichte 49 (2001), 167-214

Iovane, Massimo, 'The Italian Constitutional Court Judgment No. 238 and the Myth of the "Constitutionalization" of International Law', Journal of International Criminal Justice 14 (2016), 595-605

Jäger, Thomas/Alexander Höse/Kai Oppermann (eds), Deutsche Außenpolitik (Wiesbaden: Springer VS $2^{\text {nd }}$ ed 2011) 
Käppner, Joachim, 'Summe der Schande', Süddeutsche Zeitung (17 March 2015)

Kelemen, R Daniel, 'Europe's Authoritarian Equilibrium: Invoking Article 7 Against Poland Won't Be Enough', Foreign Affairs (22 December 2017), available at https://www.foreignaffairs.com/ articles/hungary/2017-12-22/europes-authoritarian-equilibrium

Kolb, Robert, 'The Relationship between the International and the Municipal Legal Order: Reflections on the Decision no 238/2014 of the Italian Constitutional Court', Questions of International Law: Zoom Out 2 (2014), 5-16

Krajewski, Markus/Christopher Singer, 'Should Judges be Front-Runners? The ICJ, State Immunity and the Protection of Fundamental Human Rights', Max Planck Yearbook of United Nations Law 16 (2012), 1-34

Kunz, Raffaela, 'The Italian Constitutional Court and "Constructive Contestation": A Miscarried Attempt?', Journal of International Criminal Justice 14 (2016), 621-627

Linderfalk, Ulf, 'The Application of International Legal Norms Over Time: The Second Branch of Intertemporal Law', Netherlands International Law Review 58 (2011), 147-172

Liste, Philip, Völkerrecht-Sprechen: Die Konstruktion demokratischer Völkerrechtspolitik in den USA und der Bundesrepublik Deutschland (Baden-Baden: Nomos 2012)

Moore, Bob, 'Enforced Diaspora: The Fate of Italian Prisoners of War during the Second World War?', War in History 22 (2015), 174-190

Oellers-Frahm, Karin, 'A Never-Ending Story: The International Court of Justice-The Italian Constitutional Court-Italian Tribunals and the Question of Immunity', Heidelberg Journal of International Law 76 (2016), 193-202

Oellers-Frahm, Karin, 'Das italienische Verfassungsgericht und das Völkerrecht-eine unerfreuliche Beziehung', Europäische Grundrechte-Zeitschrift 42 (2015), 8-16

Palchetti, Paolo, 'Can State Action on Behalf of Victims Be an Alternative to Individual Access to Justice in Case of Grave Breaches of Human Rights?', Italian Yearbook of International Law 24 (2015), 53-60

Palombella, Gianluigi, 'German War Crimes and the Rule of International Law', Journal of International Criminal Justice 14 (2016), 607-613

Peters, Anne, 'Let Not Triepel Triumph-How To Make the Best Out of Sentenza No. 238 of the Italian Constitutional Court for a Global Legal Order', EJIL Talk!, (22 December 2014), available at www.ejiltalk.org/let-not-triepel-triumph-how-to-make-the-best-out-of-sentenzano-238-of-the-italian-constitutional-court-for-a-global-legal-order-part-i/

Pisillo Mazzeschi, Riccardo, 'Access to Justice in Constitutional and International Law: The Recent Judgment of the Italian Constitutional Court', Italian Yearbook of International Law 24 (2015), 9-23

Preux, Jean de et al, III Geneva Convention Relative to the Treatment of Prisoners of War: Commentary (Jean Pictet ed, Geneva: ICRC 1960)

Randelzhofer, Albrecht/Oliver Dörr, Entschädigung für Zwangsarbeit? Zum Problem individueller Entschädigungsansprüche von ausländischen Zwangsarbeitern während des Zweiten Weltkrieges gegen die Bundesrepublik Deutschland (Berlin: Duncker \& Humblot 1994)

Rumpf, Helmut, 'Die deutsche Frage und die Reparationen', Heidelberg Journal of International Law 33 (1973), 344-371

Rupnik, Jacques, 'Surging Illiberalism in the East', Journal of Democracy 27 (2016), 77-87

Sankar, Hari, 'Jurisdictional and Immunity Issues in the Story of Enrica Lexie: A Case of Shoot \& Scoot turns around!', EJIL Talk!, (25 March 2013), available at www.ejiltalk.org/jurisdictionaland-immunity-issues-in-the-story-of-enrica-lexie-a-case-of-shoot-scoot-turns-around/

Schult, Christoph, 'Stunde der Bewährung', Der Spiegel Geschichte 2 (2015), 120-123

Schwarz, Walter, 'Das Recht der Wiedergutmachung und seine Geschichte', Juristische Schulung 26 (1986), 433-440

Shah, Sangeeta, 'Jurisdictional Immunities of the State: Germany v Italy', Human Rights Law Review 12 (2012), 555-573

Shelton, Dinah, Remedies in International Human Rights Law (Oxford: OUP $3^{\text {rd }}$ ed 2015) 
Staack, Michael, 'Die Außenpolitik der Bundesrepublik Deutschland', in Michael Staack (ed), Einführung in die Internationale Politik. Studienbuch (Munich: Oldenbourg $5^{\text {th }}$ ed 2012), 213-261

Stöckle, Philipp, 'Victims Caught Between a Rock and a Hard Place: Individual Compensation Claims against Troop-Contributing States', Die Friedens-Warte/Journal of International Peace and Organization 88 (2013), 119-141

Tomuschat, Christian, 'State Responsibility and the Individual Right to Compensation Before National Courts', in Andrew Clapham/Paolo Gaeta (eds), Oxford Handbook of International Law in Armed Conflict (Oxford: OUP 2014), 811-839

Trapp, Kimberley/Alex Mills, 'Smooth Runs the Water where the Brook is Deep: The Obscured Complexities of Germany v Italy', Cambridge Journal of International and Comparative Law 1 (2012), 153-168

Wuerth, Ingrid, 'International Law in Domestic Courts and the Jurisdictional Immunities of the State Case', Melbourne Journal of International Law 13 (2012), 819-837

Würkert, Felix, 'Historische Immunität?', Archiv des Völkerrechts 53 (2015), 90-120

Open Access This chapter is licensed under the terms of the Creative Commons Attribution 4.0 International License (http://creativecommons.org/licenses/by/4.0/), which permits use, sharing, adaptation, distribution and reproduction in any medium or format, as long as you give appropriate credit to the original author(s) and the source, provide a link to the Creative Commons license and indicate if changes were made.

The images or other third party material in this chapter are included in the chapter's Creative Commons license, unless indicated otherwise in a credit line to the material. If material is not included in the chapter's Creative Commons license and your intended use is not permitted by statutory regulation or exceeds the permitted use, you will need to obtain permission directly from the copyright holder. 


\title{
Moving Beyond Judicial Conflict in the Name of the Pre-Eminence of Fundamental Human Rights
}

\author{
Valerio Onida
}

\begin{abstract}
Sentenza 238/2014 can be criticized insofar as it seems to ground Italy's refusal to comply with the Jurisdictional Immunities Judgment of the International Court of Justice on the basis of the right of access to a judge for the victims of the conduct of German armed forces during World War II. Indeed, the principle of state's immunity to the civil jurisdiction of other states regarding the conduct of their own armed forces does not in itself breach a victim's right of access to a judge, which theoretically in this case might also be granted by a German court. However, Sentenza 238/2014 has the merit of highlighting, in the specific case of the Italian Military Internees (IMIs), the violation of the victims' right to an effective judicial protection of their fundamental rights, given that German jurisdictions excluded every reparation that favoured IMIs. Such fundamental rights must prevail over the international rules relating to state immunity because, according to the supreme principles of the Italian constitutional order and to international law itself, fundamental human rights violations related to crimes against humanity must benefit from an effective protection. The impasse between Italy and Germany should be solved through a new joint initiative between the two governments (carried out ideally under a common understanding of the two Presidents of the Republic), which should examine the applicants' cases in order to grant them reparation. Though symbolic, such reparation will have an important moral dimension.
\end{abstract}

\section{Introduction}

The situation following the adoption of the 2012 International Court of Justice (ICJ) Judgment-which holds that the German state is not subject to the jurisdiction of Italian courts for proceedings brought by former Italian Military Internees (IMIs) or their families, and other victims of acts carried out by German armed forces in Italy

\footnotetext{
V. Onida $(\bowtie)$

University of Milan, Faculty of Law, Milan, Italy (emeritus)

e-mail: valerio.onida@oralex.eu 
after the armistice of September $1943^{1}$ —and the adoption of Judgment 238/2014 of the Italian Constitutional Court (ItCC), which ruled the Italian law purporting to implement the 2012 ICJ Judgment unconstitutional, ${ }^{2}$ is apparently unsolvable in terms of formal law. The conflict is not in fact between the Italian and the German governments but between an international court, by the rulings of which the states of the international community are bound, and a national constitutional court, the rulings of which are binding on the Italian government and legislature and are not subject to any form of appeal (Article 137(3) of the Italian Constitution).

\section{Quid Iuris or Quid Iustum?}

The ItCC did not deny that Italy is subject in general terms to a duty to abide by the judgments of the ICJ concerning the Italian state. However, it rejected the view that the provision of international law on which this particular ICJ Judgment was based (namely the exemption of the German state from Italian civil jurisdiction for acts carried out by German armed forces, even where these acts involved the commission of war crimes and crimes against humanity) could be applied in Italy and thus annulled the provision of Italian law, which had by contrast purported to assert this exemption in line with the 2012 ICJ Judgment. ${ }^{3}$

Thus, if we pose the question of quid iuris-namely, what is the rule of law that must apply in this case?-we cannot avoid establishing the existence of an irreconcilable conflict between international law and Italian law. In keeping with a 'dualist' conception of relations between the two legal systems, we would have to content ourselves with concluding that, in this case, the two systems do not express the same rule or stipulate any rule for harmonization but rather the two rules conflict irreconcilably with each other, and therefore offer different solutions to the specific disputes.

However, if we ask the question of quid iustum - namely, what would be a fair solution to this specific case?-we can no longer content ourselves with only noting the conflict between the two legal systems but must answer a different question: within the dispute between the Italian victims of crimes against humanity committed by German armed forces and the German state (legislature and judiciary), which has refused to recognize a right of redress to victims, should not the fundamental rights of the individual prevail over the rule providing for exemption from Italian jurisdiction, which has been inferred from international law?

This case in fact involves a conflict between two values: on the one hand, the need to grant immunity from jurisdiction to the actions of the armed forces of a state

\footnotetext{
${ }^{1}$ ICJ, Jurisdictional Immunities of the State (Germany v Italy: Greece intervening), Judgment, ICJ Reports 2012, 99, paras 79, 80, 91, 97, 101-103.

${ }^{2}$ Corte Costituzionale, Judgment of 22 October 2014, No 238/2014, para 4.1.

${ }^{3}$ ItCC, Judgment 238/2014 (n 2), para 4.1.
} 
operating within the territory of another state (and in their dealings with the nationals of that other state), based on the doctrine of state sovereignty and the characteristics of the state of war; on the other hand, the requirement to respect the fundamental rights of the persons involved. Nevertheless, defending the fundamental rights of individuals, including in particular those rights that we normally consider irreducible and inviolable, must inevitably prevail not only in moral terms but also from a legal standpoint (in terms of the universal law that humanity generally recognizes as a matter of principle, though frequently violated). This may be inferred for example from proclamations such as those set forth in Article 1 of the German Constitution, which proclaims the inviolability of human dignity, or in Article 15(2) of the European Convention on Human Rights, which prohibits any derogation, even during time of emergency, from the core fundamental rights to life and to the prohibition of torture and slavery.

\section{The Right to an Effective Judicial Protection}

The principle of prevalence of the fundamental human rights is worth both for international law and for domestic law and prevails over other norms, including constitutional provisions (for Italian law, this is expressed through the assertion that the supreme principles of the constitutional order prevail over any other provision, including those of constitutional law). Moreover, it is precisely in this vein that in Sentenza 238/2014 the ItCC refused to incorporate into Italian law rules that were at odds with the principle of prevalence of human fundamental rights.

It could be objected that, in this case, the ItCC did not expressly invoke rights such as the right to life or the prohibition of torture or slavery but the right to judicial protection, which it held to prevail over the principle of state immunity from the civil jurisdiction of other states in cases involving war crimes or crimes against humanity. However, the right to effective judicial protection is an 'instrumental' right, the guarantee of which is a prerequisite for the effective protection of other rights: to deny it when protection is sought for rights violated by crimes against humanity would be tantamount to denying these other rights.

It may be observed that the ItCC perhaps did not sufficiently stress that the case involved not the right to judicial protection in general, but the fundamental right to effective judicial protection for fundamental rights that were violated by crimes against humanity committed by German troops against IMIs and other similarly situated victims of Nazi crimes. ${ }^{4}$ In fact, considered in itself, the right to judicial protection could have also been guaranteed to the interested parties via access to a German court. The point is that the German courts, acting in accordance with

\footnotetext{
${ }^{4}$ ItCC, Judgment 238/2014 (n 2), paras 3.4, 3.5. For a different perspective, see Christian Tomuschat, chapter 'The Illusion of Perfect Justice', Alessandro Bufalini, chapter 'Waiting for Negotiations', and Sabino Cassese, chapter 'Recollections of a Judge', in this volume.
} 
German law, refused the claimants the right to any redress, by failing to allow them to benefit from compensation awarded to other classes of victims. ${ }^{5}$

Theoretically, it would have been possible for the Italian victims who had also brought an action before a German court to obtain judicial protection before those courts, perhaps according to a different interpretation of German law or even by a ruling by the German Federal Constitutional Court, ruling in the name of the very same supreme principles which the Italian court invoked in order to preclude the applicability of the 2012 ICJ Judgment. However, in view of the stance taken by the German legislature and courts, the effective judicial protection sought could only specifically be achieved through the disapplication-in this specific case-of the 2012 ICJ Judgment along with the Italian law requiring compliance with it.

This is not to negate the validity and effect of international law, as it were, from the perspective of 'nationalist' closure. In fact, both international law and state law (or at least the domestic law of states that have adhered to UN conventions on the protection of human rights and the prevention and punishment of war crimes ${ }^{6}$ ) cannot avoid recognizing the pre-eminence and hence the predominance of the principle of fundamental human rights protection: even where it conflicts with other legal principles, such as the principle of state immunity before the courts of another state regarding acts carried out by the armed forces of the first one in the territory of the second. In this area, absent any ad hoc international tribunal, a universal principle that guarantees effective judicial protection to victims must also apply before civil courts.

\section{Conclusion}

Since it is difficult to give a specific (quantitative) form to the right to compensation for damages against the German state in accordance with general national principles of civil law, it is clear that it would be appropriate, and in fact necessary, for a new agreement to be reached between the German and the Italian government, something that the ICJ itself stated would be desirable.

On the other hand, to leave the Italian courts to issue rulings against the German state whilst subsequently refusing to enforce these judgments, thereby separating the

\footnotetext{
${ }^{5}$ See Bundesverfassungsgericht, Order of 28 June 2004, 2 BvR 1379/01, BVerfGK 3, 277; Verwaltungsgericht Berlin, Judgment of 9 September 2004, 9 A 336.02. In this context, see also the Distomo cases where German courts refused to grant redress to Greek victims of World War II massacres: Bundesverfassungsgericht, Order of 15 February 2006, 2 BvR 1476/03, BVerfGK 7, 303. See also Andreas von Arnauld, chapter 'Deadlocked in Dualism', in this volume.

${ }^{6}$ See for instance International Covenant on Civil and Political Rights, 16 December 1966; Convention on the Non-Applicability of Statutory Limitations to War Crimes and Crimes Against Humanity, 26 November 1968.
} 
judicial recognition of the right from the question of enforcement, ${ }^{7}$ would not be a good solution. This would in fact amount to a hypocritical and formalist solution and would not resolve the conflict, which instead calls for a substantive and mutually agreed solution.

Within the framework of the new agreement, it would be possible for the two states to recognize that under the historical circumstances that led to the crimes in question they both bear some form of responsibility. ${ }^{8}$ It would also be possible to establish criteria for defining the status of 'victims', enabling the recognition of moral responsibilities and the quantification of the (largely symbolic) compensations due. I believe that those who have taken action before the Italian courts, as victims or as family members of victims, have done so not so much with the aim of securing financial redress-given that the damages suffered cannot be compensated-but also, and perhaps principally, with the purpose to get a moral recognition of their status as victims.

It would be highly desirable for a new agreement to be called for and promoted by the Heads of State of Italy and Germany acting in concert with each other in order to express at the highest level considerations rooted in the shared recognition (also within the common European context), of the same principles of respect for and protection of fundamental human rights that would serve as a basis and a justification for such an agreement. ${ }^{9}$

Open Access This chapter is licensed under the terms of the Creative Commons Attribution 4.0 International License (http://creativecommons.org/licenses/by/4.0/), which permits use, sharing, adaptation, distribution and reproduction in any medium or format, as long as you give appropriate credit to the original author(s) and the source, provide a link to the Creative Commons license and indicate if changes were made.

The images or other third party material in this chapter are included in the chapter's Creative Commons license, unless indicated otherwise in a credit line to the material. If material is not included in the chapter's Creative Commons license and your intended use is not permitted by statutory regulation or exceeds the permitted use, you will need to obtain permission directly from the copyright holder.

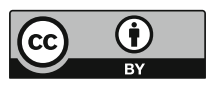

\footnotetext{
${ }^{7}$ See also Paolo Palchetti, chapter 'Right of Access to (Italian) Courts über alles?', and Giovanni Boggero/Karin Oellers-Frahm, chapter 'Between Cynicism and Idealism', in this volume.

${ }^{8}$ In fact, at the time the events occurred, there were two opposing governments in Italy: the legitimate government, which had signed the armistice along with the partisans fighting the German troops, and the Fascist Republic of Salò, which was allied with the Nazis. See also Andreas von Arnauld, chapter 'Deadlocked in Dualism', in this volume.

${ }^{9}$ See also Filippo Fontanelli, chapter 'Sketches for a Reparation Scheme', and Francesco Francioni, chapter 'Overcoming the Judicial Conundrum', in this volume.
} 


\title{
Between a Rock and a Hard Place: Italian Concerns Between Constitutional Rights and International Law
}

\author{
Andreas L. Paulus
}

\begin{abstract}
Sentenza 238/2014 has led to a sharp dissonance between the international law of state immunity as interpreted by the International Court of Justice (ICJ) and Italian constitutional law as understood and applied by the Corte Costituzionale. While the interpretation and application by the Italian Constitutional Court (ItCC) of the access-to-courts provision in the Italian Constitution may not have been inevitable, this does not remove the need for finding a solution to the stalemate between international and domestic law. On the one hand, the easy solution, namely that the rejection of German state immunity from jurisdiction does not necessarily remove immunity from execution into German property, appears unlikely to be accepted by the ItCC because it would give stones rather than bread to the complainants and render court access a futile exercise. On the other hand, bringing Sentenza to its logical conclusion would result in Italy having to return to Germany what Italian courts took from her by requiring compensation - either by way of the general international law of restitutio in integrum, which the Corte Costituzionale has neither contemplated nor contradicted, or by way of the 1961 Treaty between Germany and Italy in which Italy promises to indemnify Germany against any further claims. Thus, a compromise would have to distinguish between full access to the Italian courts notwithstanding international immunity - as required by the ItCC - and substantive law, which could accept a more symbolical recognition of the suffering of the victims. That recognition could stem from a direct source other than the two states involved, such as a common fund, and address only the small group of immediate victims who were unjustly, if arguably legally, excluded from the previous compensation scheme of the 1960s. It is by no means certain, however, whether such an outcome would be acceptable to all sides-including the Corte itself. Thus, legal certainty would have to be established as quickly as possible so that the victims can still receive at least symbolic compensation.
\end{abstract}

\footnotetext{
A. L. Paulus $(\varangle)$

Georg August University of Göttingen, Institute of International and European Law, Göttingen, Germany

e-mail: intlaw@uni-goettingen.de
} 


\section{Introduction}

Sentenza 238/2014 has created a sharp dissonance between the international law of state immunity as interpreted by the International Court of Justice (ICJ) on the one hand, and Italian constitutional law as understood and applied by the Corte Costituzionale on the other. To wit, while the ICJ maintained that a state is immune against any claim of civil damages for its acts iure imperii, ${ }^{1}$ both present or past, the Corte Costituzionale held in Sentenza 238/2014 that the Italian Constitution demanded that Italian courts provide court access to parties requesting reparation for violations of basic fundamental rights-for acts both past and present. ${ }^{2}$ Thereby, the Italian Constitutional Court (ItCC) went further than the European Court of Human Rights in cases regarding contemporary state torture ${ }^{3}$ and reparations for expropriations committed by Germany during World War II (WWII) prior to the European Convention on Human Rights had entered into force. ${ }^{4}$ By declaring Italian ratification of the UN Charter retroactively a violation of its Constitution, and thus limiting the internal purview of the most basic international treaty since WWII, the Corte Costituzionale took an unprecedented step not only in Italy but in the world at large.

\section{The Stalemate Between International and Domestic Law}

Reassuringly enough, Italy will not cease to be a member of the UN and will not try to 'bail out' of international law altogether. Indeed, and this is the good news, the ItCC explicitly confirmed the bindingness of international law on Italy, including the very immunity the Corte Costituzionale rejected in domestic law. It was only that Italy could not practically abide by the decision and deny court access for the claims

\footnotetext{
${ }^{1}$ ICJ, Jurisdictional Immunities of the State (Germany v Italy: Greece intervening), Judgment of 3 February 2012, ICJ Reports 2012, 99, para 77.

${ }^{2}$ Corte Costituzionale, Judgment of 22 October 2014, No 238/2014, paras 5 et seq.

${ }^{3}$ See ECtHR, Al-Adsani v The United Kingdom, Grand Chamber Judgment of 21 November 2001, Application No 35763/97; see also ECtHR, Nait-Liman v Switzerland, Grand Chamber Judgment of 15 March 2018, Application No 51357/07 (no extra-territorial jurisdiction for adjudication of civil claims regarding compensation for torture, with a careful analysis of domestic case law in paras 67 et seq, concluding in paras 187-188 that such jurisdiction is an exception in domestic law and not warranted by international treaties); similarly ECtHR, Jones and Others $v$ The United Kingdom, Judgment of 14 January 2014, Applications Nos 34356/06 and 43525/06, para 116 et passim (no violation of Art 6(1) ECHR by not recognizing universal jurisdiction for compensation claims); confirming UK House of Lords, Jones v Saudi Arabia [2006] UKHL 26.

${ }^{4}$ ECtHR, Kalogeropoulou and Others $v$ Greece and Germany, Decision of 12 December 2002, Application No 59021/00 (Distomo); ECtHR, Associazione Nazionale Reduci and 275 Others $v$ Germany, Decision of 4 September 2007, Application No 45563/04 (Ferrini), 12. See also ECtHR, Prince Hans Adam II of Liechtenstein v Germany, Judgment of 12 July 2001, Application No $42527 / 98$, paras 59 et seq.
} 
in question for reasons of internal law-even if its interpretation was quite singular in comparison to those of its foreign brethren in similar cases. While it is thus doubtful that the interpretation and application by the ItCC of the access-to-court provision in the Italian Constitution was doctrinally inevitable, this does not remove the need for a resolution in the resulting stalemate between international and domestic law.

On the one hand, the easy solution, according to which rejecting immunity from jurisdiction does not necessarily remove immunity from execution, appears unlikely to be accepted by the ItCC because it would render court access a futile exercisethe very access the Court had demanded so strongly in Sentenza. ${ }^{5}$ On the other hand, bringing Sentenza 238/2014 to its logical conclusion leads to the equally awkward result that Italy would have to compensate Germany for the eventual losses suffered from a success of the victims' compensation claims before Italian courts. The reason for this counterintuitive result lies in the schism Sentenza created between international and domestic law when it—even only grudgingly — accepted the authority of the 2012 ICJ Judgment as to the state of contemporary international law, though the Corte Costituzionale all but invited the World Court to eventually reverse its judgment. ${ }^{6}$ However, this does nothing to prevent Italy's international obligation to provide redress to Germany for any wrongful act it may have committed under international law. International law, in turn, in the judgment rendered by the ICJ, requires respect for Germany's immunity and provides, as a secondary remedy, restitutio in integrum for any violation of said immunity. In other words, the ICJ Judgment requires the re-establishing of the situation prior to an eventual violation of immunity: ${ }^{7}$ including, after an eventual seizure of property to indemnify the victims of crimes committed by the Wehrmacht during WWII, its return to Germany or at least compensation for the lost property. This part of international law the ItCC has neither contemplated nor contradicted. But, even in the case that Italy would not recognize this seemingly inevitable result, which derived from customary international law as codified by the International Law Commission, ${ }^{8}$ there remains the 1961 Agreement between Germany and Italy in which Italy explicitly promised to indemnify Germany against any further claims. ${ }^{9}$ One may, of course, argue that this treaty

\footnotetext{
${ }^{5}$ See also the parallel treatment of adjudication and enforcement in ECtHR, Distomo (n 4).

${ }^{6}$ ItCC, Judgment 238/2014 (n 2), paras 4.1 et seq.

${ }^{7}$ Cf Arts 31(1), 32, 34, 35 of the ILC Draft Articles on Responsibility of States for Internationally Wrongful Acts, adopted by the Commission at its fifty-third session in 2001 (Final Outcome), UN Doc A/56/10, 43, UN Doc A/RES/56/83, Annex, UN Doc A/CN.4/L.602/Rev.1, GAOR 56 ${ }^{\text {th }}$ Session Supp 10, 43 (2001). Art 39 on Contribution of the injured State will not be of much help because it cannot be used to remove immunity through the backdoor.

${ }^{8}$ ILC, Art 36 ASR, 2001 (n 7).

${ }^{9}$ Agreement between the Federal Republic of Germany and Italy on the Settlement of Certain Property-Related, Economic and Financial Questions (Bonn, 2 June 1961), German and Italian version published in Bundesgesetzblatt II 26 June 1963 No 19, 668; see therein Art 2: '(1) The Italian Government declares all outstanding claims on the part of the Italian Republic or Italian natural or legal persons against the Federal Republic of Germany or German natural or legal persons
} 
did not cover the damages in question, or that this treaty by itself amounted to a violation of ius cogens as Italy had argued before the World Court. ${ }^{10}$ However, the Corte Costituzionale's explicit acceptance of the ensuing judgment in international law - in the true spirit of Italian dualism - seems to close down this argument. Thus, on the basis of international law as recognized by Sentenza 238/2014, Italy would have to render under international law any property seized by way of domestic decisions. In the end, Italy, not Germany, would have to indemnify the victims.

\section{You Cannot Have Your Cake and Eat It}

This result shows how complicated the relationship between international and domestic law is, and how difficult it is to bridge a gap between these two systems of law. While states regularly can and do violate international rules of behaviour, and Louis Henkin's famous phrase that 'almost all nations observe almost all principles of international law and almost all of their obligations almost all of the time ${ }^{, 11}$ may turn out to be wishful thinking in the age of Donald Trump, gaps between international and domestic law lead to confusion and paradox, not to legal certainty and the rule of law. It is one thing to maintain that states are only bound by the rules they have explicitly (treaties) or implicitly accepted, or at least acquiesced to (custom or general principles), ${ }^{12}$ so that new rules may not be held against them; it is quite another thing to deny the validity of generally accepted rules and principles that an international court has explicitly declared valid and applicable to the case at hand.

To use domestic law as an excuse to not implement an international court ruling would amount to nothing less than a contradiction of the Italian insistence on the legal nullity of treaties in violation of ius cogens. In other words, Italy cannot have

to be settled to the extent that they are based on rights and circumstances which arose during the period from 1 September 1939 to 8 May 1945. (2) The Italian Government shall indemnify the Federal Republic of Germany and German natural or legal persons for any possible judicial proceedings or other legal action by Italian natural or legal persons in relation to the abovementioned claims.' Germany agreed to pay Italy DM (Deutsche Mark) 40 million in another Agreement (concluded on the same day) between the Federal Republic of Germany and Italy on the Compensation for Italian Nationals Subjected to National-Socialist Measures of Persecution (Bonn, 2 June 1961), German and Italian version published in Bundesgesetzblatt II 5 July 1963 No $22,791$.

${ }^{10}$ See Counter-Memorial of Italy, Jurisdictional Immunities of the State (Germany $v$ Italy), 22 December 2009, paras 5.46 et seq. See also Francesco Francioni, 'Access to Justice and Its Pitfalls: Reparation for War Crimes and the Italian Constitutional Court', Journal of International Criminal Justice 14 (2016), 629-636; see also Werner Wilmanns, 'Die Forderungen der Verbündeten des Deutschen Reiches gegen deutsche Schuldner nach dem Londoner Schuldenabkommen', Der Betriebs-Berater 10 (1955), 820-821.

${ }^{11}$ Louis Henkin, How Nations Behave: Law and Foreign Policy (New York: Columbia University Press $2^{\text {nd }}$ ed 1979), 47.

${ }^{12} \mathrm{Cf}$ Art 38(1) ICJ Statute. 
her cake and eat it, that is, she cannot on the one hand present herself as the true standard bearer of the highest values of the international community of states as embodied in ius cogens, and on the other flout international law as enshrined in customs and treaties for avoiding to indemnify the victims herself. This may indicate an important lesson from the present case, namely that relying on domestic law to flout the execution of international decisions carries the risk of international responsibility. Of course, states have the power to reject international law-either in general or in specific cases. But in this instance, they will have to suffer the consequences.

\section{Conclusion}

How then to solve this stalemate? Mere waiting will not do because at some point Italian courts will have to make a decision in the cases now before them, including whether to confiscate German property such as Villa Vigoni-with the added irony that this precious centre of German-Italian friendship would thereby risk to be transformed into its opposite. Thus, a practical solution is needed: a compromise that does not rely so much on the application of hard and fast legal rules but rather on the distinction between full access to the courts notwithstanding international immunity - as required by the ItCC's interpretation of Italian constitutional law-and substantive law, which does not require reparations for every singular claim but accepts lump sum payments of a compensatory nature leaving open the question of legal obligation as a form of reparations (of war claims in general), not reparation (of each individual wrong separately). ${ }^{13}$ Indeed, such a solution already exists in the 1961 Agreement between Germany and Italy, but has left gaps regarding coverage of Italian Military Internees and other victims. ${ }^{14}$ The ICJ itself has explicitly expressed regret for this gap, and thus considered further negotiations. ${ }^{15}$

\section{References}

Dolzer, Rudolf, 'The Settlement of War-Related Claims: Does International Law Recognize a Victim's Private Right of Action: Lessons after 1945', Berkeley Journal of International Law 20 (2002), 296-341

Francioni, Francesco, 'Access to Justice and Its Pitfalls: Reparation for War Crimes and the Italian Constitutional Court', Journal of International Criminal Justice 14 (2016), 629-636

\footnotetext{
${ }^{13}$ On this distinction, see Rudolf Dolzer, 'The Settlement of War-Related Claims: Does International Law Recognize a Victim's Private Right of Action: Lessons after 1945', Berkeley Journal of International Law 20 (2002), 296-341.

${ }^{14} \mathrm{Cf}$ ICJ, Jurisdictional Immunities (n 1), para 99; ECtHR, Ferrini (n 4), 13-14.

${ }^{15} \mathrm{ICJ}$, Jurisdictional Immunities (n 1), para 100.
} 
Henkin, Louis, How Nations Behave: Law and Foreign Policy (New York: Columbia University Press $2^{\text {nd }}$ ed 1979)

Wilmanns, Werner, 'Die Forderungen der Verbündeten des Deutschen Reiches gegen deutsche Schuldner nach dem Londoner Schuldenabkommen', Der Betriebs-Berater 10 (1955), 820-821

Open Access This chapter is licensed under the terms of the Creative Commons Attribution 4.0 International License (http://creativecommons.org/licenses/by/4.0/), which permits use, sharing, adaptation, distribution and reproduction in any medium or format, as long as you give appropriate credit to the original author(s) and the source, provide a link to the Creative Commons license and indicate if changes were made.

The images or other third party material in this chapter are included in the chapter's Creative Commons license, unless indicated otherwise in a credit line to the material. If material is not included in the chapter's Creative Commons license and your intended use is not permitted by statutory regulation or exceeds the permitted use, you will need to obtain permission directly from the copyright holder. 


\title{
Overcoming the Judicial Conundrum: The Road to a Diplomatic Solution
}

\author{
Francesco Francioni
}

\begin{abstract}
The role of international law and of international lawyers is at its best when it results in a 'work of reconciliation and realistic construction' (Dag Hammarskjöld, 1953). Unfortunately, it is difficult to find much of this spirit in the unfolding, regrettable and never-ending saga of Germany versus Italy. In answering the basic question of whether Germany is obliged to negotiate a settlement with Italy, this chapter argues that even if there is no hard and fast legal obligation, there is a political and moral obligation to negotiate a settlement, as indicated by paragraph 104 of the Jurisdictional Immunities Judgment of the International Court of Justice (ICJ); the same obligation is incumbent upon Italy. The current legal 'black hole' cannot be filled by further proceedings before the ICJ because immunity serves the value of the equality of states, yet equality is not a value in its own sake but is functional to the preservation of peaceful and orderly international relations and to the 'realistic construction' of conditions for the fulfilment of human rights. Negotiations in view of the creation of a joint German-Italian fund for the reparation of victims is the appropriate way to overcome the present impasse and to do justice to a whole class of victims who so far have fallen into oblivion.
\end{abstract}

\section{Introduction}

There could not have been a more appropriate time to discuss possible solutions to the legal deadlock that has followed Sentenza 238/2014 of the Italian Constitutional Court (ItCC). I appreciate that in the introductory chapter the editors have stressed that the spirit of the volume should be 'forward looking and conciliatory'. I will do my best to honour this shared ambition, convinced as I am that the very aim of

\footnotetext{
F. Francioni (四)

European University Institute, Department of Law, Florence, Italy (emeritus)

e-mail: francesco.francioni@eui.eu 
international law, and the very function of international lawyers, should be a 'work of reconciliation and realistic construction'. ${ }^{1}$

Unfortunately, I must say that it is precisely this spirit of reconciliation and realistic construction that has been lacking in the regrettable controversy between two founding members of the European Union. On the German side we have seen an insistence on a formalistic interpretation of international rules, which does justice to states and their sovereignty but hardly contributes to individual justice for victims of gross human rights violations. This has resulted in a somewhat incoherent and selective approach to reparations for victims of German World War II (WWII) crimes and in a protracted denial of justice to a whole category of victims of deportation, enslavement and massacres. On the Italian side, there has been a deplorable lack of political initiative to fill the gap resulting from the incomplete implementation of Germany's post-war reparation schemes and from the ItaloGerman agreement of 1961. This is especially regrettable since similar gaps have been filled by German compensation schemes, as already indicated in the chapter by Andreas von Arnauld. ${ }^{2}$ Faced with the passivity of the Italian government, the problem was left in the hands of judges. Italian international lawyers, or at least a significant part of them, have eagerly contributed to fuelling the hubris of ius cogens, ${ }^{3}$ convinced as they were that the problem could be solved by judges rather than by a 'work of reconciliation and realistic construction'. As is now visible, this has produced a zero-sum dispute before the International Court of Justice (ICJ) and a last-ditch defence by the ItCC declaring the unconstitutionality of the law giving effect to the ICJ judgment in the Italian legal order.

It is timely and appropriate at this point to ask whether there is, in this apparently never-ending dispute, an obligation to negotiate a settlement. The editors framed the question overall with regard to Germany, but my opinion is that the question concerns Italy as well. I will examine separately the reasons why I believe the responsibility to seek a diplomatic solution falls upon both countries.

\footnotetext{
${ }^{1}$ These are the words used by Dag Hammarskjöld in his speech at the UN General Assembly of 10 April 1953 after his election as the UN Secretary-General, reprinted in Wilder Foote (ed), Servant of Peace: A Selection of the Speeches and Statements of Dag Hammarskjöld (New York: The Bodley Head 1962), 28.

${ }^{2}$ See Andreas von Arnauld, chapter 'Deadlocked in Dualism', in this volume.

${ }^{3}$ See, for authors arguing in favour of the primacy of ius cogens norms over the principle of state immunity, Annamaria Viterbo, 'I diritti fondamentali come limite all'immunità dello Stato', Responsabilità Civile e Previdenza 69 (2004), 1030-1039; Pasquale De Sena/Francesca De Vittor, 'State Immunity and Human Rights: The Italian Supreme Court Decision on the Ferrini Case', The European Journal of International Law 16 (2005), 89-112.
} 


\section{The German Position}

There are several sources of a possible German duty to open negotiations to end the present dispute with Italy. The most immediate source is the obiter dictum pronounced by the ICJ in its Jurisdictional Immunities Judgment, ${ }^{4}$ in which, after acknowledging that recognition of Germany's immunity would unavoidably result in a form of injustice for individuals (namely the deprivation of judicial protection by their 'natural judge'), the Court went on to indicate that the claims of victims 'could be the subject of further negotiation involving the two States concerned'. 5 This judicial invitation is not perfunctory. It reflects the tension felt within the Court between two conflicting goals of international justice: on the one hand, the goal of substantive justice requiring some form of remedial action for victims of egregious violations of human rights and humanitarian standards, and, on the other hand, the goal of formal international justice arising from the core realities of international law, which require the sovereign equality of states and the rule of immunity to be respected. The ICJ was able to diffuse this tension by resorting to the rhetorical argument that immunity belongs to the category of procedural norms and that its recognition does not have any impact on rules of substantive justice, even when those rules were to belong to ius cogens. The acknowledgment of the existence of a problem of 'justice' left open by the affirmation of immunity was rendered all the more necessary after the rejection of the Italian counterclaim for reparations. What is significant in this respect is the expression of 'surprise and regret' uttered by the Court in paragraph 99 of the judgment with regard to the realization that 'Germany decided to deny compensation to a group of victims on the ground that they had been entitled to a status [prisoners of war] which, at the relevant time, Germany had refused to recognize'. ${ }^{\circ}$

These statements are not in themselves a sufficient ground to permit the construction of a perfect legal obligation for the two states to negotiate a solution to the dispute that may include some form of reparation to the victims. But their legal relevance to substantiate Germany's responsibility to begin serious negotiations in view of reparations to the surviving victims and their successors becomes more apparent when we examine the origin and overall context of this controversy. The context emerges from the attitude taken by Germany in the past two decades with regard to compensation schemes for victims of atrocities committed by the Third Reich. As already pointed out in von Arnauld's chapter, Germany has been forthcoming in accepting legal responsibility for the commission of such atrocities during the Nazi period. However, 'the patchwork of instruments set up soon after the

\footnotetext{
${ }^{4}$ ICJ, Jurisdictional Immunities of the State (Germany v Italy: Greece intervening), Judgment of 3 February 2012, ICJ Reports 2012, 99.

${ }^{5}$ Ibid, para 104. See also Paolo Palchetti, chapter 'Right of Access to (Italian) Courts über alles?', in this volume.

${ }^{6}$ Ibid, para 99. See also Jörg Luther, chapter 'A Story of 'Trials and Errors' That Might Have No Happy End', in this volume.
} 
foundation of the Federal Republic (...) was very much characterized by selectivity'. ${ }^{7}$ Certainly, such selectivity was influenced by the realities of international relations at that time, including the long Cold War period and the different degree of political pressure put on Germany by other states and groups representing victims. All this is true, but there was more: the pressure exerted upon Germany by individual claims brought by victims of Nazi crimes before national courts, especially US courts. It is well known that German reparations law was modified after the 1994 Princz case in order to cover foreign victims of Nazi crimes, ${ }^{8}$ and that in the aftermath of this case Germany agreed to set up by federal law the Foundation 'Remembrance, Responsibility and Future' (Erinnerung, Verantwortung und Zukunft) to provide a comprehensive scheme of individual compensation to former slaves, forced labourers and other victims of Nazi crimes. ${ }^{9}$ Section 11(3) of the Law provides that '[e]ligibility cannot be based on prisoner-of-war status'. Such exclusion was justified by the assumption that prisoners of war (POW) can be lawfully detained under international law. But as far as many of the Italian claimants are concerned, far from enjoying a POW-protected status under international law, they were deprived of any rights and subjected to inhuman treatment, starvation and summary execution. So, one cannot understand the logic of the POW-status argument, advanced on the German side, to exclude any form of reparation to the dwindling numbers of Italian victims. The morality of their exclusion from the compensation schemes available for similar victims of other nationalities is even more dubious when we think that the Italian deportees, and especially the 'military internees', had seen their hardship aggravated by the resentment, hatred and humiliation they received for refusing to join the Nazi-Fascist war enterprise. Considered as 'traitors', they were treated with contempt and malevolence. Now we know, however, that their silent refusal reveals their morally dignified resistance at a time of tragic uncertainty for Europe. This makes the lack of any initiative on the German side after the Ferrini judgment, and the flurry of similar cases brought before Italian courts, all the more troublesome and incomprehensible to the victims. The rigidity of Germany's denying any responsibility towards the Italian victims stands in sharp contrast to the attitude taken in the mid-1990s after the Princz case in the US. In this case, the judicial action by the victims worked as a catalyst for the establishment of a comprehensive reparation scheme; in the Italian case, it produced only a defensive reaction based on immunity, with the result of letting the dispute drag on into the present.

\footnotetext{
${ }^{7}$ See Andreas von Arnauld, chapter 'Deadlocked in Dualism', in this volume, at 319.

${ }^{8}$ Princz v Germany, 26 F 3d 1166 (DC Cir, 1 July 1994).

${ }^{9}$ See also Riccardo Pavoni, chapter 'A Plea for Legal Peace', and Filippo Fontanelli, chapter 'Sketches for a Reparation Scheme', in this volume.
} 


\section{The Italian Position}

As I have already mentioned, Italy bears its own responsibility for the continuation of this dispute and for its failure to undertake effective negotiations in view of a diplomatic solution respectful of the right of the victims. When the Ferrini judgment made clear in 2004 that the half-century pall of silence covering Nazi-Fascist war crimes and crimes against humanity was being lifted with the refusal of the Court of Cassation to grant immunity to Germany, ${ }^{10}$ it was evident that alternative diplomatic, legislative and administrative remedies were morally necessary for the respect due to the victims and politically urgent in order to defuse the time bomb that was the emerging dispute with Germany. But rather than proactively seeking a diplomatically agreed solution similar to the one reached 20 years earlier in the aftermath of the Princz case, the then Italian government found it convenient to accede to Germany's decision to bring the matter to the ICJ in the not-so-secret conviction that the real dispute was not with Germany but rather with the perceived hyperactivism of judges at a time of tense relations in Italy between the executive and the judiciary. Italy's failure in this respect is all the more regrettable because it completely sidelined the case of the victims, so belatedly claiming justice, while at the same time contradicting its own professed policy on diplomatic protection. In this respect, I wish to recall that during the preparatory work on the Draft Articles on Diplomatic Protection prepared by the International Law Commission, ${ }^{11}$ the Italian delegation at the General Assembly strongly supported a progressive development of international law on this topic and the recognition of a state's obligation to exercise the diplomatic protection of individual victims of human rights violations. ${ }^{12}$ The Italian proposal went as far as envisaging a justiciable right of victims to obtain diplomatic protection from the state. What would have been the logical implication of this legal position in the wake of the Ferrini judgment? Coherence would have required that a serious diplomatic initiative be undertaken in view of ensuring a fair recognition of the claims of the victims and at the same time eliminating the cause of the emerging dispute with Germany. Instead, the government let the matter drift further into a judicial conundrum. The parliament on its part limited itself to a cosmetic initiative by adopting Law No 296/2006, which memorialized victims of forced deportation to German camps and established procedures for the granting of medals of honour. ${ }^{13}$ Too little too late for the victims.

There is a further legal basis for Italy's responsibility to take diplomatic action in view of an international solution of this dispute. This basis is provided by a rather neglected arbitral clause contained in Article 25 of the 1961 Italo-German agreement

\footnotetext{
${ }^{10}$ Corte di Cassazione, Judgment of 11 March 2004, No 5044/2004 (Ferrini).

${ }^{11}$ ILC, Draft Articles on Diplomatic Protection, adopted by the Commission at its fifty-eighth session in 2006, UN Doc A/61/10, GAOR 61 ${ }^{\text {st }}$ Session Supp 10.

${ }^{12}$ ILC, 'Comments and Observations Received from Governments' (2006) UN Doc A/CN. 4/ 561 and Add 1-2.

${ }^{13}$ Italian Law, 27 December 2006, No 296, Art 1(1271-1276).
} 
on reparations for victims of Nazi persecution. ${ }^{14}$ That clause permits unilateral activation of an arbitral procedure to settle disputes over the interpretation and implementation of the agreement. To the best of this writer's knowledge, no initiative based on this provision has ever been undertaken by the Italian government, notwithstanding the apparent divergences between Germany and Italy over the finality of the settlement provided by this agreement and over its applicability to victims of war crimes and of crimes against humanity other than persecution. If Germany insists that the 1961 agreement should have covered all kinds of victims of Nazi crimes, why has Italy never contested such a view by seeking a third-party interpretation of the agreement on the basis of the available arbitral clause?

\section{Conclusion}

This is a sorry saga. Germany and Italy share a tragic historical role in WWII and share the responsibility for having contributed to a situation where victims of appalling crimes, including forced deportations, slave labour and civilian massacres, were not recognized as victims of war crimes and crimes against humanity eligible for compensation. This is the 'black hole' on which the ICJ expressed 'surprise and regret'.

The injustice of this situation is aggravated by the fact that victims have waited for such a long time to obtain some form of recognition and reparation, most of them are no longer alive and their descendants are also fast disappearing. This protracted injustice cannot be addressed by further proceedings before the ICJ as a response by Germany to Sentenza 238/2014. Such insistence would only exacerbate the conflict and further increase the distance between formal international justice, as administered by the ICJ, and the substantive justice sought by the individual victims. The re-affirmation of immunity by the ICJ would serve the logic of once more vindicating the realities of international relations and the related need to preserve the sovereign equality of states, but it would do little to advance the cause of individual justice, whose unavoidable place in international law was reiterated by the UN General Assembly's Resolution on Basic Principles and Guidelines on the Right to a Remedy and Reparation for Victims of Gross Violations of International Human Rights and Serious Violations of International Humanitarian Law. ${ }^{15}$ In the context of this case, and more generally from the point of view of the development of international law toward a system of global justice, the ultimate question is whether sovereign equality and immunity should be considered as values in their own sake or

\footnotetext{
${ }^{14}$ Agreement between the Federal Republic of Germany and Italy on the Settlement of Certain Property-Related, Economic and Financial Questions (Bonn, 2 June 1961), German and Italian version published in Bundesgesetzblatt II 26 June 1963 No 19, 668.

${ }^{15}$ UN General Assembly, Basic Principles and Guidelines on the Right to a Remedy and Reparation for Victims of Gross Violations of International Human Rights Law and Serious Violations of International Humanitarian Law, A/RES/60/147, 16 December 2005.
} 
rather as functional to the construction and preservation of peaceful and orderly international relations and to the fulfilment of human rights. Sentenza 238/2014 does not answer this question, being exclusively based on an argument of domestic constitutional identity and justice. But Germany and Italy could seize an opportunity that this dispute offers and attempt an answer to this question by seriously addressing the case of the victims and entering negotiations in view of reaching an agreement on the establishment of a joint fund to compensate the victims of past atrocities who have so far been left out of any available reparation scheme. Such agreement could establish criteria for the identification of 'victims', with a possible distinction between direct victims and descendants. This joint fund could also address the concern expressed by the editors of this volume about the morality and legality of 'guaranteeing the rights of "others" with the resources of a state's own citizens and taxpayers'. A joint fund would help eliminate that troubling 'other' that today seems to revisit Europe with renascent forms of nationalism. It would serve as a reminder that the European Union, and the eurozone in particular, were created not only to facilitate the market, financial transactions and transnational commerce but to reduce the historical heritage of that 'other' and of the separation of the European people.

\section{References}

De Sena, Pasquale/Francesca De Vittor, 'State Immunity and Human Rights: The Italian Supreme Court Decision on the Ferrini Case', The European Journal of International Law 16 (2005), 89-112

Foote, Wilder (ed), Servant of Peace: A Selection of the Speeches and Statements of Dag Hammarskjöld (New York: The Bodley Head 1962)

Viterbo, Annamaria, 'I diritti fondamentali come limite all'immunità dello Stato', Responsabilità Civile e Previdenza 69 (2004), 1030-1039

Open Access This chapter is licensed under the terms of the Creative Commons Attribution 4.0 International License (http://creativecommons.org/licenses/by/4.0/), which permits use, sharing, adaptation, distribution and reproduction in any medium or format, as long as you give appropriate credit to the original author(s) and the source, provide a link to the Creative Commons license and indicate if changes were made.

The images or other third party material in this chapter are included in the chapter's Creative Commons license, unless indicated otherwise in a credit line to the material. If material is not included in the chapter's Creative Commons license and your intended use is not permitted by statutory regulation or exceeds the permitted use, you will need to obtain permission directly from the copyright holder.

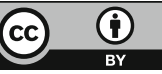




\section{Part VII \\ The Past and Future of Remedies}




\title{
Recollections of a Judge
}

\author{
Sabino Cassese
}

\begin{abstract}
As a former justice of the Italian Constitutional Court serving at the time of Sentenza 238/2014, this chapter illustrates my major concerns towards this Judgement. I outline several reasons for a possible 'dissent' (procedural, factual, constitutional, theoretical and strategic). With ex post remarks, the chapter elaborates some additional thoughts on the unnecessary opposition between national and international law and on certain Italian ambiguities towards its past.
\end{abstract}

\section{Introduction}

As I am the only author in this volume who can provide a view from the inside, I shall speak as a witness and not as a scholar, making ex-post public my dissent as a former justice of the Corte Costituzionale (ItCC) who decided Sentenza 238/2014 in October 2014.

In my dissent I was not alone. A large minority of the ItCC was opposed to the Judgment, and in my nine years at the ItCC, this was the most divisive of all its judgments. ${ }^{1}$ In fact, I was very close to resigning from the Court. For procedural reasons, if I had resigned, the judgment would not have been adopted. As it happened, however, I was convinced by those minority members who were against Sentenza that it would have been better not to resign. Nevertheless, I did not participate in the meeting in which the decision was read.

My dissent was based on five points: procedural, factual, constitutional, theoretical, and strategic, to which now, a few years later, I can add a few comments.

\footnotetext{
${ }^{1}$ Sabino Cassese, Dentro la Corte: Diario di un giudice costituzionale (Bologna: Il Mulino 2015).

S. Cassese $(\bowtie)$

LUISS Guido Carli University, School of Government, Rome, Italy

e-mail: sabino@sabinocassese.eu 


\section{Reasons for Dissent}

\section{Procedural}

As it is well known, constitutional courts engage themselves in either abstract or concrete review. The French Conseil Constitutionnel, until the question prioritaire de constitutionnalite,${ }^{2}$ had only abstract review powers. In our case, the ItCC has the power of concrete review. Concrete review means that the case has been raised in a case or controversy, to use the American legal terminology. However, the case must be ripe; and citing William Shakespeare, 'ripeness is all'. 3

The first problem for the ItCC was indeed to decide if this case was ripe or not. The Tribunale di Firenze, the court that raised the case, was in that phase of the procedure we call giudizio di cognizione and not in a giudizio di esecuzione, and did not really demonstrate whether the case before it was indeed ripe. ${ }^{4}$ Therefore, in my opinion, the correct decision for the court would have been to judge the case inadmissible without even entering into the merits of the question.

\section{Factual}

The second point is more complex. Germany had paid in the past a large amount of money to the Italian government, ${ }^{5}$ which was not given directly to the victims but instead used to rebuild those parts of the country that had been partly destroyed during the war. ${ }^{6}$ In other words, the money was directed to national purposes other than for those victims directly affected by Nazis crimes. It was not the German government but the Italian one to choose who would have been the beneficiaries of those funds.

\footnotetext{
${ }^{2}$ French Constitutional Law 23 July 2008, No 2008-724.

${ }^{3}$ William Shakespeare, King Lear, Act V, Scene II, Reginald A Foakes (ed) (London: The Arden Shakespeare new ed 1997) 363.

${ }^{4}$ Tribunale di Firenze, Orders of 21 January 2014, Nos 84/2014, 85/2014, 113/2014.

${ }^{5} \mathrm{Cf}$ Agreement between the Federal Republic of Germany and Italy on the Compensation for Italian Nationals Subjected to National-Socialist Measures of Persecution (Bonn, 2 June 1961), German and Italian version published in Bundesgesetzblatt II 5 July 1963 No 22, 791.

${ }^{6} \mathrm{Cf}$ ICJ, Jurisdictional Immunities of the State (Germany v Italy: Greece intervening), Judgment of 3 February 2012, ICJ Reports 2012, 99, para 101.
} 


\section{Constitutional}

Article 24 of the Italian Constitution provides the right to a judge. Is this a right to an Italian judge or is this a right to any judge? This question was particularly relevant for Sentenza 238/2014 because several cases had been raised before lower courts in Germany and once even before the German Federal Constitutional Court (FCC). ${ }^{7}$ If one person has a right to a judge and had the opportunity to bring their case before a judge in Germany, why raise the same case in Italy while complaining that in fact they did not have an opportunity to have their case reviewed by a judge? ${ }^{8}$

\section{Theoretical}

Why set domestic law against international law, and in the process declare international law unconstitutional (a point later raised by Stefano Battini in an excellent commentary to Sentenza 238/2014) ${ }^{9}$ ? With that Judgement, the ItCC has revived Heinrich Triepel and the dualism national-international. The Court could have taken another route: not to oppose the national to the international plan but to recognize that international law also has a well-established principle that safeguards access to justice. Therefore, the ItCC had the opportunity to oppose state immunity from jurisdiction to another international law principle.

\section{Strategic}

This Judgement was also an example of legal protectionism. To build walls around a national legal order is not a good strategy for a constitutional court; it is better to open the doors to supranational and universal principles. ${ }^{10}$ This was a contradictory behaviour in the strategy of the ItCC. We would do well to remember that the ItCC in 2007 opened its doors to the Strasbourg court and to the European Convention on

\footnotetext{
${ }^{7}$ Bundesverfassungsgericht, Order of 28 June 2004, 2 BvR 1379/01, BVerfGK 3, 277; Eg Verwaltungsgericht Berlin, Judgment of 9 September 2004, 9 A 336.02.

${ }^{8} \mathrm{Cf}$ Valerio Onida, chapter 'Moving Beyond Judicial Conflict in the Name of the Pre-Eminence of Fundamental Human Rights', in this volume.

${ }^{9}$ Stefano Battini, 'È costituzionale il diritto internazionale?', Giornale di diritto amministrativo 3 (2015), 367-377, at 372-373.

${ }^{10}$ See also Sabino Cassese, I tribunali di Babele: I giudici alla ricerca di un nuovo ordine globale (Rome: Donzelli editore 2009).
} 
Human Rights, ${ }^{11}$ and later to the law of the European Union. ${ }^{12}$ That Court had established a dialogue. Therefore, the strategy of the ItCC was inconsistent. Constitutional courts should not go in search of national 'identities', like the FCC, ${ }^{13}$ because we all have plural identities. For the same reason, courts should not oppose their national constitutions to international law.

\section{Ex Post Remarks}

Ex post, there are three additional comments I would like to make. Firstly, the majority of the Court's justices fell prey to the worst temptation for a constitutional judge: to write 'the great judgment'. You may know pages by Guido Calabresi ${ }^{14}$ against judges wanting to put their name under an important judgment. Secondly, the majority followed one epistemic community, that of international lawyers. This was another contradiction because international lawyers have put themselves against international law. Thirdly, no constitutional judge should try to write history in the courtroom: ${ }^{15}$ judges are judges, historians are historians.

That being said, let me put my opinion in a more constructive manner. I thought that the ItCC could have taken the following decision: 'Tribunal of Florence: you are raising the right question in the wrong manner. It is true that there is problem of access to justice, but you are interpreting Article 24 of the Italian Constitution in a very strict manner. There are hundreds of decisions by the Italian Council of State that establish that Article 24 covers also what we call deliberative democracy, that is taking decisions by administrative bodies after consultation and discussion with the people affected or who are going to be affected by the decisions. Therefore, I accept your point, but I conclude that there is an obligation of the two governments to consult and reach an agreement between themselves and with the affected people'.

If we recall the famous Canadian Supreme Court decision on the secession of Quebec, ${ }^{16}$ we will remember that it was simple: Quebec had right to secede, but could not exercise this right unilaterally without entering into negotiations with the rest of Canada.

A few years ago, I was at the Global Constitutionalism Seminar at Yale University, and one theme was state immunity in comparative terms. The conclusion was

\footnotetext{
${ }^{11}$ Corte Costituzionale, Judgments of 22 October 2007, Nos 348 and 349/2007.

${ }^{12} \mathrm{Cf}$ Corte Costituzionale, Order of 13 February 2008, No 103/2008; Corte Costituzionale Order of 3 July 2013, No 207/2013.

${ }^{13}$ Bundesverfassungsgericht, Decision of 15 December 2015, 2 BvR 2735/14, BVerfGE 140, 317 (European Arrest Warrant II/Identity Control).

${ }^{14}$ Guido Calabresi, Il mestiere di giudice: Pensieri di un accademico americano (Bologna: Il Mulino 2014).

${ }^{15}$ See also Andreas von Arnauld, chapter 'Deadlocked in Dualism', in this volume.

${ }^{16}$ Supreme Court of Canada, Reference Re Secession of Quebec, [1998] 2 SCR 217.
} 
that immunities are being eroded. They are similar to shared sovereignty, an oxymoron, because if states are sovereign, they cannot share sovereignty. If they share it, they are no longer sovereign. The same is true for immunity, which has been eroded in different ways by the international community. ${ }^{17}$

\section{Italian Ambiguities Towards Fascism}

I would like to make a final point on the Italian ambiguities towards Fascism. Ambiguities that are evidenced by different viewpoints on national history. Was the nature of Italian Fascism one of authoritarianism, totalitarianism (according to the Hannah Arendt definition), ${ }^{18}$ or was it in reality a dictatorship?

Renzo De Felice, Italy's preeminent historian of Mussolini and Fascism, did not entirely share the idea that it was a totalitarian state, while his pupil, Emilio Gentile, on the other hand, is in favour of defining Italy's Fascist regime as totalitarian. Historians are divided on this major point. I would like to recall how De Felice's considerable biography of Mussolini was received by the public and the critics. The subtitle of that book was 'Gli anni del consenso', ${ }^{19}$ which implied that in the central years of the 'Regime' there existed a large majority of Italians in favour of Mussolini. The publication of that book raised strong reactions. When Claudio Pavone's 'Una guerra civile ${ }^{, 20}$ was published, which put forward the idea that there had been a civil war amongst Italians, it too was received with astonishment. Furthermore, the book 'La morte della Patria', ${ }^{21}$ equally deals with very divisive aspects of national history, focusing on the problem of Italians moving from being allied with the Germans to being against the Germans and therefore being divided.

All these debates highlight the difficulty of closing the 'memory book' in Italy and put Sentenza 238/2014 into a broader historical perspective which needs to be taken into consideration when discussing possible 'ways out' to the current legal deadlock.

\footnotetext{
${ }^{17}$ See also, Anne Peters/Evelyne Lagrange/Stefan Oeter/Christian Tomuschat (eds), Immunities in the Age of Global Constitutionalism (Leiden: Brill Nijhoff 2015).

${ }^{18}$ Hannah Arendt, The Origins of Totalitarianism (London: Penguin Books new ed 2017).

${ }^{19}$ Renzo De Felice, Mussolini il duce: Gli anni del consenso 1929-1936 (Turin: Einaudi 2007).

${ }^{20}$ Claudio Pavone, Una guerra civile: Saggio storico sulla moralità nella Resistenza (Turin: Bollati Boringhieri 2006).

${ }^{21}$ Ernesto Galli Della Loggia, La morte della patria: La crisi dell'idea di nazione tra Resistenza, antifascismo e Repubblica (Rome/Bari: Editori Laterza 2003).
} 


\section{References}

Arendt, Hannah, The Origins of Totalitarianism (London: Penguin Books new ed 2017)

Battini, Stefano, 'È costituzionale il diritto internazionale?', Giornale di diritto amministrativo 3 (2015), 367-377

Calabresi, Guido, Il mestiere di giudice: Pensieri di un accademico americano (Bologna: Il Mulino 2014)

Cassese, Sabino, Dentro la Corte: Diario di un giudice costituzionale (Bologna: Il Mulino 2015)

Cassese, Sabino, I tribunali di Babele: I giudici alla ricerca di un nuovo ordine globale (Rome: Donzelli editore 2009)

De Felice, Renzo, Mussolini il duce: Gli anni del consenso 1929-1936 (Turin: Einaudi 2007)

Galli Della Loggia, Ernesto, La morte della patria: La crisi dell'idea di nazione tra Resistenza, antifascismo e Repubblica (Rome/Bari: Editori Laterza 2003)

Pavone, Claudio, Una guerra civile: Saggio storico sulla moralità nella Resistenza (Turin: Bollati Boringhieri 2006)

Peters, Anne /Evelyne Lagrange/Stefan Oeter/Christian Tomuschat (eds), Immunities in the Age of Global Constitutionalism (Leiden: Brill Nijhoff 2015)

Shakespeare, William, King Lear, Act V, Reginald A Foakes (ed) (London: The Arden Shakespeare new ed 1997)

Open Access This chapter is licensed under the terms of the Creative Commons Attribution 4.0 International License (http://creativecommons.org/licenses/by/4.0/), which permits use, sharing, adaptation, distribution and reproduction in any medium or format, as long as you give appropriate credit to the original author(s) and the source, provide a link to the Creative Commons license and indicate if changes were made.

The images or other third party material in this chapter are included in the chapter's Creative Commons license, unless indicated otherwise in a credit line to the material. If material is not included in the chapter's Creative Commons license and your intended use is not permitted by statutory regulation or exceeds the permitted use, you will need to obtain permission directly from the copyright holder.

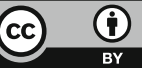




\title{
A Dialogical Epilogue
}

\author{
Joseph H. H. Weiler
}

\begin{abstract}
In this Dialogical Epilogue, I address a series of both general and specific questions to some of the contributors of this volume. The intent is to seek clarification on or even contest one or more propositions presented in the various chapters. In the role of a "Consul of the Readers" I enter into a conversation with the book's authors to discuss some of the fundamental questions to which Sentenza 238/2014 gives rise and that have, at best, received only indirect answers in the various chapters. I believe answering them will enhance the value of each contribution and of the book as a whole.
\end{abstract}

It is the nature of all law books, and edited books in particular-where authors are constrained by the space available to them - that oftentimes readers, if they could, would love to put a question, seek a clarification on, or even contest one or more propositions in what they read. My role here is to be a Consul of the Readers and to put such questions to some of the contributions to this excellent volume. The book is interesting in so many ways that go beyond the strict legal issues in question. For example: participation was limited to German and Italian nationals. (Oh, yes! I am a proud and patriotic Italian citizen). But the critical mood did not coincide (as is often the case in arbitrations or with national and ad hoc judges on the International Court of Justice (ICJ)) with nationality. Indeed, the most critical voices against the Italian Constitutional Court (ItCC) decision came from Italians and some of the most sympathetic voices to the real legal/moral dilemma it faces came from Germans.

Only a few, if any, were categorical in their conclusions; all understood that from an ethical perspective this was a tough issue - on the responsibility for which views differed - and almost all suggested various ways of squaring a circle.

In what follows I will be posing specific questions to some of the authors. In addition, there are two underlying fundamental questions to which the case gives rise and at best received only indirect answers in the various chapters. I believe these two

\footnotetext{
J. H. H. Weiler ( $\bowtie)$

New York University, School of Law, New York, NY, USA

e-mail: joseph.weiler@nyu.edu 
questions would be lurking in the minds of many readers working their way through the various contributions, and it is hoped that answering them will enhance the value of each contribution and of the book as a whole.

\section{General Questions}

JHHW: In what circumstances and under what conditions, if any, would you say that it would be justified or at least legitimate for a national court or tribunal, against whose decisions there is no judicial remedy, to defy a decision of the ICJ (or any other international tribunal), which under the rules of international law is binding on such a state? And, similarly, to give a decision which defies a rule of international law, clearly articulated by the ICJ or a relevant international tribunal, in some other case.

I want you to imagine that such a case is before a national court and one of the parties is making an impassioned plea that this is an instance where the national jurisdiction should disregard the ICJ (or a relevant international tribunal) in the two circumstances mentioned above. And imagine further that either of the parties before the national court is to use your brief and terse statement as giving guidance on how to resolve this critical issue.

I want to make two further pleas: kindly do not hide behind the it all depends on the circumstances' cop-out; and kindly make your statement relevant to any national court (it should not be Italo-German specific).

Finally, this is not an invitation to write a whole new chapter. Imagine that you are involved in litigation and the court in question requests a written submission limited to 500 words.

The second, related question, is as follows: in what circumstances and under what conditions, if any, would you consider it justified or legitimate for a national court or tribunal, against whose decisions there is no judicial remedy, to defy a clearly established rule of international law, or legal obligation deriving from a treaty -ie in this case I am not putting in question the authority of the ICJ or another relevant international tribunal. I am not interested in cases where the national court calls into question the specific interpretation of the rule, or its validity, but where it is squarely accepted by both parties before it, and then by the court itself, that there is a binding international obligation but is asked to defy it.

The three pleas above apply here too.

\section{Paolo Palchetti}

My answer relates to your second question. Let me start with the 'if any' option. It is difficult to accept that under no circumstances would a national court be correct in defying a clearly established rule of international law, or legal obligations deriving from international rules (including, eventually, from binding judgments of the ICJ). 
Nor do I think that recourse by national judges to mechanisms such as those based on the assessment of the 'equivalent protection' or the respect for controlimiti should necessarily be regarded as an expression of a nationalistic attitude or an insufficient propensity to accept values originating from the international system. Völkerrechtsfreundlichkeit can coexist with a cautious attitude towards international law; it certainly does not require invariably bowing to the dictates of international law. There are indeed good reasons justifying a cautious attitude towards, and potentially defiance of, international law. First, international law has dramatically expanded its scope of application. To invariably treat it as the 'higher law' risks having the effect of progressively limiting the scope of application of fundamental principles of domestic law. Secondly, rule-making at the international level might be used by a government (or even by a parliamentary majority) to expand their legislative power at the domestic level, eventually circumventing any possibility of constitutional scrutiny by domestic courts. And finally, while it is crucial for international law to find support in domestic law, the impact of occasional discrepancies should not be exaggerated. International law has the means for coping with these challenges. A certain degree of tension between domestic law and international law is inevitable, and may even prove beneficial for the development of international law.

'In what circumstances and under what conditions'? Unsurprisingly, the first condition is that the non-application of an international rule should be limited to cases involving a lack of consistency with a rule of internal law 'of fundamental importance'. In this respect, the doctrine of controlimiti has much to be praised. In identifying and interpreting the fundamental rules and principles that act as controlimiti, national judges should adopt, as far as possible, an internationally oriented stance: the non-application of an international rule may prove to be more 'acceptable' if the domestic principle at stake protects a value that is shared by a plurality of other states. A second condition involves the lack of any alternative solution other than disregarding international law. This may be obvious, but I find it important to insist on it. Sometimes national judges prefer to sacrifice the application of an international rule even if alternative means would be available under domestic law to protect the interests of the affected individuals. Despite the tendency to simplify the terms of the debate ('my values against your values'), it is not always an either/or situation; compromise solutions can and should be found. Finally, when defying an international rule, a judge must make every effort to clearly delimit the consequences and implications of its decision. The tension generated by the non-application of an international rule may be more easily defused if political organs can clearly identify the room-to-manoeuvre available to them.

\section{Christian Tomuschat}

It is immensely hazardous to speculate about imagined future cases the specific circumstances of which are obviously unknown. Additionally, any commentator must acknowledge that in Europe we live in an environment that has been shaped by fundamental principles: the rule of law and human rights, both at the domestic and 
international level. Miscarriages of justice, which might possibly warrant departing from a binding decision of an international court or tribunal, can therefore occur only in exceptional circumstances.

First of all, a distinction should be drawn between the ICJ and 'any other international tribunal'. The ICJ is 'the principal judicial organ of the United Nations'. Its judges, all of them eminent lawyers, are selected through a careful process in which all the nations of the world participate. Thus, the ICJ is the voice of the international community regarding international law issues. No other international court or tribunal attains a similar level of authority. In particular, international arbitral bodies do not necessarily present the same guarantees of knowledge and expertise. In some instances, one may therefore be tempted to criticize them for having taken their decision with a somewhat light touch. By contrast, to charge the ICJ with ignoring or having ignored basic tenets of the international legal order is an act of extreme temerity.

What is a 'clearly established rule of international law'? In borderline cases the existence and scope of the determinative rule will invariably be controversial. In particular, serious doubts may creep into the legal debate through the concepts of ius cogens and obligations erga omnes. Moreover, distinctions are imperative. Treaties, customary law rules, and general principles are not of the same nature.

There is no doubt that treaties of all kinds are binding. However, treaties of the past may not fully correspond to the exigencies of the present. In such circumstances, a well-informed and knowledgeable interpreter may be required for a cautious mise à jour. Here, the identity of the relevant judicial body matters decisively. Errors are more likely to be committed by an ad hoc body than a well-established permanent court. On the other hand, multilateral treaties that have come into being under the auspices of the UN, particularly since the end of decolonization, generally deserve broad confidence. During the drafting stage, they are submitted to thousands of critical eyes. Regarding such contemporary treaties, it becomes fairly arrogant to take the position that their rules are defective and do not correspond to the exigencies of law and justice.

Where the ICJ, or any other international court, has applied a rule of general international law, things are different. Customary rules cannot be framed unilaterally by one state alone. They arise from practice and consensus among the members of the international community. Customary law follows societal developments, but never abruptly from one day to the next. This time factor of slowness affords it stability but may also be a feature that awakes criticism. The rules of general international law introduce the past into the present. What happened decades ago becomes the guideline for today in a world that has seen events and upheavals that have changed the face of the earth. In many instances the precedents of the past may seem outdated and even obsolete. However, on what authority should a national judge be entitled to question propositions accepted by the entire international community? In any event, the rebel judge has to shoulder a heavy burden of proof and discharge it diligently. 


\section{Alessandro Bufalini}

There are several important reasons why it is not an easy task to answer such general and abstract questions. First, it is reasonable to presume that the normative (and in case judicial) conflict would impinge on certain fundamental norms, among which it is impossible to determine a clear hierarchy. Second, even when a primacy can be accorded to a certain rule (or value) above others, the potential sacrifice of other fundamental norms shall always be necessary and proportionate. Third, when applying the necessity and proportionality tests, one has to look at the substance of the case, to take into account the concrete and material outcomes of a certain solution. Fourth, the task of assessing the justifiability or legitimacy of a national act of defiance to an international decision (or other international obligations) implies, to a certain extent, an abandonment of the legal vocabulary in favour of the language of ethics and politics. Presumably, it is not a question here merely of solving a normative conflict but of determining who has the authority to decide on the prominence of certain societal values over others.

The legitimacy/authority issue is strictly related to the state of relations between the national and international judge (and legal order) and their degree of reliability and reputation at a given moment for a certain community. This means that the answer to the questions may depend on how the judicial organs involved in the conflict perceive their role and power and are perceived by local and global societies. Moreover, the judicial organs' perception of their own role and power may vary according to the nature of the dispute and the underlying legal determination (whether it concerns human rights protection or, for example, the interpretation of a commercial treaty). The picture is even more complex if one takes into account that political organs (at the national and international level) may be willing to have the last word on a decision that could determine the very essence of both the national and international legal order. The attitudes of political actors may also play a crucial role in tipping the balance one way or the other.

With these considerations in mind, it may be still possible to imagine a few circumstances under which a national court may legitimately defy an international decision or a state obligation stemming from a clearly established rule of customary law: (1) when the international decision denies the existence of a clearly established peremptory norm; (2) when the international decision has the effect of legitimizing a manifest abuse of power or an arbitrary act of a political organ; or (3) when the international decision (or the customary law obligation) has the effect of causing an unnecessary or disproportionate sacrifice of a fundamental value of the national legal order. In this latter scenario, two conditions need to be met: firstly, the state's failure to comply with the decision (or other international obligations) should not have the effect of unnecessarily or disproportionally sacrificing a fundamental value of the international legal order; and secondly, all attempts to explore the existence of alternative means of dispute settlement (or of reparation for the injury caused) have been made. 


\section{Giovanni Boggero and Karin Oellers-Frahm}

A domestic court of last resort should be allowed to defy a decision by an international tribunal only as an exception to the rules. Ordinarily, domestic courts are required to abide by binding international decisions insofar as the jurisdiction of the international tribunal in question has been accepted by the state. However, exceptions ought to be considered on the basis of defiance. Yet, defiance of binding international judgments by domestic judges should be the outcome of a procedural endeavour and not of a straight application of the hierarchy-of-norms principle. In fact, as long as international law exists beyond the realm of states' domestic jurisdiction, an in-depth review of the circumstances and criteria according to which an international tribunal has bindingly applied it should be carried out first by domestic judges of last resort. Should it be detected that a conflict exists between an international legal rule — as interpreted by the international tribunal—and a state's constitutional domestic law that cannot be solved by means of an interpretation whereby the latter conforms with the former, the answer cannot be found on the simplistic basis of the higher rank of one source over another, regardless of whether we assume a monistic or a dualistic approach, whatever these categories might mean. Instead, domestic judges of last resort should be vested with the power of engaging in a dialogue with the corresponding international tribunal. The purpose of this dialogue should be to reconcile the two constitutional orders, that is, of triggering a valuable compromise that satisfies both authorities and thus safeguards the foundations of both legal orders. Therefore, even if a domestic judge of last resort has the upper hand to defy the international decision, she should ordinarily abstain from doing so at her pleasure, assuming the international tribunal is willing to make concessions towards the domestic judge or at least to explain in detail and in a plausible manner the reasons on which its decision is founded.

Concerning your second question, the rule should be one of abidance by international customary law or international treaty law with the aim of fostering good relationships among the contracting parties and within the international community. Ordinary domestic judges should only be allowed to question the applicability of a clearly established rule of international treaty law or customary law before a domestic court of last resort to the extent to which no interpretation in conformity with domestic constitutional law can be provided. To this end, ordinary domestic judges should give particular consideration to the existing international case-law, as well as to statements and reports from committees and treaty bodies and to the national case-law of other states confirming or defying such a rule. The domestic court of last resort should weigh the interpretation of the rule, as given in the international legal order and as checked by the ordinary domestic judge, against its own case-law. It should defy the international rule only if no judicial dialogue with the corresponding international judge or committee is available in order to check whether the adequacy or extent of the rule could (still) justify the required restriction of the constitutional domestic principle. However, in the event that a corresponding 
international judge or committee has reaffirmed the existence and meaning of the international rule, the domestic courts should not defy its application.

\section{Francesco Francioni}

Thanks, Joseph, for raising these important and pertinent questions. As for the questions regarding the circumstances and conditions under which a national court could/should disregard a judgment of the ICJ or another international court or tribunal, or could/should decide to 'violate' an established rule of international law, my answer is the following: the concept and scope of international justice does not coincide with the concept and scope of national justice. The latter is essentially 'individual' justice, based largely on the assessment of rights and responsibility of individuals in their mutual relations and in their interaction with public authorities; the former is 'inter-state' justice involving rights of states and responsibilities of states (even in the field of human rights adjudication). This entails that there may be a 'mismatch' between the two spheres of justice and that a supreme court, or a constitutional court, may find it justifiable or even necessary, in the absence of alternative remedies, to defy a judicial decision of an international court or a norm of international law in a situation where some fundamental and inalienable rights guaranteed under the national constitution are ignored at the international level.

When the object of the disagreement is a norm of customary international law, the challenge posed by a national court may also be functional to the 'virtuous' renewal and progressive development of customary international law, provided that the initial 'violation' of the norm is followed by a widespread practice and a sense of obligation that such practice responds to a social necessity. In the case of treaty norms, the conflict between the national and the international levels should be resolved by the substantive and procedural rules of the Vienna Convention on the Law of Treaties, including Article 64 concerning the emergence of new rules of ius cogens and the procedures for the termination or suspension of operation of a treaty.

\section{Specific Questions}

Thank you for your illuminating chapters. My task here is to raise some questions that I think readers of your contributions may themselves wish to raise either by way of clarification or by way of objection. 


\section{To Paolo Palchetti}

JHHW: In the opening of your piece you write in a somewhat critical idiom:

'On the one side, there is a hyperactive judiciary, which appears determined to provide court access to victims through a controversial interpretation of international rules and, in the case of the ItCC, irrespective of the costs in terms of compliance with the international rule of law.'

I find this statement problematic in at least three ways, which I invite you to clarify.

1. Why 'hyperactive', when these courts seem to be operating in what they consider the interest of justice? If Italian courts followed a 'non-controversial' interpretation of international rules, could they not be accused, in the same vein, of 'hyperpassively' shutting their eyes to the perceived injustice of the international rule?

2. Is it a true representation of the ItCC to say that it decided irrespective of the costs in terms of compliance with the international rule of law? Surely it is a legitimate reading of its judgment to say that it is entirely based on the Court's consideration of the cost-regarding important values, moral and constitutional-of compliance with the international rule?

3. Are you not begging the most important question underlying this decision: how should one understand what the 'international rule of law'-indeed what the 'rule of law', international or otherwise-demands in a situation such as this?

I do not raise these issues simply as 'debating points' (got you!) but because of my belief that framing the issue correctly has an impact on how to understand it correctly.

Likewise, you write elsewhere:

'While the main consequence of Judgment 238/2014 is that Germany is currently being denied jurisdictional immunity before Italian courts, the inflexible conception of the right of access to court[s] adopted by the Corte Costituzionale has a number of implications (...)'.

Is it truly an 'inflexible' conception? Is it not precisely the opposite? Is not the Italian Constitutional Court acting against an inflexible position, which would accord blanket sovereign immunity, and introduce (just as they point out happened in an earlier epoch where an exception was introduced for commercial transactions by a state) some flexibility in the case of egregious violations of fundamental human rights in time of war?

PP: I answer these questions together because they prompted in me the same reaction: 'was I as critical of the Italian Constitutional Court as Professor Weiler's questions appear to suggest?'. To be clear: I am indeed critical of the ItCC. But I don't criticize the fact that the Court reacted against the situation created by the lack of any political initiative coming from the Italian and German governments following the judgement of the International Court of Justice. To the contrary, as I have written, the Court has 'the merit of forcefully raising the question of the rights of the 
victims of grave breaches of human rights and of the way in which these rights are to be protected'. My criticism is directed at how the Court reacted, namely 'by focusing exclusively on individual access to justice and on the need to promote an evolution of the law of state immunity'. In sum, it is certainly true that I focus on the empty half of the glass. If I do so, it is also because I believe that a different solution was available, as I will explain below. But I do recognize that there is also another more positive half of the glass. I concede that if this does not come across from my chapter as clearly as it should, I should like to thank you for giving me the opportunity to clarify.

The use I have made of certain terms for defining the conduct of ItCC may not be very precise or require further explanations. The intent behind their use was not necessarily to criticize the Court.

The hyperbole in my describing the judiciary as 'hyperactive' was intended to emphasize the contrast between the attitude of the judiciary and the ('hyper-passive') political organs. You may be right in pointing out that Italian courts had their reasons for acting as they did. My only point, however, was simply to stress the difference in attitude. I concede that when I wrote 'irrespective of the costs in terms of compliance with the international rule of law', I may give the mistaken impression that the ItCC took lightly the decision to defy international law. This was not my intention, and I thank you for allowing me to be more precise on this. I simply intended to indicate that the Court accepted to defy international law in order to give full effect to the principle of judicial protection.

With regards to 'the inflexible conception of the right of access to court[s]', I don't think I have anywhere in my chapter contrasted the conception of the right of access to courts retained by the ItCC and the conception of the right of foreign states to immunity retained by the ICJ. If I use the term 'inflexible' it is simply because nowhere in its judgment did the ItCC allude to the possibility that, under certain circumstances, the right of access to courts might be sacrificed. As I have tried to show, this gives rise to a number of questions, which also touch the delicate issue of the compatibility with the Italian Constitution of alternative means of redress that Germany and Italy might put in place for the purpose of putting an end to their dispute.

Finally, I tentatively addressed your question regarding "what the "rule of law", international or otherwise-demands in a situation such as this?' when responding to the second of your general questions.

JHHW: A very important section of your chapter concerns the distinction between 'immunity from jurisdiction' and 'immunity from execution'. You point out that even after Judgment 238/2014, Italian courts under Italian law will grant German authorities immunities from execution for any decision against them awarding damages to the victims. You also express dissatisfaction with this situation by rightly pointing to-also following the Greek saga where the victims of the German Distomo massacre were denied relief in Greece by virtue of immunity of execution-a decision upheld by the European Court of Human Rights (ECtHR) in 
Strasbourg. What is the point, one may summarize your position, of a right recognized if it is not accompanied by an adequate remedy?

You also point out that the question of immunity of execution will surely return to the Italian Constitutional Court in the follow up to lower court decisions in the current ongoing imbroglio. But here, somewhat frustratingly, your analysis stops. You do not seem to get off the fence. The analysis is brilliant in showing the conflicting considerations, but finally what is your position as to the correct answer the Italian Constitutional Court should give when the immunity from execution is before it? All things considered, if you were a judge on the ItCC, how would you decide this issue? Taking into account that Sentenza 238/2014 has already occurred, it is against its background that you will have to decide the case.

PP: In my view, in order to reconcile compliance with international law and respect for the fundamental rights of victims, the ItCC should establish that, in line with the Italian Constitution, the Italian state is under an obligation to assume the burden of repairing the victims. This is what the ItCC could, and in my view should, have done in 2014. The idea that, in cases involving the application of the rule of immunity from execution, the Italian state could substitute itself for the foreign state was already alluded to by the Court, albeit for different purposes, in a past judgment (Judgment 329/1992). An answer of this kind has much to be praised from a legal, moral and political perspective. Legally, not only would it reconcile two conflicting values - the interest in complying with a rule of international law and the right of the individual to obtain redress-it would also have the effect of transferring onto the state the risk that any attempt to obtain redress from Germany through interstate negotiations may be unsuccessful. In other words, this kind of solution would not imply any waiver of the claim against Germany. It would simply change the main actors in the dispute: exit the individuals and domestic courts, enter the state and interstate negotiations, in line with the suggestion contained in the 2012 ICJ Judgment. Shifting the risk from the individual to the state responds also to a wider imperative: affected individuals should not be left alone in bearing the cost of complying with international law. If there is a state interest in complying with international law, the state should be associated with the affected individual in bearing the costs. From a political perspective, such a solution might hopefully facilitate the conclusion of an agreement between the two states. After Judgment $238 / 2014$, the message sent to Germany was 'we don't comply with the ICJ's judgment, but you should negotiate an agreement on reparation with us'. In this situation, the reputational damages for not engaging in negotiations are not necessarily high. They would be much higher if Germany would leave Italy alone in providing reparation to the victims. I am aware that imposing on Italian taxpayers the cost of paying for the crimes committed during World War II (WWII) is far from the perfect solution but, given the circumstances of the present case (and the historical background of this longstanding dispute), I consider it an acceptable compromise. 


\section{To Christian Tomuschat}

JHHW: You argue that the Italian Constitutional Court failed to show the existence of any individual reparation and omitted to assess the issue of war reparations owed by Germany in their broad complexity as reasons for rejecting its renegade decision. Imagine now that the ItCC had done exactly these things and (perhaps after remitting the case back to the lower court for further fact finding) that, after careful examination, the Court would have established the existence of some individual claims and, even in the broad complexity of the German-Italian war reparations saga, that very fundamental human rights had been violated without adequate remedy.

In such hypothetical circumstances, would your appraisal of the action of the ItCC be different?

CT: This question attempts to lead me down an erroneous path. Of course, I did criticize the Italian Constitutional Court's failure to provide a solid foundation for its conclusion that any victim of a war crime must be a holder of an individual reparation claim. The ItCC avoids specifying in which legal order such a claim should be anchored. International law does not provide the requisite basis. If the ItCC had carried out any research, it would have found that in the past-before 1945-international armed conflicts had never been settled, in respect of their financial dimension, by granting the affected individuals the right to assert their own losses by way of individual claims. Recent instances have followed a different course-claims against Iraq on account of its aggression against Kuwait; reciprocal claims in the relationship between Eritrea and Ethiopia-but on the basis of special arrangements. The practice as it stood until 1945 is quite clear: violations of humanitarian law may lead to compensation claims at the interstate level in accordance with Article 3 of Hague Convention IV. This legal position cannot be altered or turned around by speculation.

The legal rule reflected in Article 3 of Hague Convention IV is reasonable. But is it effective, and has it stood the test of time? The Italian jurisprudence has remained isolated apart from the Greek judgments that were also before the ICJ. In particular, how should a mass phenomenon like World War II be otherwise dealt with? For a judicial body, which is committed to specific fact-finding rules, it is simply impossible to clarify, in an unchallengeable manner, hostilities on the battle field, allegations of mistreatment in camps for prisoners of war or civilians, attacks against fleeing populations etc. Millions of people died during WWII, in many instances as a consequence of undeniable criminal acts or other forms of atrocious conduct contrary to humanitarian law. Fortunately, alleged perpetrators may be prosecuted before national or international criminal courts or tribunals. Prosecutorial wisdom will inevitably focus on persons that are believed to be the main responsible authors. However, in civil cases, where compensation is sought, anyone considering that they have suffered damage could initiate proceedings if the obstacle of immunity fell. Accordingly, not only thousands but millions of claims would have to be processed, at a tremendous cost. Lawyers looking for sources of income would inevitably make 
use of such opportunities. A race for compensation would ensue according to the adage: first come, first served. Claimants with the best lawyers would have the best chances - to the detriment of those at the back of the line. Lastly, rights granted to Italian citizens would also have to be recognized to German victims of war crimesof which there were millions. A revival of WWII at the legal level? The legal battles would go on for decades even after reconciliation has been attained in intergovernmental relations. What horrendous perspectives!

Therefore, the settlement of compensation claims by way of international agreements between the parties concerned is certainly the best solution. Germany paid a high price for global settlement, partly imposed by the victorious Allied Powers. In the future, as was done regarding the conflict between Iraq and Kuwait, the UN Security Council could, in similar instances, establish a just mechanism with equal chances for every victim.

JHHW: The danger of providing a pretext for ignoring decisions of the ICJ is very serious and must weigh heavily in assessing such a case. But, for example, in the Melloni saga, the German Federal Constitutional Court (FCC), having no doubt examined the complexity of all issues, handed down a decision protecting fundamental human rights guaranteed by the German Constitution in what to most would appear a clear contradiction with the jurisprudence of the European Court of Justice, thus creating a similar precedent. Are there no cases in your view where a national constitutional court is justified in defying an international jurisdiction?

CT: This question has an entirely different structure. In the case of war damage claims between Germany and Italy, one of the parties has arrogated to itself the right to assess the conduct of the other party, and therefore constitutes a departure from the principle of sovereign equality. It postulates for itself the right to the truth, brushing aside one of the basic premises of the international legal order, namely the rule that no state is superior to another. In the controversy about extradition on the basis of a judgment rendered in absentia, however, three high judicial bodies - the Spanish Constitutional Court, the FCC, and the Court of Justice of the European Union (CJEU) - were in competition with one another regarding their degree of human rights protection. This was not a case where the ultimate national decision inflicted harm to any other stakeholder.

JHHW: The law of sovereign immunity is still rooted in customary law, despite the relevant treaties in question. Is it not the case that progressive changes in customary law almost by necessity require some state actors at some point to go against lex lata in the hope of other states joining them and shifting the burden of general practice and opinio iuris? You might object that this case did not justify such action. But would you also argue that it is never justified?

CT: This question invites the commentator to deeper reflection. It is true that substantively not all rules of customary law are of the same importance for the good functioning of the international legal order. Some rules, since they arise out of practice, have a contingent origin. The law of the sea provides prominent examples in this regard. The traditional canon-shot rule evolved successively in consonance 
with factual and legal developments within the framework of the UN. Similar adjustments to evolving circumstances regarding other customary rules are perfectly conceivable, and someone must then indeed take the lead in departing from the traditional pattern. However, sovereign equality and its complement, sovereign immunity, belong to the ground rules of international law and do not belong to the mass of other customary precepts that have sprung up from contingent occurrences. Whoever challenges the system of reparation for injury caused by armed hostilities would have to show that the present-day interstate model of compensation is insufficient and that the alternative, reparation by way of individual claims before the tribunals of the victim's state, is better suited to fulfil legitimate expectations. That demonstration cannot be made and was not done in the case before the ItCC - a particularly poor decision in respect of its legal reasoning where the interstate dimension was completely left aside.

\section{To Heike Krieger}

JHHW: In section II of your chapter ('Adverse Effects') you rightly point out that a judicial rebellion (my term) risks engaging the international responsibility of the state that the 'rebelling' court belongs to. I entirely agree and find the analysis convincing. What I think is lacking is a full rehearsal of the counterarguments. Now, I do not mean that the counterarguments are necessarily stronger than the weighty arguments you put forward, but they are necessary in order for the reader to arrive at an informed position.

1. Customary law develops slowly, oftentimes in a community of states that does not reflect the current composition of the international community (eg the law of expropriation) and likewise against a set of public values crystallized into customary law at the time. The well know structural problem is that it is extremely difficult to change or mutate in order to reflect the more contemporary values of a changing international community. Sometimes this can happen through the negotiation of a broad multilateral treaty, but experience has taught us how difficult and time consuming (measured in decades) it is to negotiate and then ratify such treaties - and even then it is binding only on those ratifying states. The passage from a new treaty norm modifying earlier customs can take even more time and is inured to persistent objectors. The alternative is a mutation in customary law itself through a shift in general practice and opinio juris. This has happened quite regularly, for example the 200-mile Exclusive Economic Zone recalls the Iceland-UK trawler war. But for customary law to mutate in this way, it is inevitable that at first some actors would adopt positions in violation of extant international law (the New Haven school calls these 'protonormative') claiming (and sometimes, lying through their teeth) that these reflect opinio juris in the hope of enlisting a change through silent acquiescence or imitation. Given the 'primitive' nature of international law-with the absence of 
a central legislator-could one not argue that without this process we would often be locked into a custom that is truly in need of change but for which no other mechanism exists? That sometimes there is even either a legal imperative (a national constitutional court in most systems owes its primary loyalty to its own constitution) or a moral one?

2. It is true as you state that a decision by a national court may trigger the international responsibility of its own state. This is no different from a decision of the executive branch or the legislator that may trigger state responsibility. This happens not infrequently in international life, including by liberal democracies that generally follow the rule of law. To give but one recent example, the decision of the EU to retaliate against Donald Trump's tariffs based on national security (and not on the WTO safeguard regime) was in clear violation of Article 23 of the Dispute Settlement Understanding. Morally justified, legally violative. Would you not agree, however, that when it comes to issues of justice and fundamental rights, if state responsibility is to be triggered, it should be done by, or with the authority and agreement of, constitutional or supreme courts?

3. In the same section II you object, justifiably in my view, to the argument of the democratic character of the state. You ask rhetorically: Why would not be legitimate for Russia (in the Yukos case) what would be legitimate for Germany and Italy? But could you then comment on the decision of the German Federal Constitutional Court in the famous Constitutional Identity case where it defied (indirectly) the jurisprudence of the European Court of Justice and extant EU law in the name of fundamental rights protected by the German Basic Law, ironically in a case concerning Italy. Was this decision justified in your view? Should we assess it differently from Sentenza 238/2014?

In section II.3 ('Change “desired by many”?'), you very convincingly show that there is far from consensus on the issue of human rights exceptions to sovereign immunity. But here, also, there are two structural issues on which I am sure your readers would value your comments.

1. The first echoes my first structural comment. Could not the evidence you adduce for the lack of consensus operate, too, in the opposite direction? First, as a matter of legal doctrine, it becomes a demonstration that the condition for a stable custom-general practice accompanied by opinio juris-has been fractured. As a matter of policy, wouldn't there be even more incentive for those unhappy with the current state of custom to act accordingly, seeing that an alternative approach-even if not dominant-is no longer maverick? Again, how else would custom change?

2. Second, international law privileges states and, in reality, governments. But the whole human rights revolution (of the last half century) was to insist that individuals are to be regarded not simply as objects but as subjects and meaningful stakeholders in international governance. Governments and even courts are often oblivious or not sufficiently mindful of this and, moreover, governments are often driven by a self-interest not to find themselves in analogous situations where their own sovereign immunity will be challenged; self-protective instinct 
often spills over to courts. Courts are reluctant not to follow the lead of governments in matters involving foreign affairs and relations with other states. Should we not, from time to time, celebrate a court that, in the interest of protecting human rights, is willing to take a position which might embarrass its own government or which is based on a more holistic view of what international law is about?

HK: I take the liberty to answer your questions posed to me as well as the general question in one line of argument since the relevant considerations are closely interrelated.

Law reform is a deep-seated challenge for international law and there is indeed a wide-spread perception that its rules sometimes do not change quickly enough to meet certain moral imperatives or to react to urgent demands, for instance in relation to climate change. On the other hand, high hurdles for changing rules of customary international law contribute to locking-in acquired and consented standards and to protecting them against unilateral attempts of bringing about change, in particular by powerful states. Even where these states claim to act unilaterally in the name of common values shared by the international community, a (new) rule of customary law cannot be brought about without a uniform and widespread practice and a corresponding opinio iuris. This guarantees a broad consensus of states and may work to protect weaker states.

Take the example of the right to self-defence in relation to non-state actors. The 'unable and unwilling test', which is advocated by the US and some other predominantly western states, has gained traction in recent years, in particular in the context of the conflict with Daesh. States that are under a constant or recurring threat of military attacks by non-state actors may claim a legitimate interest in changing the right of self-defence. This may be prompted by consideration of their human rights duties to protect their citizens as much as the interests of the international community to prevent terrorism. However, for states of the Global South, this perspective might be less convincing since most of the military interventions justified by this standard will be directed against non-western, non-European states in the southern hemisphere. Moreover, there is considerable doubt that the standard fits with the telos of Article 51 of the UN Charter and thus many consider unilateral efforts to establish the 'unwilling and unable test' as contributing to an erosion of the prohibition on the use of force.

Eventually, lasting changes in relation to the interpretation of Article 51 of the UN Charter will depend on a finding of the ICJ. There is a strong presumption that due to its singular role under the UN Charter, its functions within the international legal order, its composition and its long-standing authority, the ICJ is the decisive institution for determining the existence and interpretation of rules of customary international law.

National courts may contribute to processes of creating and changing customary law but as organs of the rule of law they should be careful not to challenge the authority of the ICJ by acts of non-compliance. After all, according to the idea of a 'dédoublement fonctionnel' (Georges Scelle), international law needs to rely on 
national organs, in particular national courts, for its implementation. Thus, a plea for a change to customary international law requires taking into account the international legal context and should be guided by the following three considerations:

1. A decision of a national court advocating a change of customary international law should not directly oppose a judgment of the ICJ in the very dispute in which the ICJ has only recently passed this judgment against the court's own state. Opposing a decision of the ICJ in such a case is first of all an incident of non-compliance in view of the judgment's binding effect on the parties. The plea for law reform has already been raised before the ICJ, which rejected it in its decision. Given the authority of the ICJ for determining rules of customary international law, the same applies where the ICJ has only recently determined a rule of customary international law in a case concerning other states. However, a national court may under certain circumstances and conditions argue in favour of a change of an otherwise clearly established rule of customary international law. This may either be the case where there is no international jurisprudence at all or where pertinent ICJ decisions date a long time back. The Pinochet case is a case in point where the House of Lords quite successfully pushed for law reform. In doing so, it did not directly oppose a decision of the ICJ.

2. In such a case, a court should base its reasoning not on the national constitution but on an interpretation of international law, thereby allowing other states or courts to engage in a legal discourse under international law. Refusing to comply with a judgment of the ICJ on the basis of national constitutional law does not provide legal arguments for further developing international law and thus is more a plea for (norm) conflict than for law reform. In the interpretative process, the court can indeed rely on a lack of consensus on the existence or content of a rule of customary international law as indication that the conditions for a stable custom have been fractured, which in turn legitimizes a deviation from the rule. Thus, by now a strong argument can be raised that the rules on the immunity of state officials are indeed changing. There are a number of judgments in diverse jurisdictions allowing for human rights-based exceptions for acting state officials. There was a split in the pertinent International Law Commission (ILC) debate leading to a vote where those in favour of human rights exceptions attained the majority. Likewise, there was a split in the $6^{\text {th }}$ Committee. However, in the case of Sentenza 238/2014, I do not think that the international legal discourse in regard to state immunity would reflect such a type of dissent. Criticism is still predominantly literature based.

3. The different branches of government should agree about the necessity for changing customary international law. As the Italian case demonstrates, in particular democratic states under the rule of law face the dilemma that different organs may take different positions towards customary international law. For the purposes of international law, the ILC Conclusions on Identifying Customary International Law stressed that "where the practice of a particular State varies, the weight to be given to that practice may, depending on the circumstances, be reduced.' Thus, it is preferable if these organs speak with one voice, in particular 
where there is a risk of incurring state responsibility. However, I do not think that constitutional courts are per se more legitimate actors in this process, especially where they disagree with both of the other two branches. In comparison to the legislative branch, they have lesser democratic legitimacy. In comparison to the executive, they may sometimes give too little weight to diplomatic considerations. Such diplomatic considerations should not be mistaken for governmental self-interest. There are several legitimate rationales behind such considerations, which may range from functional reasons over concerns for legal stability to broad considerations of maintaining peace and security. While deference to the executive is today often seen negatively, I still think that it may be a useful tool for courts in balancing conflicting interests in foreign relations. After all, a more holistic view of international law is not necessarily one that is based on national fundamental rights concepts.

In your questions you invite us to assume that the court is asked to defy an international legal obligation as a kind of last resort. But I already disagree with the assumption that it is inevitable that conflicts will arise. National jurisdictions have developed various techniques for mitigating norm conflicts by way of interpretation precisely in order to prevent such severe frictions from arising. Any state that faces a norm conflict between national and international law may have a bundle of further options available beyond mere non-compliance through court decisions or defying a binding international obligation. These options include parliamentary legislation, parliamentary decisions that aim to prompt the executive to pursue certain acts on the international level, diplomatic protection, issuing reservations or interpretative declarations, or even withdrawals. In deciding on the appropriate measures to be taken, state organs should act with mutual loyalty as well as with loyalty towards the international legal order, not least because of the idea of a 'dédoublement fonctionnel'. Constitutional courts have to balance democracy and rule of law considerations against each other. In this process compliance with the international legal obligations of a state is an important element of the rule of law.

My concern is that constitutional courts may be increasingly inclined to claim that demands of constitutional identity require them to defy international law or EU law. And the decision of the German Federal Constitutional Court in the 2016 Constitutional Identity case is a case in point. The decision dealt with an extradition request by Italy on the basis of a European arrest warrant for a person who was sentenced to 30 years of imprisonment in absentia proceedings without legal representation in Italy. The FCC held-by means of the identity review-that in such a case an extradition would violate the right to human dignity. Thereby, it indirectly defied the Melloni judgment of the Court of Justice of the European Union which held that member states are not allowed 'to disapply EU legal rules which are fully in compliance with the Charter where they infringe the fundamental rights guaranteed by that State's constitution'. ${ }^{1}$ In my view, there would have been other options for

${ }^{1}$ CJEU, Melloni, Judgment of 26 February 2013, Case C-399/11, EU:C:2013:107, para 58. 
the FCC to protect the applicant's human rights without relying on its concept of identity control. The Court could have either opted for a preliminary ruling by the CJEU or it could have chosen an interpretation preventing a norm conflict with EU Law. It is doubtful that the act in question had to be considered as an act of German public authority determined by Union Law. Interpreting the Framework Decision on the European Arrest Warrant in light of Article 47 and 48 of the Charter of Fundamental Rights, the Court could have concluded that EU law does not require extradition in cases of absentia proceedings. The decision of the Higher Regional Court was not determined by EU law. The part of the decision violating human dignity could have been considered exclusively as an act of German public authority, which the Court could have assessed on the basis of the German Constitution. ${ }^{2}$

Eventually, you may argue that I am evading the baseline of your argument, namely that in exceptional cases and for moral reasons a court should defy a rule of customary international law or a judgment of an international tribunal. But my worries are that such cases are not as exceptional as you suggest. In a multipolar world order characterized by increasing value contestations, arguments based on national identity as embodied in national constitutions are already being raised more frequently. Pertinent cases in recent years do not only refer to severe war crimes but they include cases on extradition, expropriation, or refugee relocation schemes. To define where there is sometimes a justified legal or moral imperative and where such imperatives are abusively claimed to protect all kinds of ostensible national values may become a slippery slope. With its reliance on human dignity in the Constitutional Identity case, the FCC may indeed have opened yet another door for widening national identity jurisprudence against international courts given that a human dignity core may well underlie all fundamental rights. In this light, I have always been sceptical about recourse to morality for creating instances of 'civil disobedience' between courts. In the end, international human rights protection exists precisely for those who get into conflict with national identities.

\section{To Riccardo Pavoni}

JHHW: I think we are all in favour of peace, not least legal peace. And I think that your use of international comparative precedents makes a strong case for how this peace may be obtained in negotiations between the parties. But the proposed 'peace agreement' you advocate for does have legal ramifications for evaluating Sentenza 238/2014. Since, assuming I and your readers understand you correctly, it is

\footnotetext{
${ }^{2}$ Dana Burchardt, 'Die Ausübung der Identitätskontrolle durch das Bundesverfassungsgericht Zugleich Besprechung des Beschlusses 2 BvR 2735/14 des BVerfG vom 15.12.2015 ("Solange III"/'Europäischer Haftbefehl II")', Heidelberg Journal of International Law, 2 (2016), 527-551, at 549.
} 
premised on the assumption that if adequate remedies for serious rights violations were not provided to victims, the parties have to negotiate such remedies.

But does that not at least implicitly vindicate the position taken by the ItCC? And had the ItCC not taken that principled position-which would lead to what you consider to be the necessary fair and equitable solution-what incentive would there be for the parties to engage in negotiations?

RP: I am very thankful for your question, Professor Weiler, as it gives me an opportunity to reiterate some of my thoughts on Sentenza 238/2014. Indeed, I believed it was more in line with the spirit and purpose of this volume to espouse a forward-looking approach in my chapter and accordingly enquire into the future prospects of the German-Italian dispute concerning outstanding compensation claims by victims of crimes committed during World War II. Yet a clarification on the interaction between my findings and Sentenza is certainly in order.

Yes, you do understand me correctly. The 'legal peace' I am advocating, preferably by way of an intergovernmental arrangement between the parties setting up meaningful compensatory procedures for uncompensated victims, is premised on the assumption that, under international law, victims of serious breaches of human rights and humanitarian law are entitled to adequate remedies and reparation. Pace the ICJ's Jurisdictional Immunities Judgment, in my view - and that of a substantial number of scholars - this international law right to a remedy and reparation ${ }^{3}$ qualifies the rule of state immunity for international crimes: the immunity of the responsible state before the courts of other states may be denied if and when effective alternative remedies are unavailable to the victims. Thus, not only should the negotiation of 'legal peace' between the parties be regarded as a reflection of their obligation to secure such remedies and reparation, it would also be a means of protecting state immunity for acta iure imperii-admittedly a key tenet of the world order-against backlashes and challenges coming from turbulent domestic courts, as the ItCC in delivering Sentenza may be depicted.

However, only indirectly and implicitly (at best) do the foregoing observations vindicate the holdings of Sentenza 238/2014. Certainly, Sentenza, by declaring in essence the 2012 ICJ Judgment incompatible with the Italian Constitution, has provided a robust incentive for the parties to come back to the negotiating table. It is easy to assume that, in the absence of Sentenza 238/2014, the whole affair would be buried once and for all, both at the judicial and-a fortiori-governmental levels. This is probably the key message arising from the Judgment and a number of comparable domestic cases, notably in the US, where the denial (or threat of denial) of state immunity has given impulse to fresh diplomatic representations and negotiations for the sake of victims' right to reparation for human rights violations. But this has little to do with the legal reasoning of the Constitutional Court. That reasoning lends itself to distinct layers of criticism.

\footnotetext{
${ }^{3}$ UN General Assembly, Basic Principles and Guidelines on the Right to a Remedy and Reparation for Victims of Gross Violations of International Human Rights Law and Serious Violations of International Humanitarian Law, Annex, GA Res. 60/147, 16 December 2005.
} 
First, the Constitutional Court was not crystal clear about the (domestic law) implications for state immunity stemming from the lack of alternative remedies for the victims. The decision may be interpreted as envisaging the commission of serious violations of human rights as the sole requirement for the loss of state immunity and, accordingly, as playing down the 'alternative remedies' test or merely using it as an a fortiori argument. This is the view expressed, for instance, by the late Benedetto Conforti in his commentary on Sentenza published in the Revue générale de droit international public and, in the judicial practice post-dating Sentenza 238/2014, by the Italian Court of Cassation in its 2015 Opačić decision involving and denying Serbia's immunity for war crimes. If this view were correct, the principle upheld by Sentenza 238/2014 would be especially broad as it would justify a withdrawal of immunity in each and every case implicating serious breaches of human rights by foreign states. I would consider this principle unacceptable as it would not draw a reasonable balance between the competing values at stake.

Secondly, one may well take the opposite view and believe-as I do- that the Sentenza was a breakthrough vis-à-vis the previous Italian jurisprudence in this area, precisely because the absence of alternative remedies was a key reason for the holdings of the Constitutional Court. Yet, Sentenza did not recognize that it could be implemented via political negotiations yielding whatever intergovernmental agreement and compensatory mechanism open to the victims. The Constitutional Court repeatedly pointed out that, in order to fulfil the victims' right to reparation, effective judicial remedies must be available. As the concerned Italian victims were denied such remedies in any other jurisdiction including before German courts, the only way forward was the repudiation of Germany's immunity and the consequent endorsement of assertions of jurisdiction by Italian courts. In short, according to the Court, 'legal peace' should be pursued through the judicial route, not by means of administrative or political processes. Of course, this does not mean that diplomatic negotiations would be a waste of time, but it does at least mean that the putative arrangements devised by the governments concerned might well be scrutinized by the Italian Constitutional Court under the high threshold of effective judicial protection set by Sentenza. Although clearly arising from frustration about the decades-long unwillingness of the German and Italian governments to engage in meaningful negotiations, the unbending position of the Court should be rejected as once again not establishing a satisfactory balance between the competing interests at play.

Thirdly, and most fundamentally, I firmly disagree with the methodological stance taken by the Court in Sentenza 238/2014. The latter contains a sort of preliminary disclaimer where the Court, relying on a confusing version of the doctrine of consistent interpretation, stated that it would only assess the consistency of the customary rule of state immunity for international crimes within the Italian constitutional order, without questioning how that rule was interpreted by the ICJ in its Jurisdictional Immunities Judgment. I do not subscribe to this view and I am not at all vindicating it in my chapter. On the contrary, and this is a good occasion to answer - at least in part - the general questions put to the volume's authors, I am unable to find any legal rule characterizing the decisions by the ICJ (or other 
international courts) and the interpretations of international law offered therein as untouchable by domestic courts. Of course, this question must be kept distinct from the binding effect of such decisions. At any rate, the Constitutional Court did not justify its domestic law approach on account on that binding effect, which it explicitly rejected, and merely highlighted the 'especially authoritative' nature of the ICJ's interpretations. The result was perverse: the ICJ's decisions addressed to Italy may not be binding as a matter of Italian constitutional law, whereas the ICJ's interpretations in those same decisions are binding under both international and domestic law. There was nothing in theory or precedent barring an autonomous review of the pertinent practice by the Constitutional Court, that might have paved the way for findings different from those of the ICJ yet still justified under international law. It is true that Sentenza 238/2014 includes a number of tacit critiques of the ICJ's holdings, and it is also true that the Constitutional Court perceived itself as contributing to the progressive development of international law. But you cannot have your cake and eat it too! With its exclusive domestic law approach and associated disregard for its consistency with international practice and opinio juris, Sentenza rests on a fragile legal basis. This consideration may easily be relied upon to depict Judgment 238/2014 as a violation of international law sic et simpliciter, one which is liable to further engage the international responsibility of Italy arising from this affair. Full stop. Game over. The practical significance of the Sentenza may militate in favour of 'legal peace' and may be conducive to an evolution of international law in this area but not its legal reasoning.

\section{To Filippo Fontanelli}

JHHW: You suggest a mutually agreed reparations scheme. If the two parties agree, this might indeed solve the problem. But one can understand German reticence to indicate their willingness to reopen settled agreements with multiple countries that fell victim to German WWII atrocities. How do you prevent such a settlement from destabilizing such agreements with claims of a differing nature surfacing from many quarters?

Be that as it may, you sidestep the question of whether Sentenza was justified. Was it?

FF: Indeed, my chapter does not speak about Sentenza 238/2014, let alone assess it. The omission is deliberate: reparation schemes derive in all or in part from the states' agreements, so their establishment is possible also (and precisely) when there is no underlying obligation to set up one or when the obligation is contested. Incidentally, I do not think Sentenza is justified under international or Italian law, and I find it ethically dubious. Being righteous with another's money is a cheap method of virtue-signalling at best, and at worst a way to pass the buck and redirect away the claims of victims. This is why the proposed Reparation Scheme would call Italy's bluff and force it to put its money where its constitutional mouth is. The 
proposal would require each state to fund the Scheme in equal parts, creating an 'Amazon-doubles-your-donation' effect whereby Germany's liability would not be measured upon an alleged duty of reparation but would spur from a (presumed) urgency to match Italy's contribution and save its Teutonic face.

Perhaps I should explain why I presume that German authorities would feel such urgency. There is something vaguely shameful in the idea that Italy, having in vain exhausted all avenues of legal redress for the IMIs, would openly pay out reparations for Nazi crimes while Germany just idly watched. I think Italy should reverse the paradigm and engage Germany in a race to the top, not the bottom: instead of a fight for responsibility, it should launch a decency challenge. Consider what happened between South Korea and Japan in the case of reparations for comfort women. Korean public opinion expressed affront at Japan's stance and Korea decided to replace the Japanese payments with its own resources. The move was a PR catastrophe for Japan: its conduct was held to be so despicable that its money was not worth taking. To publicly accept liability for the wrongdoing of others is doubling down on the injustice. Japan now has to reckon with an even greater stigma. If Italy is determined to go through with its part of the deal, Germany's refusal to participate would be hard to watch irrespective of one's views on its original responsibility vis-à-vis IMIs. If there is any force to hunger strikes, it is not that they are convincing; it is that they are compelling.

The ex gratia and Telethon-like aspects of the Reparation Scheme would also make it unfit as a precedent and an encouragement for other claims. To be sure, differential treatment triggers discontent and incites demands from those treated less favourably; ask the vineyard workers hired at dawn or the brother of the prodigal son. However, the Reparation Scheme escapes easy analogies.

First, in sidestepping the issue of responsibility, it would signal the ad hoc voluntary origin of the mechanism. Other claimants might think themselves and IMIs to be in 'like circumstances' and claim discrimination. However, absent an acknowledgment of responsibility, the simple fact that Germany would accept Italy's proposal to join the Reparation Scheme would alone differentiate the circumstances and justify differential treatment: Germany's act of goodwill would concern only certain recipients. Hence why custom does not build on practice alone: favours, donations, and graceful payments do not count. It is hard to demand for oneself the effect of generosity that benefitted others. After all, the existence of several reparation schemes managed by Germany and other states in favour of other groups of beneficiaries have so far not given any traction to the IMIs' claims, so past practice does not support the fear of snowballing. Indeed, precedents do not carry much weight: if anything, it was Sentenza that advanced the IMIs' hopes for reparation (more on this below).

Second, any hypothetical copycat claim would not fly without overcoming a gateway condition, that is, to have secured $50 \%$ of its own payment. If the Reparation Scheme would serve as a precedent (it would not), it would only do so with respect to joint payments. It is hard to imagine many claims coming out of the woodwork that could count on a 50\% promise of payment by the home government. 
Ultimately, it is possible that the Reparation Scheme could incite other claims. I am not sure that this should be opposed altogether, as indeed it might be desirable that Germany address those too, just as now it is desirable that it provide reparation to IMIs. However, I estimate this scenario to be unlikely and such potential claims to gain little mileage from the operation of the Reparation Scheme. Germany, in other words, could not escape the embarrassment of declining Italy's proposal by hiding behind an improbable snowball effect.

JHHW: If a scheme such as yours is adopted, would you not agree that it is only because the ItCC took its controversial decision? Is this a good lesson? A bad lesson?

FF: Yes, I would share that impression. In fact, there are only two imaginable scenarios: either a reparation scheme is finally established (in the wake of the hullabaloo caused by Sentenza) or it is not (in spite of Sentenza). The likelihood of the scheme arising is still quite low, but without Judgment 238/2014 it would be non-existent.

I have not reflected nearly enough on civil disobedience to have a view on the appropriateness, in general, of illegalities producing public goods. The bad lesson would be the encouragement of acts of legal disobedience motivated by the apparent success of one such act. If the Russian Constitutional Court wants to avoid Strasbourg decisions, Sentenza 238/2014 is a handy crutch to lean on. Even more worrisome would be imitation by diligent and well-intentioned courts attracted by the Italian take-away.

However, I suggest a change in perspective. If the Reparation Scheme is a desirable outcome-and I believe it is - its desirability does not depend on its chances of realization and, in turn, by the circumstance that increased them (Sentenza). Sentenza worked as an act of public shaming, itself a practice that walks the line between advocacy and abuse. Public shaming can occasion virtuous results. Something similar happened in Kadi before the CJEU. Two frankly debatable judgments by the CJEU undoubtedly caused the UN to improve its practices. I would hesitate to call Kadi a good lesson, but I also believe that a few isolated 'bad lessons' can be tolerated if they improve the world.

I also believe that there is no evident risk of a 'school for cheaters' developing. Italy taking on half of the financial burden of the Scheme, and its ex gratia nature, would tip the balance towards the 'good lesson' verdict and minimize the generalizations (ie 'international law must be observed unless it is convenient not to'). Should an agreed Scheme arise, Sentenza-for all its awkwardness-would have proved to be the catalyst for the development recommended by the ICJ to happen, namely that there be 'further negotiation involving the two States concerned, with a view to resolving the issue'. Is it fair to reward a prodigal court, which strayed away from orthodoxy? I cannot answer this question in general, but I can suggest that in this case the reward (the Scheme) is not a fattened calf. The Scheme would not benefit the Constitutional Court, nor would it clearly benefit Italy altogether (in fact, Italy would have to pay for half of it). 
In a certain sense, Sentenza might prove to be a smart trolling device: it created a controversy where the law warranted none; in so doing, it damaged both Italy and Germany. Concurrently, by creating a dispute it inevitably made its settlement desirable, and thus valuable. It created out of thin (and stagnant) air novel incentives for both states. The Reparation Scheme would constitute the reasonable solution: Italy would pay for the harm caused by trolling at the edges of the law, and Germany would pay for the trolling to stop. Both payments would go to charity (to IMIs).

\section{To Alessandro Bufalini}

JHHW: The solution that you seem to advocate would perhaps bring closure to this particular dispute. But, arguendo, the importance of Sentenza 238/2014 was not simply in pressing for a specific solution to the particular case before it but to rethink the question of sovereign immunity in cases where the state claiming immunity is responsible for grave human rights violations, some of which at least would qualify as ius cogens.

You will have noted that in its decision, the ICJ gave considerable importance to the decisions of national courts. The decision of the Italian court could be a contribution towards a new jurisprudence and could eventually lead to an adjustment of the current law, as was the case a century ago when absolute immunity was removed in relation to commercial and other acts. It is a fact of international law that customary law often changes through initially proto-normative actions-and a decision of a court is almost by definition proto-normative-which contradict lex lata.

Would not your solution squelch this potentially important development by the Italian government, itself contradicting the principled general thrust of its own constitutional court even if complying the particularistic dimension?

AB: Thank you for your thought-provoking questions as they allow me to better clarify my views.

As a premise I think it is important to emphasize that if the aim of Sentenza $238 / 2014$ was to question customary law on state immunity, as identified by the ICJ, the ItCC could have followed a different approach. The strong dualistic approach of the decision seems, in fact, to end up recognizing and confirming current law at the international level, as opposed to the fundamental principles of the Italian Constitution. A stronger claim for an adjustment of the current law would have been to critically respond to the ICJ, both underlying the existence of decisions by national courts supporting the evolution of customary law and arguing against the contradiction inherent in preventing a reparation for a breach of ius cogens rules by applying a customary norm on immunity.

That said, the crucial issue here is whether a 'political solution', namely the involvement of the Italian government, would somehow arrest the potential 
development of customary law on state immunity. In this regard, while it is certainly true that changes in customary international law may often happen through violations of current law, the latter is not always the best way to pursue a change. In particular, these violations might be successful when changing forces are strong enough to cause the breach of the rule to become the rule itself. As regards state immunity, one is currently faced with a clear-cut ICJ judgment and a multitude of national governments (including, perhaps, the Italian government) and domestic courts that do not seem to be disposed to let the change happen. Other paths, however, are available for a development of international law. National judges may have called on the Italian government to grant reparation to victims, and thus engaging in the affirmation (or consolidation) of the existence of an individual right to reparation for gross violations of international human rights and humanitarian law. At the end of the day, while Sentenza 238/2014 might be a potential element of support for the current law on state immunity, the call for a necessary and urgent intervention of the Italian government could have been an important step towards the recognition of an individual right to reparation at the international level.

\section{To Christian J. Tams}

JHHW: I think that your critique that the Italian Constitutional Court did not integrate international legal norms and sensibilities into its reasoning on Italian constitutional law is powerful. That was, inter alia, part of the critique faced by the majority of the Court by the minority (see, for example, Sabino Cassese's chapter in this volume).

Is it true? Did not the ItCC address the process of change of international law in relation to sovereign immunity and ius gestionis?

CJT: This is an important question and I hope that I can clarify and situate points that my chapter attempted to make in my reading of Judgment 238/2014. Was there not, you ask, in the judgment some openness towards international law? My short response would be 'perhaps some, but not enough'.

I remain concerned with how marginal international legal rules governing immunity were to the ItCC's reasoning in Judgment 238/2014. As you noted in your question (and as I probably should have noted in my chapter), the ItCC did reflect on changes in the scope of sovereign immunity and as an example mentioned the move towards the restrictive doctrine: this is described as a 'progressive definition of the content of the international norm [on immunity, which] (...) originated in the national jurisprudence' of a number of states (paragraph 3.3). However, this reference to developments in the law of sovereign immunity serves to make a fairly basic point, namely to illustrate that change in international law is possible, and that domestic courts can be agents of change. That in itself is not controversial. But it did not help with the real question on which Judgment 238/2014 turned: whether 'the international norm [on immunity]', insofar as it mattered in Judgment 238/2014, 
had been 'progressive[ly] defin[ed]' so to exclude immunity for grave breaches, or to require immunity to yield to remedial claims based on human rights (paragraph 3.3).

It mattered so little, in fact, that the arguments about changes in international law all but disappear from the relevant parts of the ItCC's reasoning. As we will discuss below, in engaging with international law, the ItCC accepts the construction by the ICJ as binding: rules of international law reach into the Italian legal order 'as interpreted in the international legal order', that is by the ICJ. On the ItCC's home turf of Italian constitutional law, changes in international law do not matter either. The balancing is between two constitutional values - the right to remedy and respect for human rights on the one hand, and respect for international law on the other-and the outcome is the result of a constitutional assessment: 'insofar as the law of immunity from jurisdiction of States conflicts with (...) fundamental principles [of the Constitution protecting human rights and the right to a remedy], it has not entered the Italian legal order and, therefore, does not have any effect therein' (paragraph 3.5). On the key questions that mattered, domestic law controlled.

JHHW: Be that as it may, there seems to be an assumption in your critique that if only the Italian Court had integrated international legal elements the decision would (necessarily) be different. This I think is questionable. Grant me at least that a non-specious case could be made that a combination of the robust development of human rights law in the last decades as well as a better understanding of ius cogens could call into question extant positive international law. Could you at least point out some internal contradictions that might suggest the necessity for rethinking and change?

The argument that positive law on the whole has not shown signs of welcoming a reconsideration of sovereign immunity in the face of grave violations is correct, but your argument would make it remain such, since the deep logic of your argument is that if positive law is $x$, not least in the area of customary law, then it must remain $x$. How will it ever change if any attempt to push for change is met by your kind of argument? Do you not accept that there have been many examples where progressive developments of customary law were initiated by actions that at the time went against positive law? Consider Solange I by the German Federal Constitutional Court, which was clearly in defiance of the established jurisprudence of the European Court of Justice. But, without that defiance, it is not clear if the CJEU would have rethought its prior 'positive law' position and developed a new jurisprudence that gave just weight to. . . human rights. Is there not some kind of lesson here in the relationship between international tribunals and constitutional courts?

Even if you do not accept this argument, imagine now that in its decision the ItCC had in fact taken into account international legal norms and come to the conclusion that it reached. Would you appraise Sentenza 238/2014 any differently? And if not, why? In assessing international legal norms, should the Court necessarily adopt your own view on how that law should impact their decision?

CJT: This set of questions addresses issues that to me seem closely related. They go to the heart of the debate triggered by Judgment 238/2014 and identify tensions in my discussion of it. They also suggest that I may not have been entirely clear in 
setting out my position; perhaps, while chiding the ItCC for its 'Lutheran' approach, I was in fact sounding a bit Lutheran myself. Be that as it may, I appreciate this opportunity to reclaim my inner agnostic. I do so in three steps that seek to respond to this set of questions.

1. I proceed from two points of agreement. We both consider that at present international law does not recognize a grave-breaches exception to sovereign immunity. In your words, 'positive [international] law on the whole has not shown signs of welcoming a reconsideration of sovereign immunity in the face of grave violations'. I put matters more firmly in the second part of my chapter because I wanted to emphasize that the international law case for such an exception-'ha[ving] been made in dozens of settings, and almost inevitably rejected'-is at present fairly weak. But that difference (to which I will come back shortly) may be a matter of style or degree. In any event (and this is the second point of agreement), neither you nor I think the current state of the law is set in stone. Of course, it can change, of course arguments for an exception remain plausible, but the question is whether in the future those involved in the process of international law-making will be persuaded. ${ }^{4}$

2. In such a discourse about future directions of the law, disobedience with international law - or with ICJ decisions - is one possible strategy. Domestic courts can be powerful agents of legal development, and there are, as you rightly stated, 'many examples where progressive developments of customary law were initiated by actions that at the time went against positive law'. 5

I have no principled concerns with that. In the on-going process of affirming, adjusting, and developing customary international law, disobedience has a role. It is not so uncommon, and in cases pitting human rights against sovereign immunity, domestic courts voicing disobedience are likely to do so with the approval of groups on whose support international law counts: from NGOs, human rights lawyers, and the media to the wider public. This is why I purposefully ended my chapter with a call for argumentative disarmament, suggesting we move beyond scandalizing Judgment 238/2014. Judging from your questions, I should have put this more clearly and I hope to have done so now.

3. While not so much concerned about domestic court disobedience as such, my chapter contrasted two strategies for voicing such disobedience. I emphasized that Judgment 238/2014 marked a change of tack: rather than arguing that international

\footnotetext{
${ }^{4} \mathrm{My}$ chapter looked at the present state of the law: Joseph Weiler considers it to be based on a 'deep logic' of continuity: 'the deep logic of your [the CJT's] argument is that if positive law is $x(\ldots)$ it must remain $x$ '. However, my main point was (meant to be) more limited: the argument for a gravebreaches exception under international law in my assessment had so far simply not persuaded states, international organizations, or the majority of international and domestic courts. As part of the constant evolution and adjustment of custom, this may well change (as noted on page 245); arguments in favour of a grave-breaches exception 'remain plausible, and who knows, they might one day find greater acceptance'.

${ }^{5}$ As an aside, there may be more examples of regressive development initiated by domestic court disobedience, but who could authoritatively say which changes are progressive and which regressive? It does not seem obvious to me that the recognition of a grave-breaches exception would illustrate the progress of international law.
} 
law recognized a grave-breaches exception, the ItCC took the debate to the home turf of constitutional law and refused to give effect to sovereign immunity as 'defined' by the ICJ. I took this to be a conscious move, reflecting the ItCC's acceptance that under contemporary international law, the argument for a grave-breaches exception to sovereign immunity was weak. This view, which of course may be wrong, makes it difficult for me to respond properly to this set of questions. Is it really 'questionable' that if the ItCC had argued on the basis of international law, Judgment 238/2014 would have been decided differently? My reading is that the ItCC — unlike the Italian Supreme Court in Ferrini-conceded the international law argument. Rather than seeking to rehearse the debates about immunity exceptions under international law, it took the debate to the home turf of constitutional law. By the same token, as regards your third question, I do not mean to suggest that the ItCC 'should adopt [my] own view' of the scope of sovereign immunity, but it seems to me that Judgment 238/2014 is in fact based on the view that international law does not at present recognize a grave-breaches exception to sovereign immunity. This is how I read the ItCC's reference to 'the interpretation by the ICJ of the customary law of immunity of States from the civil jurisdiction of other States', which did 'not allow further examination by national governments and/or judicial authorities, including this Court' (paragraph 3.1). Judgment 238/2014 is intriguing because it takes the debate to a different level.

JHHW: Your analysis is acute in pointing out the retreat to domestic constitutional law. But can you dismiss such a retreat in all cases and all circumstances? Are there not cases where you would consider this the best way? The only way?

CJT: This different level is the constitutional law provisions regulating the impact of international law within the domestic legal order: the foreign relations law of Italy. Rereading the chapter, I do not think I articulated my position as clearly as I should have, and you press me on this, with good reason, in your question. In response, let me offer three clarifications. First, in the aforementioned spirit of argumentative disarmament, there is nothing wrong as such with relying on foreign relations law to limit the impact of international legal rules. Domestic courts have done this frequently and often successfully. (You mention Solange I, I referred to Görgülü, Medellin, and Kadi). Judgment 238/2014 is not the first 'Triepelian' domestic court decision. Second, domestic foreign relations law will often be an effective line of defence: state responsibility is the price to pay, but international law does not rule out constitutional overrides. In cases such as the present one, it may be perhaps not the only but the most obvious way of avoiding the implications of international law. Third, is it the 'best way', you ask? I would say it is a high-risk strategy, and this is where I felt that the ItCC was on a dangerous course, and not sufficiently aware of the implications of its change of tack. High-risk because a domestic court refusing to give effect to intrusive, undesired rules of international law-and doing so by reference to constitutional law provisions - uses a very broad argument that is open to all courts in all jurisdictions and no longer limited to the field of immunity. (If Italian courts rely on the Italian Constitution to justify Italy's non-compliance with an undesired ICJ decision, what stops courts elsewhere from invoking their 
constitutional principles to justify non-compliance with other undesired decisions?) In Judgment 238/2014, the ItCC seemed to ignore these dangers. Unlike German courts under the Solange approach, it does not threaten disobedience but orders itthe judgment is not a shot across the bow but one that hits home. Unlike many other domestic courts, it does not present disobedience as an ultima ratio; nothing in the judgment suggests that, even on the home turf of constitutional law, respect for international law should be the norm. Perhaps most importantly, Judgement 238/2014 does not accept that international law should guide the interpretation of domestic values, at least in the normal run of events. In short, while a 'retreat to domestic constitutional law' (to use your words again) is a plausible strategy, domestic courts should in my view use it with care, exceptionally, and within clearly articulated limits. The absence of these limitations is my main concern with Judgment 238/2014.

\section{To Raffaela Kunz}

JHHW: It is difficult to argue with your informative, thoughtful, and realistic analysis of the interaction of domestic and international tribunals.

There will, I think, remain among your readers possible doubts.

First, why do you seem to suggest, at least implicitly-and I am happy to stand corrected if proved wrong_that in some ways Sentenza is worse than several other cases where we have witnessed direct or indirect defiance? No one has gone to the gallows here, as indeed was the case when the American Supreme Court committed its acts of defiance. Is there anything structurally different in this case?

RK: Thank you, Professor Weiler, for your thought-provoking question. It is an honour for me to enter into this dialogue with you, all the more because my own chapter deals with dialogue in a broad sense, namely with judicial dialogue between courts of different legal orders.

Indeed, is there a structural difference between this case of defiance of an international court decision and, let's say, Medellin, the case in which the US Supreme Court decided not to implement the ICJ judgment in the Avena case? Let me retrace the facts of this case. The ICJ found that the US had violated the Vienna Convention on Consular Rights, but the main issue regarded the consequences this would have for the concerned individuals who were all waiting on death row in American prisons. Medellín tried to enforce the international judgment before the US Supreme Court and to reach the review and reconsideration of his case. This case is thus not just a typical inter-state dispute; it fundamentally touched upon individual rights and in fact dealt with life and death questions.

When I make the point that there is a difference between the ItCC's judgment and that of the US Supreme Court, my aim is thus not to judge the outcome, or to say one was worse than the other. As I just tried to show, the Medellin judgment had very serious consequences. In fact, I think that the Supreme Court should have 
implemented Avena, but this is another question. My point about the difference between Medellin and Sentenza is structural and concerns the changed quality or tone the two judgments have. I believe that something has really changed since Medellín, which was issued in 2008. But let me explain.

In Medellin the defiance was somehow indirect. The US Supreme Court argued that the judgment was not directly applicable and thus phrased the issue as one of a separation of powers - it was up to the parliament and not the judiciary to implement the judgment. Of course, this can be-and has been-seen as an 'avoidance strategy' by the Supreme Court, but the difference of this line of reasoning to judgments where domestic courts declare international judgments to be altogether unconstitutional is that technically the judgments could still be implemented, (which in the case of the complainant in Medellin is not entirely true given that the death sentence against him has been executed).

The judgment of the ItCC, on the other hand, stands for a more recent type of jurisprudence, one in which domestic courts do not shy away from openly contradicting international courts. The ItCC's defiance of the ICJ is not an isolated example, as I argue in my chapter, and there are a number of examples by other domestic courts taking a similar stance. To come back to the Medellín comparison, today it seems that domestic courts are more confrontational and direct in their defiance. Thus, it could be said that Sentenza 238/2014 stands for a new selfperception of domestic courts. This goes in the direction of what you called the 'third wave' of judicial review.

I think that the change of this self-perception has to do with the proliferation of international courts and the fact that the interplay between legal orders has become even more complex.

JHHW: A second, more substantive and substantial doubt is the following.

Your analysis is premised on the assumption that national courts are attempting to 'cushion' the domestic impact of international decisions. This might be true in some or even all of the cases you mention. But it might not be the only explanation or justification for the behaviour of domestic courts. You seem to argue that ensuring compliance with decisions of international tribunals is the supreme value. You call this compliance partners. I agree that this is an important part of a well-functioning international legal system. But there is a 'but'.

With the much-discussed proliferation of international tribunals-sometimes (and this is hugely important to my question) with contradictory jurisprudence, and with many of them operating as courts of first and last instance in the same case (namely lacking the possibility of appeal)—the system does not perhaps provide for appeal and review of such decisions by many of these tribunals, including the ICJ. The European Court of Human Rights has a laudable system of chambers and the Grand Chamber. But absent such mechanisms, would you not agree that it might by necessity fall to national constitutional courts to act in such role? With prudence, with caution and all other good advice you give, but see themselves also acting in such a role? Would it not be better if there was actually a mechanism for dialogue between the national constitutional court and the international tribunal so that the 
latter can be informed by the sensibility of the former? Should not the Taricco saga in which, in the face of such a dialogue by the Italian Constitutional Court, the European Court of Justice climbed down from the high branch it had perched itself? But absent such a mechanism?

RK: There is no doubt that in times of global governance, there are tensions and even clashes between legal orders, and that these pose challenges to courts. With regard to international judgments, it is of course unsatisfying that they are commonly first and last instance at the same time, and I agree that domestic courts can to a certain extent step in and make up for this gap. In other words, there might be legitimate reasons for domestic courts not to follow an international judgment-this has been called 'constructive contestation'. This highlights the productive side that this 'dialectic' interplay between different legal orders can have, which arguably in the end leads to better — and in this case especially more legitimate-results. (I prefer not to use the term 'judicial dialogue' for cases of actual defiance).

The more cautious stance of domestic courts that we see today may also have a positive consequence. And in any case, is it not something that has always been present but only recently become more explicit? Is open defiance not more honest than hiding behind 'avoidance doctrines'? To some extent yes, but there is a 'but', and this is the point I try to make: I think that there is a real risk that courts go too far. It is true that international courts are powerful players today, but they nonetheless remain vulnerable and dependent on the cooperation of their domestic counterparts. Even though today it is widely recognized that the superiority of international law in the sense of a strict monism is neither realistic nor even desirable, a very dualist approach, according to which international judgments systematically have to pass a domestic (constitutional) law test before being followed domestically, cannot be the answer to our complex legal reality either. This neglects the interest in an overall functioning system of adjudication across systems and levels.

What then might be a middle-ground solution? We cannot deny that the application of international law can have problematic consequences, and at the same time it remains true that in times of global governance there is no way around international law. Rather than secluding ourselves behind a dualist vision of the world, we need to face reality and productively think about how to best cope with the challenges of our times.

In my opinion, this is done most convincingly by pluralist thinkers such as Paul Schiff Berman or Nico Krisch. They recognize on a descriptive level the complex, maybe even 'messy' legal reality; but rather than trying to bring order into it, they try to work productively with it. What does this entail for our constellation? My reading is that under such a pluralist vision, rather than defining clear criteria about how to solve different types of norm conflicts, what is required is a flexible approach, one that allows the circumstances of each case to be considered. The different legal claims and interests at play should be balanced according to their importance and weight rather than their provenance from the domestic or international sphere. Rather than big theories, we need solutions for those complex cases of clashing normative claims. 
It is probably quite self-explanatory why Sentenza 238/2014 does not fulfil this pluralist ideal. In my view, the justices, seeking to find simple answers to complex problems, fell into the 'dualist trap'. I do not want to delve deeper into this againmy position is already stated in the chapter. But let me highlight once more that, while acknowledging that there can be cases where 'defiance' is necessary and 'resistance' against international institutions has a productive and constructive side, I do not think that Sentenza 238/2014 is an exemplary case of legitimate resistance against a wrong or unjust international judgment. And I do not think that we should use it as a blueprint for judicial interactions.

To illustrate my point, and delving a bit deeper into your more general question about justified or legitimate cases of defiance, allow me to name an example of a court that in my view did a better job at respecting the overall interest of a functioning system of adjudication when it refused to follow an international judgment.

The example is the judgment of the Argentinian Supreme Court following the ruling of the Inter-American Court of Human Rights (IACtHR) in the case of Bueno Alvez, in 2007. In this case, the complainant was accused of having mistreated an arrested man by beating him and refusing him his medicine. The IACtHR had qualified these acts as torture and ordered an investigation into the allegations. In Argentina, however, the case had already been closed through final judgement, as the court in charge found the offense to be time-barred.

Even though the Argentinian Supreme Court usually follows the IACtHR and indeed for many years was said to be one of its strongest allies, on this occasion it refused to do so, arguing that this would violate basic rule-of-law standards, namely the procedural rights of the accused in the sensitive area of criminal law, enshrined both in the Argentinian Constitution and the American Convention on Human Rights (ACHR). The Supreme Court in this case, always highlighting its general loyalty towards the IACtHR and careful not to make a principled case, comprehensively described the norm conflict and stressed that the implementation of the order would not only violate the Argentinian Constitution but also the ACHR itself. At the same time, it distinguished the case from other cases, namely cases involving crimes against humanity. The reason not to follow the Court-even though it later changed its position-was thus that in this case the domestic court considered the interest to uphold the due process rights of the concerned individual higher than the interest to implement the international judgment. Let me conclude by stating that interestingly, this is one of the few reported cases in which the IACtHR indeed seems to have listened to a domestic court disagreeing with it and subsequently adjusted its position.

\section{To Giovanni Boggero and Karin Oellers-Frahm}

JHHW: One cannot argue with the first set of considerations that you meticulously raise, and which would need to be resolved in operationalizing Sentenza 238/2014. 
But I do not think that you are suggesting that these inevitable dilemmas should have meant that the Italian Constitutional Court should have refrained from taking the decision it did. It could, as you suggest, give more guidance, draw more lines, but do you question the principled aspects of the decision against immunity in this case?

GB/KOF: Professor Weiler's question concerns a central aspect of our argument. We are pleased to have the opportunity to explain our line of reasoning and yet, at the same time, we are afraid that our answer will not be positively accepted. But this is exactly the value of judicial dialogue, especially at a time when the role of states and state-related legal norms as compared to individual rules/human rights is declining. The problem of state immunity in cases of grave violations of human rights is a developing field and where a limitation of all-over immunity is challenged with good reason.

The question of Professor Weiler concerns our argument that Sentenza raises a lot of problems for Italian courts and tribunals, and this question is, moreover, directly related to Professor Weiler's first general question regarding the reaction of national courts to ICJ decisions, in particular the defiance of an ICJ judgment. Professor Weiler says that 'one cannot argue' as we did without giving reasons for such a categorical statement concerning a well-pondered scientific opinion. However, our argument is based on an analysis of the decisions of Italian courts or tribunals directly following Sentenza 238/2014 which are facing a dilemma: by abiding by Sentenza they are violating international law; by not abiding by Sentenza they would be in violation of national law. Professor Weiler supposes that these 'inevitable dilemmas' would not result in us believing that 'the Constitutional Court should have refrained from taking the decision'. But this is exactly what we meant and the reasons underlying our opinion have been elaborated and further explained in a number of publications, some of them cited in our chapter. There might be situations where it may be justified to disregard a judgment of an international court—although such situations appear to be rare exceptions_-but the 2012 ICJ Judgment, as well as a judgment of the European Court of Human Rights in the same vain, is not such a judgment. The main reasons may be summarized shortly in the following points. The ICJ was asked to find out whether state immunity before the judiciary of states is still a rule of customary international law even if acts of grave human rights violations are at stake. Thus, the question was whether the customary law rule had changed-a possibility that exists but requires, as the coming into existence of a new customary law rule, opinio iuris and general practice. As such the ECtHR and the ICJ came to the conclusion that this was not yet the case. On the basis of this finding, the ICJ did not have to answer the question of the retroactivity of such a new rule, as the acts committed dated back more than 70 years, or whether such a rule would also be applicable to war related crimes where reparation agreements had been concluded as usual in order to come to peaceful terms between former enemies.

According to Article 59 of the ICJ Statute, the 2012 ICJ Judgment was binding upon Italy and, by becoming a party to the UN Charter, Italy had 'undertake(n) to comply with the decision of the ICJ' (Article 94 (1) of the UN Charter). This fact had led the Italian Parliament - the representative of the people, the sovereign - to adopt Law No 5/2013 obliging the national judiciary to comply with the ICJ Judgment. 
Despite not only the existence of treaty obligations under the most important treaty, short of a universal constitution (the UN Charter), but also the national law representing the intent of the Italian sovereign, the Constitutional Court decided that the national law was unconstitutional and, with regard to the UN Charter, the law ratifying it was also unconstitutional, but only with regard to Article 94(1) and the Court's Jurisdictional Immunities Judgment. For the rest, Italy considered itself to be a party to the UN Charter.

With regard to the limited space accorded to our answers, it may be sufficient to mention here only that it seems evident that the reasoning of the Italian Constitutional Court is unacceptable as it disregards the basic principle of international law, namely the principle of pacta sunt servanda, thus leaving it to the discretion of states to pick and choose which of the accepted obligations shall be honoured or not, and whether they shall be honoured permanently or only for a period-or even single moment-defined by the state. The implications of this approach undermine the validity and security of international law as such, which requires that states comply with their international obligations and with the decisions of courts whose jurisdiction they have voluntarily accepted. Disregard of international judgments may be justified in the extremely hypothetical case of a judgment gravely violating basic/ peremptory rules of international law, but in such cases other means (for example the involvement of the UN Security Council) should first be sought because defying decisions of international courts and tribunals risks generating unforeseeable implications for the whole system of international law.

As to the additional questions of Professor Weiler in this context, in our view a change of customary international law usually starts by non-application of the 'old' rule by states. This is an unavoidable implication of the development of international law. However, in the event that an international court has been asked explicitly to discover whether that particular rule of customary law has changed or not, the decision found by the court has to be complied with. As international courts are composed of judges from different regions of the world, and as the ICJ in particular represents the main forms of civilization and of the principal legal systems of the world (Article 9 ICJ Statute), they are best qualified to assess whether opinio iuris and general state practice are present. To comply only with court decisions supporting the view of the claimant would undermine the ideal of settling disputes peacefully. The alternative of not complying with international law and international judgments reminds us of the old reservation of 'vital state interests' dating as far back as the beginnings of international arbitration. This reservation was always under discussion because it leaves the assessment of what are the vital interests to the concerned state; it therefore allows the state to escape from its general submission to the jurisdiction of an international court rendering such a submission unreliable.

Besides the concerns it raises with regard to general international law, Sentenza $238 / 2014$ left it to the ordinary judiciary to decide on basic questions, such as the time-limit for bringing claims - are 'only' claims from World War II admissible or also claims dating back to World War I, or for that matter any war? - as well as the definition of who may bring claims (family members of which generation?), 
guidelines for reparation/compensation issues, the requirement of a territorial link and lastly, the question of execution. It thus risked opening the floodgates for an unforeseeable number of claims leading to inconsistent decisions with regard to questions that would have required a framework predetermined by the Italian Constitutional Court if not probably by the parliament.

JHHW: You raise a floodgate argument, or rather two: one macro and another micro. The first is that other courts in other jurisdictions would follow a similar line of jurisprudence in the face of sovereign immunity claims in cases of grave violations of human rights. Would you consider that this, should it happen, might be a positive development: unsettling the extant law in favour of a new rule on sovereign immunity that would not allow states to shield themselves behind sovereign immunity when they are the authors of grave human rights violations and in the absence of other effective remedies?

You also seem to suggest that the floodgates would open with claimants from other jurisdictions, like the Greek plaintiffs in this case, and would therefore flood Italian courts with similar claims. Floodgate arguments are difficult to predict. But do not Italian courts and the Italian legal system have adequate mechanisms to squelch such a flood: with doctrines of the family of forum non conveniens, rules of standing and the like? How realistic is this fear of an avalanche of cases?

GB/KOF: These questions can be succinctly answered. The macro floodgate argument, namely that other jurisdictions might follow the Italian approach, may, although starting from a breach of international law, contribute to the development or change of the international customary law rule on state immunity. Such a development may be considered positive, especially if an evolution towards denial of state immunity becomes part of an accepted custom shared by an increasing number of governments. As to the micro floodgate argument, namely that even victims lacking a territorial link to Italy, as in this case the Greek plaintiffs, could and would bring their claims before Italian courts, Professor Weiler objects that Italian jurisdiction could itself limit the flood by using the legal mechanisms foreseen in the Italian legal order. This might be true, but there remains the question, which cannot be answered definitively, whether Italian courts and tribunals would be willing to 'squelch' such a flood, which in our opinion seems rather questionable with regard to the previous practice.

\section{To Andreas von Arnauld}

JHHW: You are commendably forthright and intellectually honest in accepting that Germany, like Italy, holds to the doctrine that it is the duty of the judiciary-not least of the Constitutional Court-to disregard international obligations if they are incompatible with fundamental rights (and perhaps other fundamental principles such as 'constitutional identity') guaranteed by the national constitution. The German Federal Constitutional Court asserted this principle even against 
European Union norms-which in the eyes of many, including the European Court of Justice, constitute a much 'tighter' legal order compared to general international law. You raise this as a reason to dissuade a second 'appeal' to the ICJ even though you claim that Germany has as strong a position under international law 'as one could wish for'.

I wish to probe this interesting dialectical position a bit further.

Imagine a second appeal or even the original trial before the ICJ. Imagine a very direct question to the Counsel for Germany: is it the German position that a national constitutional court has to comply with international norms, or even a decision of the ICJ itself, in a case where said national constitutional court would consider that such compliance would violate its most fundamental constitutional principles?

1. Would you agree that under international law the answer must be 'Yes'-under the equally fundamental principle of international law that a violation cannot be excused by reference to domestic municipal law?

2. Would you agree, that if asked in such a direct manner, the Counsel for Germany could only respond in one of two ways: 'Yes, but the German legal order does not accept such compulsion'; or 'No, we believe that under international law in such a case a state would be justified in not applying the international norm or the decision of the ICJ (or any other international tribunal)'?

3. The first answer (Yes, but the German legal order does not accept such compulsion) is not so uncommon. It occurs in dualist systems in the face of non-incorporated treaties - the situation of British courts, for example. It could still be the case that the answer is 'Yes, but the internal constitutional order simply does not allow national judges to comply with the state obligations under international law with the result that state responsibility would be engaged'. Be this as it may, does not another general principle of international law, reciprocity, entail that Germany cannot demand of Italy compliance in a situation where analogously it would not offer compliance itself? (The French Constitution famously enshrines this principle of reciprocity in its Article 55). If this is the case, maybe the German position in international law is not quite as strong as one may wish for.

AvA: Concerning this first set of questions, the Counsel for Germany would most probably agree that, according to its own standards, a violation of international law can never be justified by reference to municipal law, even though she would have to concede that the German legal order is based on dualism and that it gives precedence to the Basic Law in case of an otherwise unresolvable conflict between international obligations and constitutional principles. If she is worth her salt, however, the Counsel for Germany would stress that this does not affect the present dispute. Reciprocity might be an underlying concept of international law but has no binding force in itself. Estoppel might turn the concept into a norm of procedural international law. But for Germany to be estopped from bringing claims, there would have to be an inherent connection between the present dispute and a similar violation of its international legal obligations towards Italy by Germany. Since this is not the case, Germany maintains its formally strong position under international law. 
If she is more audacious, the Counsel for Germany might argue that well-founded disobedience can sometimes, though not in the case at hand, be beneficial for the international legal system itself (and I would follow her here). International institutions might sometimes be at fault. Notwithstanding the general obligation to obey international law and binding decisions by international institutions, there should also be room for contestation within the international legal system. This is basically the Kadi problem where the CJEU challenged with good reasons the Security Council's binding decisions. To avoid a deadlock, however, such acts of disobedience should be framed as an offer to engage in a discourse about the law, not as a mere act of refusal. This is why, firstly, the reference should (also) be to shared norms and principles not (only) to domestic law. Compare the Court of First Instance's original approach to Kadi, though it only referred to international ius cogens and eventually shied back from finding the obvious violation. Secondly, there should be space for compromise as a way out. Paradigmatically, this is the Solange strategy, which communicates a willingness to give in as soon as certain standards are met. Such forms of constructive dissent could be seen as an exercise in 'compensatory constitutionalisation' (Anne Peters) bottom-up.

JHHW: I find interesting, constructive and morally commendable your willingness to pierce the intertemporal rule-especially with your very important caveat that it must be based on moral principles prevailing as part of the law at the time-a matter for empirical analysis. The consequence of your analysis would be to trigger an obligatio de negotiando. Would you, however, be willing to take the reader one step further. Given the decision of the Italian Constitutional Court, the hands of the Italian negotiators would be tied-they could not accept a solution that their own Court indicated would violate the Italian Constitution. (A German government would be in a similar situation if the shoe were on the other foot.) So, let's imagine that the negotiations reach an impasse-not an impossible possibility. (And to take the hard case so as not to make life easy for ourselves, let's further imagine that it is clear that both parties negotiated in good faith, as sometimes even good faith negotiations result in an impasse.) Having acknowledged that the intermingling of the dry positive law and the ethical principles are sufficient to breach the principle of intertemporality. What then?

AvA: I would like to swerve away from your question by providing a rather pragmatic answer. Given that the issue of German wartime reparations has been pushed by the Italian judiciary, and has only reluctantly been taken up by Italian governments so far, I am more optimistic about reaching an agreement in those tripartite negotiations, at least as far as both governments are concerned. Of course, there is no guarantee here, and of course it is possible that on the side of the victims some will not agree with a proposed solution. So, the matter could be referred back to the Italian courts. In such a scenario my hope would be that a scheme redressing the past wrongs, and supported by a sound majority in the negotiations, will prove a game-changer. After all, it was the perceived lack of engagement on the German side, government and courts alike, that prompted Italian judges to 'step in' (compare the references to the denial of 'any possibility of judicial examination' and the 
'absolute sacrifice of the right to judicial protection'). Once a widely agreed solution has been found, the Corte Costituzionale might give up its principled oppositionalongside the lines I sketched out in my answer to your first question.

I understand that you want to push me further, though. A procedural obligation is always a sly suggestion-assuming that the procedure works. If negotiations reach an impasse, don't we then need a decision based on substantive legal principles? I think that there are inherent problems in applying this kind of decisionist logic to historical events. Courts can ascertain facts (even 'historical' facts) to be applied to legal norms. They cannot solve, however, the underlying historical conflict; that issue can only be addressed discursively. As far as court proceedings offer a forum 'to tell one's story' (even to a reluctant opponent), they contribute to this purpose; judicial decisions that create winners and losers do not. Where there are binding legal norms in force, we accept this 'jurispathic' (Robert Cover) office of judges. In our case, however, the principles of intertemporality still weigh in (although I have attempted to loosen them up a bit). So, in case of an impasse and Sentenza 238/2014 still being upheld, the ICJ in a second judgment should 'pepper up' paragraphs 99 and 104 of its previous judgment and admonish the parties to sit down again and come up with an equitable solution.

JHHW: Imagine, finally, that the Italian government expropriates, say, Villa Vigoni, in compliance with the decision of their constitutional court. What should be the reaction of the German government in light of your own progressive and moderate position?

AvA: If this were to happen, Germany should protest against this violation of international law and should consider another judgment from the ICJ, including a request for provisional measures to halt the expropriation proceedings. As much as I am in favour of relaxing the strict rules of intertemporality in certain cases to 'bring the parties to the table', I am highly sceptical of a deconstruction of state immunity before foreign domestic courts. Allowing charges against a foreign state is ever more prone to abuse when 'lawfaring' states are attempting to impress their own ideas on others by excessive claims of jurisdiction. In my perception, as mentioned earlier, the Italian judiciary opposed the ICJ's decision on jurisdictional immunity as it perceived a lack of engagement from the German side. Its aim was thus to create a judicial forum for bringing (and eventually deciding) such claims. In Sentenza 238/2014, the Court was wise enough not to touch upon the issue of immunity from execution (which, by the way, is less intrinsically connected to the right to judicial protection, at least regarding its core guarantee). Thus, whether such an expropriation of Villa Vigoni would really be 'in compliance with' the Court's decision might be open for discussion. 


\section{To Francesco Francioni}

JHHW: I find myself in agreement with all the important points you make-the voice of reason and I say this with no irony. But I also find myself somewhat unclear in regard to where you position yourself on the hard legal issues.

You make an important point regarding Article 25 of the 1961 Italo-German Agreement and the failings of Italy in that respect. You make the equally important point of what would appear to be not only the discriminatory position of the German government vis-à-vis different groups of victims but also the legally incoherent position regarding the status of the Italian victims as prisoners of war. And you are of course right that, as time passes, biology is taking care of the immediate problem; although I should add that compensation to the families (as would be the case in a situation of wrongful death) will survive, at least as a moral right, the death of the victims themselves. So, yes, let's try and negotiate a satisfactory solution as soon as possible.

But assuming failed negotiations (even good faith negotiations can fail), where do you come out on the hard legal issues? Given all the circumstances to be taken into account, do you think the ItCC was right-for the reasons it gave or for other reasons - to take the position it took, under Italian Constitutional Law and, more intriguingly in light of your evocative comments on sovereign equality and immunity, in light of international law itself?

Accepting, arguendo, your seductive suggestion of the functionality of these two principles to ensure a peaceful international order, should one not add also that this functionality should serve not only a peaceful but also a just international order, which seems to me more germane in this case.

FF: Thanks, Joseph, for raising these thoughtful questions. You ask whether the Italian Constitutional Court was right in applying the 'counterlimits' doctrine to the Italian statutory enactment implementing the ICJ's Jurisdictional Immunities Judgment. My answer to this question is negative. This clearly transpires from my contribution. But here I can further articulate the reasons for my negative opinion.

First, I think that the judgment of the ItCC was wrong in its using of Article 24 of the Italian Constitution - access to justice — as a parameter for declaring illegitimate the domestic law implementing the judgment of the ICJ. The cases involving the responsibility of German armed forces for mass atrocities committed in Italy, and against Italians during the period of Nazi occupation of the country, called for the recognition of a right to compensation for the harm suffered by the victims, not a right of access to justice.

Second, as a right to compensation under the Constitution was at stake, the ItCC had good reasons to consider the question of constitutionality not 'ripe' for adjudication, both because the avenue of diplomatic protection was still open and because alternative remedies were still available, such as Article 25 of the 1961 Italo-German Agreement.

Third, even without considering the above reasons, the judgment of the ItCC is wrong from the point of view of judicial policy. It is a missed opportunity to bring an 
innovative impulse to international practice in the field of immunity. If the Court was so convinced of the incompatibility between the rule of immunity and the respect of the inalienable right of victims of mass atrocities to obtain compensation, why did it not state explicitly that it wanted to vindicate such a right at the international level and contribute to the consolidation of the 'territorial tort exception', an exception that still remains in a sort of limbo of international practice? Instead it paid a perfunctory homage to the authority of the ICJ and retrenched itself behind the argument of constitutional identity and the doctrine of the 'duality' of legal orders.

Finally, my argument regarding the functionality of the rule of immunity to serve a peaceful international legal order was meant to underscore that immunity is not a value in itself. It is only an instrument to safeguard other substantive values: the sovereign equality of states and the orderly conduct of international relations. These values often trump the value of individual justice, as sadly witnessed by the Jurisdictional Immunities Judgment. My chapter suggests that there are valid alternative remedies-executive action with negotiation, diplomatic protection, and legislative measures - to the constitutional doctrine of 'counterlimits' and to the hubris of judicial activism.

Open Access This chapter is licensed under the terms of the Creative Commons Attribution 4.0 International License (http://creativecommons.org/licenses/by/4.0/), which permits use, sharing, adaptation, distribution and reproduction in any medium or format, as long as you give appropriate credit to the original author(s) and the source, provide a link to the Creative Commons license and indicate if changes were made.

The images or other third party material in this chapter are included in the chapter's Creative Commons license, unless indicated otherwise in a credit line to the material. If material is not included in the chapter's Creative Commons license and your intended use is not permitted by statutory regulation or exceeds the permitted use, you will need to obtain permission directly from the copyright holder.

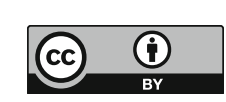


Annex 


\title{
Sentenza 238/2014
}

\author{
ITALIAN REPUBLIC \\ IN THE NAME OF THE ITALIAN PEOPLE
}

\section{THE CONSTITUTIONAL COURT}

\section{Composed of:}

President Giuseppe TESAURO; Judges: Sabino CASSESE, Paolo Maria NAPOLITANO, Giuseppe FRIGO, Alessandro CRISCUOLO, Paolo GROSSI, Giorgio LATTANZI, Aldo CAROSI, Marta CARTABIA, Sergio MATTARELLA, Mario Rosario MORELLI, Giancarlo CORAGGIO, Giuliano AMATO,

Delivered the following

\section{JUDGMENT}

in the cases concerning the constitutionality of Article 1 of Law No. 848 of 17 August 1957 (Execution of the Statute of the United Nations, signed in San Francisco on 26 June 1945) and of Article 1 (recte: Article 3) of Law No. 5 of 14 January 2013 (Accession by the Italian Republic to the United Nations Convention on Jurisdictional Immunities of States and their Property, signed in New York on 2 December 2004, as well as provisions for the amendment of the domestic legal order), brought by the Tribunal of Florence through Orders Nos. 84, 85 and 113 of 21 January 2014, and published in the Official Gazette of the Italian Republic Nos. 23 and 29, First Special Series, Year 2014.

Having regard to the appearance of S.F., A.M. and others, and B.D., as well as the intervention of the President of the Council of Ministers; 
having heard in the public hearing of 23 September 2014 the Judge-Rapporteur Giuseppe Tesauro;

having heard Mr Joachim Lau, attorney for S.F., for A.M. and others, and for B.D., and Ms Diana Racucci, state attorney for the President of the Council of Ministers.

\section{Conclusions in Point of Fact}

1. By means of three identical orders adopted on 21 January 2014 (Orders Nos. 84, 85, and 113/2014), the Tribunal of Florence raised the question of constitutionality:

1) of the "norm created in our legal order by the incorporation, by virtue of Article 10 , para. 1 of the Constitution", of the international custom, as found by the International Court of Justice (ICJ) in its Judgment of 3 February 2012, insofar as it denies the jurisdiction [of civil courts] in the actions for damages for war crimes committed jure imperii by the Third Reich, at least in part in the State of the Court seized;

2) of Article 1 of Law No. 848 of 17 August 1957 (Execution of the United Nations Charter, signed in San Francisco on 16 June 1945), insofar as, through the incorporation of Article 94 of the U.N. Charter, it obliges the national judge to comply with the Judgment of the ICJ, which established the duty of Italian courts to deny their jurisdiction in the examination of actions for damages for crimes against humanity, committed jure imperii by the Third Reich, at least in part in Italian territory;

3) of Article 1 (recte: Article 3) of Law No. 5 of 14 January 2013 (Accession by the Italian Republic to the United Nations Convention on Jurisdictional Immunities of States and their Property, signed in New York on 2 December 2004, as well as provisions for the amendment of the domestic legal order), insofar as it obliges the national judge to comply with the Judgment of the ICJ, even when it established the duty of Italian courts to deny their jurisdiction in the examination of actions for damages for crimes against humanity, committed jure imperii by the Third Reich in Italian territory, in relation to Articles 2 and 24 of the Constitution.

These norms are questioned in relation to Articles 2 and 24 of the Constitution. They are said to conflict with the principle of absolute guarantee of judicial protection, enshrined in Article 24 of the Constitution, as they preclude the judicial examination of the case and compensation for damages for the gross violations of human rights suffered by the victims of war crimes and crimes against humanity, committed in the territory of the Italian State (which has the duty to ensure judicial protection) by another State in the exercise of its sovereign powers (jure imperii). The principle of absolute guarantee of judicial protection is a supreme principle of the Italian constitutional order and, as such, constitutes a limit to the introduction [in the domestic legal order] of generally recognized norms of international law (under Article 10, para. 1 of the Constitution), as well as of norms contained in treaties establishing international organizations furthering the ends envisaged by Article 11 of the Constitution, or deriving from such organizations. 


\subsection{The referring judge indicates that he was seized:}

with regard to the first case, by Mr F.S., in order to obtain compensation from the Federal Republic of Germany for damages suffered during World War II. F.S. was abducted by German military forces in Italian territory and deported to Mauthausen on 8 June 1944. He was only set free on 25 June 1945, after untold sufferings;

with regard to the second case, by the legitimate heirs of Mr L.C., in order to obtain compensation from the Federal Republic of Germany for damages suffered by L.C. during World War II. L.C. was abducted in Italian territory by German military forces on 8 September 1943 and deported to Germany to slave labor. He was killed in one of the concentration camps of Kahla (Thuringia) in Germany and, according to the International Red Cross, was buried in a mass grave together with six thousand prisoners reduced to slavery;

with regard to the third case, by Mr D.B., in order to obtain compensation from the Federal Republic of Germany for damages suffered during World War II. D.B. was abducted by German military forces in Italian territory on 9 September 1943. [He was taken prisoner] in Verona (where he had been hospitalized) and deported to slave labor. He was segregated in the Zeitz concentration camp, a subcamp of Buchenwald, and was then transferred to the Hartmannsdorf Stammlager IVF concentration camp, and then again to Granschutz, where he was eventually set free by Allied forces at the end of the war.

The referring judge recalls that the Federal Republic of Germany filed appearances in the cases and raised the lack of jurisdiction of Italian judicial authorities. [The Federal Republic of Germany] requested that the judge apply the Judgment of the ICJ of 3 February 2012 and therefore did not accept to proceed to examine the merits of the case. Hence, the referring judge raised the aforementioned question of constitutionality of the norms that required the Tribunal to deny its jurisdiction.

1.2. - The Tribunal of Florence notes that the subject-matter of the cases is the examination of whether the [Italian] legal order (which conforms to generally recognized norms of international law) requires that the courts of the State in which the international crime has been committed deny the examination of actions for damages even in cases of war crimes and crimes against humanity, in breach of fundamental rights, perpetrated in [Italian] territory by a foreign State, although in the exercise of sovereign powers.

The referring judge points out that the nature of the acts forming the subject-matter of the claims, amounting to international crimes, and their potential to breach fundamental rights are uncontested. He also recalls that, before the ICJ rendered its Judgment, the Court of Cassation had affirmed the non-absolute character of the immunity of foreign States from civil jurisdiction recognized by international law. [The Court of Cassation had indeed] held that immunity can be limited even when the State exercises its sovereign powers, insofar as the acts complained of constitute crimes against humanity, which are considered international crimes (Judgments No. 5044/2004 and No. 14202/2008).

The referring judge notes, however, that the Court of Cassation changed its jurisprudence after the Judgment of the ICJ of 3 February 2012. In that Judgment, the ICJ 
held that "customary international law continues to require that a State be accorded immunity in proceedings for torts allegedly committed on the territory of another State by its armed forces and other organs of State in the course of conducting an armed conflict", even if [the foreign State] is accused of serious violations of international human rights law. The Court of Cassation aligned itself with the ruling of the ICJ and held that Italian courts lacked jurisdiction, since "the doctrines put forward by the Court of Cassation in Judgment No. 5044/2004 have remained isolated and have not been upheld by the international community, of which the ICJ is the highest manifestation. Therefore the principle (...) can no longer be applied" (Judgments No. 32139/2012 and No. 4284/2013).

In line with this orientation, [the Legislator] passed Law No. 5 of 14 January 2013 (Accession by the Italian Republic to the United Nations Convention on Jurisdictional Immunities of States and their Property, signed in New York on 2 December 2004, as well as provisions for the amendment of the domestic legal order), which explicitly excludes (in Article 3) the jurisdiction of Italian courts for war crimes committed by the Third Reich, including in instances of ongoing proceedings.

The Tribunal of Florence points out that the ICJ maintained that it was not necessary to examine the interference between fundamental human rights and the principle of sovereignty of the State accused of an unlawful act. The ICJ held that there was no conflict between substantive jus cogens norms and norms considered to have a formal or procedural character (such as the norms of immunity), since they operate at different levels. Hence, the referring judge submits that, while on the one hand Italian courts cannot interpret the imperative and non-derogable character of jus cogens, since the International Court of Justice has exclusive and absolute competence over the matter, on the other hand Italian courts cannot be denied the competence to assess whether the indiscriminate grant of immunity to States-to the detriment of the victims [of gross human rights violations] - complies with the Italian Constitution, as well as with complementary sources thereof (including supranational sources). In other words, [Italian courts have competence to assess] whether or not the receptiveness [of the Italian legal order] to external legal orders (as enshrined in Articles 10, 11, and 117 of the Constitution) is to some extent limited, with the consequence of affecting, in the case at issue, the preliminary question raised by the Federal Republic of Germany.

According to the referring judge, it can be doubted that the immunity of States (European Union States in particular) still allows, by effect of international customs existing prior to the entry into force of the Constitution and of the Charter of Fundamental Rights of the European Union, for the indiscriminate denial of judicial protection of fundamental rights violated by war crimes and crimes against humanity, in breach of inviolable human rights.

The ICJ itself acknowledged that this situation results in the concrete and irreversible violation of judicial protection of the rights infringed, and nevertheless it considered that the violation of substantive jus cogens norms (fundamental human rights infringed by a widespread practice of war crimes and crimes against humanity) does not conflict with the norms of international law of state immunity of procedural 
nature. In light of this, the Tribunal of Florence questions that, as far as domestic law is concerned, the principle of sovereign equality of States (in particular, its corollary in matters of immunity) can justify the sacrifice of judicial protection of fundamental rights, in cases where judicial protection is invoked against a State-different from the State of the Court seized-which committed an international crime, albeit in the exercise of sovereign powers.

[The referring judge acknowledges] that, following the ruling of the ICJ, which does not leave any discretion on the matter, domestic courts do not have competence to establish whether or not the criminal acts committed by the Third Reich in occupied Italian territory can be considered jure imperii under international law. Nevertheless, the referring judge submits that the absolute character of international immunity cannot entail that the individuals affected are denied any possibility of judicial examination and remedy, both of which, in the case at issue, are also denied by the German legal order.

The Tribunal of Florence recalls that, since an early Judgment (No. 48/1979), the Constitutional Court has upheld that, in case of conflict between generally recognized norms of international law (incorporated in the Italian legal order by virtue of Article 10, para. 1 of the Constitution) and fundamental principles of the Italian legal order, the latter shall prevail.

In a later decision (Judgment No. 73/2001), this Court-as the referring judge recalls-reaffirmed the principle that "the tendency of the Italian legal order to be open to generally recognized norms of international law and international treaties is limited by the necessity to preserve its identity; thus, first of all, by the values enshrined in the Constitution".

Therefore, [the referring judge contends that] the fundamental principles of constitutional order and inalienable human rights constitute a limit to the introduction of generally recognized norms of international law (to which the Italian legal order conforms under Article 10, para. 1 of the Constitution), as well as of norms contained in treaties establishing international organizations furthering the ends envisaged by Article 11 of the Constitution, or deriving from such organizations.

Considering that the principle in Article 24 of the Constitution is one of the supreme principles of the Italian constitutional order, since it is "intrinsically connected to the principle of democracy itself and to the duty to ensure a judge and a judgment to anyone, anytime and in any dispute" (Judgment No. 18/1982), the referring judge questions the constitutionality of the customary norm [of immunity]. [According to the referring judge], the norm of customary international law at issue (as defined by the ICJ) cannot prevail over the supreme principle of absolute guarantee of judicial protection, when fundamental rights were violated as a result of a crime against humanity, committed in the State of the Court seized, even if that crime was committed by another State in the exercise of sovereign powers.

In short, according to the referring judge, Italian courts cannot follow the ruling of the ICJ and therefore deny their jurisdiction. Italian courts cannot leave the 
protection of individuals to the dynamics of the relationships between the political organs of the States involved, since these organs have not been able to come up with a solution for decades. If judicial adjudication and compensation for the perverse actions perpetrated by the Third Reich were denied, the right to an effective remedy would be irretrievably sacrificed.

Moreover, the referring judge clarifies that he had to raise the question of constitutionality as a result of the ruling of the Constitutional Court in Judgment No. 311/2009. [In that Judgment, this Court held] that when international law conflicts with the Constitution, "the referral to the international norm does not operate, and thus the international norm does not constitute a parameter under Article 117, para. 1 of the Constitution." Therefore, since "there can be no effect on the lawfulness of the external norm itself, this results (...) in the unconstitutionality (...) of the law of adaptation (Judgments Nos. 348 and 349/2007)".

In light of the above, the Tribunal of Florence refers the question of constitutionality to this Court. The Tribunal considers that the question of constitutionality of the domestic norm (created by virtue of Article 10, para. 1 of the Constitution, in conformity with the international custom, the formation of which took place before the entry into force of the Italian Constitution) which, in case of actions for damages for war crimes, denies the jurisdiction of the State where the unlawful acts had, at least in part, detrimental effects, is not manifestly ill-founded.

The referring judge further notes that Article 94 of the United Nations Charterwhich provides that "each Member of the United Nations undertakes to comply with the decision of the ICJ in any case to which it is a party"- -has been incorporated into the domestic legal order through of a law of ratification-sub-constitutional in nature - but by virtue of a constitutional norm (i.e., Article 11 of the Constitution). Hence, it has binding effects in the domestic legal order only to the extent that it is compatible with the Constitution. Accordingly, the referring judge submits that the question of constitutionality also concerns Law No. 848/1957, insofar as it incorporates the United Nations Charter, in particular Article 94, and thus obliges all state organs to comply with the judgments of the ICJ, including the Judgment of 3 February 2012.

For the same reasons, the referring judge also questions Article 3 of Law No. 5/2013, which regulates the duty of the national judge to comply with the ruling of the ICJ that denied the jurisdiction of Italian courts in the examination of action for damages for crimes considered jure imperii, committed by the Third Reich in Italian territory.

Lastly, the Tribunal of Florence clarifies that the constitutionality of each questioned provision bears independent relevance in the main judgment, as any of these norms, even taken individually, can exclude the exercise of its jurisdiction.

2. The President of the Council of Ministers, represented and defended by the Avvocatura Generale dello Stato [the Office of the State attorney, hereafter "Avvocatura"], intervened in the cases. The President requested that the question of constitutionality be declared inadmissible and/or ill-founded. 
Firstly, the Avvocatura contends that the question raised is inadmissible, because it entails a constitutional review of the customary norm of immunity, the formation of which took place before the adoption of the Constitution. [According to the Avvocatura], this norm cannot be subject to constitutional review in light of consistent jurisprudence of the Constitutional Court, which is said to have stated that constitutional review of customary international norms is only allowed in the case of norms formed after the Constitution entered into force (in alleged support of this argument, Judgments Nos. 48/1979, 471/1992, 15/1996, and 262/2009 are recalled).

The President of the Council of Ministers further contends that the issue of jurisdiction logically needs to be addressed preliminary to the examination of the merits of the case. The establishment of jurisdiction of the territorial State merely on the basis of a claim filed for compensation for damages, caused by acts in breach of substantive jus cogens norms, results in an "unacceptable reversal of the relationship of logical priority between distinct procedural and substantial judicial assessments".

In the merits, the Avvocatura calls attention on the fact that the Constitutional Court (allegedly) affirmed that Article 10, para. 1 of the Constitution incorporates generally recognized norms of international law and thus grants them the status of constitutional law. This Court is said to have resolved the alleged conflict between immunity and the right of judicial protection, protected by Article 24 of the Constitution, by applying the principle of lex specialis, i.e. by recognizing that the limitation to the principle provided by Article 24 of the Constitution can be justified in light of the prevailing interests implied in the need to accord immunity from territorial jurisdiction to foreign States. Given the reasonableness of the scope of the right of defense in view of the need to respect the immunity of the foreign State, the questions of constitutionality of the impugned provisions are said to be ill-founded.

[The Avvocatura further contends that] the duty to respect the immunity of the foreign State is confirmed by other (impugned) provisions, in particular by Article 94 of the UN Charter (incorporated into the Italian legal order by Law No. 848/1957), which obliges each Member State to comply with the decisions of the ICJ, as well as by Article 3 of Law No. 5/2013, which complements [Article 94 of the UN Charter] itself.

The duty of Italy to conform to customary international law, as well as to the decisions of the ICJ (as established in the aforementioned Article 94 of the UN Charter) is said [by the Avvocatura] to be confirmed by Article 11 of the Constitution as well, since this Article obliges Italy to respect customary international law, the content of which is defined by the ICJ in the judgments Italy has to comply with under the UN Charter.

3. - The claimants in the main proceedings filed appearances in all three cases (Orders Nos. 84, 85, and 113/2014) and have requested that the Constitutional Court accept the questions raised by the Tribunal of Florence.

3.1. - Firstly, the defense of the claimants in the main proceedings recalls that the actions for damages were only filed after sixty-seven years because of the 
moratorium the Federal Republic of Germany and the Allies had agreed upon. Italy was bound to respect the moratorium as well, by virtue of Article 18 of the Peace Treaty. The defense further notes that, since the end of the moratorium, requests for compensation have been rejected by the Federal Republic of Germany, which has also denied any other form of redress for the crimes committed by the Third Reich and its government.

With specific regard to the questions raised by the Tribunal of Florence, the defense of the claimants in the main proceedings makes a number of preliminary observations.

The defense recalls that on 26 June 1945, in San Francisco, in response to serious human rights violations, the States of the international community undertook to respect human rights and fundamental freedoms, without distinction as to race, sex, language, or religion (Article 1, para. 3 and Article 55 (c) of the UN Charter). Among these rights was the right of access to justice (Article 14 of the International Covenant for Civil and Political Rights of 19 December 1966), which later became a cornerstone of the international system of protection of human rights (UN General Assembly Resolution No. 60/147 on "Basic principles and Guidelines on the Right to a Remedy and Reparation for Victims of Gross Violations of International Human Rights Law and Serious Violations of International Humanitarian Law"). Therefore, the conflict between human rights protection and the principle of non-interference in internal affairs (to which the issue of jurisdictional immunity of States is connected) cannot be resolved to the detriment of fundamental rights.

Hence, the defense contends that Law No. 5/2013 is unconstitutional not only because it is in violation of Article 24 of the Constitution, but also because it conflicts with international law, which protects fundamental rights, including the right of access to a court with jurisdiction over the matter.

Therefore, the defense of the claimants requests that the Constitutional Court accept the questions of constitutionality raised by the Tribunal of Florence, also in order to avoid that the ICJ be accused of exceeding its competence.

The defense further contends that, according to current international law, Italian courts have jurisdiction. Therefore, the questioned provisions conflict with Articles 10 and 117 of the Constitution as well, insofar as they exclude the jurisdiction of Italian courts in cases of actions for damages for crimes against humanity committed by German military forces during World War II. As far as [the questioned provisions] affect the right of private parties to bring cases before a court of law in order to protect their rights under civil and administrative law, they conflict with customary and conventional international law.

In light of the above, the defense of the actors in the main proceedings requests that the Constitutional Court declare the unconstitutionality of Law No. 5/2013 for contravening Articles 24, 11, and 117 of the Constitution, and thus recognize the jurisdiction of Italian courts (thereby also excluding any indirect effects of the Judgment of the ICJ of 3 February 2012). 


\section{[omissis]}

4. - At the public hearing, the parties to the proceedings and the President of the Council of Ministers requested that the Court uphold the submissions laid down in their written pleadings.

\section{Conclusions in Point of Law}

1. The Tribunal of Florence questions the constitutionality of certain provisions that require that the Tribunal deny its jurisdiction (as argued by the defendant) with regard to three proceedings brought against the Federal Republic of Germany (FRG). [These proceedings were initiated] by three Italian citizens in order to obtain compensation for damages suffered during World War II, when they were captured by German military forces and deported to Germany to slave labor in concentration camps.

More specifically, the Tribunal of Florence questions the constitutionality of:

1) the norm "created in our legal order by the incorporation, by virtue of Article 10, para. 1 of the Constitution", of the international custom of immunity of States from the civil jurisdiction of other States, as interpreted by the International Court of Justice (ICJ) in its Judgment Germany v. Italy of 3 February 2012, insofar as it considers war crimes and crimes against humanity, in breach of inviolable human rights, committed in Italy and Germany against Italian citizens in the period 1943 to 1945 by Third Reich troops, to be acts jure imperii and thus excluded from the jurisdiction of civil courts;

2) Article 1 of the Law of Adaptation to the Charter of the United Nations (Law No. 848 of 17 August 1957 on the "Execution of the Statute of the United Nations, signed in San Francisco on 16 June 1945"), insofar as it obliges the national judge to comply with the Judgment of the ICJ, even when it established the duty of Italian courts to deny their jurisdiction in the examination of action for damages for crimes against humanity, committed jure imperii by the Third Reich in Italian territory;

3) Article 1 (recte: Article 3) of Law No. 5 of 14 January 2013 (Accession by the Italian Republic to the United Nations Convention on Jurisdictional Immunities of States and their Property, signed in New York on 2 December 2004, as well as provisions for the amendment of the domestic legal order), which obliges the national judge to comply with the judgment of the ICJ and thus to deny their jurisdiction in future cases concerning acts committed jure imperii by a foreign State, even when those acts constitute gross violations of international humanitarian law and of fundamental rights, such as the war crimes and crimes against humanity committed in Italy and in Germany against Italian citizens in the period 1943 to 1945 by Third Reich troops, [and which also obliged the national judge] to allow the revision (revocazione) of final judgments that did not recognize the immunity.

The aforementioned norms are questioned in relation to Articles 2 and 24 of the Constitution. They are said to conflict with the principle of the absolute guarantee of 
judicial protection, enshrined in Article 24 Constitution, since they preclude the judicial examination of the action for damages for the gross violations of human rights suffered by the victims of war crimes and crimes against humanity, committed by another State, albeit in the exercise of sovereign powers (jure imperii). The principle of absolute guarantee of judicial protection is a supreme principle of the Italian constitutional order and, as such, constitutes a limit to the introduction [in the domestic legal order] of generally recognized norms of international law under Article 10, para. 1 of the Constitution, as well as of norms contained in treaties establishing international organizations furthering the ends envisaged by Article 11 of the Constitution (or deriving from such organizations) and subject of laws of adaptation.

The referring judge notes that the ICJ upheld, in its Judgment of 3 February 2012, the ongoing existence of the customary international norm that establishes the immunity of States from the civil jurisdiction of other States, for all acts indiscriminately considered jure imperii. The ICJ thus excluded the formation of an exception with regard to acts jure imperii that can be considered war crimes or crimes against humanity, in breach of fundamental human rights - as expressly recognized in the case at issue with regard to the episodes of deportation, slave labor, and massacres, committed in Italy and in Germany against Italian citizens in the period from 1943 to 1945 by Third Reich troops. The ICJ also denied the existence of a conflict between substantive jus cogens norms (international human rights law) and procedural norms (immunity of States from the jurisdiction of other States), as they operate at different levels.

Nevertheless, the Florentine judge, albeit recognizing that the ICJ has "absolute and exclusive competence" as to the interpretation of international law, questions the constitutionality of the domestic norm corresponding to the customary international norm - which is limited by the fundamental principles and constitutionally guaranteed inviolable rights, including the right to judicial protection of inviolable rights—as well as of the relevant incorporation provisions.

The referring judge points out that it cannot be ignored that "if international immunity is given an absolute character, as upheld by the ICJ, the individuals affected are denied any possibility of judicial examination and remedy, both of which, in the case at issue, are also denied by the German legal order" (Referring Orders No. 84/2014, page 7; No. 85/2014, page 7; No. 113/2014, page 7).

Accordingly, [the referring judge] raises analogous concerns over the constitutionality of the provisions contained both in the Law of Adaptation to the United Nations Charter (Article 1 of the Law No. 848/1957), and in the Law of Accession to the New York Convention (Article 3 of the Law No. 5 of 2013), insofar as they require, similarly to the aforementioned customary international norm, that the judge deny their jurisdiction in compliance with the Judgment of the ICJ. 
Lastly, the Tribunal of Florence clarifies that the constitutionality of each questioned provision bears independent relevance in the main judgment, as any of these norms, even taken individually, can exclude the exercise of its jurisdiction.

Moreover, the referring judge limits the questions raised to the issue of the jurisdiction to examine the claim for compensation for damages, and does not include the issue of enforcement action.

As the claims and the arguments are identical in all three cases, they shall be discussed and decided jointly.

2. - Preliminarily, this Court shall assess the objections to admissibility of the questions of constitutionality raised by the Tribunal of Florence.

2.1. - With the first objection, the Avvocatura submits that the immunity from jurisdiction at issue here is subject to a generally recognized norm of customary international law the formation of which took place before the entry into force of the Italian Constitution, and therefore cannot be subject to constitutional review. This Court is said to have stated, in its Judgment No. 48 of 1979 (see para 2. of the Conclusions in Point of Fact) that constitutional review of customary international norms is only allowed in the case of norms formed after the Constitution entered into force.

The objection is ill-founded.

As a matter of fact, on the occasion mentioned by the Avvocatura, this Court examined precisely the constitutionality of the customary international norm of immunity of diplomatic agents, which expressly defined a "centuries-old custom of States in their reciprocal relations". [The Court also] stated that "The question as it was raised by the referring judge - concerning the execution order contained in Law No. 804/1967, in relation to Article 31, paras. 1 and 3 of the Vienna Convention appears to be only formally correct because, in the relevant part, the conventional provision is merely declaratory of the norm of general international law described above. The [legal] basis for the question must thus be determined in relation to that latter norm, and the actual subject-matter of the proceedings before the Court concerns the compatibility between the domestic norm of adaptation to the international custom and the abovementioned constitutional principles" (para. 3. of the Conclusions in Point of Law).

Later in that Judgment, the Court added: "At any rate, it should be noted, more generally, with regard to the generally recognized norms of international law that came into existence after the entry into force of the Constitution, that the mechanism of automatic incorporation envisaged by Article 10 of the Constitution cannot allow the violation of the fundamental principles of our constitutional order, as it operates in a constitutional system founded on popular sovereignty and on the rigidity of the Constitution" (para. 3. of the Conclusions in Point of Law). 
Regardless of whether the interpretation of the Decision No. 48/1979 made by the Avvocatura is correct or not, this Court wishes to specifically confirm what it clearly noted in its Judgment No. 1 of 1956:

"The assumption that the new notion of "unconstitutionality" concerns only laws subsequent to the Constitution, and not laws prior to it, cannot be accepted. From a textual standpoint, both Article 134 of the Constitution and Article 1 of Constitutional Law No. 1 of 9 February 1948 address questions of constitutionality of laws, without any distinction. From a logical standpoint, it is undeniable that the relationship between ordinary laws and constitutional laws, as well as their respective status in the hierarchy of sources remain unchanged, irrespective of whether ordinary laws are subsequent or prior to constitutional laws".

Hence, it must be recognized today that the principle set out in Judgment No. 1/1956, according to which the control of constitutionality concerns both norms subsequent to the republican Constitution and those prior to it, also applies to generally recognized norms of international law automatically incorporated by Article, para. 1 of the Constitution, irrespective of whether they formed before or after the Constitution.

Likewise, the norm subject to the referral made by Article 10, para. 1 of the Constitution to customary international law, cannot be excluded from constitutional review only because Article 134 of the Constitution does not explicitly envisage this specific possibility. According to that provision, all laws, acts and norms that have the same legal effects as formal laws (ordinary or constitutional), but came into being through means other than the legislative process-including the aforementioned [customary international] norms-are subject to centralized constitutional review. The scrutiny of this Court is excluded only for acts that are hierarchically below the law, and do not enjoy the same legal force as the law.

In short, there is no reason, from a logical and systematic standpoint, to exclude the constitutional review of international customs, or to limit it to customs subsequent to the Constitution. The latter have the same legal force as customs previously formed, and both [types of customary law] are limited by the respect of the identifying elements of the constitutional order, i.e. the fundamental principles and inviolable human rights.

The first objection raised by the defense of the President of the Council of Ministers is therefore ill-founded.

2.2. The second objection is founded on the assumption that the lack of jurisdiction cannot be assessed on the basis of the scope of the international norm of state immunity for acts considered jure imperii, since otherwise this would result in an "unacceptable reversal of the relationship of logical priority between distinct procedural and substantial judicial assessments". 
This objection is not well-founded either, simply because an objection concerning jurisdiction necessarily requires an examination of the arguments put forward in the claim, as formulated by the parties.

2.3. - Also, preliminarily, it has to be reaffirmed that the statements of the private party that aimed at broadening the subject-matter of the cases by invoking additional constitutional parameters, are inadmissible.

The subject-matter of an incidental constitutional review consists of the provisions and the parameters as indicated in the referring orders (Judgment No. 32/2014; but also Judgments No. 271/2011 and 56/2009). Therefore, the questions [of constitutionality] raised by the claimants in the main proceedings (who appeared in the cases before this Court) in relation to Article 117, para. 1 of the Constitution, as well as to the norms of international law invoked by means of Article 117 itself, cannot be taken into consideration.

2.4. - Lastly, it is appropriate to point out that, although the operative part of all three referring orders indicates Article 1 of Law No. 5/2013 as one of the questioned provisions, it is clear from the whole context of the three orders that the complaint does not concern Article 1, which contains the authorization to the accession to the United Nations Convention on Jurisdictional Immunities of States and Their Property of 2 December 2004, but rather Article 3 of the same Law, insofar as it incorporated - with ordinary adaptation procedure-the ruling of the ICJ as laid down in its Judgment of 3 February 2012.

Therefore, Article 3 of Law No. 5/2013 - and not Article 1—is subject to constitutional review. This is in line with consistent constitutional jurisprudence, according to which the subject-matter of the dispute must be identified-with regard to the questioned provision-keeping in mind the motivation of the orders and the context of the referral (ex plurimis, Judgment No. 258/2012 and No. 181/2011; Order of the Court No. 162/2011).

3. - In the merits, the question of constitutionality of the norm "created in our legal order by the incorporation, by virtue of Article 10, para. 1 of the Constitution" of the international custom of immunity of States from the civil jurisdiction of other States, is ill-founded under the terms set out below.

3.1. - First, it should be noted that the referring judge excluded from the subjectmatter brought before this Court any assessment of the interpretation given by the ICJ on the norm of customary international law of immunity of States from the civil jurisdiction of other States.

The Court, indeed, cannot exercise such a control. International custom is external to the Italian legal order, and its application by the government and/or the judge, as a result of the referral of Article 10, para. 1 of the Constitution, must respect the principle of conformity, i.e. must follow the interpretation given in its original legal order, that is the international legal order. In this case, the relevant norm has been interpreted by the ICJ, precisely with a view to defining the dispute between 
Germany and Italy on the jurisdiction of the Italian judge over acts attributable to the Federal Republic of Germany (FRG).

In its Judgment of 3 February 2012, the ICJ stated that, for the time being, there are insufficient elements in international practice to infer the existence of a derogation from the norm of immunity of States from the civil jurisdiction of other States for acts jure imperii in case of war crimes and crimes against humanity, in breach of fundamental human rights. [That such crimes were committed] was established by the ICJ and was also admitted by the FRG itself.

The same Court also expressly recognized (see Judgment, page 144, para. 104) that the lack of jurisdiction of the Italian judges entails the sacrifice of fundamental rights of the individuals who suffered from the consequences of crimes committed by the foreign State. This was confirmed by the defense of the FRG as well, which excluded the existence of other judicial remedies for the victims of the aforementioned crimes (Reply of the FRG, 5 October 2010, page 11, para. 34). The ICJ pointed out that the opening of new negotiations is the only means available to settle the dispute in international law.

It has to be recognized that, at the international law level, the interpretation by the ICJ of the customary law of immunity of States from the civil jurisdiction of other States for acts considered jure imperii is particularly qualified and does not allow further examination by national governments and/or judicial authorities, including this Court. This principle was clearly stated in Judgments Nos. 348 and 349/2007 in relation to the interpretation of the norms of the European Convention on Human Rights and Fundamental Freedoms (ECHR) given by the Strasbourg Court.

As a matter of fact, the referring judge does not question the interpretation given by the ICJ of the international norm of immunity for acts considered jure imperii. The judge notes (with concern) that the scope of the norm has been so defined by the ICJ. Further, he recalls that it is uncontested that the acts attributed to the FRG are unlawful, and that they have been qualified by the FRG itself and the ICJ as war crimes and crimes against humanity, in breach of fundamental human rightsnevertheless, this issue belongs to the merits of the main claim and therefore falls outside the subject-matter brought before this Court.

That said, it is nevertheless clear that another issue has to be examined and resolved, namely the envisaged conflict between the norm of international law (a norm that is hierarchically equivalent to the Constitution through the referral of Article 10, para. 1 of the Constitution) incorporated and applied in the domestic legal order, as interpreted in the international legal order, and norms and principles of the Constitution, to the extent that their conflict cannot be resolved by means of interpretation.

This is the case of the qualifying essential principles of the state constitutional order, including the principles of protection of fundamental human rights. In those situations it is up to the national judge, and in particular exclusively to this Court, to exercise the constitutional review, in order to preserve the inviolability of fundamental principles of the domestic legal order, or at least to minimize their sacrifice. 
And this is precisely the subject-matter brought before this Court by the Tribunal of Florence when it raised the questions of constitutionality cited above. The Tribunal asked to review the compatibility of the international norm of immunity of States from the civil jurisdiction of other States, as interpreted by the ICJ, with a fundamental principle of our constitutional order, namely the right to a judge (Article 24), in conjunction with the principle of protection of fundamental human rights (Article 2). It is indeed possible to review the [constitutional] compatibility even when both norms - as in the case at issue - have constitutional status, since balancing is one of "the ordinary tasks that this Court is asked to undertake in all cases within its competence" (Judgment No. 236/2011).

3.2 - As was upheld several times by this Court, there is no doubt that the fundamental principles of the constitutional order and inalienable human rights constitute a "limit to the introduction (...) of generally recognized norms of international law, to which the Italian legal order conforms under Article 10, para. 1 of the Constitution" (Judgment No. 48/1979 and No. 73/2011) and serve as "counterlimits' [controlimiti] to the entry of European Union law (ex plurimis: Judgments No. 183/1973, No. 170/1984, No. 232/1989, No. 168/1991, No. 284/2007), as well as limits to the entry of the Law of Execution of the Lateran Pacts and the Concordat (Judgments No. 18/1982, No. 32, No. 31 and No. 30/1971). In other words, they stand for the qualifying fundamental elements of the constitutional order. As such, they fall outside the scope of constitutional review (Articles 138 and 139 Constitution, as was held in Judgment No. 1146/1988).

In a centralized constitutional review system, it is clear that this assessment of compatibility pertains to the Constitutional Court alone, and not to any other judge, even with regard to customary international law. The truth is, indeed, that the competence of this Court is determined by the incompatibility of a norm with constitutional law - this obviously includes a fundamental principle of the State's constitutional order or a principle that guarantees inviolable human rights. The examination of this contrast is a task of the constitutional judge alone. In this centralized constitutional review system, any different solution goes against the exclusive competence given by the Constitution to this Court, which stated in its very first case that "The declaration of unconstitutionality of a law can be made only by the Constitutional Court according to Article 136 of the Constitution itself"' (Judgment No. 1/1956).

Moreover this Court has reaffirmed, even recently, that it has exclusive competence over the review of compatibility with the fundamental principles of the constitutional order and principles of human rights protection (Judgment No. 284/2007). Further, precisely with regard to the right of access to justice (Article 24 Constitution), this Court stated that the respect of fundamental human rights, as well as the implementation of non-derogable principles are safeguarded by the guaranteeing function assigned to the Constitutional Court (Judgment No. 120/2014).

3.3 - The customary international norm of immunity of States from the civil jurisdiction of other States was originally absolute, since it included all state 
behaviors. More recently, namely in the first half of the last century, this norm undertook a progressive evolution by virtue of national jurisprudence, in the majority of States, up until the identification of acta jure gestionis (an easily understandable expression) as the relevant limit. And it is well known that this limit to the application of the norm of immunity was progressively established mainly thanks to Italian judges (ex multis, Tribunal of Florence, 8 June 1906, Rivista di Diritto Internazionale 1907, 379; Court of Cassation, 13 March 1926, idem 1926, 250; Court of Appeal of Naples, 16 July 1926, idem 1927, 104; Court of Appeal of Milan, 23 January 1932, idem 1932, 549; Court of Cassation, 18 January 1933, idem 1933, 241 ) and to Belgian judges (ex multis, Court of Cassation, 11 June 1903, Journal de Droit International Privé 1904, 136; Court of Appeal of Brussels, 24 June 1920, Pasicrisie Belge 1922, II, 122; Court of Appeal of Brussels, 24 May 1933, Journal de Droit International 1933, 1034)—the so-called "Italian-Belgian theory".

In short, national judges limited the scope of the customary international norm, as immunity from civil jurisdiction of other States was granted only for acts considered jure imperii. The purpose was mainly to exclude the benefit of immunity at least when the State acted as a private individual, as that situation appeared to be an unfair restriction of the rights of private contracting parties.

This process of progressive definition of the content of the international norm has long been established in the international community (Judgment No. 329/1992). It is of significant importance that the evolution as described above originated in the national jurisprudence, as national courts normally have the power to determine their competence, and leave to international organs the recognition of the practice for the purposes of identifying customary law and its evolution.

Since such a reduction of immunity for the purposes of protection of rights took place, as far as the Italian legal order is concerned, thanks to the control exercised by ordinary judges in an institutional system characterized by a flexible Constitution (in which the recognition of rights was supported by limited guarantees only), the exercise of the same control in the republican constitutional order (founded on the protection of rights and the consequent limitation of powers, as guaranteed by a rigid Constitution) falls inevitably to this Court. It falls exclusively to this Court to ensure the respect of the Constitution and particularly of its fundamental principles, and thus to review the compatibility of the international norm of immunity of States from the civil jurisdiction of other States with those principles. The result is a further reduction of the scope of this norm, with effects in the domestic legal order only. At the same time, however, this may also contribute to a desirable — and desired by many_evolution of international law itself.

3.4 - Furthermore, such a control is essential in light of Article 10, para. 1 of the Constitution, which requires that this Court ascertain whether the customary international norm of immunity from the jurisdiction of foreign States, as interpreted in the international legal order, can be incorporated into the constitutional order, as it does not conflict with fundamental principles and inviolable rights. [On the contrary], if there were a conflict, "the referral to the international norm [would] not 
operate" (Judgment No. 311/2009). Accordingly, the incorporation, and thus the application, of the international norm would inevitably be precluded, insofar as it conflicts with inviolable principles and rights.

This is exactly what has happened in the present case.

This Court has repeatedly observed that the fundamental principles of the constitutional order include the right to appear and to be defended before a court of law in order to protect one's rights guaranteed by Article 24, i.e. the right to a judge. This is especially true when the right at issue is invoked to protect fundamental human rights.

In the present case, the referring judge aptly indicated Articles 2 and 24 of the Constitution as inseparably tied together in the review of constitutionality required of this Court. The first [Article 2] is the substantive provision, in the fundamental principles of the Constitutional Charter, that safeguards the inviolability of fundamental human rights, including - this is crucial in the present case-human dignity. The second [Article 24] is a safeguard of human dignity as well, as it protects the right of access to justice for individuals in order to invoke their inviolable right[s].

Although they belong to different fields, the substantial and the procedural, the two provisions share a common relevance in matters of constitutional compatibility of the norm of immunity of States from the civil jurisdiction of other States. It would indeed be difficult to identify how much is left of a right if it cannot be invoked before a judge in order to obtain effective protection.

As early as in Judgment No. 98/1965 concerning European Community law, this Court held that the right to effective judicial protection "is one of the inviolable human rights protected by Article 2 Constitution. This is also clear from the consideration given to this principle in Article 6 of the ECHR" (Para. 2 of the Conclusions in Point of Law). More recently, this Court unequivocally defined the right to judicial protection as "one of the supreme principles of our constitutional order, intrinsically connected to the principle of democracy itself and to the duty to ensure a judge and a judgment to anyone, anytime and in any dispute" (Judgment No. 18/1982, as well as No. 82/1996).

With an eye to the effectiveness of judicial protection of fundamental rights, this Court also noted that "the recognition of rights goes hand in hand with the recognition of the power to invoke them before a judge in judicial proceedings. Therefore, "the recourse to a legal remedy in defense of one's right is a right in itself, protected by Articles 24 and 113 of the Constitution. [This right is] inviolable in character and distinctive of a democratic State based on the rule of law. (Judgment No. 26/1999, as well as No. 120/2014, No. 386/2004, No. 29/2003). Further, there is little doubt that the right to a judge and to an effective judicial protection of inviolable rights is one of the greatest principles of legal culture in democratic systems of our times.

Nonetheless, precisely with regard to cases of immunity from jurisdiction of States envisaged by international law, this Court has recognized that, in cases involving 
foreign States, the fundamental right to judicial protection can be further limited, beyond the limitations provided by Article 10 of the Constitution. However, this limit has to be justified by reasons of public interest potentially prevailing over the principle of Article 24 Constitution, one of the "supreme principles" of the constitutional order (Judgment No. 18/1982). Moreover, the provision that establishes the limit has to guarantee a rigorous assessment of the [public] interest in light of the concrete case (Judgment No. 329/1992).

In the present case, the customary international norm of immunity of foreign States, defined in its scope by the ICJ, entails the absolute sacrifice of the right to judicial protection, insofar as it denies the jurisdiction of [domestic] courts to adjudicate the action for damages put forward by victims of crimes against humanity and gross violations of fundamental human rights. This has been acknowledged by the ICJ itself, which referred the solution to this issue, on the international plane, to the opening of new negotiations, diplomatic means being considered the only appropriate method (para. 102, Judgment of 3 February 2012).

Moreover, in the constitutional order, a prevailing public interest that may justify the sacrifice of the right to judicial protection of fundamental rights (Articles 2 and 24 Constitution), impaired as they were by serious crimes, cannot be identified.

Immunity from jurisdiction of other States can be considered tenable from a legal standpoint, and even more so from a logical standpoint, and thus can justify on the constitutional plane the sacrifice of the principle of judicial protection of inviolable rights guaranteed by the Constitution, only when it is connected-substantially and not just formally - to the sovereign functions of the foreign State, i.e. with the exercise of its governmental powers.

Respect for fundamental principles and inviolable human rights, identifying elements of the constitutional order, is the limit that indicates (also with a view to achieving the goal of maintaining good international relations, inspired by the principles of peace and justice, for whose realization Italy agrees to limitations of sovereignty by virtue of Article 11 of the Constitution) the receptiveness of the Italian legal order to the international and supranational order (Articles 10 and 11 of the Constitution), as this Court has repeatedly upheld (with regard to Article 11 of the Constitution, Judgment No. 284/2007, No. 168/1991, No. 232/1989, No. 170/1984, No. 183/1973; with regard to Article 10, para. 1 of the Constitution, Judgment No. 73/2001, No. 15/1996, No. 48/1979; also, Judgment No. 349/2007). This in itself rules out that acts such as deportation, slave labor, and massacres, recognized to be crimes against humanity, can justify the absolute sacrifice in the domestic legal order of the judicial protection of inviolable rights of the victims of those crimes.

The immunity of the foreign State from the jurisdiction of the Italian judge granted by Articles 2 and 24 Constitution protects the [sovereign] function [of State]. It does not protect behaviors that do not represent the typical exercise of governmental powers, but are explicitly considered and qualified unlawful, since they are in breach 
of inviolable rights, as was recognized, in the present case, by the ICJ itself, andbefore that Court - by the FRG (see above, para. 3.1). These rights are deprived of an effective remedy, as acknowledged in the ICJ Judgment. The ICJ stated that it was not unaware "that the immunity from jurisdiction of Germany in accordance with international law may preclude judicial redress for the Italian nationals concerned" (para. 104), thus hoping for the re-opening of negotiations.

Therefore, in an institutional context characterized by the centrality of human rights, emphasized by the receptiveness of the constitutional order to external sources (Judgment No. 349/347), the denial of judicial protection of fundamental rights of the victims of the crimes at issue (now dating back in time), determines the completely disproportionate sacrifice of two supreme principles of the Constitution. They are indeed sacrificed in order to pursue the goal of not interfering with the exercise of the governmental powers of the State even when, as in the present case, state actions can be considered war crimes and crimes against humanity, in breach of inviolable human rights, and as such are excluded from the lawful exercise of governmental powers.

Lastly, it has to be noted that the right to a judge established by the Italian Constitution, as in all democratic systems, requires effective judicial protection for individual rights (on the effectiveness of judicial protection of rights under Article 24 Constitution see, inter alia, the recent Judgments No. 182/2014 and No. 119/2013; see also Judgment No. 281/2010 and No. 77/2007).

This Court had in the past recognized, as mentioned above, that the judicial control system in the Community legal order appeared to satisfy the requirements of judicial protection equivalent to those set out by Article 24 Constitution (Judgment No. 98/1965). However, this Court evaluated in a different manner the practice of the EU Court of Justice of delaying the beneficial effects of a judgment in the preliminary ruling also for the parties that had invoked the later recognized rights. As a result, the function of the reference for a preliminary ruling was indeed frustrated and the effectiveness of the requested judicial protection was strongly reduced, in violation - for the purposes of the review of this Court-of the requirements of the right to a judge established by the Italian Constitution (Judgment No. 232/1989, which led the EU Court of Justice to change its jurisprudence on that matter).

It is equally important [to recall the ruling of] the EU Court of Justice concerning the action for annulment of a Council regulation that provided for the freezing of assets of individuals included in a list of alleged terrorists drawn up by a body of the United Nations Security Council (the Sanctions Committee). First, the EU Court of Justice rejected the argument of the Court of First Instance that essentially held that the Community judicature lacked jurisdiction. [On the contrary, the EU Court of Justice] held that [the Community judicature] must ensure the review of the lawfulness of all Union acts, including review of [Union measures] designed to give effect to resolutions of the United Nations Security Council. The Court then held that the 
obligations imposed by an international agreement cannot prejudice the principle that all Union acts must respect fundamental rights.

As a result, the Community regulation was annulled, insofar as it violated the principle of effective judicial protection, since the United Nations system lacks an adequate mechanism of review of the respect of fundamental rights (EU Court of Justice, Judgment of 3 September 2008, cases C-402 P and 415/05 P, paras. 316 ff., $320 \mathrm{ff}$.

3.5. - In the present case, the impossibility of effective judicial protection of fundamental rights, acknowledged by the ICJ and confirmed before that Court by the FRG, makes apparent the contrast between international law, as defined by the ICJ, and Articles 2 and 24 of the Constitution.

This contrast, insofar as the international law of immunity of States from the civil jurisdiction of other States includes acts considered jure imperii that violated international law and fundamental human rights, obliges this Court to declare that, to the extent that international law extends immunity to actions for damages caused by such serious violations, the referral of Article 10, para. 1 of the Constitution does not operate.

Consequently, insofar as the law of immunity from jurisdiction of States conflicts with the aforementioned fundamental principles [of the Constitution], it has not entered the Italian legal order and, therefore, does not have any effect therein.

The question posed by the referring judge with regard to the norm "created in our legal order by the incorporation, by virtue of Article 10, para. 1 of the Constitution", of the customary international law of immunity of States from the civil jurisdiction of other States is, therefore, ill-founded. International law, to which our legal order conforms under Article 10, para. 1 of the Constitution, does not include the norm of immunity of States from civil jurisdiction in case of actions for damages for war crimes and crimes against humanity, in breach of inviolable human rights. These rights are therefore not deprived of the necessary effective judicial protection.

4. - Different conclusions can be drawn with regard to the question of constitutionality of Article 1 of the Law of Adaptation to the United Nations Charter (Law No. 848 of 17 August 1957). That provision is said to be in breach of Articles 2 and 24 of the Constitution, insofar as it gives execution to the United Nations Charter, and in particular Article 94, which provides that "each Member of the United Nations undertakes to comply with the decision of the ICJ in any case to which it is a party", and therefore requires that the domestic legal order conform to the Judgment of the ICJ even when it established (as in the present case) the duty of Italian courts to deny their jurisdiction in case of acts of the [foreign] State that constituted serious violations of international humanitarian law and of fundamental rights, as is the case of war crimes and crimes against humanity. 
4.1 - The question is well-founded under the terms set out below.

Article 1 of Law No. 848/1957 gave "full execution" to the United Nations Charter, signed in San Francisco on 26 June 1945, whose goal was to maintain international peace and security. The ICJ was established (Article 7) as the United Nations Organization's principal judicial organ (Article 92), whose decisions are binding on each Member State in any case to which it is a party (Article 94). This binding force produces effects in the domestic legal order through the Special Law of Adaptation (authorization to ratification and execution order). It constitutes one of the cases of limitation of sovereignty the Italian State agreed to in order to favour those international organizations, such as the UN, that aim to ensure peace and justice among the Nations (Article 11 of the Constitution), always within the limits, however, of respect for the fundamental principles and inviolable rights protected by the Constitution (Judgment No. 73/2001). Hence, the obligation to comply with the decisions of the ICJ, imposed by the incorporation of Article 94 of the United Nations Charter, cannot include the Judgment by which the ICJ obliged the Italian State to deny its jurisdiction in the examination of actions for damages for war crimes and crimes against humanity, in breach of fundamental human rights, committed jure imperii by the Third Reich in Italian territory.

In any case, the conflict between the Law of Adaptation to the United Nations Charter and Articles 2 and 24 of the Constitution arises exclusively and specifically with regard to the Judgment of the ICJ that interpreted the general international law of immunity from the jurisdiction of foreign States as to include cases of acts considered jure imperii and classified as war crimes and crimes against humanity, in breach of inviolable human rights. As has been repeatedly recalled, judicial protection of fundamental rights is one of the "supreme principles of the constitutional order". Accordingly, the questioned provision (Article 1 of the Law of Adaptation) cannot be opposed to this principle, insofar as it binds the Italian State, and thus Italian courts, to comply with the Judgment of the ICJ of 3 February 2012, which obliges Italian courts to deny their jurisdiction in the examination of actions for damages for crimes against humanity, in blatant breach of the right to judicial protection of fundamental rights.

In any other case, it is certainly clear that the undertaking of the Italian State to respect all of the international obligations imposed by the accession to the United Nations Charter, including the duty to comply with the judgments of the ICJ, remains unchanged.

The impediment to the incorporation of the conventional norm [Article 94 of the United Nations Charter] to our legal order-albeit exclusively for the purposes of the present case-has no effects on the lawfulness of the external norm itself, and therefore results in the declaration of unconstitutionality of the special law of adaptation, insofar as it contrasts with the abovementioned fundamental principles of the Constitution (Judgment No. 311/2009). 
This is consistent with the constant practice of this Court, as significantly emerges from Judgment No. 18/1982, where this Court upheld, inter alia, "the unconstitutionality of Article 1 of the Law No. 810 of 27 May 1929 (Execution of the Treaty, of the Four Annexes, and of the Concordat, signed in Rome, between the Holy See and Italy, on 11 February 1929), so far as it concerns the execution of Article 34, para. 4, 5 and 6 of the Concordat, and of Article 17 of the Law No. 847 of 27 May 1929 (Provisions for the Implementation of the Concordat of 11 February 1929 between the Holy See and Italy, in Matters of Marriage), to the extent that these provisions state that the Court of Appeal can render enforceable under civil law the ecclesiastical dispensation for the unconsummated marriage, and order the indication in the civil status records, next to the marriage record" (in the same sense, inter alia, Judgment No. 223/1996, No. 128/1987, No. 210/1986, and No. 132/1985).

The remainder of the Law of Adaptation No. 848/1957 continues to be undisputedly in full force and effect.

Hence, Article 1 of the Law of Adaptation No. 848/1957 has to be declared unconstitutional, so far as it concerns the execution of Article 94 of the United Nations Charter, exclusively to the extent that it obliges Italian courts to comply with the Judgment of the ICJ of 3 February 2012, which requires that Italian courts deny their jurisdiction in case of acts of a foreign State constituting war crimes and crimes against humanity, in breach of inviolable human rights.

5. - Lastly, the question of constitutionality of Article 3 of Law No. 5/2013 has to be examined. On the basis of arguments similar to those put forward in support of her other questions (see above, paras. 3 and ff.), the referring judge questions, with regard to Articles 2 and 24 of the Constitution, the constitutionality of the aforementioned Article [3 of the Law No. 5/2013], to the extent that it obliges the national judge to comply with the Judgment of the ICJ even when, as in the case at issue, it requires the national judge to deny their jurisdiction in the examination of the action for damages for crimes against humanity, committed by the Third Reich in Italian territory. [According to the referring judge], that provision conflicts with the principle of judicial protection of inviolable rights, enshrined in Articles 2 and 24 of the Constitution, insofar as it precludes judicial examination and compensation for damages for gross violations of human rights suffered by victims of war crimes and crimes against humanity, committed in the territory of the Italian State (which has the duty to ensure judicial protection) by another State, albeit in the exercise of sovereign powers.

\section{1. - The question is well-founded.}

The questioned provision falls within the scope of Law No. 5/2013, by which Italy authorized the accession and the full execution of the United Nations Convention on Jurisdictional Immunities of States and Their Property, adopted in New York on 2 December 2004. That Convention, which shall enter into force thirty days after the date of deposit of the thirtieth instrument of ratification, aims to incorporate in a treaty the generally recognized principle of customary international law of 
jurisdictional immunity of States, and to define its scope through the identification of cases in which State immunity cannot be invoked (such as, e.g., commercial transactions, contracts of employment, and personal injuries and damage to propertyArticles 10,11, and 12 respectively), with a view to guaranteeing "legal certainty, particularly in dealings of States with natural or juridical persons" (so reads the Preamble). Hence, the Italian legislator incorporated through Law No. 5/2013 the aforementioned Convention into the domestic legal order and thus became bound to respect all its provisions. Article 1, as mentioned above, provided for the authorization to accession, whereas Article 2 provided for the execution order. Moreover, [the Legislator] included the questioned Article 3, which provides that "1. For the purposes of Article 94, para. 1, of the United Nations Charter, (...) when the ICJ, in a judgment settling a dispute in which Italy is a party, excluded the possibility of subjecting certain specific conducts of another State to civil jurisdiction, the judge before whom a dispute concerning the same conducts has been brought shall declare ex officio at any stage of the proceedings their lack of jurisdiction, even when they have already rendered an interlocutory judgment with final effect as to the existence of jurisdiction [sentenza non definitiva passata in giudicato] in which they upheld their jurisdiction. 2. The final judgments contrary to the judgment of the ICJ referred to in para. 1, even when the latter has been passed subsequently, can be impugned for revision [revocazione] for lack of civil jurisdiction, in addition to the grounds provided for by Article 395 of the Code of Civil Procedure. In such circumstances, Article 396 of the Code of Civil Procedure shall not apply".

This is essentially a provision of ordinary adaptation that executes the Judgment of the ICJ of 3 September 2012. In other words, this article specifically regulates the obligation of the Italian State to comply with all of the rulings by which the ICJ excluded certain conducts of a foreign State from civil jurisdiction. It requires that the judge declare ex officio at any stage of the proceeding their lack of jurisdiction, and also provides for an additional ground for the revision [revocazione] of final judgments when they conflict with the ruling of the ICJ.

The Parliamentary proceedings clearly show that this article was adopted (shortly after the judgment of the ICJ of 3 February 2012) in order to ensure explicitly and immediately respect [of that judgment] and to "avoid unfortunate situations such as those created by the dispute before the Court of The Hague" (Acts of the Chamber of Deputies No. 5434, Third Commission - Foreign Affairs, meeting of 19 September 2012).

And this without excluding the cases in which the ICJ, as in the Judgment of 3 February 2012, upheld the immunity of States from civil jurisdiction in cases of actions for damages for acts regarded as war crimes and crimes against humanity, in breach of inviolable human rights, even if they were committed by the armed forces of a [foreign] State on the territory of the State of the court seized.

As such, the impugned law also derogates from the what has been explicitly established in the United Nations Convention on Jurisdictional Immunities of States and their Property. This is confirmed by the interpretative declaration deposited by 
the Italian government at the time of the accession, which explicitly excludes the application of the Convention and its limitations to the norm of immunity in case of damages or injuries caused by the activity of armed forces in the territory of the State of the court seized.

The duty of the Italian judge-established in the questioned Article 3-to comply with the ruling of the ICJ of 3 February 2012 (which requires that Italian courts deny their jurisdiction in the examination of the action for damages for crimes against humanity, committed jure imperii by a foreign State in Italian territory, without any other form of judicial redress for the fundamental rights violated) contrasts-as has been extensively demonstrated above with regard to the other questions [of constitutionality] (see above, paras. 3. and 4.) -with the fundamental principle of judicial protection of fundamental rights guaranteed by Articles 2 and 24 of the Constitution. As observed above, the absolute sacrifice of the right of judicial protection of fundamental rights - one of the supreme principles of the Italian legal order, enshrined in the combination of Articles 2 and 24 of the republican Constitution-resulting from the immunity from Italian jurisdiction granted to the foreign State, cannot be justified and accepted insofar as immunity protects the unlawful exercise of governmental powers of the foreign State, as in the case of acts considered war crimes and crimes against humanity, in breach of inviolable human rights.

Therefore, Article 3 of Law No. 5/2013 has to be declared unconstitutional.

6. - The declaration of jurisdiction of the referring judge is without prejudice to the merits of the main proceedings, whose examination is a duty of the referring judge.

The claim for damages filed by the applicants is not included in the subject-matter brought before this Court, nor is any assessment of matters of facts or of law that may confirm or deny the validity of their claim.

\section{FOR THESE REASONS}

\section{THE CONSTITUTIONAL COURT}

1) declares the unconstitutionality of Article 3 of Law No. 5 of 14 January 2013 (Accession of the Italian Republic to the United Nations Convention on Jurisdictional Immunities of States and their Property, signed in New York on 2 December 2004 , as well as provisions for the amendment of the domestic legal order);

2) declares the unconstitutionality of Article 1 of Law No. 848 of 17 August 1957 (Execution of the United Nations Charter, signed in San Francisco on 26 June 1945), so far as it concerns the execution of Article 94 of the United Nations Charter, exclusively to the extent that it obliges the Italian judge to comply with the Judgment of the ICJ of 3 February 2012, which requires that Italian courts deny their jurisdiction in case of acts of a foreign State constituting war crimes and crimes against humanity, in breach of inviolable human rights; 
3) declares ill-founded, under the terms set out in the reasoning, the question of constitutionality of the norm "created in our legal order by the incorporation, by virtue of Article 10, para. 1 of the Constitution", of the customary international law of immunity of States from the civil jurisdiction of other States, raised in relation to Articles 2 and 24 of the Constitution by the Tribunal through the Orders mentioned above.

So decided in Rome, at the seat of the Constitutional Court, Palazzo della Consulta, on 22 October 2014.

Giuseppe TESAURO, President and Drafter

Gabriella Paola MELATTI, Registrar

Deposited in the Registry on 22 October 2014.

Gabriella Paola MELATTI, Director of the Registry 